\title{
DEBATES CONTEMPORÂNEOS:
}

TEMAS

INTERDISCIPLINARES

GABRIELLA ELDERETI MACHADO

RODRIGO DUARTE FACCIN

SABRINA COPETTI DA COSTA

ORGANIZADORES
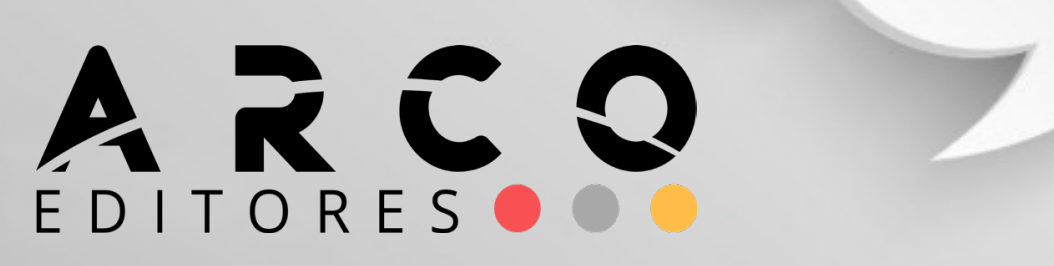


\section{CONSELHO EDITORIAL}

Prof. Dr. Adilson Tadeu Basquerote Silva

UNIDAVI/SC

http://lattes.cnpq.br/8318350738705473

Profa. Msc. Jesica Wendy Beltrán UFCE- Colômbia

http://lattes.cnpq.br/0048679279914457

Profa. Dra Fabiane dos Santos Ramos UFSM- Santa Maria/RS

http://lattes.cnpq.br/0003382878348789

Dr. João Riél Manuel Nunes Vieira de Oliveira Brito

UAL - Lisboa- Portugal.

http://lattes.cnpq.br/1347367542944960

Profa. Dra. Alessandra Regina Müller

Germani

UFFS- Passo Fundo/RS

http://lattes.cnpq.br/7956662371295912

Prof. Dr. Everton Bandeira Martins

UFFS - Chapecó/SC

http://lattes.cnpq.br/9818548065077031

Prof. Dr. Erick Kader Callegaro Corrêa UFN- Santa Maria/RS

http://lattes.cnpq.br/2363988112549627

Prof. Dr. Pedro Henrique Witchs

UFES - Vitória/ES

http://lattes.cnpq.br/3913436849859138

Prof. Dr.Thiago Ribeiro Rafagnin

UFOB

http://lattes.cnpq.br/3377502960363268
Prof. Dr. Mateus Henrique Köhler

UFSM- Santa Maria/RS

http://lattes.cnpq.br/5754140057757003

Profa. Dra. Liziany Müller

UFSM- Santa Maria/RS

http://lattes.cnpq.br/1486004582806497

Prof. Dr. Camilo Darsie de Souza

UNISC- Santa Cruz do Sul/RS

http://lattes.cnpq.br/4407126331414

Prof. Dr. Dioni Paulo Pastorio

UFRGS - Porto Alegre/RS

http://lattes.cnpq.br/7823646075456872

Prof. Dr. Leonardo Bigolin Jantsch

UFSM- Palmeira das Missões/RS

http://lattes.cnpq.br/0639803965762459

Prof. Dr. Leandro Antônio dos Santos

UFU- Uberlândia/MG

http://lattes.cnpq.br/4649031713685124

Dr. Rafael Nogueira Furtado

UFJF- Juiz de Fora/MG

http://lattes.cnpq.br/9761786872182217

Profa. Dra. Angelita Zimmermann

UFSM- Santa Maria/RS

http://lattes.cnpq.br/7548796037921237

Profa. Dra. Francielle Benini Agne

Tybusch

UFN - Santa Maria/RS

http://lattes.cnpq.br/4400702817251869

Copyright (c) Arco Editora, alguns direitos reservados.

Copyright do texto (c) 2022 os autores e as autoras.

Copyright da edição (c) 2022 Arco Editora. 
Diagramação e Projeto Gráfico : Gabriel Eldereti Machado

Imagen capa: $w w w$ freepik.com

Revisão: dos/as autores/as.

Dados Internacionais de Catalogação na Publicação (CIP) (Câmara Brasileira do Livro, SP, Brasil)

Debates contemporâneos [livro eletrônico] : temas
interdisciplinares / organização Gabriella
Eldereti Machado, Rodrigo Duarte Faccin,
Sabrina Copetti da Costa. -- Santa Maria, RS :
Arco Editores, 2022.
PDF.
Bibliografia.
ISBN 978-65-89949-67-1
1. Debates 2. Interdisciplinaridade na educação
Temas transversais (Educação) I. Machado,
Gabriella Eldereti. II. Faccin, Rodrigo Duarte.
III. Costa, Sabrina Copetti da.
22-99151 CDD-370.1

Índices para catálogo sistemático:

1. Interdisciplinaridade : Educação 370.1

Aline Graziele Benitez - Bibliotecária - CRB-1/3129

\section{dol 10.48209/978-65-89949-D2-1}

O padrão linguístico-gramatical, bem como o sistema de citações e referências bibliográficas são prerrogativas de cada autor. Da mesma maneira, o conteúdo e teor de cada capítulo é de inteira e exclusiva responsabilidade de seu respectivo autor. 


\section{APRESENTAÇÃO}

Esta obra busca reunir discussões sobre temáticas que permeiam o contexto da contemporaneidade. Entende-se por contemporâneo o tempo atual, bem como, os Temas Contemporâneos em sua abordagem transversal, por se referirem a diversos assuntos e aspectos da vida e formação dos sujeitos como a: política, sociedade, arte, cultura, tecnologia, gênero, relações sociais, saúde, meio ambiente, ética, linguagens, pluralidade e multiculturalidade, trabalho, consumo e direitos humanos. Áreas contemplados no escopo do Livro Digital: Ciências Sociais; Humanidades e Linguagens; Ciências Humanas; Ciências da Natureza; Ciências Exatas; Tecnologia; Educação; Ensino; Ciências Jurídicas; Economia; Política.

\section{Boa leitura!}




\section{SUMÁRIO}

\section{CAPÍTULO 1}

EDUCAÇÃO POPULAR E ECONOMIA SOLIDÁRIA: SABERES E VIVÊNCIAS QUE PERMEIAM AS ATIVIDADES DO PROJETO ESPERANÇA/COOESPERANÇA NO MUNICÍPIO DE SANTA MARIA - RS

Gabriella Eldereti Machado

Ivanio Folmer

doi: 10.48209/978-65-89949-D2-2

\section{CAPÍTULO 2}

UM OLHAR SOBRE BRASÍLIA A PARTIR DA FICÇÃO DE "BRANCO SAI, PRETO FICA".

Rodrigo Duarte Faccin

doi: 10.48209/978-65-89949-D2-3

\section{CAPÍTULO 3}

GAMIFICAÇÃO ALIADA AS PRÁTICAS PEDAGÓGICAS: DIÁLOGOS POSSÍVEIS.

Amanda Marinho Rodrigues

doi: 10.48209/978-65-89949-D2-4

\section{CAPÍTULO 4}

FORMAÇÃO CONTINUADA DE PROFESSORES DE EDUCAÇÃO FÍSICA PARA O ENSINO DA SAÚDE: GAMIFICAÇÃO COMO RECURSO PEDAGÓGICO.

Amanda Marinho Rodrigues

doi: 10.48209/978-65-89949-D2-5

\section{CAPÍTULO 5}

NOÇÃO DE TEMPO LIVRE EM THEODOR ADORNO .60

Angelo Maurício de Amorim

doi: 10.48209/978-65-89949-D2-6 


\section{CAPÍTULO 6}

RELAÇÕES DE TRABALHO E DE GÊNERO: ESTUDO DE CASO EM UM ASSENTAMENTO RURAL.

Rodrigo Duarte Faccin

doi: 10.48209/978-65-89949-D2-7

\section{CAPÍTULO 7}

OS DESAFIOS DA EDUCAÇÃO INLUSIVA NO MUNICÍPIO DE ITABAIANA SE: O CASO DA ESCOLA MUNICIPAL PROFESSSORA ANAILDE SANTOS DE JESUS.

Fábio Ferreira Santos

doi: 10.48209/978-65-89949-D2-8

\section{CAPÍTULO 8}

EDUCAÇÃO AMBIENTAL NAS ESCOLAS DO CAMPO: UMA PRÁTICA PARA ALÉM DA SALA DE AULA .....................................................................109

Cauana Peyrot Conceição

Pedro Valdir da Conceição

Liziany Müller

Rogério Oliveira Pinheiro

doi: 10.48209/978-65-89949-D2-9

\section{CAPÍTULO 9}

DIVERSIDADE E EDUCAÇÃO INCLUSIVA.

Mirian Luzia de Lima Vaz

Liliana Bernardo de Oliveira Onofre

Luciano Araujo da Costa

doi: 10.48209/978-65-89949-D2-0

\section{CAPÍTULO 10}

O TEMPO DA ESPERA NA PANDEMIA DA COVID-19: COMO O DISTANCIAMENTO SOCIAL PODE FACILITAR O ENCONTRO COM NÓS MESMOS. 


\section{CAPÍTULO 11}

"O HOSPEDEIRO ESTÁ MORRENDO, O CARA VIROU UM PARASITA, O DINHEIRO NÃO CHEGA NO POVO E ELE QUER AUMENTO AUTOMÁTICO”: UMA ANÁLISE CRÍTICA DO DISCURSO. 157

Renata Freitas Siqueira

doi: 10.48209/978-65-89949-DA-1

\section{CAPÍTULO 12}

AGRONEGÓCIO E A QUESTÃO DA MORADIA NA CIDADE DE CAMPO VERDE-MT. 171

Ariel Costa dos Santos

doi: 10.48209/978-65-89949-D3-1

\section{CAPÍTULO 13}

A PARTICIPAÇÃO OBRIGATÓRIA DOS SINDICATOS NAS NEGOCIAÇÕES COLETIVAS DE TRABALHO: UMA ANÁLISE DO ART. $8^{\circ}$, VI DA CONSTITUIÇÃO DE 1988. 189

Carla Letícia Oliveira Figueiredo

doi: 10.48209/978-65-89949-D4-1

\section{CAPÍTULO 14}

A GESTÃO DA DIVERSIDADE NO CAMPO EDUCACIONAL .204

Edileuza Gomes de Souza Ueudison Alves Guimarães Anair Meirelles Quadrado Wanderson Teixeira Gomes doi: 10.48209/978-65-89949-D5-1

\section{CAPÍTULO 15}

A DIVERSIDADE NA PERSPECTIVA DA SALA DE AULA: O PAPEL DA GESTÃO ESCOLAR NESSE PROCESSO

Ueudison Alves Guimarães

Edileuza Gomes de Souza

doi: 10.48209/978-65-89949-D6-1 


\section{CAPÍTULO 16}

IDEOLOGIA E DIREITO DO HOMEM: UMA ANÁLISE CRÍTICA SUBJACENTE.

Giovanna Martins Sampaio

doi: 10.48209/978-65-89949-D7-1

\section{CAPÍTULO 17}

APONTAMENTOS SOBRE MARCAS COLETIVAS E COOPERATIVAS AGRICOLAS. 236

Giovanna Martins Sampaio

Hermes Oliveira Gomes

doi: 10.48209/978-65-89949-D8-1

\section{CAPÍTULO 18}

MARCAS COLETIVAS ENQUANTO ESTRATEGIAS COMPETITIVAS

.249

Giovanna Martins Sampaio

Alanna Rodrigues

doi: 10.48209/978-65-89949-D9-1

\section{CAPÍTULO 19}

APONTAMENTOS INTERDISCIPLINARES E JURIDICOS SOBRE A EDUCAÇAO NO CAMPO.

Giovanna Martins Sampaio

Hermes Oliveira

doi: 10.48209/978-65-89949-D0-1

\section{CAPÍTULO 20}

A TATUAGEM E A PROPRIEDADE INTELECTUAL: ANÁLISE DA LEI DE DIREITO AUTORAL E O DIREITO DA PERSONALIDADE..

Alanna Rodrigues Santana

Giovanna Martins Sampaio

doi: 10.48209/978-65-89949-D2-A 


\section{CAPÍTULO 21}

AED: A LEI DOS SALÕES DE BELEZA E EFICIÊNCIA

Giovanna Martins Sampaio

doi: 10.48209/978-65-89949-D2-B

\section{CAPÍTULO 22}

GEOGRAFIA E CONCEITOS: UM OLHAR TRANSFORMADOR 300

Giovanna Martins Sampaio

Hermes Gomes

doi: 10.48209/978-65-89949-D2-C

\section{CAPÍTULO 23}

PROSPECÇÃO DE TECNOLOGIAS SUSTENTÁVEIS: UM OLHAR SOBRE AS PATENTES.

Hermes Oliveira Gomes

Giovanna Martins Sampaio

doi: 10.48209/978-65-89949-D2-D

\section{CAPÍTULO 24}

DIREITOS HUMANOS NO SISTEMA PRISIONAL NA PANDEMIA. 326

Naiara Ferreira Paim

doi: 10.48209/978-65-89949-D2-F

\section{CAPÍTULO 25}

DIGNIDADE HUMANA COMO PRINCÍPIO REITOR À EDUCAÇÃO DO (RE) EDUCANDO: DA ILHA AO CONTINENTE.

Ulysses Fonseca Louzada

Denise Santos da Cruz

Adriana Moreira da Rocha Veiga

doi: 10.48209/978-65-89949-D2-G

\section{CAPÍTULO 26}

OS DESAFIOS DAS TECNOLOGIAS E DA SAÚDE EMOCIONAL: UMA REFLEXÃO DA PRÁTICA DOCENTE

Maricélia de Almeida Vieira

Denise Santos da Cruz

doi: 10.48209/978-65-89949-D2-H 


\section{CAPÍTULO 27}

ESTRATÉGIA UTILIZADA PELAS COOPERATIVAS DE CRÉDITO PARA OBTER VANTAGEM COMPETITIVA EM RELAÇÃO A BANCOS

Sonia Aparecida Machado

doi: 10.48209/978-65-89949-D2-J

\section{CAPÍTULO 28}

USO DE JOGOS DIDÁTICOS NO ENSINO DE BIOLOGIA: UMA REVISÃO.

Soleika Gorete Lunkes

Maria Fatima Menegazzo Nicodem

José Gilmar Kurtz

Paulo Sérgio Mohr

Natalina das Graças Bitencourt

Ronny Ramos da Silva

doi: 10.48209/978-65-89949-D2-K

\section{CAPÍTULO 29}

O FINANCIAMENTO PÚBLICO PARA A EDUCAÇÃO ESPECIAL: UMA ANÁLISE DO FUNDEF E DO FUNDEB.

Diniz da Cunha Silveira

doi: 10.48209/978-65-89949-D2-L

SOBRE OS ORGANIZADORES 


\section{doi $10.48209 / 978-65-89949-D 2-2$}

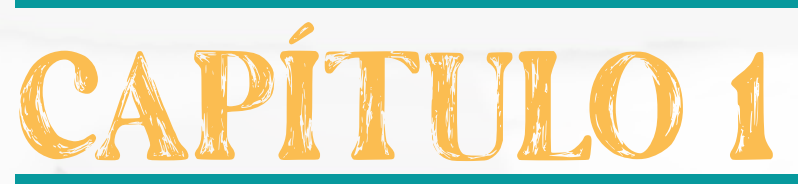

\section{EDUCAÇÃO POPULAR E ECONOMIA SOLIDÁRIA: SABERES E VIVENCIAS}

QUE PERMEIAM AS ATIVIDADES DO PROJETO ESPERANÇA/COOESPERANÇA NO MUNICÍPIO DE SANTA MARIA - RS

Gabriella Eldereti Machado Ivanio Folmer 


\section{INTRODUÇÃO}

A economia solidária torna-se uma alternativa para o fortalecimento de famílias no campo e outros tipos de comerciantes, sendo relevantes as ações que o Projeto Esperança/Cooesperança desempenha na cidade de Santa Maria - RS. Onde os saberes e vivências são compartilhados entre sujeitos urbanos e rurais no espaço do Centro de Referência em Economia Solidária Dom Ivo Lorscheiter através do Feirão Colonial. Significando a educação popular com debates, formações continuadas, oficinas, entre outras, sendo o resultado da construção coletiva, objetivando não delimita-se apenas a comercialização, e priorizar as relações de trocas. Propõem-se nessa escrita demonstrar brevemente os processos educativos e a valorização dos saberes populares nas atividades do Projeto Esperança/Cooesperança no município de Santa Maria - RS.

A economia popular solidária torna-se um processo educativo para a discussão das dinâmicas sociais, culturais e de trabalho que compõem a agricultura familiar e as suas discussões atuais, pois se destaca a heterogeneidade de contextos para com a constituição como grupo social, visto que atualmente tem-se uma complexidade que permeia os entendimentos sobre o meio rural. No qual, diversos grupos sociais o integram, sendo eles: agricultores familiares, quilombolas, pescadores, comunidades resultantes de programa de reforma agrária, povos indígenas; ou seja, tem - se em cada comunidade uma cultura própria, referente a uma tradição transmitida entre gerações, que se inserem e se constituem parte do local de vida e trabalho, (TONIN, et. al., 2009).

Demonstra-se atualmente a importância de espaços educativos que valorizam os saberes locais através da abertura social para construção do conhecimento através do diálogo, realizando-se pela concretização de diversas inter-relações entre a teoria e a práxis campesina (LEFF, 2010) e buscando outra ótica para o desenvolvimento e geração de renda. Assim, neste intuito de valorização dos sujeitos, insere-se a prática do comércio justo, ético e solidário, através das 
feiras de economia popular solidária. Que segundo Paul Singer (2002, p.10) a economia solidária pode ser caracterizada como "outro modo de produção, cujos princípios básicos são a propriedade coletiva ou associada do capital e o direito à liberdade individual", buscando destoar-se do atual sistema, o capitalismo, no qual os princípios de produção e direitos ao capital e liberdade são individuais separando a sociedade opressores e oprimidos ${ }^{1}$, havendo uma divisão de classes através do capital econômico².

Assim, o que ocorre nesses espaços de economia solidária é a valorização da cultura e saberes dos sujeitos, através da união da massa oprimida, tendo sua síntese cultural fundamentada na fortificação do processo dialógico que resulta na conscientização dos sujeitos em relação à estrutura social, (FREIRE, 1987). Nesse sentido que se configura a economia solidária, como outro modo de produção, baseada nos princípios de propriedade coletiva ou associada, na prática realiza-se a união de todos que produzem numa única classe de trabalhadores, possuidores de capital cooperativo, no sentido de busca da solidariedade e igualdade (SINGER, 2002).

No Feirão Colonial realizado no Centro de Referência em Economia Solidária Dom Ivo Lorscheiter, sendo uma das atividades do Projeto Esperança/Cooesperança, é promovido um ambiente de trocas de saberes e vivências em um espaço de educação popular resultado da construção coletiva, onde não delimita-se apenas a comercialização, mas as relações de trocas entre sujeitos rurais e urbanos torna-se um fato relevante. Assim como os processos formativos que ocorrem através de formação continuada a agricultores e população em geral, mostrando que o desenvolvimento dos sujeitos é relevante. Esse espaço é re-

1 A relação opressor - oprimido, realiza-se em um sistema antidialógico, descrito por fatores, sendo eles: a conquista, método em que o opressor impõem sua cultura sobre o opressor; a divisão das massas, para dominação, pois o mesmo não efetua-se quando um grupo está; a invasão cultural dos saberes que o grupo possui (FREIRE, 1987).

2 Compreende o espaço social como um campo de lutas em que indivíduos e grupos formulam estratégias que permitem manter ou melhorar sua posição social. Relacionadas a tipos de capital, nesse contexto o capital econômico pode ser entendido como as formas dos diferentes fatores de produção, terras, fábricas, trabalho; e os bens econômicos sendo: dinheiro, patrimônio, bens materiais (BOURDIEU, 1989). 
sultante de um empenho cooperativo de diversos agricultores e grupos urbanos para sua realização inicial no ano de 1989, sendo fundamentada na construção da consciência do consumidor e do produtor em relação ao consumo justo, ético e solidário.

A educação popular e a economia solidária se entrelaçam em relação às experiências educativas, onde o encontro das duas constrói o conhecimento em economia solidária (DUBEUX, et. al., 2012) em reflexões críticas sobre a prática, significando a proposta da autogestão, como um diálogo metodológico. Cabe destacar que a possibilidade que a valorização dos saberes populares tem em desconstruir a hierarquia de construção do conhecimento, de modo que percebemos essa construção coletiva nesses espaços de economia solidária, sendo necessário que os sujeitos se disponham a $(R e)$ descobrir os saberes, a fim de valorizá-los.

A aproximação do Projeto Esperança/Cooesperança ocorre através do Grupo de Agroecologia Terra Sul (GATS) da UFSM1ㅗㄴ no qual se pode (re) afirmar no presente ano uma parceria antiga entre grupo e atividades do Projeto. O despertar da vontade de realização da presente pesquisa ocorre devido à possibilidade de presenciar e aprender mais sobre os saberes que permeiam as atividades do Feirão e do Projeto, podendo evidenciar/vivenciar na prática a educação popular refletida por Paulo Freire, sendo um aspecto relevante a ser fortificado e inserido nas atividades docentes. A partir das disposições iniciais, propõem-se investigar os processos educativos e a valorização dos saberes populares nas atividades do Projeto Esperança/Cooesperança no município de Santa Maria - RS.

\section{DISCUSSÃO TEÓRICA}

A economia solidária é formada por um conjunto de grupos e coletivos sociais, que buscam através de seus potenciais e possibilidades produzir, distribuir, poupar e investir, segurar. Formatando-se em um modelo de luta contra a

$1 \quad$ Universidade Federal de Santa Maria. 
exclusão social, por meio da construção de uma economia solidária, organizada e formada de unidades produtivas autogestionárias. Possuindo também uma finalidade multidimensional, no qual envolve a âmbito social, econômica, político, ecológico e cultural. As suas relações econômicas de geração de trabalho e renda realizam-se no espaço público, propondo-se a priorizar a perspectiva de construção de um ambiente socialmente justo e sustentável.

Este processo é organizado a partir do momento em que os trabalhadores assumem o comando do empreendimento solidário de forma igualitária, democratizando o saber e as informações gerais da produção (SINGER, 2002), ainda em relação a essas reflexões sobre as unidades produtivas autogestionárias menciona Paul Singer (1998, p. 181-182):

Mas, elas têm um respeitável potencial de crescimento político, se o movimento operário - sindicatos e partidos - apostar nelas como alternativa viável ao capitalismo. Está comprovado que cooperativas de espécies complementares podem formar conglomerados capitalistas. Mas, as cooperativas carecem de capital. É o seu calcanhar-de-aquiles. Se o movimento operário, que partilha o poder estatal com o capital, quiser alavancar o financiamento público da economia solidária, a cara da formação social vai mudar. Um novo modo de produção pode se desenvolver, este capaz de competir com o modo de produção capitalista.

A organização do coletivo acontece por uma autogestão, que desloca o mérito econômico para a visão e reflexão sobre o desenvolvimento humano que ocorre entre os praticantes, através de suas participações nas discussões e decisões do grupo, fortificando o que diz Paul Singer (2002, p.21) no qual se "educa e conscientiza, tornando a pessoa mais realizada, autoconfiante e segura". Assim se propõe uma redefinição dos movimentos sociais, que ao organizarem-se como coletivos compartilham dos mesmos interesses cooperando na luta por direitos sociais (ARROYO, 2007), sendo essencial a tomada de consciência através de processos educativos relacionados à realidade local, cultural e de produção da comunidade, possibilitando a efetivação do processo de empoderamento ${ }^{1}$.

1 Para Freire (1979), o empoderamento é resultante de um processo de conscientização, envolvendo a passagem de um pensamento ingênuo para uma consciência crítica. Sendo um processo de conscientização em relação ao conhecimento resultante da relação dialética homem-mundo, refletidos na reflexão e ação, ocorrendo na práxis. 
A concretização de uma conscientização crítica e do empoderamento, é possível através das relações de mediação da realidade por meio da problematização da mesma, efetivando-se na análise crítica mediante a reflexão e ação (FREIRE, 1987). Evidenciando a importância da educação como forma de emancipação crítica, na medida em que o sujeito em sua construção do conhecimento supera o condicionamento histórico que se impõe a frente das possibilidades de buscar ser mais, ir além do que é instituído ao grupo social. Como Freire (2010, p.57) sintetiza no trecho a seguir, partindo-se da consciência do inacabamento dos seres humanos para educabilidade:

A consciência do mundo e a consciência de si como ser inacabado necessariamente inscrevem o ser consciente de sua inconclusão num permanente movimento de busca. Na verdade, seria uma contradição se, inacabado e consciente do inacabamento, o ser humano não se inserisse em tal movimento. É neste sentido que, para mulheres e homens, estar no mundo necessariamente significa estar com o mundo e com os outros.

Na ciência e no meio acadêmico possui-se o estigma de que os saberes populares tornam-se ciência a partir do momento em que são "comprovados", deixando de lado e afastando os conhecimentos que permeiam os espaços do cotidiano das comunidades rurais ou grupos sociais, e baseiam-se na realidade dos sujeitos envolvidos, sendo encarado como caracteriza Bourdieu (1989) como um poder simbólico, sendo entendido através dos condicionamentos presentes.

Perde-se nessa concepção do saber como um produto ou bem os conhecimentos e saberes presentes na educação popular, como menciona Torres (1987, p. 16) "todos podemos contribuir para a educação popular, porque todos temos experiências". Deste modo, a construção do conhecimento ocorre através de formas dialéticas reconhecendo como parte fundamental as relações entre os indivíduos e as suas relações com o mundo, como refere Paulo Freire (1983, p.16) no trecho a seguir:

O conhecimento, pelo contrário, exige uma presença curiosa do sujeito em face do mundo. Requer sua ação trans-formadora sobre a realidade. Demanda uma busca constante. Implica em invenção e em reinvenção. Reclama a reflexão crítica de cada um sobre o ato mesmo de conhecer, pelo qual se reconhece conhecendo e, ao reconhecer-se assim, percebe 
o "como" de seu conhecer e os condicionamentos a que está submetido seu ato.

Neste contexto de educação popular e economia solidária destaca-se o papel do Projeto Esperança/Cooesperança, que surge de uma parceria entre a Cáritas Regional1, tendo como ponto de partida o livro: "A Pobreza e a Riqueza Dos Povos" do autor africano Albert Tévoèdjeré. Em 1982 a 1985 foram criados os $\mathrm{PACs}^{2}$, o Projeto Esperança é criado em 15 de agosto de 1987, objetivando proporcionar a articulação e de experiências de economia popular solidária, na cidade e no meio rural. Por meio da construção do associativismo, o trabalho e cidadania organizados em um modelo autogestionário de cooperativismo (CASSOL \& WIZNIEWSKY, 2013). No ano de 1989 cria-se a Cooesperança ${ }^{3}$, em conjunto ao Projeto Esperança, desempenhando o papel de congregar e articular os grupos organizados da região central do estado do Rio Grande do Sul com o objetivo de viabilizar a comercialização direta dos produtos do campo na cidade (Ibidem., 2013).

\section{MÉTODO DE INVESTIGAÇÃO}

Toda pesquisa possui um propósito, no qual se espera aventurar-se pelos conhecimentos e aprendizagem que irão possibilitar a compreensão da realidade pesquisada, em um sentido amplo, como reflete Pádua (2004, p.31) é a "atividade de busca, indagação, investigação, inquirição da realidade, é a atividade que vai nos permitir, (...)". Desta forma, a pesquisa é um processo de olhares, no qual a originalidade encontra-se na criação, se distanciando da mera constatação. Levando-se em conta o privilégio de se ter um Projeto que vem sendo construído desde 1987, priorizando o trabalho através da solidariedade, da cidadania, e desenvolvimento humano e social.

Pretende-se inicialmente realizar a pesquisa bibliográfica, em relação aos processos que se vinculam e resultam nas ações atuais do Projeto; juntamente

1 Confederação Humanitária da Igreja Católica.

2 Projetos Alternativos Comunitários.

3 Cooperativa Mista de Pequenos Produtores Rurais e Urbanos. 
aos estudos sobre as dinâmicas históricas associadas às conjunturas politicas que influenciaram ou não o andamento do Projeto, e compreensões e reflexões sobre economia popular solidária. Nesta etapa serão utilizadas fontes como livros, artigos, trabalhos de pesquisa, entre outros, para estabelecer as relações que permeiam o tema abordado, visto que não é algo isolado, podendo-se conhecer as contribuições sobre a temática realizadas por outros autores, (KÖCHE, 1997). É a base para o decorrer da pesquisa, permitindo a abertura ao que já foi ou não produzida nas áreas, contribuindo e fortalecendo a ideia central.

Havendo a partir dessas ações uma base teórica para a formação de um espaço participativo de pesquisa, podendo identificar problemas e estabelecer as prioridades do grupo, chegando - se ao planejamento de ações significadas na realidade em que se encontram os sujeitos envolvidos (KUMMER, 2007). O método a ser utilizado para o decorrer da proposta de pesquisa é o estudo de caso, possibilitando em decorrência de suas aplicações em diversas áreas do conhecimento, facilitar a percepção holística e real do espaço social observado. Assim, ressalta Yin (2015, p.4) permite estudar "os ciclos individuais da vida, o comportamento dos pequenos grupos, os processos organizacionais, (...)" demonstrando a abrangência de possibilidades que o estudo de caso dispõe. Desenvolvendo-se através das vivências e experiências dos sujeitos envolvidos, realizada por meio de visitas, contato, entrevistas ou métodos grupais.

\section{CONSIDERAÇÕES FINAIS}

O Projeto Esperança/Cooesperança e a Teia Esperança atuam através dos seguintes eixos: a organização, a formação, a agroindústria familiar, a agricultura familiar agroecológica, o trabalho dos catadores (as), o artesanato e confecção, a economia popular solidária, a comercialização direta, a reforma agrária, o consumo justo, ético e solidário, o tabaco zero, o resgate das sementes crioulas, as políticas públicas. A comercialização ocorre no Centro de Referência de Economia Solidária Dom Ivo Lorscheiter, sendo o espaço fixo de integração da Teia Esperança, no qual os sujeitos além da compra e venda se dispõem a compartilhar 
suas experiências, saberes e vivências, tradicionalmente realizado nos sábados, e denominado o "Feirão Colonial Semanal".

Um espaço relevante de educação popular e economia solidária acontece durante a realização da Feira Latino Americana de Economia Solidaria e Feira Internacional do Cooperativismo, realizadas anualmente sendo parceira as atividades do Fórum Social Mundial. As atividades da Feira tornam-se um momento educativo de participação, integração entre diferentes culturas e Democracia Participativa, por meio de: Conferências, Seminários, Oficinas, Debates, Caminhada Internacional e Ecumênica pela Paz e Justiça Social, Momentos Culturais, Shows, Acampamento do Levante da Juventude, entre outras. Colocando em voga diversas discussões sobre o contexto social, cultural e econômico que temos atualmente.

\section{REFERÊNCIAS}

BOURDIEU, Pierre. O poder simbólico. Rio de Janeiro/Lisboa: Berthand Brasil/ Difel, 1989.

BOURDIEU, Pierre. Introdução à Economia Solidária. São Paulo: Fundação Perseu Abramo, 2002.

CASSOL, Kelly Perlin; WIZNIEWSKY, Carmen Rejane Flores. Projeto Esperança/Cooesperança, Santa Maria, RS: 0 caso dos agricultores familiares associados. Geografia Ensino \& Pesquisa, v. 17, n.1, jan./abr. 2013.

DUBEUX, Ana; MEDEIROS, Alzira; VILAÇA, Mônica; SANTOS, Shirley. Sistematização de experiências de educação em economia solidária: o prazer desafiador da produção coletiva de conhecimentos. In: A construção de conhecimento em economia solidária: sistematização de experiências no chão do trabalho e da vida no Nordeste. Organização: UBEUX, Ana; MEDEIROS, Alzira; VILAÇA, Mônica; SANTOS, Shirley. - Recife: F\&A Gráfica e Editora Ltda, 2012.

ESPERANÇA COOESPERANÇA. Quem somos. Disponível em: http://www.esperancacooesperanca.org/\#!quem-somos/c22rc. Acesso em: 28/09/2015. 
FREIRE, Paulo. Extensão ou comunicação? $7^{\text {a }}$ ed. Rio de Janeiro, Paz e Terra, 1983.

. Pedagogia da Autonomia: saberes necessários à prática educativa. $41^{\text {a }}$ reimpressão. São Paulo: Paz e Terra, 2010.

. Pedagogia do Oprimido. $17^{\mathrm{a}}$ ed. Rio de Janeiro, Paz e Terra, 1987.

KÖCHE, J. C. Fundamentos de metodologia científica: teoria da ciência e prática da pesquisa. 15. ed. Petrópolis, RJ: Vozes, 1997.

KUMMER, Lydia. Metodologia participativa no meio rural: uma visão interdisciplinar, conceitos, ferramentas e vivencias. - Salvador: GTZ, 2007.

LEFF, Enrique. Discursos Sustentáveis. - São Paulo: Cortez, 2010.

PÁDUA, Elisabete Matallo Marchesini de. Metologia da pesquisa: abordagem teórico-prática. - 10ª ed. Rev e atual - campinas, São Paulo: Papirus, 2004.

TONIN, Cléia Margarete Macedo da Costa; MEDEIROS, Luis Aquiles Martins; WANDERLEY, Maria de Nazareth Baudel. O Mundo Rural como um Espaço de Vida - reflexões sobre a propriedade da terra, agricultura familiar e ruralidade. Porto Alegre: Editora da UFRGS, 2009.

YIN, Robert K. Estudo de Caso: planejamento e métodos. $5^{\mathrm{a}}$ ed. Porto Alegre: Bookman, 2015. 


\section{doi $10.48209 / 978-65-89949-D 2-3$}
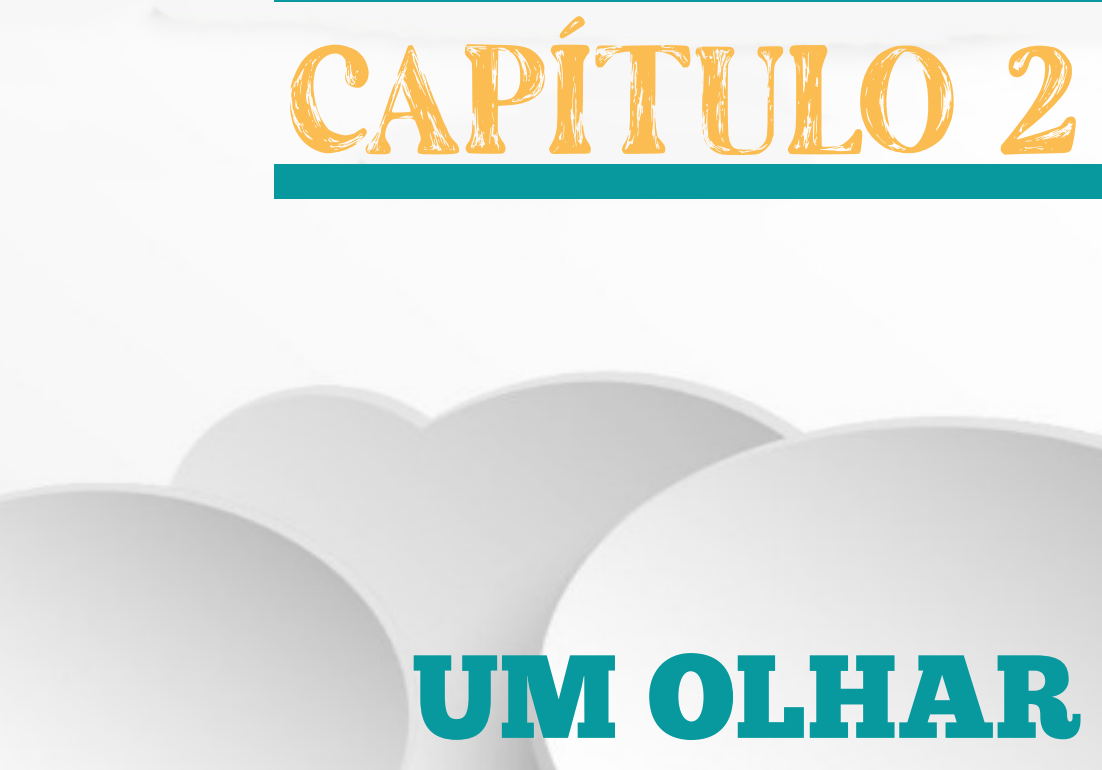

SOBRE BRASÍLIA A PARTIR DA FICÇÃO DE "BRANCO SAI, PRETO FICA" 


\section{INTRODUÇÃO}

O presente artigo busca apresentar discussões atinentes ao filme cult brasileiro "Branco sai, preto fica", com o intento de realizar uma análise crítica desta referida ficção científica, sendo embasada por ideias de utopia e distopia e com as noções de desenvolvimento e visão de futuro.

Embora a pouca tradição do gênero de ficção científica no Brasil, o filme do diretor Adirley Queirós não deixou de ser premiado em diversos festivais de cinema no país e no exterior, sendo considerado por muitos críticos como o meIhor filme brasileiro do ano de 2014. Ao debater o tema da desigualdade social e racial, "Branco sai, preto fica" torna-se um convite para uma reflexão social profunda sobre o Brasil.

Para desenvolver o estudo foi realizado uma análise de conteúdo do filme em questão, sendo complementada por uma ampla pesquisa bibliográfica. $O$ filme apresenta um universo de distopia e de ficção científica, sendo situado na cidade de Brasília. Com base nisso, foi elaborado análises que buscam relacionar a utopia e a ideia de futuro presentes na criação da cidade, em meados do século $\mathrm{XX}$, com os elementos presentes no filme.

\section{COMPREENDENDO O FILME "BRANCO SAI, PRETO FICA"}

"Branco sai, preto fica", aborda os dilemas reais de dois homens que tiveram as vidas marcadas após um tiroteio de uma ação truculenta e racista da policia, em uma festa na Ceilândia, cidade-satélite do Distrito Federal, em março de 1986. Além de retratar a vida de dois homens que tiveram seus corpos mutilados pelo Estado, um paraplégico e outro com uma perna amputada, o filme busca construir narrativa documental a partir de uma história ficcional fantasiosa. Para isso, um homem vem do futuro para averiguar o que ocorreu na noite da festa, buscando angariar provas para processar o Estado. Relatos verdadeiros resgatados a partir de depoimentos reais e construídos em sequências ficcionais tentam demonstrar o cotidiano e as relações sociais destes homens. 
A escolha deste filme se deu pelo interesse em trabalhar com o uma ficção científica brasileira, justamente por este gênero ser pouco desenvolvido na história do cinema nacional. Na visão de Suppia (2017, p. 218) a ficção científica no cinema brasileiro "é uma aventura esporádica", visto que de acordo com o autor, "na Europa, nos EUA e no Japão, o cinema de ficção científica encontra terreno fértil. (...) No Brasil, entretanto, a situação é um pouco diferente, uma vez que a ficção científica cinematográfica tem sido frequentemente encarada como algo fora de lugar". E, talvez seja esta a grande possibilidade de trabalhar com o filme, uma vez que ele se constrói diferente da tradição hegemônica do gênero de ficção científica, já que em "Branco sai, preto fica" os elementos tecnológicos são bastante limitados, não apenas por uma questão de baixo orçamento, mas por uma escolha visual dos diretores, que buscaram construir um cinema "contra-estético", ao mesmo tempo em que estabelecem uma ficção da e na periferia de Brasília.

O longa-metragem, lançado no ano de 2014, aborda assuntos atuais da sociedade brasileira, como a violência policial nas comunidades periféricas, o preconceito e o racismo contra pessoas negras e o apartheid social. Nesse sentido, tanto a segregação racial quanto a espacial são assuntos centrais no filme. Marquin e Sartana, personagens centrais em "Branco sai, preto fica", constroem seus mundos e seus lugares na história a partir de suas próprias territorialidades, no caso, a periferia da cidade, a Ceilândia. O diretor Adirley Queirós, filho de migrantes que chegaram à Brasília na década de 1970, constrói um cinema a partir de sua própria realidade. "Branco sai e preto fica" não é o único filme de Adirley que retrata Brasília, tanto "Rap, o canto da Ceilândia", de 2005, "A cidade é uma só?", de 2011, como o recém-lançado "Era uma vez Brasília”, de 2017, buscam se diferenciar no cenário cinematográfico nacional ao recorrerem a atores não profissionais, utilizando a própria realidade destas pessoas para construir histórias híbridas entre ficção e documentário.

Neste sentido, buscando compreender a realidade do local em que o filme se passa, busca-se a seguir evidenciar elementos da concepção da cidade de 
Brasília, recuperando a utopia que trilhou a cidade do futuro, e, consequentemente, as contradições deste projeto ao descrever o contexto de desigualdade social das cidades-satélites, em específico a Ceilândia. Posteriormente, se faz a apresentação e discussão do filme com o intento de realizar uma análise crítica desta referida ficção científica, sendo embasada por ideias de utopia e distopia, relacionando com a noção de desenvolvimento e visão de futuro.

\section{CIDADE MOdERNISTA, CIDADE dO FUTURO: A UTOPIA DE BRASÍLIA}

Segundo Oliveira (2008), Brasília nasceu da implantação de um projeto de planejamento urbano modernista, já consolidado em alguns países industrializados, que visava à ampliação de mercados consumidores internos e a integração da nação, por meio do que foi denominado de nacional-desenvolvimentismo do Plano de Metas, colocado em prática durante o governo de Juscelino Jubitscheck, tendo como slogan de governo "cinquenta anos em cinco". Segundo Holston (1993, p. 92), Brasília foi idealizada como "modelo, uma imagem construída, não a partir das condições existentes, mas do futuro do país", no entendimento do autor, a cidade é idealizada a partir da própria expressão do "futurismo", estando associada a um projeto nacional-desenvolvimentista.

Neste sentido, é possível relacionar a construção de Brasília com o que Morin (1984, p. 345) explicitou em sua análise sobre o mito do desenvolvimento, ao afirmar que o termo desenvolvimento se tornou uma palavra-chave para descrever "solução" e "progresso", se projetando como a única saída para a humanidade. "(...) é uma palavra-chave na qual se encontram todas as vulgatas ideológicas-políticas dos decênios 50 e 60”, expõe o autor ao expressar que esta noção era "obscura, incerta, mitológica, pobre".

A construção de Brasília estava baseada em um mito de desenvolvimento, visto que se idealizava alcançar o patamar de país desenvolvido, além de estimular o desenvolvimento econômico da nação a partir da concepção de que a nova capital iria gerar "progresso" econômico da região do Centro-Oeste. Neste 
sentido, o Cerrado, marcado pelo "atraso" e pela inexistência de grandes ações efetivas do Estado, alcançaria o seu próprio "desenvolvimento" com a construção da Capital Federal. Furtado (1974), ao abordar o mito do desenvolvimento, faz duras críticas ao questionar a ideia de que um país subdesenvolvido só poderia desenvolver seguindo o modelo estabelecido pelos países ricos, os chamados desenvolvidos, visto que nesta noção de desenvolvimento se desviaria a atenção para as necessidades básicas da população, como saúde e educação, onde deveriam se direcionar os olhares do Estado, pois de acordo com o autor o desenvolvimento de uma nação só será atingido mediante o atendimento das necessidades básicas da população.

Na visão de Almino (2007, p. 300), Brasília é:

Imagem forjada pelo mito e também pela história de uma ideia, que se conclui com a execução do seu projeto modernista. Para dizer de outra forma, aquela cidade sem história é rica em carga simbólica. E o que Brasília simboliza? A democracia. A racionalidade. A nação. A integração e o desenvolvimento. A aspiração de igualdade. $O$ moderno. $O$ futuro. $E$ também, claro, o poder, a alienação, o encastelamento, a corrupção, o autoritarismo, o misticismo e a irracionalidade.

Para Oliveira (2008), o projeto modernista de Brasília se configurou com uma tentativa de ruptura com o passado atrasado da sociedade brasileira, a fim de alcançar uma inversão desenvolvimentista, ou nas palavras de Juscelino Jubitscheck apud Holston (1993, p. 92): "uma metrópole com características diferentes, que ignorasse a realidade contemporânea e se voltasse, com todos os seus elementos constitutivos para o futuro". De acordo com Alves (2005), a perspectiva modernista, presente na idealização de Brasília, é uma das referências na busca da identidade nacional que marcou a história do pensamento brasileiro do século passado. Este período foi marcado por um "utopismo", em que Brasília materializa, segundo Silva (1997, p.67) apud Alves (2005, p. 125), em "uma época em que a identidade era fornecida pelo sonho, ao mesmo tempo em que o sonho era a própria identidade".

Assim, a cidade foi construída como "símbolo da ideologia nacional capitalista", almejando desenvolvimento econômico e progressista para o país, "na qual 
não haveria pobreza e habitações precárias" (ALVES, 2005, p. 130). Já Barroso (2008, p. 22) entende que a cidade foi construída sendo ela mesma a "própria imagem de futuro", tendo a intenção de "brotar o novo, fazer brotar uma sociedade moderna enraizada na racionalidade modernizadora", oferecendo ao Brasil a condição de país desenvolvido. Para Duarte (2009, p. 35), a cidade nasceu como "prova da criatividade humana", sendo vista pelo autor, "como exemplo de uma aventura moderna na periferia capitalista". Para Ortiz (1996) apud Froehlich (1999), a identificação do capitalismo com a modernidade se faz via nacionalidade, pois a Revolução Industrial superou o localismo instalado pelo feudalismo, assim a nação se afirmou como o espaço da modernidade, sobrepondo em relação às identidades locais.

Barroso (2008), em tese que analisou as controvérsias da cidade modernista, expõe que desde sua idealização havia pretensões de criar cidades-satélites, com o objetivo de abrigar os trabalhadores da construção civil da própria construção da cidade. Segundo o autor, estas cidades-satélites surgem não apenas a partir da demanda habitacional dos migrantes que chegam à Capital Federal, mas do crescimento urbano desordenado de Brasília. Hoje esses lugares estão distantes do centro da cidade, o Plano Piloto, e sem possuir infraestrutura e serviços públicos adequados, concentrando "uma série de problemas comuns do espaço periférico e pauperizado das grandes cidades" (BARROSO, 2008, P. 20).

O mesmo autor aborda que o espaço social de Brasília faz existir um apartheid social, sendo que essa segregação já estava prevista desde a sua concepção, visto que o Plano de Expansão Territorial do Distrito Federal recomendava a construção de cidades-satélites distantes da área próxima do Plano Piloto. Neste contexto, de acordo com Almino (2007), com a expansão das cidades-satélites, o sonho de "progresso" tornava a desigualdade mais acentuada que em qualquer outra grande metrópole brasileira. Assim, criou-se uma cidade marcada pela desigualdade social e pelas diferenças no acesso aos benefícios, criando dois mundos, o dos privilegiados e o dos pobres periféricos. Nas palavras de Holston (1993, p. 35): “considerados em relação com a pobreza das cidades satélites, os 
privilégios do Plano Piloto contradizem as premissas que nortearam a fundação da cidade".

Holston (1993) acentua que, depois da construção de Brasília, não tardou para surgir o seu legado distópico, ou, como referido pelo autor, os "paradoxos da utopia". Já Almino (2007, p. 304) mostra que "com a cidade inaugurada, a utopia de Brasília começava a se confrontar com a Brasília real”. Buscando alcançar o desenvolvimento econômico, o Estado brasileiro reiterou algumas das condições básicas do que ele buscava superar, visto que, segundo Holston (1993), para eliminar a pobreza que a nova cidade não conseguiu superar, o governo foi o grande responsável pela expansão das periferias e de promover desigualdades sociais ao invés de combatê-las. Para Freitag (2003, p.75) a cidade "recebeu em seu espaço urbano todos os problemas da sociedade brasileira sem correções prévias", acrescentando, “que neste verdadeiro 'laboratório social' vejamos a olho nu e convivamos de forma mais direta com os problemas globais da sociedade brasileira como um todo".

Ceilândia, cidade-satélite de Brasília, surgiu em 1971 com a Campanha de Erradicação de Invasões, uma política do Estado brasileiro para combater as invasões de terras no Plano Piloto de Brasília. De acordo com Monteiro (2014), Ceilândia surge perto do aeroporto da cidade, na "cara de todo mundo", constituindo uma favela de migrantes, "oposto, a total negação da proposta da nova capital". Duarte (2009, p. 26) chama a atenção sobre o fato da construção de Brasília, ao expor que os "candangos" que construíram a nova Capital Federal eram movidos pelo "desejo de estar no coração da realidade" e pela "nostalgia do paraíso", porém já na chegada estes migrantes não tiveram direito de usufruir a nova cidade, constituíram "vilas e invasões onde, apesar de toda resistência, reconstruíram seu cotidiano instalando suas famílias em barracos feitos de sacos de cimento e lona, ou mesmo dentro dos acampamentos". Assim, desde sua construção, Brasília ficou marcada pela exclusão e pela desigualdade. 


\section{A CONTRA UTOPIA DE BRASÍLIA EM "BRANCO SAI, PRETO FICA"}

Retornando a análise do filme, a primeira sequencia de "Branco sai, preto fica" destaca o relato do cadeirante Marquin, através da Rádio Comunitária em que é DJ, sobre o episódio, em 1986, onde em uma casa de shows, chamada de Quarentão, foi invadida por policiais. Misturando imagens da festa e o som do rap, os gritos dos policiais, que evidenciaram a partir de poucas palavras a preconceituosa ação na noite da festa, se destacam no relato do personagem: "Puta prum lado e veado pro outro! Tô falando que branco pra fora e preto aqui dentro! Branco sai e preto fica, porra!".

Para contar a história real de maneira ficcional, mas ao mesmo tempo não deixando de lado o peso que a realidade dramática exerce nos personagens, o filme é costurado por sequências de ficção científica. Longe de ser um produto convencional, o filme se vende como um documentário sobre dois homens, Marquin e Sartana, vitimados e amputados em confrontos com a polícia, além de Dimas Cravalanças, um viajante do tempo que vem do ano 2070 para solucionar os problemas do passado. Um híbrido entre documentário e ficção científica, que busca expor o que há de ficção no que chamamos de realidade e o que há de realidade na mais fabulosa ficção.

Um dos elementos fundamentais presentes no filme, no que se refere à distopia, é o fato dos moradores das cidades-satélites só poderem entrar na área do Plano Piloto se tiverem um passaporte especial, sendo passível de abordagem pela polícia do Bem-Estar Social. Assim, a ficção multiplica os mecanismos da segregação social que já existem na cidade. Além disso, o filme utiliza outros elementos da ficção para construir a imagem quem vive às margens da Capital Federal, com o auxílio de avisos sonoros, seja a partir de recados na rádio comunitária ou de carros de som da Polícia do Bem-Estar Social, são emitidos os avisos aos moradores, como o toque de recolher que é tocado toda noite nas regiões periféricas. Entre os avisos estão: "Retirem as crianças das ruas, tenham 
em mãos os documentos" e "a Polícia do Bem-Estar Social informa: retorne ao seu núcleo habitacional, caso não possua passaporte para entrar na cidade".

Esta distopia ilustra, com um pouco de exagero, o apartheid social que os moradores da periferia poderão vivenciar em um futuro, mas também está relacionada com a própria realidade da cidade, como observou Barroso $(2008$, p. 18), ao apontar que a estrutura urbana da cidade estabelece ações conflitosas:

$\mathrm{Na}$ oposição centro e periferia a classe média ergue seus muros de proteção, coloca suas cercas elétricas, cerca bairros, controla edifícios... para se protegerem. Essas estratégias adotadas alteram a paisagem urbana e produzem uma compartimentalização da cidade, onde se explicitam as diferenças, entre o Plano Piloto e as cidades-satélites.

Sobre distopia, Ferreira (2015) aponta que não é adequado tratá-la simplesmente em contraposição ao conceito de utopia. Na visão do autor, distopia caracteriza-se pela "extrapolação negativa do status quo à época de sua funcionalização ficcional", ou seja, não cabe apontar como um conceito relativo a superação, como o conceito de utopia é construído. Na visão do mesmo autor, o pensamento utópico não se limita apenas ao exercício da reflexão e da imaginação, mas assume formas concretas de intervenção e de ação na realidade social, caracterizando o "espírito distópico" como fruto de uma descrença no progresso social, projetado pelo avanço do desenvolvimento científico e tecnológico.

Mesquita (2016), ao analisar o filme, aborda que entre um futuro "ficcional utópico" e um passado real traumático, situa-se o tempo dominante da narrativa em "Branco sai, preto fica": o presente. O autor evidencia que o presente surge especulado pela ficção, redefinindo as características da realidade de Brasília, "de modo a tornar mais nítido o desenho distópico". Com a chegada na história de Dimas Cravalanças, quem vem do ano de 2070, é articulado passado, presente e futuro. Esta articulação busca contrapor a utopia do passado, que moveu a construção da cidade, com a realidade atual, em que negros e pobres estão situados às margens da cidade, e também com a inclusão de um cenário futurista. Na visão de Barroso (2008, p, 22), Brasília "foi definida por uma ideia e, por 
isso, transformou-se numa utopia já que sua projeção visava o futuro e não as contingencias imediatas do presente", assim tornou-ser "uma fabricação artificial da possibilidade de um desenvolvimento natural".

Cravalanças ao viajar do futuro para o presente em um contêiner, embalado com os mesmos estilos músicas da festa de 1986, relata que a viagem foi difícil e o deixou melancólico. Sua nave está constantemente em contato com a nave-mãe, situada em 2070, e que determina as coordenadas para seu plano de intervenção e investigação sobre o acontecido em 1986. Porém, o personagem relata que possui dificuldades para encontrar as provas para processar o Estado. Nesse sentido, o tempo passa e a nave-mãe já está situada em 2073 em um cenário ainda mais distópico, que informa para Cravalanças que a "vanguarda cristã" assumiu o poder e o conservadorismo está avançando rapidamente. Posteriormente, Cravalanças inicia a analise das provas e o contato com as vitimas da ação policial.

A ficção científica também entra no filme a partir do momento em que Marquin e Sartana constroem uma bomba sonora, que possui a intenção de estabelecer uma represália contra os danos causados pelo Estado no episódio da década de 80 , além de ser uma resposta à segregação social em que os personagens estão imersos. Sem usar armas letais, o longa-metragem se constrói com um filme contraterrorismo, em que a própria cultura popular em forma de música é a arma, visto que a bomba é uma arma com munição musical. A intenção com a bomba é enviar a cultura popular periférica em forma de música para a Capital Federal, uma vez que fica explícito que a periferia está afastada do centro político do país. Para isso, os dois personagens passam boa parte do filme gravando o som de artistas da Ceilândia para incluir na bomba. A cena final do filme é a bomba atingindo os famosos monumentos de Brasília ao som do funk.

Para Survin apud Suppia (2007, p. 419), "a ficção científica se distingue pela dominância narrativa ou hegemonia de um novum (novidade, inovação) ficcional, validado pela lógica cognitiva". Assim, o novum provoca uma desconstrução com a realidade conhecida, caracterizado pelo autor como "qualquer aparelho, 
engenhoca, técnica, fenômeno, localidade espaço-temporal, agente(s) ou personagem(ns) que venha(m) a introduzir algo novo ou desconhecido no ambiente empírico". Porém, as novidades construídas a partir da ficção científica não estão completamente isoladas da realidade como se pensa, elas são "(...) uma maneira de se obter um melhor ponto de vista para a compreensão das relações humanas ao redor do autor". Ou na visão de Ranciere (2010, p. 97):

A fiç̧ão não é criação de um mundo imaginário oposto ao mundo real. É antes o trabalho que opera dissentimentos, que modifica os modos de apresentação sensível e as formas de enunciação, alterando os quadros, as escalas ou os ritmos, construindo relações novas entre a aparência e a realidade, o singular e o comum, o visível e sua significação. Este trabalho muda as coordenadas do representável; altera a nossa percepção dos acontecimentos sensíveis, a nossa maneira de os pôr em relação com os sujeitos, o modo segundo o qual o nosso mundo está povoado de acontecimentos e de figuras.

É importante salientar que o filme, mesmo incluindo elementos futuristas e de ficção científica, aparenta um ar de pobreza tecnológica de forma intencional. Fios soltos e remendados com fitas isolantes e engenhocas improvisadas pelos personagens para viajar no tempo e lançar bombas, constroem a realidade estética da vida cultural periférica. Além disso, a nave na qual Cravalanças viaja no tempo não passa de um contêiner de lata que sacode incansavelmente. Neste contexto, podemos entender que em "Branco sai, preto fica" existe uma tentativa de contrapor a precariedade estética das parafernálias tecnológicas com à crença no modernismo e no progresso fundadores de cidade de Brasília. Assim, as criações tecnológicas presentes no filme não passam de gambiarras e engenhocas, fazendo um contraponto com a utopia modernista e desenvolvimentista que esteve presente na construção da Capital Federal.

Embora a pouca tradição do gênero de ficção científica no Brasil, o filme do diretor Adirley Queirós não deixou de ser premiado em diversos festivais de cinema no país e no exterior, sendo considerado por muitos críticos como o meIhor filme brasileiro do ano de 2014. Ao debater o tema da desigualdade social e racial, "Branco sai, preto fica" torna-se um filme potente e necessário para compreender a realidade social brasileira. 


\section{CONCLUSÃO}

Com a intenção de finalizar a presente discussão, recupero ideias sobre desenvolvimento local com a intenção de contrapor com a utopia desenvolvimentista presente na criação de Brasília. Para o referido Souza $(1996,1997)$, desenvolvimento não é sinônimo, e muito menos se esgota na ideia de desenvolvimento econômico, visto que a ideia hegemônica de desenvolvimento econômico está, exclusivamente, atrelada à manutenção de benefícios e privilégios para determinados grupos sociais e na perpetuação de um modelo capitalista. $O$ referido autor, contrapondo esta noção, apresenta que o conteúdo do desenvolvimento deve estar associado a cada universo cultural e social, evidenciando a ideia de espaço social como uma categoria de análise do desenvolvimento.

Arocena (2001) colabora com a discussão apresentando que o desenvolvimento local só será possível através de um componente de identidade forte que estimule o potencial de iniciativas de um grupo. Nesse sentido, o autor destaca a importância do território para criar o sentimento de pertencimento na comunidade, visto que assim as pessoas se enxergam enquanto integrantes e protagonizam a busca pela melhoria do local em que vivem.

O espaço é visto para Souza (1997) como fonte de poder, de disputa e de territorialização, devendo ser pensado de forma multifacetada no que se refere ao desenvolvimento. Neste contexto, sugere para não pensar o desenvolvimento de modo fechado, devendo este ser proposto acompanhado de uma descentralização teórica e, consequentemente, extraindo um princípio norteador. Para isso, o autor resgata a ideia de autonomia de Catoriadis para nortear sua visão de desenvolvimento, entendido por ele como o melhor princípio para entender o desenvolvimento. Para Souza (1996), a ideia de autonomia assume um papel ético e político na construção das concepções de desenvolvimento.

Assim, para pensar no desenvolvimento do Brasil e de Brasília é necessário incluir a dimensão do espaço e não apenas a do tempo. Um desenvolvimento que não esteja apenas associado a um futuro inimaginável, uma utopia, mas que 
inclua o espaço, o território e as "suas Ceilândias" em seu contexto de análise e execução. Em outras palavras: um desenvolvimento que não se "abstraia com futuro" na busca da modernidade e do progresso, mas que esteja "atento com o presente", norteado pela autonomia dos sujeitos e aprimorando as condições do viver em sociedade da e na periferia.

\section{REFERENCIAS}

ALMINO, J. O mito de Brasília e a literatura. Revista ESTUDOS AVANÇADOS, 21 (59), 2007.

ALVES, Lara Moreira. "A construção de Brasília: uma contradição entre utopia e realidade". Revista de História da Arte e Arquitetura. Campinas: Programa de Pós-Graduação do Departamento de História, 2005.

BARROSO, E. Brasília: As controvérsias da Utopia Modernista na Cidade das Palavras. Tese apresentada ao Programa de Pós-Graduação em Sociologia, UnB. 2008.

DUARTE, L. A Construção de Brasília como experiência moderna na periferia capitalista: a aventura. Revista UFG. Junho 2009. Ano XI nº 6.

FERREIRA, V. Utopia e distopias no século XXI e pós-modernismo. Revista do Programa de PósGraduação em estudos de Linguagens - UFMS. n. 38, v. 19, 2015.

FREITAG, B. A cidade dos homens. Editora Tempo Brasileiro: Rio de Janeiro, 2003.

FROEHLICH, J. O 'local' na atribuição de sentido ao desenvolvimento. Revista Textos CPDA. Rio de Janeiro: CPDA-UFRRJ, 1999.

FURTADO, C. O mito do desenvolvimento econômico. Rio de Janeiro: Paz e Terra, 1974.

HOLSTON, J. A cidade modernista: uma crítica de Brasília e sua utopia. São Paulo: Cia das Letras, 1993. 
MESQUITA, C. Memória contra utopia: Branco sai preto fica (Adirley Queirós, 2014). In: Anais do Congresso da Associação Nacional dos Programas de Pós-Graduação em Comunicação. São Paulo: 2016.

MORIN, E. Sociologia. Lisboa: Publicações Europa-Améria, 1984.

OLIVEIRA, R. Brasília e o paradigma modernista: planejamento urbano do moderno atraso. Dissertação apresentada à Faculdade de Arquitetura e Urbanismo, USP. 2008.

SOUZA, M. A teorização sobre desenvolvimento em uma época de fadiga teórica, ou: sobre a

necessidade de uma "teoria aberta" do desenvolvimento sócio-espacial. Revista Território, n. 1, v. 1. 1996.

SOUZA, M. Algumas notas sobre a importância do espaço para o desenvolvimento social. Revista Território, n. 3, v. 2, 1997.

SUPPIA, A. Limite de alerta! Ficção científica em atmosfera rarefeita: uma introdução ao estudo da FC no cinema brasileiro e em algumas cinematografias off-Hollywood. Tese apresentada ao Programa de Pós-Graduação em Multimeios, Unicamp. 2007. 


\section{doil $10.48209 / 978-65-89949-D 2-4$}

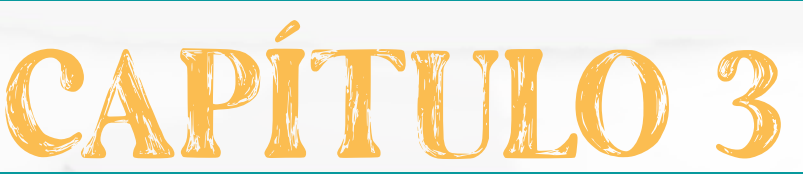

\section{GAMIFICAÇÃO ALIADA AS PRÁTICAS PEDAGÓGICAS: DIÁLOGOS POSSÍVEIS \\ Amanda Marinho Rodrigues}




\section{INTRODUÇÃO}

O termo gamificação compreende a aplicação de elementos de jogos em atividades de não jogos.( Ulbricht; Fadel, 2014, p. 06). Assim, como afirma Burke (2015) origem do termo vêm de um programador e inventor britânico, Nick Pelling, em 2003 . A ideia de Pelling era que conceitos e mecânicas do mundo dos games poderiam ser aplicadas a contextos do mundo real e motivar as pessoas a resolverem problemas.

Nesse sentido, várias abordagens apresentaram- se como mediadores do processo de construção do conhecimento e dos conceitos científicos. Uma delas que se firmou na educação a partir da década passada é "denominada como aprendizagem baseada em games, que envolve a integração dos videogames, educacionais ou mesmo comerciais, ao processo de ensino e aprendizagem". (Mattar e Nesteriuk, 2016, p.92). Surge, então a ideia do uso das características dos jogos como uma das possíveis ferramentas para auxiliar a educação, principalmente quando se objetiva proporcionar motivação e engajamento. Kapp (2012) em seu Livro "Gamification of Learning and Instruction", define como gamificação o uso das mecânicas baseadas em jogos, da sua estética e lógica para engajar as pessoas, motivar ações, promover a aprendizagem e resolver problemas.

Zichermann e Cunningham (2011) corroboram ao afirmar que os mecanismos encontrados em jogos funcionam como um motor motivacional do indivíduo, contribuindo para o engajamento deste nos mais variados aspectos e ambientes. Para os autores, o engajamento é definido por tempos e espaços, tendo como objetivo principal o engajamento, desafiando os indivíduos a resolverem os mais diferentes problemas a ele propostos de uma forma criativa e investigativa e permitindo que eles se apropriem de suas próprias percepções para encontrar o melhor caminho.

Diante das possibilidades inerentes ao uso da games no âmbito educacional, formulou-se a seguinte pergunta que permeia este trabalho: Quais os benefí- 
cios e possibilidades da gamificação para o processo de ensino e aprendizagem? Questionamentos como esses são recorrentes no cotidiano de professores. Por este motivo este estudo se justifica, pois buscou-se analisar as contribuições do uso dos elementos dos jogos como um reformulador no auxílio ao aprendizado, identificando seu alto poder motivacional e atrativo, diferentemente do que muitos alunos pensam sobre a sala de aula. Baseado nesta questão-problema, o objetivo deste estudo foi analisar como a gamificação, auxiliadas por plataformas de jogos digitais, vêm impactando no processo de ensino e aprendizagem, identificando seus principais beneficios, combinadas com suas várias possibilidades de aplicabilidade.

\section{REFERENCIAL TEÓRICO}

Para explicitar jogo, Huizinga (2007) enxerga-o como elemento da cultura humana, trazendo essa visão até o seu extremo, onde jogo é anterior à cultura, visto que esta pressupõe a existência da sociedade humana. O autor acrescenta: "A existência do jogo não está ligada a qualquer grau determinado de civilização ou a qualquer concepção do universo" (HUIZINGA, 2007, p.32).

Pode-se definir jogo, como um sistema em que jogadores se envolvem em um conflito artificial, regido por regras e resultados quantificáveis. (SALEN; ZIMMERMAN, 2003, p.96). Complementando os autores, Jane Mcgonigal (2011) apud Sena(2017) expõem quatro características comuns que fazem parte de todo jogo e o definem: meta, regras, sistema de feedback e participação voluntária. A saber,

1. meta é o resultado específico que os jogadores vão trabalhar para conseguir. Ela foca a atenção e orienta continuamente a participação deles ao longo do jogo. A meta propicia um senso de objetivo.

2. As regras impõem imitações em como os jogadores podem atingir a meta. Removendo ou limitando as maneiras óbvias, as regras estimulam os jogadores a explorar possibilidades anteriormente desconhecidas para atingir o objetivo final. Elas liberam a criatividade e estimulam o pensamento estratégico. 
3. O sistema de feedback diz aos jogadores o quão perto eles estão de atingir as metas. O sistema pode assumir a forma de pontos, níveis, placar ou barra de progresso.

4. Participação Voluntária exige que cada um dos jogadores aceite, consciente e voluntariamente, a meta, as regras e o feedback. (MCGONIGAL, 2011 APUD SENA, 2017 , P. 16)

Apesar de utilizar de estratégias e de um planejamento semelhante, um sistema gamificado não é a mesma coisa que um jogo. Pois, como afirma Montonaro (2018) são formas de se trabalhar diferentes e que inclusive não se tornam excludentes, já que é possível se apropriar de um jogo como parte de uma estrutura gamificada. Em outras palavras,

A gamificação não implica em criar um game que aborde o problema, recriando a situação dentro de um mundo virtual, mas sim em usar as mesmas estratégias, métodos e pensamentos utilizados para resolver aqueles problemas nos mundos virtuais em situações do mundo real. (FARDO, 2016, APUD MONTONARO, 2018, P.03).

Para tanto, é fundamental compreender não apenas o conceitos, mas a mecânica, dinâmica,estilo e pensamento da gamificação em contextos educacionais. Burke (2015) explicita que o termo gamificação alcançou massa critica necessária na segunda metade do ano de 2010, porém a palavra já existia há mais tempo. Em 2012 o consultor Britânico Nick Pelling, criou o termo para descrever a criação de interfaces cuja aparência era similar a jogos para tornar transações eletrônicas mais rápidas e confortáveis para o cliente. E complementa "a gamificação é responsável por engajar e motivar pensamentos e aprimorar a vida das pessoas" ( BURKE, 2015, P. 13).

Isso significa dizer que um ensino gamificado não é simplesmente adotar sistemas e todo tipo de atividade, usada para desenvolver habilidades, alterar comportame de pontuação, classificação e de conquistas, mas principalmente possibilitar práticas que envolvam a resolução de problemas, engajamento, resiliência, entre outros. Portanto, faz-se necessária sua inserção na educação. 


\section{METODOLOGIA}

Este estudo leva em conta os processos metodológicos de um estudo de caso. Quanto ao objetivo, será uma pesquisa exploratória e descritiva. Exploratória, pois tem a finalidade de ampliar o conhecimento a respeito de um determinado fenômeno. Segundo Zanella (2013) esse tipo de pesquisa aparentemente simples, explora a realidade buscando maior conhecimento para depois planejar uma pesquisa descritiva.

O cenário foi a Escola Municipal de Ensino Fundamental II Osmar de Sá Ponte, localizada na cidade de Sobral-CE. Os sujeitos da pesquisa foram 61 alunos que cursam do $7^{\circ}$ ao $9^{\circ}$ ano do Ensino Fundamental II.

A coleta de dados foi realizada por meio de observações de aulas, que aconteceram dos meses de fevereiro a junho de 2021, com uma periodiciadade quinzenal, sendo intercaladas as disciplinas observadas. Também foram usadas para coletas, um questionário com questões abertas e fechadas acerca das informações iniciais sobre o perfil dos participantes, contribuições e percepções acerca da gamificação, fazendo um levantamento das plataformas de jogos digitais que eles mais avaliaram como satisfatorias, usadas nas aulas, durante o periodo de 2021.1. Para a elaboração do questionário foi usado o aplicativo Google Forms, aplicado no dia 21 de junho de 2021. Os alunos foram convidados a responderem e logo após enviar para o pesquisador. Logo após a coleta de dados, realizamos a análise dos dados e resultados.

Foram usados análises de conteúdos e de estatísticas descritivas no Google Forms. Bardin (2011) indica que a utilização da análise. 


\section{RESULTADOS E DISCUSSÃO}

Em relação à amostra foram identificados entre os respondentes os seguintes dados:

\section{Perfil dos Alunos}

\section{Gráfico 1}

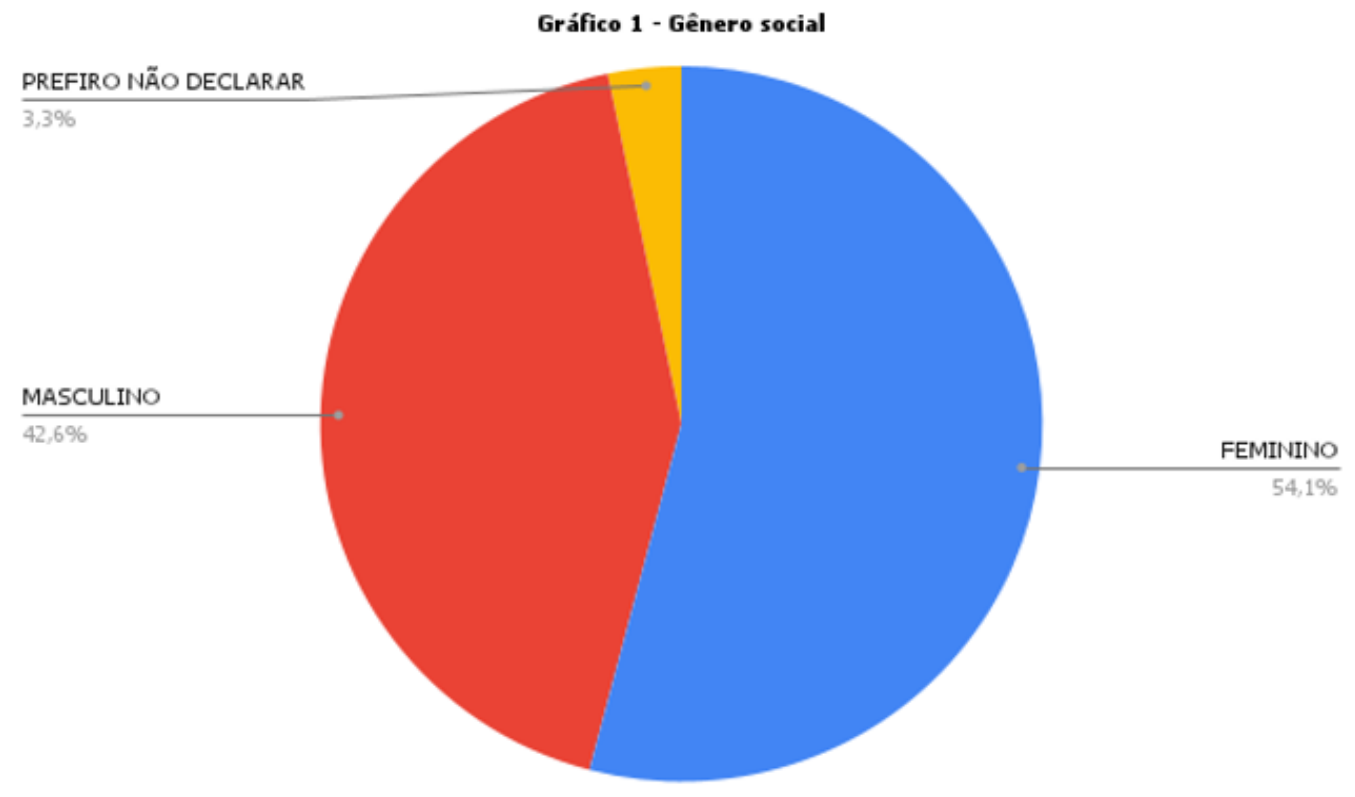

Fonte: autor

\section{Gráfico 2}

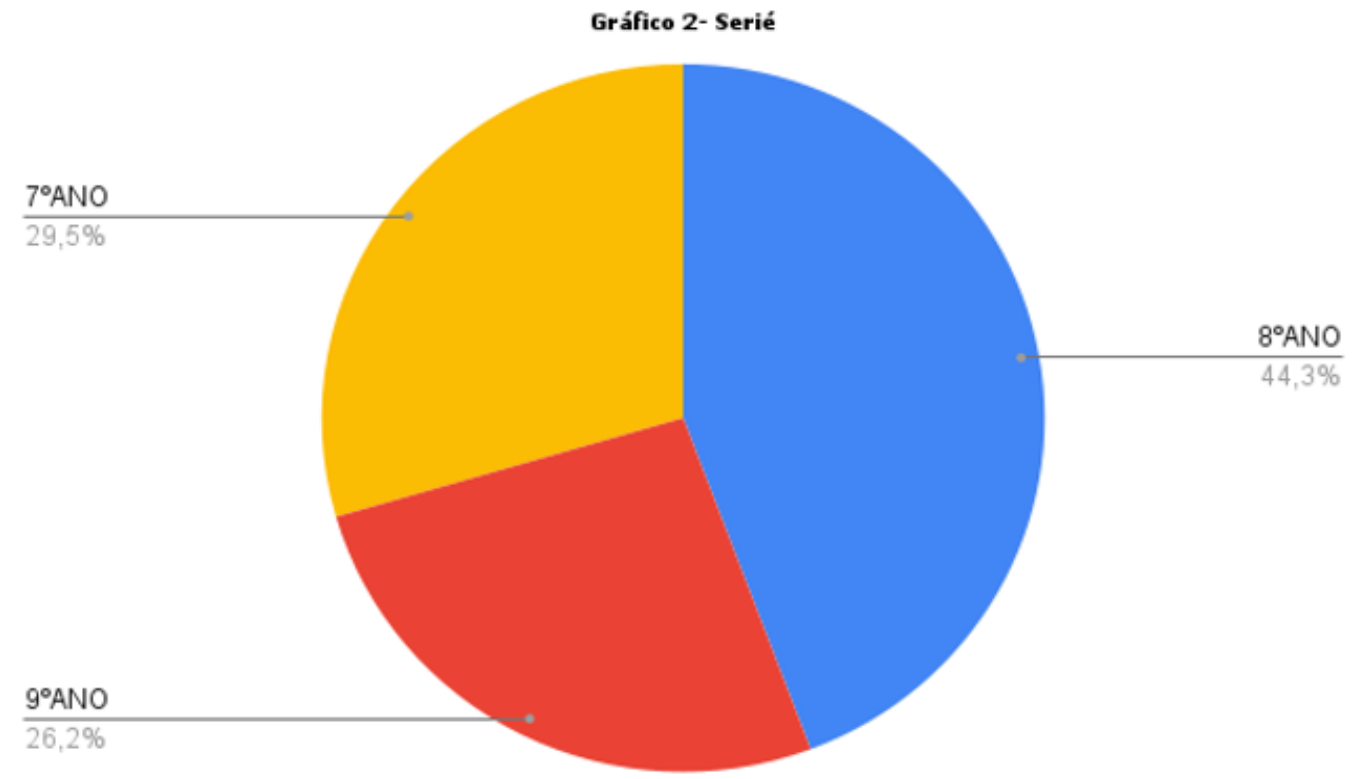

Fonte: autor 
Em relação ao sexo, $42,6 \%$ são do sexo masculino e $54,1 \%$ feminino. Destes, $44,3 \%$ cursam o $8^{\circ}$ ano , $29,5 \%$ o $7^{\circ}$ ano e $26,2 \%$ o $9^{\circ}$ ano. Isso mostra que as seriés finais, como o $9^{\circ}$ ano, estão mais distantes da escola, o que é preocupante, pois estes estarão ingressando no ensino médio e portanto, deveriam estar mais presentes nas aulas.

\section{Acessibilidade dos alunos}

\section{Gráfico 3}

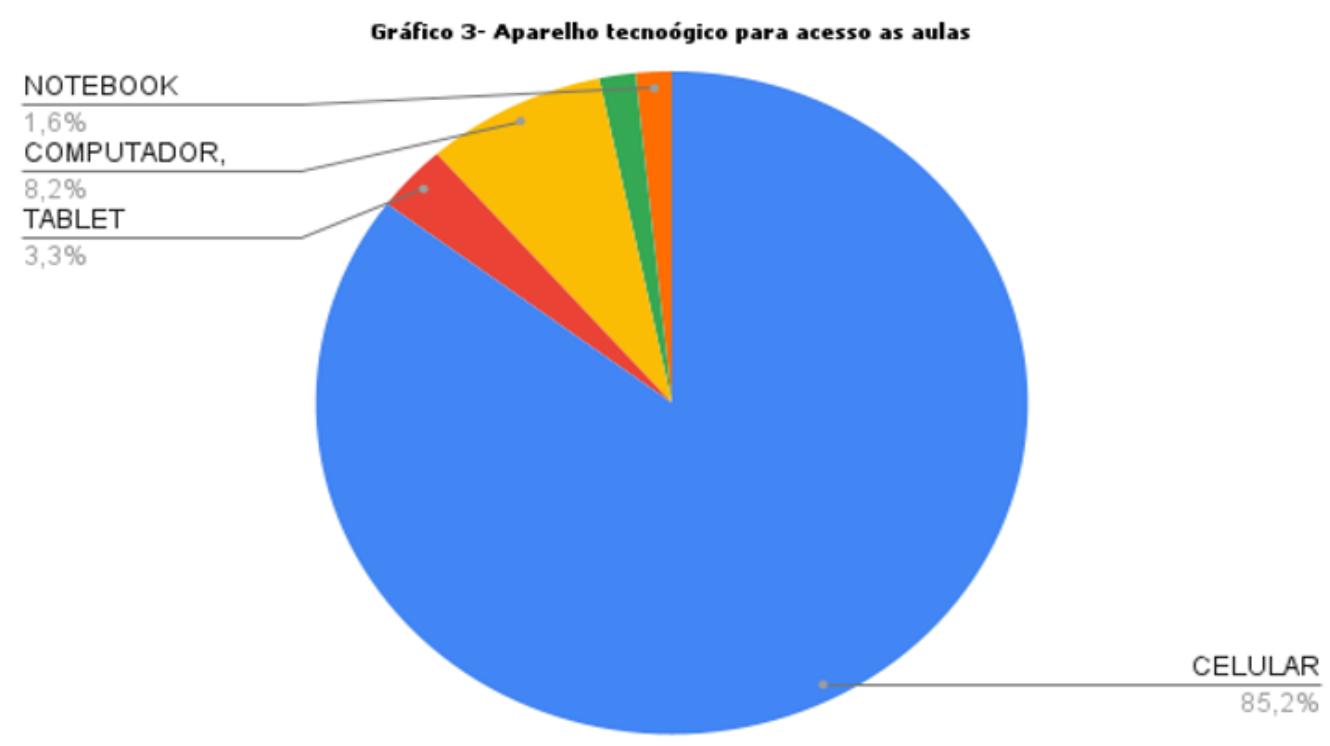

Fonte: autor

\section{Gráfico 4}

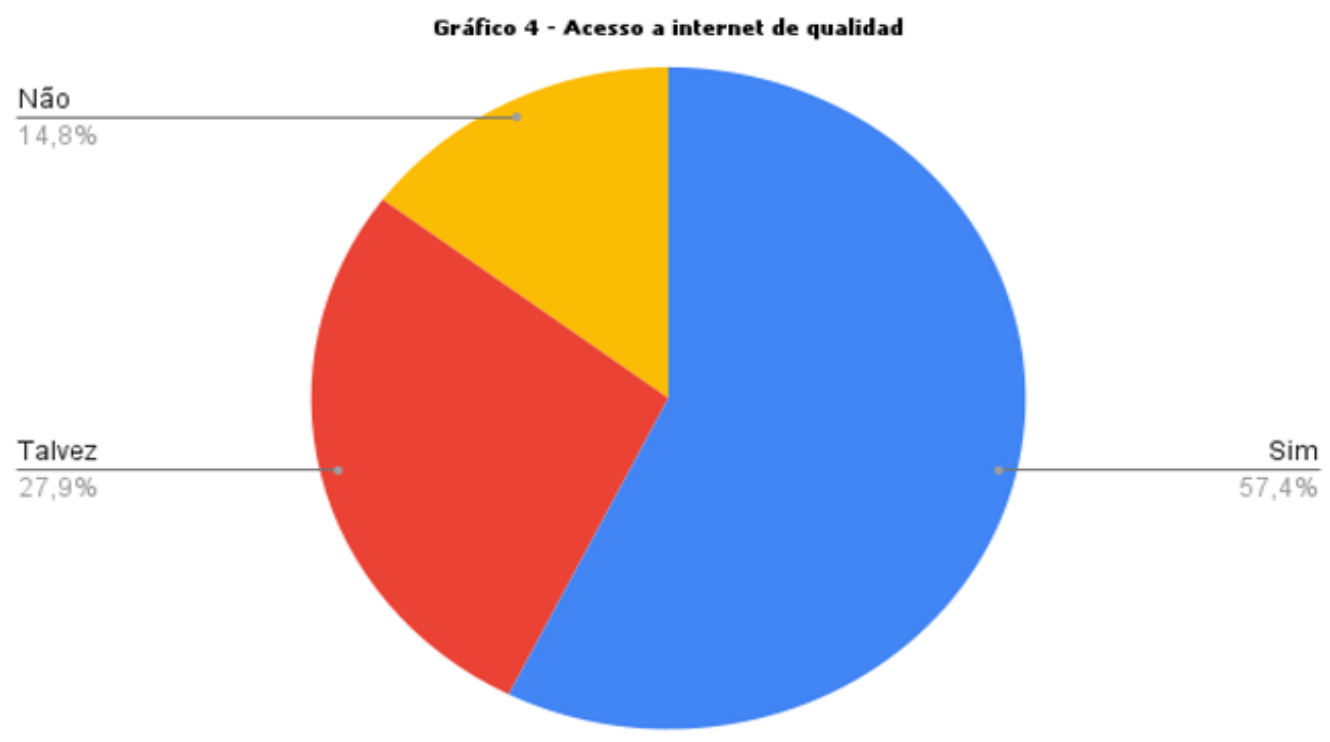

Fonte: autor 
Quando perguntados sobre a acessibilidade dos alunos aos equipamentos tecnológicos, descobrimos que a grande maioria, 95,1\%, têm apenas o celular para acesso e manuseio das atividades e que apenas $57,4 \%$ têm acesso a internet de qualidade. Esses dados são importantes, pois neles identificamos as principais dificuldades no que diz respeito a participação dos alunos nas aulas. Nesse contexto, consideramos que os fatores que possibilitam a melhoria na qualidade do processo de ensino e aprendizagem vão para além do preparo administrativo e pedagógico das instituições de ensino. Diz respeito também as desigualdades no acesso à equipamentos tecnológicos e internet de qualidade, que têm impedido que o ensino on-line e o uso das plataformas digitais interativas sejam ofertados de maneira equitativa aos estudantes. Portanto, faz-se necessário a formulação de políticas públicas para minimizar tais desigualdades e firmar bases para concretização da inclusão digital, a fim de reformular o sistema de ensino daqui em diante para que haja sucesso na aprendizagem dos alunos

\section{Grau de satisfação}

\section{Gráfico 5}

Gráfico 5 - Grau de satisfação dos alunos

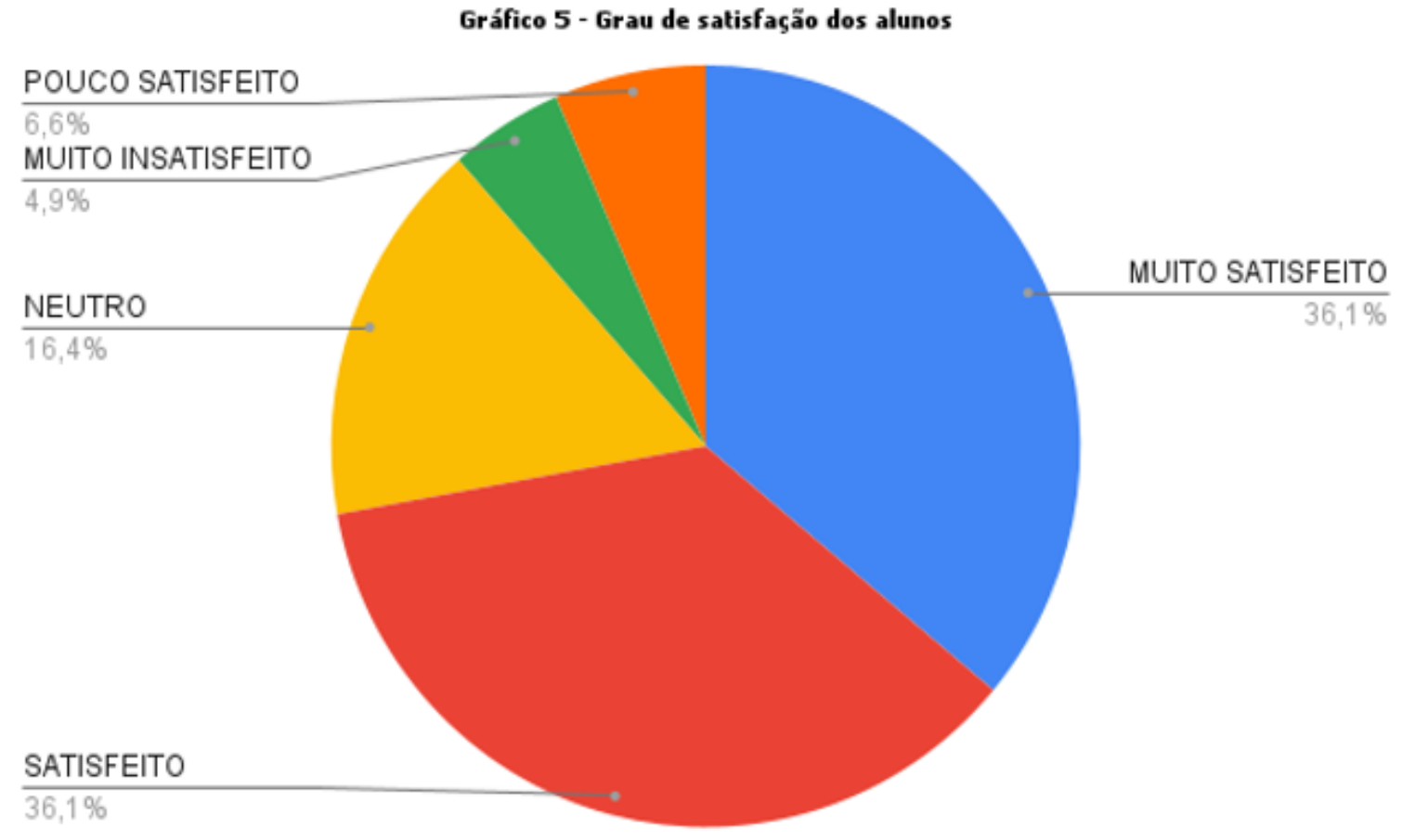

Fonte: autor 
No segundo bloco de perguntas, buscamos investigar o grau de satisfação dos discentes em relação as aulas, onde a gamificação faz parte da prática docente, quais as principais plataformas de jogos digitais usadas pelos professores que impactaram nas aulas de forma positiva, bem como os principais benefícios da gamificação durante as aulas. Nesse estudo, 36,1\% consideram-se satisifeitos, $36,1 \%$ muito satisfeitos e $16,4 \%$ neutros. Portanto, constatamos que essa estratégia metodológica contribui de forma significativa para a motivação e engajamento dos alunos. Percebemos que apesar da satisfação, há um ponto a ser observado, no que diz respeito as desigualdades no acesso a equipamentos tecnológicos, o que têm impedido que o ensino remoto interativo seja ofertado de maneira equitativa aos estudantes.

\section{Plataformas de jogos digitais usadas com maior aceitação dos alunos}

As principais plataformas de jogos digitais usadas pelos professores que impactaram nas aulas de forma positiva,segundo os alunos foram: Kathoot, Word Wall e Padlet. Cada um com suas particularidades. Nas observações de aulas, podemos perceber a aplicabilidade desses jogos. O Kathoot, muito utilizado pelos professores de Ciências e Língua Portuguesa, é uma plataforma de aprendizado baseada em jogos, como são testes de múltiplas escolhas, desenvolve muitas habilidades, uma delas é o engajamento e motivação para aprender. $O$ Word Wall, usado muito pelos professores de Língua Portuguesa, Matemática, Educação Física e Artes é muito aceito pelos alunos devido sua facilidade de aplicabilidade, onde os professores podem criar seus próprios recursos didáticos e personalizados, em modelo gamificado. E o Padlet usado principalmente nas aulas de Ciência e Língua Portuguesa chamam atenção por ser uma ferramenta digital para construção de murais virtuais colaborativos, a interação é em tempo real, o que permite criar eventos como feiras de Ciências ou apresentação de seminários. 


\section{Principais benefícios da gamificação durante as aulas}

Nas questões abertas, foram perguntados quais principais benefícios da gamificação durante as aulas, os alunos responderam:

"Porque você além de aprender, você ainda se diverte e deixa a aula mais dinâmica" ( ALUNO 1);

"As aulas ficam mais divertidas, e a gente até aprende melhor".( ALUNO 2)

"Impulsionar o engajamento e a motivação do aluno, facilidade na transmissão do conhecimento e absorção e retenção de conteúdo".(ALUNO 3) e

"Ajuda a aula a ficar mais participativa e as vezes muito competitiva e legal". (ALUNO 4).

Portanto, percebe-se nas falas dos alunos que, essas metodologias vêm a somar de forma significativa a prática docente e ajuda os discentes a valorizar o poder criativo, potencializar suas qualidades e desafia-se para a superação das dificuldade

\section{CONCLUSÃO}

De acordo com os resultados obtidos neste estudo, intui-se que a gamificação, por meio das plataformas de jogos digitais, incentivam a aprendizagem colaborativa dos alunos e os motiva na realização das atividades. Consiste, portanto, em um recurso didático fecundo para a construção cooperativa de conhecimentos científicos no ambiente educacional.

\section{REFERENCIAS}

BARDIN, L. Análise de conteúdo. São Paulo: Edições 70, 2011.

BURKE, B. Gamificar: como a gamificação motiva as pessoas a fazerem coisas extraordinárias. São Paulo: DVS Editora,2015. 
HUIZINGA, J. Homo ludens:o jogo como elemento da cultura. 5edição. São Paulo: Perspectiva, 2007.

KAPP, K. M.The Gamification of Learning and Instruction: Game - Based Methods and Strategies for Training and Education. Washington: Pfeiffer \& Company, 2012.

MATTAR, J and NESTERIUK, S. Estratégias do design de games que podem ser incorporadas à educação a distância. Revista Iberoamericana de Educación a Distancia, v. 19, n. 2, pp. 91-106, 2016.

MONTANARO,P. R. Gamificação para a Educação. São Carlos: Editora Pixel, 2018.

PERRENOUD, P. Dez novas competências para ensinar. Porto Alegre: Artmed, 2000.

SALEN, K and ZIMMERMAN, E. Rules of play: Game design fundamentals. Cambridge, MA: MIT Press, 2003.

SENA, V. O. Gamificação em biblioteca escolar. 2017. 46 f.Monografia (Graduação em Biblioteconomia) - Universidade Federal do Rio Grande do Norte.Centro de Ciências Sociais Aplicadas. Departamento de Ciência da Informação. Natal, RN, 2017.

ULBRICHT, Vania Ribas; FADEL, Luciane Maria. Educação gamificada: valorizando os aspectos sociais. In:Luciane Maria Fadel et al (Org.). Gamificação na educação. São Paulo: Pimenta Cultural, 2014.

ZANELLA, L. C. H.. Metodologia de pesquisa. 2. ed. Florianópolis: Departamento de Ciências da Administração/UFSC, 2013.

ZICHERMANN, G. and CUNNINGHAM, C. Gamification by Design:Implementing Game Mechanics in Web and Mobile Apps. +Sebastopol, CA: O'Reilly Media, Inc. 2011. 


\section{dol 10.48209/978-65-89949-D2-5}

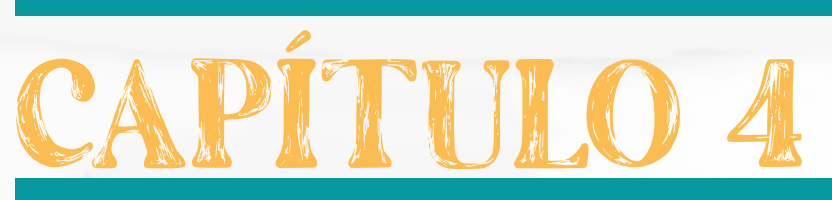

\section{FORMAÇÃO CONTINUADA}

\section{DE PROFESSORES DE}

EDUCAÇÃO FÍSICA PARA

O ENSINO DA SAÚDE:

GAMIFICAÇÃO COMO

RECURSO PEDAGÓGICO 


\section{INTRODUÇÃO}

Em meados de março de 2020, o Brasil passou por um momento de grande impacto em todos os âmbitos, devido a pandemia de Covid-19¹. Segundo a Organização das Nações Unidas para a Educação, a Ciência e a Cultura UNESCO (2020), desde que a pandemia começou, centros educacionais foram fechados totalmente ou parcialmente. Dentre as áreas mais afetadas, a Educação e a Saúde encontraram-se alvos de discussões e debates. Dessa forma, desenhou-se um grande desafio para a prática docente: "planejar, elaborar e propor metodologias que façam uso de ferramentas educacionais para nortear de forma eficiente o aluno no processo de sua aprendizagem".( SALES; SANTOS, 2016. p. 21).

Nesse cenário, várias abordagens apresentaram- se como mediadores do processo de construção do conhecimento e dos conceitos científicos interdisciplinares. Uma delas que se firmou na educação a partir da década passada é "denominada como aprendizagem baseada em games, que envolve a integração dos videogames, educacionais ou mesmo comerciais, ao processo de ensino e aprendizagem". (MATTAR E NESTERIUK, 2016, p.92).

Inseridos nestes processos de mudanças ocorridas nas últimas décadas e consequentemente alimentados por esta grave crise, vivemos um tempo de transformação digital. Para tanto, foi preciso pensar na formação do professor frente a esses novos desafios. Pois como pontua Ferreira et al é preciso superar a concepção de que não basta somente o domínio tecnológico ou teórico, sendo "necessária uma integração entre ambos, ou seja, aliar a experiência no contexto on-line com a teoria e a prática em sala de aula".( FERREIRA et al. 2020, p. 171).

No que tange a relação da Educação Física com o uso dessas ferramentas

1 Segundo a Organização Mundial de Saúde( OMS) a COVID- 19 é uma doença infecciosa causada pelo novo coronavírus ( SARS-CoV -2) e tem como principais sintomas febre, cansaço e tosse seca. 
pode-se dizer que apesar de não ser algo "novo", ganhou maior popularidade devido ao modelo de aulas remotas. Já sua relação com o ensino da saúde não é algo recente, desde a origem da EF sempre estiveram associadas, porém, em momentos distintos da história, caracterizados por diversas tendências e abordagens. Já na década de 1930, a abordagem higienista, segundo Darido (2003) trazia como preocupação central os hábitos de higiene e saúde, valorizando o desenvolvimento do físico e da moral, a partir do exercício. A mesma autora explica que, na década de 1990, ocorreu a existência de outra abordagem voltada para as questões da saúde, não apenas repetindo os conceitos da tendência Higienista, mas ampliando a discussão. Esta nova abordagem, que fez parte dos Movimentos Renovadores da Educação Física, buscava ampliar a forma de conceber a saúde na escola, e foi denominada, por Darido e Rangel (2005), de Saúde Renovada

Para Ghiraldelli Júnior (1998), a Educação Física, em todas as suas tendências, é encarada como atividade capaz de assegurar a aquisição e a manutenção do status de saúde individual. Ferreira et al (2020) corrobora quando afirma ser importante o conhecimento entre as relações ambientais e os diversos contextos relacionados à saúde de crianças e adolescentes, haja vista ser um período de transição caracterizada pelo aumento crescente das expectativas acadêmicas, mudanças nas relações sociais com familiares e colegas e as mudanças físicas e emocionais associadas à maturação.

Dessa forma, este projeto teve como sujeitos da pesquisa os professores que lecionam a disciplina de EF e participam do Programa de Formação Continuada de Educação Física da rede municipal de Sobral-Ceará. Os critérios de inclusão dos sujeitos na pesquisa foram: (a) fazer parte do quadro de professores da rede pública de ensino da cidade de Sobral; (b) lecionarem a disciplina de EF ; (c) participarem de formações continuadas ofertadas pela Escola Escola de Formação Permanente do Magistério e Gestão Educacional- ESFAPEGE. O 
objeto a ser estudado foi a formação continuada dos professores de EF e as relações estabelecidas entre gamificação e o ensino para a saúde.

Para tanto, elencamos alguns objetivos que foram propostas a pesquisa, a saber:

\section{OBJETIVOS}

\section{Geral}

- Investigar quais as contribuições do uso de plataformas digitais de jogos educativos na perspectiva da aplicabilidade e inserção do conteúdo saúde e suas implicações para a formação continuada de professores de Educação Física da rede municipal de Sobral- CE, que compõem a Escola de Formação Permanente do Magistério e Gestão Educacional- ESFAPEGE.

\section{Específicos}

- Diagnósticar os conhecimentos prévios que os professores têm em relação as plataformas digitais: Word Wall, Pixton e Google Arts e Culture e suas aplicabilidades no ensino da saúde.

- Planejar momentos formativos com os professores de EF acerca das plataformas digitais e o ensino da saúde, abordando o bloco de conteúdos "conhecimento sobre o corpo";

- Promover momentos de interações por meio de seminários, com a finalidade educacional de compartilhar experiências docentes;

- Avaliar as implicações das formações continuadas e sua relação com a práxis docente. 


\section{FUNDAMENTAÇÃO TEÓRICA}

\section{Formação continuada e a práxis pedagógica}

Os estudos acerca da formação continuada de professores, há tempos, estão em crescente relevo no campo educacional, sobretudo em relação aos estudos internacionais (ANDREWS; BARTELL; RICHMOND, 2016). Dentre os estudos nacionais, Pimenta e Lima (2006) afirmam que a atividade docente é a práxis, que por sua vez, é a reflexão da ação, assim, o conceito de práxis é aprimorado de acordo com quem a desenvolve. Nessa perspectiva, é de suma importância olhar a formação docente no sentido de superar a dicotomia entre teoria e prática, tendo como objetivo primordial o exercício da práxis.

Para tanto, para exercer a docência faz-se necessário uma pluralidade de conhecimentos que englobem desde os conceitos específicos de cada área e envolvam as dimensões sociais dialogando com as diferentes concepções de sujeito e de mundo.(MAGALHÃES JÚNIOR; NETA, 2016. p. 423). Nóvoa (2017) corrobora ao afirmar que formação continuada se desenvolve através da reflexão compartilhada entre os professores, no espaço da profissão, e com o objetivo de compreender e aprimorar o trabalho docente. Portanto, entendemos que a formação continuada é um elo entre o trabalho docente, o conhecimento e o desenvolvimento profissional do professor e está intimamente relacionada à construção de novos saberes.

O professor que busca, estuda e tem subsídios e incentivo para tais ações, com certeza, torna sua prática mais significativa. Do mesmo modo, Paulo Freire (1996) fala com insistência no professor pesquisador. No entender do autor, o que há de pesquisador no professor não é uma qualidade ou uma forma de ser ou de atuar que se acrescenta à de ensinar, ou seja, faz parte da natureza da prática docente a indagação, a busca, a pesquisa. Diante do exposto sobre a importância das formações continuadas para a práxis docente, é imprescindível investimentos 
nestas formações, a fim de que possibilitem a reflexão sobre os desafios atuais no próprio contexto da atuação profissional, ou seja, pensar formação continuada como ferramenta geradora de possibilidades para a resignificação da práxis pedagógica.

\section{A gamificação e o ensino para a saúde: Possibilidades e desafios para o professor de Educação Física}

O jogo é um elemento da cultura humana, trazendo essa visão até o seu extremo, onde jogo é anterior à cultura, visto que esta pressupõe a existência da sociedade humana.(HUIZINGA, 2007, p.32). Visando a motivação como elemento fundamental que impulsa as ações do ser humano, os jogos foram ganhando novos materiais, linguagens, conceitos e dinâmicas, demandando do professor uma nova abordagem na construção de sua metodologia de ensino.

Nesse sentindo, para atender as necessidades dos exigências sociais, Lévy (1996) enfatiza que o uso da virtualização, cada vez mais presente no nosso cotidiano, amplia as potencialidades humanas,criando, inclusive, um novo modo de aprender e de pensar. Populariza-se então o termo Cyber, que segundo Magalhães Júnior (2011) passa a representar todo conjunto de novas relações, espaços, objetos e tudo que está vinculado às comunicações, redes de internet e tecnologias digitais, integrantes de uma sociedade que convive com a realidade da virtualidade.

Surgem então para fins pedagógicos, a ideia do uso das características dos jogos como uma das possíveis ferramentas para auxiliar a educação, principalmente quando se objetiva proporcionar motivação e engajamento. Kapp (2012) em seu Livro "Gamification of Learning and Instruction", define como gamificação o uso das mecânicas baseadas em jogos, da sua estética e lógica para engajar as pessoas, motivar ações, promover a aprendizagem e resolver problemas. 
Dentro do contexto da EF, os conteúdos dos Parâmetros Curriculares Nacionais - PCNs (1998) do Ensino Fundamental apresentao bloco conhecimentos sobre o corpo. Especificamente, nesse bloco, Guedes (1999) faz uma reflexão acerca do conteúdo nas aulas de Educação Física escolar. Conforme o autor existe muitos professores de EF, que em função de sua formação profissional, demonstram forte resistência à ideia de introduzir modificações nos atuais programas por acreditarem que as atividades competitivas enaltecem determinadas qualidades pessoais.

No entanto, reforça-se a necessidade de insistir em um equilíbrio quanto à abordagem do conjunto de conteúdos em termos teórico e prático nos programas de EF direcionados à educação para a saúde, pois nunca se falou tanto em saúde e fortalecimento do sistema imunológico, bem como tecnologias digitais, como nos dias atuais.

Diante disto, no que tange as possibilidades da gamificação inseridas nas aulas de EF e o ensino da saúde, integrar a tecnologia no processo de ensino-aprendizagem mostra-se como caminho para uma escola que precisa emergir neste espaço virtual. Pois essas ferramentas apresentam-se como auxiliar e diferencial no processo de aprendizagem dos alunos em relação à dimensão conceitual, presente nos conteúdos da disciplina. Em outras palavras, "permite ampliar os campos de conhecimento entre passado, presente e a visualização do futuro, oportunizando diferentes experiências, motivação, vontade em fazer, conhecer, saber e aprender." ( ATHAYDE, 2016, p. 13).

Diante das possibilidades apresentadas, é preciso reconhecer também que há desafios à serem enfrentados, inclusive na EF, disciplina de preferência da grande maioria dos alunos. Dentre eles podemos destacar: acreditar nas tecnologias digitais como ferramentas essenciais para as práticas pedagógicas, formação docente continuada que promova engajamento e motivação e fortalecimento por políticas públicas para firmar bases para concretização da inclusão digital. Resultados mais satisfatórios relacionados a prática educativa e o uso das plata- 
formas digitais, não dependem somente do preparo administrativo e pedagógico das instituições de ensino. Diz respeito também as desigualdades no acesso a equipamentos tecnológicos e à internet de qualidade, que têm impedido que o ensino on-line e o uso das plataformas digitais interativas seja ofertado de maneira equitativa aos estudantes. Afinal, devidamente mediadas por esses fatores, essas ferramentas trazem para o universo escolar o mundo digital, realidade de vivência no qual estão inseridos os alunos, os sujeitos da aprendizagem; a chamada nova geração digital.

\section{METODOLOGIA}

Este projeto levou em conta os processos metodológicos da pesquisaação. Segundo Thiollent (1986), esse tipo de pesquisa possui grandes possibilidades de aplicação, contribuindo em diversas áreas, como, por exemplo, a escolar. Dito isso, quanto ao objetivo, foi uma pesquisa exploratória e descritiva. Quanto à abordagem, a pesquisa teve um cunho quali- quantitativo.

\section{Cenário e sujeitos da pesquisa}

O cenário foi a Escola Escola de Formação Permanente do Magistério e Gestão Educacional- ESFAPEGE.- Sobral. Os sujeitos da pesquisa foram o grupo de professores que lecionam a disciplina de EF para o Ensino Fundamental II( $6^{\circ}$ ao $9^{\circ}$ ) das escola municipais de Sobral. Participaram da pesquisa 15 professores de Educação Física. O período da pesquisa foram 5 meses, sendo 2 para o levantamento bibliográfico e 3 para a pesquisa ação ( setembro a dezembro de 2021).

A) O primeiro passo foi levantamento bibliográfico e a busca das fontes. Implicou em vasta leitura sobre o assunto em pesquisa, embasada em estudos que constroem um dialogo focado nos objetivos já apresentados neste projeto, dentre eles podemos destacar alguns: Freire (1996), Nóvoa (2017), Pimenta e Lima (2006), Pimenta (1999), Tardif (2002), Huizinga (2007), Kapp (2012), Ferreira el al (2020), Magalhães Júnior ( 2011), Lévy ( 1996), entre outros. 
B) Logo após o levantamento bibliográfico, fomos para a organização de um plano de ação, onde foram realizados entre os meses de setembro a dezembro de 2021.

C) As oficinas foram organizadas em 03 encontros mensais durante a formação de professores de EF ofertadas pela ESFAPEGE, com duração máxima de 02 horas. O bloco de conteúdos " conhecimento sobre o corpo" foi apresentados aos professores como proposta de atividades a serem refletidas.

As plataformas digitais de jogos educativos que foram apresentados tiveram como principal objetivo somar criativamente às potencialidades tecnológicas de convergência midiática em um desenho de mundo imersivo, permitindo utilizar mecânicas, dinâmicas, estilo e pensamento de jogos em contextos educacionais como meio para resolução de problemas e engajamento dos sujeitos da aprendizagem. Cada plataforma propõem um eixo temático acerca de conceitos sobre o conhecimento sobre o corpo . Serão três plataformas, a saber:Word Wall, Pixton e Google Arts e Culture.

As oficinas tiveram quatro objetivos principais:

1. Identificar quais os conhecimentos prévios que os professores têm em relação as plataformas digitais de jogos educativos e o eixo conhecimento sobre o corpo, proposto pelos PCNs ;

2. Fazer uma apresentação teórica e prática acerca das plataformas digitais de jogos educativos, no intuito deles compreenderem os elementos e aplicabilidade, para logo após levarem para sua prática em sala de aula;

3. Promover momentos de interações por meio de seminários, com a finalidade educacional de compartilhar experiências com o uso das plataformas nas aulas, como os alunos interagem e se eles conseguem perceber os implicações dessas práticas na sua aprendizagem;

4. Na última fase, foi um o momento da reflexão sobre as ações efetuadas. 


\section{RESULTADOS}

Para o primeiro objetivo a pesquisa mostrou que cerca de $70 \%$ dos professores pesquisados tem um breve conhecimento acerca das plataformas digitais, $25 \%$ conhecem e usam nas suas aulas e $5 \%$ não conhece e nunca usaram. No ponto dois, observamos que após a apresentação das plataformas digitais, $80 \%$ dos professores conseguiram compreender os elementos e aplicabilidade e $20 \%$ mostraram-se desmotivados a utiliza-los na sua prática docente. Todos os professores participaram dos momentos de interações, porém ao serem questionados sobre sua possível utilização na sala, alguns mostraram-se com pouca interação e disposição a usá-las. Na última fase, quando feito um momento de reflexão, alguns inquietações foram colocadas como impactantes: "Até tenho interesse em usá-las, porém minha escola não apresenta estrutura necessária, seja pela a excessiva quantidade de alunos, seja pela falta de material mesmo." PROFESSOR 1. "Eu as ultilizo nas aulas e percebo uma grande interação entre os alunos, espero que haja mais investimentos para melhorar ainda mais essa prática." PROFESSOR 2.

Portanto, concluimos que apesar de apresentar opções inovadoras, as ferramentas digitais ainda possuem muitas limitações dentro do âmbito educacional, precisando de fato, que haja politicas publicas de investimento não apenas para o acesso destas, mas principalmente uma formação docente de qualidade.

\section{Instrumentos Utilizados}

Os instrumentos utilizados para a coleta dos dados foram a observação participante, diário de campo, registros fotográficos e o uso de questionários digitais. Ao final das oficinas, foi disponibilizado um questionário com questões a fim de detectar o grau de familiaridade dos professores com as ferramentas digitais. 


\section{REFERENCIAS}

ANDREWS, Dorinda Carter; BARTELL, Tonya ; RICHMOND, Gail. Teaching in de humanizing times: the professionalization imperative. Journal of Teacher Education, v. 67, n. 3, p. 170-172, 2016.

ATHAYDE, Rafael. Jogos digitais na Educação Física Escolar: Just dance now vai para sala de aula. Monografia. 43 f. (Especialização). Curso de Educação na Cultura Digital, Universidade Federal de Santa Catarina. Florianópolis, SC, 2016.

BARDIN, Laurence. Análise de conteúdo. São Paulo: Edições 70, 2011.

BRASIL. Secretaria de Educação Fundamental.Parâmetros curriculares nacionais : Educação Física /Secretaria de Educação Fundamental. Brasília : MEC /SEF, 1998.

BRASIL. Ministério da Educação. Base Nacional Comum Curricular. Brasília, 2017.

DARIDO, Suraya Cristina. Educação Física na escola: questões e reflexões. Rio de Janeiro: Guanabara - Koogan, 2003.

DARIDO, Suraya Cristina.; RANGEL. Irene Conceição Andrade. Educação Física na escola: Implicações para a prática pedagógica. Rio de Janeiro: Guanabara Koogan, 2005.

FERREIRA, Heraldo Simões. Educação Física e Saúde em Escolas Públicas Municipais de Fortaleza: uma proposta de ensino. Fortaleza: EDUECE, 2011.

FERREIRA, Heraldo Simões; CAMPOS, Aline Soares; VIANA, Gardênia Coelho; SIMÕES, Luiza Lúlia Feitosa. O jogo como auxílio no processo ensinoaprendizagem: as contribuições de Piaget, Wallon e Vygotsky. Brazilian Journal of Development, Curitiba, v. 6, n.5, p.27127-27144, 2020.

FREIRE, Paulo. Pedagogia da autonomia: saberes necessários à prática educativa. 25. ed. São Paulo: Paz e Terra, 1996.

GHIRALDELLI JUNIOR, Paulo. Educação Física Progressista. São Paulo: Edições Loyola, 1998. 
GUEDES, Dartagnan Pinto. Educação para a saúde mediante programas de educação física escolar. Revista Motriz, v. 5, n. 1, p. 10- 14, 1999

HUIZINGA, Johan. Homo ludens:o jogo como elemento da cultura. 5edição. São Paulo: Perspectiva, 2007.

KAPP, Karl M.The Gamification of Learning and Instruction: Game - Based Methods and Strategies for Training and Education. Washington: Pfeiffer \& Company, 2012.

LÉVY, Pierre. O Que é o Virtual. São Paulo: Editora 34, 1996.

MAGALHÃES JUNIOR, Antonio Germano. Imagens, Mídia e Educação:desafios na formação do professor/pesquisador. In: Aristonildo Chagas Araújo Nascimento; Arminda Rachel Botelho Mourão. (Org.). Educação, Culturas e Diversidade. 1ed.Manaus: Editora da Universidade Federal de Manaus, 2011, v. 2, p. 109-122.

MAGALHÃES JUNIOR, Antonio Germano; SILVA NETA, Maria de Lourdes. Formação de professores no Brasil: Política, História e Espaços Educacionais. In: Francisco Ari de Andrade; José Geraldo Vasconcelos; José Rogério Santana; Raimundo Elmo de Paula Vasconcelos Júnior; Rui Martinho Rodrigues. (Org.). LDB 20 anos: Política, História e Espaços Educacionais. 1ed. Fortaleza: UFC, 2016, v. , p. 404-426.

MATTAR, João; NESTERIUK, Sérgio. Estratégias do design de games que podem ser incorporadas à educação a distância. Revista Iberoamericana de Educación a Distancia, v. 19, n. 2, pp. 91-106, 2016.

NÓVOA, Antonio. Firmar a posição como professor, afirmar a profissão docente. Cadernos de pesquisa. n. 166, v. 47, p. 1106-1133, out/dez 2017.

PIMENTA, Selma Garrido; LIMA, Maria Socorro Lucena. Estágio e docência: diferentes concepções. Revista Poíesis . n. 3 e 4, v. 3, p. 5-24, 2005/2006. 
SALES, Gilvandenys Leite; Rubens Lopes, SANTOS. O uso de objetos de aprendizagem e a aplicação do IMS moodle numa escola pública de ensino médio do Estado do Ceará: Um estudo de caso. In: Ana Carolina Costa Pereira, Francisco Herbert Lima Vasconcelos, Francisco Regis Vieira Alves. (Org.).Ensino de Ciências e Matemática: Enfoques de práticas docentes. 1ed. Editora Recife : Imprima, 2016, p 21-42.

THIOLLENT, Michel. Metodologia da pesquisa-ação. 2. ed. São Paulo: Cortez, 1986.

UNESCO. A Comissão Futuros da Educação da Unesco apela ao planejamento antecipado contra o aumento das desigualdades após a COVID-19. Paris: Unesco, 16 abr. 2020. Disponível em: https://pt.unesco.org/news/comissaofuturos-da-educacao-da-unesco-apela-ao-planejamento-antecipado-oaumento-das Acesso em: 4 jun. 2021. 


\section{doi $10.48209 / 978-65-89949-D 2-6$}
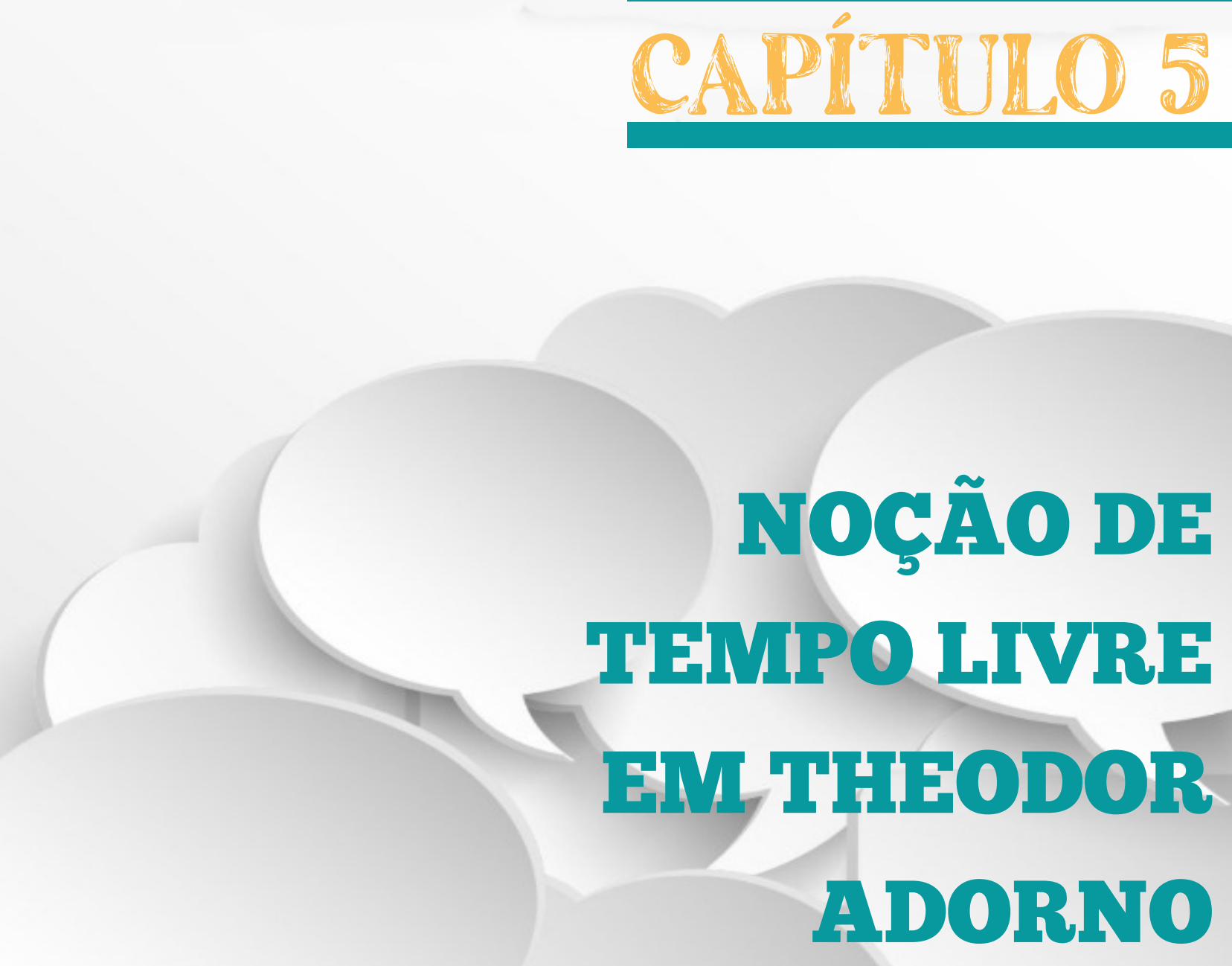

Angelo Maurício de Amorim 


\section{INTRODUÇÃO}

O tempo ganha uma dimensão nas atuais relações de trabalho e de convivência que o termo tempo livre ganha conotações que reforçam a existência do tempo de trabalho. Em meio as medidas de isolamento social que afligem parte da população, a noção de utilidade do tempo ganha uma perspectiva que pode contribuir para aproximar o homem de sua emancipação ou reforçar sua condenação a servidão.

Em contextos contemporâneos a noção de tempo livre assume no imaginário coletivo termos pejorativos e sem relevância, apesar de que essa condição foi fundante para o desenvolvimento do pensamento filosófico na Grécia antiga. Com a advento do capitalismo, o trabalho tornou aquilo que porventura dignificaria o homem e o tempo livre associado ao desenvolvimento intelectual e pessoal é invertido.

Assim, a medida em que há o avanço do processo de alienação do tempo livre, aquilo que seria a liberdade com potencial ao desenvolvimento humano, torna-se meio para reforçar paradigmas como descansar para o trabalho, recrear em forma de entretenimento pronto e acabado que não suscita reflexões e o consumo desenfreado do que se fazer no tempo livre. Apesar de almejar a liberdade, ter tempo livre tem sido uma problemática e sua terceirização uma prática, em especial em condições de isolamento social propostos pela Pandemia de COVID $-19$.

O presente texto possui como objetivo comentar sobre a noção de tempo livre, presente em uma conferência de 1969, de Theodor Adorno. Trata de um ensaio cujas apropriações filosóficas proporcionam enlaces teóricos de conceitos que rompem com o processo temporal. Neste caso, a conferência tempo livre (Freizeit), de 1969, posta em análise 50 anos depois, com implicações consistentes na realidade. 


\section{TEMPO LIVRE EM ADORNO}

Theodor Adorno, de origem paterna judaica e materna italiana, nasceu em 1903, em Frankfurt, na Alemanha. Estudou filosofia, sociologia e música na Universidade de Frankfurt. Foi um dos expoentes da Escola de Frankfurt" ${ }^{1}$, que contribuiu para o renascimento intelectual da Alemanha após a segunda guerra mundial.

Pensador de um contexto histórico problemático do século $X X$, como os desdobramentos da revolução industrial, primeira e segunda guerra mundial. Teve que sair da Alemanha, radicando-se nos Estados Unidos. Lá, em conjunto com Horkheimer ${ }^{2}$, na obra dialética do esclarecimento, aparece as primeiras considerações sobre o termo indústria cultural.

Em sua Teoria Crítica, em linhas gerais, há destaque ao impacto dos meios massivos de comunicação em nossa sociedade. Os meios de comunicação em massa fizeram da arte um produto. Este produto passou a estar a serviço do capital. A arte deixou de ser exclusiva. Deixou de ocupar lugares dedicados a contemplação, passou ocupar lugares comuns. Popularizou-se a ponto de perder si em si. Mediante o processo de produção em escala para homogeneizar e harmonizar as formas de recebimento do agora, entretenimento (ADORNO, HORKHEIMER, 1985).

Em 25 de maio de 1969, já bem próximo ao final de sua vida ${ }^{3}$, proferiu uma conferência sobre o conceito e a prática do tempo livre (Freizeit) ${ }^{4}, 20$ anos após os escritos primeiros sobre indústria cultural. Este será o texto de referência a ser feito considerações.

$1 \quad$ Um grupo de intelectuais de distintas áreas do conhecimento que produziram a Teoria Crítica, tais como Walter Benjamin, Theodor Adorno, Max Horkheimer, Hebert Marcuse.

2 Max Horkheimer. 1895-1973. Sociólogo e filósofo alemão.

$3 \quad$ Faleceu em 06 de agosto de 1969.

4 Em linha portuguesa, o texto foi traduzido por Maria Helena Ruschel, sob supervisão de Álvaro Valls. Publicado na obra Palavras e Sinais, modelos críticos, Petrópolis: Editora Vozes, 1995, pp. 70-82. 
Adorno inicia suas considerações sobre o tempo livre com base no que é o tempo não livre. Prendendo um ao outro, reforçando a existência de um pelo outro. "[...] uma diferença específica que o distingue do tempo não livre, aquele que é preenchido pelo trabalho e, poderíamos acrescentar, na verdade, determinado desde fora. O tempo livre é acorrentado ao seu oposto". (ADORNO, 2009, p. 62)

Só surge a necessidade de se pensar no tempo livre pelo reconhecimento do tempo de trabalho. Trabalho tomado como referência a atividade laboral, consequente do modo de produção capitalista. Assim, o tempo do trabalho não é livre. Ele requer obrigações, compromissos que estão para além das dimensões dos sujeitos envolvidos no processo. O direito ao tempo livre aparece como uma demanda do trabalhador frente as grandes cargas horárias (LAFARGUE, 2019).

A relação de oposição entre tempo livre e tempo não livre, "imprime-lhe traços essenciais. Além do mais, muito mais fundamentalmente, o tempo livre dependerá da situação geral da sociedade" (ADORNO, 2009, p.62). Na contemporaneidade, o tempo de fazer, de ser e de existir se dilui na velocidade, onde o tempo de ter, de correr e de consumir se tornam referências nos modos de agir. Preocupações sobre os modos de vida na contemporaneidade emergem em estudos de Bauman (2011) e processo de fragilidade das relações humanas.

Para Pais (2010) avançamos do paradigma da lentidão, marca de outro tempo em que vivemos, onde as ações do cotidiano aconteciam de uma forma mais lenta, mais vivida, mais sentida, e estamos no paradigma do encontrão, onde damos nas vistas, mas não damos ouvidos e, assim, deixamos de perceber aspectos significativos que justificam a nossa existência.

Como desdobramento deste processo, uma dimensão de existência que leva a um processo de coisificação do homem, uma perda de si. Para Adorno, a existência em sociedade entra em conflito com o que as pessoas são ou poderiam ser. "Decerto, não se pode traçar uma divisão tão simples entre as pessoas em si e seus assim chamados papéis sociais. Estes penetram profundamente nas próprias características das pessoas, em sua constituição íntima." (ADORNO, 2009, p. 62) 
Alguns dilemas da contemporaneidade nos remetem à forma como são estabelecidas as relações entre os seres humanos, constituídas ao longo de toda a história de uma civilização conformada pela "con-vivência" entre os povos. A atual sociedade industrializada, com avanços significativos no campo técnico-científico, leva o ser humano a uma dependência das máquinas, a um afastamento do homem e da mulher, como seres da natureza, em direção a seres donos da natureza.

Na sequência do texto, Adorno remete no texto às perguntas feitas em jornais sobre os hobbys das pessoas. O que elas fazem no tempo livre? Considera isto um escarnio e posiciona-se contra esta denominação, afinal induz um caráter de obrigatoriedade de ter algo a ser feito dentro deste tempo.

Adorno faz menção ao pensamento de Marx ${ }^{1}$ para estabelecer uma relação de que o comportamento humano frente ao trabalho é deslocado para o tempo livre, onde o mesmo, ao criar hobbys, necessidades de acampar e todo o aparato que a atividade em si traz, a necessidade de viajar e atribuir uma dimensão de utilidade ao tempo livre, como se uma pessoa que entrou de férias e não voltou bronzeada pelo sol não gozou deste "benefício".

Quando se aceita como verdadeiro o pensamento de Marx, de que na sociedade burguesa a força de trabalho tornou-se mercadoria e, por isso, o trabalho foi coisificado, então a palavra 'hobby' conduz ao paradoxo de que aquele estado, que se entende como o contrário de coisificação, como reserva de vida imediata em um sistema total completamente mediado, é, por sua vez, coisificado da mesma maneira que a rígida delimitação entre trabalho e tempo livre. Neste prolongam-se as formas de vida social organizada segundo o regime do lucro (ADORNO, 2009, p. 64)

A alienação em Marx (2008) é definida como um processo onde criamos um determinado mundo e não somos capazes de nos reconhecer como autor. Trata de um fenômeno estruturante da sociedade que leva a separação entre a riqueza e os produtores da riqueza em função do não reconhecimento daquilo que foi produzido.

$1 \quad$ Karl Marx, viveu no século XIX, entre 1818 e 1883, tendo nascido na Alemanha. Deixou contribuições para diversas áreas do conhecimento, tais como direito, economia, história, sociologia, filosofia. 
A existência humana decorre de processos de sobrevivência. E para sobreviver o humano preciso respirar, alimentar, descansar. Os mecanismos de sobrevivência são frutos de elementos externos a ele. Uma outra dimensão da existência humana está atrelada a busca por evoluir as formas de sobrevivência, que pode ser atribuída ao polegar opositor que the permite pegar e manusear distintos elementos da natureza e ao telencéfalo altamente desenvolvido, que lhe possibilita uma capacidade de agir de forma racional.

Estes elementos habilitam o ser humano a não se contentar com o que a natureza lhe oferece, por poder criar o que precisa. Assim, o homem cria as condições materiais de sua existência. Este criar, projetar e pensar ao longo do tempo o colocou em relação de dominação com a natureza. Para Marx , a ação do homem sobre a natureza para criar ou reproduzir suas criações materiais de sobrevivência tem o nome de Trabalho.

Para Marx (2008, p. 83) "o Trabalho não é, por isso, a satisfação de uma carência, mas somente um meio para satisfazer necessidades fora dele". Quando as necessidades são satisfeitas, um rol de necessidades novas surge. E assim, instaura um ciclo onde o homem por meio do Trabalho modifica a natureza, em contrapartida, a natureza modifica o homem, criando outras demandas.

A palavra trabalho tem por origem etimológica o termo latino tripalium, que designava um instrumento de tortura. Na Antiguidade greco-latina, somente os escravos e as mulheres realizavam trabalhos penosos. Na tradição judeu-cristã o trabalho aparece como o castigo imposto por Deus a Adão: "Ganharás o pão com o suor do teu rosto".

O trabalhador se torna um tanto mais pobre quanto mais riqueza produz, quanto mais sua produção aumenta em poder e extensão. o trabalhador se torna uma mercadoria tão mais barata quanto mais mercadorias cria. Com a valorização do mundo das coisas aumenta em proporção direta a desvalorização do mundo dos homens. O trabalhado não produz somente mercadorias; ele produz a si mesmo e ao trabalhador como uma mercadoria, e isto na medida em que produz, de fato, mercadorias em geral (MARX, 2008, p. 80) 
Assim, a natureza humana orientada para sua sobrevivência desloca-se criando uma segunda natureza que passa a ser incorporada como se fosse a primeira, levando ao processo de naturalização daquilo que é artificial, por exemplo, o uso de roupas. A esta condição, funde o termo alienação/estranhamento. $O$ processo de estranhamento ao trabalho coaduna tanto no resultado do trabalho como no ato da produção. Os impactos subjetivos de estranhamento do mundo que ele cria compromete a formação do sujeito. "o trabalhador encerra sua vida no objeto, mas agora ela não pertence mais a ele, mas sim ao objeto" (MARX, 2008, p. 81).

Neste ínterim, da alienação do trabalho à alienação do tempo livre, movidos pela busca desenfreada de ter coisas e consumir, perdemos a essência do que somos e nos tornamos o que temos. Este mecanismo revelam um deslocamento da liberdade do sujeito de ter o controle sobre as atividades a serem realizadas no tempo livre por conta dos mecanismos de coação externa que lhe conferem códigos, significados e orientam condutas de como deve se dar a apropriação do tempo livre em meio aos ditames da não liberdade (MUSSE, 2016).

Foi incutido que as formas de apropriação da relação trabalho e tempo livre devem estar a serviço de mecanismos de descanso e restauração das forças de trabalho do segundo, tempo livre, para o primeiro, trabalho. "segundo a moral do trabalho vigente, o tempo em que se está livre do trabalho tem por função restaurar a força de trabalho, o tempo livre do trabalho - precisamente porque é um mero apêndice do trabalho" (ADORNO, 2009, p. 64)

Sem a relação potencializadora, a manutenção da ordem vigente se impõe. A partir de um processo de formação alienada, onde o trabalho se transforma em atividade principal a ser desenvolvida e, nos espaços do chamado tempo livre, somos estimulados a um consumo alienante, pelo bombardeio de informações dos meios de comunicação que, visando à continuidade da extração e da produção de coisas a serem consumidas, contribui-se para o processo de desumanização dos seres humanos. 
As práticas de atividades no tempo livre utilizadas para descanso, distração e recuperação das forças para o trabalho. Os modos de vida balizados pela regulação do trabalho e as condições para trabalhar. A mídia contribui para este contexto por meio da publicidade atuando de forma onipresente, padronizando informações, evidenciando a atração obsessiva por novas formas de conforto, de deslocamento, induzindo de forma incisiva para tipos de evasão real levando sociedades inteiras a ter idênticas formas de utilização do tempo livre (WAICHMAN, 2003).

Os meandros da alienação e o processo de ausência da liberdade que foi subtraída das pessoas apontam os pilares da subversão que ocorre no âmbito do trabalho também no tempo livre: "a integração do tempo livre é alcançada sem maiores dificuldades; as pessoas não percebem o quanto não são livres lá onde mais livres se sentem, porque a regra de tal ausência de liberdade foi abstraída delas" (ADORNO, 2009, p. 65).

A indústria cultural captura a subjetividade do sujeito, dando-lhe meios de diversão e descanso dos quais não requer compromissos par além do campo do apelo as dimensões visíveis, cujas formas de sentir, reagir, impactar, estão previamente definidas nas distintas produções que fazem mais do mesmo e cada vez mais são consumidas, levando a apropriação do tempo livre a reforçar os preâmbulos alienantes das esferas do trabalho. (ADORNO; HORKHEIMER, 1985).

$\mathrm{Na}$ parte final do texto, Adorno retoma as prerrogativas inerentes ao conceito de indústria cultural apresentando em conjunto com Horkheimer vinculando a noção de tempo livre e a indústria cultural "enquanto meio de domínio e de integração [...] ela domina e controla, de fato e totalmente, a consciência e inconsciência daqueles aos quais se dirige e de cujo gosto ela procede, desde a era liberal" (ADORNO, 2009, p. 68).

Contextualiza a problemática dos críticos reafirmando os mecanismos de aprisionamento dos quais todos que estão inseridos neste contexto se sucumbem. Em continuidade reafirma a dimensão do sempre igual que leva ao afasta- 
mento das pessoas, levantando questionamentos se a "a equação entre a indústria cultural e a consciência dos consumidores é precedente" (ADORNO, 2009, p. 69).

De toda forma, apesar de no seio da indústria cultural a arte ter perdido sua originalidade e as pessoas perderam sua sensibilidade em relação a arte, Adorno finaliza a conferência fazendo considerações a respeito de uma possível emancipação destas amarras.

Conta a respeito de um estudo referente ao comportamento do povo alemão frente ao casamento da princesa Beatriz, da Holanda com um jovem diplomata alemão, chamado Claus Von Amsberg, que dominou os noticiários o bombardeamento de informações a respeito. Na dimensão do impacto sobre os sujeitos os resultados foram coerentes com os pressupostos levantados dentro da dimensão do aqui e agora.

Quando foi considerado o nível de significação deste fato aos sujeitos que foram entrevistados possuíam um comportamento bem realista e avaliavam com sentido crítico a importância política e social de um acontecimento que lhes fora exposto de maneira massiva.

as pessoas aceitam e consomem o que a indústria cultural lhes oferece para o tempo livre, mas com um tipo de reserva, de forma semelhante à maneira como mesmo os mais ingênuos não consideram reais os episódios oferecidos pelo teatro e pelo cinema Talvez mais ainda: não se acredita inteiramente neles (ADORNO, 2009, p.69)

Apesar de não tecer grandes considerações sobre esta afirmativa, anuncia que este pode ser a lacuna que pode contribuir para uma emancipação dos sujeitos, pois existe uma distinção entre o conteúdo recebido e a singularidade dele na vida dos envolvidos, não representando assim, que todos os modos de agir e orientar condutas são modulados pelos conteúdos que aparecem nos meios de comunicação, no caso, a televisão. De toda forma reconhece que ainda não há motivos fortes para as pessoas resistirem à estes condicionantes que lhes são postos. 
Todavia, conclui o texto com as seguintes palavras: "Renuncio a esboçar as consequências disso; penso, porém, que se vislumbra aí uma chance de emancipação que poderia, enfim, contribuir algum dia com a sua parte para que o tempo livre [Freizeit] se transforme em liberdade [Freiheit]" (ADORNO, 2009, p. 70).

Em meio ao declínio da experiência estética em um mundo estetizado por normas e padrões sistematicamente induzidos, quem sabe uma Revolução Cultural do Tempo Livre não seja o caminho para emancipação?

Neste cenário, a emergência do tempo livre, como possibilidade, arrebatadora e significativa, de pararmos, para que possamos transcender o aspecto utilitário das coisas e valorizar a poesia, o respeito, o diálogo, a participação e a consciência da finitude do meio ambiente, constitui uma aposta. A partir de um possível diálogo, de valorização e respeito, estimulando a consciência e a formação, crítica e consciente, dos pares que nos cercam, podemos potencializar melhores condições de "con-viver".

Livrar-se das necessidades criadas pela segunda natureza que naturalizou padrões e condutas por meios dos mais diversos mecanismos e colocou o homem cada vez mais distante de si. Quiçá não seja a chave o fato narrado na poesia de Drummond de Andrade "o homem: as viagens". Depois do homem viajar o universo desbravando e conquistando, cabe a ele a viagem de si a si mesmo...

Restam outros sistemas fora do solar a colonizar. Ao acabarem todos só resta ao homem (estará equipado?) a dificílima dangerosíssima viagem de si a si mesmo: pôr o pé no chão do seu coração experimentar colonizar civilizar humanizar o homem descobrindo em suas próprias inexploradas entranhas a perene, insuspeitada alegria de con-viver. (ANDRADE, 1973).

\section{CONSIDERAÇÕES FINAIS}

O texto analisado de Adorno é fruto de uma conferência realizada bem próximo ao seu falecimento em 1969. Aborda temáticas que questionam sobre o real sentido e formas de utilização do tempo livre dentro do contexto em que os sujeitos se inserem numa relação direta com o trabalho e não oposta. Atribuin- 
do assim, toda as prerrogativas do conceito de alienação do Trabalho, de Marx, também ao tempo livre, orientado para o descanso e divertimento nutrido pela indústria cultural.

Anuncia, ao final, apesar de todo cenário tenso e pessimista de suas obras uma possibilidade de uma possível emancipação do tempo livre, sem tecer maiores aprofundamentos, ao considerar que as dimensões do aqui e agora que advém dos meios de comunicação não implicam, em necessidade, de significação aos sujeitos que, com isto, podem posicionar com distinções aos fatos a eles impostos pelos meios de comunicação.

\section{REFERENCIAS}

ADORNO, T. Industria Cultural e Sociedade. São Paulo: Paz e Terra, 2009. 5ed.

ANDRADE, Carlos Drummond. O homem, as viagens. In: ANDRADE, C. D. As impurezas do branco. São Paulo: José Olympio Editora,1973.

BAUMAN, Z. Modernidade líquida. Rio de Janeiro: Jorge Zahar, 2011.

HORKHEIMER, M.; ADORNO, T. W. Dialética do esclarecimento. Rio de Janeiro: Jorge Zahar, p. 19-52, 1985.

LAFARGUE, P. O direito à preguiça. Editora Nova Alexandria, 2019.

MARX, K. Crítica da filosofia do direito de Hegel-Introdução. Crítica da filosofia do direito de Hegel, v. 2, p. 145-157, 2008.

MUSSE, R. A ADMINISTRAÇÃO DO TEMPO LIVRE. Lua Nova, São Paulo , n. 99, p. 107-134, Dec. 2016.

PAIS, J. Dolências e indolências da vida cotidiana. Lufa-Lufa Quotidiana. isboa: ICS, 2010.

WAICHMAN, P. Tempo livre e recreação: um desafio pedagógico. 4 ed. Campinas, SP: Papirus, 2003. 


\section{dol 10.48209/978-65-89949-D2-7}

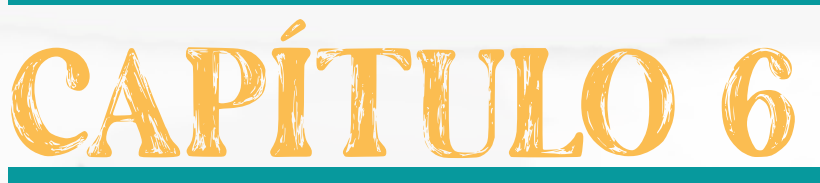

\section{RELAÇÕES DE TRABALHO E DE GENERO: ESTUDO DE CASO EM UM}

ASSENTAMENTO RURAL.

Rodrigo Duarte Faccin 


\section{INTRODUÇÃO}

Baseado em uma profunda divisão de tarefas entre homens e mulheres, o trabalho familiar é elemento central da reprodução camponesa, estando culturalmente e socialmente determinadas as atividades próprias para cada membro da família, situação que estabelece a invisibilidade do trabalho feminino. Heredia (2006, p. 4) chama a atenção para os estudos que assinalaram as desigualdades de gênero no meio rural, em que identificaram que o chamado "trabalho invisível" é uma das causas que favorece este cenário de desigualdade, visto que "[...] esse trabalho invisível é em geral identificado com as tarefas do lar, enquanto as atividades realizadas pelos homens se restringem ao trabalho fora da casa".

Para Esmeraldo (2008), a opressão e a situação de desigualdade da mulher rural se dão através de duas esferas, primeiro, no interior da unidade familiar, em que a mulher é restrita ao mundo privado; e o segundo aspecto, em que retrata o mundo político, público e produtivo, onde se inviabilizam as atividades e ações produtivas e políticas da mulher. Além disso, a autora chama a atenção para o fato de que:

Enquanto aos rapazes são destinadas as tarefas de gestãoda propriedade, recebendo a transmissão dos saberes agrícolas e administrativos necessários ao processo sucessório, as moças são requisitadas para as atividades ditas produtivas apenas quando estas necessitam do pleno emprego da mão-de-obra familiar (colheita, plantio) (ESMERALDO, 2008, p. 2).

Schwendler (2009) colabora com o debate expondo que a divisão sexual dos papéis sociais, na realidade da agricultura familiar camponesa, não se configura apenas com o trabalho, mas em todo o universo da vida dos agricultores e agricultoras, sendo representadas em diversos espaços sociais, como o de lazer, da religião, da escola, das lutas sociais. Schefler (2008, p. 7), em pesquisa sobre gênero e gerações na agricultura familiar apresentou que o fato dos "trabalhos realizados pelas mulheres rurais e identificados como 'ajuda', [...] é estratégico 
no sistema de atividades e, portanto, desmente seu caráter complementar", definição que cria uma hierarquização das posições sociais entre as pessoas da unidade familiar.

De acordo com Schefler (2008, p. 3), as pesquisas sobre gênero aplicadas ao meio rural têm contribuído para evidenciar e denunciar, entre outros aspectos, a subordinação e invisibilidade do trabalho feminino nas atividades reprodutivas e produtivas. De acordo com a autora, "o paradigma dominante na economia" fortalece essas desigualdades duplamente, pois “[...] ignora o trabalho reprodutivo não pago, tornando invisível a maior parte do trabalho feminino e ignora a divisão sexual do trabalho".

Paulilo (1987), em análise sobre o trabalho familiar da agricultura familiar, chama a atenção para as concepções sobre trabalho "leve" e trabalho "pesado", mostrando que o entendimento sobre o trabalho ser leve ou ser pesado depende de quem o realiza. De acordo com Wedig e Menasche (2013, p. 150), o estudo de Paulilo, mostra que "as diferentes atividades são valoradas a partir da classificação hierárquica dos membros da família que as executam".

Trabalho "leve" e "pesado" são, portanto, categorias que variam segundo o sexo do trabalhador e as condições de exploração da terra nas várias regiões agrícolas. Invariávelé a convicção de que o trabalho feminino é mais barato. Essa constatação é frequente na literatura sociológica sobre a força de trabalho feminina nas cidades: as profissões consideradas femininas tem remuneração sempre inferior à daquelas consideradas masculinas. Mesmo em profissões iguais e cargos iguais, os dois sexos tem remunerações distintas (PAULILO, 1987, p. 67).

Diante do contexto de invisibilidade da participação das mulheres no mundo rural, o presente estudo procurou compreender a realidade do trabalho feminino e como se configuram as relações de gênero no cotidiano de um Assentamento. Um fator importante para escolha deste Assentamento como local de estudo foi à presença de dois modelos de organização do trabalho, (1) individual e (2) coletivo, sendo que no primeiro grupo as terras são utilizadas individualmente por cada família através do modelo de produção agrícola de agricultura familiar, já no se- 
gundo grupo as famílias utilizam um sistema de produção coletiva da terra a partir de uma Cooperativa. Neste contexto, diferem- se a organicidade do trabalho nos dois grupos de trabalho, ficando visíveis diferenças nas responsabilidades e atribuições assumidas pelas mulheres.

\section{Aspectos metodológicos}

Como o objetivo de obtenção de conhecimentos detalhados foi realizado um estudo de caso, em que se buscou recuperar as experiências das mulheres e analisar a percepção delas sobre o trabalho, caracterizando-se como um tipo de pesquisa cujo objetivo é uma unidade que se analisa profundamente. O estudo de caso foi realizado no Assentamento Conquista da Liberdade, localizado no município de Piratini, região sul do estado do Rio Grande do Sul. Possuí uma população de aproximadamente 20.655 habitantes (IBGE, 2016), tendo sua principal base econômica a pecuária e o reflorestamento de pinheiros. Para dar continuidade à realização do estudo de caso, foi realizado o procedimento de observação, a partir de uma etapa de "vivência", período caracterizado com saída a campo, entre os dias de 11 de fevereiro e 20 de fevereiro do ano de 2016, além da realização de entrevistas. A etapa de observação resultou em um grande envolvimento com a área de estudo, com seus sujeitos e seus modos de vida, ocorrendo todos os dias da vivência no local do estudo (totalizando dez dias), incluindo vivenciar diversas atividades, desde rotinas das famílias até atividades agrícolas. Após os primeiros dias de observação e de vivência com as famílias, ocorreu a definição da amostragem da pesquisa. Como o foco de estudo é um único assentamento, a população em questão é a totalidade de indivíduos que vivem no local, sendo cerca de 110 pessoas, divididas em 48 núcleos familiares. Com isso, a escolha da amostra se deu através do entendimento do que poderia ser mais útil para o estudo. Neste sentido, foram escolhidas oito mulheres, sendo que cinco delas estão inseridas no modelo de trabalho individual e três inseridas no modelo de trabalho coletivo. 
Depois de já ter sido construído uma relação com a agricultura, se buscou realizar a entrevista, sendo feita a partir de pautas semiestruturadas. Durante as entrevistas, o que foi percebido foram falas muito ricas, demonstrando características semelhantes na organização familiar ou nas rotinas de trabalho, porém cada uma com suas peculiaridades, histórias de vida e percepções diferentes.

\section{BREVE CARACTERIZAÇÃO DO ASSENTAMENTO ESTUDADO}

A história do Assentamento Conquista da Liberdade está intimamente ligada à história da luta pela terra no estado do Rio Grande do Sul. Com a fundação do MST (Movimento dos Trabalhadores Rurais Sem Terra), em meados de 1985, e com o fortalecimento da luta pela reforma agrária, resultou, em 1989, através da participação de diversas famílias, um dos primeiros acampamentos de reforma agrário do Rio Grande do Sul. O acampamento Pinheiros, localizado no município de Cruz Alta, envolveu mais de 1.500 famílias de todo estado do Rio Grande do Sul.

A caracterização das famílias é bem diversificada no assentamento, sendo quase todas elas do tipo nucleares, onde possuem a presença de pai, mãe, filhos e filhas. O perfil das famílias se assemelha ao que vem acontecendo em outras regiões de agricultura do sul do país nas últimas décadas, na qual se destaca o processo de redução e envelhecimento da população e também da masculinização da população, através da migração das moças para cidade, bem como da diminuição do número de filhos e filhas por família. Observou-se que, na comunidade estudada, a população é constituída por um número significativo de agricultores e agricultoras em fase de aposentadoria. Além disso, verificou- se a quase ausência de jovens no trabalho agrícola, tornando a sucessão rural um dos principais desafios do assentamento.

A escolaridade da maioria das pessoas adultas do assentamento é o ensino fundamental, tendo algumas pessoas com ensino médio e até mesmo 
uma professora formada. Não foi possível observar uma diferença no nível na escolaridade entre homens e mulheres. A juventude e as crianças possuem um maior nível de escolaridade que os pais, e todas as crianças estão regularmente matriculadas em escolas públicas. As crianças menores estudam em escola presente no assentamento, Escola Municipal Mário Quintana, que oferece somente ensino fundamental, enquanto as crianças mais velhas se deslocam para outras escolas de Piratini, e outras conciliam o ensino médio com o ensino técnico em uma escola de um município vizinho. Fora da faixa escolar do ensino básico, as crianças não possuem acesso à educação infantil, potencializando um dos principais desafios enfrentados pelas mulheres, o de conciliar o cuidado dos filhos e filhas com o trabalho agrícola e doméstico.

O Assentamento Conquista da Liberdade está organizado, atualmente, em estrutura de agrovila, onde grande parte das famílias possuem suas moradias próximas uma das outras, sendo que cada moradia compreende um terreno de 20x40m; porém, nem todas as famílias vivem na agrovila, algumas moradias estão localizadas nos lotes individuais das famílias, que se encontram ao redor da agrovila. No centro está o grande lote coletivo de terras, pertencente às famílias que integram a Cooperativa.

\section{A ORGANIZAÇÃO DO TRABALHO}

Há uma disparidade na organização da produção no assentamento, existindo um modelo individualizado, em que as terras são utilizadas individualmente por cada família, e outro modelo em que é utilizado um sistema de produção coletiva da terra, com famílias utilizando áreas comuns. Das 48 famílias que residem atualmente no assentamento, 13 trabalham de forma coletiva, através da Cooperativa Agropecuária Vista Alegre - COOPAVA, e as demais trabalham de forma individual, sob o modo de produção agrícola de agricultura familiar, que, segundo Kunzler (2009), boa parte se dá em base agroecológica. 
No período em que as famílias foram assentadas, 1992, o MST influenciava seus integrantes ao desenvolvimento de um modelo de trabalho centrado na cooperação. Neste contexto, posteriormente à chegada das 50 famílias na localidade, foi estabelecida a forma de trabalho, que baseava-se em um modelo coletivo de produção, sendo que cerca de três anos depois se consolidou com a criação de uma Cooperativa. Porém, a experiência coletiva, ao longo do tempo, foi cedendo espaço com a saída de famílias para a produção individual.

As famílias que permaneceram com a intenção de trabalhar coletivamente no assentamento compreenderam que a melhor forma de consolidar o trabalho coletivo seria a partir de sua legalização. Nesse sentido, a experiência de cooperação no Assentamento Conquista da Liberdade deu vida, no ano de 1995, a uma Cooperativa de Produção Agropecuária (CPA), um dos modelos estimulados de cooperação pelo MST. A Cooperativa foi chamada de Cooperativa Agrícola Vista Alegre, tendo atualmente uma administração coletiva, dividida em núcleos.

O modelo de cooperação esteve presente desde a chegada das famílias no assentamento estudado, com a terra sendo um recurso de todos, não sendo divididos os lotes de maneira individual. Porém, conflitos e desentendimentos resultaram na ruptura do grande grupo coletivo, com isso, as famílias que se afastaram receberam seus lotes individuais. Foi com o argumento da busca de uma maior estabilidade enquanto agricultores familiares e a construção de meIhores condições de sobrevivência, que diversas famílias foram se desligando da Cooperativa, em diferentes momentos de sua história. Com isso, atualmente, 35 famílias do assentamento atuam de forma individual, exercendo atividades produtivas variadas.

As famílias que continuaram de forma coletiva construíram, ao longo dos anos, uma cooperativa destacada na região e dentro do próprio MST. No que se refere aos tipos de produção desenvolvidos pela cooperativa, podemos dizer que na mesma existem dois núcleos: animal, que abrange a criação de abelhas, peixes, suínos, ovinos e bovinos de leite e de corte; e vegetal, na qual são cultiva- 
dos produtos para alimentação (horta de legumes, verduras e frutas) (ARAUJO, 2009).

A quantidade satisfatória de gado leiteiro permitiu à Cooperativa dar atenção especial para a atividade leiteira. Nesse sentido, a Cooperativa é responsável pelo armazenamento, pasteurização, embalagem e comercialização de leite, tornando o leite o carro-chefe da mesma, sendo comercializado no varejo de Piratini, que segundo as interlocutoras é acessado por um consumidor diferenciado, por este ser um leite ecológico. A demanda do leite industrializado varia de dois a três mil litros de leite por semana. Também há a comercialização dos demais produtos em feiras e eventos em que o MST frequenta e organiza, mas sempre de forma esporádica.

Em relação às famílias individuais, foi possível observar que a diversidade nas formas de reprodução social é demonstrada também na qualidade das moradias, no acesso aos bens de consumo, nos aparelhos dentro de casa e nos automóveis, permitindo verificar que a sobrevivência desse grupo é bastante diferenciada, possuindo uma maior disparidade socioeconômica em relação ao grupo coletivo. Grande parte das famílias do modelo individual possui gado para a produção de leite, vendendo a produção para a Cooperativa do próprio assentamento, sendo a principal fonte de rende destas famílias. É possível verificar uma disparidade no número do rebanho leiteiro por parte das famílias, variando de cinco a quinze animais. Nos lotes individuais as culturas produzidas são bastante diferenciadas, sobretudo de alimentos essenciais para o autoconsumo das famílias, sendo as sobras desses cultivos destinados à comercialização.

As famílias individuais foram, ao longo do tempo, desenvolvendo diversas estratégias para sobreviver enquanto grupo social, como a organização de feiras. Nesse sentido, em busca de maior autonomia econômica e social, nasceu em 2014, com a união de algumas das famílias, a Associação dos Produtores Agroecológicos do Assentamento Conquista da Liberdade, composta somente por famílias assentadas do modo de produção agrícola familiar. Entre as atividades 
realizadas por esta Associação está a realização das duas feiras, uma no centro da cidade, tendo periodicidade semanal, e outra localizada em uma rodovia próxima ao Assentamento, tendo periodicidade de segunda a sábado.

\section{O TRABALHO E AS RELAÇÕES DE GÊNERO: A PERCEPÇÃO DAS MULHERES}

Para Brumer (1996, p. 96), quando falamos do trabalho da mulher rural, encontramos uma realidade muito peculiar, pois ela é integrante de uma unidade familiar em que "produção e reprodução do patrimônio e das pessoas constituem um processo único". Neste sentido, as pessoas que fazem parte da unidade familiar participam de diferentes momentos do processo produtivo, sendo que a organização do trabalho da família não é definida somente partir do ciclo das culturas, mas também a partir do gênero e da idade.

Sobre o papel da agricultura familiar, as interlocutoras da pesquisa apontam a sua importância para a preservação da vida ao produzir alimentos e para a estabilidade econômica do grupo social. Já sobre o papel da mulher na agricultora familiar, as entrevistadas destacam a importância de seu trabalho para a continuidade da agricultura familiar e seu protagonismo em atividades específicas como, por exemplo, horta, cuidado de pequenos animais e trabalho doméstico.

Para compreendermos as atribuições das mulheres no Assentamento e como se estrutura a divisão do trabalho é importante separarmos os dois modelos de trabalho presentes no assentamento estudado, pois cada um deles apresenta suas particularidades em relação ao trabalho da mulher.

\section{O trabalho das mulheres do grupo individual}

Primeiramente, se fez necessário entender os motivos que levaram as famílias destas mulheres a optarem pelo modelo de trabalho individual. Nesse sentido, alguns fatores foram apontados pelas entrevistadas, como conflitos com 
o modelo de gestão desenvolvido pela cooperativa, força física limitada para cumprir atividades pesadas na Cooperativa e busca de uma maior autonomia, que neste caso também é declarado em relação a divergências na Cooperativa.

As mulheres do modelo individual, assim como suas famílias, apresentam uma variedade de produtos comercializados e de culturas desenvolvidas. No geral, foi possível observar, durante a vivência no assentamento, que as mulheres do modelo individual, além das atividades dentro de casa, assumem responsabilidade nas seguintes atividades agrícolas: atividades manuais relacionadas ao trabalho agrícola, principalmente durante a fase de colheita dos produtos; atividades relativas ao processamento de produtos agrícolas, como a fabricação de produtos lácteos; cuidado de pequenos animais destinados ao consumo doméstico, incluindo a ordenha das vacas; preparo dos produtos para feira livre, além do atendimento na banca, conforme revezamento das famílias; responsabilidade pelos pequenos cultivos, especialmente os trabalhos com a horta.

A atividade leiteira é uma das principais atividades desenvolvidas por estas famílias, sendo que os homens, na maioria das vezes, se responsabilizam pelo cuidado das pastagens para o rebanho e o manejo dos animais, já as mulheres na grande parte das ocasiões se responsabilizam pela retirada do leite.

"Quem mais trabalha na produção do leite são as mulheres" é como uma agricultora descreve a divisão do trabalho nas famílias individuais do assentamento. Para Hernández (2010), no contexto da agricultura familiar, a produção de leite é vista como uma atividade importante pelo fato de ser uma fonte de alimento para a família, fornecendo uma renda mensal através da comercialização do que é considerado como excedente para o consumo familiar. Segundo Freitas (2007, p. 10), a divisão do trabalho "determinada histórica e culturalmente, não apenas destina os homens à esfera produtiva e as mulheres à esfera reprodutiva, como também atrela os primeiros às funções de maior valor social”. Essa ideia se baseia em dois princípios, o da separação, na qual existem trabalhos de homens 
e trabalhos de mulheres, e o da hierarquia, que faz os trabalhos de homens serem mais valorizados socialmente. Nesse sentido, Hernádez (2010), quando analisa a atividade leiteira na agricultura familiar camponesa, mostra que as mulheres, geralmente, são as responsáveis pela ordenha, especialmente quando essa atividade é realizada de forma manual. Além disso, comenta que quando a atividade é realizada por ordenhadeira é comum a participação dos homens.

Bourdieu (2014, p. 17), em seu livro A Dominação Masculina, expõe:

Aprimazia universalmente concedida aos homens se afirmanaobjetividade de estruturas sociais e de atividadesprodutivas e reprodutivas, baseadas em uma divisão sexual do trabalho e de reprodução biológica e social, queconfere aos homens a melhor parte.

De acordo com as entrevistadas, a divisão atual do trabalho no interior das famílias é fruto da iniciativa das próprias mulheres, conforme relato de uma agricultora, pois ao longo do tempo as mulheres "foram pra cima, pegaram as responsabilidades e tomaram peito, pois se esperassem pelos homens muitas coisas não aconteceriam." Expressando sobre as responsabilidades assumidas pelos homens no trabalho outra agricultora respondeu: "Alguns homens são bem acomodados, a mulher tem que tomar a iniciativa de fazer o que tem que ser feito".

Embora as mulheres reconheçam as atividades que exercem protagonismo no trabalho agrícola, ficou percebido que para aquelas do modelo individual, de um modo geral, o trabalho é assimilado como uma obrigação natural, onde as responsabilidades e a "chefia" de cada espaço de trabalho, "casa" e "lavoura", são muito bem definidas (WOORTMANN, 1995). "Sou a chefe apenas dentro de casa", assim descreve uma agricultora sobre as responsabilidades assumidas no trabalho familiar.

Nesse sentido, Kergoat e Hirata (2007) afirmam que a divisão do trabalho está ligada às relações sociais entre homens e mulheres, na qual as esferas econômica e doméstica se articulam, contribuindo para a manutenção das diferen- 
ças das práticas sociais de homens e mulheres. Para as autoras, as duas esferas estão estreitamente ligadas, uma estruturando e definindo a outra. Além disso, ficou evidente em vários depoimentos a percepção de que elas são "ajudantes" do marido na lavoura.

Nesse sentido, as tarefas executadas pelas mulheres no âmbito da esfera produtiva só são contabilizadas como parte de um esforço coletivo, na maioria das vezes aparecendo como ajuda, como uma agricultora comenta: "a mulher é o principal, mas escondida". Paulilo (2004) destaca que a invisibilidade do trabalho das mulheres rurais está na dificuldade de separar as atividades produtivas e não produtivas e, consequentemente, reconhecê-las, pois no campesinato é complexa a separação entre unidade familiar e de produção. Além disso, a dificuldade de separar o trabalho produtivo do trabalho reprodutivo também está no fato da atividade agrícola e da vida familiar se desenrolarem no mesmo espaço social, em que as relações sociais do casal são ao mesmo tempo relações de cônjuges e de colaboradores.

O modelo de agricultura caracterizado no Assentamento Conquista da Liberdade, desenvolvido a partir da unidade familiar é fundamental para a sobrevivência e reprodução de suas famílias, na qual é possível observar que nos exercícios das atividades agrícolas, os papéis são muito bem delimitados e definidos dentro da família, sendo que para uma mulher assumir atividades destinadas aos homens pode ser visto como um confronto aos valores hierárquicos.

Outro aspecto percebido durante a vivência foi relativo às tomadas das decisões pelos homens das famílias do modelo de trabalho individual, que ficaram evidentes no processo de comercialização do leite para a Cooperativa, pois é o homem que vai negociar e realizar a venda da produção. No entanto, em quase todas as famílias foi possível observar que o homem não negocia sem escutar a opinião de sua esposa sobre as negociações. Posteriormente, é o homem que terá acesso aos recursos financeiros oriundos das vendas para a Cooperativa, sendo decidido em conjunto o que comprar com o valor adquirido. Além disso, 
foi possível notar que são os homens praticamente os únicos responsáveis pelos contatos com extensionistas, bancos, cooperativa e vendedores de insumos.

Em estudo sobre assentamentos rurais, Ferrante (1998, p. 274) afirma que "a participação das mulheres nas diferentes estratégias de formação de renda convive com a reprodução de desigualdades e exclusões no âmbito das decisões". Para a autora, as responsabilidades de homens e mulheres não são tão rígidas em todos os momentos da vida dos assentamentos, pois em alguns momentos ocorre uma relativa cooperação entre homens e mulheres, como, por exemplo, nas definições de ações futuras do lote.

Não foi possível observar um consenso entre as entrevistadas sobre o acesso aos recursos financeiros decorrentes das atividades que desempenham. Algumas mulheres, principalmente aquelas que participam da feira livre, apontam que são elas que administram os recursos oriundos da feira, porém, quando questionadas sobre os outros recursos oriundos do trabalho familiar, afirmam que os recursos do trabalho na lavoura são acessados apenas pelos homens. Nesses casos, se verificou que as mulheres não possuem uma renda fixa. Além disso, outra agricultora, já aposentada, afirma que sua aposentadoria é administrada em conjunto com seu esposo e outra entrevistada afirma nunca ter participado da gestão dos recursos financeiros em sua casa, ficando apenas para seu esposo essa atribuição.

Foi possível verificar que a inserção das mulheres na feira livre tem contribuído para romper com a ideia de que a mulher está limitada à esfera privada, possibilitando a desconstrução do papel de mulher ajudante, uma vez que essa atividade tem grande protagonismo feminino, seja na produção dos produtos ou na comercialização. Além disso, as agricultoras destacam a troca de conversa com o consumidor como a principal motivação para realizar esta atividade, como descreve uma agricultora: "a gente saí do nosso mundinho e começa a conhecer outras pessoas". Porém, não se pode idealizar o espaço da feira livre no sentido de promover a igualdade de homens e mulheres, pois só a participação na feira 
não garante isso. Além disso, o preparo dos produtos para comercialização na feira faz com que as mulheres passem maior tempo dentro de casa, aumentando a rotina e carga de trabalho na medida em que a procura pelos produtos também aumenta.

Sobre conciliar o trabalho agrícola e o trabalho doméstico, as mulheres do modelo individual afirmam não sentirem muitas dificuldades, pois diferente do grupo coletivo, elas não precisam cumprir horários; porém algumas relatam não gostarem de realizar as atividades domésticas, remetendo que esta atividade é uma obrigação, algo já naturalizado em suas vidas, assim uma agricultora comenta: "só faço porque tem que fazer". Já outra entrevistada relata que "não tenho aquela neurose, mas gosto de manter as minhas coisas organizadas, não gosto de ver minha casa suja".

\section{O trabalho das mulheres do grupo coletivo}

Atualmente, a Cooperativa conta treze famílias cooperadas, sendo que apenas sete mulheres trabalham de forma direta, as demais atuam apenas nas atividades domésticas no interior de suas casas. $O$ trabalho é divido a partir de equipes, sendo que as mulheres desempenham atividades, em sua maior parte, na equipe da usina do leite, na qual se responsabilizam, principalmente, pela pasteurização do leite, na equipe da ordenha e na equipe da horta. A responsabilidade do trabalho não é exclusiva a uma única equipe, pois uma mesma agricultora pode estar envolvida em atividades de mais de uma equipe.

A Cooperativa, em sua organização interna, possui um Conselho em que as decisões são tomadas para, posteriormente, serem decididas na Assembleia Geral, a qual é a instância superior da organização. A tomada das decisões se dá por meio de votações, com a participação de todas as famílias inseridas. A terra é usada de forma coletiva entre todas as famílias deste grupo e as decisões sobre o uso da terra são realizadas através de acordo coletivo entre as famílias. A divisão dos valores entre os agricultores e agricultoras é realizada conforme a 
participação individual, para isso é utilizado um banco de horas que fixa o valor da hora, e o valor recebido por cada pessoa é correspondente ao número de horas trabalhadas (ARAUJO, 2009).

As relações sociais que se estabelecem na Cooperativa são objetos de conflitos e de discussões constantes. De acordo com Lechat (1996), o modelo de produção coletivo proposto pelo MST possui um caráter político, em que a forma de trabalho potencializa diversas reuniões para que todas as questões sejam discutidas de forma democrática.

A organização em grupo coletivo modificou o trabalho e a representação tradicional de agricultura familiar, mas também modificou as formas como se estabelecem as relações hierárquicas, pois a família não assume o papel de unidade produtiva individual e nem o homem o seu no trabalho agrícola, já que na Cooperativa a relação com a esposa não é como em casa. Entretanto, não quer dizer que os homens não façam parte do topo da hierarquia, pois são eles que assumem a chefia da produção, cuidam das atividades financeiras, além de realizarem as negociações.

No que tange à representatividade das mulheres, no momento da pesquisa nenhuma delas ocupava função de liderança ou chefia na Cooperativa. As interlocutoras, em suas falas, atribuem este fato à dificuldade de conciliar o trabalho domestico e o cuidado dos filhos com as reuniões da Cooperativa, porém todas relatam participar das assembleias. Sobre este fato, uma interlocutora resumiu: "a mulher está no comando, mas ao mesmo tempo não está". O que parece levar as mulheres a não ocupar cargos representativos na Cooperativa é a dupla jornada, conforme uma agricultora relata: "Umas querem mais é se livrar de muitas responsabilidades, pois já possuem a rotina de casa e dos filhos. Possuímos muitas mulheres com condições de lideres, mas elas não querem, eu também não quero".

Bourdieu (2014, p. 60), em seu livro “A dominação masculina”, estuda a divisão sexual da sociedade da Cabília, em que comenta: 
A divisão sexual está inscrita, por um lado, na divisão das atividades produtivas a que nós associamos a ideia de trabalho, assim como, mais amplamente, na divisão do trabalho de manutenção do capital social e do capital simbólico, que atribuiu aos homens o monopólio de todas as atividades oficiais, públicas, de representação, e em particular de todas as trocas de honra, das trocas de palavras (nos encontros cotidianos e sobretudo nas assembleias).

Lechat (1996, p. 123), estudando a questão de gênero no MST, destaca que as mulheres "[...] entraram na política não como seres assexuados, mas enquanto mulheres, mães de família participando de tudo, mesmo estando grávidas e levando consigo os bebês de colo". Segundo uma das entrevistadas "com o passar do tempo, às mulheres foram se arredando, porque chegam a suas casas e precisam fazer o serviço e cuidar dos filhos", em outro momento a mesma agricultura ressalta, "para o homem é mais fácil participar das reuniões, aí acabou que com o tempo ficou só os homens tomando as decisões".

Não foi só o fato de não ocuparem cargos representativos que transpareceu, mas também a posição subordinada destas mulheres no exercício de suas atividades e na tomada de decisões cotidianas, aquelas que não vão para apreciação em assembleia. Além disso, muitas vezes o trabalho destas mulheres na Cooperativa representa uma extensão do trabalho que elas executam em suas residências, como por exemplo, a responsabilidade pelas atividades domésticas. Em alguns processos da fabricação dos produtos lácteos a mulher foi conduzida a fazer atividades desempenhadas por elas em seus lares, como tarefas tediosas, repetitivas e de limpeza.

Neste contexto, Tedescchi (2009, p. 147), estudando a divisão sexual do trabalho, comenta:

A argumentação que usa a natureza para justificar a divisão sexual do trabalho traz implícita uma diferenciaçãoque está na formação cultural de homens e mulheres, nasrepresentações, nas imagens que se fazem do masculino e do feminino. A imagem do feminino está ligada aos afazeres domésticos, sem visibilidade, enquanto que aos homens 
são destinadas funções mais qualificadas e mais valorizadas no espaço público.

Dessa forma, a mulher entrou na vida pública através da Cooperativa, mas não abandonou o espaço privado, pois ela ainda continua sendo a responsável pelo trabalho doméstico, o que leva à manutenção e reprodução das relações familiares já estabelecidas. Neste sentido, Ferrante (1998, p. 267), ao discutir os modos de vida de famílias assentadas, destaca a inserção das mulheres em espaços de discussão e de decisões políticas, em que evidencia que "[...] em reuniões e assembleias as mulheres se colocam próximas às portas, como se de fato estivessem prestes a sair de um espaço que não é o seu".

Como já exposto anteriormente, além das atividades na Cooperativa, as mulheres também são as responsáveis pelos afazeres domésticos em suas casas. Igualmente ao grupo individual, as mulheres responsabilizam-se sozinhas pelo trabalho doméstico, na qual são auxiliadas, geralmente, por suas filhas. $\mathrm{Na}$ esfera doméstica, as mulheres possuem autonomia, tomando decisões relativas ao

preparo dos alimentos, cuidados da casa e da roupa, orientação e educação dos filhos, assim como o controle dos recursos destinados ao consumo doméstico.

Sobre conciliar o trabalho agrícola e o trabalho doméstico, as mulheres do modelo de trabalho coletivo mostram maiores dificuldades do que as inseridas no modelo individual. Assim, afirma uma interlocutora: "Tem dias que é corrido, que eu acho que não vou conseguir fazer tudo, tem que fazer comida, limpar a casa, mas no fim a gente faz tudo".

Não é de se surpreender que algumas mulheres prefiram exercer as atividades da Cooperativa, mesmo com a dureza do trabalho e de seu papel subalterno na mesma. Elas preferem exercem essa atividade ao trabalho doméstico, usando justificativas como; "Em casa a gente faz porque tem que fazer". Este fato também pode ser explicado pela invisibilidade do trabalho 
doméstico e por esta atividade não gerar remuneração. Neste sentido, Tedeschi (2009, p. 158) expõe que "o trabalho doméstico da dona de casa, seu valor e esforço, sua contribuição ao bem estar social, não é reconhecido como trabalho e não se reveste, portanto, de prestígio social".

No Assentamento Conquista da Liberdade, tanto as mulheres do grupo coletivo como as do modelo individual se responsabilizam pelo quintal de suas casas, onde exercem o cuidado com a horta e com pequenos cultivos para o consumo da própria família, além do trato com animais, especialmente aqueles de pequeno porte destinados ao consumo direto da família, como, por exemplo, galinhas. Porém, essas atividades, por não serem contabilizadas em valores monetários, não são percebidas para algumas mulheres entrevistadas como trabalho, já para outras é visto como trabalho, mas relatam não ser reconhecidos pelos demais membros da família como trabalho. Essa realidade contribui para fazer dessas atividades a extensão das tarefas domésticas.

Outro aspecto analisado foram às condições de trabalho, onde se verificou que as mulheres do modelo de trabalho coletivo estão inseridas em condições mais desgastantes que as mulheres do modelo individual, visto que enfrentam rotinas de trabalho mais pesadas e menos flexíveis. Elas apontam que "sempre lutaram para fazer tudo que os homens fazem", inclusive as atividades que exigem maior força física. Nesse sentido, também se constatou que a Cooperativa não possui programas ou ações para cuidar do bem-estar das agricultoras.

Em relação à percepção sobre o reconhecimento do trabalho, uma agricultura relata: "não posso dizer 100\%, pois às vezes na Cooperativa tem pessoas que não reconhecem". Já outra entrevistada expõe: "em casa sempre reclamam da comida feita ou acham que poderia ser feita alguma coisa de outro jeito". Neste contexto, o que percebemos é que a mulher não quer ocupar o espaço de autoridade na família destinado ao homem, mas deseja uma posição menos desigual, com o seu trabalho reconhecido e com o mesmo poder de decisão. 
As agricultoras comentam que nem sempre a divisão do trabalho é justa, pois as mulheres foram "decidindo ocupar espaços de trabalho que eram realizados por homens". O papel que a família desempenha no sentido de reforçar a invisibilidade feminina representa um dilema para o reconhecimento do trabalho da mulher em atividades produtivas e domésticas. Fora da Cooperativa, a mulher é reduzida à esfera doméstica, igualmente ao grupo individual, embora se reconheçam como agricultoras, será no interior da família que os papéis sociais de gênero serão constantemente estabelecidos e reestabelecidos. Assim, a tradicional distinção dos papéis para mulheres e homens e a construção social dos gêneros se sustentam numa rígida divisão do trabalho.

\section{CONCLUSÃO}

Toda pesquisa acadêmica, por mais objetiva que seja, nos coloca a grande responsabilidade de concluir. Nossa intenção não é de encerrar o debate da temática discutida ao longo deste estudo, mas colaborar com o seu fortalecimento em novas pesquisas e reflexões que tenham a intenção de mostrar a realidade das relações de gênero no rural, contribuindo para a transformação destas, rumo à igualdade.

A partir das singularidades apresentadas sobre as relações sociais em que as mulheres desta pesquisa estão inseridas e da proposta teórica das relações de gênero, nos fazem pensar em não propor um modelo ideal de trabalho e de relações de gênero. Aqui, o que interessa é analisar os resultados do estudo, descortinando suas desigualdades e compreendendo como ocorre a construção social dos gêneros a partir do trabalho.

Este trabalho, que teve como objetivo analisar as relações de gênero no Assentamento Conquista da Liberdade a partir do relato das agricultoras sobre o trabalho, nos permitiu conhecer a dura realidade na qual as mulheres estão inseridas, tendo seu trabalho inferiorizado ao mesmo tempo em que homens ocupam os espaços de poder e decisão. Neste sentido, vista a complexidade de abordar 
a desigualdade de gênero, primeiramente, cabe destacar o seu protagonismo na construção do espaço social em que estão inseridas e a sua importância no desenvolvimento da agricultura familiar.

O assentamento estudado é um espaço de múltiplas relações sociais, em que a vida em comunidade é construída a partir de vários aspectos, entre eles se destaca a interação que o trabalho provoca entre as famílias, sendo estabelecido a partir de uma profunda divisão nos papéis sociais de gênero.

No que se refere ao reconhecimento de seu papel na agricultura familiar, é preciso destacar que ainda falta um maior entendimento e valorização por parte dos homens e da sociedade de um modo geral sobre o trabalho desempenhado pelas mulheres. Além disso, estas mulheres ainda não reconhecem como trabaIho todas as atividades que desempenham principalmente aquelas realizadas na esfera doméstica, e percebem ser ajudantes de seus esposos em outras atividades, especialmente naquelas ligadas ao trabalho agrícola.

De acordo com a divisão do trabalho apresentada e a desvalorização do trabalho feminino presente no interior das famílias, entre outras questões, cabe destacar a relação entre a invisibilidade do trabalho das mulheres e o êxodo rural. O crescimento da saída dos jovens para a cidade, principalmente das moças, somado ao envelhecimento da população do assentamento, podem evidenciar a dificuldade de renovar quadros na Cooperativa e de permitir a sucessão rural, de um modo geral.

As mulheres inseridas nos dois modelos de trabalho reconhecem que muitas vezes são as que mais trabalham em uma determinada atividade, que estão inseridas em condições de trabalho mais desgastantes e que sentem dificuldades para conciliar o trabalho agrícola e o doméstico, alegando que ocuparam alguns espaços por iniciativas próprias. Neste sentido, foi possível perceber que os dois modelos de trabalho contribuem para sustentar desigualdades entre os homens e as mulheres, que se apresentam a partir de uma naturalização da divisão do trabalho. Esta divisão do trabalho impossibilita a participação feminina 
nos espaços de liderança, estabelecendo aos homens o poder das decisões, produz sobrecarga e desvalorização do trabalho da mulher, além de contribuir com a manutenção da dominação masculina, que perpassa vários campos e espaços sociais, Cooperativa, família e feira livre.

\section{REFERÊNCIAS}

ARAUJO, F. A Luta Continua Depois De Conquistá-La Uma Visão Acerca Do Assentamento Conquista Da Liberdade. Anais do XIX Encontro Nacional De Geografia Agrária, São Paulo, 2009.

BOURDIEU. P. A dominação masculina. 12 ed. Rio de Janeiro: Bertrand Brasil, 2014.

BRUMER, A. Mulher e Desenvolvimento Rural. In: PRESVELAV, Clio; ALMEIDA, Francesca R.; ALMEIDA, Joaquim Anécio. Mulher, família e desenvolvimento rural. Santa Maria: Editora da UFSM, 1996.

ESMERALDO, G. Mulheres da Via Campesina: ação política por novas formas de libertação. Anais do VIII Seminário Internacional Desfazendo Gênero. Florianópolis, 2008.

FERRANTE, V. Assentamentos rurais: espaços masculinos/femininos na construção de um novo modo de vida. In: ABRAMO, L.; e ABREU, A. (Orgs.) Gênero e trabalho na sociologia latino-americana. São Paulo; Rio de Janeiro: ALAST, 1998.

FREITAS, Taís Viudes; SILVEIRA, Maria Lúcia. Trabalho, corpo e vida das muIheres: crítica a sociedade de mercado. São Paulo: SOF, 2007.

HEREDIA, B. Gênero e acesso a políticas públicas no meio rural brasileiro. Revista Nera, Vol. (9), № 8. jan./jun. 2006.

HERNANDES, C. Reconhecimento e autonomia: o impacto do Pronaf-Mulher para as mulheres agricultoras. In: SCOTT, P.; CORDEIRO, R.; MENEZES, M.(Org.). Gênero e geração em contextos rurais. Ilha de Santa Catarina: Ed. Mulheres, 2010.

HIRATA, H.; KERGOAT, D. Division sexualle de travail professionel et domenestique: evolution de la problématique et paradigmes de la "conciliation". Anais Seminário Internacional Mercado de Trabalho Brasil França. São Paulo. 2007 
INTITUTO BRASILEIRO DE GEOGRAFIA E ESTATÍSTICA. Mapas Físicos. Disponível em: http://cidades.ibge.gov.br/xtras/perfil.php?codmun=431460. Acesso em: 10 abri. 2016..

KUNZLER, E. Agroecologia e a transformações sociais no espaço rural: o caso do Assentamento Conquista da Liberdade, Piratini, RS. Dissertação apresentada ao Programa de Pós-graduação em Geografia, Universidade Federal de Santa Maria. 2009.

LECHAT, N. A questão de Gênero no Movimento dos Trabalhadores Rurais Sem-Terra (MST): estudo de dois assentamentos no Rio Grande do Sul. ljuí, RS:UNIJUÍ, 1996.

PAULILO, M. Trabalho familiar: uma categoria esquecida de análise. Revista Estudos Feministas, Florianópolis, v. 12, n. 1, jan./abr. 2004.

O peso do trabalho leve. Ciência hoje, Rio de Janeiro. Vol. 5. (28) p. 64-70. Jan/fev. 1987.

SCHEFLER, M. Temas transversais na agricultura familiar: pesquisa e método sob enfoque de gênero e gerações. Anais do VIII Seminário Internacional Desfazendo Gênero. Florianópolis, 2008.

SCHWEDLER, S. F. A participação da mulher na luta pela terra: dilemas e conquistas. In: FERNANDES, B.; MEDEIROS, L.; PAULILO, M. I. S.

(organizadores). Lutas camponesas contemporâneas: condições, dilemas e conquistas. São Paulo: Editora UNESP - Núcleo de Estudos Agrários e Desenvolvimento Rural, 2009.

TEDESCHI, L. O uso da categoria gênero na história das mulheres camponesas: uma ferramenta necessária. In: MENEGAT, A.; TEDESCHI, A.; FARIAS, M.. Educação, relações de gênero e movimentos sociais: um diálogo necessário. Dourados: UFGD, 2009.

WEDIG, J.; MENASCHE, R. Práticas alimentares entre camponeses: expressão de relações familiares e de gênero. In: NEVES, D.; MEDEIROS, L. (Organ.) Mulheres camponesas: trabalho produtivo e engajamentos políticos. Niterói: Alternativa, 2013.

WOORTMANN, E. Herdeiros, parentes e compadres. São Paulo: Hicitec, 1995. 
doi $10.48209 / 978-65-89949-D 2-8$

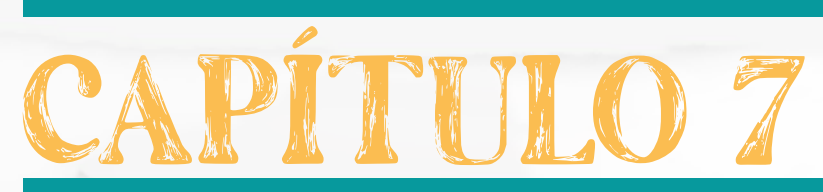

\section{OS DESAFIOS DA EDUCAÇÃO INLUSIVA NO MUNICÍPIO DE ITABAIANA SE:} $O$ CASO DA ESCOLA MUNICIPAL PROFESSSORA ANAILDE SANTOS DE JESUS 


\section{INTRODUÇÃO}

A educação tem um papel fundamental do desenvolvimento da sociedade, e principalmente na democratização do acesso a uma escola pública, gratuita e de qualidade. Nesse sentido, cabe estabelecer e garantir direitos a educação para todos, conforme estabelece a constituição federal de 1988. A partir desse viés, propomos refletir sobre o papel do professor na educação inclusiva, tendo como foco de pesquisa o caso da Escola Municipal Professora Anailde Santos de Jesus (EMPASJ) situada no povoado Cajaíba, município de Itabaiana - SE.

Tendo foco na aprendizagem, percebeu-se que para além do acesso à escola, os alunos especiais necessitavam de garantia de aprendizagens na sala de aula, e a inclusão seria um viés de socialização do conhecimento e principalmente na motivação para o desenvolvimento das habilidades e competências destes indivíduos.

Para tal, buscou-se historicamente a leitura de algumas leis que estabeleciam os direitos de alunos com necessidades educacionais especiais na educação. Desse modo, compreendendo as contradições no processo de ensino-aprendizagem, utilizou-se o materialismo histórico-dialético para entender a educação inclusiva no desenvolvimento da educação.

Os trabalhos de campo e os estudos bibliográficos serviram de suporte para a compreensão da educação inclusão no contexto atual. Nesse caso, observou-se que a secretaria municipal de educação (SEDUC) DE Itabaiana busca melhorar o atendimento a educação inclusiva na escola, tendo como referências a Lei de Diretrizes e Bases da Educação Nacional de 1996 e a Declaração de Salamanca. Estas iniciaram avanços importantes na legislação da educação inclusiva, e nos abre possibilidades de entender a relação ensino-inclusão na educação itabaianense. 
As ações na EMPASJ por meio das diretrizes estabelecidas pela SEDUC possibilitaram melhoramento no atendimento educacional especializado (AEE), visando garantir o acesso à educação para todos.

No tocante, percebe-se que o papel do professor como mediador na proposta de educação inclusiva é fundamental no AEE, no qual receber os alunos com necessidades educacionais especiais, e garante o direito do acesso ao processo de ensino-aprendizagem de forma inclusiva. Desse modo, observou-se que é necessária uma ampliação do projeto político pedagógico da escola analisada, para garantir aos professores e alunos especiais um suporte na inclusão de qualidade.

Assim, para que haja uma educação inclusiva é fundamental que os professores busquem capacitação, aperfeiçoamento e formação continuada, a fim de contribui no processo de ensino-aprendizagem e consequentemente, respeitar as diferenças e particularidades de cada aluno.

\section{O PAPEL DO PROFESSOR NA EDUCAÇÃO INCLUSIVA: 0 PROCESSO DE ENSINO-APRENDIZAGEM EM SALA DE AULA}

A Escola Municipal Professora Anailde Santos de Jesus (EMPASJ) localiza-se no Povoado Cajaíba, zona rural do município de Itabaiana-SE. Fundada em 1960 no governo de Oviedo Teixeira, com denominação de Escola Rural Cajaíba, na qual era administrada inicialmente pelo poder público estadual. Na decada de 1970, a unidade de ensino passou por problemas de falta de professores para ministrar as aulas, e no ano de 1978, o governo estadual resolveu tranferir a escola para o gerencimaneto do município, onde a mesma passa a ser uma escola municipal até os dias atuais, passando por diversas reformas em sua esrutura física para atender a demanda local e circuvizinhas.

A escola é um ambiente educativo de múltiplas culturalidades que exige do professor posicionamentos teórico-metodológico no desenvolvimento didático-pedagógico em sala de aula. Nesse ponto, o uso de método de ensino, a sua 
escolha e a organização dos conteúdos de aprendizagem são fundamentais para que o aluno consiga cognitivamente aprender reflexivamente o objeto de estudo.

As construções de metodologias de ensino na sala de aula podem apresentar resultados positivos para os alunos, em especial, os alunos que possuem alguma deficiência, pois, eles precisam de atenção e interação com os outros alunos para a construção do conhecimento.

Nesse bojo, baseado no construtivismo, entendemos que o professor é o mediador entre o sujeito que aprende e o objeto do conhecimento. Aliás essa mediação está na origem da aprendizagem, onde a intervenção planejada do educador favorece a ação do aprendiz sobre o objeto de estudo.

Na EMPASJ, observa-se que a equipe diretiva juntamente com os professores buscam instrumentos para detectar com clareza as dificuldades de aprendizagem dos alunos, e principalmente, se existem alunos com deficiências especiais. Assim, na sala de aula, o professor tem em suas metodologias de ensino instrumentos que serão utilizados para identificar com clareza a aprendizagem dos alunos, observando o que seus alunos já sabem e o que eles não sabem, tendo uma relação professor-aluno reciproca.

Nesse aspecto,

o conjunto de procedimentos lógicos, de acordo com uma concepção de ensino (fundamentação teórica), que possibilitam a articulação coerente dos diferentes elementos didáticos: conteúdos, objetivos, métodos/técnicas, recursos didáticos e processos avaliativos. (LIBÂNEO, 2013).

O professor tem em seu suporte teórico-metodológico ferramentas capazes de fazer a prática de ensino acontecer de forma clara e objetiva, enfatizando a aprendizagem de diversas maneiras com o uso apropriado de metodologias de ensino que media a relação professor aluno na construção do conhecimento.

No obstante, como ponto de partida para entender a formação de professores, Garcia (1999) conceitua que: 
a formação de professores é a área de conhecimentos, de investigação e de propostas teóricas e práticas que, no âmbito da Didática e da Organização Escolar, estuda os processos através dos quais os professores — em formação ou em exercício — se implicam individualmente ou em equipa, em experiências de aprendizagem através das quais adquirem ou melhoram os seus conhecimentos, competências e disposições, e que lhes permite intervir profissionalmente no desenvolvimento do seu ensino, do currículo e da escola, com objetivo de melhorar a qualidade da educação que os alunos recebem. (GARCIA, 1999, p.26)

Nesse contexto de ensino-aprendizagem, a escola torna-se fundamental na construção do lugar com a comunidade, e principalmente, como instituição de ensino que constituirá pilares para que concretize a aprendizagem do aluno. Corroboro com Bartnik (2012), ao enfatizar que

Os estudantes precisam ter uma formação que lhes permita compreender a lógica e as relações do mercado de trabalho, dominar as novas tecnologias, estar abertos às diversas relações humanas e, consequentemente, adquirir uma formação tanto para a cidadania como para o mercado de trabalho. (BARTNIK, 2012, p. 49)

Dessa forma, o momento atual exige o discernimento das contradições das relações sociais na construção do conhecimento, onde "na grande maioria, as políticas de desenvolvimento partem do estado, embora na prática observemos que os maiores responsáveis pela mudança e pelo desenvolvimento de uma localidade ${ }^{1}$ são as pessoas que nela vivem". (Ibid. p.86)

Assim, o papel do professor em sala de aula é necessariamente fundamental na inclusão dos alunos especiais, e principalmente, na mediação teoria-prática de ensino. Concordo com a afirmação de Rocha (2017),

a educação inclusiva no modelo atual é um desafio aos professores, pois obriga-os a repensar sua maneira de ensinar, sua cultura, sua política e suas estratégias pedagógicas, adotando uma postura receptiva diante da singularidade que irá encontrar, a fim de detectar potencialidades e expor habilidades de acordo com a demanda de cada aluno. (ROCHA, 2017, p.7)

$1 \quad O$ conceito de lugar diz respeito às localidades onde as pessoas constroem referências pessoais por meio de relações afetivas, subjetivas, além de estabelecerem suas identidades e valores. Alias, é no lugar que podemos vislumbrar nitidamente as contradições que ocorrem em nossa localidade com maior nitidez. 
Dessa forma, ao compreender o papel do professor em sala de aula, devemos entender que a inclusão social se torna necessária para o desenvolvimento da sociedade e a superação das contradições no processo de ensino-aprendizagem.

\section{EDUCAÇÃO ESPECIAL NA PERSPECTIVA DA EDUCAÇÃO INCLUSIVA: DESAFIOS NA SALA DE AULA}

A escola tem um papel fundamental no desenvolvimento da sociedade. Contudo, as nuances sobre o atendimento educacional direcionado as pessoas com deficiência foi construído historicamente numa perspectiva separatista da educação oferecida a população que não apresentava diferenças, ou melhor, ditas "normais".

Essa construção histórica teve rebatimentos significativos na educação especial, no qual as lutas cotidianas por direitos de igualdade perpetuaram ao longo dos anos por uma educação inclusiva. Corroboro com ao afirmar que

a educação especial constituiu-se como um campo de atuação específico, muitas vezes sem interlocução com a educação comum. Esta separação materializou-se na existência de um sistema paralelo de ensino, de modo que o atendimento de alunos com deficiência ocorreu de modo incisivo em locais separados dos outros alunos. (KASSAR, 2011, p.62)

Cabe salientarmos que a Constituição Federal de 1988 configurou-se como um marco jurídico para o Brasil. Sucintamente, observa-se que está se caracteriza pelo envolvimento da sociedade civil organizada, no qual se tem estabelecido na constituição uma ênfase nos direitos sociais e pelo estabelecimento dos princípios de descentralização e municipalização para a execução das políticas públicas sociais, inclusive na educação, que passa a ser considerada direito subjetivo, conforme se verifica nos princípios constitucionais no estado democrático de direito brasileiro. 
Nesse viés, corroboro com as colocações de Kassar (2011), ao enfatizar que

Constitucionalmente implicado, o Governo Federal desde a década de 1990 tem implantado e/ou fomentado um conjunto de ações nas várias áreas dos serviços públicos como parte do sistema de proteção social. No entanto, também a partir dessa década, o governo brasileiro passou claramente a adequar-se à organização do mercado mundial globalizado na expansão do modelo econômico capitalista. Desde o governo de Fernando Collor de Mello (1990-1992), tornou-se constante um discurso sobre a modernização da economia com críticas à ação direta do Estado, principalmente nos setores de proteção social. Na continuidade dessa tendência, Fernando Henrique Cardoso (1994- 1998; 1998-2002) assumiu o governo brasileiro e seu discurso sustentou-se na construção de uma "terceira via", expresso desde a aprovação do Plano Diretor da Reforma do Aparelho de Estado (BRASIL, 1995). Nessa reforma, setores importantes como a educação e a saúde deveriam ter como corresponsáveis o "terceiro setor", através da ação das instituições públicas não estatais. (KASSAR, 2011, p.69)

Em face de essa lógica desenvolvimentista está em curso, observou-se que a universalização da educação para todos ganhou ênfase a partir dos anos de 1990, na Conferencia Mundial da Educação para todos, ocorrido na Tailândia, na qual o movimento da educação para todos teve rebatimentos no direito a educação para pessoas com deficiências.

No bojo das mudanças no cenário educacional no Brasil não podemos deixar de enfatizar os avanços na década de 1990, no qual o processo de educação inclusiva teve significativas conquistas com a criação da Lei de Diretrizes e Bases da Educação Nacional 9394/96, que em consonância com a Constituição Federal garante a todos os mesmos direitos. Corroboro com a leitura dos autores Pires, Sanches e Torres (2011), ao enfatizar que [...] a luta pela inclusão das pessoas com deficiência é fortalecida no mundo todo, deixando para trás a história de séculos de descaso e discriminação em relação às suas necessidades diferenciadas. (PIRES; SANCHES; TORRES, 2011, p. 02). 
Objetivando essas mudanças, entende-se por inclusão social como

Processo pelo qual a sociedade e o portador de deficiência procuram adaptar-se mutuamente, tendo em vista a equiparação de oportunidade e, consequentemente, uma sociedade para todos (...). A inclusão significa que a sociedade deve adaptar-se às necessidades da pessoa com deficiência para que esta possa desenvolver-se em todos os aspectos de sua vida (SASSAKI, 1997, p. 167).

Nesse sentido, cabe estabelecer que o cenário educacional de uma proposta de inclusão social na educação ocorreu avanços com a A promulgação da LDB de 1996, e paralelemente, com a Resolução CNE/CEE nº 02/2001, na qual a educação especial oferta apoios e serviços especializados aos alunos com necessidades educacionais especiais.

Enfatizando a leitura sobre a educação especial, observamos que na obra de Fernandes (2006(, intitulada de "Metodologia da Educação Especial" traz significativos apontamentos na perspectiva inclusiva, conforme destacam-se:

- Alunos surdos, que, por suas necessidades linguísticas diferenciadas, precisam conhecer a língua de sinais e exigem profissionais intérpretes;

- Alunos com deficiência visual, que necessitam de recursos técnicos, tecnológicos e materiais especializados;

- Alunos com deficiência física neuromotora, que exigem a remoção de barreiras arquitetônicas, além de recursos e materiais adaptados à sua locomoção e comunicação;

- Alunos com deficiência intelectual, que demandam adaptações significativas no currículo escolar, respeitando-se seu ritmo e estilo de aprendizagem;

- Alunos com condutas típicas de síndromes e quadros neurológicos, psiquiátricos e psicológicos que demandam apoios intensos e contínuos, além de atendimentos terapêuticos complementares à educação;

- Alunos com altas habilidades/superdotação, que, devido às motivações e aos talentos específicos, requerem enriquecimento, aprofundamento curricular e/ou aceleração de estudos. (FERNANDES, 2006, p. 30)

Nesse contexto, o papel do professor é de suma importância na educação especial, visto que o professor é a "autoridade competente, direciona o processo pedagógico, interfere e cria condições necessárias à apropriação do conheci- 
mento" (GAZIM et. al, 2005, p.51). Sendo assim, veremos como a proposta de especial no município de Itabaiana - SE, e especialmente, o caso da escola Municipal professora Anailde Santos de Jesus.

De acordo com a Secretaria de educação de Itabaiana

todo trabalho da rede é fundamentada na Constituição Federal garante ao cidadão com necessidade especial o direito de acesso ao ensino regular, conforme o artigo 208, inciso III, assim como a Lei 10 845/2004 institui a complementação ao Atendimento Educacional Especializado as Pessoas Portadoras de Deficiência, pode citar a resolução Municipal de Educação nos seus artigos assegura a educação das pessoas com necessidades educacionais especiais na rede regular de ensino. Como também, fundamentada na LDB 9394/96 nos artigos 58 a 60 define a Educação Especial como uma modalidade de educação escolar que perpassa numa ação transversal em todos os níveis. (SECRETARIA DE EDUCAÇÃO DO MJUNICIPIO DE ITABAIANA - SE, 2021, p.02)

A partir dessa concepção, procuramos perceber que a educação no município de Itabaiana busca meio para tentar melhorar a educação especial. Ainda nesse contexto, observa-se que

O município de Itabaiana através do Conselho Municipal de Educação Inclusiva institui a Resolução de $N^{\circ}$ 02/2012 que busca garantir a matricula ou seja o acesso e a permanência do aluno portador de necessidades educacionais especiais. Ao mesmo tempo entendemos que uma escola inclusiva é muito mais que construir rampas e banheiros adequados. A rede já realizou nas escolas algumas mudanças nas estruturas e funcionamento das escolas. (Ibid., p.02)

Apesar dos esforços evidenciados na concretização da educação especial no município, algumas escolas ainda necessitam de reparos físicos e adequações em suas instalações para garantir o acesso físico a escola e comprometer uma melhoria na qualidade educacional no município. No que tange a educação especial, destacamos a Lei 13146/2015, Lei Brasileira de Inclusão (LBI) traz importante contribuição ao definir que: três profissionais atendam as demandas no atendimento ao estudante com deficiência: o atendente pessoal, o acompanhante e o profissional de apoio escolar. 
Nesse viés, o relatório da Secretaria municipal de Itabaiana, mostra que

O inciso XII do Art. $3^{\circ}$ da LBI, diz que o "atendente pessoal é a pessoa, membro ou não da família, que, com ou sem remuneração, assiste ou presta cuidados básicos e essenciais à pessoa com deficiência no exercício de suas atividades diárias, excluídas as técnicas ou os procedimentos identificados com profissões legalmente estabelecidas. " (...) Como eu disse lá no início do texto o inciso XIII do mesmo artigo determina, que o profissional de apoio escolar é aquele que presta apoio em atividades de alimentação, cuidados pessoais e locomoção, bem como na inclusão pedagógica do estudante com deficiência, sob a forma de acompanhamento individualizado e de promoção, em caráter geral, da inclusão na instituição de ensino e na sua proposta político-pedagógico". Já o inciso XIV diz que o acompanhante é "aquele que acompanha a pessoa com deficiência, podendo ou não desempenhar as funções de atendente pessoal". (lbid., p.03)

Dessa maneira, no município de Itabaiana - SE, a Educação Especial apresenta como um grande desafio exigindo investimentos, tanto na estrutura física das escolas como também na estrutura pedagógica. Para tanto, a EMPASJ busca diversas maneiras para garantir uma educação de qualidade para todos os alunos.

\section{POR UMA EDUCAÇÃO ESPECIAL NO MUNICÍPIO DE ITABAIANA: A EMPASJ E SEUS DESAFIOS ATUAIS}

O processo de ensino-aprendizagem busca meios para que o aluno consiga sistematizar os conteúdos de ensino e consigo desenvolver habilidades e competências que venham a acarretar transformações na sociedade. Nesse sentido, observar-se que o papel do professor é o mediara relação teoria-prática, visto que este

é mediador entre o aluno e o conhecimento e cabe a ele promover situações pedagógicas em que os alunos com necessidades educacionais especiais superem o senso comum e avance em seu potencial humano afetivo, social e intelectual, quebrando as barreiras que se impõem. (ROCHA, 2017, p. 6)

A partir dessa realidade, cabe salientar que a proposta de inclusiva no município de Itabaiana - SE vem sendo trabalhada conforme a realidade des- 
te território. Apesar disso, várias vezes os professores apresentam resistências quando o assunto é mudança, causando certo desconforto, conforme MINETTO (2008) ressalva,

Quanto mais conhecemos determinado fato ou assunto, mais nos sentimos seguros diante dele. O novo gera insegurança e instabilidade, exigindo reorganização, mudança. É comum sermos resistentes ao que nos desestabiliza. Sem dúvida, as ideias inclusivas causaram muita desestabilidade e resistência (MINETTO, 2008, p.17).

Apesar de algumas vezes o professor fazer resistência, ele acaba sendo inserido e conseguindo adequa-se a nova realidade trazendo novos elementos que serão agregados à educação especial, contribuindo para a melhoria da qualidade de ensino. Nesse sentido, a presente proposta da Secretaria de Educação Municipal de Itabaiana - Se traz algumas explanações, dentre elas:

o nosso principal objetivo é melhorar e ampliar o atendimento das crianças com deficiência na rede municipal de Educação. Assim, o planejamento estratégico contribui para o fortalecimento da Educação Municipal como um todo. Segundo os dados do Registro de matricula de 2021 a rede possui 200 alunos com deficiência matriculados e com relatórios médicos informando a CID e 35 alunos com dificuldade aprendizagem. Destes, 61 alunos são autistas e os demais diferentes deficiências. A rede possui 69 Apoio Escolar que atende a 97 alunos da rede no ano de 2019, que não foram recontratados devido a pandemias iniciada em 2020 e as aulas presenciais forma suspensas presencial. As atividades são enviadas para os alunos com deficiência e transtorno do espectro de autismo (TEA) para serem realizadas em casa. (SECRETÁRIA MUNICIPAL DE EDUCAÇÃO DE ITABAIANA - SE, 2021, p. 01)

Ainda de acordo com o relatório disponibilizado pela Secretária de Educação (SEDUC) do município de Itabaiana - SE, verificou-se que

a rede municipal possui um Centro de Atendimento Educacional Especializado (AEE) fundado no ano de 2013 com uma equipe multidisciplinar (psicóloga, psicopedagoga e assistente social) que realiza a triagem dos alunos da rede e faz atendimento a uma média de 35 alunos com dificuldade de aprendizagem. No ano de 2019 foi implantada (03) três salas de recursos multifuncionais funcionando com (06) turmas sendo (03) três no turno matutino e(03) três pra o turno vespertino e aumentando mais uma agora em 2021 mais uma sala de SRM com mais duas turmas na rede. 
Em resumo, possui 4 salas de Recursos Multifuncionais com 08 turmas, assim, atendendo uma média de 80 alunos com deficiência nestas. (Ibid., p.01)

As ações disponibilizadas pela SEDUC do munícipio descentralizar as ações para as unidades escolares, dando suporte aos profissionais da educação na melhoria do atendimento especializado aos alunos com necessidades especiais. Para além dos muros da escola, as ações socializam-se na comunidade afim de quebrar os "preconceitos" ainda enraizados na sociedade com as pessoas com necessidades especiais.

Na EMPASJ, a estrutura da unidade escolar oferece oportunidade de deslocamento físico para estes alunos, além do acompanhamento pedagógico oriundo da relação da SEDUC - EMPASJ via necessidade de monitor em sala de aula para orientar e auxiliar os alunos especiais no desenvolvimento cognitivo, além de facilitar o processo de assimilação do conhecimento.

Diante desse contexto, o município de Itabaiana vem dando suporte as escolas nas transformações de suas estruturas físicas para atender os alunos com necessidades educacionais especiais. Nesse sentido, a EMPASJ passou por reformas em suas estruturas físicas ao longo dos anos de 2000 até os dias atuais para atender as demandas locais e corroborar com a inclusão social na escola. Como podem-se observar na figura 01, a estrutura física da escolar traz um suporte para receber estes alunos conforme as leis vigentes na educação para facilitar o acesso a educação. 
Figura 01. ESTRUTURA FÍSICA DA ESCOLA MUNICIPAL PROFESSORA ANAILDE SANTOS DE JESUS 2021

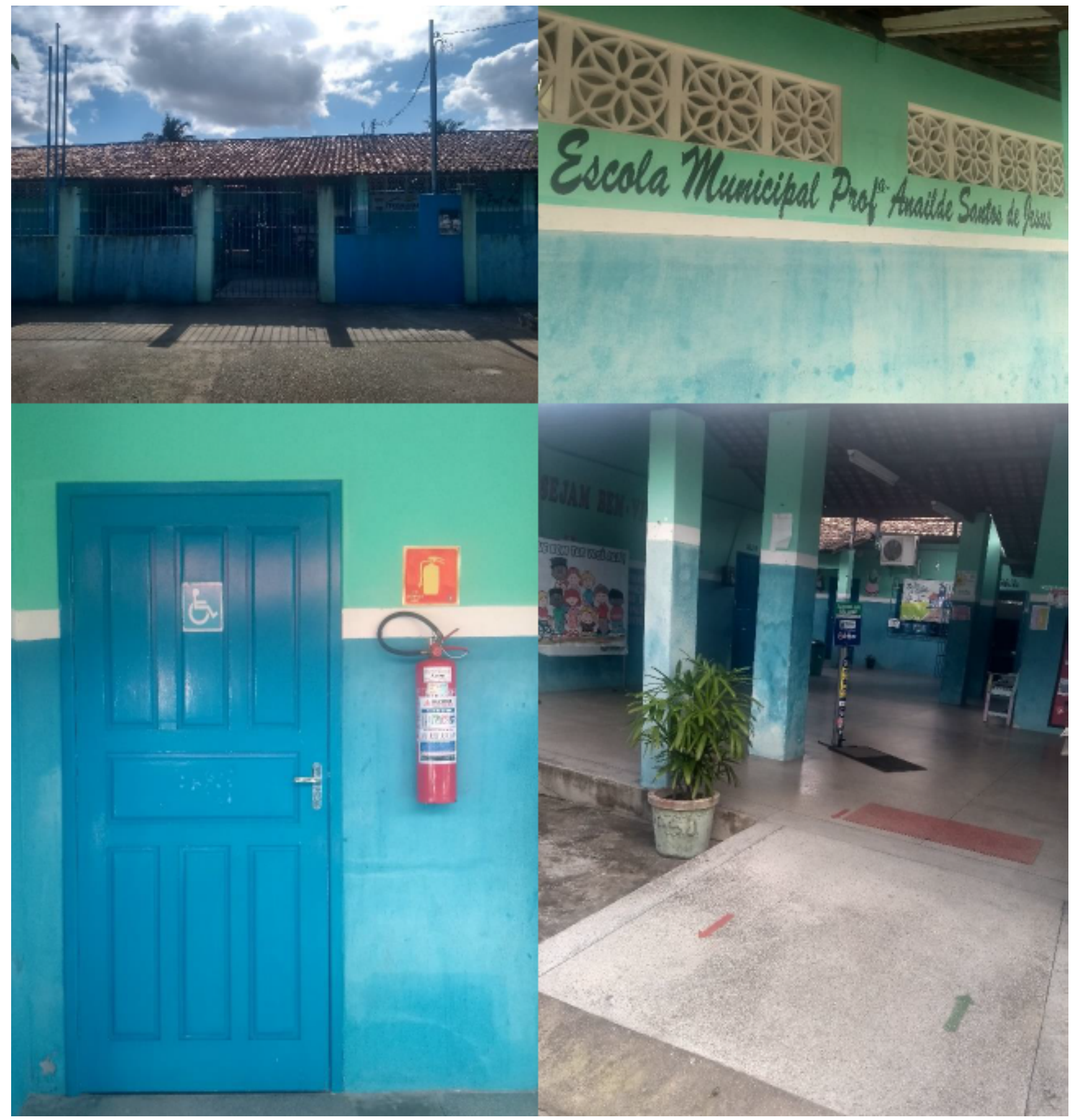

Fonte: Trabalho de campo, 2021.

Organização: Fábio Ferreira Santos, 2021.

Como percebe-se a EMPASJ atende os protocolos vigentes nas leis da educação inclusiva, e busca melhoria no atendimento dos alunos por meio da inserção de metodologias ativas que venham a acarretar no desenvolvimento das competências e habilidades destes alunos. No tocante, ao desenvolvimento 
das atividades verifica-se que a SEDUC disponibiliza meios para que a aprendizagem possa ocorrer processualmente e com qualidade no ensino. Dessa forma,

Quanto ao perfil dos profissionais que atuam nas salas de recursos, verificou-se que são (08) oito professores, eram 04 efetivos e 4 do PSE, mais agora temos (05) três efetivos e (03) três do processo seletivo, todos possuem a formação em especialização Educação em Inclusiva. As turmas são organizadas de acordo a proximidade do local que a criança mora com a sala de atendimento. $O$ atendimento ocorre duas vezes por semana, para cada aluno em horário contrário da escola regular, sendo um momento individual e outro em grupo de dois ou três crianças. (Ibid., p.01)

Para além dos muros da escola, a socialização com a comunidade escolar no desenvolvimento dos projetos pedagógicos da EMPASJ serve como instrumento de aproximação e conscientização da importância do atendimento educacional especializado para os alunos especiais nas unidades de ensino, visto a complexidade e a dificuldade destes em desenvolver suas habilidades e competências devido aos seus distúrbios especiais.

Embora, as dificuldades sejam frequentes, estas estimulam os professores e a equipe diretiva a solucionar os problemas e buscar métodos e metodologias de ensino que sejam capazes de trazer os alunos especiais a dinâmica na sala de aula e a buscar a interação entre teoria-prática na construção do conhecimento.

Dessa forma, a EMPASJ vem contribuindo para a inclusão social na educação, construindo pilares entre comunidade escolar e atendimento educacional especializado no desenvolvimento das atividades didático-pedagógicas na educação básica do povoado Cajaíba, no município de Itabaiana - SE.

\section{CONSIDERAÇÕES FINAIS}

Os desafios da educação especial e inclusiva no município de Itabaiana vem mostra que as iniciativas tomadas pela secretaria de educação e pela EMPASJ tem sido viável para a melhoria do acesso dos alunos especiais a educa- 
ção e a socialização do conhecimento. Nesse sentido, a legislação brasileira vem contribuindo para que o atendimento especial especializado fosse garantido aos alunos com necessidades educacionais especiais.

Na sala de aula, os professores têm um papel fundamental na educação inclusiva, visto o desafio de inserir no processo de inclusão novas propostas de ensino, atuando de forma diferenciada e com um olhar diferente em sala de aula, sendo um agente mediador e facilitador no processo de ensino-aprendizagem. Desse modo, os professores da EMPASJ buscam metodologias que insiram os alunos com necessidades educacionais especiais no contexto da sala de aula, fazendo interação com os outros alunos e trabalhando em grupos para que a coletividade possa ser uma ferramenta de inserção destes no processo educacional.

Na EMPAJ, os professores buscam novas posturas e habilidades na construção de uma proposta inclusiva, tendo metodologias ativas que permitirá uma visão positiva das pessoas com necessidades especiais. Além do mais que, estes profissionais buscam formação continuada para construir uma nova proposta de educação especial e inclusiva.

Sendo assim, a EMPASJ vem permitindo a inclusão educacional dos alunos com necessidades educacionais especiais, garantindo desde o acesso a escola e a sala de aula até a prática de ensino, uma vez que os professores estão aptos a ensinar estes alunos, além de buscar uma formação continuada que contribuirá ainda mais para a formação profissional e a melhoria da qualidade de ensino nesta unidade escolar.

\section{REFERÊNCIAS}

FERNANDES, S. Metodologia da Educação Especial. $1^{\text {a }}$ ed. Curitiba. IBPEX, 2011. 
Lei $n^{0}$ 13.146, de 06 de julho de 2015. Institui a Lei Brasileira de Inclusão da Pessoa com Deficiência (Estatuto da Pessoa com Deficiência). Disponível em: http:// www.planalto.gov.br/ccivil_03/_Ato2015-2018/2015/Lei/L13146.htm Acesso em: 20 de junho. 2021.

LIBÂNEO, J. C. Didática. 2 ed. São Paulo: Cortez, 2013.

KASSAR, Mônica de Carvalho Magalhães. Educação especial na perspectiva da educação inclusiva: desafios da implantação de uma política nacional. Editora UFPR, Educar em Revista, Curitiba, Brasil, n. 41, p. 61-79, jul./set. 2011.

SECRETÁRIA MUNICIPAL DE EDUCAÇÃO DE ITABAIANA. TEXTO SOBRE A MODALIDADE DE ENSINO EDUCAÇÃO ESPECIAL DA REDE MUNICIPAL DE ITABAIANA/SE/2021: Uma proposta de Educação Inclusiva vivências e desafios. SEDUC, Itabaiana - SE, 2021.

ROCHA, Artur Batista de Oliveira. O PAPEL DO PROFESSOR NA EDUCAÇÃO INCLUSIVA. Revista Ensaios Pedagógicos, v.7, n.2, Jul/Dez 2017.

PIRES, E. C. S.; SANCHES, A. A.; TORRES, W. R. Dificuldades dos portadores de necessidades especiais na inclusão educacional. Unitins, 2011. Disponível em: <http://ava2.unitins.br/ava/files/projetoconteudo/cccfd876821308039570f71ae697d083

.html> Acesso em 10 março de 2021.

SASSAKI, R. K. Inclusão: construindo uma sociedade para todos. Rio de Janeiro, WVA, 1997. 


\section{dol 10.48209/978-65-89949-D2-9}

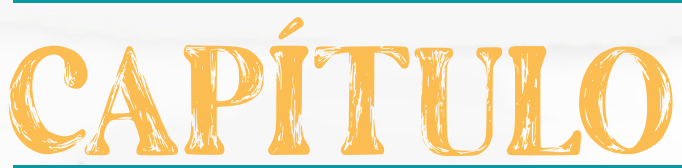

\section{AMBIENTAL NAS}

ESCOIAS DO CAMPO:

\section{UMA PRÁTICA} PARA ALÉM DA

\section{SALA DE AULA}

Cauana Peyrot Conceição Pedro Valdir da Conceição Liziany Müller Rogério Oliveira Pinheiro 


\section{INTRODUÇÃO}

O presente artigo foi desenvolvido a partir da proposição da disciplina, Seminário Integrador II, do curso de Licenciatura em Educação do Campo da UFSM. Foi desenvolvido em uma escola municipal de ensino fundamental localizada em um assentamento de trabalhadores sem-terra-MST (Assentamento Ceres), no município de Joia (RS). Teve como foco a educação ambiental através do reaproveitamento de resíduos orgânicos descartado na cozinha escolar. O objetivo principal é a ênfase na educação ambiental, levando a conscientização sobre as práticas corretas de cuidados ambientais como uma questão também social e econômica.

Acreditamos que a escola sempre foi e será o melhor lugar para formação do ser humano. Nesse sentido, entendemos esse espaço como privilegiado, de valorização, reconstrução e formação de novos saberes. Visando aproveitar meIhor a oportunidade de trabalhar as questões ambientais, nos propomos a desenvolver o projeto de educação "Educação Ambiental: um estudo para além da sala de aula" com a turma do $5^{\circ}$ ano da escola.

Numa sociedade ao qual visa atender aos interesses de um sistema econômico capitalista, embasado na obtenção do lucro a qualquer custo, a problemática ambiental foi ignorado por muito tempo. No entanto, discussões existentes sobre, nos últimos anos, têm envolvido as diversas áreas do conhecimento em debates, buscando a melhor maneira de abordar o tema. Estamos a cada dia percebendo práticas, as quais consideramos inadequadas em relação aos cuidados com o meio ambiente.

Nesse sentido nos apropriamos da "pesquisa-ação" em virtude de constatar que seria a mais adequada no sentido de aliar teoria e prática na aplicação da proposta pedagógica, possibilitando incluir os materiais impressos e audiovisuais para o desenvolvimento teórico e nos apropriarmos da prática na construção da composteira, contando com o envolvimento dos alunos. 


\section{CONCEITO DE EDUCAÇÃO DO CAMPO}

O campo é um local de trabalho, de vida, de cultura, de produção de conhecimentos, de subsistência. A educação do campo surge nesse âmbito em meio aos movimentos sociais no final do século $X X$, visando uma melhor qualidade de vida aos sujeitos e a valorização dos mesmos no espaço social onde vive. Educação do Campo, Segundo Fernandes, Cerioli e Caldart (2004, p. 25).

A utilização da expressão campo tem o intuito de propiciar uma reflexão sobre o sentido do atual trabalho camponês e das lutas sociais e culturais dos grupos que hoje tentam garantir a sobrevivência deste trabalho. No final dos anos de 1990, a proposta educativa construída pelo Movimento Sem Terra (MST) passa a ser discutida no âmbito das reflexões sobre a Educação do Campo com o propósito de conceber uma educação básica do campo, voltada aos interesses e ao desenvolvimento sociocultural e econômico dos povos que habitam e trabalham no campo, atendendo às suas diferenças históricas e culturais.

A educação do Campo se articula a um projeto político sustentável de desenvolvimento local a partir dos interesses e necessidades dos povos que vivem no local. O que caracteriza os povos do campo é a sua relação com a natureza, com a maneira de lidar com a terra, fazendo-a produtiva, dos valores, do culto as festas e a valorização da comunidade local, bem como a celebração pela colheita, fruto do suar de seu trabalho e a relação com a terra.

[...] o homem não só se adapta ao mundo, como também o transforma. Essa transformação ocorre em dois níveis: em primeiro lugar no nível da interação do homem com a natureza e como ser da natureza, modificando o ambiente natural com o uso de ferramentas. Ocorre também no nível da consciência, da interação comunicativa entre os indivíduos e sua organização social (SCHELLING, 1991, p.32).

E nessa interação do homem como sujeito social o ambiente onde vive com a sua cultura que o mesmo se modifica, se adapta ao ambiente, bem como se transforma como sujeito do campo. A educação do campo é o contraponto a educação rural que via o campo como local de atraso, de pouco desenvolvimento. A educação do campo valoriza essa prática como capaz de ajudar no 
desenvolvimento do sujeito, na sua formação trabalhando e transformando-se como sujeito social de valor enfrentando o sistema capitalista que o esmaga, que os suga.

\section{MARCO HISTÓRICO DA EDUCAÇÃO DO CAMPO NO BRASIL}

No Brasil, mais precisamente, em meados dos anos 80 que a "Educação do Campo" se consolida. Essas práticas surgem a partir dos movimentos sociais, em especial do $\mathrm{MST}^{159}$ nos assentamentos da Reforma Agrária com a construção de escolas. Nesse momento, o movimento entendia que só a terra não seria suficiente para contemplar as demandas. Precisava ter escolas com educação baseada na realidade do povo assentado e acampado da época. Nesse sentido, "Escolas Itinerantes" davam conta da demanda, com professores do próprio acampamento. Conforme Dal Ri e Vieitez (2004, p. 44). “Nesse campo de preocupações inseremse os esforços pedagógicos do Movimento dos Trabalhadores Rurais Sem Terra (MST) surgem formulações tais como, a educação para a cidadania, a formação de consciência crítica, o cultivo dos valores humanistas e várias outras”.

Na história da "educação do campo" dentro dos assentamentos sempre se pensou numa proposta voltada para a formação de sujeito crítico em condições de intervir na realidade e contribuir com a sociedade. É na escola que a educação se completa e desenvolve- se. Quanto a educar na realidade Freire (2011) diz:

Por que não discutir com os alunos a realidade concreta a que se deva associar a disciplina cujo conteúdo se ensina, a realidade agressiva em que a violência é a constante e a convivência das pessoas é muito maior com a morte do que com a vida? Por que não estabelecer uma necessária "intimidade" entre os saberes curriculares fundamentais aos alunos e a experiência social que eles têm como indivíduos? Por que não discutir as implicações políticas e ideológicas de tal descaso dos dominantes pelas áreas pobres da cidade? A ética de classe embutida neste descaso? Porque, dirá um educador reacionariamente pragmático, a escola não tem nada que ver com isso. A escola não é partido. Ela tem que ensinar os conteúdos, transferí-los aos alunos. Aprendidos, estes operam por si mesmos. (Freire, 2011, p 15). 
Em contra ponto as práticas utópicas e pela garantia de uma educação destinada as Escolas do Campo, surgem às políticas para "Educação do Campo" que ainda se apresentam algumas dificuldades de implementação das práticas pedagógicas para promoção do ser humano. Nesse cenário destaca-se o Movimento dos Trabalhadores Rurais Sem Terra, ao qual luta não só por terra, mas por escolas, por dignidade e pela valorização do sujeito no campo. Mesmo que o cenário atual, socioeconômico não mostre boas perspectivas de futuro é a cultura que nos liga a terra, as lutas pelos direitos humanos e sociais.

No ano de 1990 a lei 9.394/96 (Lei de diretrizes para a educação - LDB) reconheceu a diversidade sociocultural e o direito à igualdade e as diferenças. Essa lei estabelece que os sistemas de ensino devam promover adequações do ensino as peculiaridades da vida rural e de cada região, (adequando o calendário escolar as fases agrícolas e as condições climáticas).

A partir de 1970 houve um aumento considerável do êxodo rural, o que prejudicou ainda mais a evolução da educação na região rural. Conforme Nascimento 2003.

A educação foi vista como um processo desnecessário para aqueles/as que estavam emergidos num mundo onde ler, escrever, pensar e refletir não tinha nenhuma utilidade e serventia. Assim, trabalhar na roça, criar cultura a partir do manejo com a terra, estar inteiramente ligado ao ecossistema do mundo campesino, era condição sine qua non para não se ter acessibilidade ao mundo do conhecimento. (NASCIMENTO, 2003, p.02).

O autor se posicionava criticamente sobre as políticas educacionais. Para ele estas e os projetos pedagógicos não reconheciam o povo do campo como sujeitos da política.

Toda vez que houve alguma sinalização de política educacional ou de projeto pedagógico específico isto foi feito para o meio rural e muito poucas vezes com os sujeitos do campo. Além, de não reconhecer o povo do campo como sujeito da política e da pedagogia, sucessivos governos tentaram sujeita-lo a um tipo de educação domesticadora e atrelada a modelos econômicos perversos. (CALDART, 2002, p. 28). 
Diferentemente da forma abordada por Caldart (2002), em 2001 foram aprovadas pelo Conselho Nacional de Educação as Diretrizes Operacionais para a Educação Básica das Escolas do Campo, que segundo (BRASIL, 2007, p.17) foi muito importante para a educação do campo:

Um importante marco para a educação do campo porque contemplam e refletem um conjunto de preocupações conceituais e estruturais presentes historicamente nas reivindicações dos movimentos sociais. Dentre elas o reconhecimento e valorização da diversidade dos povos do campo, a formação diferenciada de professores, a possibilidade de diferentes formas de organização da escola, a adequação dos conteúdos às peculiaridades locais, o uso de práticas pedagógicas contextualizadas, a gestão democrática, a consideração dos tempos pedagógicos diferenciados, a promoção, através da escola, do desenvolvimento sustentável e do acesso aos bens econômicos, sociais e culturais.

A classificação das escolas do campo (BRASIL, 2007, p.14) partem da definição que considera a localização da escola no município e foco de produção econômica social e cultural:

Nesse contexto, as escolas do campo são aquelas que têm sua sede no espaço geográfico classificado pelo IBGE como rural, assim como as identificadas com o campo, mesmo tendo sua sede em áreas consideradas urbanas. Essas últimas são assim consideradas porque atendem a populações de municípios cuja produção econômica, social e cultural está majoritariamente vinculada ao campo.

\section{EDUCAÇÃO AMBIENTAL NAS ESCOLAS DO CAMPO}

A educação ambiental no âmbito escolar, surge por força de legislação com objetivo de assumir o papel de transversalidade da educação. Nesse sentido, a educação ambiental não nasce fora de um contesto social e político onde os educandos vivem e produzem cultura juntamente com a sua família, tendo o meio ambiente lugar de vida, de transformações naturais e de produção de cultura.

[...] enquanto saber que, por força das políticas públicas implementadas no Brasil precisa ser trabalhada na escola enquanto tema transversal, entendida a partir desta compreensão, ganha contornos políticos e assume papel transformador, uma vez que compreender a Natureza como totalidade na qual o próprio ser social está inscrito, é compreender que 
as relações materiais de produção da vida social desenvolvem-se como relações materiais de produção da própria natureza, ou seja, que há uma relação dialética entre o desenvolvimento das relação de produção humanas e o desenvolvimento da natureza não-humana. (BIGLIARDI\& CRUZ, 2012, p.324)

Na relação do ser humano com a natureza gera resíduos, aos quais provocam grandes desastres ecológicos, sociais e ambientais, além do grande desconforto para população, quando não é dado atenção necessária para o destino correto. Com isso acaba gerando "lixo", deixando de ser resíduos, pois, acreditamos que resíduos são reaproveitáveis, diferente de "lixos" ao qual consideramos o descarte de materiais inadequados em locais impróprios ao qual apenas irá gerar problemas socioambientais.

Toda a atividade humana ou animal gera resíduos, e estes podem ser aproveitados para a manutenção da vida. A geração desses resíduos passa a ser problema quando for em quantidade e qualidade tal que impeça o desenvolvimento harmônico dos seres vivos em dado ecossistema e já vem preocupando os homens há milhares de anos, em função das epidemias de doenças surgidas pela contaminação de águas. (ADEDE Y CASTRO, 2003, p.94)

A concepção de meio ambiente se fundamenta no conhecimento e na consciência, na atividade política e no desenvolvimento de uma nova economia, registrando-se na evolução do tempo.

[...] "a problemática ambiental abriu um processo de transformação do conhecimento, expondo a necessidade de gerar um método para pensar de forma integrada e multivalente os problemas globais e complexos, assim como a articulação de processos de diferente ordem de materialidade". (LEFF, 2005, p.56).

Segundo Pelicioni (2005, p. 596, 597):

A educação ambiental, então, além de ser um processo de mudança e de formação de valores, bem como de preparo de exercício da cidadania, constitui-se em um conjunto de ideias contrárias às ideias prevalentes no sistema social atual, contrárias às ideias de egoísmo e de individualismo, a favor da transformação social com ética e com democracia. É uma luta a favor, portanto, de novas ideias e de valores éticos, em que deve prevalecer a melhoria da qualidade de vida para todos. 
Para Barbieri (2011) os objetivos da educação ambiental, de acordo com a Carta de Belgrado, são:

Conscientização: contribuir para que indivíduos e grupos adquiram consciência e sensibilidade em relação ao meio 51 ambiente como um todo e quanto aos problemas relacionados com ele. 2. Conhecimento: propiciar uma compreensão básica sobre o meio ambiente, principalmente quanto às influências do ser humano e de suas atividades. 3. Atitudes: propiciar a aquisição de valores e motivação para induzir uma participação ativa na proteção ao meio ambiente e na resolução dos problemas ambientais. 4. Habilidades: proporcionar condições para que os indivíduos e grupos sociais adquiram as habilidades necessárias a essa participação ativa. 5. Capacidade de avaliação: estimular a avaliação das providências efetivamente tomadas em relação ao meio ambiente e aos programas de educação ambiental. 6. Participação: contribuir para que os indivíduos e grupos desenvolvam o senso de responsabilidade e de urgência com relação às questões ambientais (BARBIERI, 2011, p.55-56).

A educação ambiental tem como principal objetivo a produção de um novo saber sobre o meio ambiente, no qual a natureza seja valorizada e preservada, construindo uma nova cultura, a partir da forma que as pessoas se utilizem apenas do necessário de recursos naturais para subsistência, por meio da sustentabilidade, mantendo um equilíbrio ambiental.

Nos deparamos com inúmeros problemas que surgem ao longo dos anos, e assim, percebe-se a necessidade de construir um novo saber ambiental o qual tenha como princípio a valorização do meio, tendo consciência da sua importância, para a vida humana, para a vida animal, vegetal e para todos as espécies de vida, seja animal ou vegetal.

A relação que o homem exerce com o meio ambiente é de posse, ou seja, o ser humano se considera dono dos recursos naturais, tendo consigo o poder de manipulação de recursos. Através dessa atitude está conseguindo destruir a natureza, criando um desequilíbrio. O homem transforma e altera os organismos da natureza, degradando-os.

Compreende-se que o crescimento populacional é um fator determinante na grande produção de resíduos, ou seja, os centros urbanos estão cada vez 
maiores, com inúmeras pessoas aglomeradas em lugares inapropriados, produzindo muitos danos ambientais, tanto com a produção de resíduos, a forma desorganizada da construção das moradias, enfim. ..

Vale apena destacar que nas áreas de apropriação rural também ocorre a produção de resíduos, não na mesma dimensão, mas existem outras formas de poluição tais como: o uso de agrotóxicos ou venenos, derrubadas de matas, assoreamento de rios, lagos, vertentes, caça de animais em extinção, entre outros fatores.

A tomada de consciência produzida juntamente aos alunos, relativas à preservação, conservação e valorização dos recursos naturais, terão como ponto principal a construção dos mesmos princípios de família, sendo uma das atividades, o compartilhamento do conhecimento para os pais e demais familiares, proporcionando uma interação entre todos. Nesse sentido BEL, 2003 expõe o seguinte:

As mudanças devem ocorrer em nossos movimentos em relação a nós mesmos, aos outros e ao mundo. Cada gesto nosso tem repercussões sobre todo o planeta. Cada gesto nosso precisa ser consciente. Ele reflete nossa maneira de pensar e, então, é o que precisa ser modificado. $\mathrm{O}$ quadro que temos hoje é resultado de milênios de histórias. As mudanças serão, portanto, pequenas e gradativas. (BEI, 2010, p.12).

Nesse sentido, a escola deve propor atitudes favoráveis à preservação do meio ambiente, buscando a construção de uma nova visão de educação, ou seja, uma educação sócio ambiental, que interaja com as demais áreas do conhecimento, potencializando a conscientização de que o meio ambiente é primordial para todas as formas de vida no planeta terra.

Acreditamos que a consciência ambiental, é gerada na família e na escola, adquirindo princípios que lhes acompanharão para a vida toda. Quanto a esse tema, se faz necessário orientar os filhos e/ou educandos/as da melhor forma possível. Na escola é possível direcionar atividades variadas, proporcionando o 
despertar para diversos conhecimentos, onde possibilite a reflexão sobre a vida e a ação do ser humano na sociedade. BRASIL 2001.

A complexidade da natureza exige uma abordagem sistêmica para seu estudo, isto é, um trabalho de síntese, com os diversos componentes vistos como um todo partes de um sistema maior, bem como em suas correlações e interações com os demais componentes e seus aspectos. Fazendo-se uma analogia entre um sistema natural em estudo e uma rede de pesca, da mesma forma que para conhecer a rede não basta observar os seus nós, para se conhecer um sistema não basta observar suas partes, mas é preciso enxergar como elas se interligam e se modificam, em sua própria estrutura e sentido de ser, por causa dessas interações. (BRASIL 2001, p.22)

"A Educação Ambiental é condição indispensável para modificar o quadro crescente de degradação socioambiental". (ALVES; SILVA; VASCONCELOS, 2007, p.112). A educação que promove a sustentabilidade é uma educação transformadora, reflexiva e crítica e não apenas uma educação transmissora de conhecimentos. Jacobi (2003) destaca que a Educação Ambiental tem como compromisso a função política orientada para a transformação social, onde associa a natureza, o homem e o universo nos inúmeros campos de conhecimento, promovendo uma educação para a cidadania fundamentada na educação participativa.

Nessa mesma linha de reflexão Lima (2002, p.136) ressalta que, "a ausência de participação na educação reforça o seu caráter autoritário assim como anula as possibilidades de crescimento, autonomia e emancipação do educando."

Lima (2002) considera que a Educação Ambiental foi criada socialmente para minimizar os resultados da crise ambiental e para promover a sustentabilidade e ainda compartilha com os autores acima a ideia de que a Educação Ambiental é política e transformadora da realidade socioambiental ou não tem razão de existir, conforme segue:

Se esse reconhecimento da natureza política da EA não é capaz de ultrapassar o nível da retórica, se o medo da mudança for maior que o desafio de inovar, então podemos apagar as luzes e procurar desafios mais sérios com que nos ocupar, posto que se a EA não tem compromisso com a 
transformação social e individual, ela converte-se em mero artifício para justificar, legitimar e conservar a exploração e degradação- do homem e da natureza- praticadas pelo sistema capitalista (LIMA, 2002, p.132).

Os estudos referentes ao funcionamento do meio ambiental são bastante complexos, mas com dedicação e união de todos é possível compreender a dimensão da importância de aprender a lidar de forma correta com a natureza. A partir do momento que se percebe que tudo está interligado ao meio natural, se torna possível desenvolver uma nova fórmula de usufruir da natureza, cuidando, protegendo e se comprometendo com o meio ambiente de forma responsável.

Diante dessa dimensão percebe-se que muitos são os desafios, e muitas as questões de educação ambiental que devem ser compreendidas e refletidas, a Comissão Mundial sobre o Meio Ambiente e Desenvolvimento (1988: 46), vem definir como "aquele que atende às necessidades do presente sem comprometer a possibilidade de as gerações futuras atenderem a suas próprias necessidades".

Neste sentido nos remetemos a compreender melhor a da qualidade de vida, Dias (2003), nos ajuda a pensar de que nada adianta sermos desenvolvidos economicamente, sem o desenvolvimento social, e ainda não basta. É necessário termos desenvolvimento econômico, social e ainda no viés ambiental, sustentável e ecologicamente equilibrado.

Este teve como objetivo principal desenvolver atividades práticas, no intuito de reciclar resíduos orgânicos até então considerados "lixos", culminando com a construção de uma composteira para produção de adubo orgânico. Para Alves e Pereira (2015), a escola tem o papel de formar cidadãos críticos, conscientes e reflexivos, capazes de interferir na sociedade para uma melhora ambiental.

Freire (1996) considera a questão de educação ambiental, a pobreza, a politica e a dimensão d aética como a necessidade de aproveitar as experiências dos alunos, para abordar problemáticas de nível ambiental. Nessa direção a escola do campo, deve ser agenciadora de transformações sociais, pautadas em uma pedagogia libertadora, com abordagens adequadas ao local. 


\section{A ESCOLA MUNICIPAL DE ENSINO FUNDAMENTAL CONQUISTA DEZESSEIS DE OUTUBRO NO CONTEXTO DA EDUCAÇÃO DO CAMPO}

No ano de 1995 um grupo de agricultores Sem Terra querendo oferecer condições mais dignas as suas famílias resolve acampar num acampamento do MST, cujo sua formação inicial foi na cidade de Palmeira das Missões. Por se localizar nesse cidade foi nomeado como Palmeirão. Passado algum tempo, muitos de seus integrantes foram sendo assentados em áreas de terras, e o mesmo foi enfraquecendo. Então resolve se juntar na cidade de Júlio de Castilhos com o acampamento que lá existia e, que também já havia enfraquecido por muitas famílias já terem sido assentadas.

Alguns tempos de espera a área de terra do Assentamento ceres ao qual vinha em negociação com o INCRA- Instituto de Colonização e Reforma Agrária, área pertencente a Varig acaba de ser comprada pelo órgão. Então o acampamento se organiza para realizar o sorteio da área. No momento inicial foram 114 famílias beneficiadas, essas vindas de várias cidades do estado.

Das famílias contempladas, 4 foram de funcionários que trabalhavam na empresa no momento da efetivação da compra. No ano de 1996, no mês de dezembro, muitas das famílias sorteadas chegaram à área para cuidar da mesma. No início de 1997 dá-se o processo de medidas de perímetro da área e divisão dos lotes de terras por empresa contratada para isso. Ainda no primeiro semestre inicia a organização das famílias nos lotes com a construção de galpões/moradias e manejo de solo para plantio de subsistência

Para legalização da reserva, a qual consta com uma área aproximadamente de 326 hectares de mata nativa, o INCRA realizou a readequação dos lotes. Foi usado da negociação do INCRA com as famílias, visto que, dos 46 lotes vistoriados, 38 destes ocupavam parte da mata nativa com uma média de 5 ha. Assim, os lotes foram reformulados com de área e compensação em outro local. 
A readequação numa área de aproximadamente 200 hectares que pertencia a uma antiga cooperativa dos assentados e também com a extinção de alguns lotes, reconduzindo as famílias para essa área.

A regularização do assentamento atende ao Código Florestal Brasileiro, que determina que pelo menos $20 \%$ da sua área deve ser de reserva legal, necessária ao uso sustentável dos recursos naturais, à conservação e reabilitação dos processos ecológicos, à conservação da biodiversidade e ao abrigo e proteção de fauna e flora nativas. (INCRA, 2008, p.1)

\section{Figura 1- Mapa do Assentamento Ceres}

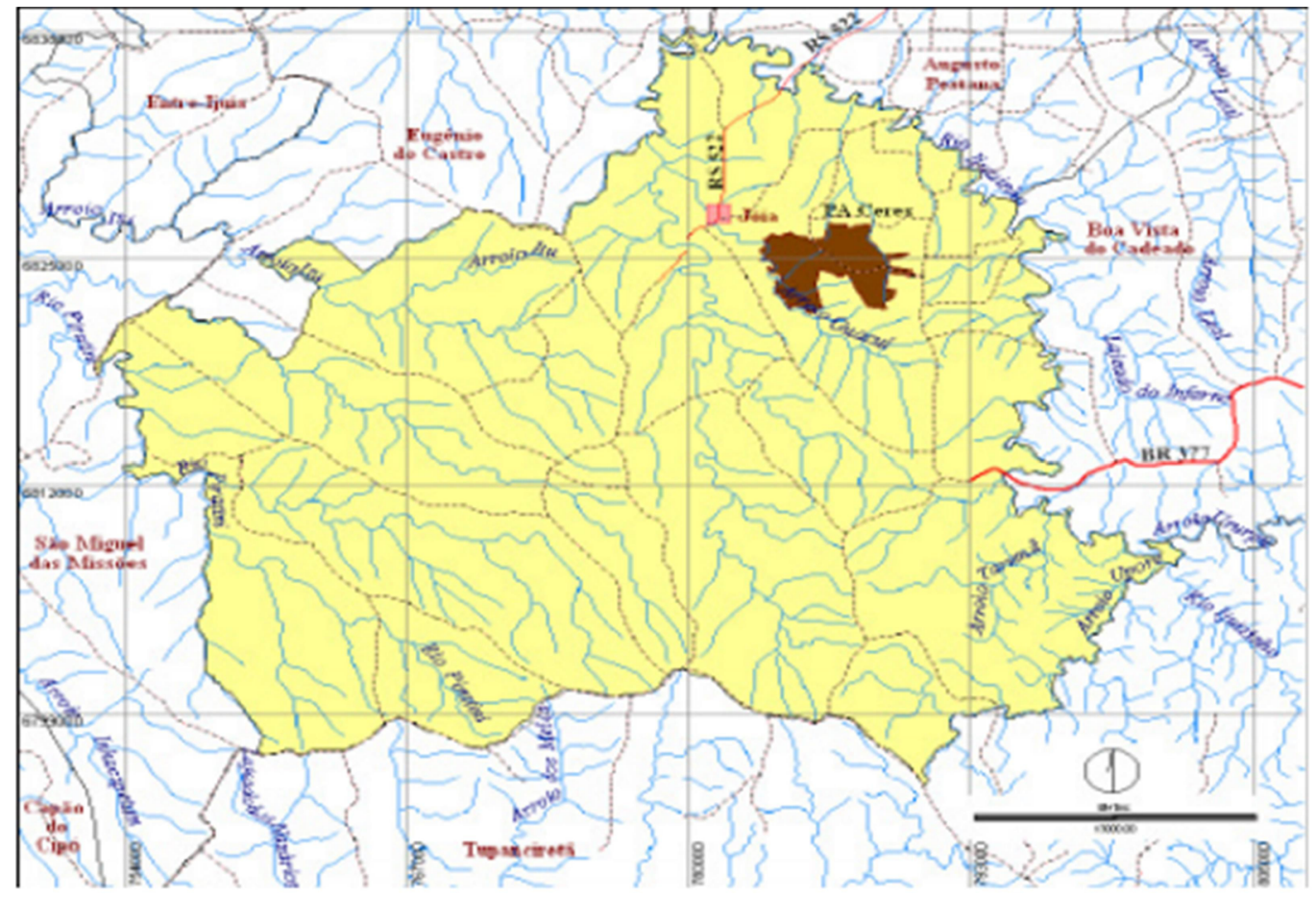

Fonte: INCRA - RS. Relatório Ambiental do Projeto Assentamento Ceres. Porto Alegre, INCRA, 2007.

\section{METODOLOGIA DA PESQUISA}

A característica desse trabalho é a pesquisa de ação, devido ao fato que envolve um plano de ação, como assim é definida.

Pesquisa-ação é uma forma de investigação baseada em uma autorreflexão coletiva empreendida pelos participantes de um grupo social de maneira a melhorar a racionalidade e a justiça de suas próprias práticas sociais e educacionais, como também o seu entendimento dessas práticas e de situações onde essas práticas acontecem. A abordagem é de uma pesquisa-ação apenas quando ela é colaborativa (...) KEMMIS e MC TAGGART (1988 apud Elia e Sampaio, 2001, p.248). 
Neste sentido, a metodologia de pesquisa está baseada em objetivos e num processo de aprendizagem, troca de conhecimentos, de acompanhamento de análise, de observação, de reflexão e de mudança.

A pesquisa-ação educacional é pensada em uma estratégia para o desenvolvimento de saberes, sobretudo de professores e pesquisadores envolvidos de alguma maneira com a temática. Tem-se como objetivo que a pesquisa possa modificar, qualificar e aprimorar a sua forma de ensino.

\section{Diagrama 1: Representação em quatro fases do ciclo básico da investigação-ação.}

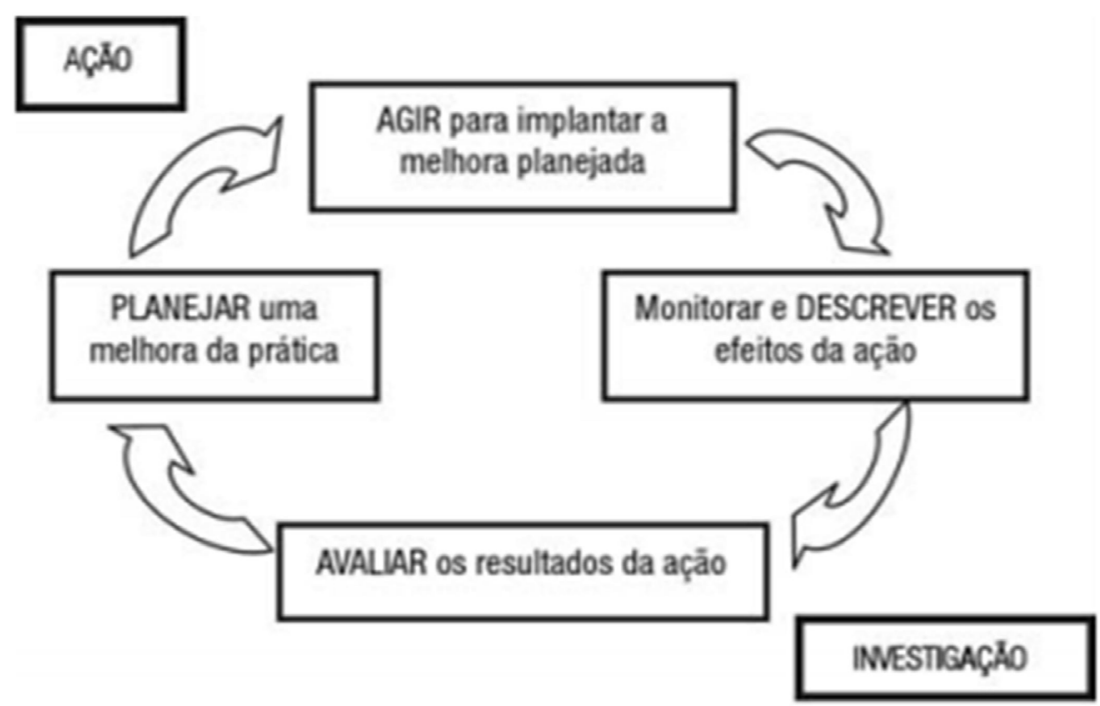

Figura 2- fonte: Tripp (2005).

A Pesquisa ação remete-nos a um diagnostico inicial, planejamento, a uma ação programada e após implantasse e avaliam-se as possíveis mudanças. Considera-se que a avaliação é essencial a prática, para repensá-la, sobretudo aquelas que propõem impactos e promovem a reflexão dos sujeitos da pesquisa.

As atividades com os alunos foram ministradas de duas maneiras: uma teórica através de materiais impressos e uso de equipamentos audiovisuais, a outra, a prática da construção de uma composteira para reaproveitar os resíduos orgânicos retirados da cozinha escolar com a finalidade de transformar em adubo orgânico para uso na horta, pomar e jardim escolar. 


\section{RESULTADOS E DISCUSSÕES}

Através do trabalho desenvolvido no citado projeto, procuramos destacar a importância da separação dos resíduos, levando a conscientização de que a natureza é muito rica e capaz de transformar aquilo que considerávamos "lixo" em um adubo orgânico muito rico em nutrientes para uso em plantas. Para desenvolvimento do projeto com os educandos/as, conforme o planejado usamos de duas aulas de 4 horas cada. Sendo a primeira parte teórica e de observações na escola e, a segunda totalmente prática de construção da compostagem.

Na primeira aula, a teórica nos dedicamos sensibilizar os educandos numa postura crítica diante de situações concretas observadas com relação à problemática do "lixo" nos entornos e dentro do ambiente escolar, bem como o destino que os mesmos recebem.

Nessa aula, dividimos em vários momentos, sendo o primeiro de reconhecimento do ambiente. Nesse momento, os educandos foram convidados a andar pelas dependências internas e externas da escola para verificar como está sendo tratado o tema na escola. Após, os alunos assistiram vídeo lixo nosso de cada dia, disponível endereço eletrônico: https://www.youtube.com/watch?v=fR_JTGiAuiA "o lixo nosso de cada dia" para começarmos a reflexão sobre o assunto levando em conta a realidade onde vivem.

A seguir, fomos à cozinha da escola olhar a lixeira para ver o que era descartado e se poderíamos usar do reaproveitamento na composteira buscando o despertar para uma nova consciência de preservação, de redução e de reaproveitamento de materiais recicláveis, antes considerados "lixo". A natureza clama pelo desenvolvimento de atitudes de ecológicas.

Com isso, ainda debatemos sobre o exagero de lixo que produzimos todos os dias, para onde vão? Não poderíamos reutilizar diminuindo os impactos ambientais, e, ainda gerando renda para família? Com isso, acreditamos elevar a consciência socioambiental dos educandos dessa turma esperando que eles levem para vida como aprendizagem o que viram e debatemos nessa aula. 
Na segunda aula, retomamos o que foi trabalhado na aula anterior, visando o trabalho prático da construção de uma composteira com aproximadamente $1 \mathrm{~m}$ x $1 \mathrm{~m}$ por mais ou menos uns cm de altura para produção de adubo orgânico para uso da escola.

O interessante foi que ao construir a composteira nos demos conta de que estávamos reciclando matéria orgânica, por que não reciclar pedaços de zincos e de madeiras para construção da mesma. Com isso reaproveitamos os materiais citados, o que acreditamos sermos coerentes com a proposta de atividade desenvolvida no projeto.

Bom destacar que nesse dia havia sido solicitado que os educandos trouxessem restos de cascas e outaras matérias orgânicas para nos usar na composteira. Teve uma educanda que trouxe uma sacolinha com esterco de galinha par misturar. Uma iniciativa muito linda dessa aluna o que nos leva a pensar que o trabalho da aula anterior já estava surtindo efeito ao despertara a consciência para o reaproveitamento.

A seguir foi à vez dos educandos/as rastelarem o pátio para juntar as folhas de uva de inverno. Foi um momento muito lindo. Nesse momento cada educando teve seu envolvimento fosse para rastelar, para juntar as folhas ou para levar até a cisterna. Na prática, colocamos uma camada de folha. Logo após, uma camada de matéria orgânica, seja cascas, restos de frutas, aboboras apodrecidas e esterco de galinha.

Como resultado desse processo, lançamos junto aos educandos e professora da turma, o desafio de dar segmento às atividades realizando as observações como a medida de temperatura ambiente, o processo de formação do adubo orgânico. O mais importante disso, não é o resultado da transformação da matéria orgânica, mas a formação da consciência socioambiental nos educandos, estendendo para sua família, através do reaproveitamento. Esperamos com isso, obter matéria orgânica para adubar a horta escolar ao qual fornecerá alimentação saudável, incrementando a merenda escolar. 


\section{REFERENCIAS}

ADEDE Y CASTRO, João Marcos. Resíduos perigosos no direito ambiental internacional sua internalização nos países do MERCOSUL. Porto Alegre: Sérgio Antonio Fabris Editor, 2003.

ALVES, Evandro; SILVA, Maria Beatriz Gomes da. Sala-ambiente "Projeto Vivencial" como estratégia teórico-metodológica para a formação de gestores escolares. In: SILVA, Maria Beatriz Gomes da; FLORES, Maria Luiza

ALVES, L. I. F.; SILVA, M. M. P. e VASCONCELOS, K. J. C. Educação Ambiental em Comunidades Rurais de Juazeirinho - PB: Estratégias e Desafios. Fundação Universidade Federal do Rio Grande. Programa de Pós-Graduação em Educação Ambiental. Revista Eletrônica do Mestrado em Educação Ambiental, Rio Grande - RS, v.19, jul./dez. 2007.

ALVES, Talita Ferreira; PEREIRA, Marlene de Paula.A educação ambiental como ferramenta pedagógica no ensino infantil - Projeto reciclando com o s.r. Pet. VI Congresso Brasileiro de Gestão Ambiental. Porto Alegre/RS - 23 a 26/11/2015.

AZEVEDO; Eder dos Santos e MENDONÇA, Marcela Paula de: Democracia e Cotidiano Escolar: A Escola Como Possibilidade de Participação (...)

BARBIERI, Jacobi. Desenvolvimento sustentável e educação ambiental: uma trajetória comum com muitos desafios. Rev. Adm. Mackenzie, V. 12, N. 3 p. 51- 82, São Paulo, SP Maio/Jun. 2011

BEI. Coleção Entenda e Aprenda. Como Cuidar do Seu Meio Ambiente/ Coordenação Projeto editorial e gráfico BEI Comunicação; $3^{\mathrm{a} e d . r e v . ~ e ~ a t u a l . ~ S a ̃ o ~}$ Paulo: Bei Comunicação, 2010.

BRASIL. Educação do campo: diferenças mudando paradigmas (Cadernos Secad 2). Secretaria de Educação Continuada, Alfabetização e Diversidade (Secad/MEC), 2007.

CALDART, Roseli Salete. Por Uma Educação do Campo: traços de uma identidade em construção. In.: Por Uma Educação do Campo: Identidade e Políticas Públicas. V. 4. Brasília, 2002, p. 25-36. 
BRANDÃO, Carlos Rodrigues em PALUDO 2005. Trinta anos depois: alguns elementos de crítica atual aos projetos de cultura popular dos movimentos de cultura popular dos anos 60. Diálagos e Pespectivas. Coleção Educação Para Todos. Brasilia, 2005, Diretório da UNESCO.

BRASIL, Secretaria de Educação Fundamental. Parâmetros Curriculares Nacionais. Brasília, MEC, 1997

BRASIL, Constituição (1988). Constituição da República Federativa do Brasil. Brasília, DF: Senado Federal, 1988.

Lei $n^{\circ}$ 9.394, de 20 de dezembro de 1996. Estabelece as diretrizes e bases da educação nacional. Diário Oficial da União, Brasília, DF, 1996.

Lei $n^{\circ}$ 10.172, de 9 de janeiro de 2001. Aprova o Plano Nacional de Educação e dá outras providências. Diário Oficial da União, Brasília, DF, 2001

Ministério da Educação. Secretaria de Educação Básica. Programa Nacional de Fortalecimento dos Conselhos Escolares. Gestão da educação escolar. Brasília: UnB, CEAD, 2004 vol. 5. p. 25).

Parâmetros Curriculares nacionais: meio ambiente: saúde/Ministério da Educação. -3. Ed. - Brasília: A secretaria, 2001. 128p.: II.;16x23cm.

CALDART, Roseli S. Por uma educação do campo: traços de uma identidade em construção. In: Educação do campo: identidade e políticas públicas- Caderno 4. Brasília: Articulação Nacional “Por Uma Educação Do Campo”, 2002.

CANARIO, Rui. A escola tem futuro? Das promessas às incertezas. Porto Alegre: Artmed, 2006.

CANDAU; Ferrão Maria: Direito a Educação, Diversidade e Educação em Direitos Humanos Educ. Soc, Campinas, v. 33, n. 120, p. 715-726, jul. - set. 2012 Disponível em http://www.cedes.unicamp.br

CRUZ, R. G.; BIGLIARDI, R. V.; MINASI, L. F. Crise ambiental e crise do modo de produção: os limites sócio-metabólicos do capital. Revista Eletrônica do Mestrado em Educação Ambiental, FURG - RS, v.30, jan./jun. 2013, p. 102-119. Disponível em http://www. seer.furg.br/remea/article/view/3571 - Acessado em 19/06/2018. 
DAL RI, Neusa Maria e VIEITEZ, Candido Giraldes. A Educação do Movimento dos Sem- Terra Revista Brasileira de Educação. Maio /Jun /Jul /Ago 2004 No 26

DICK, Bobe, (2000) postgraduate programs using action research [on line] available at http://www.scu.edu.au/schools/gcm/ar/arp/ppar.html (visita realizada em 11 de maio de 2015)

FERNANDES, Bernardo Mançano; CERIOLI, Paulo Ricardo; CALDART, Roseli Salete (Org.). Por uma educação básica do Campo. Texto-Base da Conferência Nacional. Brasília, DF: Ed. UnB, 1998.

FRANCO, Maria Amélia Santoro. Pedagogia da Pesquisa- Ação. Educação e Pesquisa, São Paulo, v. 31, n. 3, p. 483-502, set./dez. 2005.

FREIRE, Paulo. Pedagogia da autonomia: saberes necessários à prática educativa. 43. ed., São Paulo: Editora Paz e Terra, 2011.

INCRA. Reserva legal em Assentamento no Rs. Disponível em: http://www.incra.gov.br/index.php/noticias-sala-de-imprensa/noticias/2270-incraregulariza- reserva-legal-em-assentamento-no-rs.

JACOBI, Pedro. Educação Ambiental, cidadania e sustentabilidade. Cadernos de pesquisa $n^{\circ}$ 118. P. 189-205. São Paulo, 2003.

KEMMIS e MC TAGGART,1988, apud Elia e Sampaio, 2001, p.248

LEFF, E. Pensar a complexidade ambiental. In: LEFF, E. (Org.). A complexidade ambiental A complexidade ambiental. São A complexidade ambiental Paulo: Cortez, 2005.

LIMA, Gustavo Ferreira da Costa. Crise ambiental, educação e cidadania: os desafios da sustentabilidade emancipatória. In: LAYRARGUES, P. P.; Castro, R. S; LOUREIRO, C. F. B. (orgs) Educação ambiental: repensando o espaço da cidadania, São Paulo: Cortez, 2002.

NASCIMENTO, C.G.A Educação Camponesa como espaço de resistência e recriação da cultura: um estudo sobre as concepções e práticas educativas da Escola Família Agrícola de Goiás - EFAGO. Dissertação de Mestrado (Educação). Campinas: FE/Unicamp, 2003. 265 p. 
OLIVEIRA; João Ferreira. A Construção Coletiva do Projeto político Pedagógico da Escola (PPP). (ano...).

PALUDO, Conceição. Educação Popular na América Latina: Diálagos e Pespectivas. Coleção Educação Para Todos. Brasilia, 2005, Diretório da UNESCO.

PELICIONI, M. C. F. Educação Ambiental: evolução e conceitos. In: PHILIPPI, Arlindo Junior. Saneamento, saúde e ambiente: fundamentos para um desenvolvimento sustentável. Barueri, SP: Manole, 2005, p. 587-598.

Revista Retratos da Escola Brasília, 165 A escola em debate: gestão, projeto político- pedagógico e avaliação v. 7, n. 12, p. 159-166, jan./jun. 2013. Disponível em: http//www.esforce.org.br

RICHARDSON; Roberto Jarry-Como fazer a pesquisa-ação?

RODRIGUES (Orgs.). Formação à distância para gestores da Educação Básica: olhares sobre uma experiência no Rio Grande do Sul. Porto Alegre: Evangraf, 2014.

SCHELLING, Vivian. A presença do povo na cultura brasileira. Campinas: Editora da UNICAMP, 1991.

SOUZA, M.A. Educação do campo: propostas e práticas pedagógicas desenvolvidas no MST. Petrópolis: Vozes, 2006.

VEIGA, IIma Passos Alencastro. A escola em debate: gestão, projeto políticopedagógico e avaliação. Retratos da Escola, Brasília: CNTE, v. 7, n. 12, p. 159166, jan./jun. 2013. 


\section{dol $10.48209 / 978-65-89949-D 2-0$}

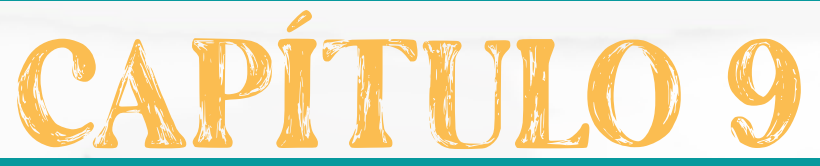

\section{DIVERSIDADE}

E EDUCAÇÃO INCLUSIVA

Mirian Luzia de Lima Vaz

Liliana Bernardo de Oliveira Onofre Luciano Araujo da Costa 


\section{INTRODUÇÃO}

A ideia de uma abordagem necessária em consideração à diversidade pelas políticas públicas, práticas sociais, culturais ou profissionais ocupa, há muitos anos, um lugar crescente nas recomendações dos organismos internacionais e nos textos produzidos pelas instituições nacionais, sendo que algumas liminares dizem respeito à escola. A prolixidade das evocações desta diversidade levanta a questão da sua instalação no debate público e na escola, e no sentido em que Ihe é atribuído, de sua utilização prática.

Reconstruir a origem da emergência da diversidade como tema e, em seguida, sua construção como categorias descritiva e normativa, identificar algumas consequências de sua transformação é abrir caminhos para a análise desse fenômeno primordial na tentativa de se dar os primeiros passos em prol de uma inclusão social e educacional. Ela se baseia no estudo de um corpo de organismos oficiais e textos desde o século passado, momento em que a educação se faz questionada (OLIVEIRA; SOUZA, 2011, p.128).

A noção de diversidade refere-se ao universo semântico da heterogeneidade e da variedade, mesmo contraditória ou divergente, segundo os dicionários de língua nativa portuguesa. E, como nota Silva (2011, p.4), é um conceito com geometria variável, que atualmente, encontra dois tipos de preocupações: os pedidos de reconhecimento pelos indivíduos de suas especificidades (culturais, memoriais, físicas etc.) e a luta contra a discriminação.

O trabalho se baseia em um referencial teórico produzido através de pesquisas e estudos bibliográficos numa abordagem qualitativa, com dados e informações coletadas a partir de artigos, sites científicos, revistas especializadas em educação, legislação, levando-se em consideração a análise, conceito e contextualização do assunto abordado. Em vez de partir de uma concepção a priori do que seria a diversidade, deve-se examinar - dentro dos limites deste artigo - sua trajetória que a levou a suplantar termos semelhantes como diferenças e desi- 
gualdades, historicamente associada à ideia de hierarquia e conflitos, sejam estes sociais, militares e, até mesmo, coloniais. Essa observação leva a formular a seguinte questão: seria a diversidade uma nova estrutura de pensamento e ação para atender às expectativas sociais contemporâneas?

\section{DESENVOLVIMENTO}

\section{Diversidade: uma Velha Questão Reinterpretada}

A questão da diversidade dos alunos e seu impacto no trabalho dos professores não é nova. Os docentes do passado já se depararam com a diversidade social e cultural de seus alunos. Recorde-se a difícil escolarização das crianças do campo ou da periferia, de famílias pobres, por vezes analfabetas e preocupadas com a contribuição econômica do trabalho dos filhos, ou as consequências da briga por leis que, por vezes, conduzem ao questionamento de conteúdos e as práticas de ensino, sem esquecer os debates profissionais sobre o que ainda não se chamava de democratização da escola (RODRIGUES, 2013, p.14).

No entanto, a percepção de diversidade no âmbito escolar mudou por vários motivos, tais como a transformação da população escolar após a massificação do ensino médio nos anos 1960-1980 (DELORS, 2001), o vínculo estabelecido entre o fracasso escolar e a normatização sistemática do ensino, a prescrição do estabelecimento de uma educação inclusiva (SILVA, 2001, p. 04). As origens do movimento que favoreceu a formulação da liminar para levar em conta a diversidade na escola devem, no entanto, ser buscadas fora da própria escola.

Pesquisas sobre a emergência da palavra diversidade na linguagem pública e política mostram que se trata de um daqueles conceitos nômades (BORIN; FIENO, SAMPAIO, 2015) que, de acordo com suas migrações entre os universos político, científico e profissional, foi investido de significado, conotações e projetos divergentes. Surgem duas primeiras linhas de força que dominam o pensamento internacional: a diversidade das culturas e a das espécies. Os mundos 
econômico e educacional também abordam a questão à sua maneira. O próprio termo "diversidade", de uso recente no vocabulário político, foi valorizado pela antropologia que defendia a diversidade das culturas, contribuindo, assim, para a nova doutrina antirracista da UNESCO após a Segunda Guerra. A unidade biológica da espécie humana e a ausência de hierarquia entre as culturas abriram caminho para uma nova unidade humana por meio da ação educativa, segundo o projeto da UNESCO (UNESCO, 1947).

Porém, em 1971, durante uma conferência na própria sede da UNESCO, Lévi-Strauss questionou o conceito que ele próprio havia construído. A partir de agora, ele afirma que a preservação da diversidade cultural passa pela proteção ou mesmo pelo isolamento das culturas mais do que por trocas generalizadas que deveriam produzir cruzamentos e tolerância, na medida em que essas trocas resultam na imposição do modelo cultural ocidental. A diversidade cultural não é mais um fato que deve ser admitido, mas reduzido, é uma qualidade a ser protegida, ela própria uma fonte de progresso (FRANÇA, 2013).

Ao mesmo tempo, durante a década de 1960, a biodiversidade passou a ser uma preocupação de organismos internacionais enquanto se observava a degradação do estado do meio ambiente sob o efeito de um século de industrialização. Ecologia e biologia serão a base da nova reflexão, cujo desdobramento é a Convenção sobre Diversidade Biológica, adotada no Rio de Janeiro em 1992. Baseia-se no trabalho de biólogos americanos a favor da biologia da conservação descrito como a ciência da escassez e da diversidade (PARO, 2007, p.108).

Esta breve visão geral mostra a extensão do campo coberto: a diversidade abrange o meio ambiente, bem como as minorias nacionais, as mulheres, os processos de aprendizagem e treinamento. A dimensão composta da concepção de "diversidade" é evidente: tanto a serviço da igualdade de direitos segundo um princípio de justiça cívica, como a serviço da equidade com base em um conceito de justiça cujo principal critério é a eficiência (SANT'ANA, 2005, p. 228). 


\section{A Diversidade e a gestão democrática no contexto educacional}

A diversidade na educação é assunto de extrema importância, e é necessária ser levada em consideração visando a existência de um ambiente inclusivo e que respeite a individualidade de todos os alunos e membros da comunidade escolar, dando lugar para os mais variados aspectos culturais que existem na sociedade. Ela envolve a variedade cultural que pode ser observada através do comportamento, da linguagem, das crenças, dos posicionamentos políticos, da vestimenta, das tradições e valores, da arte, orientação sexual e toda maneira de expressão em convívio social. Deve-se respeitar cada indivíduo e considerar o pleno exercício da cidadania.

A sociedade civilizada possui normas e padrões a serem seguidos para que ela funcione, o que muitas vezes acaba excluindo certos grupos de pessoas - as minorias. Para que isso não ocorra, é preciso conviver com a diversidade, e a melhor forma de construir uma sociedade que respeite as diferenças é inclui-la na escola, para que desde jovens os cidadãos aprendam a considerar as outras formas de ser no mundo. (SAE DIGITAL)

Os Parâmetros Curriculares Nacionais (PCN's) abordam a questão da Pluralidade Cultural como sendo uma referência ao conhecimento e ao reconhecimento dos valores culturais e étnicos dos mais diversos grupos sociais que convivem no território nacional, às desigualdades socioeconômicas e à crítica às relações sociais de discriminação e exclusão que rodeiam a sociedade brasileira, oferecendo ao discente, possibilidades de entender o Brasil como sendo um país complexo, heterogêneo e infelizmente insensato e incoerente em algumas situações.

Este tema propõe uma concepção da sociedade brasileira que busca explicitar a diversidade étnica e cultural que a compõe, compreender suas relações, marcadas por desigualdades socioeconômicas, e apontar transformações necessárias. Considerar a diversidade não significa negar a existência de características comuns, nem a possibilidade de constituirmos uma nação, ou mesmo a existência de uma dimensão universal 
do ser humano. Pluralidade Cultural quer dizer a afirmação da diversidade como traço fundamental na construção de uma identidade nacional que se põe e repõe permanentemente, e o fato de que a humanidade de todos se manifesta em formas concretas e diversas de ser humano. (MEC/SEF, p. 19, 1997)

A UNESCO (2002) conceitua a diversidade cultural no artigo $1^{\circ}$ da Declaração Universal sobre a Diversidade Cultural, como sendo um patrimônio coletivo da humanidade, devendo este ser respeitado e preservado.

A cultura adquire formas diversas através do tempo e do espaço. Essa diversidade manifesta-se na originalidade e na pluralidade das identidades que caracterizam os grupos e as sociedades que compõem a humanidade. Fonte de intercâmbios, de inovação e de criatividade, a diversidade cultural é tão necessária para o género humano como a diversidade biológica o é para a natureza. Neste sentido, constitui o patrimônio comum da humanidade e deve ser reconhecida e consolidada em benefício das gerações presentes e futuras. (UNESCO, art. $1^{\circ}, 2002$ )

Ainda em seu artigo $5^{\circ}$ pontua que os direitos culturais são um marco propício da diversidade cultural, sendo indissociáveis, interdependentes e universais, garantindo liberdade e pleno direito de cidadania a todos os indivíduos, independente de quaisquer situações e particularidades, sua cultura deve ser mantida e respeitada.

Os direitos culturais são parte integrante dos direitos humanos, que são universais, indissociáveis e interdependentes. Toda pessoa deve poder expressar-se, criar e difundir suas obras na língua que deseje e, em particular, na sua língua materna; toda pessoa tem direito a uma educação e uma formação de qualidade que respeite plenamente sua identidade cultural; toda pessoa deve poder participar na vida cultural que escolha e exercer suas próprias práticas culturais, dentro dos limites que impõe o respeito aos direitos humanos e às liberdades fundamentais. (UNESCO, art. $\left.5^{\circ}, 2002\right)$

A partir de marcos legais, como a LDB nº. 9394/1996 temas extremamente relevantes como a diversidade e a inclusão começaram a fazer parte das operações desenvolvidas pelo governo, frente às políticas compensatórias e práticas afirmativas direcionadas ao atendimento população historicamente deixada de 
lado, levando-se em consideração a necessidade de compensar ou corrigir direitos negados no passado. O caráter democrático simbolizado pela universalização da educação de qualidade para todos foi um marco que legitimou a educação como sendo direito de todos e dever do Estado, sendo observado no capítulo II da LDB n. 9394/1996, que dispõe sobre os princípios e fins dos que orientam a organização da educação nacional:

Artigo $2^{\circ}$ - A educação, dever da família e do Estado, inspirada nos princípios de liberdade e nos ideais de solidariedade humana, tem por finalidade o pleno desenvolvimento do educando, seu preparo para o exercício da cidadania e sua qualificação para o trabalho.

Artigo $3^{\circ}$ - $O$ ensino será ministrado com base nos seguintes princípios:

I - igualdade de condições para o acesso e permanência na escola; II - liberdade de aprender, ensinar, pesquisar e divulgar a cultura, o pensamento, a arte e o saber; III - pluralismo de ideias e de concepções pedagógicas; IV - respeito à liberdade e apreço à tolerância; VIII - gestão democrática do ensino público, na forma desta Lei e da legislação dos sistemas de ensino; $\mathrm{XI}$ - vinculação entre a educação escolar, o trabalho e as práticas sociais; XII- consideração com a diversidade étnico-racial (BRASIL, 2017, p. 08-09).

É expressamente necessário trabalhar na sociedade, o quão importante é manter o convívio social e respeito com a diversidade cultural, sendo papel da escola como formadora de opinião e conhecimentos, conscientizar os indivíduos a manterem o respeito e garantia de liberdade de expressão e defesa das particularidades de cada um. Cabe ao gestor escolar trabalhar de forma democrática, levando-se em consideração o trabalho em equipe e a tomada de decisões coletivas, sempre respeitando as particularidades e diversidades de cada membro da equipe e da comunidade escolar.

A gestão escolar democrática é um movimento natural nas escolas e faz parte do cotidiano. Além da formação do professor visa-se afinar as ações da escola, conversas são abertas, ideias são expostas e decisões são tomadas no coletivo. Esse processo evidencia o que Paulo Freire já dizia "Educar não é um ato neutro". O processo para que tenhamos uma gestão democrática não é simples, nem tão pouco descomplicado, exige por parte de todos os envolvidos uma postura ativa e proativa. Postura essa que não se tem a partir do discurso, mas sim da prática! (ROSANA, BLOG, 2014) 


\section{Desenvolvendo a educação inclusiva}

A chamada igualdade de direitos e oportunidades, participação e cidadania das pessoas com deficiência enfatiza a ligação entre a diversidade e o indivíduo, e a importância dada à dimensão fisiológica e cognitiva da diversidade. O quadro legal para a integração educacional e profissional de pessoas com deficiência foi redefinido (ALVES, 2012). A inclusão de alunos deficientes em escolas normais rompe com décadas de tratamento separado de crianças, então consideradas através de suas características não padronizadas e suas possíveis patologias, em vez de como alunos e futuros profissionais, cidadãos e trabalhadores a quem a escola deve se adaptar (PEREIRA, 2007).

Figura 1 - Diversidade Cultural Inclusiva

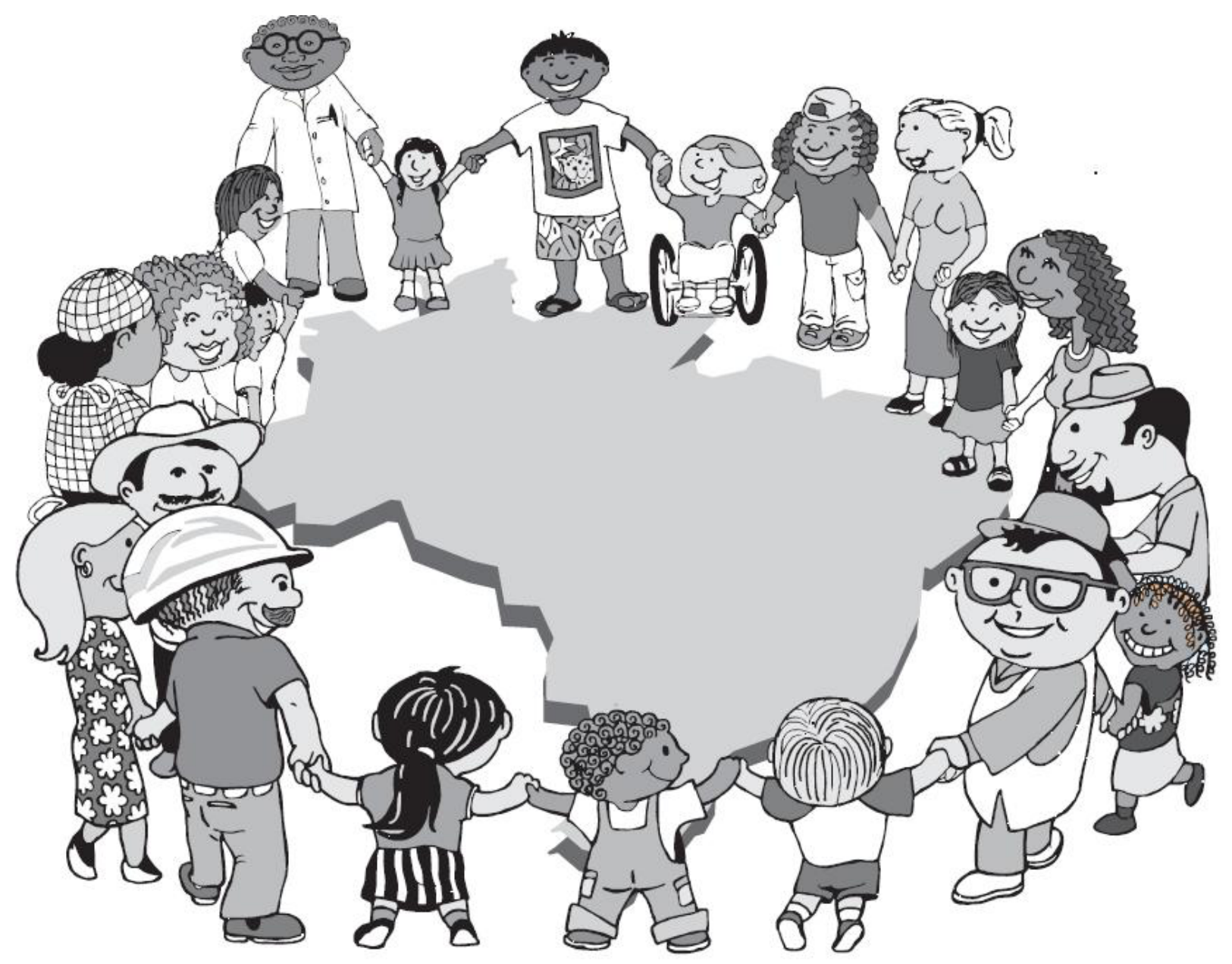

Fonte: http://4.bp.blogspot.com/-aKIny8IfBoA/UbEvIVuFT5I/AAAAAAAAAC0/yluouBSMGjk/ s1600/partel.jpg 
As iniciativas políticas têm mostrado que um novo quadro normativo sobre a questão da diversidade forma-se gradativamente, não sem compromissos, associações surpreendentes e polêmicas permanentes. A polissemia da palavra "diversidade" segundo os universos onde é utilizada, faz com que ela seja sua força e sua fraqueza ao mesmo tempo. A força de uma palavra-chave cuja capacidade de inscrever e suscitar concordâncias é óbvia, a fragilidade de uma categoria com atributos maleáveis e utilizações muito variadas (PARO, 2007).

O combate à exclusão orienta recomendações para que o aluno não seja marginalizado e a aprendizagem faz parte de uma rede de sistemas de diferenciação, ajuda e apoio. Quanto mais se proclama a consideração da diversidade em nome da liberdade e da especificidade de cada aluno, tanto mais parece exigir uma supervisão atenta para responder a um número cada vez maior de características desta tão comentada diversidade (PIMENTEL, 2012).

A flexibilização escolar para fortalecer a diversidade social dentro das escolas estabelece o objetivo de dar a todos os alunos uma chance de sucesso, sejam eles socialmente desfavorecidos, deficientes ou doentes, oprimidos por desânimo, absentismo ou abandono. A natureza composta dessa enumeração é uma espécie de culminação de vários anos de injunção para levar em conta a diversidade. O resultado é uma redução do vínculo entre origem social e fracasso escolar (THOMAS, 2011, p.13-29). A partir de agora, origens culturais e características individuais são apresentadas para explicar as dificuldades escolares ou para prescrever o que a escola e os professores devem fazer para lutar contra a exclusão. A categoria diversidade, traduzida de acordo com o contexto da educação nacional, reclassifica o diagnóstico do fracasso escolar como um problema individual (WERTHEIN, 2013).

\section{CONSIDERAÇÕES FINAIS}

A apresentação, em linhas gerais, do desenvolvimento do tema da diversidade e sua introdução no ensino mostra a pluralidade de origens e intenções que a tornaram uma categoria ativa no mundo político, social e científico. Um 
processo de tradução alinhado de organizações internacionais para a educação nacional é observável.

Em vez de considerar que a diversidade seria fazer da equidade um meio para a igualdade ou que o surgimento de uma concepção global de diversidade inclui injunções conformistas interpreta-se, neste presente trabalho, a construção da diversidade como categoria difusa. Como um conector entre dimensões e aspirações antes separadas no espaço público político e, portanto, institucional. É um meio de criar equivalências entre três lógicas: a das competências segundo a interpretação liberal dominante ligada aos princípios da equidade e da eficiência; a da ancoragem dos indivíduos em universos culturais singulares, que remete ao princípio da comunidade; e a da igualdade (de oportunidades, de direitos) ligada ao interesse geral.

Em nome da diversidade, o aluno é descrito de forma oca como vinculado a uma comunidade de suposta origem e à comunidade política da qual fará parte na concepção cívica, sendo radicalmente único e exigindo um percurso.

A atenção às necessidades de cada aluno e às afiliações culturais chama a atenção para a concepção educacional da escola, na qual uma certa indiferença às diferenças que visa a igualdade de tratamento dos alunos, e na qual a universalidade do conhecimento e dos valores compartilhados são um bem comum dos membros de uma mesma comunidade.

A afirmação dos princípios de equidade e eficiência, novos operadores das políticas públicas de educação, leva a tensões entre diferentes modelos de uma escola justa. Neste contexto, a injunção de ter em conta a diversidade aumenta a perturbação e confronta os professores com uma tripla injunção: levar em conta a diversidade, criar algo em comum, ser mais eficiente. Os textos prescritos para as escolas funcionam como amortecedores, confirmando a autonomia relativa do sistema educacional. 
No entanto, a reconfiguração parcial do prescrito em torno da categoria "diversidade" põe em causa o sentido da profissão docente pelo fato de "diversidade" se traduzir de forma diferente nos textos: como condição para melhor concretizar a promessa de igualdade, como elemento-chave da equidade ou como novo princípio universal.

\section{REFERENCIAS}

ALVES, I. K. A formação docente no contexto da educação inclusiva. Universidade Federal do Rio Grande do Sul. Faculdade de Educação/PPGEDU. Porto Alegre, 2012.

BORIN, F., FIENO, P., SAMPAIO, B. Diversidade: inclusão ou estratégia? Harvard Business Review, 2015.

DELORS, J. (ORG.). Educação: um tesouro a descobrir. 3. ed. São Paulo: Cortez, 2001.

OLIVEIRA, E. D., SOUZA, M. L. D. Multiculturalismo, diversidade cultural e direito coletivo na ordem contemporânea. Cadernos da Escola de Direito e Relações Internacionais. Curitiba. v. 1, n. 15, p. 121-139, 2011. Disponível em: <http://apps.unibrasil.com.br/revista/index.php/direito/article/viewFile/806/69>. Acesso em: 11/11/2021.

PARO, V. H. Gestão escolar, democracia e qualidade de ensino. São Paulo: Ática, 2007.

PEREIRA, J. B. C.; HANASHIRO, D. M. M. (2007). A gestão da diversidade: uma questão de valorização ou de dissolução das diferenças? Rio de Janeiro, 2007.

PIMENTEL, S.C. (2012). Formação de professores para a inclusão: saberes necessários e percursos formativos.

MIRANDA, T.G., FILHO, T.A.G (ORGS.). O professor e a educação inclusiva: formação, práticas e lugares. Salvador: EDUFBA,

RODRIGUES, P.C.R. Multiculturalismo: a diversidade cultural na escola. Escola Superior de Educação João de Deus. Lisboa, 2013. 
SANT'ANA, I.M. Educação inclusiva: concepções de professores e diretores. Psicologia em Estudo, Maringá, v. 10, n. 2, p. 227-234, maio/ago, 2005.

SILVA, N. N. A diversidade cultural como princípio educativo. Paideia Revista do Curso de Pedagogia da Faculdade de Ciências Humanas, Sociais e da Saúde. [on-line] Belo Horizonte, v.8, n.11, p.13-29, jul./dez, 2011.

THOMAS JR., R. R. From affirmative action to affirming diversity. Harvard Business Review, v. 68, p. 107-118, 1990.

UNESCO. (1960). Convenção contra a discriminação na educação 1960. Disponível em: <http://portal.unesco.org/fr/ev.php-URL_ID=12949\&URL_DO=DO_TOPIC\&URL_SECTION=201.html>. Acesso em: 11 nov. 2021.

\section{UNESCO. DECLARAÇÃO UNIVERSAL SOBRE A DIVERSIDADE CULTURAL. CLT, 2002.}

WERTHEIN, J. (2000). A sociedade da informação e seus desafios. Disponível em: <http://www.scielo.br/pdf/ci/v29n2/a09v29n2.pdf>. Acesso em: 11 nov. 2021.

FRANÇA, M. M. Tristes trópicos, de Claude Lévi-Strauss: entre a etnografia e a literatura. Dissertação (Mestrado em Teoria Literária). Universidade de São Paulo, São Paulo, 2006.

MEC/SEF. Parâmetros curriculares nacionais: pluralidade cultural, orientação sexual. Secretaria de Educação Fundamental - Brasília, MEC/SEF, 1997.

SAE DIGITAL. Diversidade na Educação no ambiente escolar. Disponível em: $<$ https://sae.digital/diversidade-na-educacao/>. Acesso em: 01/12/2021.

ROSANA (BLOG). Vivência de Gestão Democrática Escolar. TGD na perspectiva da Diversidade Cultural Inclusiva, BLOG, Ribeirão Pires, São Paulo, Brasil, 2014. Disponível em: <http://tgdci.blogspot.com/2014/05/vivencia-degestao-democratica-escolar.html?spref=pi>. Acesso em 06/12/2021. 
dol $10.48209 / 978-65-89949-D 1-1$

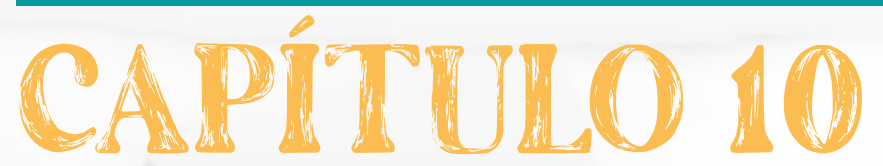

\section{O TEMPO DA ESPERA NA} PANDEMIA DA

COVID-19: COMO O DISTANCIAMENTO SOCIAL PODE FACIIITAR O ENCONTRO COM NÓS MESMOS 


\section{INTRODUÇÃO}

Todo período da história tem seu mito. Com o nosso, não poderia ser diferente. Há quem diga que a ausência de barreiras e o livre consumo de informações possam ser sempre positivos. Ainda mais na era da Globalização, na qual tudo é compartilhado em questão de cliques e segundos. Porém, a essa altura, já deveríamos saber que os excessos são sempre ruins. E, caso ainda teimássemos em não acreditar nisso, a pandemia da Covid-19 escancarou essa dura verdade.

Será que o sentido da vida está somente no desbravar do mundo externo, ou estamos tão viciados nessa busca que nos esquecemos de refletir sobre o que temos dentro de nós mesmos? Seria essa a nossa dificuldade e nosso mito a ser vivido? Habituamo-nos ao constante movimento, à vida sem fronteiras, às resoluções rápidas e descartáveis. Tudo foi intensificado a tal ponto que, subitamente, lidar com a espera se tornou um abominável pesadelo.

Como a pior reviravolta do destino, surge a pandemia da Covid-19. Pandemia que, para além das novas medidas de higiene, ressuscitou a importância do isolamento, não somente para os limites físicos, mas também emocionais. Afinal, como pode haver autoconhecimento sem reflexão? E como a vivência da pandemia e do isolamento se reflete em nossos consultórios de Psicologia Clínica? Antes de responder a essas perguntas, voltemos um pouco no tempo.

Wuhan, China, 31 de dezembro de 2019. A data e o local fatídicos em que se confirmou o primeiro caso de uma pneumonia com origem até então desconhecida (BRITO et al, 2020). Poucos dias depois, o genoma sequencial da doença foi identificado e, em 12 de janeiro de 2020, a China compartilhou com a OMS e com o mundo o que viria a ser a doença mais infecciosa e perigosa dos últimos tempos: a Covid (BRITO et al., 2020). Uma infecção respiratória aguda, de origem zoonótica, que causa febre, dificuldades respiratórias, perda de olfato, paladar, extremo cansaço físico, diarreia, entre outros sintomas peculiares (BRITO et al., 2020). 
Curiosamente - ou não -, declarou-se que a melhor forma de combater o vírus, disseminado por simples conversas e trocas de ar aparentemente inofensivas, seria o isolamento. Assim, desde março de 2020, tornamo-nos vítimas de nossos próprios cativeiros. A finalidade do isolamento social foi restringir o trânsito por locais públicos, bem como possíveis aglomerações, circunstâncias propícias à propagação do vírus (DIAS et al, 2020). Além disso, outra intervenção necessária, para aqueles que adoeceram, foi a realização da quarentena. Sintomáticas ou não, tais pessoas deveriam evitar qualquer contato, pelo prazo de 14 dias, a fim de superar o período da transmissão viral (DIAS et al, 2020).

Manter-se sitiado, por tanto tempo, deixou marcas em nossa Saúde Mental. Entre elas, diversas psicopatologias, sentimentos de exclusão social, sentimentos de negligência e de abandono (HOSSAIN et al, 2020), fixação na perspectiva de ser acometido pela Covid-19, somatização, insônia, sentimento de solidão (DE LIMA, et al, 2020), além da piora de quadros psicopatológicos existentes antes da pandemia, aumentando sintomas psicóticos, depressivos, ansiosos, entre outros (SANTOS, 2020).

Por fim, devemos mencionar que as pessoas que contraem a doença podem demonstrar raiva, medo, culpa, melancolia, solidão, ansiedade, insônia, além de, possivelmente, a longo prazo, desenvolver TEPT (Transtorno de Estresse Pós Traumático), Transtorno do Pânico e Depressão (PEREIRA et al, 2020).

E aqui começa nosso mito: a população bitolada em expandir, conquistar e agir, é obrigada a repetir, recordar e elaborar. Como lidar com a frustração da espera e o que devemos com ela aprender? É exatamente sobre isso que pensaremos aqui.

\section{A ESPERA NA LITERATURA COMO EXEMPLO CLÍNICO}

Hans Castorp de Thomas Mann, em A Montanha Mágica (1980), ou Giovani Drogo de Dino Buzzati, em Deserto dos Tártaros (1984), são dois personagens literários que nunca foram tão atuais. Poder-se-ia citar também Dr. Rieux e seus 
colegas de A Peste, de Albert Camus (2017), mas esses personagens já estão mais do que desgastados nesses tempos em que vivemos.

Dois jovens, em início de carreira, cheios de sonhos e algumas angústias, são convocados pela vida para o ato da espera. Há, entretanto, importante diferença entre ambos a ser mencionada.

Castorp, ao visitar seu primo tuberculoso num belíssimo sanatório, nos Alpes Suíços, diante da paisagem pacífica e dos excêntricos pacientes, decide, por livre e espontânea vontade, a eles se juntar. Já Drogo é alistado para servir no Forte Bastiani, nas fronteiras da Itália, aguardando a batalha contra os Tártaros, guerra que há muito deixou de existir e que, pelo visto, tampouco tonará a ocorrer. Para um deles, houve escolha. Para o outro, demanda. Afinal, ainda que Drogo tenha recebido uma proposta de transferência de seu comandante, não seria demasiada covardia desistir de seu primeiro posto?

Logo, os dois rapazes estão "presos" nas instituições, sem nada a fazer além de admirar a vista, sonhar com o futuro, conversar com colegas e aguardar a vida passar. Os dias parecem iguais, experiências marcantes são escassas e o convívio parece enfadonho e repetitivo. Será mesmo?

Há um simbolismo comum nas duas histórias que merece destaque. Para além da passagem do tempo, temos a imagem do distanciamento provido pela altura. Tanto o sanatório de Mann quanto o forte de Buzzati são estruturas erguidas em altos planos: na altura dos Alpes e na região montanhosa do deserto. $O$ distanciamento físico e emocional da vida cotidiana e agitada torna-se um desafio para ambos os personagens.

Estar suspenso nas alturas é uma imagem importante, ligada à operação da sublimatio na Alquimia. Conhecida também como o fenômeno da sublimação, viver essa etapa, num processo psíquico, significa separar para construir, distanciar para entender. É tomar distância de nossos desafios e problemas para refletirmos qual o próximo passo a ser tomado (EDINGER, 1990). 
Todo aquele que se distancia de uma questão emocional e situacional o faz por dois motivos: a necessidade de elaborar para, então, agir, ou a fuga dissimulada. Como isso se relaciona a esses personagens? Já voltaremos a essa pergunta. Primeiro, devemos olhar para como essas imagens - a espera do tempo, a imponência da altura e a força da interiorização - se relacionam com o desafio que é clinicar na pandemia.

\section{CLÍNICA NA PANDEMIA: PERFIS DE PACIENTES}

É de praxe que, enquanto psicólogos clínicos, aguardemos, a cada sessão, as atualizações de nossos pacientes sobre suas semanas. Dessa forma, aprendemos o que foi visto, ouvido e sentido por eles nos dias em que nos separamos. Na pandemia, entretanto, esses eventos ganharam novo tom. Os cenários e as pessoas são os mesmos. A vida torna-se um roteiro sem grandes reviravoltas.

A partir da minha prática clínica, observei três perfis diferentes: 1) pacientes em isolamento, conectados com seus processos pessoais, refletindo sobre todos os âmbitos de suas vidas; 2) pacientes em isolamento, mas indiferentes ao que o momento de introspecção forçada pode proporcionar; e 3) pacientes em total negação da pandemia.

No primeiro grupo, os questionamentos começam da seguinte forma: mudo esses móveis de lugar? Que tal uma parede azul? Melhor ainda: que tal mudar de endereço? Logo, as perguntas se aprofundam: Será que devo continuar nesse emprego? Estou satisfeito com a minha carreira? Estou feliz nesse relacionamento? Gosto da pessoa que me tornei?

Essa parcela são os pacientes que souberam se adaptar e aproveitar as circunstâncias. Enquanto aguardam a vacina, valeram-se da altura encontrada na sublimação, diante do terrível de nossa realidade, para refletir acerca deles mesmos. Entenderam que na espera há riqueza e, na solidão, encontro. A solidão é associada ao sentimento subjetivo de "estar só", ou seja, com a quanti- 
dade reduzida de interações sociais (KILLGORE, et al, 2020). Tal estado, além de facilitar o desenvolvimento de sentimentos depressivos, pode também gerar alteração na pressão arterial, nas funções do coração e déficits na visão (KILLGORE, et al, 2020).

Entretanto, ainda que a pessoa possa conviver com outras em sua casa, faça uso da tecnologia para se manter em contato com amigos, ou pratique um exercício ao ar livre, não há ferramenta mais eficaz do que ser capaz de manejar e controlar emoções e pensamentos negativos, seja por meditação, exercícios de respiração ou ajuda profissional (KILLGORE, et al, 2020). Logo, percebemos que, mesmo aliviando o sentimento de solidão no contato com o outro, ele ainda se faz presente caso não o confrontemos.

O segundo grupo é aquele que respeita o distanciamento social, mas não se conforma com ele. Lamenta pelos dias mal vividos, pelas lembranças que não serão criadas e pelas oportunidades perdidas. Além disso, ainda se torturam acessando, diariamente, sites de cálculos sobre quando serão vacinados.

Esse também é o grupo que procura, em excesso, encontros com amigos ou vídeo chamadas constantes. A perspectiva de olhar para si mesmo é aterrorizante, logo, é preciso se manter constantemente ocupado. Afinal, perceber a si mesmo, em espaço restrito, pode levar ao tédio, reflexão sobre as próprias atitudes, confronto com as dinâmicas familiares e, em casos extremos, violência física ou emocional (BANERJEE et al, 2020).

Observou-se, inclusive, a correlação entre baixos níveis de resiliência com pensamentos frequentes acerca da pandemia. Exemplos desses pensamentos são o medo de adoecer, ou indagações sobre quando a pandemia irá passar (KILLGORE et al, 2020). Nos tempos em que vivemos, a resiliência precisa ser nossa melhor amiga.

Percebemos, aqui, neste grupo, que embora tenha havido a decisão de se adaptar e respeitar as circunstâncias, isolando-se, não se soube aproveitar a oportunidade para refletir a respeito de si próprio. 
O terceiro grupo é aquela parcela que se negou - e ainda se nega - a aceitar a nova realidade que é viver no isolamento social. Seguem saindo, aglomerando e, egoisticamente, contaminando a todos.

As justificativas habituais desse grupo para seu comportamento costumam ser: "não aguento ficar em casa, enlouquecerei"; ou a controversa ideia de que "a situação já esteve pior" - a despeito da segunda onda e das vindouras. Não é preciso dizer que esse grupo nega totalmente a possibilidade de aprender com o período que estamos vivendo.

Precisamos, também, destacar o desafio ainda maior para as pessoas que moram sozinhas, ou para aquelas que possuem difícil convívio com seus familiares. As pessoas que moram sozinhas enfrentam o sentimento de vazio e de solidão de forma mais intensa, já que não há a presença de outro ser humano para compartilhar suas frustrações. Em contrapartida, aquelas que convivem com parentes tóxicos que, muitas vezes, são os facilitadores para o desenvolvimento de questões de Saúde Mental, estão em frequente contato com estímulos estressores (MAGALHÃES, 2020). Nesses dois perfis, somam-se ainda mais essas dificuldades, além do desafio de olhar para si mesmo.

Por fim, façamos uma menção honrosa aos pacientes que, não satisfeitos com a retenção da vida, também se contaminaram e tiveram de se isolar num cômodo. Os casos mais "suspeitos" são aqueles que se contaminaram por livre e espontânea irresponsabilidade, pois não respeitaram o isolamento. Aos que precisaram sair por motivos profissionais, prestemos empatia e compaixão.

De qualquer forma, adoecer proporcionou um aumento do isolar-se: os doentes transformam-se em leprosos asmáticos, contagiosos, privados de qualquer contato com o Outro. Os efeitos disso na psique são devastadores: a solidão abraça com força - e, de quebra, ainda nos deixa sem fôlego e com pulmões pesados.

Dos pacientes que abraçaram o sanatório ou o forte, aos que neles "tiveram" de se internar e servir, emburrados, de braços cruzados, negando-se a fazer 
a viagem, uma coisa é certa: a pandemia obrigou-nos a nos deparar com quem somos através do isolamento.

Logo, para além das mudanças sanitárias, descobrimos a necessidade da transformação de nossa postura. Como agir quando não podemos escapar de nossa realidade com uma viagem de final de semana, com um jantar com bons amigos ou com um filme recém-lançado no cinema? Não há como fechar olhos: só nos resta parar e ver.

\section{CLÍNICA NA PANDEMIA: INTERVENÇÕES E REFLEXÕES}

Antes de abordarmos a possibilidade de usar o tempo do isolamento para trabalharmos nossas questões internas, ressaltemos algumas estratégias de manejo e intervenção importantes na clínica nesse momento.

Inicialmente, é preciso informar as pessoas dos efeitos da doença, assim como as formas de se proteger. Além disso, com auxílio profissional, pode-se ensinar técnicas de respiração ou relaxamento para ajudar a manejar momentos de ansiedade, pânico e estresse. Por fim, quando a situação estiver mais controlada, será necessário acolhimento e instrução para a retomada das rotinas que perdemos (FARO et al, 2020). Enquanto em muitos casos a ignorância é uma benção, hoje, a informação é o que nos salvará.

Para diminuir o sentimento de solidão, são recomendadas intervenções psicológicas, em grupo ou individuais, planejamento de atividades coletivas, caso mais de uma pessoa viva na mesma casa, e a utilização, com equilíbrio, de redes sociais para manter vínculos externos (SMITH et al, 2020). De fato, a tecnologia mostrou-se ferramenta essencial nesses tempos pandêmicos: não apenas por encurtar as distâncias e permitir conversas com amigos e familiares que não podemos encontrar pessoalmente, mas também como principal veículo de informação sobre profilaxias, andamento do número de casos, novos estudos sobre formas de contaminação e o caminhar da vacinação (ESPINEL et al, 2020). Ainda assim, deve-se haver cuidado para não acessar notícias falsas ou sensacionalistas. 
Manter uma rotina equilibrada, na medida do possível, entre trabalho e lazer; providenciar informações claras e condizentes às crianças e aos idosos em estágio demencial para minimizar a angústia; praticar alguma atividade física, de modo seguro; e, se possível, prestar auxílio aos vizinhos que possam estar impossibilitados, seja pela idade, seja por comorbidades, de realizar tarefas fora de casa, são recomendações importantes (LIMA, 2020).

Após manejar e informar, em contexto clínico, essa série de questões que todos já conhecemos, o trabalho fica mais desafiador. Tornam-se tarefas do psicólogo clínico acolher a ansiedade de "quando tudo vai passar?" e também de sustentar o encontro dos pacientes com eles mesmos.

Observar não só o nosso presente, mas como chegamos a ele, é a maior possibilidade psicológica nesses tempos pandêmicos. Explorar o contexto profissional, social e pessoal, ou seja, a profundidade do nosso mundo interior, é o que nos resta nesse momento de paralização do mundo externo. Cada traço ignorado, plano empoeirado ou pessoas entulhadas nas nossas vidas foram - ou deveriam ser - revistos. Só assim poderemos compreender, antes do retorno, o que nos tem atrasado na vida.

Em seu texto Recordar, Repetir e Elaborar (2010), Freud já nos avisava as consequências de não observarmos os padrões repetitivos que alimentam nossas neuroses e não nos permitem seguir em frente. Justamente pela vida corrida que levamos, com demandas diárias, nem sempre pausamos e refletimos a respeito das experiências traumáticas pelas quais passamos. Parece mais "fácil" - e rápido - ignorá-las e reprimi-las. Entretanto, mesmo que esquecidas, essas vivências seguem intrínsecas em nossos comportamentos, sendo tais feridas repetidas em atitudes ou pensamentos que temos frente à vida, sem nem ao menos entendermos o porquê de atuamos dessa forma (FREUD, 2010).

É justamente a segurança do setting terapêutico que permitirá, ao paciente, atuar essa repetição na transferência com seu terapeuta. É essa atuação que permitirá ao clínico encontrar a raiz dos problemas enfrentados pelo seu analisando. Assim, ao interpretá-las, ajudará o seu paciente a encarar, com aco- 
Ihimento e coragem, os fragmentos dolorosos de sua história que não estão sob controle de sua consciência. Finalmente, o analisando poderá elaborar suas repressões (FREUD, 2010). Contudo, a compulsão da repetição é o que permite acessarmos, em terapia, aquilo que nos assombra e nos impede de prosseguir. É a forma como o paciente consegue, de modo inconsciente, recordar aquilo que foi vivido (FREUD, 2010).

No início desse capítulo, mencionei que todo período do tempo tem seu mito. Percebo, em nossos dias, a dificuldade de nos depararmos com quem somos, fomos ou gostaríamos de ser. Isso foi exacerbado pela extrema ausência de fronteiras e pela dificuldade de voltar-se a si próprio. É o mito do mundo livre, expansivo e igualitário. Ou será que nosso o mito é justamente o inverso: aprender a não nos descaracterizarmos diante de oportunidades plásticas, repetidas e compulsivas?

Um vírus que fecha nossas fronteiras e nossos corpos ao contato com o Outro, seja ele uma pessoa, cidade ou país, reflete exatamente o que nos falta e precisamos aprender: retermo-nos um pouco mais em nós mesmos.

Estamos adoecidos - e viciados - em direcionar nossa energia apenas ao coletivo. Repetimos o comportamento de buscar sempre mais "experiências", mais "amigos", mais "casos amorosos", mais viagens, mais consumo, muitas vezes sem nem conseguirmos recordar tudo o que vivemos, tamanha a agilidade com que substituímos nossas memórias e desejos. Elaborar e refletir sobre o que foi positivo ou destrutivo em nossas vidas? Mais raro ainda. Em níveis extremos, chegamos ao ponto de não saber se aquilo que nos tornamos foi por escolha ou por influência de um grupo ou do que consumimos.

Desde 2020, fomos todos obrigados a desacelerar. O contato externo tornou-se virtual e, ainda assim, queremos mais. Não é curioso que esse "mais" nunca é saciado?

Vivemos em sociedade e somos influenciados pelo coletivo. Mas isso não significa que devemos nele nos misturar. Saber pausar, refletir e colocar nossos 
projetos e paisagens em perspectiva é fundamental para sermos menos contaminados, tanto pelos comportamentos neuróticos dos outros, quanto por ideologias extremistas ou religiões fanáticas (JUNG, 2016).

O Coranavírus representa, assim, um símbolo daquilo que, por excelência, precisamos aprender: "feche-se, senão você adoecerá". É claro que vivemos, hoje, uma situação radical. Mas essa é justamente a função de um símbolo: algo em parte desconhecido, inconsciente, nos mobiliza e perturba, até conseguirmos, em parte, apreendê-lo com nossa consciência. Nunca iremos compreendê-lo por inteiro, caso contrário, sua energia deixaria de atuar em nós. Os símbolos surgem justamente para nos fazer reavaliar aquilo que está compulsivo e negativo em nossa atitude frente à vida (JUNG, 2016).

Viver em grupo pode nos enriquecer, à medida que temos contato com o Diferente, providenciando outros conhecimentos e sentimentos. Entretanto, é necessário que saibamos nos diferenciar do meio. É preciso fazer uma síntese daquilo que nos é proveitoso do externo com a nossa identidade e percepção interiores (JUNG, 2016).

Numa rotina tumultuada, cheia de compromissos, um tempo a sós é mais raro. Contudo, o isolamento social providenciou, compulsoriamente, que nos tranquemos e olhemos para nós mesmos. Fez-nos distanciar da realidade e observar cada fresta esquecida em nossas histórias pessoais. Um encontro poderoso e assustador.

\section{QUANDO A ARTE E A VIDA SE ENCONTRAM}

O distanciamento social é uma imagem, menos romantizada, do sanatório de Hans Castorp ou do Forte de Giovani Drogo. É o manter-se fixo em somente um cenário, em uma só rotina, por tempo indeterminado. É ter como "entretenimento" o revisitar de nossos sentimentos e de nossas visões de mundo. Como nossos corajosos personagens, vivemos a história ociosa - e, por vezes, tediosa - da pausa. Do colocar-se no alto e olhar, com cautela e distanciamento, o que se tornaram as nossas vidas. 
Hans Castorp, antes em dúvida e desgostoso consigo mesmo, permitiu-se aconchegar entre os cobertores quentes nas varandas frias, nas comidas calorosas que engrandeceram o apetite, nas conversas marcantes com os colegas doentes. Entendeu mais sobre a vida - nem sempre concordando com ela -, e pôde descer das montanhas com mente mais afiada e olhos mais abertos para o seu presente.

Já Giovanni Drogo escorregou ao sonhar em demasiado com o futuro. À espera das glórias de uma guerra imaginária e das condecorações inexistentes, esqueceu-se de viver. Perdeu o ar seco, a areia brilhosa, os colegas frustrados. Mais importante: deixou de se questionar se aquele cargo tinha um propósito e se combinava com o seu projeto de vida. Ao tornar-se uma pessoa sonhadora, voou tão alto que não conseguiu mais colocar os pés no chão. Descolou-se de si mesmo: infeliz por não realizar suas ilusões, desenraizou-se do presente, o qual tornou-se insípido diante de tamanhas fantasias. Mesmo sabendo da possibilidade de se transferir para outro posto, obrigou-se a ficar. Mas não soube fazer bom uso da experiência.

Temos, em nossos representantes fictícios, imagens claras de dois grupos que conheci nos meus atendimentos pandêmicos: os pacientes que, percebendo o quanto a pandemia iria demorar e seus planos externos precisariam ser pausados, decidiram "internar-se nos sanatórios" de suas casas e observar a si mesmos. O segundo grupo se negou a encontrar o presente, vivendo pelas bataIhas futuras, ainda que respeitando as circunstâncias em que nos encontramos. Vemos, portanto, a similaridade de Castorp e Drogo com meus pacientes. O primeiro, aceitou o isolamento e seu adoecimento psíquico. Assim como Castorp, que, apesar de não ser tuberculoso como os demais pacientes da instituição, internou-se no sanatório para cuidar das suas feridas psíquicas. Escolheu parar e refletir sobre a vida. O segundo aceitou o posto ao qual foi indicado, mesmo sabendo que podia ser transferido caso quisesse - leia-se, desrespeitar o isolamento -, mas não conseguiu corresponder às expectativas realistas de seu cargo e tampouco aprendeu a usar o tédio como oportunidade de reflexão. 
E o terceiro grupo, aquele que negou tudo? Não temos um representante literário. Parece-me que eles não souberam encontrar beleza na espera.

Acompanhar o desenvolvimento psicológico de qualquer pessoa nunca é tarefa fácil. Na pandemia, menos ainda. Entretanto, para além de intensificar a dificuldade, percebo que os processos terapêuticos nunca foram tão intensos e em alguns casos - tão belos.

Encontrar a si mesmo e se reconectar com suas perdas e escolhas do passado são ferramentas importantes para podermos cuidar de nosso presente e planejar nosso futuro. Mas isso, é claro, requer esforço e dedicação. Além de boas horas de um aprofundado distanciamento de nossas atividades. Um cenário que traduz o isolamento social: o tempo de sobra para nos debruçarmos sobre nós mesmos, solitários, sem distrações. Tragicamente perfeito.

O mito de nosso tempo, convocado por um período tão horrendo como essa pandemia, foi devastador. É necessário muita resiliência e criatividade para ultrapassá-lo, além de, quem sabe, fazer dele bom proveito. Não podemos controlar o quão rápido ele passará: aliás, tal cálculo pode até intensificar nosso sofrimento. A única escolha que temos é decidir como iremos lidar com a passagem do tempo pandêmico. Se ele será bem utilizado, eis escolha que cabe a cada um.

\section{CONCLUSÃO}

A impossibilidade de transitar livremente, viajar, conviver, aglomerar, foi, para além da doença em si, a maior dificuldade enfrentada do ponto de vista psicológico. Não poder se refugiar no mundo externo nos obrigou a nos fechar em nossos pensamentos.

O consultório de um psicólogo já é, por excelência, um espaço de reflexão. Com o isolamento social, entretanto, a quantidade de tempo "livre" e que não pode ser usado em ambiente externo, intensificou a quantidade de momentos em que paramos e olhamos para nós mesmos. 
Aqueles que souberam parar e aproveitar essa lacuna da Covid-19, digna de ficção científica, puderam reavaliar questões há muito tempo não visitadas. Como será o retorno de todas essas pessoas ao mundo sem pandemia? Serão as que mais refletiram as mais conscientes? Não podemos afirmar com certeza. Só o tempo dirá.

Ainda assim, a pandemia da Covid-19 exacerbou a grande dificuldade de nossos tempos: o introjetar. Olhar para dentro. Olhar para si. A tarefa de confrontar-se a si próprio é urgente. Não é apenas o vírus que anda nos contaminando: sem pausa, somos um risco a nós mesmos.

\section{REFERENCIAS}

BANERJEEN, D; RAI, M. Social isolation in Covid-19: The impact of loneliness. International Journal of Social Psychiatry, Londres, v. 66 , n. 6, p. 525-527, 2020.

BRITO, S. B. P.; BRAGA, I. O.; CUNHA, C. C.; PALÁCIO, M. A. V.; TAKENAMI, I. Pandemia da COVID-19: o maior desafio do século XXI. Visa em Debate, Rio de Janeiro , v.8, n.2, p. 54-63, 2020.

BUZZATI, D. O Deserto dos Tártaros. Rio de Janeiro: Nova Fronteira, 1984.

CAMUS, A. A Peste. Rio de Janeiro: Record, 2017.

DIAS, J. A. A.; DIAS, M. F. S. L.; OLIVEIRA, Z. M.; FREITAS, L. M. A.; SANTOS, N. C. N.; FREITAS, M. C. A. Reflexões sobre distanciamento, isolamento social e quarentena como medidas preventivas da COVID-19. Revista de Enfermagem do Centro-Oeste Mineiro, São João Del Rei, v. 10, p. 1-8, 2020.

EDINGER, E. F. Anatomia da Psique, O Simbolismo Alquímico na Psique. São Paulo : Cultrix, 1990.

FARO, A.; BAHIANO, M. A.; NAKANO, T. C.; REIS, C.; SILVA, B. F. P.; VITTI, L. S. COVID-19 e Saúde Mental: a emergência do cuidado. Estudos de Psicologia, Campinas, v. 37, p. 1-14, 2020. 
FREUD, S. Observações Psicanalíticas sobre um caso de Paranoia relatado em em autobiografia ("O Caso Schreber"), Artigos sobre Técnica e outros textos. São Paulo: Companhia das Letras, 2010.

HOSSAIN, M. M.; SULTANA, A.; PUROHIT, N. Mental health outcomes of quarantine and isolation for infection prevention: an umbrella review of the global evidence. Epidemiology and Health, Seoul, v. 42, p.1-20,2020.

HWANG, T. J.; RABHERU, K; PEISAH, C.; REICHMAN, W.; IKEDA, M. Loneliness and social isolation during the Covid-19 pandemic. International Psychogeriatrics, Cambridge, v. 32, n. 10, p. 1217-1220, 2020.

JUNG, C. G. Civilização em Transição. Rio de Janeiro: Vozes, 2016.

JUNG, C. G. A Natureza da Psique. Rio de Janeiro: Vozes, 2016.

KILLGORE, W. D. S.; TAYLOR, E. C.; CLOONAN, S. A.; DAILEY, N. S. Psychological resilience during the COVID-19 lockdown. Psychiatry Research, Irlanda, v. 291, p. 1-2, 2020.

LIMA, R. C. Distanciamento e isolamento sociais pela Covid-19 no Brasil: impactos na Saúde Mental. Revista de Saúde Coletiva, Rio de Janeiro, v. 30, n. 2, p. 1-10, 2020.

LIMA, C. V. C.; CÂNDIDO, E. L.; SILVA, J. A.; ALBUQUERQUE, L. V.; SOARES, L. M.; NASCIMENTO, M. M.; OLIVEIRA, S. A.; ROLIM, M. L. Effects of quarentine on mental health on population affected by Covid-19. Journal of Affective Disorders, Londres, v. 275, p. 253-254, 2020.

MAGALHÃES, A. M. M. A Pandemia exacerbou os relacionamentos ou a solidão. Boletim Academia Paulista de Psicologia, São Paulo, v. 40, n. 99, p. 192-204, 2020.

MANN, T. A Montanha Mágica. Rio de Janeiro: Nova Fronteira, 1980.

PEREIRA, M. D.; OLIVEIRA, L. C.; COSTA, C. F. T.; BEZERRA, C. M. O.; PEREIRA, M. D. A pandemia de COVID-19, o isolamento social, consequências na saúde mental e estratégias de enfrentamento: uma revisão integrativa. Research, Society and Development, Vargem Grande Paulista, v. 9, n. 7, p. 1-31, 2020. 
SANTOS, C. F. Reflections about the impact of SARS-COV-2/COVID-19 pandemic on mental health. Revista Brasileira de Psiquiatria, São Paulo, v. 42, n. 3, p. 329-332, 2020.

SMITH, B. J; LIM, M. H. How the Covid-19 pandemics is focusing attention on loneliness and social isolation. Public Health Research \& Practice, Sidney, v. 30, n.2, p. 1-4, 2020.

ZHU, S.; WU, Y.; ZHU, C.; HONG, W.; YU, Z.; CHEN, Z.; JIANG, D.; WANG, Y. The immediate mental health impacts of the COVID-19 pandemic among people with or without quarantine managements. Brain, Behavior and Immunity, Pennsylvania, v. 87, p. 56-58, 2020. 


\section{doi $10.48209 / 978-65-89949-D A-1$}

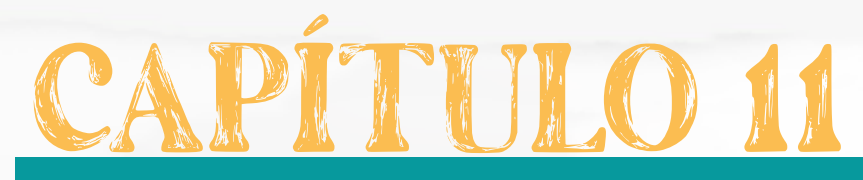

\section{“O HOSPEDEIRO}

ESTÁ MORRENDO,

O CARA VIROU UMPARASITA,

O DINHEIRO NÃO CHEGA NO POVO E ELE QUER AUMENTO AUTOMÁTICO": UMA ANÁLISE CRÍTICA DO DISCURSO 


\section{INTRODUÇÃO}

O Governo Federal, através do Ministério da Economia, propõe algumas alterações no Pacto Federativo estabelecido na Constituição Federal de 1988, o qual altera várias regras estabelecidas à época, com as formulações das PEC's, sendo que uma delas é a Reforma da Previdência já implantada.

Em 2020 foi proposta a PEC 32/2020, que se trata da Reforma Administrativa.

Para defender a atual PEC 32/2020, o atual Ministro da Economia, Paulo Guedes, faz usos de determinadas argumentações, tentando convencer e estabelecer seu pensamento particular, sua ideologia e seu domínio de maneira pejorativa aos servidores públicos. Para isto, Paulo Guedes utiliza, numa primeira análise, um linguajar inapropriado à liturgia do cargo que ocupa, ao lançar mão de termos desrespeitosos, referindo-se aos servidores. Nossa análise se pautará numa pequena biografia do atual Ministro da Economia, onde será dada ênfase em seu processo de constituição, enquanto Ser; sem, contudo, adentrarmos em questões filosóficas. O que buscamos nesse ponto é apresentar e, minimamente, saber quem é Paulo Guedes. Recorremos também a informações que nos permitam entender o que é, elucidar alguns aspectos da PEC 32 - Reforma Administrativa e os impactos resultantes de sua aprovação.

Neste artigo, procuraremos investigar o porquê de Paulo Guedes, Ministro da Economia, usar de tais argumentos contra os funcionários públicos para defender sua posição favorável ao Projeto da PEC 32, bem como analisar o significado representacional do discurso presente em seus enunciados na notícia: "Paulo Guedes compara funcionário público a'parasita' ao defender reforma administrativa", veiculada pelo jornal online g1.globo.com, no dia 07 de fevereiro de 2020. Esta é uma pesquisa qualitativa, com apoio da reportagem da mídia (internet). A declaração dos enunciados a serem analisados foi dada pelo referido Ministro em palestra na Escola Brasileira de Economia e Finanças da Fundação 
Getúlio Vargas (FGV EPGE), no encerramento de um seminário sobre o Pacto Federativo.

Como teoria metodológica, utilizaremos a Análise Crítica do Discurso e a categoria analítica interdiscursividade do Significado Representacional do Discurso (FAIRCLOUGH, 2003), e nessa perspectiva faircloughiana, a ideologia é compreendida como representações de aspectos do mundo que contribuem para estabelecer e manter relações de poder, dominação e exploração. Quanto à abordagem, essa pesquisa pode ser classificada como qualitativa e se configura como um estudo de caso simples de cunho documental.

Pretende-se, portanto, demonstrar ao final do trabalho, a importância da Análise do Discurso para a compreensão e interpretação de fenômenos linguísticos e, por conseguinte, a demonstração da ideologia do Governo e sua tentativa de manter a hegemonia em seu discurso, denegrindo a imagem do servidor público.

\section{BREVE BIBLIOGRAFIA SOBRE PAULO ROBERTO NUNES GUEDES - MINISTRO DA ECONOMIA E SOBRE A PEC 32/2020 - REFORMA ADMINISTRATIVA}

Paulo Roberto Nunes Guedes, mais conhecido como Paulo Guedes, pertence à base governista do Presidente da República como ministro da economia. Entretanto, o cargo de Ministério da Economia ainda não existia, e passou a existir no dia de sua posse. Sua nomeação se deu no dia primeiro de janeiro de 2019, e está em exercício até então. (BCB.GOV, 2021).

Como ainda não se tem uma bibliografia publicada sobre Paulo Roberto, encontramos dificuldade em aprofundar mais sobre ele, por isso faremos aqui um breve relato sobre sua vida.

Constatamos que Guedes nunca teve envolvimento público antes, exceto em1989, quando participou da composição do plano de governo do ex-minis- 
tro Guilherme Afif Domingos. Segundo GOV.BR (2021, p. 01), Paulo Guedes é formado em economia pela Universidade de Chicago.

PhD em economia pela Universidade de Chicago. Foi professor da PUC-RJ, da Fundação Getúlio Vargas (FGV) e do Instituto de Matemática Pura e Aplicada (IMPA). Fundador do Banco Pactual, da Abril Educação, das Faculdades Ibmec e do Instituto Millenium. Integrou conselhos de administração de grandes empresas. Paulo Guedes também foi colunista dos jornais Folha de S. Paulo e O Globo e das Revistas Exame e Época.

\section{Atuação de Paulo Guedes no governo}

Conforme o site suno.com.br, a indicação de Paulo Guedes como Ministro da Fazenda, em 2018, chamou a atenção do mercado e da população em geral, já que o posicionamento de Guedes sempre foi voltado para privatizações e enfraquecimento do Estado. Contudo, sua visão macroeconômica e a atenção que dá ao empresário contribuíram para a escolha de seu nome ao cargo. Sua principal medida como Ministro da Economia foi a realização da reforma da previdência. Além disso, defende a privatização de empresas estatais,além das reformas tributária e administrativa. Sobre esta última, será dada mais ênfase neste trabalho.

\section{Artigo 37A da PEC 32/2020: Modernização do Serviço Público ou Mecanismo de Transferência do Orçamento Público para a Iniciativa Privada?}

Antes de adentrarmos no que está proposto nesse ponto do artigo, qual seja, analisar os reflexos do artigo 37A da Proposta de Emenda Constitucional número 32 de 2020, considera pertinente tecer algumas considerações sobre o que disse o Ministro da Economia ao se referir aos servidores públicos. Vale ressaltar, que tal comentário lhe rendeu uma condenação, proferida pela juíza Cláudia da Costa Tourinho Scarpa, da $4^{a}$ Federal Cível da Seção Judiciária da Bahia, em ação por danos morais movida pelo sindicato dos Policiais Federais da Bahia (Sindipol-BA). 
Disse o Ministro:

"O hospedeiro está morrendo, o cara virou um parasita, o dinheiro não chega no povo e ele quer aumento automático", disse na ocasião. Ele também pediu que eles "não assaltem o Brasil, quando o gigante está de joelhos e eles em casa com geladeira cheia". (destaques nossos)

Ministro Paulo Guedes ${ }^{1}$

Na opinião de Guedes, o servidor público é um "parasita" que viveria de se locupletar do "hospedeiro" Brasil, enquanto a maioria da população padece necessidades.

Em seu entendimento, os servidores públicos formam uma casta composta por pessoas privilegiadas, bem remuneradas, o que, por conseguinte, permite que suas geladeiras estejam sempre cheias, contrastando com a maioria dos trabalhadores brasileiros, o que está longe de ser realidade.

\section{O que diz o DIEESE?}

A Pesquisa Nacional da Cesta Básica de Alimentos, realizada mensalmente pelo Departamento Intersindical de Estatística e Estudos Socioeconômicos $(\text { Dieese })^{2}$, demonstrou ser necessário a uma família brasileira, composta por dois adultos e duas crianças, perceber, a título de salário mínimo, o correspondente a $\mathrm{R} \$ 5.351,11$, para que possa viver dignamente.

Isso representa mais de quatro vezes, o valor do salário mínimo nominal, ou seja, aquele pago atualmente.

O gráfico abaixo demonstra a disparidade entre o valor necessário e o valor real do salário mínimo brasileiro, numa série histórica entre os anos de 1994 a 2020

1 Paulo Guedes é condenado por chamar servidores de "parasitas". Disponível em: $<$ https://www.conjur.com.br/2020-set-18/paulo-guedes-condenado-chamar-servidores-parasitas>. Acesso em: 07 de maio de 2021.

2 Salário mínimo ideal subiu para $\mathrm{R} \$ 5.351,11 \mathrm{em}$ maio, diz Dieese. Disponível em: <https://www.cnnbrasil.com.br/business/2021/06/08/salario-minimo-ideal-subiu-para-r-5351-11-em-maio-diz-dieese>. Acesso em: 24 de junho de 2021. 


\section{Salário mínimo nominal $X$ necessário (em R\$) \\ Valores do piso necessário são referentes a dezembro de cada ano, com exceção do valor de 2021}

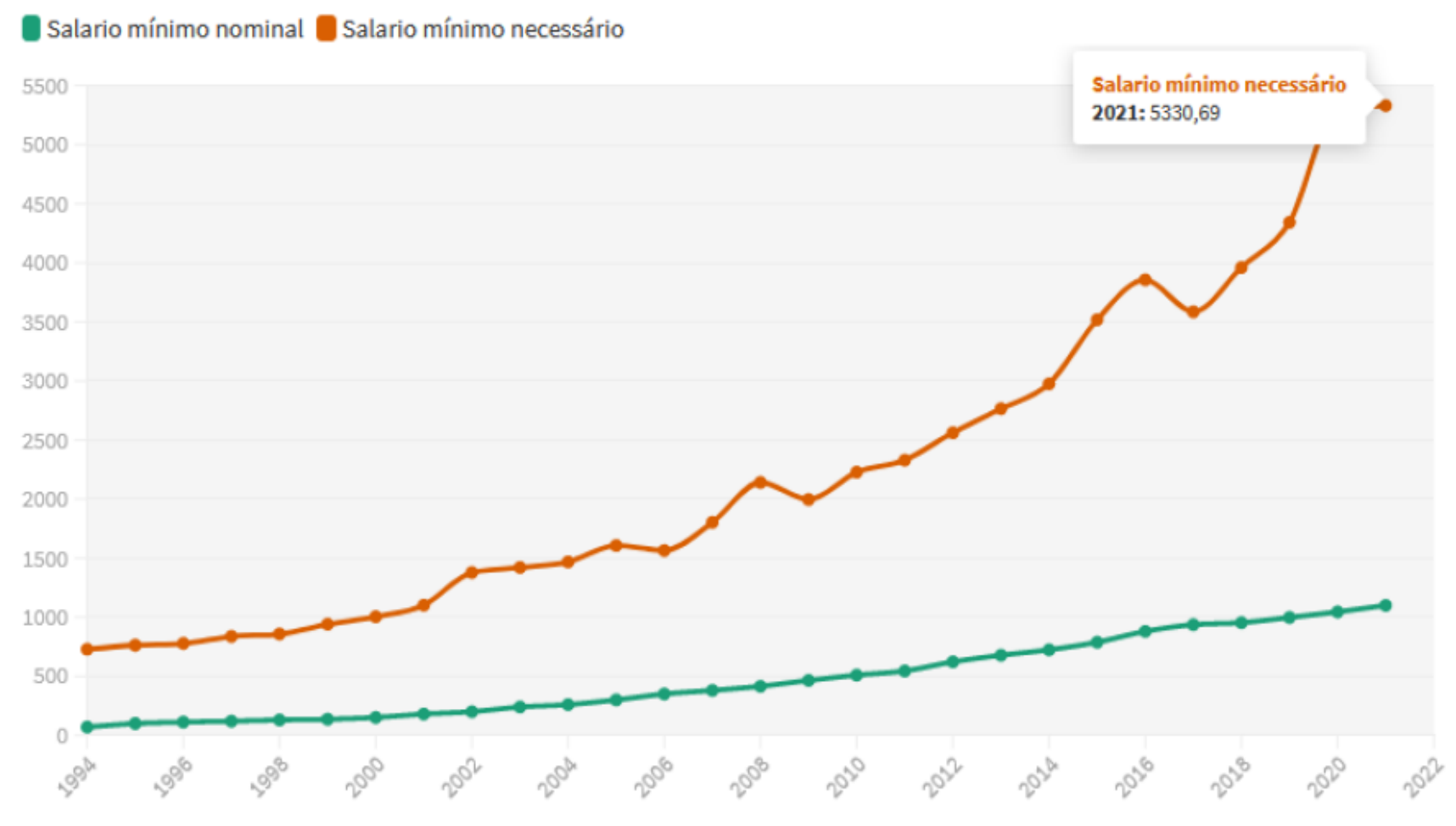

Fonte: Dieese

Depreende-se daí ao menos duas informações:

A primeira, e mais óbvia, que o trabalhador brasileiro é muito mal remunerado.

A segunda, que está muito distantes de nos constituirmos em uma sociedade verdadeiramente evoluída, que preza pelo bem estar coletivo, uma sociedade da inclusão, que garanta o mínimo necessário para a sobrevivência de seus cidadãos.

Primeiramente, queremos deixar claro que discordamos do que diz Guedes, e principalmente da sua visão, em nosso entendimento, propositadamente distorcida, quando se refere ao funcionalismo público.

Para subsidiar o posicionamento que ora assumimos neste artigo, lançamos mãos dos resultados apresentados por Felix Lopez e Erivelton Guedes ${ }^{1}$,

1 Respectivamente Técnico de planejamento e pesquisa na Diest/Ipea; técnico de planejamento e pesquisa na Divisão de Estudos em Inovação (DVINO) do Ipea 
no estudo intitulado: TRÊS DÉCADAS DE EVOLUÇÃO DO FUNCIONALISMO PÚBLICO NO BRASIL (1986 - 2017): ATLAS DO ESTADO BRASILEIRO.

Nele, os autores analisam a situação dos vínculos formais de trabalho mantidos com o setor público, ao longo de três décadas, trazendo à baila informações quanto: a) Evolução no total de vínculos do setor público e privado; b) Vínculos por poderes e níveis federativos; c) Escolaridade dos ocupados no setor público; d) Remunerações, em geral, no setor público; e) Vínculos e remuneração, por sexo e; f) despesa com servidores ativos.

Debruçamos sobre o item "d", o que se trata das "Remunerações, em geral, no setor público", focando, especificamente, no Poder Executivo, sem, contudo, fazermos um rápido comparativo entre os salários pagos pelo Executivo e os demais Poderes.

A partir do estudo de LOPEZ e GUEDES, elaboramos a tabela abaixo, onde apresentamos uma comparação entre a média e mediana das remunerações, relativas aos três poderes, no ano de 2017.

\begin{tabular}{|c|c|c|c|c|c}
\multirow{2}{*}{} & \multicolumn{3}{c|}{ Remuneração média e mediana (2017) } & \multicolumn{2}{c}{$\begin{array}{c}(\%) \text { em relação } \\
\text { aos poderes }\end{array}$} \\
\cline { 2 - 6 } & Judiciário & Legislativo & Executivo & Judiciário & Legislativo \\
\hline Média & $12.081,71$ & $6.025,95$ & $3.895,91$ & 32,25 & 64,65 \\
\hline Mediana & $10.542,22$ & $3.419,63$ & $2.589,15$ & 24,56 & 75,71
\end{tabular}

Na média, verificamos que o investimento na remuneração de pessoal do executivo é bem aquém dos padrões praticados nos demais Poderes.

\section{ANÁLISE CRÍTICA DO DISCURSO DE NORMAN FAIRCLOUGH}

Norman Fairclough, fundador da ACD, também foi professor de linguística na Universidade de Lancaster. Seus livros que representam marcos do desenvolvimento teórico-metodológico da ACD são: Language and Power (1989), Discourse and Social Change (1992) e Analysing Dicourse (2003). 
O principal da proposta de Fairclough é explicar como os efeitos sócios???? agem nos textos, bem como as mudanças que podem favorecer a superação das relações sociais de poder, discriminação, dominação e controle que são manifestadas em ideologias por meio de discurso.

A proposta de Fairclough para a ACD tem conceitos em três influências importantes: O Marxismo Ocidental, que reforça os aspectos culturais da vida social ao entender que as relações de dominação e exploração são determinadas e perpetuadas cultural e ideologicamente; de Foucault, o qual definiu o discurso como um sistema de conhecimento que tem como objetivo controlar a sociedade através de controle do saber e do poder e, por fim, influência de Mikhail Bakhtin, que tem o conceito que a linguagem é sempre usada de forma ideológica.

O trabalho desenvolvido por Fairchough é considerado inovador para ACD por não delimitar no desvelamento das relações sociais envolvendo poder e dominação, já que seu objetivo como proposta é de atuar nas transformações sociais, contribuindo com a superação das desigualdades e das injustiças que operam na sociedade. Com isto, fazer pesquisa baseado na ACD exige do pesquisador um questionamento acerca da vida social em termos políticos e sociais, sendo critico e engajado na transformação. Para Fairchough (2001), ser critico é mostrar conexões e causas que estão ocultas; implica em intervenção através de recursos por meio da mudança para aqueles que possam estar em desvantagem.

Em sua proposta, Chouliaraki e Fairchough (1999 apud Barros, 2015) propõem modelo de análise que identifique os problemas sociais materializados em texto orais ou escritos, com base na crítica defendida por Bhaskar $(1998,2002)$ a partir de cinco estágios: 1 - dar ênfase a uma injustiça social, um problema que afeta a vida social; 2 - identificar os obstáculos para que a injustiça seja resolvida; 3 - funções do problema na prática; 4 - considerar se há injustiça social; 5 - refletir sobre a análise e como proposta de Barros (2015), incluir um sexto estágio que seja definir um novo problema. 
Para Fairchough (2001), o discurso contribui para a construção das relações sociais entre as pessoas, já que consiste no "uso da linguagem como forma de prática social e não como atividade puramente individual". Desta forma, o discurso não é estático, e sim, é uma maneira de interação e agir sobre o mundo e sociedade, pois é através do discurso que é possível se posicionar e apresentar as representações sobre o mundo material, social e mental.

Nesta perspectiva, para Fairchough, o discurso se apresenta em três momentos de prática social: gênero (modo de agir), discurso (modo de representar) e estilos (modo de ser). Estes elementos linguísticos são nomeados como ordens do discurso que regulam nossas ações discursivas. E como isto, ele propõe três tipo de significados que atuam simultaneamente em todo e qualquer discurso: significado acional (modo de agir), significado representacional (modos de representar) e significado identificacional (modo de ser).

O significado acional vê o texto como modo de inter(ação) em eventos sociais e possui como categoria de análise a estrutura genérica e a intertextualidade. O significado representacional já foca na representação de aspectos do mundo - físico, mental, social em textos e possui uma categoria de análise: processos (verbos), participantes (grupos nominais) e circunstâncias associadas ao processo. E por fim, o significado identificacional enfatiza em considerar o estilo atrelado ao discurso, por ser a identidade social construída por meio das práticas discursivas com o outro e suas categorias de análise são a modalidade e a avaliação. Em de acordo com esse significado, Barros (2015), diz que "as relações de poder existentes entre os indivíduos, por meio de atitudes ora opressivas, ora emancipatórias, pode determinar a construção da identidade".

\section{ANÁLISE CRÍTICA DO DISCURSO SOBRE O ENUNCIADO}

O Ministro da Economia, Paulo Guedes, tem um posicionamento político voltado para privatizações e enfraquecimento do Estado. Contudo, sua visão de macroeconomia e a atenção que o Ministro dá ao empresariado, são fatores que 
contribuem para escolha do seu nome, para assumir o cargo no Governo atual do Presidente Bolsonaro.

Entre suas principais medidas como encarregado pelo Ministério da Economia, pode-se destacar a realização da Reforma da Previdência, amplamente discutida nos anos anteriores. Além da Reforma da Previdência, Guedes é a favor da privatização de empresas estatais, além de uma Reforma Tributária e uma Reforma Administrativa. Ou seja, projetos de acordo com a ideologia do atual Governo.

Os enunciados falados por Paulo Guedes no Encontro sobre Pacto Federativo na Fundação Getúlio Vargas foram:

"O hospedeiro está morrendo, o cara virou um parasita, o dinheiro não chega no povo e ele quer aumento automático" (Paulo Guedes, 2020)

A primeira situação já verificada é a Relação de poder existente no discurso:

O espaço socialmente discursivo no qual o servidor público é ineficiente e só gera gastos ao Governo com privilégios, isto mostra que o discurso hegemônico é de que o serviço público é ruim por culpa dos servidores concursados/ estabilizados, para isto utiliza as palavras: hospedeiro, parasita, aumento automático, cara.

O que resulta na ideologia dominante acerca do conceito que deve privatizar e acabar com estabilidade e reajustes automáticos para os servidores públicos é que é isto que a sociedade quer, ou seja, socialmente aceito e desejado por todos.

Para Fairclough, 2003a, apud Resende e Ramalho, 2020, "diferentes discursos são diferentes perspectivas de mundo, associadas a diferentes relações que as pessoas estabelecem com o mundo e que dependem de suas posições no mundo e das relações que estabelecem com outras pessoas", e neste con- 
senso que Paulo Guedes parte para defender sua posição, que seu discurso, sua ideologia é compartilhada por toda sociedade.

Este discurso de heterogeneidade de um texto em termo de articulação de diferentes discursos é chamado de interdiscursividade, o qual pode se observar em duas etapas: a identificação de que partes do mundo são representadas e a identificação da perspectiva particular pela qual são representadas (RESENDE, RAMALHO, 2010).

A primeira análise que podemos perceber é o uso da figura de linguagem que utiliza termos usados em biologia para fazer uma metáfora, ou seja, Paulo Guedes usou a palavra hospedeiro, que é um organismo que abriga outro em seu interior ou o carrega sobre si, seja este um parasita, um comensal ou um mutualista e a palavra parasita, que é um organismo que vive de e em outro organismo, dele obtendo alimento e não raro causando-lhe dano, para se referir ao Governo como hospedeiro que carrega um parasita, o servidor público, e este parasita está matando o hospedeiro. Assim, faz a relação, que os servidores públicos apenas dão prejuízo ao Governo.

Outro termo também conhecido para expressar um elogio, ou usado para valorizar uma pessoa - "o cara". Neste enunciado deixa claro que o servidor público era alguém de valor, que mostrava "serviço", trabalhador, mas quando se torna servidor público ele passa do empregado bom para um parasita, que se acomodou e se tornou apenas um explorador do Governo.

Nos dois últimos enunciados, analisamos pelo lado econômico, o qual deixa claro que o dinheiro não chega ao povo, porque é totalmente gasto com privilégios e altos salários de servidores públicos, e não pela ineficiência do Governo em administrar as receitas. $E$ já que os servidores públicos têm privilégios demais, na opinião do Ministro, não é justo que o mesmo tenha aumento automático a cada período conforme lei de carreira.

Assim, podemos perceber que o Ministro acredita que não deve investir no servidor público, que este deve trabalhar por menores salários e condições, pois 
só assim ele será um bom empregado, que o governo que deve pagar ao servidor público o valor que ele quiser, sem valorizar as carreiras ou só valorizar as quais são de interesse do Governo.

Se considerarmos os Estágios para análise temos:

1) Dar ênfase a um problema/injustiça social: Servidor público visto como parasita, incompetente e desnecessário e quer apenas aumento de salário - preconceito, desrespeito.

2) Identificar os obstáculos para que a injustiça seja superada: Discurso de discriminação e imposição de uma dominação da ideologia do Governo de que o servidor público é desnecessário e ineficiente além de só gerar gastos e ter privilégios.

3) Função do problema na prática: Alguns dos problemas causados por essa injustiça social são: falta de respeito com os servidores públicos, humilhação, imagem de incompetência/ineficiência, preconceito pela sociedade, incentivo a privatização.

4) Possíveis maneiras de superar os obstáculos: Realizar a reflexão sobre a temática em análises através de artigos, teses, dissertação, documentário, mídia, palestras. Expor dados a sociedade.

5) Reflexão sobre a análise: A poder do discurso padronizado de que o servidor público é um parasita, para fazer a sociedade ficar contra os trabalhadores desta classe, passando a imagem de um serviço ruim, sendo que muitos investimentos dependem do Governo. Prática de ideologia empregada no governo, para que tudo seja privatizado. O nosso objetivo é refletir para a realidade de qual intenção tem este tipo de discurso, a quem beneficia com o fim deste serviço, proporcionando uma formação de cidadãos mais conscientes nas suas práticas e relações interpessoais.

6) Definição de um novo problema de pesquisa: $O$ que gerou essa discriminação aos servidores públicos e os métodos que utilizam. 


\section{CONSIDERAÇÕES FINAIS}

Primeiro, concluímos que a PEC 32/2020 está longe de ser uma proposta de modernização do Estado, que se reconhece ser necessária para adaptação do aparato burocrático aos tempos atuais. Sem que, contudo, essa modernização resulte em perda de direitos trabalhistas conquistados ao longo do tempo, bem como do comprometimento das políticas públicas que visam o desenvolvimento do bem-estar social.

Como demonstramos, o funcionalismo público está longe de ser o parasita que se alimenta do hospedeiro. O que precisa ficar claro é que a proposta de emenda constitucional número 32/2020 representa o conjunto de prioridades traçadas por um grupo que administra a coisa pública no momento presente e que entende ser a terceirização o caminho para o desenvolvimento. Posição diametralmente oposta a que defendemos.

A ideologia do Governo que gasta muito com o servidor público e por isto o dinheiro não chega a população é apenas um discurso para tentar convencer a sociedade a fazer pressão para que a PEC 32/2020 seja aprovada e que a população defenda as propostas do Governo.

Infelizmente, o Governo atual não percebeu que ele não precisa gerar lucros como uma empresa privada, que quando o governo tem superávit significa que o Governo deixou de investir, ou seja, ele foi ineficiente, pois não gerenciou todos os recursos para que atendesse de maneira eficiente a sociedade. Então, realmente o dinheiro não chega ao povo porque não foi administrado de maneira correta. E investir em servidor público é investir em bens públicos, os quais atendem toda sociedade, tanto ricos como os pobres.

O enunciado falado pelo Ministro só demostrou um grande preconceito e desrespeito para com os servidores, sem uma justificativa aplausível, já que todos os dados e fatos deixam claro que os servidores são eficientes e que não são responsáveis pelos problemas orçamentários do Governo. Discurso ideológico do atual governo não consiste com a realidade do país. 


\section{REFERENCIAS}

BARROS, S. M. de. Realismo Crítico e emancipação humana - contribuições ontológicas e epistemológicas para os estudos críticos do discurso. Campinas, SP: Pontes Editores, 2015.

BATISTA JR., J. R. L.; SATO, D. T. B.; MELO, I. F de (Orgs.). Análise de discurso crítica para linguistas e não linguistas. São Paulo: Parábola, 2018.

CEOLIN, M. Pacto Federativo: o que é e o que pode mudar? Disponível em: https://www.politize.com.br/o-que-e-pacto-federativo/, publicado em 28/11/2019 - Acessado em 05/04/2021

CUNHA, M. A. e SOUZA, M. M. Transitividade e seus contextos de uso. Rio de Janeiro: Lucerna, 2007.

DE MELO, I. F. Análise do discurso e análise crítica do discurso: desdobramentos e intersecções, 2009, Revista Eletrônica de Divulgação Científica em Língua Portuguesa, Lingüística e Literatura Ano 05 n. 11 - $2^{\circ}$ Semestre de 2009ISSN 1807-5193.

FAIRCLOUGH, N. Analysing discourse: textual analysis for social research. London; New York: Routledge. 2003.

, Discurso e mudança social. Brasília, UnB, 2001.

HALLIDAY, M. A. K.; MATTHIESSEN, C. M. I. M. An introduction to functional grammar. London. Hodder Education, 2004.

MAGALHÃES, C. M. (org.). Reflexões sobre a análise crítica do discurso. Belo Horizonte: Faculdade de Letras, UFMG, 2001.

Perfil de Paulo Guedes - Economista, disponível em: https://www.suno.com. br/tudo-sobre/paulo-guedes/amp/ - Acessado em 05/04/2021

RESENDE, V.; RAMALHO, V. C. V. S.. Análise de Discurso Crítica, São Paulo, Contexto, 2006.

SILVA, D. Paulo Guedes compara funcionário público a 'parasita' ao defender reforma administrativa, disponível em: https://g1.globo.com/economia/ noticia/2020/02/07/paulo-guedes-compara-funcionario-publico-a-parasita-ao-defender-reforma-administrativa.ghtml, Rio de Janeiro, publicado em 07/02/2020 Acessado em 05/04/2021 


\section{dol 10.48209/978-65-89949-D3-1}

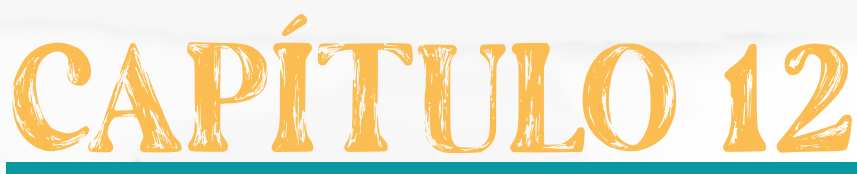

\section{AGRONEGÓCIO}

E A QUESTÃO DA MORADIA NA CIDADE DE

\section{CAMPO VERDE-MT}




\section{INTRODUÇÃO}

A agricultura sempre foi presente e responsável por diversas mudanças na e pela sociedade brasileira, seja como modo de acumulação capitalista, ou como forma de subsistência.

Uma das transformações mais significativas, diz respeito à recente modernização da agricultura no país que ocorreu a partir da metade do século $X X$, com isso, a produção se interligou diretamente ao processo de intensificação da atividade industrial que estava acontecendo, confluindo veio a se chamar de agroindústria, e teve seu crescimento orientado pela demanda do mercado internacional. Houve ainda uma gama de grandes inovações nessa área, que se tornou mais intensivo em capital, com o uso de máquinas e insumos agrícolas para produzir em maior quantidade.

Dentro destas mudanças que foram significativas dentro do território nacional sobretudo no campo, houve o surgimento e desenvolvimento do agronegócio, que se configura como sendo o conjunto de todas as operações e transações envolvidas desde a fabricação de insumos agropecuários, das operações de produção nas unidades agropecuárias, até o processamento e distribuição e consumo dos produtos agropecuários 'in natura' ou industrializados que se expandiram dentro do território brasileiro. (PLATA 2001).

É importante destacar, que o agronegócio foi responsável por diversas transformações em diversas regiões brasileiras, principalmente na região centrooeste, no estado de Mato Grosso. Nos dizeres de Lopes (2006) o estado de Mato Grosso neste contexto, se notabilizou como região atrativa de migrantes provenientes de todas as regiões do país, tendo a região sul a partir da década de 1970 uma migração de expansão muito intensiva. Com isso, como fronteira agrícola, o estado tem sido uma alternativa para pressões sociais e distribuição da população do território nacional, principalmente de colonos do sul e pessoas 
do sudeste, nordeste e da própria região centro oeste, caracterizando-o como um território de oportunidades.

Diante desse contexto de expansão da fronteira agrícola, a cidade de Campo Verde-MT é criada para atender a demanda do capital que se expandia no momento (Figura 1). Considerada uma cidade com características sulistas, esta, tem se destacado no cenário nacional como uma das cidades do agronegócio, apresentando anualmente um alto crescimento econômico. Contudo, apresenta disparidades em diversos setores, principalmente no que se refere a desigualdade socioespacial e o acesso a moradia.

Figura 1 - Mapa de Localização do município de Campo Verde-MT

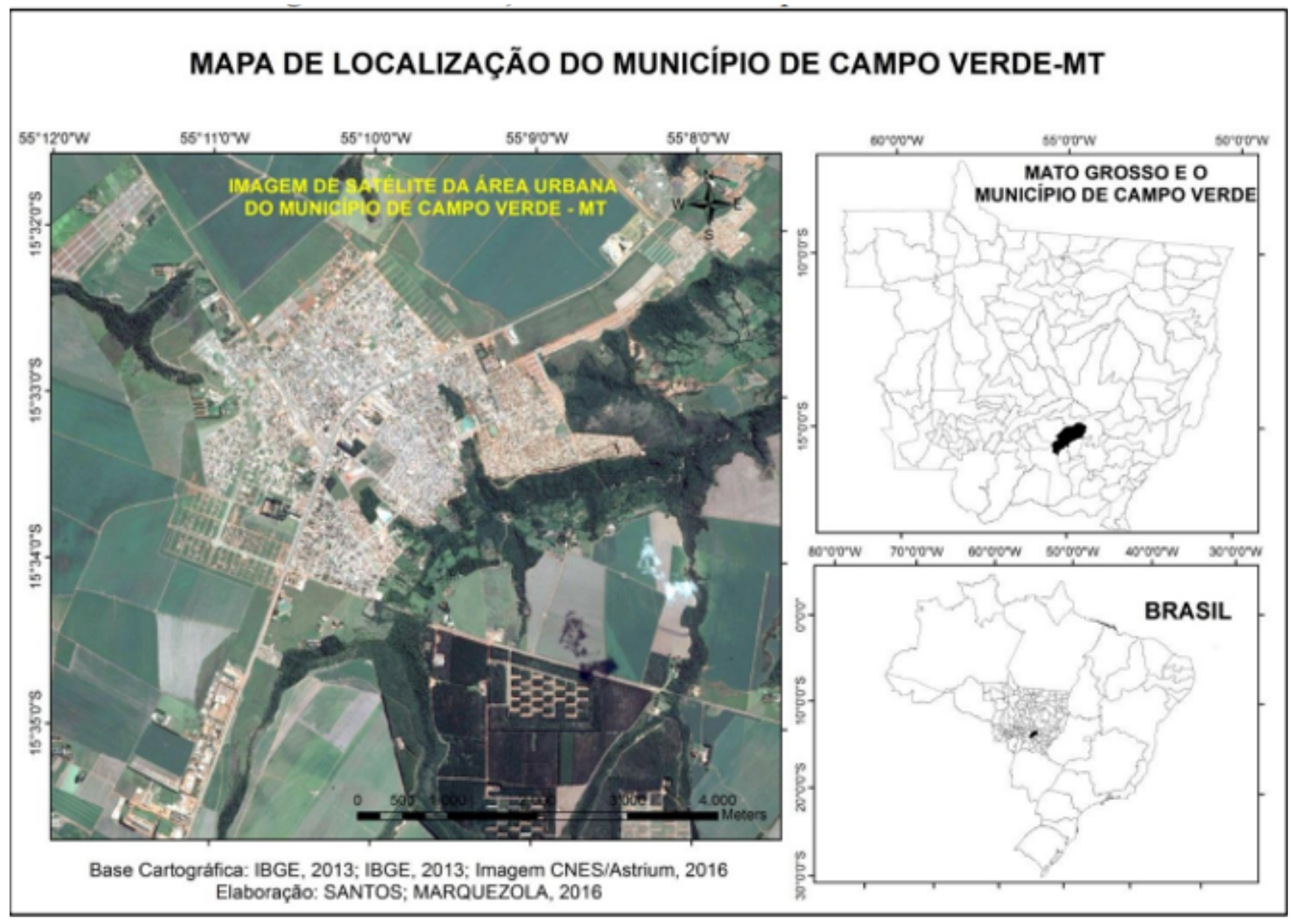

Fonte: Santos, Marquezila, 2016.

A partir desta problemática, no que diz respeito a questão da moradia, empreendemos nesta pesquisa a compreensão de demonstrar como o agronegócio, 
fonte de renda, não determina o crescimento igualitário de todas as cidades, além de contribuir para o aumento significativo da desigualdade socioespacial. Para isso, ocorreu primeiramente uma pesquisa bibliográfica, posteriormente, ocorreu a pesquisa de campo nos órgãos municipais da cidade, e por fim, ocorreu a compilação dos dados alcançados e a discussão proposta no presente artigo.

\section{EVOLUÇÃO URBANA DE CAMPO VERDE-MT E SUA RELAÇÃO COM O AGRONEGÓCIO}

Conforme dados do IBGE (2013) antes de ser criada a cidade de Campo Verde, o primeiro núcleo de povoamento no território campoverdense foi denominado Capim Branco ou Coronel Ponce. Essa denominação é lembrada até os dias de hoje, e os mais antigos moradores se referem ao lugar, ainda nos tempos presentes, por este nome.

Conforme Fonseca (2006) que se ateve a compreender a evolução urbana da cidade, a ocupação do município de Campo Verde é fruto da expansão do agronegócio, representado pela agricultura mecanizada da soja e do algodão, que acentuaram e continuam ainda nos dias atuais, acentuando o crescimento populacional acelerado do município.

No ano de 1985 ocorreu a criação do distrito de Campo Verde, através da lei $n^{\circ} 4.898$, sob o comando do vice-governador do estado Wilmar Peres da Faria. Destaca-se que o nome Campo Verde, foi escolhido através de votação popular. Contudo Campo Verde pertencia ao município de Dom Aquino, porém a população residente acreditava que em futuro breve ocorreria à emancipação. Sendo assim, após três anos, no dia 4 de julho de 1988, através da lei $n^{\circ} 5,314$ houve a emancipação do distrito de Campo Verde se desmembrando do território de Dom Aquino, sob o comando do até então governador Carlos Bezerra. Em divisão territorial datada de 1995, o município é constituído de dois distritos: Campo Verde e Coronel Ponce. Assim permanecendo em divisão territorial datada de 2009 (IBGE, 2013). 
Depois de sua emancipação no ano de 1988, aos poucos a vegetação nativa do Cerrado presente de forma extensiva até aquele momento, foi dando lugar às extensas plantações, primeiramente de arroz e milho, e depois de soja e algodão (Figura 2). A partir deste momento, ocorrer um crescimento da produção agrícola e pecuária, como consequência, ocorreu o aumento da migração de pessoas que se instalavam na cidade para trabalhar nas grandes plantações.

Figura 2 - Vista panorâmica da cidade de Campo Verde na década de 1980

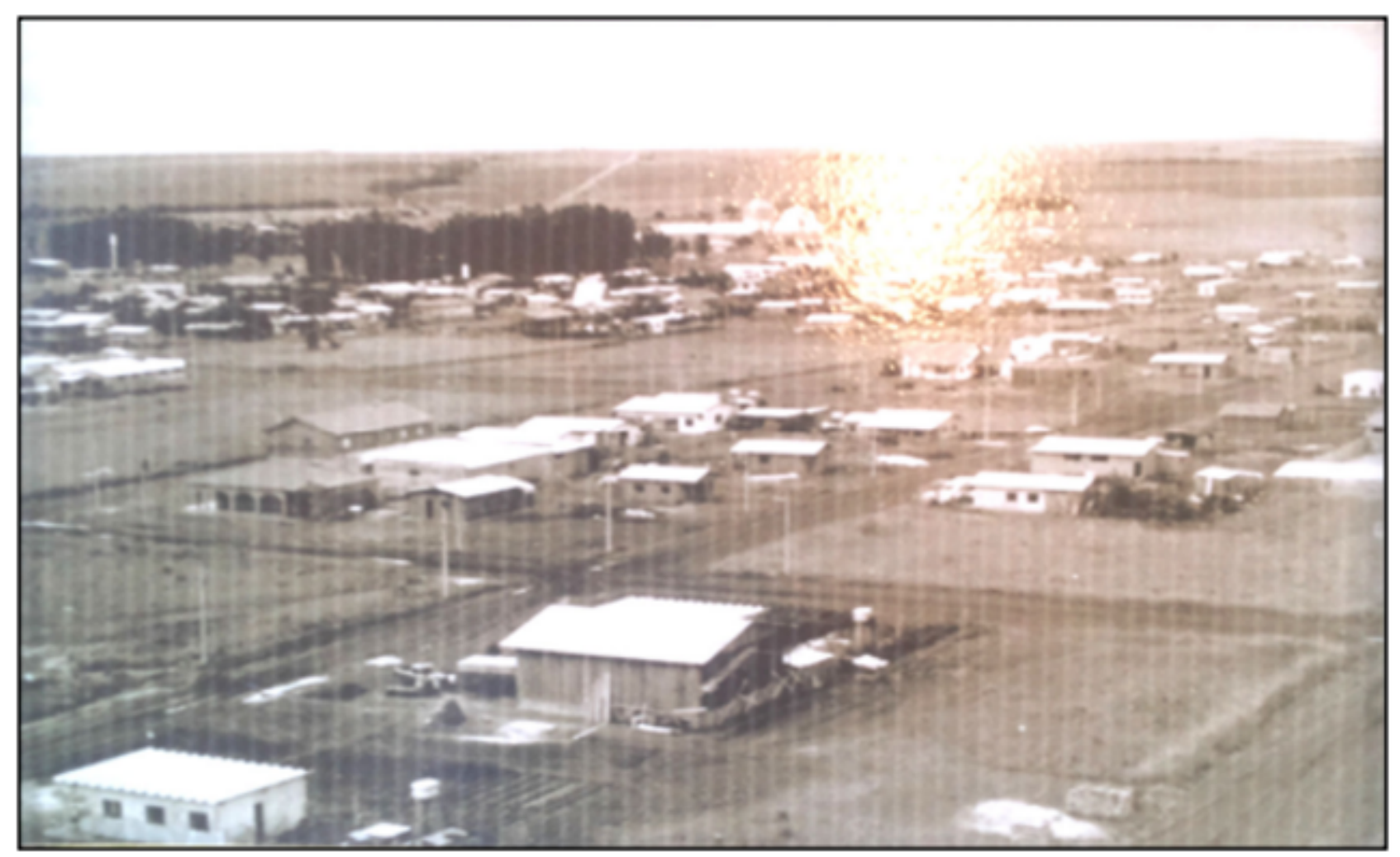

Fonte: Acervo disponível no Museu Capim Branco em Campo Verde-MT.

Nos primeiros seis anos após a emancipação, que compreende o período de 1988 a 1994, Campo Verde contava com quatro loteamentos residenciais, Jupiara que foi criado pela iniciativa privada antes mesmo da emancipação do município, visto a necessidade de moradia no local que atraia migrantes para trabalhar na produção agrícola. Contudo, esse bairro era voltado para a população de baixa renda, que exercia na cidade o papel de mão de obra barata. Em seguida foi criado o Campo Real, que também foi desenvolvido pela iniciativa privada, e visava atender a população de melhor poder aquisitivo, sendo os preços dos terrenos mais elevados. 
No começo da década de 1990 houve a criação de mais dois bairros, Jar$\operatorname{dim}$ Cidade Verde e Jardim Campo Verde. Este período foi de firmação do município e de consolidação da economia agrícola como grande produtor de grãos e fonte de crescimento constante, produzindo oportunidades. Nesta época estabeleceram-se no município as primeiras empresas do setor agrícola, distribuídas ao longo da margem da BR 070 que corta a cidade.

Conforme Lopes (2006) essas empresas foram instaladas em uma área adquirida junto a prefeitura e ao loteador Otavio Eckert, as empresas de armazenagem graneleiros foram instaladas no Distrito Industrial I, que hoje faz parte da área central da cidade. Dentre essas empresas podemos destacar a Sadia, empresa agro avícola que trabalha por meio da implantação do sistema de aviários integrados, e foi uma das primeiras a se instalarem em Campo Verde, e até os dias atuais se encontra no local (Figura 3).

Figura 3 - Unidade da Sadia em Campo Verde-MT

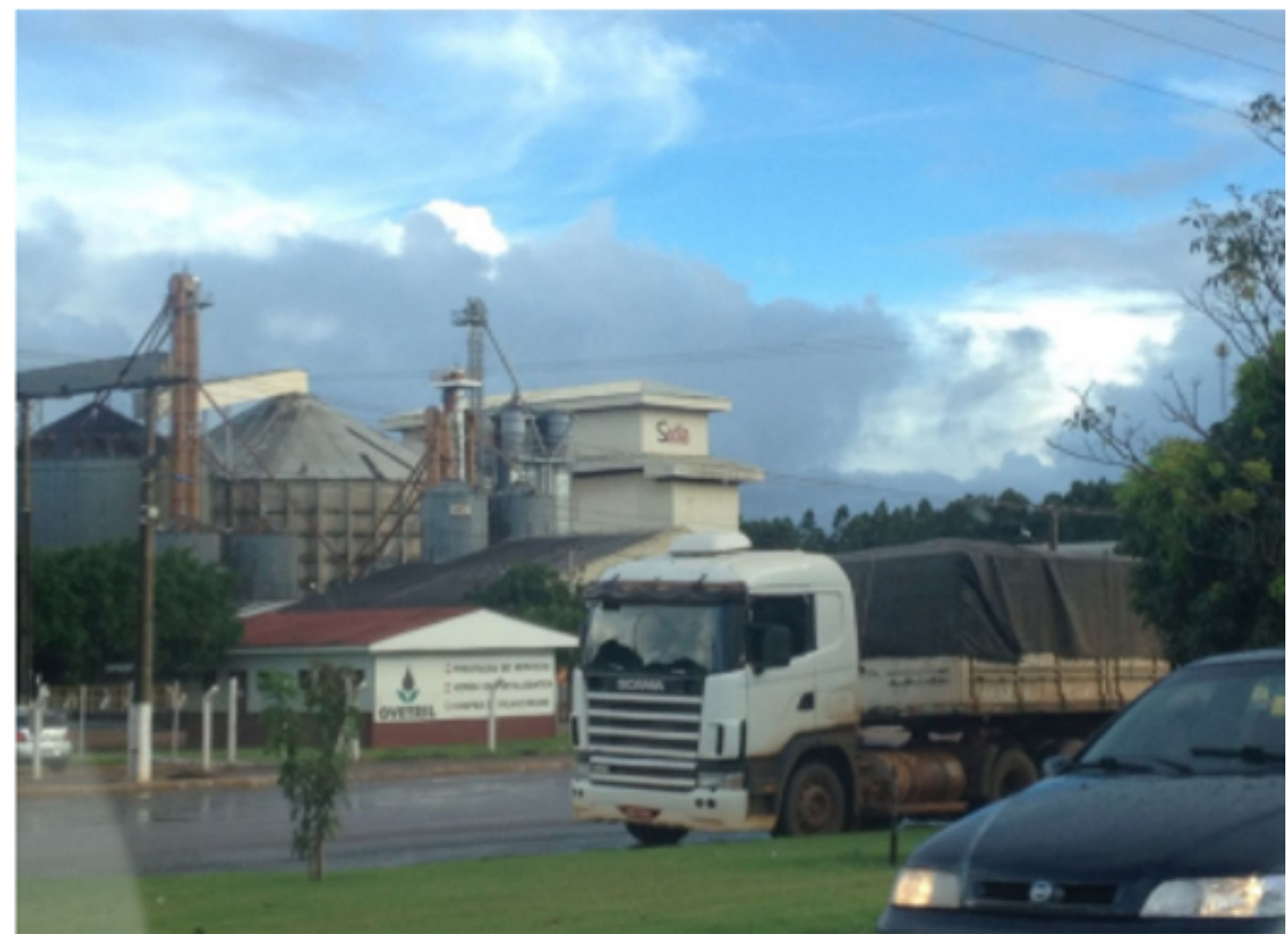

Fonte: Trabalho de Campo (2017). 
A geograficização desses equipamentos agrícolas no espaço urbano, confere-Ihes uma composição de paisagem híbrida, onde, paradoxalmente, o urbano e o rural se articulam para atender aos interesses de expansão do capital. Destarte, a logística constitui-se como agente indutor na cidade entre os centros de mercados, as agroindústrias e o mercado consumidor, alterando a dinâmica preexistente e criando novas relações cidades-campo e os mercados distantes. Essas condições materiais e organizacionais decorrentes desse feixe de eventos provocados pelo agronegócio têm dimensionado uma nova configuração urbana, pois a operação e logística, concebidas hoje como uma fornecedora de serviços, têm contribuído para a intensificação de fluxos materiais e imateriais, dinamizando a economia urbana e intensificando o processo de urbanização nessas áreas (ARRUDA, 2007).

A cidade de Campo Verde continuava a crescer e consequentemente os problemas urbanos aumentavam. À medida que as grandes empresas voltadas para o agronegócio se instalavam na região, o crescimento era certo, contudo, o valor da terra era cada vez mais inacessível a população de baixa renda residente na cidade.

O período de 1995 a 2000 foi o de maior desenvolvimento do município, média de crescimento de $12,40 \%$ ao ano, ainda assim, representou um dos maiores índices do estado de Mato Grosso. O aumento da mecanização do campo foi um dos motores que impulsionou a evolução urbana de Campo Verde, com a expansão do tecido urbano beneficiando a produção do espaço na cidade com a consolidação e o crescimento do comércio especializado no centro para atender a demanda do campo, pois as indústrias que chegavam para se estabelecer em Campo Verde, eram todas voltadas para a agricultura e pecuária (Figura 4).

Nesse período o incremento populacional foi de 5.946 habitantes, esse aumento populacional ocorrido em Campo Verde possibilitou o surgimento de mais 
nove loteamentos: Loteamento Eckert, São Lourenço, Vale do Sol, Jardim Ipanema, Recanto do Bosque, Bom Clima, Jardim Bela Vista, Campo Real II e Chácara das Uvas. Desta forma, surgem vários loteamentos a fim de abrigar a demanda por habitação que existia na época. A população de baixa renda, então passa a ocupar os bairros periféricos de Campo Verde, visto que a centralidade comercial já não comportava estes moradores, ficando então disponível aos detentores do capital, pois a cidade começou a crescer em um ritmo mais acelerado.

É importante destacar, que desses nove loteamentos criados no período, somente Campo Real II era considerado loteamento destinado a classe detentora do capital, todos os outros eram bairros populares que foram criados visando a estadia dos migrantes que chegavam na cidade de Campo Verde para atender a demanda de mão de obra, atraída pelas novas agroindústrias, principalmente, aquelas ligadas a cultura do algodão (LOPES, 2006).

Figura 4 - Cidade de Campo Verde no ano de 2000

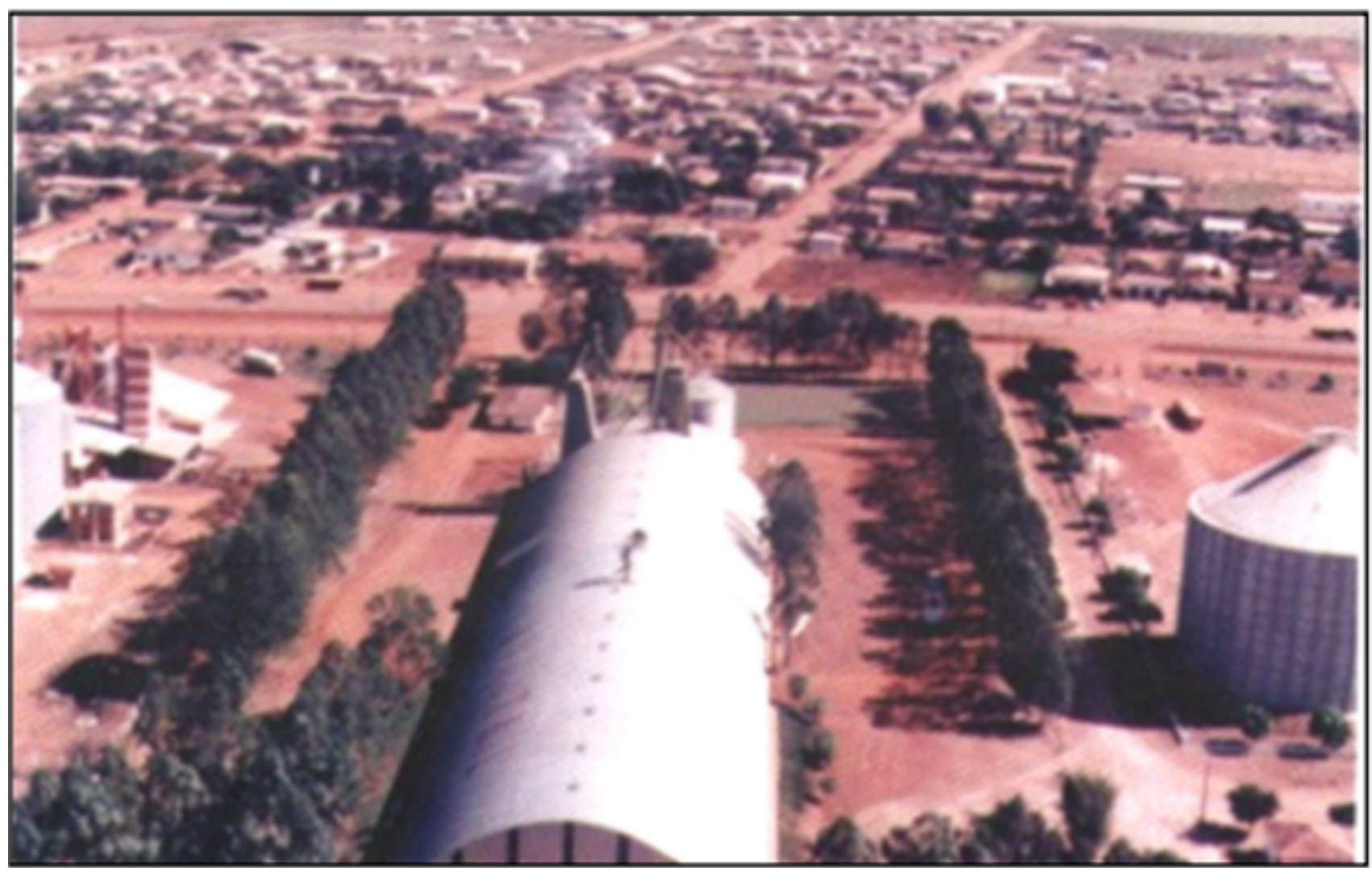

Fonte: Acervo disponível na imobiliária Eckert. 
No começo do século XXI, com o constante desenvolvimento econômico, o investimento na cidade se ampliou de forma significativa, gerando o aumento populacional na cidade. Entretanto entre os anos de 2004 e 2006, houve um menor crescimento populacional, devido a uma crise na agricultura existente nesse período, que afetou o desenvolvimento de Campo Verde.

Conforme Lopes, (2006) nos anos entre 2000 a 2006 surgiram cincos novos loteamentos: Residencial Belverede, Bordas do Lago, Jardim Campo Verde II, Residencial Cuiabá e Recanto do Bosque II, para atender a demanda de 4.481 novos moradores no núcleo urbano. O menor crescimento populacional deve-se ao retrocesso econômico nos últimos três anos, ocasionado pela crise na agricultura, que provocou a queda da produção dos principais produtos cultivados no município, e que nos permite afirmar que a dinâmica populacional de Campo (Figura 7).

A evolução urbana continuou em Campo Verde, conforme dados do IBGE (2010) o número de habitantes no ano de 2010 era de 31. 589. Nos anos entre 2007 a 2016, houve um alto incremento populacional em Campo VerdeMT, sendo criados mais nove bairros: Cidade Alta I, Cidade Alta II, Jardim Campo Verde III, São Miguel, Loteamento Buritis, Loteamento Santa Rosa, Loteamento Jardim América, Loteamento Recanto dos Pássaros e Loteamento Gren Ville.

Conforme pesquisa do IBGE (2016), a população de Campo Verde-MT saltou de 5.975 em 1991, há 38.814 em 2016.

Nos dias atuais nota-se o predomínio de população oriundas da região sul do Brasil na cidade de Campo Verde, desde as empresas instaladas nessa a região, a cultura do chimarrão. Percebeu-se também na construção deste tópico que Campo Verde já nasceu urbano, pois já tinha a função de servir a cadeia produtiva do agronegócio. 


\section{DESIGUALDADES SOCIOESPACIAIS NA CIDADE DE CAMPO VERDE-MT}

Conforme Fonseca (2006), a ocupação urbana do município de Campo Verde é fruto da expansão do agronegócio, representado pela agricultura mecanizada da soja e do algodão, que acentuaram o crescimento populacional acelerado do município. Com isso, diferentemente de outras cidades, Campo Verde-MT já nasceu com o predomínio urbano.

O crescimento econômico de Campo Verde é considerado acima da média nacional. Em 2007, a cidade foi destaque entre as 100 cidades com maior Valor Adicionado Bruto (VAB) da agropecuária, ocupando o segundo lugar nacional e o primeiro lugar no Estado de Mato Grosso (FERREIRA, 2012).

Desde o princípio foi possível notar no trabalho de campo, que a cidade de Campo Verde se expandiu em várias direções, porém de uma forma muito seletiva, visto que ambas as partes pobre e rica da sociedade não se misturavam, pois, uma parte possuía o capital investido na agricultura, e outra parte era a população que vinha em busca de trabalho, com isso a segregação em Campo Verde, sempre foi algo muito claro.

Sobre isso, Frederico (2011), aponta que nas cidades do agronegócio convivem dois tipos de migrantes: os que possuem condições de consumo e cuja infraestrutura urbana é feita para seu usufruto; e os excluídos do consumo moderno, migrantes expulsos do campo pela modernização agrícola ou provenientes das áreas mais pobres do território brasileiro, que se alojam nas áreas periféricas e aumentam o número de desempregados, subempregados e trabalhadores informais.

Por se configurar como uma das cidades do agronegócio, a cidade foi criada para determinada função, e sempre apresentou disparidades no seu espaço urbano. Sobre isso essas cidades, Arruda (2007, p. 156) destaca que: 
E, como produto das relações capitalistas de produção reproduz-se no espaço urbano as contradições inerentes a tal processo, evidenciado no jogo contraditório dos interesses do capital monopolista, representado pelas grandes corporações e, luta pelo direito a cidadania evidenciado pelo direito a cidade: moradia, educação, etc. Essa realidade comprova que o crescimento econômico das cidades pautadas no agronegócio não reflete, entretanto, melhores condições de vida para a maioria da população. As disparidades sociais tornam-se evidentes na paisagem urbana altamente segregadora, manifestada pela presença de moradias com padrões arquitetônicos modernos, bairros exclusivos etc., contrastando com moradias precárias, bairros sem iluminação pública, asfalto, etc. A grande da população, principalmente os considerados "forasteiros" vivem em precárias condições de vida, contrastando com o desperdício verificado nas áreas tidas como nobres.

Nesse sentido Lopes (2006) ao relata que essa separação espacial começou juntamente com a formação do núcleo urbano da cidade. No processo de formação do Município surgiram quase que simultaneamente dois bairros: Campo Real que hoje fica na parte central da cidade e o Bairro Jupiara na entrada da cidade. Enquanto no bairro Campo Real concentrou a população de renda mais elevada que vinham investir na cidade, em contrapartida no Jupiara estabeleceram pessoas de baixa renda que vieram em sua maioria da região norte e nordeste para trabalhar em Campo Verde-MT.

Além disso, o bairro Campo Real encontra-se localizado em uma área mais plana da cidade de Campo Verde, sendo o valor da terra urbana nessas localidades maior, devido a ação do mercado imobiliário, dificultando o acesso a população de baixa renda, à moradia. Sendo assim, a outra parte da população direcionada a residir em áreas mais distantes, como é o caso do bairro Jupiara, localizado nas proximidades do rio São Lourenço. Aos fundos do bairro, encontra uma área de pastagem que devido a declividade, dificulta o plantio em larga escala, porém servindo de habitação para as pessoas de baixa renda.

Parafraseando Santos (1987) pode-se dizer que o espaço urbano é diferentemente ocupado em função das classes em que a divide a sociedade urbana (Figura 5). 
Figura 5 - Localização dos bairros Campo Real e Jupiara (2017).

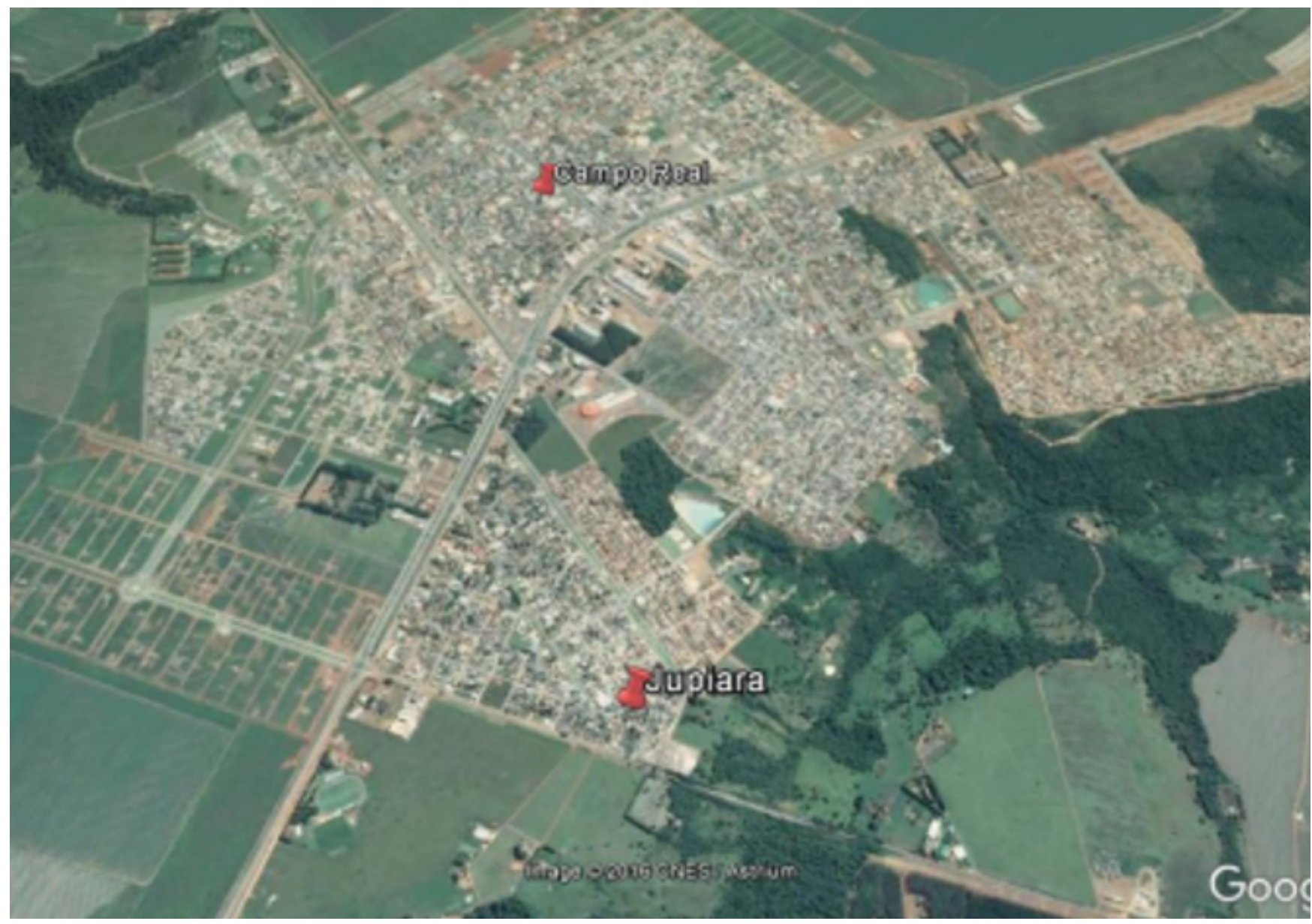

Fonte: Google Earth

Essas diferenças que acontecem nesses dois bairros veem-se diariamente em cidades com predomínio da agricultura mecanizada, onde a especulação imobiliária, em muitos casos, acaba condicionando a moradia de cada classe, que se estruturam a partir de uma segregação socioespacial.

Ao se analisar as casas, nota-se uma grande diferença desde o valor chegando em alguns casos a custar mais de um milhão de reais, a cor das casas, ambas localizadas nos dois primeiros bairros criados na cidade de Campo Verde-MT. Percebe-se que um dos sintomas do crescimento e da desigualdade de acesso vivenciada pelas cidades do agronegócio é a falta de moradias e a precariedade das condições de habitação (Figura 6 e 7). 
Figura 6 - Residência do bairro Campo Real em Campo Verde-MT.

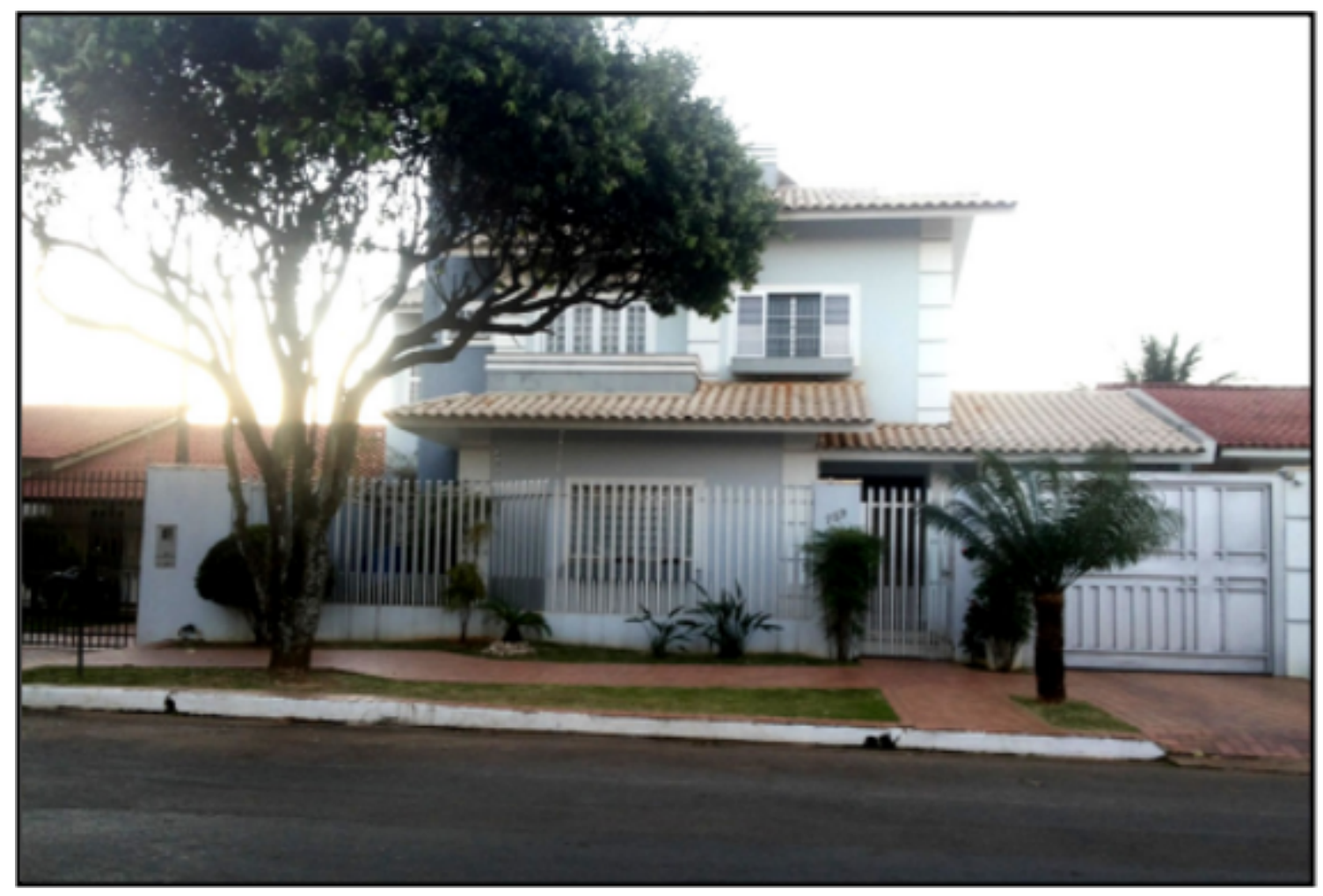

Fonte: Trabalho de Campo 2016

Figura 7 - Residência do bairro Jupiara em Campo Verde-MT.

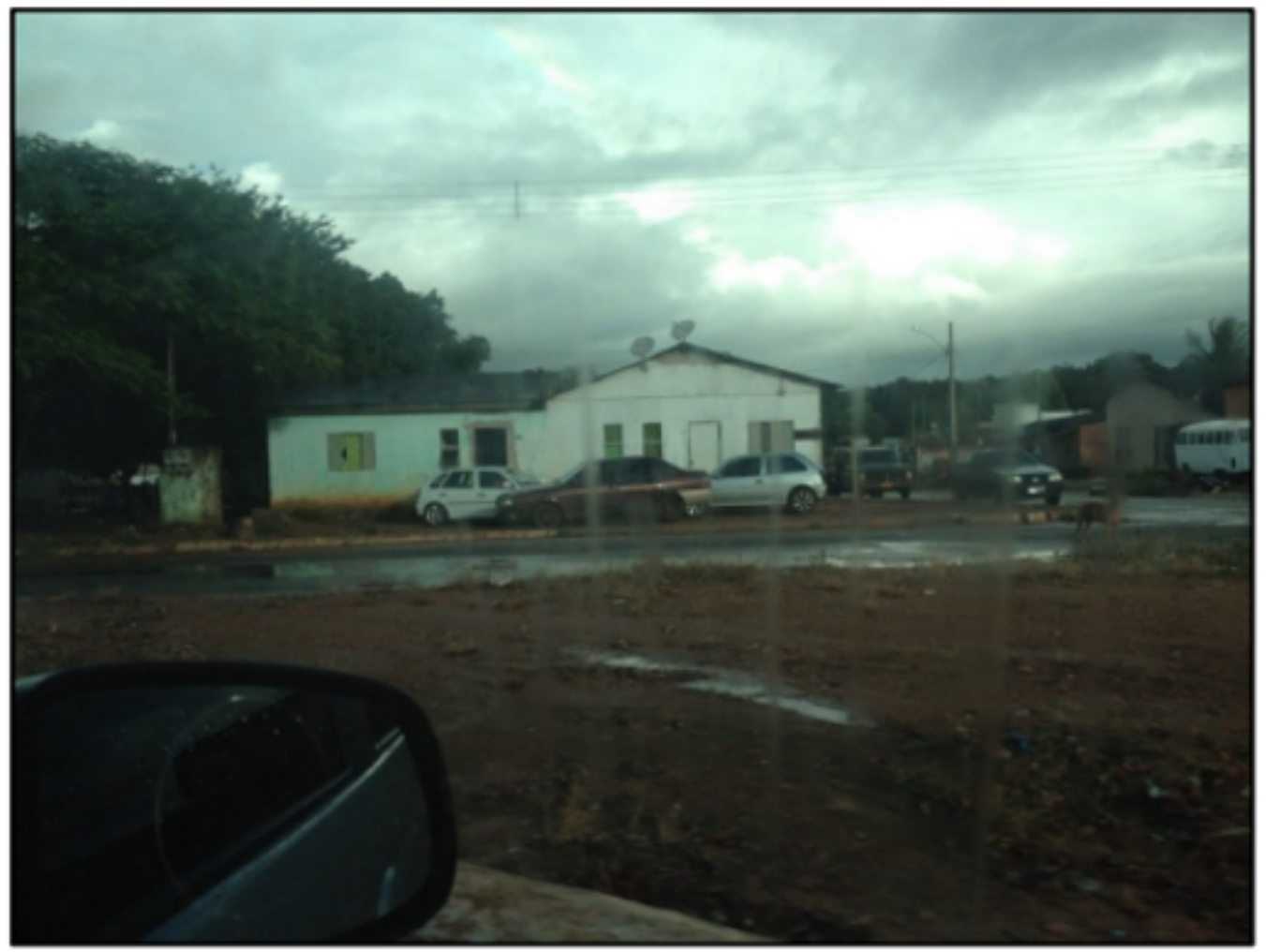

Fonte: Trabalho de Campo 2016 
Atualmente, essa diferença é bastante notória em ambos os bairros. Enquanto um abriga os mais belos padrões arquitetônicos da cidade, além de ruas largas, e bastante próximas do centro, o outro com predominância do sistema de autoconstrução, apresentam ruas e casas menores típicos de bairros periféricos.

Conforme Santos (1987) há, em todas as cidades, uma parcela da população que não dispõe de condições para se transferir da casa em que mora, isto é, para mudar de bairro, e que pode ver explicada a sua pobreza pelo fato de o bairro de sua residência não contar com serviços públicos, vender serviços privados a alto preço, obrigar os residentes a importantes despesas de transporte.

O processo de segregação continuou com o crescimento da cidade, a crescente urbanização que ocorreu no território gerou as diferentes realidades nos bairros residenciais. Neste contexto podemos trazer à tona a afirmação do geógrafo Milton Santos (1996) ao afirmar, que cada cidade é criada com uma determinada função, podemos aplicar essa afirmativa a cidade de Campo Verde, que devido a presença de um relevo predominantemente plano e solo propicio, foi criada visando atender a demanda do capital financeiro investido no agronegócio.

Com o investimento na cidade, grandes empresas do ramo agropecuário se alocaram com a promessa de geração de mais geração de empregos para a população, dentro desse emaranhado, concordamos com Arruda (2007) ao destacar que a instalação das grandes corporações no espaço (urbano/rural), pautadas no discurso da geração de emprego, no aumento da renda e na geração de desenvolvimento, torna-se atrativas aos olhos daqueles que almejam melhores oportunidades de vida. Como consequência, ocasiona para a cidade um movimento de mão de obra em um jogo dialético de oportunidades e "exclusões" intensificam as condições socioespaciais na cidade que se expressam pela desigualdade.

Neste contexto, o crescimento dos bairros pobres acompanhou o processo de urbanização, marcado por profundas desigualdades sociais que se materializam no espaço urbano, através da carência de infraestrutura e irregularidade 
fundiária que se manifestaram como características centrais para a problemática habitacional.

Com a rápida urbanização da cidade atrelada ao desenvolvimento econômico, o número de habitantes que não possuíam residências na cidade era alto, com isso a alternativa do poder público foi a criação de três bairros: Loteamento dos Pássaros, Loteamento Santa Rosa e por fim o Loteamento Jardim América com a finalidade de abrigar a população que se encontrava sem casa. Concordamos, portanto com Vilarinho Neto (2002) ao dizer que a cidade deve ser compreendida e apreendida como um processo que cria e recria as condições que permitem a reprodução ampliada do capital.

Essa população que se configurava como os "sem terra" e estavam inscritos no cadastro habitacional da prefeitura, e foram contemplados com o programa minha casa minha vida, para residir no Loteamento Santa Rosa, Loteamento Jardim América e Loteamento Recanto dos Pássaros. Contudo esses bairros criados visando sanar o déficit habitacional da cidade, foram criados muito distantes do centro comercial, em uma área próximo ao leito do rio São Lourenço, com declividade relativamente acentuada.

Ao analisarmos esses três bairros criados no ano de 2013 na cidade de Campo Verde-MT, podemos nos atentar ao que Santos (1987) diz, ao tratar do espaço urbano no modo de produção capitalista, ao relatar que grande parte da população é deixada ao quase exclusivo jogo de mercado, o espaço vivido consagra desigualdades e injustiças e termina por ser, em sua maior parte, um espaço sem cidadãos.

Uma problemática presente nesses bairros, é a distância de sete quilômetros em relação ao centro comercial. No começo da pesquisa, em 2016 os moradores se deslocavam para trabalhar no centro da cidade de bicicleta, moto ou em muitos casos de carona, pois não havia transporte público. Já ano de 2017, o 
transporte público foi inserido na cidade, contudo os horários que atendia esses bairros, eram bem escassos, dificultando o acesso a outras localidades (Figura 8).

Figura 8: Loteamento Santa Rosa, Loteamento Jardim América e Loteamento Recanto dos Pássaros.

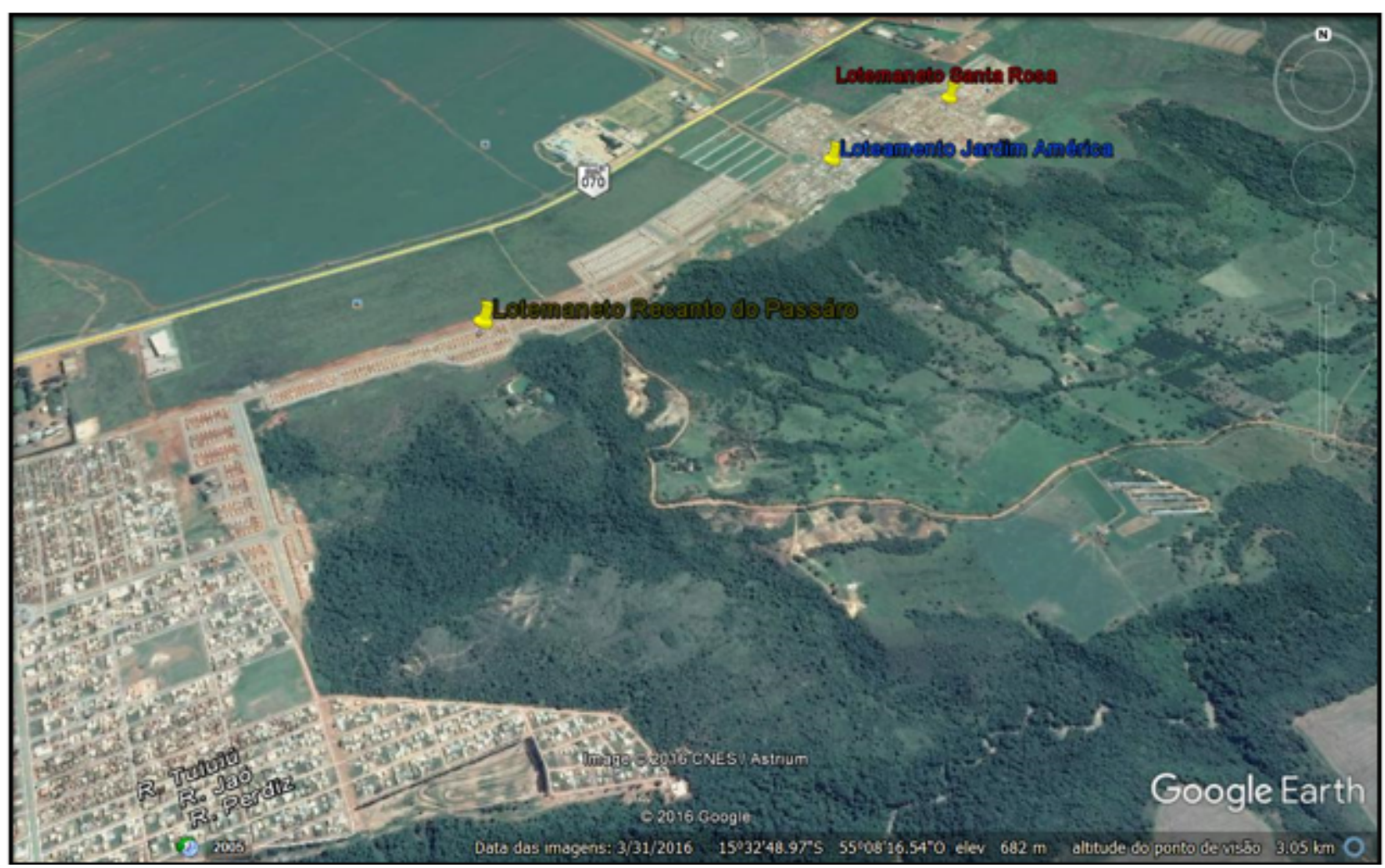

Fonte: Google Earth Org: Santos, A. C.

Outra problemática que se encontra nesses três bairros, é o esquecimento por parte do poder público. Grande parte dos moradores se queixam a ausência do Estado em relação a serviços públicos básicos para os moradores. Foi possível notar ao transitar pelos bairros, resíduos sólidos nas ruas, em épocas de chuvas problemas com alagamentos em algumas casas por se encontrar em áreas de declividade, entre outras problemáticas.

Nota-se que, pelo fato da economia ser voltada para o agronegócio, os conjuntos habitacionais, que são para aqueles que não podem pagar por uma moradia, são construídos, ou melhor "conduzidos" pela especulação imobiliária 
para áreas que pouco favoreça o capital. A população de baixa renda em meio a esta problemática, não tem vez, nem voz diante da força do capital agroindustrial em Campo Verde-MT

\section{CONSIDERAÇÕES FINAIS}

Como proposto no objetivo, ao resgatar a ocupação territorial de Campo Verde-MT, fica claro que a cidade já nasceu com a função de servir de cadeia produtiva ao agronegócio, com isso, as melhores áreas (geomorfologia e pedologia) sempre foi de uso para a produção agrícola. Os migrantes vindo em sua maioria da região sul do país, através de incentivos governamentais para ocuparem o cerrado, desbravaram as melhores áreas e se instalaram, em contrapartida as pessoas que chegavam para servir de mão de obras iam sendo direcionadas as localidades mais distantes.

Essa separação social que ocorre em Campo Verde, se encontra também em grande parte das cidades que são regidas pelo agronegócio, onde a população paga pelo valor da terra, independentemente onde a mesma esteja localizada. Com isso o espaço urbano da cidade de Campo Verde, caracteriza-se por ser altamente fragmentado.

\section{REFERÊNCIAS}

ARRUDA, Z. A. Onde Está o Agro Deste Negócio? Transformações Sociespaciais em Mato Grosso. Campinas-SP: UNICAMP, 2007. (Tese de Doutorado).

CASTRO, Iná Elías de Corrêa et al. Geografia: conceitos e temas. Bertrand Brasil, 1995. FERREIRA, J. C. V.. Mato Grosso e seus municípios. 2001.

FREDERICO, Samuel. As cidades do agronegócio na fronteira agrícola moderna brasileira. Caderno Prudentino de Geografia, v. 1, n. 33, p. 5-23, 2011. 
FONSECA, A. A. A problemática da habitação em Campo Verde-MT. Campo Verde-MT: UFMT, 2006. (Trabalho de conclusão de curso). IBGE- Instituto Brasileiro de Geografia e Estatística. Disponível em: http://cod.ibge.gov.br/SM7M. Acessado em: 02/10/2016.

IBGE CIDADES. Disponível em: https://cidades.ibge.gov.br/brasil/mt/campo-verde/historico. Acessado em: 17/12/2019.

LOPES, G. J. A produção do espaço no núcleo urbano de Campo Verde-MT. Campo VerdeMT: UFMT, 2006. (Trabalho de conclusão de curso).

PLATA, L. Mercado de Terras no Brasil: Gênese, Determinação de seus Preços e Políticas, Tese de doutorado, 2001.

SANTOS, Milton. O Espaço do Cidadão. São Paulo: Hucitec, 1987.

VILARINHO NETO, Cornélio Silvani. Metropolização regional, formação e consolidação da rede urbana do Estado de Mato Grosso. Universidade de São Paulo, 2002 (Tese de Doutorado em Geografia). 


\section{doi $10.48209 / 978-65-89949-D 4-1$}

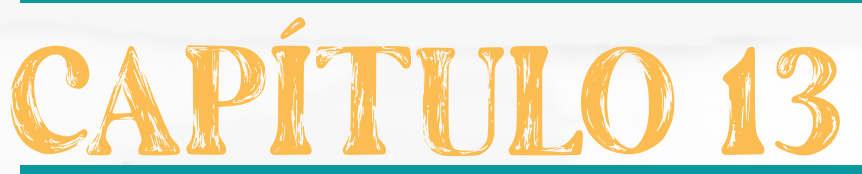

\section{A PARTICIPAÇÃO OBRIGATÓRIa}

\section{DOS SINDICATOS}

NAS NEGOCIAÇÕES COLETIVAS DE TRABALHO: UMA ANÁIISE DO ART. 8', VI DA CONSTITUIÇÃO DE 1988 
RESUMO: A presente pesquisa tem o intuito de analisar a participação obrigatória dos sindicatos nas negociações coletivas de trabalho a partir da análise do art. $8^{\circ}$, inciso VI da Constituição da República Federativa do Brasil de 1988, utilizando livros, artigos científicos e legislações. Pretende-se estudar a evolução histórica constitucional do referido dispositivo. Parte-se do conceito de negociação coletiva de trabalho, convenção coletiva, acordo coletivo, unicidade sindical para entender como funcionam as limitações e as contradições encontradas no ordenamento jurídico brasileiro. Em relação à liberdade sindical, conclui-se que, no Brasil, ocorre violação injustificada à Convenção $n^{\circ} 87$ da Organização Internacional do Trabalho.

Palavras-chave: Sindicato; negociação coletiva; liberdade sindical.

ABSTRACT: This research aims to analyze the mandatory participation of unions in collective bargaining based on an analysis of art. 8, VI Constitution of Brazil, using books, scientific articles and legislation. It is intended to study the historical constitutional evolution of the referred provision. It starts from the concept of collective labor negotiation, collective agreement, union unity to understand how the limitations and contradictions found in the Brazilian legal system work. Regarding freedom of association, it is concluded that, in Brazil, there is an unjustified violation of Convention $n^{\circ} 87$ of the International Labor Organization.

Key-words: Syndicate; collective bargaining; freedom of association.

\section{INTRODUÇÃ O}

O Direito coletivo do trabalho e o Direito sindical são ramos muito estudados e debatidos pela doutrina e jurisprudência brasileira. No ordenamento jurídica pátrio, é possível perceber desdobramentos interessantes relacionados com estas temáticas.

A liberdade sindical garantida pela Carta Magna de 1988 não é completa, pois possui uma série de limitações constitucionais e infraconstitucionais, como a imposição da unicidade e a obrigatoriedade de participação dos sindicatos nas negociações coletivas. 
Por esse motivo, a abordagem do tema é fundamental para o estudo científico, já que contribui para a compreensão e o aprimoramento do Direito do trabaIho, evidenciando questões de destaque no âmbito constitucional.

É preciso ressaltar que a pesquisa tem grande importância não só para estudiosos do ramo, mas também para a sociedade, pois é imprescindível que os indivíduos conheçam mais sobre o assunto, tornando-o mais visível, visto que a liberdade sindical deve ser respeitada, conforme disposições da Organização Internacional do Trabalho (OIT).

Diante disso, indaga-se: de que modo a Constituição da República Federativa do Brasil de 1988 (CRFB/88) regula a participação obrigatória dos sindicatos nas negociações coletivas?

Para tanto, partiu-se do seguinte objetivo geral: analisar o art. $8^{\circ}, \mathrm{VI}$ da CRFB/88 que dispõe sobre a obrigatoriedade de participação dos sindicatos nas negociações coletivas. A fim de alcançá-lo, foram desenvolvidos os objetivos específicos mencionados a seguir: compreender a evolução histórica do dispositivo estudado por meio de alguns textos constitucionais anteriores; entender determinados conceitos básicos, como as definições de negociação coletiva e liberdade sindical; identificar de que modo se configura a participação obrigatória dos sindicatos nas negociações coletivas de trabalho.

Metodologicamente, esta pesquisa possui natureza qualitativa e teórica, podendo ser caracterizada como exploratória e bibliográfica, pois busca soluções para o problema a partir de materiais já produzidos, como livros, legislações e artigos científicos (FINCATO; GILLET, 2018).

\section{AS NEGOCIAÇÕES COLETIVAS NAS CONSTITUIÇÕES BRASILEIRAS}

Para estudar o art. $8^{\circ}, \mathrm{VI}$ da Carta Magna atual, é necessário analisar alguns textos constitucionais anteriores e compreender a evolução histórica do dispositivo que ocupa lugar de destaque no título do presente artigo. 


\section{Constituição da República dos Estados Unidos do Brasil de 1934}

A Constituição de 1934, promulgada em 16/07/1934, foi influenciada pelo corporativismo fascista, Constituição espanhola de 1931, Carta austríaca de 1920, Constituição mexicana de 1917, Constituição alemã de 1919 e pelo texto constitucional soviético de 1918 (SARLET; MARINONI; MITIDIERO, 2020).

Estipulava a separação dos poderes, sistema presidencialista, República, Federação e um regime democrático-representativo. Além disso, a Carta Magna de 1934 "[...] marcou a introdução do constitucionalismo social no Brasil" (SARLET; MARINONI; MITIDIERO, 2020, p. 317), pois incorporou uma série de temas que não eram objeto de atenção das constituições pretéritas como:

[...] amparo à maternidade e à infância, incumbindo ao Poder Público a adoção de medidas legislativas tendentes a restringir a mortalidade e a morbidade infantis [...] salário mínimo, jornada máxima de oito horas de trabalho, repouso semanal, férias anuais remuneradas, indenização para o trabalhador pela dispensa sem justa causa, assistência médica ao trabalhador e à gestante, reconhecimento das convenções coletivas de trabalho (SARLET; MARINONI; MITIDIERO, 2020, p. 319).

A Carta Magna de 1934 retratou a negociação coletiva em seu artigo 121, $\S 1^{\circ}$, alínea $j:$ "A legislação do trabalho observará os seguintes preceitos, além de outros que colimem melhorar as condições do trabalhador: [...] reconhecimento das convenções coletivas, de trabalho" (BRASIL, 1934).

Dessa forma, pode-se perceber que a Constituição da República dos Estados Unidos do Brasil de 1934 reconhecia a existência das convenções coletivas de trabalho como um preceito constitucional que visava a melhoria das condições do trabalhador brasileiro.

\section{Constituição dos Estados Unidos do Brasil de 1937}

A Constituição outorgada em 1937 teve seu texto redigido por Francisco Campos, com influência da Constituição da Polônia de 1935, era autoritária, de cunho corporativista, estatizante e nacionalista, tinha total desprezo pelas instituições democráticas (FERNANDES, 2015). 
Estipulava um Governo Republicano, porém o Federalismo indicado na Carta Constitucional foi apenas de cunho nominal e não havia a preocupação com o equilíbrio entre os três poderes (FERNANDES, 2015).

O artigo 139 proibia a realização de greve a qual era vista como um recurso antissocial, nocivo ao trabalho e ao capital e incompatível com os superiores interesses da produção nacional (BRASIL, 1937).

Existe, na doutrina, toda uma problemática sobre a entrada em vigor desta Constituição, pois, segundo seu artigo 187, para entrar em vigor, o texto constitucional deveria ter sido aprovado em um Plebiscito que não foi realizado (BRASIL, 1937).

A Carta de 1937 estabelecia, no art. 138, que somente o sindicato reconhecido pelo Estado teria a liberdade para exercer suas funções:

Art. 138 - A associação profissional ou sindical é livre. Somente, porém, o sindicato regularmente reconhecido pelo Estado tem o direito de representação legal dos que participarem da categoria de produção para que foi constituído, e de defender-lhes os direitos perante o Estado e as outras associações profissionais, estipular contratos coletivos de trabalho obrigatórios para todos os seus associados, impor-lhes contribuições e exercer em relação a eles funções delegadas de Poder Público (BRASIL, 1937).

Pela leitura do artigo citado anteriormente, é possível perceber que o constituinte escolheu a expressão "contratos coletivos de trabalho" para identificar a função sindical de participar das negociações coletivas.

Convém lembrar que este dispositivo foi suspenso pelo Decreto $\mathrm{n}^{\circ}$ $10.358 / 1942$, assinado por Vargas, que declarava o estado de guerra em todo o território nacional (BRASIL, 1942).

\section{Constituição dos Estados Unidos do Brasil, de 18 de setembro de 1946}

A Constituição de 1946 adotou como texto-base a Carta Magna de 1934, protegendo os direitos sociais (especialmente os trabalhistas) e garantindo os direitos individuais (SARLET; MARINONI; MITIDIERO, 2020). 
Embora com um tom menos incisivo, relativamente à Constituição de 1934, os direitos sociais foram objeto de proteção, especialmente no campo trabalhista, onde foi, por fim, reafirmado o direito de greve. No campo da garantia dos direitos individuais, situa-se a incorporação ao ordenamento jurídico brasileiro da inafastabilidade do controle jurisdicional [...] (SARLET; MARINONI; MITIDIERO, 2020, p. 324).

Sobre o assunto, o texto da Constituição de 1946, assim como ocorreu na Constituição de 1934, reconhece as convenções coletivas de trabalho como sendo uma espécie de preceito:

Art. 157 - A legislação do trabalho e a da previdência social obedecerão nos seguintes preceitos, além de outros que visem a melhoria da condição dos trabalhadores: [...] XIII - reconhecimento das convenções coletivas de trabalho.

$[\ldots]$

Art. 159 - É livre a associação profissional ou sindical, sendo reguladas por lei a forma de sua constituição, a sua representação legal nas convenções coletivas de trabalho e o exercício de funções delegadas pelo Poder Público (BRASIL, 1946).

Nota-se que a liberdade sindical aparece no art. 159 que utiliza a expressão "convenções coletivas de trabalho", não sendo mais necessário que o Estado autorize o funcionamento dos sindicatos (como era exigido na Carta Magna anterior).

\section{Constituição da República Federativa do Brasil de 1967}

A Constituição de 1967 manteve a forma de Estado Federativa e a forma de Governo Republicano, porém com um viés extremamente centralizador, pois a União era detentora exclusiva de várias competências. Além disso, a Carta Magna de 1967 também manteve a separação dos três poderes, entretanto o Poder Executivo tinha maior influenciada e peso em relação aos outros (FERNANDES, 2015).

Sobre o assunto, convém citar o art. 158 da Constituição da República Federativa do Brasil de 1967 que utiliza novamente a expressão "convenções 
coletivas de trabalho": "A Constituição assegura aos trabalhadores os seguintes direitos, além de outros que, nos termos da lei, visem à melhoria, de sua condição social: [...] XIV - reconhecimento das convenções coletivas de trabalho" (BRASIL, 1967).

Como visto na citação do art. 158, diferentemente dos textos constitucionais anteriores, o reconhecimento das convenções coletivas de trabalho passou a ser um direito constitucional (e não um preceito).

\title{
Emenda Constitucional n 1, de 17 de outubro de 1969 (Constituição de 1969)
}

Segundo José Afonso da Silva (2003) e parte da doutrina, a Emenda Constitucional no 1 de 17/10/1969 foi, na realidade, uma nova Constituição outorgada por uma junta militar. Devo dizer que, nesse aspecto, concordo o referido autor.

\begin{abstract}
Teórica e tecnicamente, não se tratou de emenda, mas de nova Constituição. A emenda só serviu como mecanismo de outorga, uma vez que verdadeiramente se promulgou texto integralmente reformulado, a começar pela denominação que se Ihe deu: Constituição da República Federativa do Brasil, enquanto a de 1967 se chamava apenas de Constituição do Brasil (SILVA, 2003, p. 89).
\end{abstract}

A EC n $n^{\circ}$ de 17/10/1969 ou Constituição de 1969 tinha um texto muito semelhante à redação da Constituição de 1967, colocando o reconhecimento das convenções coletivas de trabalho como um direito do trabalhador, além de outros direitos: "Art. 165. A Constituição assegura aos trabalhadores os seguintes direitos, além de outros que, nos termos da lei, visem à melhoria de sua condição social: [...] XIV - reconhecimento das convenções coletivas de trabalho" (BRASIL, 1969).

Convém citar também o art. 166 que tratava sobre a liberdade sindical no Brasil: "Art. 166. É livre a associação profissional ou sindical; a sua constituição, a representação legal nas convenções coletivas de trabalho e o exercício de funções delegadas de poder público serão regulados em lei” (BRASIL, 1969). 
Nota-se que apenas a Constituição de 1937 usou a expressão "contratos coletivos de trabalho" para tratar sobre as negociações coletivas. Nas demais Constituições, é possível encontrar a denominação "convenções coletivas de trabalho".

\section{Constituição da República Federativa do Brasil de 1988}

A Constituição atual, promulgada em 05/10/1988, manteve a Republica e o Federalismo, concedendo autonomia política aos entes federativos (União, Estados, Municípios e Distrito Federal). Esta Carta Magna também é chamada de Constituição democrática e cidadã (FERNANDES, 2015).

Possui grande números de direitos Fundamentais, garantias e instrumentos processuais, inclusive acrescentou novidades como a inadmissibilidade da prova ilícita, devido processo legal, publicidade e motivação das decisões judiciais e razoável duração do processo (SARLET; MARINONI; MITIDIERO, 2020).

O artigo $8^{\circ}$ possui um rol de considerações sobre a liberdade sindical, inclusive estabelece que a participação dos sindicatos nas negociações coletivas tem caráter obrigatório. Além disso, é importante citar o artigo anterior que reconhece as convenções e acordos coletivos como um direito dos trabalhadores (BRASIL, 1988).

Art. $7^{\circ}$ São direitos dos trabalhadores urbanos e rurais, além de outros que visem à melhoria de sua condição social: [...] XXVI - reconhecimento das convenções e acordos coletivos de trabalho.

[...]

Art. $8^{\circ} E$ É livre a associação profissional ou sindical, observado o seguinte: [...] VI - é obrigatória a participação dos sindicatos nas negociações coletivas de trabalho (BRASIL, 1988).

Para entender o assunto, além de examinar as Constituições anteriores, é necessário também analisar certos conceitos que estruturam o assunto estudado no presente artigo. 


\section{CONCEITOS E DEFINIÇÕES IMPORTANTES}

Para entender as críticas sobre a obrigatoriedade da participação dos sindicatos e as restrições indevidas à liberdade sindical, é interessante elucidar certos conceitos.

\section{Negociação coletiva de trabalho}

De acordo com Delgado (2017, p. 1557), “a negociação coletiva é um dos mais importantes métodos de solução de conflitos na sociedade contemporânea". Trata-se de método autocompositivo democrático, pois envolve e administra interesses de categorias econômicas e profissionais (ZAFFARI et al., 2021).

As negociações coletivas são maneiras de resolver os conflitos coletivos de trabalho que aparecem entre empregados e empregadores. O conflito pode ser resolvido através de convenção coletiva, acordo coletivo, alteração do regulamento da empresa ou inclusão de cláusula nos contratos individuais de trabalho dos empregados (BRITO FILHO, 2019).

Sem dúvida, as convenções coletivas e os acordos coletivos ocupam um lugar de destaque na doutrina e na legislação do Brasil. A Consolidação das Leis do Trabalho (CLT) apresenta as definições para estes dois institutos:

Art. 611 - Convenção Coletiva de Trabalho é o acordo de caráter normativo, pelo qual dois ou mais Sindicatos representativos de categorias econômicas e profissionais estipulam condições de trabalho aplicáveis, no âmbito das respectivas representações, às relações individuais de trabalho.

$\S 1^{\circ} \mathrm{E}$ facultado aos Sindicatos representativos de categorias profissionais celebrar Acordos Coletivos com uma ou mais empresas da correspondente categoria econômica, que estipulem condições de trabalho, aplicáveis no âmbito da empresa ou das acordantes respectivas relações de trabalho (BRASIL, 1943).

Além de apresentar os conceitos citados anteriormente, a CLT também orienta, no artigo 620, que "as condições estabelecidas em acordo coletivo de 
trabalho sempre prevalecerão sobre as estipuladas em convenção coletiva de trabalho" (BRASIL, 1943).

Em suma, a convenção coletiva é o resultado da negociação entre dois ou mais sindicatos, enquanto o acordo coletivo é o resultado da negociação entre o sindicato dos trabalhadores e uma ou mais empresas da categoria econômica (empregadores). A principal distinção se dá na participação dos representantes da categoria econômica (se são entidades sindicais ou apenas uma ou mais empresas).

\section{Liberdade sindical}

Segundo Nascimento (2009, p. 446), "[...] a negociação coletiva é expressão do princípio da autonomia coletiva dos particulares e da liberdade sindical. Uma das principais funções do sindicato é, exatamente, a negociação coletiva". Assim, nota-se que a negociação coletiva possui uma forte ligação com a liberdade sindical.

Sobre o assunto, a doutrina aponta a existência de duas dimensões: liberdade sindical individual e liberdade sindical coletiva. A primeira dimensão significa a liberdade do indivíduo se filiar, permanecer filiado, desfiliar e não se associar (BRITO FILHO, 2019).

Por outro lado, a segunda hipótese está relacionada com as liberdades sindicais coletivas de administração, organização, exercício das funções sindicais, ou seja, é a capacidade do sindicato "[...] executar as ações necessárias ao cumprimento de suas finalidades" (BRITO FILHO, 2018, p. 84).

De acordo com Gilberto Stürmer (2005, p. 89), "a liberdade sindical, especialmente no seu viés coletivo, se enquadra no feixe dos direitos humanos", inclusive está presente nos textos da OIT. 


\section{A PARTICIPAÇÃO OBRIGATÓRIa dOS SINDICATOS NAS NEGOCIAÇÕES COLETIVAS DE TRABALHO}

De acordo com o art. $8^{\circ}, \mathrm{VI}$, da Constituição atual, a função negocial somente é exercida pelos sindicatos. Esta obrigatoriedade de participação sindical nas negociações coletivas acaba impedindo a existência de uma atuação mais livre das entidades de grau superior, como a federação e confederação que somente atuarão nos casos de categorias inorganizadas, conforme o art. $611, \S 2^{\circ}$ da CLT:

As Federações e, na falta desta, as Confederações representativas de categorias econômicas ou profissionais poderão celebrar convenções coletivas de trabalho para reger as relações das categorias a elas vinculadas, inorganizadas em Sindicatos, no âmbito de suas representações (BRASIL, 1943).

Para agravar esse quadro, temos ainda mais uma limitação à liberdade sindical prevista no art. 8, II da CRFB/88:

Art. $8^{\circ}$ É livre a associação profissional ou sindical, observado o seguinte: [...] II - é vedada a criação de mais de uma organização sindical, em qualquer grau, representativa de categoria profissional ou econômica, na mesma base territorial, que será definida pelos trabalhadores ou empregadores interessados, não podendo ser inferior à área de um Município (BRASIL, 1988).

A unicidade sindical é uma imposição constitucional que restringe a liberdade sindical, pois permite a existência de apenas um único sindicato representando determinada categoria, na mesma base territorial mínima (municipal) (TEIXEIRA FILHO, 2019). "No Brasil, não é obrigatória somente a participação do sindicato, mas do único sindicato reconhecido como representante do grupo." (BRITO FILHO, 2019, p. 491). Ademais, essas limitações afrontam a Convenção $n^{\circ} 87$ da OIT:

Art. 2 - Os trabalhadores e os empregadores, sem distinção de qualquer espécie, terão direito de constituir, sem autorização prévia, organizações de sua escolha, bem como o direito de se filiar a essas organizações, sob a única condição de se conformar com os estatutos das mesmas.

Art. 3 - 1. As organizações de trabalhadores e de empregadores terão o direito de elaborar seus estatutos e regulamentos administrativos, de 
eleger livremente seus representantes, de organizar a gestão e a atividade dos mesmos e de formular seu programa de ação. 2. As autoridades públicas deverão abster-se de qualquer intervenção que possa limitar esse direito ou entravar o seu exercício legal.

Art. 4 - As organizações de trabalhadores e de empregadores não estarão sujeitas à dissolução ou à suspensão por via administrativa.

Art. 5 - As organizações de trabalhadores e de empregadores terão o direito de constituir federações e confederações, bem como o de filiar-se às mesmas, e toda organização, federação ou confederação terá o direito de filiar-se às organizações internacionais de trabalhadores e de empregadores (OIT, 1948).

Além disso, o ordenamento jurídico brasileiro apresenta algumas contradições, na medida em que aplica um tratamento desigual injustificado para os sindicatos dos empregadores e dos empregados, pois, de acordo com o art. 611, $\S 1^{\circ}$ da CLT, na celebração de acordo coletivo, ocorre a participação dos empregadores por meio de empresa(s) (BRASIL, 1943). Portanto, a participação obrigatória nas negociações coletivas só vale para os sindicatos dos trabalhadores.

Sobre o assunto, Teixeira Filho (2019) aponta mais uma contradição legislativa ao analisar a diferença de tratamento direcionada aos servidores públicos. Estes indivíduos possuem a liberdade sindical em toda a sua extensão, na medida em que a Constituição afirma, em seu art. 37, VI, que "é garantido ao servidor público civil o direito à livre associação sindical" (BRASIL, 1988).

Diante disso, é evidente que a liberdade sindical brasileira não é completa, pois o ordenamento jurídico do Brasil estabelece uma série de limitações e contradições indevidas a respeito do tema, desrespeitando até mesmo documentos internacionais como a convenção citada anteriormente.

\section{CONCLUSÃO}

Objetivou-se com esta abordagem expor de forma prática e fundamentada acerca da participação obrigatória dos sindicatos nas negociações coletivas de trabalho, imposição prevista no art. 8 , VI da Constituição Federal de 1988. 
Primeiramente, discutiu-se sobre a evolução histórica do referido dispositivo por meio da análise de seis Constituições brasileiras. Verificou-se que apenas a Carta Magna de 1937 usou a expressão "contratos coletivos de trabalho". Atualmente, o reconhecimento das convenções e acordos coletivos de trabalho é um direito do empregado.

Em seguida, foi feita uma análise sobre conceitos indispensáveis para a pesquisa, como as definições de negociação coletiva e liberdade sindical, efetuando a diferenciação entre convenção coletiva de trabalho e acordo coletivo que, por sua vez, não constituem as únicas formas de resolver conflitos entre trabalhadores e empregadores.

Ademais, discutiu-se acerca das contradições e limitações indevidas que o ordenamento jurídico aplica à liberdade sindical, retratando a imposição da unicidade pela Carta Magna de 1988 e o tratamento diferenciado existente nas hipóteses dos empregadores em acordos coletivos e servidores públicos.

Portanto, esse tema proporcionou um amplo entendimento sobre Direito Constitucional e Direito do Trabalho. Diante disso, recomenda-se que este assunto seja cada vez mais debatido e aprofundado, pois é inadequado que os brasileiros aceitem dispositivos legislativos violadores de documentos internacionais importantes como a Convenção n 87 da Organização Internacional do Trabalho.

\section{REFERÊNCIAS}

BRASIL. Consolidação das Leis do Trabalho (CLT). Decreto-lei $n^{\circ} 5.452$, de $1^{\circ}$ de maio de 1943. Disponível em: http://www.planalto.gov.br/ccivil_03/decreto-lei/del5452.htm. Acesso em: 29 set. 2021.

BRASIL. [Constituição (1988)]. Constituição da República Federativa do Brasil de 1988. 54. ed. Brasília: Câmara dos Deputados, Edições Câmara, 2019.

BRASIL. Constituição da República dos Estados Unidos do Brasil, de 16 de julho de 1934. Disponível em: http://www.planalto.gov.br/ccivil_03/constituicao/ constituicao34.htm. Acesso em: 29 set. 2021. 
BRASIL. Constituição da República Federativa do Brasil de 1967. Disponível em: http://www.planalto.gov.br/ccivil_03/constituicao/constituicao67.htm. Acesso em: 29 set. 2021.

BRASIL. Constituição dos Estados Unidos do Brasil, de 10 de novembro de 1937. Disponível em: http://www.planalto.gov.br/ccivil_03/constituicao/constituicao37.htm. Acesso em: 29 set. 2021.

BRASIL. Constituição dos Estados Unidos do Brasil, de 18 de setembro de 1946. Disponível em: http://www.planalto.gov.br/ccivil_03/constituicao/constituicao46.htm. Acesso em: 29 set. 2021.

BRASIL. Decreto $n^{\circ}$ 10.358, de 31 de agosto de 1942. Disponível em: http:// www.planalto.gov.br/ccivil_03/decreto/1930-1949/d10358.htm. Acesso em: 29 set. 2021.

BRASIL. Emenda Constitucional $n^{\circ} 1$, de 17 de outubro de 1969. Disponível em: http://www.planalto.gov.br/ccivil_03/constituicao/emendas/emc_anterior1988/emc01-69.htm. Acesso em: 29 set. 2021.

BRITO FILHO, José Claudio Monteiro de. VI - É obrigatória a participação dos sindicatos nas negociações coletivas de trabalho. In: MARTINEZ, Luciano; TEIXEIRA FILHO, João de Lima (coord.). Comentários à Constituição de 1988 em matéria de direitos sociais trabalhistas (arts. $6^{a}$ a 11): uma homenagem aos 30 anos da Constituição da República e aos 40 anos da Academia Brasileira de direito do trabalho. São Paulo: LTr, 2019. p. 489-492.

BRITO FILHO, José Claudio Monteiro de. Direito sindical. 7. ed. São Paulo: LTr, 2018.

DELGADO, Mauricio Godinho. Curso de direito do trabalho. 17. ed. São Paulo: LTR, 2017.

FERNANDES, Bernardo Gonçalves. Curso de direito constitucional. 7. ed. Salvador: Jus Podivm, 2015.

FINCATO, Denise Pires; GILLET, Sérgio Augusto da Costa. A pesquisa jurídica sem mistérios: do projeto de pesquisa à banca. Porto Alegre, RS: Fi, 2018. Disponível em: https://www.editorafi.org/419direito. Acesso em: 10 set. 2021. 
NASCIMENTO, Amauri Mascaro. Compêndio do direito sindical. 6. ed. São Paulo: LTr, 2009.

OIT. Convenção $n^{\circ} 87$ de 17 de junho de 1948. Liberdade sindical e proteção ao direito de sindicalização. Disponível em: https://www.ilo.org/brasilia/temas/ normas/WCMS_239608/lang--pt/index.htm. Acesso em: 10 out. 2021.

SARLET, Ingo Wolfgang; MARINONI, Luiz Guilherme; MITIDIERO, Daniel. Curso de direito constitucional. 9. ed. São Paulo: Saraiva, 2020.

SILVA, José Afonso da. Curso de direito constitucional positivo. 22. ed. São Paulo: Malheiros, 2003.

STÜRMER, Gilberto. A liberdade sindical na Constituição da República Federativa do Brasil de 1988 e sua relação com a Convenção 87 da Organização Internacional do Trabalho. Orientadora: Professora Doutora Olga Maria Boschi Aguiar de Oliveira. 2005, 262 f. Tese (Doutorado em Direito) - Centro de Ciências Jurídicas da Universidade Federal de Santa Catarina, UFSC, Florianópolis, 2005.

TEIXEIRA FILHO, João de Lima. Art. $8^{\circ}$ É livre a associação profissional ou sindical, observado o seguinte. In: MARTINEZ, Luciano; TEIXEIRA FILHO, João de Lima (coord.). Comentários à Constituição de 1988 em matéria de direitos sociais trabalhistas (arts. $6^{\text {a }}$ a 11): uma homenagem aos 30 anos da Constituição da República e aos 40 anos da Academia Brasileira de direito do trabalho. São Paulo: LTr, 2019. p. 434-463.

ZAFFARI, Eduardo Kucker et al. Direito coletivo do trabalho. Porto Alegre: SAGAH, 2021. 
dol 10.48209/978-65-89949-D5-1

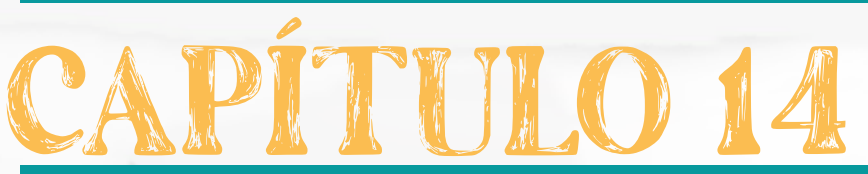

\section{A GESTÃO DA DIVERSIDADE NO CAMPO EDUCACIONAL}

Edileuza Gomes de Souza Ueudison Alves Guimarães Anair Meirelles Quadrado Wanderson Teixeira Gomes 


\section{INTRODUÇÃO}

Ao analisarmos etimologicamente a palavra diversidade, podemos constatar que, em concordância com o Minidicionário Aurélio (2010, p. 261) diversidade significa: "qualidade ou condição do que é diverso, diferença, dessemelhança; divergência, contradição (entre ideias, etc.); multiplicidade de coisas diversas: existência de seres e entidades não idênticos ou dessemelhantes, oposição".

Desse modo, gerenciamento da diversidade conceitua-se como políticas e práticas instituídas para contestar à posição, progressivamente mais diversa no ambiente de trabalho. Refere-se, então, às diversas atuações que as empresas estabelecem para assegurar tratamento justo e sem discriminação a todos os funcionários, independente de suas diferenças.

A gestão da diversidade foi inicialmente pensada nos Estados Unidos com a promulgação, no final da década de 1960, da affirmative action como resultado da necessidade de acomodar uma população cada dia mais plural, no que tange à nacionalidade, etnia, filiação religiosa e 'deficiências'. A regulamentação veio como resposta à discriminação racial observada nas empresas e instituições de ensino.

No Brasil, a discussão sobre diversidade cultural nas empresas surgiu no final dos anos de 1990 com Maria Teresa Fleury (2000), a qual elaborou o estado da arte sobre o tema a partir da literatura estadunidense, bem como realizou uma pesquisa de campo em sete empresas brasileiras sobre adoção da gestão da diversidade.

Discutir a diversidade na educação significa discutir as relações das práticas educacionais cotidianas (desconstruindo e redescobrindo significados), questionar conceitos pré-concebidos e determinações que sutilmente permeiam essas práticas e, sobretudo, refletir e ressignificar a própria história, o que nos leva à necessidade de compreendê-la sob a ótica das diferenças e das desigualdades. Isso implica em: 
Compreender a multiplicidade de sujeitos que compõe esse espaço: de homens, mulheres, trabalhadores e trabalhadoras, negros e brancos, adultos e adolescentes, enfim, todos os seres humanos concretos, reais, sujeitos sociais e históricos, presentes na história, determinantes dela e por ela determinado (AOYAMA \& PERRUDE, 2009, p.173).

Nas últimas décadas, as políticas educacionais para a diversidade têm ocupado lugar de destaque, com vistas a expressar o desafio enfrentado por educadores e gestores na construção de novas práticas administrativas e pedagógicas para superação dos processos de preconceito e discriminação. Isso significa o cumprimento do que prevê a Constituição Federal Brasileira que assegura nos artigos 206, 210 e 215, respectivamente, a pluralidade de ideias e de manifestações culturais e o respeito aos valores culturais e artísticos, combatendo estereótipos e discriminações.

Aprender a viver em um ambiente de diversidade é um dos principais desafios do mundo contemporâneo e, portanto, da Educação, uma vez que a escola é um ambiente frequentado por uma vasta diversidade de pessoas que ao longo da vida escolar se deparam com todo tipo de diferença: de gênero, raça, valores, religião, idade, classes sociais, expressão da sexualidade, ritmos de aprendizagem, configurações familiares, visões de mundo diferentes, entre outros, que são confrontados no mesmo espaço com as experiências escolares. Normalmente, essas diferenças criam elos entre os discentes, mas também proporcionam diversos conflitos, os quais devem ter uma atenção especial da escola.

Dessa forma, cabe à escola repensar a efetivação de uma gestão que respeite e valorize as diferenças, pois, é nela onde as diferentes presenças se encontram e apreendem os valores sociais e morais.

O objetivo deste estudo consiste em discorrer sobre como deve se dar a gestão da diversidade, especialmente no campo educacional, quais os desafios da diversidade e das novas tecnologias concentradas nas distintas configurações do corpo social em que habitamos atualmente e qual o papel da gestão escolar nesse processo. 
Este trabalho está estruturado em seções específicas. Na seção 2 iniciamos com uma abordagem acerca da gestão da diversidade no contexto educacional, apresentando os conceitos de diversidade e de gerenciamento da diversidade. Em seguida, trazemos algumas contribuições de teóricos renomados que discutem a respeito do assunto, justificando a relevância do tema pesquisado.

Na seção 3 discorremos a respeito dos desafios da diversidade e das NTIC centralizadas nos diferentes formatos da sociedade em que estamos inseridos e qual o papel da gestão educacional nesse contexto.

Na seção 4, apresentamos algumas considerações finais relevantes acerca do tema e recomendações para realização de trabalhos futuros de pesquisa sobre o assunto.

Este estudo foi realizado no mês de novembro do corrente ano e conduzido pelas tutoras do mestrado, tendo como metodologia a pesquisa bibliográfica, desenvolvida mediante publicações realizadas em meios digitais, como obras e artigos científicos referentes aos temas abordados.

\section{OS DESAFIOS DA DIVERSIDADE E DAS NOVAS TECNOLOGIAS EM MEIO ÀS DIFERENTES CONFIGURAÇÕES DA SOCIEDADE ATUAL}

É incontestável que a disponibilidade das tecnologias da informação e comunicação e a diversidade humana constituem suportes geradores de mudanças nos domínios sociais, incluindo a educação, onde as mudanças são mais emergentes, mas é onde parecem ocorrer de forma mais lenta e contraditória. Apesar da progressiva disposição de acesso à informação através das NTIC, não tem sido fácil o reconhecimento pela instituição de ensino e pelos profissionais de educação de que esse processo os posiciona, gradativamente, mais distantes da importância que exercem na distribuição da informação.

E mesmo com a expansão da diversidade humana no espaço escolar, ela continua percebida de maneira excludente, o que coloca em questão os procedi- 
mentos de ensino dos docentes, alicerçados em situações didáticas monoculturais, predominando a resistência em perceber o discente culturalmente diferente. Além disso, a gestão do currículo é dirigida para a exclusiva assimilação de conhecimentos, modos e valorização da cultura dominadora, desconsiderando os traços identitários mais relevantes dos alunos.

Este pensamento é confirmado pelo Conselho Nacional de Educação no seu Parecer n. 017/2001 ao reconhecer que:

A consciência do direito de constituir uma identidade própria e do reconhecimento da identidade do outro se traduz no direito à igualdade e no respeito às diferenças, assegurando oportunidades diferenciadas (equidade), tantas quantas forem necessárias, com vistas à busca da igualdade. O princípio da equidade reconhece a diferença e a necessidade de haver condições diferenciadas para o processo educacional (BRASIL, 2001, p.11).

Para que haja mudanças dessas atitudes, é necessária adesão da escola a mecanismos corporativos e individuais organizados e contínuos que ponham em questão práticas docentes anteriores, desafiando atitudes reflexivas referentes à nova realidade global e do papel dos educadores na promoção de significativas possibilidades de aprendizagem a todos os estudantes. O uso das NTIC pode contribuir significativamente nesse processo, pois, por meio delas é possível desenvolver novas formas e métodos de ensino tanto no âmbito escolar, quanto familiar, social e cultural, atingindo as diferentes configurações da sociedade contemporânea.

Conforme Oliveira e Moura:

As NTIC possibilitam a adequação do contexto e as situações do processo de aprendizagem às diversidades em sala de aula. As tecnologias fornecem recursos didáticos adequados às diferenças e necessidades de cada aluno. As possibilidades constatadas no uso das NTIC são variadas, oportunizando que o professor apresente de forma diferenciada as informações (OLIVEIRA \& MOURA, 2015, p.78).

O respeito pela diversidade e a ação em busca da igualdade de condições educacionais configura-se na promoção da solidariedade, da participação e da 
intervenção nos ambientes em que cada um vive, propiciando o exercício da cidadania. Isso demanda clara orientação do currículo visando a cidadania, os princípios e valores que a sustentam, a explicitação das competências essenciais que norteiam para o exercício dessa cidadania e os desafios à flexibilização e à transversalidade curricular.

A escola tem o importante papel de transformação da humanidade e precisa desenvolver seu trabalho de forma democrática, comprometendo-se com o ser humano em sua totalidade e respeitando-o em suas diferenças. O tema diversidade humana abre um leque de conteúdos que devem ser trabalhados no espaço escolar, no sentido de ampliar a reflexão e a prática da tolerância e do respeito, buscando garantir uma educação voltada para a emancipação e humanização de todos os estudantes.

A realização de propostas pedagógicas focadas no princípio da igualdade de condições, na grandeza da diversidade humana, na importância das novas vias de acesso e uso da informação para fins particular e social e as intenções curriculares dirigidas para uma educação voltada à cidadania, recorrem para ações de formação que norteiem, em novas direções, as competências docentes.

As competências esperáveis dos profissionais da educação associam-se numa representação de educador crítico, intelectual e reflexivo, com capacidade de leitura e interpretação da sociedade onde vive e para quem educa.

Para além de competências técnicas para manejar as NTIC com a finalidade de inseri-las no currículo, espera-se que os docentes apresentem ações que Ihes propiciem a análise crítica e atenta dos contratempos e questões sociais que direta ou indiretamente alimentam essas tecnologias; ou seja, um profissional apto à abertura democrática frente a diferentes expectativas ideológicas. É uma exigência advinda da necessidade de defrontar com a variedade de informação de estudantes e respectivas famílias, determinados por conhecimentos, costumes e crenças muito diversificadas. 
É essa habilidade de leitura crítica, compenetrada e constante das mudanças na sociedade e a projeção para a sua atividade cotidiana e, em particular, para o currículo, que se espera de um docente para a sociedade da informação. É, essencialmente, um padrão que demanda uma concepção transformadora, dinâmica e atualizada do conhecimento, fundamentada na atitude crítica de como cada indivíduo lê, ouve e compreende as interações no meio em que vive e, em função disso, (re) constrói o currículo formal.

As competências do professor para essa (re) construção procedem, dessa maneira, da conjugação dos comportamentos ante as mudanças sociais com as capacidades relacionadas aos conhecimentos e atitudes a desencadear nos discentes, visando proporcionar-Ihes mais condições de aprendizagem.

Para Perrenoud (1999), os professores que assumem o ensino por competências se apropriam de responsabilidades na escolha de práticas sociais. Além disso, modificam suas próprias visões a respeito da cultura e da sociedade, principalmente, ao construir conhecimentos. Aqueles que não optarem por essa abordagem, continuarão trabalhando a partir de seus modelos de professores, de forma segregada e disciplinar.

A abertura para esta concepção de prática curricular depende da consciência que cada professor tem acerca de sua autonomia e de suas expectativas sociais em relação a situações de injustiça social, bem como, da consciência da importância do seu papel na instituição escolar para atenuá-las, reconhecendo o seu potencial para construir procedimentos curriculares com finalidades.

Em síntese, a diversificação das sociedades, a intercomunicação a nível global e a universalização dos direitos fundamentais do homem projetados para a educação, exigem a afirmação do docente enquanto intelectual compenetrado. É a condição essencial para adequar o currículo à heterogeneidade dos estudantes. 
Portanto, é determinante que o docente faça uso da internet e das ferramentas tecnológicas disponíveis; conheça os objetos de conhecimento, os aspectos metodológicos do processo educativo, as características e condições dos seus alunos e das pessoas na comunidade em que vive; esteja atento às questões e dificuldades sociais; tenha consciência da sua autonomia profissional para inserir no currículo conteúdos e conhecimentos de mundo; decida e questione as suas práticas em função de cada situação (estudantes, turma, instituição escolar e sociedade); tenha capacidade de análise crítica das ações sociais e educacionais e, avalie constantemente, os resultados das suas decisões e ações junto à diversidade dos discentes.

\section{O PAPEL DA GESTÃO ESCOLAR NA QUESTÃO DA DIVERSIDADE E DAS NOVAS TECNOLOGIAS}

A educação é motivo de muitas discussões, uma vez que, ainda se vê em muitas escolas, um ensino que não atende as perspectivas e os novos paradigmas educacionais e sociais que estão sendo propostos pela legislação nacional. A temática da diversidade e o uso das tecnologias têm trazido grandes desafios à educação, evidenciando que a igualdade de direitos exige alterações importantes nos sistemas de ensino. E, para tanto, o gestor escolar é peça fundamental, pois ele é capaz de garantir a abertura de novos espaços à transformação do cotidiano escolar.

Mesmo com os avanços na área educacional e de projetos inovadores que contemplam o atendimento à diversidade e múltiplas possibilidades de uso das NTIC, muitas escolas ainda não implementaram ações que favoreçam a formação de seus professores para trabalharem com o tema e com as ferramentas tecnológicas, favorecendo, dessa maneira, o contexto sócio histórico da exclusão e dos mecanismos que geram a desigualdade social.

O diretor precisa refletir sobre seus conceitos com relação à diversidade, perceber a importância das tecnologias da informação e comunicação como su- 
porte na disponibilização de conteúdos, metodologias e diversos recursos relacionados ao assunto e favorecer formação continuada aos professores para que eles possam atuar com eficiência e consciência, visando o rompimento de alguns paradigmas excludentes.

A escola como lugar privilegiado de formação humana precisa se constituir, por meio de uma estrutura curricular, como espaço fundamental no processo de reconhecimento, reflexão e ressignificação das múltiplas identidades vivenciadas pelos alunos em suas práticas sociais e culturais. Diante disso, surge a necessidade de romper com velhos paradigmas de uma educação tradicionalista, presa em padrões e modelos arcaicos baseados na visão homogênea, reconstruindo o modelo de educação que exclui, marginaliza e segrega aqueles que não se encaixam nos padrões estabelecidos pela sociedade.

Por isso, segundo Aoyama e Perrude (2009), faz-se necessário investimentos em formação continuada que gere discussões, reflexões e justificativas a respeito das atividades diárias. Ou seja, cabe aos profissionais da educação trilhar por caminhos do conhecimento para desconstruir e reconstruir conceitos que reproduzem pré-conceitos e discriminações.

Conforme Campos (2010), para o gerenciamento adequado da diversidade é fundamental que o gestor conheça a legislação sobre o tema, o planejamento estratégico da unidade de ensino (com o qual é possível conhecer o cenário e compreender o contexto em que a instituição está inserida), o projeto político pedagógico (documento que orienta as ações da instituição escolar) e, por último, o regimento escolar, que deve ser compatível com as normas legais vigentes para a educação básica. De posse destas ferramentas e orientados pelos instrumentos jurídicos, os gestores podem implementar diversas estratégias para gerenciar os conflitos advindos da diversidade escolar.

Portanto, é fundamental que o diretor perceba o seu papel e as suas funções a partir dos objetivos educacionais e dos projetos que a escola se propõe 
a desenvolver. Pois, não se pode mais conceber uma administração que defina prioridades com base em critérios internos da própria função, permitindo uma expansão desmedida desse setor em detrimento do ensino e aprendizagem. Sendo assim, a formação para gestores é um aspecto que merece atenção, pois esse deve primar pela busca da equidade e da qualidade do ensino.

É preciso pensar em sistemas mais modernos de gestão escolar, nos quais o diretor dispõe de informações necessárias para acompanhar tanto as atividades pedagógicas quanto as administrativas, desenvolver procedimentos de gestão compartilhada e viabilizar a comunicação, favorecendo o diálogo entre todos os membros da comunidade escolar.

Enquanto principal responsável pelo desempenho escolar compete ao diretor prover das condições necessárias para que o trabalho pedagógico possa ser desenvolvido da melhor forma possível e em conformidade com a proposta pedagógica estabelecida em conjunto com a comunidade escolar.

Espera-se desse profissional, ações que favoreçam a construção de um ambiente saudável e motivador para a sua equipe através do trabalho colaborativo, reduzindo as distâncias entre eles, alunos e a comunidade, rompendo, assim, com as barreiras criadas pela hierarquia, pois o sucesso do trabalho educativo é produto de uma interação entre todos os envolvidos.

O diretor tem um papel essencial para que mudanças de postura aconteçam na escola, proporcionando resultados significativos. Cabe a ele desenvolver algumas competências, como: estar em sintonia com as mudanças, identificar e mobilizar os diferentes talentos na escola e na comunidade, aprimorar seus conhecimentos, trabalhar com as diferenças, monitorar as ações educacionais e perceber a importância de a escola se abrir para a comunidade e torná-la sua maior parceira. 


\section{CONCLUSÃO}

O presente estudo buscou trazer algumas considerações acerca da gestão da diversidade, cujo objetivo incide em discorrer sobre como ela deve se dar, especialmente no âmbito educativo, apresentado seus principais desafios e das novas tecnologias situadas nas diversas configurações da sociedade atual, bem como sobre o papel da gestão do sistema de ensino nesse cenário.

Por meio dessa pesquisa constatou-se que a disponibilidade das tecnologias da informação e comunicação no estabelecimento de ensino e a diversidade humana têm evidenciado que a igualdade de direitos demanda mudanças consideráveis nessas instituições e, sobretudo, são apoio para gerar transformações nesse ambiente, onde são mais urgentes, mas é onde acontece de forma mais vagarosa e incoerente.

Observou-se, ainda, que saber viver em um espaço de diversidade é um dos principais desafios contemporâneos e, por conseguinte, da Educação. Por isso, a escola tem um papel fundamental na construção de uma sociedade que respeite e saiba conviver com as diferenças.

Cabe à escola, então, repensar a concretização de uma gestão que contemple a prática do respeito às diferenças, pois, é nela onde se encontra uma vasta diversidade de pessoas que se deparam com características diversas, afrontadas com as experiências escolares.

Entretanto, para o gerenciamento adequado da diversidade é fundamental que o gestor conheça a legislação sobre o tema, o planejamento estratégico da escola, o projeto político pedagógico, o regimento escolar e realize mudanças estruturais na rotina da escola. É extremamente importante sua adesão a procedimentos oficiais e individuais organizados e sucessivos que ressignifiquem antigas práticas docentes, visando atitudes reflexivas referentes à atual conjuntura social e ao dever dos docentes frente à aprendizagem dos alunos. Para tanto, faz-se necessário investimentos em formação continuada de toda a equipe escolar. 
Tendo em vista a extrema relevância deste tema, considerando o contexto vivido no interior das escolas, espera-se que este trabalho possa permitir a reflexão e a motivação para novas pesquisas referentes ao assunto.

\section{REFERENCIAS}

AOYAMA, A. L. \& PERRUDE M. R. S.(2009). Educação e Diversidade: as armadilhas produzidas e reproduzidas no espaço escolar. Londrina, PR: Editora da UEL. Disponível em: http://www.diaadiaeducacao.pr.gov.br/portals/cadernospde/ pdebusca/producoes_pde/2016/2016_artigo_gestao_uel_marliaparecidarivelinimartinelli.pdf Acesso em: 02 novembro. 2021.

BRASIL, (1988). Constituição Federal. Disponível em: https://www2.camara.leg. br/atividade-legislativa/legislacao/constituicao1988 Acesso em: 12 novembro. 2021.

BRASIL, (2001). Conselho Nacional de Educação. Diretrizes Nacionais para a Educação Especial na Educação Básica. Parecer CNE/CEB n.017/2001. Disponível em: https://www.nre.seed.pr.gov.br/arquivos/File/toledo/ed_especial/legislacao/politica_estadual.pdf Acesso em: 16 novembro 2021.

CAMPOS, C. M. (2010). Gestão escolar e docência. São Paulo, SP: Paulinas. Disponível em: https://www.paulinas.com.br/produto/gestao-escolar-e-docencia-1752 Acesso em: 06 novembro 2021.

FERREIRA, A. B. (2010). Mini Aurélio: o dicionário da língua portuguesa. 8 ed. Curitiba, PR: Positivo. Disponível em:https://periodicos.sbu.unicamp.br/ojs/index. php/cel/article/view/8649150. Acesso em: 03 novembro 2021.

FLEURY M. T. (2000). Gerenciando a diversidade cultural: experiência de empresas brasileiras. RAE - Revista de Administração de Empresas, vol. 40, n. 3, jul-set São Paulo, SP. Disponível em: https://rae.fgv.br/rae/vol40-num3-2000/ gerenciando-diversidade-cultural-experiencias-empresas-brasileiras Acesso em: 19 novembro 2021.

OLIVEIRA, C. \& MOURA, S. P. (2015). TIC'S na educação: a utilização das tecnologias da informação e comunicação na aprendizagem do aluno. Pedagogia em Ação, Belo Horizonte, v. 7, n. 1. Disponível em: http://periodicos.pucminas.br/ index.php/pedagogiacao/article/download/11019/8864/0 Acesso em: 21 novembro 2021 
PERRENOUD, P, (1999). Construir competências é virar as costas aos saberes? Porto Alegre, RS: Artmed. Disponível em: https://integra.univesp.br/courses/2626/modules/items/206034http://www.unige.ch/fapse/SSE/teachers/perrenoud/php_main/php_1999/1999_39.html. Acesso em 21 novembro 2021. 


\section{dol 10.48209/978-65-89949-D6-1}

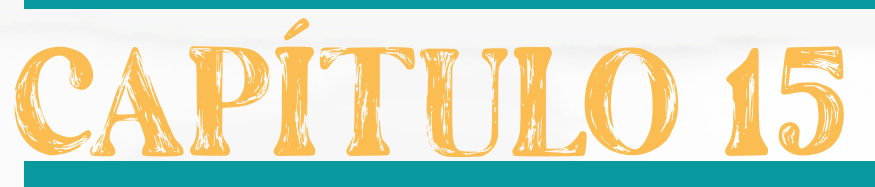

\section{A DIVERSIDADE}

NA PERSPECTIVA DA SAIA DE AULA: O PAPEL DA GESTÃO ESCOLAR

\section{NESSE PROCESSO}

Ueudison Alves Guimarães Edileuza Gomes de Souza 


\section{INTRODUÇÃO}

Neste novo cenário que estamos vivenciando, a diversidade, a redução da desigualdade em um determinado cenário organizacional são temas ainda polêmicos e desafiadores, especialmente quando consideramos a responsabilidade delegada ao professor e aos gestores. Mesmo que prevista na legislação e garantida na escola através das políticas educacionais, permanece uma fonte de constantes discussões.

O gestor escolar possui a função de articular o âmbito escolar, cumprindo assim sua função social na construção do conhecimento. O gestor possui um papel essencial nas instituições de ensino, afinal, é coordenador, articulador e estimulador de ações (PARO, 2001).

O gestor escolar é um dos responsáveis principais pelo meio coletivo que se cria dentro da escola. Deste modo, é importante frisar que o profissional que desenvolve a função de gestor precisa ter formação, dialética e capacidade de interagir com pessoas com objetivo de promover uma melhor educação.

A confecção deste artigo foi com finalidade de ajudar os docentes, gestores e supervisores deixando de lado um olhar diferente ao do plano escolar, de maneira a fazer a diferença, visando a melhoria do ambiente escolar.

\section{AS MUDANÇAS NO ÂMBITO EDUCACIONAL}

As mudanças no âmbito educacional, ao longo da história, estão relacionadas às estruturas organizacionais da sociedade. A mais recente alteração social, que influenciou o modo de gerir a escola, ocorreu na década de 1980, ao ingressar numa era de globalização e redemocratização do país. Desta forma, as bases legais que regiam a educação, também sofreram alterações (VIEIRA; VIDAL, 2006). A partir desta época se inicia o movimento em favor da descentralização e democratização da gestão das escolas públicas, com a realização de diversas reformas educacionais, que reconhecem e fortalecem tal movimento, com a 
proposta de qualidade da educação e alterações nas atribuições legislativas por parte do governo, para com a educação (LUCK, 2005).

A descentralização da educação ocorre a partir do momento em que as atribuições governamentais são reelaboradas. Pode-se notar nos artigos $9^{\circ}$ ao $20^{\circ}$ da Lei de Diretrizes e Bases da Educação (LDB) n 9.394/96, os objetivos principais que cada esfera governamental deve cumprir na educação. Mediante as diversas mudanças ocorridas na sociedade, as quais se refletiram no contexto escolar, houve a alteração no perfil do diretor escolar. De acordo com Oliveira (2002), o administrador escolar, passa a ter um comportamento técnico, porém agora denominado.

\section{O PAPEL DO GESTOR ESCOLAR NA GESTÃO DA DIVERSIDADE EDUCACIONAL}

O gestor escolar é tido como "um agente de mudanças, um facilitador, um mediador e também um interlocutor" (LIBÂNEO, 2012, p. 35). Por este motivo, é um profissional capaz de realizar a comunicação entre educandos, direção escolar, educadores e os outros todos funcionários que fazem parte da instituição. Para Ferreira (2007, p. 327), o gestor escolar tem ligação com a formação humana no processo educacional. Portanto, para que a gestão escolar ocorra de forma democrática e participativa, faz-se necessário a figura do gestor escolar para intervir e organizar o ambiente educacional, como também para que o ensino-aprendizado seja realizado de forma positiva.

É essencial frisar que o gestor escolar tem uma ligação com o planejamento escolar curricular, cuja finalidade é promover uma grande qualidade na aprendizagem, levando a realidade à sala de aula e a escola para seu âmbito familiar (VASCONCELLOS, 2002). Ainda para o autor: "não podemos ser ingênuos; para se criar uma outra ordem das coisas, existiu uma necessidade de uma ação em certa direção, pois esta não é qualquer ação que nos levará ao que certamente desejamos" (VASCONCELLOS, 2002, p. 42). O planejamento é 
essencial para que os objetivos sejam alcançados, por este motivo o gestor tem papel importante na hora de elaborar o plano político-pedagógico que a instituição deverá usar como modelo (PARO, 2001).

Por este motivo é essencial conhecer o Projeto Político e Pedagógico, seus fundamentos teóricos que mantém a aprendizagem nas instituições e os princípios direcionados na prática escolar. O gestor também tem obrigação de compartilhar suas práticas pedagógicas para com os que são tocados pela mesma. Todo âmbito escolar deve estar incluso no poder de decisão destas práticas para que o planejamento realmente seja participativo.

Segundo Boschetti, Mota e Abreu (2016), o grande diferencial de uma gestão democrática nas instituições de ensino versa a participação dos atores sociais envolvidos com a escola, na escolha e planejamento de ações, de modo a reduzir a sobrecarga de problemas gerados pela convivência diária entre seres completamente diferentes entre si. Ademais, pautada as premissas básicas para a gestão democrática, entende-se que de modo geral a gestão escolar compreende um fenômeno educativo, por cujos atores envolvidos ainda que subordinados a um gestor, atuam conjuntamente nas unidades de ensino, de modo a cada qual exercer um papel relevante à formação continua do próprio gestor; dos docentes; e é claro, dos alunos (CROTI; IKESHOJI; RUIZ, 2014). Mas se a gestão democrática no âmbito escolar requer, como o próprio nome já diz, a participação ativa de todos envolvidos no processo de ensino e aprendizagem, surge a dúvida de qual seria o papel real que um gestor toma neste contexto.

Segundo Silva (2009), o gestor atua como um gerador de ideias, cujos pensamentos trazem ao grupo possibilidades de organizar o processo educativo; bem como a chance de romper alguns pré-conceitos buscando sempre uma abordagem para além do tradicional. A autora loc. cit. destaca a importância desta figura para que sejam construídos novos destinos à educação e articular ações coletivas que transformem a realidade. Neste contexto, discute-se o papel do diretor gestor na gestão escolar democrática. De acordo com a auto- 
ra, é de responsabilidade máxima de um gestor escolar garantir que a política educacional atue de maneira organizada, coordenada e concreta, contudo, ainda que assuma uma posição hierarquizada, tal característica não confere ao gestor o poder absoluto de decisões. Desta forma, ainda segundo o mesmo autor, o processo de gestão democrática no âmbito escolar emancipa o sentido técnico de gestão.

Em complemento, Silva (2009) afirma que esta autonomia na gestão escolar é concretizada em três áreas: [i] a pedagógica; [ii] a administrativa; e [iii] a financeira. Diferenciando esta trinca, a autora loc. cit. define como autonomia pedagógica, a possibilidade de cada unidade de ensino formular sua própria proposta pedagógica, conforme políticas vigentes no sistema de ensino; já a autonomia administrativa, decorre-se da escolha dos gestores e conselheiros escolares, que ocorre via eleição, além da formulação e implementação do Projeto Político e Pedagógico e do Regime Escolar. Por fim a autonomia financeira, é expressa pela escolha dos recursos financeiros em consonância com o Programa Dinheiro Direto na Escola - PDDE. Neste contexto, o gestor escolar assume uma importância fundamental para além de uma conceituação técnica, cabendo a ele e a mais ninguém proporcionar condições favoráveis o cumprimento do caráter democrático da instituição de ensino, de modo a atuar como um ator privilegiado no processo de inovação das escolas.

Paro (1994) sugere que a escola não tenha apenas um gestor, mas sim um grupo de pessoas que possam atuar na tomada de decisões, a fim de atender os objetivos da educação garantidos pela Constituição Federal. O autor loc. cit. ainda menciona que termos oriundos de uma gestão hierarquizada tendem a manter esta submissão de cargos, propondo, inclusive a troca do cardo de diretor para o cargo de coordenador geral de escola, que, segundo o autor, forneceria maior abertura para que demais membros sociais envoltos com a escola tivessem menos temor em participar das tomadas de decisões 
Ainda sobre as dificuldades elencadas pelos gestores das escolas, llha e Krug (2009) entendem que existe uma grande necessidade de se investir na formação destes gestores, para que eles possam compreender a direção e os métodos que devem adotar em suas funções, evitando, desta maneira, o retorno à educação hierarquizada e segmentada presente no Brasil antes da redemocratização. O planejamento é essencial para que os objetivos sejam alcançados, por este motivo o gestor tem papel importante na hora de elaborar o plano político-pedagógico que a instituição deverá usar como modelo. Por este motivo é essencial conhecer o Projeto Político e Pedagógico, seus fundamentos teóricos que mantém a aprendizagem nas instituições e os princípios direcionados na prática escolar. O gestor também tem obrigação de compartilhar suas práticas pedagógicas para com os que são tocados pela mesma. Todo âmbito escolar deve estar incluso no poder de decisão destas práticas para que o planejamento realmente seja participativo.

Para Luck (2005), a escola é uma organização social criada pela sociedade para transmitir e cultivar valores sociais além de contribuir para a formação dos alunos, através de experiências de aprendizagem e objetivos da educação. Para a escola ter um bom desempenho, é preciso tomar cuidado com a prática pedagógica de alguns professores e qual o tipo de indivíduos que ele está lidando, se preocupando sempre com o tipo de aprendizagem, e que esta tenha significado social e seja formadora de opiniões.

As mudanças no âmbito educacional, ao longo da história, estão relacionadas às estruturas organizacionais da sociedade. A mais recente alteração social, que influenciou o modo de gerir a escola, ocorreu na década de 1980, ao ingressar numa era de globalização e redemocratização do país. Desta forma, as bases legais que regiam a educação, também sofreram alterações (VIEIRA; VIDAL, 2006). A partir desta época se inicia o movimento em favor da descentralização e democratização da gestão das escolas públicas, com a realização de diversas reformas educacionais, que reconhecem e fortalecem tal movimento, com a 
proposta de qualidade da educação e alterações nas atribuições legislativas por parte do governo, para com a educação (LUCK, 2005).

Gandin (1984), mostra acerca da grande necessidade de planejamento participativo, Aqui está um grande limite e uma grande possibilidade da educação, inclusive a educação escolar: a escola pode somente reproduzir a sociedade, ou seja, ela tem como objetivo incorporar as novas gerações ao espírito, à cultura da geração já existente; quando a cultura e este espírito entram em colapso, ou, quando a sociedade começa a duvidar sobre que é bom ou o que é mau, as escolas esmaecem sua segurança e adentram nesta dúvida; como o padrão sempre é o de uma escola reclusa que reflete o que lhe mandam repetir, a crise na escola significa o desentendimento entre o "ser responsável por algo" e não ter "este algo realmente aceito".

São inúmeros os desafios enfrentados por dia pelo profissional da gestão escolar e são também bem diversificados. Vasconcellos (2002), aponta que pela da necessidade de planejamento que o fator crucial para o significado do planejamento é a percepção feita pelo sujeito da sua necessidade de mudança. É óbvio que se tudo está bem, se nada há para se mudar na escola, para quê incluir esse tal de "plano"? É difícil crer, mas muitos professores parecem muito satisfeitos ou alienados... - com suas práticas, que não sentem nenhuma necessidade de aperfeiçoamento. Talvez, se indagados sobre a escola, até tenham o que falar a respeito; ou não, com medo que dizendo algo possa sobrar alguma tarefa para os próprios. Todo o trabalho da ideologia relevante vai no sentido de se mudar a percepção das contradições e a constante necessidade de mudança.

O planejamento educacional deve ter como objetivo, principal, transformações no dia-a-dia escolar, para se melhorar a qualidade do ensino e da aprendizagem. No que diz respeito ao planejamento participativo, conforme Gandin (1984, p.13), "sua ação na crença de que o melhor para as pessoas é tudo aquilo que elas decidiram em seus grupos". Sander (1995), afirma que o gestor da escola não é apenas o profissional que se preocupa com a ordem, horário, disciplinas, 
exigências e formulários e sim um líder intelectual responsável por coordenar o projeto pedagógico do âmbito escolar, possibilitando assim um processo coletivo de aprendizagem com mis facilidade. As primeiras menções acerca da gestão democrática nas escolas datam o período da República Militar, quando o assunto educação estava entre os mais mencionados nos protestos de redemocratização do país. A partir daí, com a conquista da democracia e a elaboração de uma nova Constituição Federal, o assunto tomou proporções maiores, sendo incluído no contexto jurídico do país.

\section{CONCLUSÃO}

A escola é o ambiente onde acontecem a aprendizagem e o desenvolvimento humano. Ainda há várias dificuldades existentes pelos fatores externos e internos da instituição. Por isso, uma das funções do Gestor escolar é gerar novas formas de participação em incentivar o trabalho em grupo com membros da comunidade. Em outra função do Gestor, desenvolve mecanismos de comprometimento e também cooperação entre todos nas tomadas de decisões na escola.

Dentre os vários desafios do gestor escolar, mostram-se: a falta de previsão legal com relação à sua profissão; a falta de formação para si; e o não conhecimento da comunidade escolar e da sua importância dentro da escola. Esse profissional é também responsável pela formação continuada dos professores, sendo assim, não recebe uma formação que dê continuidade nos seus conhecimentos. $E$ recebe muitas por muitas vezes um salário equivalente ao de um professor, mesmo que desempenhe um cargo técnico e com uma carga horária diferenciada. Assim muitos integrantes da escola desconhecem qual é realmente sua função, e os quais são as suas responsabilidades.

O gestor escolar que visa cumprir com todas as suas responsabilidades, que também deseja cumprir com o seu papel de forma plena, precisa ter várias qualidades, que vão desde a formação adequada, de reflexão até a capacidade 
de se inter-relacionar com os indivíduos que compõem a escola, dialética, com a finalidade de realizar uma educação com qualidade que consiga juntar o conhecimento compartilhado e produzido com a afetividade.

\section{REFERENCIAS}

BRASIL. Lei no 11.274, 6 de fevereiro de 2006. Altera a redação dos arts. 29, 30, 32 e 87 da Lei no 9.394, de 20 de dezembro de 1996, que estabelece as 129 diretrizes e bases da educação nacional, dispondo sobre a duração de 9 (nove) anos para o ensino fundamental, com matrícula obrigatória a partir dos 6 (seis) anos de idade. Diário Oficial da União. Brasília, DF, 7 fev. 2006. Disponível em: https://www.gov.br/mec/pt-br. Acesso em:1 7 de novembro de 2021.

BRASIL. Ministério da Educação. Lei de Diretrizes e Bases da Educação Nacional. Lei n. 9.394/96. Disponível em: http://www.planalto.gov.br/ccivil_03/Leis/ L9394.htm. Acesso em 17 de novembro de 2021.

BOSCHETTI, V. R.; Mota, A. B.; Abreu, D. L. F. Gestão escolar democrática: desafios e perspectivas. Santa Maria, 2016.

CROTI, A.; Ikeshoji, E. A. B.; Ruiz, A. R. Gestão Escolar: Reflexões e Importância. Colloquium Humanarum, 2014.

CUNHA L. A. O legado da ditadura para a educação brasileira: a simbiose estado-capital. Palestra proferida em 30 de maio de 2014, na Universidade Estadual de Campinas. Disponível em: http://www.ige.unicamp.br/cact/wpcontent/ uploads/2014/06/CUNHA-Luiz-Antonio-O-legado-da-ditadura-paraa-educacao-brasileira.pdf . Acesso em: 17 de novembro de 2021.

FERREIRA, A. B. de H. Novo Dicionário Aurélio da Língua Portuguesa. Rio de Janeiro: Nova Fronteira, 2007.

GANDIN, D. Planejamento como processo educativo. Revista de Educação AEC, Brasília: AEC do Brasil, 1984.

ILHA, F. R. da S.; Krug, H. N. A gestão educacional/escolar numa perspectiva democrática. São Paulo, 2009.

LIBANEO, J. C. Educação Escolar: políticas, estrutura e organização. São Paulo: Cortez, 2012. 
LUCK, H. et al. A escola participativa: o trabalho do gestor escolar. Petrópolis: Vozes, 2005.

OLIVEIRA, D. A.; Rosar, M. de F. F. Política e gestão da educação. Belo Horizonte: Autêntica, 2002.

PARO, V. H. Gestão Democrática da escola pública. São Paulo: Ática, 2001.

PARO, V. H. Gestão da Escola Pública: alguns fundamentos. Revista Brasileira Est. de Pedagogia. Brasília, n. 179/180/181, 1994.

SANDER, B. Gestão da Educação na América Latina: construção e reconstrução do conhecimento. Campinas, 1995.

SILVA, E. P. da. A importância do Gestor Educacional na Instituição Escolar. Conteúdo, n.2, 2009.

VASCONCELOS, C. S. Coordenação do Trabalho Pedagógico: do projeto político pedagógico ao cotidiano de sala de aula. São Paulo: Libertad, 2002.

VIEIRA, S. L.; Vidal, E. M. Educação básica: a equidade numa perspectiva territorial. In: XVIII Encontro de Pesquisa Educacional do Norte e Nordeste. Maceió, Alagoas, 2006. 
doi $10.48209 / 978-65-89949-D 7-1$
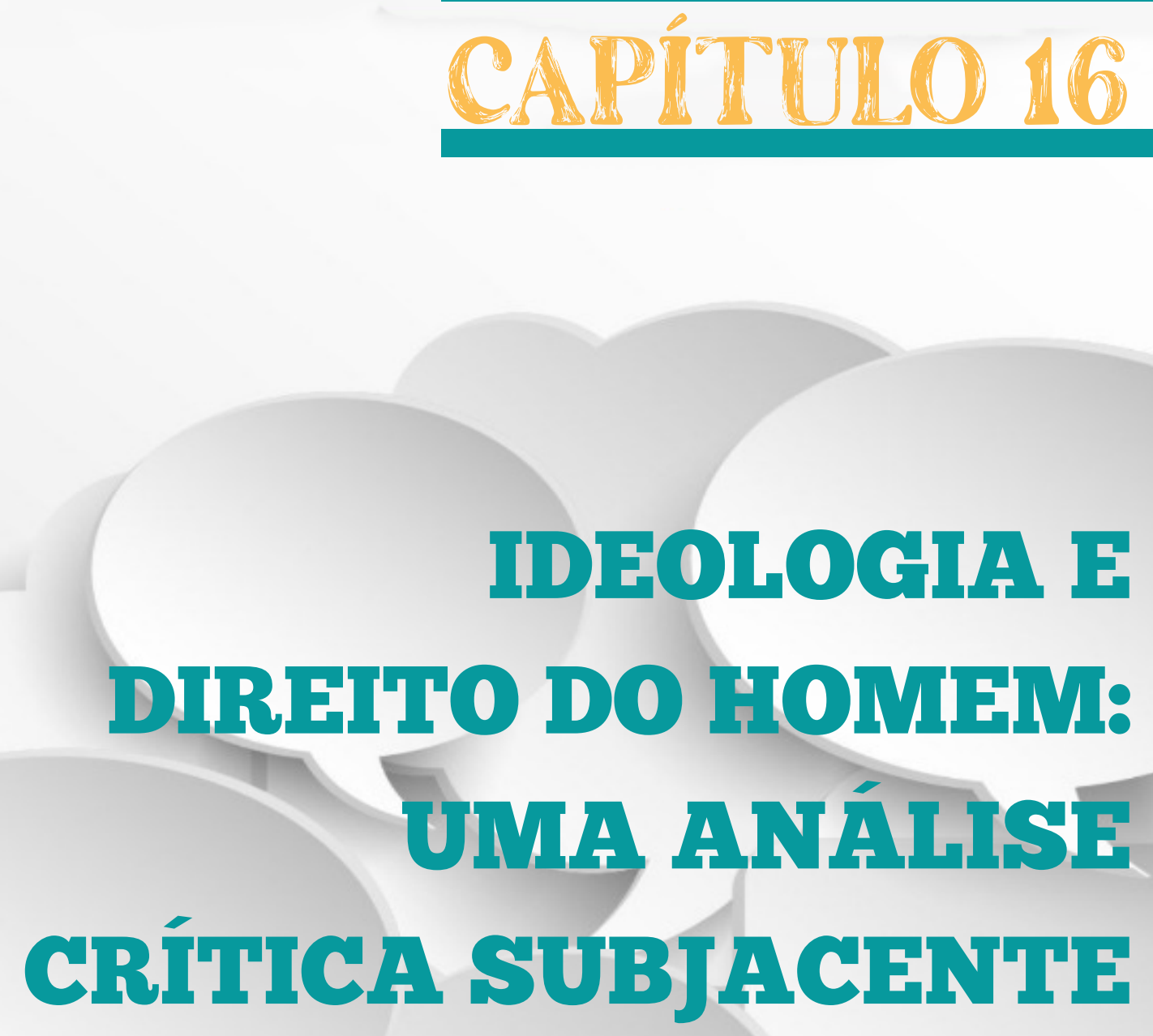

Giovanna Martins Sampaio 


\section{INTRODUÇÃO}

O presente trabalho detém como objetivo principal Articular, pautando-se numa circularidade, alguns dos principais pontos das ciências políticas e sociais, considerando o contexto atual, sob o enfoque do direito e suas imbricações, correlações tangentes ao Estado, Economia e meio Social;

A metodologia aplicada neste artigo, segundo a forma de abordagem do problema, foi primordialmente do tipo qualitativa, posto que a representação quantitativa não se conformou no foco e sentido deste trabalho. Segundo o objetivo da pesquisa, a sua metodologia foi do tipo exploratória e descritiva. A pesquisa descritiva visa descrever as características dos fatos e dos fenômenos e o estabelecimento das relações entre as variáveis consideradas". Gil (2010, p. 42) traz que, "as pesquisas descritivas identificam as características de determinada população ou fenômeno". A pesquisa exploratória visa promover uma aproximação com o objeto de estudo. Também conforme o mesmo autor, "a pesquisa exploratória visa proporcionar maior familiaridade com o problema, com vistas a torná-lo mais explícito ou a constituir hipóteses, sendo isso feito ao longo do trabalho".

Segundo a coleta de dados, a pesquisa foi do tipo bibliográfica e sistemática, na qual foi realizada a busca de trabalhos relacionados às temáticas correlatas das ciências humanas e política, a fim de demonstrar a riqueza e multidisciplinariedade inerentes e necessárias para se avaliar essas questões sociais relativas ao Estado, poder, e Direito.

Para tanto, foi realizado um levantamento crítico relacionado aos principais trabalhos que trouxeram o mais direto possível a correlação entre os respectivos fatores e variáveis.

Portanto, foi investigado o estado da técnica existente sobre o tema no que se refere ao referencial teórico de discussão. Ademais, quanto aos métodos potenciais e relacionados ao presente trabalho, tem-se o emprego de sistemas de inteligência em relação à busca dessa revisão de literatura ora empregada. 
Ainda, abarca-se também a utilização de estratégias de pesquisa relacionadas a RoadMapping, bem como que o emprego de cenários para a obtenção de resultados mais satisfatórios e apropriados ao objetivo deste estudo.

Ultimamente, foi feita uma espécie de prospecção para a definição do tema/ recorte (e justificativa), e primordialmente como filtragem dos trabalhos que comporiam o Referencial teórico do presente artigo; Por fim, Foram considerados também dados obtidos de livros, dissertações, artigos publicados em revistas e periódicos indexados, bem como demais materiais disponíveis online na internet e em formato digital.

\section{DESENVOLVIMENTO: ANARQUISMO}

Neste primeiro momento, tangenciamos e discutimos brevemente a temática da formação militante "anárquica e libertária, e suas correlações e diferenciações com a social-democracia, analisando também a perspectiva histórica sobre o assunto.

Para tanto, é necessário trazer também a definição, origem e etimologia do tema, problematizando ainda a questão do poder, do mercado, da hierarquia e da "existência do Estado enquanto exploração do indivíduo; Assim, na busca por uma comunidade igualitária, pautada na horizontalidade, os adeptos a essa corrente acreditam no autogoverno, descentralizado, no caos, na desordem, na "falta de organização, considerando-se as atribuições positivas de uma gestão que deve ser em prol do social; Assim, define-se a Improcedência de um suposto anarco-capitalismo.(BARCHI, 2008)

Ademais, debate-se acerca do anarquismo enquanto princípios geradores, estes com base na participação popular a partir da revolução francesa segundo um panorama eminentemente histórico, e a partir de narrativas pessoais, através da contextualização do ensino e da leitura, integrando-se inclusive as diferentes dimensões do aprender e da "pedagogia do risco, no âmbito econômico, político, e filosófico dessa discussão. 
Além disso, apresenta-se aqui, portanto, a ideia essencial anarquista da defesa da democracia direta, problematizando a construção e criação de novos lugares enquanto heterotopias, e visualizando as várias compreensões em torno dessa "ideologia. Destarte, questiona-se sobre o anarquismo na pandemia e na cidade, na questão dos impostos e dos partidos e voto, problemática a partir da qual foram definidas as hipóteses de redução/contenção de danos em paralelo à validade da vontade do anarquista na "suposta escolha pelos representantes políticos. Finalmente, indicamos como pontos interessantes dessa temática a avaliação das interfaces para/com as terapias corporais "disruptivas-literárias de Freire, abarcando-se ainda a gênesis internacionalista e transacional inerentemente "contida no anarquismo. (GUIMARAES, 2009)

\section{DESENVOLVIMENTO: MST, DIREITOS HUMANOS E CRISES}

Iniciamos esse subtópico levantando a discussão sobre a intersecção entre direitos humanos e reforma agrária, assim abarcando a concepção de utopia em relação aos bens sociais e minorias, e trazendo-se também a perspectiva histórica da Guerrilha da Araguaia, debatendo-se os diferentes fatores/variáveis correlatos ao movimento Ambientalista e à reforma agrária, como as questões religiosa, social, econômica e Necropolítica:

- O poder necropolítico opera por um gênero de reversão entre vida e morte, como se a vida não fosse o médium da morte. Procura sempre abolir a distinção entre os meios e os fins. Daí a sua indiferença aos sinais objetivos de crueldade. Aos seus olhos, o crime é parte fundamental da revelação, e a morte de seus inimigos, em princípio não possui qualquer simbolismo. Este tipo de morte nada tem de trágico e, por isso, o poder necropolítico pode multiplicá-lo infinitamente, quer em pequenas doses (o mundo celular e molecular), quer por surtos espasmódicos - a estratégia dos pequenos massacres do dia a dia, segundo uma implacável lógica de separação, de estrangulamento de vivissecção, como se pode ver em todos os teatros contemporâneos do terror e do contraterror ... Dessa 
forma, em vez de pensarmos que a noção de necropolítica nos paralisa diante da morte, torna-se necessário entender que tomá-la como importante assinala uma relação com a vida ou ao menos com o que podemos construir como possibilidades de vidas a partir das ruínas do humanismo como paradigma da modernidade. (Mbembe, 2017, p. 65).

Assim, expõe-se a lógica do capital, e a necessidade liberal enquanto sistemas e formas organizativas irreformáveis, contextos nos quais ocorre/existe a extração da mais-valia dos sujeitos. Nesse sentido, são abordados os fenômenos das cadeias globais de valor a partir da concentração expressiva das riquezas, bem como da financeirização do próprio capitalismo, problematizando-se as especificidades em torno da ideia do "declínio da taxa média de valor e lucro e a consequente superprodução e autovalorização do capital. Então, é preciso trazer como exemplos o panorama do comércio de commodities em detrimento da alimentação e do conhecimento enquanto direitos Humanos que compõem o patrimônio da humanidade. (REIS, 2012)

Trazemos ainda que é relevante a realização de um verdadeiro planejamento estratégico na articulação das "forças revolucionárias para a luta e mudança do "paradigma vigente, com a integração e inclusão das populações mais jovens ao cenário sócio-político e coletivo com base em "parâmetros de solidariedade, salientando-se justamente ainda a necessidade da formação e educação segundo princípios sociais: essa construção deve estar em movimento, segundo um processo que se desenrola e conforma uma práxis eminentemente crítica. Seguindo a partir de Buarque, conversa-se rebeldemente a respeito dos deveres no Estado no âmbito das políticas públicas, bem como discute-se acerca da culpabilização e criminalização das ocupações e movimentos sociais, debatendo-se acerca de inúmeras variáveis que compõem esta problemática.

Nessa senda, contextualiza-se o âmbito da Utopia, de uma sociedade mais justa e igualitária em oposição a modelos aristocráticos ou mesmo burocráticos, trazendo a questão da falta de apoio governamental em frentes essenciais como 
as distintas formas de coletivos e cooperativismos; Ademais, tangenciamos a perspectiva freudiana do ensino compartilhado, da participação e da escuta críticas para o aperfeiçoamento das lutas e mitigação das desigualdades sociais ora mais aparentes e escancaradas no cenário nacional de insegurança, que compreende ainda a "supressão atual do governo frente às políticas públicas de assistência social, comprometendo a obtenção da renda básica/mínima das famílias brasileiras bem como sua sobrevivência. (SANTOS, 2021)

Assim, trata-se também da reiteração e concretização de violações de direitos das minorias, portadores de deficiência e populações de ruas, traçando o panorama dos abrigos/albergues e entidades assistenciais públicos, e abarcando as questões dos abusos e conflitos internos a esses espaços que afastam esses sujeitos de seus direitos e garantias básicos; Dessa forma, exemplifica através do Ministério do "juntadão, da cidadania e desenvolvimento social justamente a descontinuidade-ausência de tutela de inúmeras "pastas, políticas e ações em prol dos direitos sociais, ressaltando o desmantelamento das diversas estruturas no âmbito jurídico, político e histórico no Brasil.

Dessa forma, assevera-se a extensiva crise humanitária vivida pela população brasileira, com a falta de centros referenciais em assistência ou espaços de inclusão social de "populações minimizadas, "evocando os episódios de responsabilidade por omissão a serem "conferidos ao Estado e também ao poder judiciário frente a contextos de Crises em que se consta a "ocorrência de esquemas de corrupção e balcões de negócios com empresas estrangeiras para a comercialização de bens e produtos essenciais à população.

Dessa maneira, debate-se acerca da interface entre constitucionalidade e democracia, asseverando que o caminho, a chave está na participação com base no compromisso ante o pacto social institucionalizado na conformação e Constitucionalização Cidadã da Nova República, em que se estabelecem os objetivos e diretrizes a ser perseguidos pelo Estado enquanto representante dos anseios do povo, dos interesses populares. 
Considerando a crise que vivemos em nosso regime político e o controle social extensivo "perpetrado contra esses sujeitos e indivíduos da nossa comunidade', afirmamos aqui a necessidade de se entender a problemática numa visão e sentido orgânicos, articulados, pautando-se nos conceitos essenciais de direitos humanos e fundamentais.

\section{DESENVOLVIMENTO: A CORRELAÇAO ENTRE ESTADO, ECONOMIA E SOCIEDADE}

Começamos abordando as diferenças entre as teorias primordialmente de Weber e Marx, e Durkheim enquanto expoentes das ciências sociais que situam de forma distinta os termos e fenômenos relativos ao estado, sociedade e economia; Assim, Weber diferencia-se de Marx pois não aceita uma causalidade linear ou necessária entre economia e sociedade, enfocando seus estudos em como acontecem e se estabilizam as relações sociais, estendendo o eixo de compreensão do Estado para além da questão econômica;

Trazemos então ao debate as questões inevitáveis da organização da produção, distribuição de riqueza, participação da população no produto do trabalho, e exclusão da mão-de-obra, enquadrando-se ainda as divergências entre povo e nação, em relação à concepção de riqueza, considerando-se ainda o contexto das reformas regulatórias atuais da previdência-trabalho-tributos no Brasil.

Nesse sentido, abarca-se o debate sobre a mercantilização e comercialização, e até mitigação/alijamento de direitos "naturais e básicos na ótica de defesa do Estado Mínimo, desconectado à sociedade, em contraposição à conformação do Estado Social; Dessa forma, contextualizamos o panorama das privatizações dos bens jurídicos essenciais para a vida em sociedade, relativamente ao controle por parte do capital estrangeiro e das empresas internacionais.

Em complemento, Celso Furtado nos traz, sobre a concepção de desenvolvimento social, um encontro ao mito do desenvolvimento econômico, cenário no qual se discute a relação entre centro e periferia, tendo em conta os alinhamentos 
geopolíticos, trazendo também a perspectiva epistemológica de Hélio Jaguaribe no que tange ao projeto Brasil 2000 desenvolvido na época de José Sarney em que se propunha um novo pacto social a partir do diagnóstico das problemáticas e desigualdades vigentes;

Finalmente, assevera-se a economia enquanto elo entre o estado e a sociedade, traçando um "referencial histórico da distinção de Noberto Bobbio entre as "funções econômicas ou políticas" de governo e estado em relação à sociedade civil gramschiana, enquanto um "sofisma que atende aos interesses da classe dominante, hegemônica; Ainda, discute-se sobre as diferentes vertentes que compõe o liberalismo, como o político e o econômico, e suas interfaces com a estruturação da democracia enquanto "Regime. Assim, ressalta-se as metodologias lançadas pela Elite para o convencimento e imposição aos "outros/demais Sujeitos, em relação a sua verdade, a partir da "ocorrência/existência do apoio da opinião pública e do senso comum, e com base na repetição de máximas e ideias que ignoram a complexidade dos fatos e circunstâncias sociais.

\section{CONCLUSAO}

O breve paper aqui apresentado buscou trazer, de forma circular, alguns dos principais pontos das ciências políticas e sociais, considerando o contexto atual, sob o enfoque do direito e suas imbricações, correlações tangentes ao Estado, Economia e meio Social;

Considerando a crise que vivemos em nosso regime político e o controle social extensivo "perpetrado contra esses sujeitos e indivíduos da nossa comunidade', afirmamos aqui a necessidade de se entender a problemática numa visão e sentido orgânicos, articulados, pautando-se nos conceitos essenciais de direitos humanos e fundamentais.

Através deste estudo, pudemos e conseguimos demonstrar a riqueza e multidisciplinariedade inerentes e necessárias para se avaliar as questões sociais relativas ao Estado, poder, e Direito. 


\section{REFERENCIAS}

ANDRADE, E. A intervenção do estado na economia. Disponível em: https:// portal.tce.go.gov.br/documents/20181/91849/A\%20intervenção\%20do\%20Estado\%20na\%20economia-\%20uma\%20tarefa\%20coletiva/187ce100-fef6-49e0-968e-aef243f4a0d8 . Acesso em: 09 nov. 2021.

BRACHI, R. Pedagogia libertária. Rev. Bras. Educ, 13, 38, 2008. Disponível em: https://www.scielo.br/j/rbedu/a/W7zFnvTxBrZCVjVNryPf5hk/?lang=pt . Acesso em: 12 nov. 2021.

GOULART, D. O anticapitalismo do MST. 2011. 247 fl. Tese - UNESP. Marília, 2011. Disponível em: https://www.marilia.unesp.br/Home/Pos-Graduacao/CienciasSociais/Dissertacoes/goulart_dc_do_mar.pdf. Acesso em: 08 nov. 2021.

GUIMARAES, A. Anarquismo e ação-direta com o estratégia ético-política. 2009. 142 fl. Dissertação (Mestrado em História) - Universidade Federal de Uberlândia. Uberlândia, 2009. Disponível em: https://repositorio.ufu.br/bitstream/123456789/16367/1/dis.pdf . Acesso em: 11 nov. 2021.

LUZ; LEITE; CASTRO. O papel do Estado na sociedade. Disponível em: http:// www.joinpp.ufma.br/jornadas/joinpp2017/pdfs/eixo1/opapeldoestadonasociedade.pdf . Acesso em: 08 nov. 2021.

REIS, J. Estado e mercado. Revista crítica de ciências sociais, 95, 2011. Disponível em: https://journals.openedition.org/rccs/4355 . Acesso me: 10 nov. 2021.

REIS, R. O direito à terra como um direito humano. Lua Nova, 86, 2012. Disponível em: https://www.scielo.br/j/In/a/ZHct3GQN5bWGLcvzvTMmk4n/?lang=pt . Acesso em: 05 nov. 2021.

SANTOS. Verde e preto: ideias e experiências anarquistas. Revista estudos libertários, vol 3, n. 8, 2021. Disponível em: https://revistas.ufrj.br/index.php/estudoslibertarios/article/view/41170/23967 . Acesso em: 09 nov. 2021.

SILVEIRA, C. MST, altermundialismo, democracia e direitos humanos. Albuquerque revista de história, vol 9, n 17, 2017. Disponível em: https://periodicos. ufms.br/index.php/AlbRHis/article/view/5193 . Acesso em: 07 nov. 2021. 


\section{dol 10.48209/978-65-89949-D8-1}

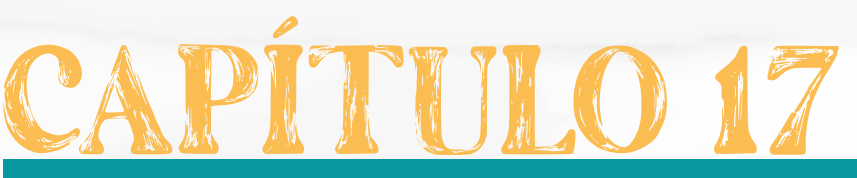

\section{APONTAMENTOS}

SOBRE MARCAS COLETIVASE COOPERATIVAS AGRICOLAS

Giovanna Martins Sampaio Hermes Oliveira Gomes 


\section{INTRODUÇÃO}

O presente trabalho detém como objetivo principal Articular as marcas coletivas ao âmbito, cenário da Agricultura familiar e cooperativismo; visando encontrar, apontar justamente para as marcas coletivas enquanto instrumentos de competitividade em Diferentes cenários, agregando valor à produção, promovendo uma maior capacidade competitiva a inúmeros atores e assegurando uma gestão e desenvolvimento mais mais sustentáveis dos recursos, demonstrando assim as inúmeras vantagens da obtenção do registro de marcas coletivas.

A metodologia aplicada neste artigo, segundo a forma de abordagem do problema, foi primordialmente do tipo qualitativa, posto que a representação quantitativa não se conformou no foco e sentido deste trabalho. Segundo o objetivo da pesquisa, a sua metodologia foi do tipo exploratória e descritiva. A pesquisa descritiva visa descrever as características dos fatos e dos fenômenos e o estabelecimento das relações entre as variáveis consideradas”. Gil (2010, p. 42) traz que, "as pesquisas descritivas identificam as características de determinada população ou fenômeno". A pesquisa exploratória visa promover uma aproximação com o objeto de estudo. Também conforme o mesmo autor, "a pesquisa exploratória visa proporcionar maior familiaridade com o problema, com vistas a torná-lo mais explícito ou a constituir hipóteses, sendo isso feito ao longo do trabalho".

Segundo a coleta de dados, a pesquisa foi do tipo bibliográfica e sistemática, na qual foi realizada a busca de trabalhos relacionados aos ativos de propriedade intelectual - marcas coletivas, setoriais e de certificação - a fim de demonstrar de que forma tais ferramentas podem ser utilizadas para promover a inovação tecnológica, a competitividade e o desenvolvimento sustentável das cooperativas de agricultura familiar.

Portanto, foi investigado o estado da técnica existente sobre o tema no que se refere ao referencial teórico de discussão. Ademais, quanto aos métodos po- 
tenciais e relacionados ao presente trabalho, tem-se o emprego de sistemas de inteligência em relação à busca dessa revisão de literatura ora empregada.

Ainda, abarca-se também a utilização de estratégias de pesquisa relacionadas a Mapping, bem como que o emprego de cenários para a obtenção de resultados mais satisfatórios e apropriados ao objetivo deste estudo. Ultimamente, foi feita uma espécie de prospecção para a definição do tema/recorte (e justificativa), e primordialmente como filtragem dos trabalhos que comporiam o Referencial teórico do presente artigo;

Por fim, as palavras chaves utilizadas na busca de bibliografia para compor o aporte teórico-conceitual deste trabalho (em várias combinações) foram: agricultura familiar, cooperativas, desafios da agricultura familiar, marcas coletivas e de certificação, Marcas setoriais, dentre outras. Foram considerados também dados obtidos de livros, dissertações, artigos publicados em revistas e periódicos indexados, bem como demais materiais disponíveis online na internet e em formato digital.

\section{DESENVOLVIMENTO}

Em meados dos anos 1990, diante dos problemas relativos à enorme concentração fundiária, à variedade de cenários e especificidades de cada região brasileira, e aos diferentes modelos de organização sociopolítica e econômica, a agricultura familiar foi finalmente conceituada e legitimada pelo Estado com a criação do Pronaf (Programa Nacional de Fortalecimento da Agricultura Familiar). Com o decorrer do tempo, passou a compor as agendas políticas de governo, resultando, por exemplo, no Programa Nacional de Alimentação Escolar (PNAE) que, por meio do artigo 14 da Lei $n^{0}$ 11.947, de 16 de junho de 2009, prevê que trinta por cento do valor destinado ao Fundo Nacional de Desenvolvimento da Educação (FNDE) será utilizado na compra de “...gêneros alimentícios diretamente da agricultura familiar e do empreendedor familiar rural ou de suas organizações, priorizando-se os assentamentos da reforma agrária, as comunidades tradicionais indígenas e comunidades quilombolas." 
A agricultura familiar tem como legislação específica vigente, o Decreto $\mathrm{n}^{\circ}$ 9.064, de 31 de maio de 2017. Nela, vale destacar aqui, o disposto no artigo $1^{\circ}$ :

"As políticas públicas direcionadas à agricultura familiar deverão considerar a Unidade Familiar de Produção Agrária - UFPA, os empreendimentos familiares rurais, as formas associativas de organização da agricultura familiar e o Cadastro Nacional da Agricultura Familiar - CAF. (Redação dada pelo Decreto no 10.688, de 2021)". (grifo nosso).

No artigo $3^{\circ}$ deste mesmo Decreto, consta que a Unidade Familiar de Produção Agrícola (UFPA) e o empreendimento familiar rural devem atender aos seguintes requisitos:

"I - possuir, a qualquer título, área de até quatro módulos fiscais;

II - utilizar, predominantemente, mão de obra familiar nas atividades econômicas do estabelecimento ou do empreendimento; (Redação dada pelo Decreto $n^{0} 10.688$, de 2021)

III - auferir, no mínimo, metade da renda familiar de atividades econômicas do seu estabelecimento ou empreendimento; e

IV - ser a gestão do estabelecimento ou do empreendimento estritamente familiar."

Hugo Lamarche afirmou que a exploração é compreendida como "uma unidade de produção agrícola onde propriedade e trabalho estão intimamente ligados à família". Para Abramovay (1997), a agricultura familiar se estabelece na interface entra a gestão, propriedade e trabalho por meio de indivíduos que tem vínculo familiar entre si.

A Lei $n^{0} 5.764 / 71$ aborda que as atividades realizadas pelas cooperativas em relação aos seus cooperados referem-se à transferência de mercadorias/ recursos, tendo como finalidade precípua o atendimento aos interesses e às necessidades daqueles, e ainda, nos casos de sobras obtidas, existe a previsão e permissão aos mesmos para decidirem o destino dos meios restantes levando à reaplicação na própria cooperativa.

Regulamentado pela Lei 9.279 - Lei da Propriedade Industrial (LPI), as marcas coletivas são: "aquelas usadas para identificar produtos ou serviços provindos de membros de uma determinada entidade". 
O registro destas somente poderá ser requerido especificamente através de pessoas jurídicas e representativas de coletividade, conforme art. $128, \S 2^{\circ}$, da Lei n 9279/96 (LPI), e tem a finalidade de identificar serviço/produto originário de membro de uma certa instituição. Vale ressaltar que entidades governamentais poderão requerer uma marca coletiva.

O registro de uma marca coletiva deve ser renovado a cada dez anos, e caso não haja pedido de renovação, o registro será extinto. No entanto, diferentemente dos demais registros de marcas, a marca coletiva, ao ser extinta, não estará disponível para registro por outros terceiros, exceto após cinco anos (artigo 154 da Lei $n^{\circ}$ 9279/96).

O registro será extinto caso a entidade deixe de existir ou a marca seja usada em condições contrárias ao previsto propriamente no regulamento de utilização (artigo 151, incisos I e II).

As marcas coletivas geralmente são definidas como sinais para distinguir a origem geográfica, o material, o método de fabricação ou qualquer outra característica comum dos produtos ou serviços das diferentes empresas que os utilizam coletivamente. O titular pode ser uma associação de que essas empresas são parte ou qualquer outra entidade, incluindo uma instituição pública ou uma cooperativa (WIPO, 2021).

Dessa forma, é comum estudar as marcas coletivas em paralelo e comparação relativamente a outras demais figuras da propriedade intelectual, primordialmente e mais diretamente as marcas de Certificação e os Registros de indicação geográfica, gênero mais complexo de proteção; Percebe-se então desde já vantagens na obtenção de marcas coletivas para o fortalecimento de pequenos produtores rurais.

Segundo o Instituto Nacional da Propriedade Intelectual, competente para a concessão das marcas e ativos imateriais e intangíveis no país, deve-se também ter em mente a necessidade e elaboração de um Regulamento de utilização da marca coletiva para ser observado pelos agentes autorizados a lançarem 
mão de seu uso, com a respectiva descrição do Coletivo requerente, a forma de adesão `a marca por parte de agentes potenciais e interessados, as condições de utilização e ainda as eventuais sanções por descumprimento, irregularidade, desvio ou uso indevido da marca:

O pedido de registro de marca coletiva deve vir acompanhado do regulamento de utilização da marca, de acordo com o disposto no art. 147 da LPI e conforme a Instrução Normativa $n^{\circ} 19 / 2013$. Caso o regulamento não acompanhe o pedido, este documento deve ser protocolizado no prazo de até 60 (sessenta) dias da data do depósito da referida marca, sob pena de arquivamento definitivo do pedido, em conformidade com o disposto no parágrafo único do mesmo artigo.

O regulamento submetido pelo requerente deve conter os itens a seguir, sob pena de formulação de exigência para eventual correção ou clarificação:

a) Descrição da entidade coletiva requerente, indicando sua qualificação, objeto, endereço, e pessoas físicas ou jurídicas autorizadas a representá-la;

b) Condições para eventual desistência do pedido de registro ou renúncia ao registro da marca (parcial ou total), caso as mesmas não estejam previstas no contrato social, em observância ao art. 152 da LPI;

c) Pessoas (físicas ou jurídicas) autorizadas a utilizar o sinal em exame, devendo ser descritos quaisquer requerimentos ou condições necessárias para a utilização do sinal;

d) Condições de utilização do sinal, caso as mesmas existam. No caso de falta de detalhamento das condições de uso do sinal, entende-se que as condições aplicáveis se limitam ao estabelecido pelas normas legais;

e) Sanções aplicáveis no caso de uso inapropriado do sinal, caso as mesmas existam. Se o requerente não detalhar a definição de uso inapropriado, este será entendido como o emprego da marca coletiva de forma contrária ao estabelecido pelas condições previstas no item "d". (INPI, 2021)

O desenvolvimento econômico, segundo BRESSER-PEREIRA (1986):

"é o processo de acumulação de capital e incorporação de progresso técnico ao trabalho e ao capital que leva ao aumento da produtividade, dos salários, e do padrão médio de vida da população."

Nesse contexto, é imprescindível o planejamento de estratégias, sendo o maior desafio determinar o tipo apropriado de participação, que deve seguir algumas linhas, quais sejam primordialmente, o nível estratégico, as questões inter/ 
setoriais e integrativas, e questões abrangentes e Significativas de desenvolvimento sustentável, e a análise das partes interessadas com a identificação dos grupos com maior probabilidade de serem afetados.

Ademais, o Desenvolvimento Sustentável, ao Requerer uma Abordagem Estratégica e Participativa, exige que quatro objetivos sejam alcançados:

- Atendimento às necessidades das gerações de amanhã através das decisões de hoje com base numa solidariedade intergeracional implicando no acesso a inúmeras visões e obtenção de informações adequadas para desenvolver e comparar cenários complexos e sistêmicos, e permitindo incertezas; estabelecendo uma mistura de políticas e enfatizando uma abordagem adaptativa com a melhoria contínua, uma visão do ponto certo no horizonte, um passo de cada vez no caminho, com a incorporação de diversas perspectivas e ajudando-se mutuamente na definição da visão e no Trajeto a ser percorrido, trabalhando juntos na busca por soluções, particularmente em ambientes que enfrentam múltiplas demandas.

- Equilíbrio dos objetivos e Metas sociais, econômicos e ambientais: Fazer isso requer a aplicação de ciências sociais, econômicas e ambientais bem como a aplicação de abordagens centradas nas pessoas, ou seja, no conhecimento, ideias e valores locais.

- Gerenciamento de sistemas naturais dentro de seus limites: implica reconhecer todos os valores desses sistemas, reconciliando vários fatos, opiniões e necessidades e garantindo direitos, responsabilidades, poderes, habilidades, tecnologia e capacidade adequados.

- Foco no desenvolvimento, não no crescimento: implica preservar a qualidade a longo prazo através da coordenação todas as áreas e instituições responsáveis por elas, fomentando investimentos e aplicando genuinamente o princípio da precaução. 
O desafio de alcançar a sustentabilidade nos sistemas ambiental, social e econômico implica que um ecossistema seja capaz de apoiar organismos saudáveis, mantendo sua produtividade, adaptabilidade e capacidade de renovação, ocorrendo alguma forma de transferência de capital equivalente para as gerações seguintes, de forma equitativa e segundo uma abordagem diversificada baseada na diversidade e faseada, e exigindo novos Rumos na qualificação/capacitação e facilitação " catalizadora dos agentes sociais resultando em novas configurações institucionais e em formulações inovadoras relativas às políticas públicas.

O conceito central desse novo paradigma emergente consagra novas maneiras de aprender sobre o mundo. Ensinar e aprender, no entanto, não são a mesma coisa. Aprender não resulta necessariamente do ensino. Ensinar implica a transferência de conhecimento de alguém que conhece alguém que não conhece. O ensino é o modo normal de curricularização e disciplinarização do saber, sustentando o modelo de transferência de tecnologia de pesquisa e extensão que é central para muitas estruturas organizacionais.

Podemos dizer que agora estamos começando a perceber que o objetivo da educação é aprender, no âmbito de um aprendizado sensível e Significativo sobre as condições particulares de cada localidade e Comunidade. Onde o ensino não inclui um foco no autodesenvolvimento e no aprimoramento da capacidade de aprender, ele ameaça o desenvolvimento sustentável.

O foco é menos no que aprendemos e mais em como aprendemos e com quem. As instituições precisarão fornecer ambientes de aprendizado e Trabalho criativos, condições nas quais o aprendizado e o trabalho podem ocorrer através da experiência, através de interações abertas e igualitárias, e através da exploração e experimentação pessoal considerando-se a ideologia freiriana da pedagogia da alternância.

Existem ainda alguns Critérios para estabelecer maior confiabilidade dos processos participativos: Engajamento prolongado e ou intenso entre os vários atores (Para criar confiança, é necessário entender os detalhes do contexto e 
manter os atores envolvidos abertos a múltiplas influências); Observação persistente e crítica, com a análise da amplitude das variáveis, perspectivas e realidades encontradas; auditabilidade e escalabilidade com a manutenção e avaliação da qualificação; Impacto na capacidade das partes interessadas de conhecer e agir (ação); Verificação e integração de pares relativamente aos grupos sociais.

Nesse sentido, Um dos elementos-chave no processo estratégico é a construção de consenso, relacionando-se primordialmente com a forma como as outras partes podem ser persuadidas a se envolver ou influenciar a contribuição de outras partes, por exemplo via Educação.

Devemos compreender ainda que as marcas coletivas envolvem uma reflexão interdisciplinar inexorável em relação à propriedade intelectual, adicionando justamente o caráter coletivo e potencializador do empreendimento coletivo e produtivo idealizado, abarcando até anotações e considerações relacionadas aos chamados EES - Empreendimentos econômicos solidários.

O debate acerca das marcas coletivas, particularmente no âmbito da(s) chamada(s) Ruralidade(s) e da agricultura camponesa e familiar (HANZEN; PLEIN; COLTRE, 2020), alude a outras demais discussões "coletivas e dotadas de/com caráter ativo e eminentemente histórico, como já foi trazido no presente trabalho que explica e justifica a atual conformação agrária brasileira a partir dos acontecimentos coloniais históricos que Demarcaram e estruturaram nossa sociedade e território.

Destacam-se os denominados Movimentos sociais, sobressaindo o intuito e "missão de participação integrada e integrativa na arena de ação/atuação social (NIEMEYER, 2007), e o teor resistência e luta contra a hegemonia do capital e exploração da maioria dos atores sociais (VIEIRA), valorizando-se as redes de apoio e cooperação através de incentivos mútuos coletivos no âmbito das Cooperativas, e respeitando-se a gestão coletiva da produção e da Marca respectiva por meio de instrumentos "burocráticos legítimos de organização e envolvimento de atores (BRITO; MATOS; PEDROZO; DA SILVA, 2020). 


\section{CONCLUSÕES}

As marcas coletivas estão enquadradas em fenômenos macro, pois relacionam-se com os aspectos físicos, econômicos, sociais e culturais de determinado meio e território, pelo que englobam ainda aspectos de competitividade, organização e gestão; e diferenciação, Especificação, qualificação, governança e desenvolvimento territoriais.

O desenvolvimento territorial pode ser definido como qualquer processo de mobilização dos atores que leva a estratégias de adaptação, com base em uma identificação coletiva no âmbito de determinada cultura e território.

Já a Governança territorial é entendida como um processo de coordenação dos atores, particularmente público, sobrelevando o viés institucional e promovendo construções geográficas e da territorialidade através da apropriação de recursos.

Segundamente, as marcas coletivas ainda conseguem promover os produtos e bens "referentes de forma única, através da "Agregação de valor e da articulação de redes de Coopetição, com a participação de diferentes instituições e organizações públicas, privadas, e interprofissionais e associativas.

Ademais, o presente estudo demonstrou o cenário ainda em desenvolvimento das marcas coletivas no Brasil, denotando ainda a sua desarticulação com o contexto da agricultura familiar; Devido ao impacto e constatação da relevância da agricultura familiar na economia nacional, segundo os dados encontrados durante a pesquisa, é justamente preciso que se incentive e se promova esses registros de propriedade intelectual, principalmente das marcas de caráter coletivo, pois estimulam o desenvolvimento de estratégias e competitividade gerando o posicionamento estratégico desses agentes "cooperativos existentes e integrantes do mercado (CARRARO, IMLAU, 2019), diversificando e fortalecendo a produção nacional. 
Nesse sentido, estudos sobre as epistemologias da ação coletiva em função dos aspectos sócio-econômicos e produtivos no enquadramento rural e agrícola poderão se conformar como perspectivas futuras de continuação da presente pesquisa.

Ademais, reitera-se na presente finalização que a marca inclusive coletiva confere maior valor agregado aos produtos, pois oferece maior credibilidade aos mesmos junto aos agentes do mercado inclusive através da acessibilidade a novos nichos mercadológicos, ainda que possuam suas respectivas diferenciações quanto aos selos e marcas de certificação.

Além disso, em se tratando do contexto agrícola em específico, o teor das marcas coletivas carrega consigo a possibilidade de maior promoção da sustentabilidade na produção, podendo ser adequadamente aplicada a diferentes realidades regionais e agrícolas brasileiras (ex. comunidades de fundo de pastos), pelo que fortalece também esses grupos familiares e valoriza as tradições comunitárias de cultivo e produção.

\section{REFERENTCIAS}

ABRAMOVAY, Ricardo (1992). Paradigmas do Capitalismo Agrário em questão. São Paulo: Hucitec e Campinas: UNICAMP.

BENECKE, D. W. Coopera e desenvolvimento: o papel das cooperativas no processo de desenvolvimento econômico nos países de terceiro mundo. Recife: Assocene, 1980.

BRESSER-PEREIRA, Luiz Carlos (1986) Lucro, Acumulação e Crise. São Paulo: Editora Brasiliense, 1986.

BRITO; MATOS; PEDROZO; DA SILVA. Contexto cooperativo. BJD, vol 6, n. 10. 2020. Disponível em: https://www.brazilianjournals.com/index.php/BRJD/article/ view/19219/15422. Acesso em: 19 out. 2021.

CANÇADO, A. C.; A. S. RIGO; J. R. PEREIRA; M. C. H. GONTIJO. (2012). Movimento e Princípios Cooperativistas: Evolução e Reflexões para Novos Estudos. In CANÇADO, A. C.; F. G. TENÓRIO; J. T. SILVA JR (orgs.). Gestão Social: aspectos teóricos e aplicações. Ijuí: UNIJUÍ, 2012a 
CARRARO, W; IMLAU, J. Relações de ambiente, posicionamento estratégico e performance organizacional no cooperativismo do Rio grande do norte. BJD, vol 5, n. 1, 2019. Disponível em: https://www.brazilianjournals.com/index.php/BRJD/ article/view/4402/4130. Acesso em: 24 out. 2021.

CASTRO; GIRALDI. Estratégias de marcas para setores brasileiros. Revista espacios, vol. 39, n. 33, 2018. Disponível em: http://www.revistaespacios.com/ a18v39n33/18393308.html . Acesso em: 21 out. 2021.

INPI. Análise de pedidos de marcas coletivas. Disponível em: http://manualdemarcas.inpi.gov.br/projects/manual/wiki/5.14_Análise_de_pedidos_de_marca_coletiva. Acesso em: 15 out. 2021.

KOTLER, Phillip. Administração de Marketing: análise, planejamento, implementação e controle. 1998.

LAMARCHE, H. (1993). A agricultura familiar: uma realidade multiforme. Campinas: Editora da Unicamp.

NIEMEYER, C. Via campesina. Raízes, vol 26, n 1 e 2, 2007. Disponível em: http://raizes.revistas.ufcg.edu.br/index.php/raizes/article/view/275/257 . Acesso em: 23 out. 2021.

REGALADO et al. Marcas coletivas brasileiras. Disponível em: http://nbcgib. uesc.br/nit/ig/app/papers/0646282901133319.pdf . Acesso em: 22 out. 2021.

RODRIGUES, T; KAMIMURA, Q. Agroecologia e agricultura familiar através do desenvolvimento regional. BJD, vol 7, n. 3, 2021. Disponível em: https://www. brazilianjournals.com/index.php/BRJD/article/view/27196/21487 . Acesso em: 25 out. 2021.

SAVIAN, M. Juventude rural e sucessão geracional na agricultura familiar. BJD, vol 7, n. 3, 2021. Disponível em: https://www.brazilianjournals.com/index.php/ BRJD/article/view/27022/21374 . Acesso em: 18 out. 2021.

SCHNEIDER, J. O. Democracia, participação e autonomia cooperativa. 2. ed. São Leopoldo: UNISINOS, 1999. 496 p. 
SGUAREZI et al. Incubação de EES e a cultura da solidariedade. BJD, vol 6, $\mathbf{n}$. 7, 2020. Disponível em: https://www.brazilianjournals.com/index.php/BRJD/article/view/12576/10646. Acesso em: 03 nov. 2021.

SILVA, G; DIAS; C. Competitividade nas PMES. Disponível em: https://www. unaerp.br/revista-cientifica-integrada/edicoes-anteriores/volume-3-edicao-3/ 2719-rci-competitividade-nas-micro-e-pequenas-empresas/file . Acesso em: 25 noov. 2021.

SOUZA, W; QUALHARINI, E; O planejamento estratégico nas PMES. Disponível em: https://www.sp.senac.br/pdf/24848.pdf . Acesso em: 03 dez. 2021.

TEIXEIRA, C; DANTAS, G; BARRETO, C. A importância do planejamento estratégico para as PMES. Disponível em: http://www.faesb.com.br/revista/wp-content/uploads/2015/05/artigo_giane_2015.pdf . Acesso em: 21 nov. 2021.

THESING, N. J. Por um mundo melhor: cooperação e desenvolvimento. Porto Alegre: Buqui, 2015.

VIEIRA, F. Via campesina. Disponível em: http://www.uel.br/grupo-pesquisa/gepal/terceirosimposio/flaviabraga.pdf . Acesso em: 28 out. 2021 


\section{dol 10.48209/978-65-89949-D9-1}

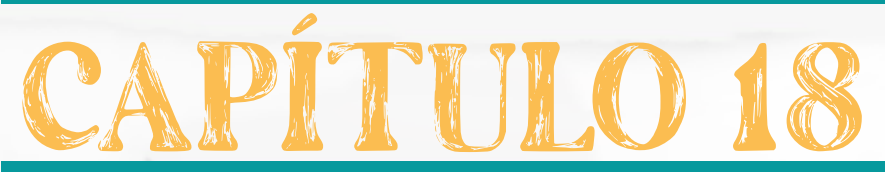

\section{MARCAS COLFTIVAS ENQUANTO ESTRATEGIAS COMPETITIVAS}

Giovanna Martins Sampaio Alanna Rodrigues 


\section{INTRODUÇAO}

O presente trabalho detém como objetivo principal Articular as marcas coletivas ao âmbito, cenário do planejamento estratégico e competitivo dos diversos gêneros de empreendimentos; visando encontrar, apontar justamente para as marcas coletivas enquanto instrumentos de competitividade em Diferentes cenários pois revestem-se de um caráter de tecnologias sociais, agregando valor à produção, promovendo uma maior capacidade competitiva a inúmeros atores e assegurando uma gestão mais sustentável dos recursos, demonstrando assim as inúmeras vantagens da obtenção do registro de marcas coletivas.

A metodologia aplicada neste artigo, segundo a forma de abordagem do problema, foi primordialmente do tipo qualitativa, posto que a representação quantitativa não se conformou no foco e sentido deste trabalho. Segundo o objetivo da pesquisa, a sua metodologia foi do tipo exploratória e descritiva. A pesquisa descritiva visa descrever as características dos fatos e dos fenômenos e o estabelecimento das relações entre as variáveis consideradas”. Gil (2010, p. 42) traz que, "as pesquisas descritivas identificam as características de determinada população ou fenômeno". A pesquisa exploratória visa promover uma aproximação com o objeto de estudo. Também conforme o mesmo autor, "a pesquisa exploratória visa proporcionar maior familiaridade com o problema, com vistas a torná-lo mais explícito ou a constituir hipóteses, sendo isso feito ao longo do trabalho".

Segundo a coleta de dados, a pesquisa foi do tipo bibliográfica e sistemática, na qual foi realizada a busca de trabalhos relacionados aos ativos de propriedade intelectual - marcas coletivas, setoriais e de certificação - a fim de demonstrar de que forma tais ferramentas podem ser utilizadas para promover a inovação tecnológica, a competitividade e o desenvolvimento sustentável.

Para tanto, foi realizado um levantamento relacionado às definições, características, legislações e vantagens das marcas coletivas e demais aspectos e bens imateriais da propriedade intelectual; 
Portanto, foi investigado o estado da técnica existente sobre o tema no que se refere ao referencial teórico de discussão. Ademais, quanto aos métodos potenciais e relacionados ao presente trabalho, tem-se o emprego de sistemas de inteligência em relação à busca dessa revisão de literatura ora empregada.

Ainda, abarca-se também a utilização de estratégias de pesquisa relacionadas a Mapping, bem como que o emprego de cenários para a obtenção de resultados mais satisfatórios e apropriados ao objetivo deste estudo.

Ultimamente, foi feita uma espécie de prospecção para a definição do tema/ recorte (e justificativa), e primordialmente como filtragem dos trabalhos que comporiam o Referencial teórico do presente artigo;

Por fim, Foram considerados também dados obtidos de livros, dissertações, artigos publicados em revistas e periódicos indexados, bem como demais materiais disponíveis online na internet e em formato digital;

\section{DESENVOLVIMENTO}

\section{TECNOLOGIAS SOCIAIS: CONCEITOS}

Segundo o Governo Brasileiro, "O conceito de Tecnologia Social remete para uma proposta inovadora de desenvolvimento, considerando uma abordagem construtivista na participação coletiva do processo de organização, desenvolvimento e implementação, aliando saber popular, organização social e conhecimento técnico-científico." (MCTIC, 2021)

Complementa ainda a funcionalidade inerente a essas tecnologias diversas com finalidade e teor sociais:

Tem como base a disseminação de soluções para problemas voltados a demandas de renda, trabalho, educação, conhecimento, cultura, alimentação, saúde, habitação, recursos hídricos, saneamento básico, energia, ambiente, igualdade de raça e gênero, dentre outras, importando essencialmente que sejam efetivas e reaplicáveis e promovam a inclusão social e a melhoria da qualidade de vida das populações em situação de vulnerabilidade social. (MCTIC, 2021) 
Para tanto, articula indiretamente o contexto das tecnologias sociais, ressaltando sua relevância e ampliando seu escopo numa macro visão que engloba o sentido das políticas públicas, planos e ações, e dos indicadores de sustentabilidade estabelecidos internacionalmente, relacionando ainda com outros conceitos-chave das ciências sociais e humanas.

Já o Instituto ITS aprofunda especificamente esse panorama, definindo as variáveis das tecnologias sociais conforme se segue:

\section{CONHECIMENTO, CIÊNCIA, TECNOLOGIA}

A TS tem como ponto de partida os problemas sociais; A TS é feita com organização e sistematização; A TS introduz ou gera inovação nas comunidades.

2. PARTICIPAÇÃO, CIDADANIA E DEMOCRACIA

A TS enfatiza a cidadania e a participação democrática; A TS adota a metodologia participativa nos processos de trabalho; A TS impulsiona sua disseminação e reaplicação.

3. EDUCAÇÃO

A TS realiza um processo pedagógico por inteiro; A TS se desenvolve num diálogo entre saberes populares e científicos; A TS é apropriada pelas comunidades, que ganham autonomia.

4. RELEVÂNCIA SOCIAL

A TS é eficaz na solução de problemas sociais; A TS tem sustentabilidade ambiental; A TS provoca a transformação social. (ITS, 2021)

Em terceiro plano, o Sebrae, 2017, em cartilha dedicada ao tema, vai classificar essas tecnologias enquanto produtos, processos, serviços, organizacionais e de gestão, traçando ainda as áreas prioritárias de desenvolvimento e evolução das tecnologias sociais, quais sejam, meio ambiente, educação, saúde, segurança alimentar, energia e acessibilidade; A partir daí, Perspectiva o processo de desenvolvimento de determinada tecnologia social.

Por fim, apenas trazemos para ressaltar, portanto, que "A Tecnologia Social compreende produtos, técnicas ou metodologias reaplicáveis, desenvolvidas na interação com a comunidade e que representem efetivas soluções de transformação social." (FBB, 2021) 
Desse modo, salienta-se que "As Tecnologias Sociais podem aliar saber popular, organização social e conhecimento técnico-científico. Importa essencialmente que sejam efetivas e reaplicáveis, propiciando desenvolvimento social em escala." (BB, 2021)

\section{MARCAS COLETIVAS}

Continuamente, a parte da articulação Direta entre agricultura familiar e desenvolvimento, que já foi identificada por diferentes autores aqui elencados e destacando-se recentemente Rodrigues e Kamimura (2021), seguindo-se o recorte do presente trabalho, abordaremos brevemente os principias pontos e concepções acerca das marcas coletivas.

As marcas coletivas geralmente são definidas como sinais para distinguir a origem geográfica, o material, o método de fabricação ou qualquer outra característica comum dos produtos ou serviços das diferentes empresas que os utilizam coletivamente. O titular pode ser uma associação de que essas empresas são parte ou qualquer outra entidade, incluindo uma instituição pública ou uma cooperativa (WIPO, 2021).

Dessa forma, é comum estudar as marcas coletivas em paralelo e comparação relativamente a outras demais figuras da propriedade intelectual, primordialmente e mais diretamente as marcas de Certificação e os Registros de indicação geográfica, gênero mais complexo de proteção; Percebe-se então desde já vantagens na obtenção de marcas coletivas para o fortalecimento de pequenos produtores rurais.

Complementarmente, CASTRO \& GIRALDI (2018) ainda abordam de forma didática as marcas setoriais, ressaltando o caráter coletivo e de compartilhamento que pode ser considerado até mesmo inerente ao direito marcário pois traduz a ideia de um diferencial a ser conferido ao produto, bem ou serviço, até enquanto estratégia de valore posicionamento no ^âmbito de determinado mercado; Pelo 
que esses esses autores trazem ainda a ideia de repartição de riscos entre os membros do Grupo associado/relaciona à marca coletiva:

- "A marca coletiva é um símbolo visual usado para proteger a atividade econômica de um grupo de produtores de uma determinada região, sendo registrada em nome de uma entidade coletiva como associação, cooperativa ou sindicato e não pode ser feita em nome de pessoa física. Quem utiliza a marca podem ser pessoas físicas ou jurídicas desde que vinculados como associados, cooperados ou sindicalizados."

- "A valorização do produto através da informação contida na marca coletiva baseia-se na relação de confiança entre produtor-consumidor, o que confere ao detentor da marca uma vantagem competitiva. Esta vantagem, no caso da marca coletiva, é ainda incrementada ao considerarmos que os custos e os riscos da implantação de uma marca própria no mercado são divididos pela coletividade. Os primeiros dez anos de vigência da marca deverão ser mais do que suficientes para saber se os esforços coletivos realmente valeram a pena em termos de desenvolvimento do negócio e do próprio local de origem do produto ou serviço."

- "É necessário que os produtores se organizem em associações para requerer o registro da marca coletiva junto ao INPI. O detalhamento de documentação para uma indicação geográfica é consideravelmente maior do que o necessário a uma marca coletiva, mas a marca coletiva deve ser renovada a cada dez anos, tal qual a marca individual, enquanto a indicação geográfica não precisa de renovação (Silva \& Peralta, 2011; Barbosa \& Regalado, 2013; E4, E5). A marca coletiva apresenta menos custos que o pedido de IG e não tem a necessidade da delimitação geográfica estudada e concedida pelo IBGE, o que economiza tempo e esforços. A documentação requerida também é mais prática que no caso de IG e o registro da marca não tem necessariamente que ter o nome geográfico."

- "A marca coletiva pode ainda auxiliar a coletividade, ajudando as pequenas empresas em um processo que individualmente seria oneroso, a promover 
seu posicionamento no mercado permitindo que pequenos produtores alcancem mercados onde, isoladamente, não conseguiriam. Pode também ser usada para indicar qualidade, tradição, respeito e algumas normas que os membros associados deverão cumprir. Divide os gastos de divulgação, facilita a entrada em novos mercados, estimula a organização de grupos produtores locais e valoriza a cultura local".

Em segundo lugar, do ponto de vista mais prático, segundo o Instituto Nacional da Propriedade Intelectual, competente para a concessão das marcas e ativos imateriais e intangíveis no país, deve-se também ter em mente a necessidade e elaboração de um Regulamento de utilização da marca coletiva para ser observado pelos agentes autorizados a lançarem mão de seu uso, com a respectiva descrição do Coletivo requerente, a forma de adesão `a marca por parte de agentes potenciais e interessados, as condições de utilização e ainda as eventuais sanções por descumprimento, irregularidade, desvio ou uso indevido da marca:

- "O pedido de registro de marca coletiva deve vir acompanhado do regulamento de utilização da marca, de acordo com o disposto no art. 147 da LPI e conforme a Instrução Normativa $n^{\circ}$ 19/2013. Caso o regulamento não acompanhe o pedido, este documento deve ser protocolizado no prazo de até 60 (sessenta) dias da data do depósito da referida marca, sob pena de arquivamento definitivo do pedido, em conformidade com o disposto no parágrafo único do mesmo artigo."

- O regulamento submetido pelo requerente deve conter os itens a seguir, sob pena de formulação de exigência para eventual correção ou clarificação: a) Descrição da entidade coletiva requerente, indicando sua qualificação, objeto, endereço, e pessoas físicas ou jurídicas autorizadas a representá-la; b) Condições para eventual desistência do pedido de registro ou renúncia ao registro da marca (parcial ou total), caso as mesmas não estejam previstas no contrato social, em observância ao art. 152 da LPI; c) Pessoas (físicas ou jurídicas) autorizadas a utilizar o sinal em exame, devendo ser descritos quaisquer requerimentos ou 
condições necessárias para a utilização do sinal; d) Condições de utilização do sinal, caso as mesmas existam. No caso de falta de detalhamento das condições de uso do sinal, entende-se que as condições aplicáveis se limitam ao estabelecido pelas normas legais; e) Sanções aplicáveis no caso de uso inapropriado do sinal, caso as mesmas existam. Se o requerente não detalhar a definição de uso inapropriado, este será entendido como o emprego da marca coletiva de forma contrária ao estabelecido pelas condições previstas no item "d". (INPI, 2021)"

Assim, devemos compreender ainda que as marcas coletivas envolvem uma reflexão interdisciplinar inevitável em relação à propriedade intelectual, adicionando justamente o caráter coletivo e potencializador do empreendimento coletivo e produtivo idealizado, abarcando até anotações e considerações relacionadas aos chamados EES - Empreendimentos econômicos solidários.

Além dos EES, o debate acerca das marcas coletivas, particularmente no âmbito da(s) chamada(s) Ruralidade(s) e da agricultura camponesa e familiar (HANZEN; PLEIN; COLTRE, 2020), alude a outras demais discussões "coletivas e dotadas de/com caráter ativo e eminentemente histórico, como já foi trazido no presente trabalho que explica e justifica a atual conformação agrária brasileira a partir dos acontecimentos coloniais históricos que Demarcaram e estruturaram nossa sociedade e território.

Dentre esses eventos coletivos, destacam-se os denominados Movimentos sociais, sobressaindo o intuito e "missão de participação integrada e integrativa na arena de ação/atuação social (NIEMEYER, 2007), e o teor resistência e luta contra-hegemonia do capital e exploração da maioria dos atores sociais (VIEIRA, s/a), valorizando-se as redes de apoio e cooperação através de incentivos mútuos coletivos no âmbito das Cooperativas, e respeitando-se a gestão coletiva da produção e da Marca respectiva por meio de instrumentos "burocráticos legítimos de organização e envolvimento de atores (BRITO; MATOS; PEDROZO; DA SILVA, 2020). 


\section{CONCLUSÕES}

As marcas coletivas estão enquadradas em fenômenos macro, pois relacionam-se com os aspectos físicos, econômicos, sociais e culturais de determinado meio e território, pelo que englobam ainda aspectos de competitividade, organização e gestão; e diferenciação, Especificação, qualificação, governança e desenvolvimento territoriais.

O desenvolvimento territorial pode ser definido como qualquer processo de mobilização dos atores que leva a estratégias de adaptação, com base em uma identificação coletiva no âmbito de determinada cultura e território; Já a Governança territorial é entendida como um processo de coordenação dos atores, Particularmente público, sobrelevando o viés institucional e promovendo construções geográficas e da territorialidade através da apropriação de recursos.

Segundamente, as marcas coletivas ainda conseguem promover os produtos e bens "referentes de forma única, através da "Agregação de valor e da articulação de redes de Coopetição, com a participação de diferentes instituições e organizações públicas, privadas, e interprofissionais e associativas.

Ademais, o presente estudo demonstrou o cenário ainda em desenvolvimento das marcas coletivas no Brasil, denotando ainda a sua desarticulação com o contexto do Cooperativismo, por exemplo, sendo justamente preciso que se incentive e se promova esses registros de propriedade intelectual, principalmente das marcas de caráter coletivo, pois estimulam o desenvolvimento de estratégias e competitividade gerando o posicionamento estratégico desses agentes "cooperativos existentes e integrantes do mercado (CARRARO, IMLAU, 2019), diversificando e fortalecendo a produção nacional.

Nesse sentido, estudos sobre as epistemologias da ação coletiva em função dos aspectos socioeconômicos e produtivos no enquadramento rural e agrícola poderão se conformar como perspectivas futuras de continuação da presente pesquisa. 
Ademais, reitera-se na presente finalização que a marca inclusive coletiva confere maior valor agregado aos produtos, pois oferece maior credibilidade aos mesmos junto aos agentes do mercado inclusive através da acessibilidade a novos nichos mercadológicos, ainda que possuam suas respectivas diferenciações quanto aos selos e marcas de certificação.

Além disso, o teor das marcas coletivas carrega consigo a possibilidade de maior promoção da sustentabilidade na produção, podendo ser adequadamente aplicada a diferentes realidades regionais brasileiras, valorizando as tradições comunitárias e locais de produção.

\section{REFERENCIAS}

ABRAMOVAY, Ricardo (1992). Paradigmas do Capitalismo Agrário em questão. São Paulo: Hucitec e Campinas: UNICAMP.

BENECKE, D. W. Coopera e desenvolvimento: o papel das cooperativas no processo de desenvolvimento econômico nos países de terceiro mundo. Recife: Assocene, 1980.

BRESSER-PEREIRA, Luiz Carlos (1986) Lucro, Acumulação e Crise. São Paulo: Editora Brasiliense, 1986.

BRITO; MATOS; PEDROZO; DA SILVA. Contexto cooperativo. BJD, vol 6, n. 10. 2020. Disponível em: https://www.brazilianjournals.com/index.php/BRJD/article/ view/19219/15422 . Acesso em: 19 out. 2021.

CANÇADO, A. C.; A. S. RIGO; J. R. PEREIRA; M. C. H. GONTIJO. (2012). Movimento e Princípios Cooperativistas: Evolução e Reflexões para Novos Estudos. In CANÇADO, A. C.; F. G. TENÓRIO; J. T. SILVA JR (orgs.). Gestão Social: aspectos teóricos e aplicações. Ijuí: UNIJUÍ, 2012a

CARRARO, W; IMLAU, J. Relações de ambiente, posicionamento estratégico e performance organizacional no cooperativismo do Rio grande do norte. BJD, vol 5, n. 1, 2019. Disponível em: https://www.brazilianjournals.com/index.php/BRJD/ article/view/4402/4130 . Acesso em: 24 out. 2021. 
CASTRO; GIRALDI. Estratégias de marcas para setores brasileiros. Revista espacios, vol. 39, n. 33, 2018. Disponível em: http://www.revistaespacios.com/ a18v39n33/18393308.html . Acesso em: 21 out. 2021.

FBB. Tecnologia social. Disponível em: https://fbb.org.br/pt-br/viva-voluntario/ conteudo/tecnologia-social . Acesso em: 09 nov. 2021.

INPI. Análise de pedidos de marcas coletivas. Disponível em: http://manualdemarcas.inpi.gov.br/projects/manual/wiki/5·14_Análise_de_pedidos_de_marca_coletiva. Acesso em: 15 out. 2021.

ITS. Tecnologia social. Disponível em: http://itsbrasil.org.br/conheca/tecnologia-social/ . Acesso em: 11 nov. 2021.

KOTLER, Phillip. Administração de Marketing: análise, planejamento, implementação e controle. 1998.

LAMARCHE, H. (1993). A agricultura familiar: uma realidade multiforme. Campinas: Editora da Unicamp.

MCTIC. Tecnologia social. Disponível em: https://antigo.mctic.gov.br/mctic/ opencms/ciencia/politica_nacional/_social/Tecnologia_Social.html . Acesso em: 12 nov. 2021.

NIEMEYER, C. Via campesina. Raízes, vol 26, n 1 e 2, 2007. Disponível em: http://raizes.revistas.ufcg.edu.br/index.php/raizes/article/view/275/257 . Acesso em: 23 out. 2021.

REGALADO et al. Marcas coletivas brasileiras. Disponível em: http://nbcgib. uesc.br/nit/ig/app/papers/0646282901133319.pdf . Acesso em: 22 out. 2021.

RODRIGUES, T; KAMIMURA, Q. Agroecologia e agricultura familiar através do desenvolvimento regional. BJD, vol 7, n. 3, 2021. Disponível em: https://www. brazilianjournals.com/index.php/BRJD/article/view/27196/21487 . Acesso em: 25 out. 2021.

SAVIAN, M. Juventude rural e sucessão geracional na agricultura familiar. BJD, vol 7, n. 3, 2021. Disponível em: https://www.brazilianjournals.com/index.php/ 
BRJD/article/view/27022/21374 . Acesso em: 18 out. 2021.

SCHNEIDER, J. O. Democracia, participação e autonomia cooperativa. 2. ed. São Leopoldo: UNISINOS, 1999. 496 p.

SEBRAE. Tecnologias sociais. Disponível em: http://sustentabilidade.sebrae. com.br/Sustentabilidade/Para\%20sua\%20empresa/Publicações/Tecnologias-Sociais-final.pdf . Acesso em: 10 nov. 2021.

SGUAREZI et al. Incubação de EES e a cultura da solidariedade. BJD, vol 6, $\mathbf{n}$. 7, 2020. Disponível em: https://www.brazilianjournals.com/index.php/BRJD/article/view/12576/10646. Acesso em:

THESING, N. J. Por um mundo melhor: cooperação e desenvolvimento. Porto Alegre: Buqui, 2015.

VIEIRA, F. Via campesina. Disponível em: http://www.uel.br/grupo-pesquisa/gepal/terceirosimposio/flaviabraga.pdf . Acesso em: 28 out. 2021. 


\section{dol 10.48209/978-65-89949-D0-1}

\section{CAPITULLO 19}

\section{APONTAMENTOS INTERDISCIPLINARES E JURIDICOS SOBRE A EDUCAÇAO NO CAMPO}

Giovanna Martins Sampaio Hermes Oliveira 


\section{INTRODUÇAO}

O presente trabalho detém como objetivo principal traçar alguns dos principais pontos que compõem o panorama da educação no/do campo, trazendo definições e metodologias específicas, bem como seu contexto regulatório e das políticas públicas correlatas, sob o enfoque do direito e suas imbricações, correlações tangentes ao Estado, Economia e Sociedade.

A metodologia aplicada neste artigo, segundo a forma de abordagem do problema, foi primordialmente do tipo qualitativa, posto que a representação quantitativa não se conformou no foco e sentido deste trabalho. Segundo o objetivo da pesquisa, a sua metodologia foi do tipo exploratória e descritiva. A pesquisa descritiva visa descrever as características dos fatos e dos fenômenos e o estabelecimento das relações entre as variáveis consideradas". Gil (2010, p. 42) traz que, "as pesquisas descritivas identificam as características de determinada população ou fenômeno". A pesquisa exploratória visa promover uma aproximação com o objeto de estudo. Também conforme o mesmo autor, "a pesquisa exploratória visa proporcionar maior familiaridade com o problema, com vistas a torná-lo mais explícito ou a constituir hipóteses, sendo isso feito ao longo do trabalho".

Segundo a coleta de dados, a pesquisa foi do tipo bibliográfica e sistemática, na qual foi realizada a busca de trabalhos relacionados à temática da educação no/do campo e das políticas públicas, a fim de demonstrar a riqueza e multidisciplinariedade inerentes e necessárias para se avaliar as questões sociais relativas `a educação no/do campo.

Para tanto, foi realizado um levantamento crítico relacionado aos principais trabalhos que trouxeram o mais direto possível a correlação entre os respectivos fatores e variáveis.

Portanto, foi investigado o estado da técnica existente sobre o tema no que se refere ao referencial teórico de discussão. Ademais, quanto aos métodos 
potenciais e relacionados ao presente trabalho, tem-se o emprego de sistemas de inteligência em relação à busca dessa revisão de literatura ora empregada. Ainda, abarca-se também a utilização de estratégias de pesquisa relacionadas a roadMapping, bem como que o emprego de cenários para a obtenção de resultados mais satisfatórios e apropriados ao objetivo deste estudo.

Ultimamente, foi feita uma espécie de prospecção para a definição do tema/recorte (e justificativa), e primordialmente como filtragem dos trabalhos que comporiam o referencial teórico do presente artigo. Por fim, foram considerados também dados obtidos de livros, dissertações, artigos publicados em revistas e periódicos indexados, bem como demais materiais disponíveis online na internet e em formato digital.

\section{DESENVOLVIMENTO: PEDAGOGIA DO MOVIMENTO}

Caldart apresenta um verbete introdutório à temática pedagógica crítica, abordando a articulação com os movimentos sociais e MST bem como seu conceito e categoria específicos, e a base material e o sentido dialético tangentes `a pedagogia do movimento, a partir da questão originária: entender como se dá a constituição do ser humano, como ser social e histórico, processo que tem exatamente no movimento - historicidade um dos seus componentes essenciais.

Complementa-se, assim, que a associação da teoria e prática/práxis pedagógicas para a formação humana na educação no/do campo consiste num processo em constante "motricidade, aludindo aos ideais marxistas/socialistas, crítico-dialéticos, e elevando o trabalho, a luta social, a organização coletiva e a cultura e história às categorias-chave do ensino campesino:

- "A Pedagogia do Movimento afirma os movimentos sociais como um lugar, ou um modo específico, de formação de sujeitos sociais coletivos que pode ser compreendida como um processo intensivo e historicamente determinado de formação humana. Ela também afirma que essa compreensão nos ajuda a pensar e a fazer a educação dos sujeitos da transformação das relações sociais, que produzem, na atualidade e contraditoriamente, organizações de trabalhadores como o MST" 
- "Esta é a Pedagogia do Movimento Sem Terra, cujo sujeito educador principal é o próprio movimento, não apenas quando trabalha no campo específico da educação, mas fundamentalmente quando sua dinâmica de luta e de organização intencionaliza um projeto de formação humana."

- "No diálogo com a teoria pedagógica e social, trata-se de tomar posição diante do embate de tradições distintas de pensar e de fazer a formação humana. A Pedagogia do Movimento recupera, reafirma e, ao mesmo tempo, continua, desde uma realidade específica, com seus sujeitos particulares e em um tempo histórico determinado, a construção teórico-prática de uma concepção de educação de base materialista, histórica e dialética. É herdeira da filosofia da práxis como concepção que radicaliza a ideia do ser humano (ser social e histórico) como produto de si mesmo: ao mesmo tempo produto e sujeito da história, formado pela sociedade e construtor da sociedade - sujeito de práxis." (CALDART, 2009)

Dessa forma, são estabelecidas as relações necessárias e de "herança" com a pedagogia socialista e do capital, associando o debate com a ideologia da conscientização e emancipação do oprimido proposta por Freire (apud ECCO; NOGARO, 2015), conceituando-se o panorama das lutas sociais no "enquadramento" do indivíduo social, ou seja, aquele que "reintegra" a sociabilidade à individualidade na construção identitária e na reivindicação pelos seus direitos básicos, pautando-se na eminente fraternidade existente nas comunidades campesinas:

- "Lutas sociais são enfrentamentos organizados, portanto coletivos, de determinadas situações sociais, na defesa de interesses também coletivos, feitos, de forma massiva, pelas próprias pessoas envolvidas na situação". (ECCO; NOGARO, 2015)

- "Um sujeito social coletivo se refere à associação de pessoas que passam a ter uma identidade de ação na sociedade, e, portanto, de formação e organização em vista de interesses comuns e de um projeto coletivo." CALDART, 2009)

Ademais, trazemos ainda de forma comparativa as matrizes do ensino e educação, traduzindo o agir e a ação, o trabalho e a práxis enquanto princípios educativos, constitutivos e norteadores da formação campesina:

- "Matrizes formadoras e matrizes pedagógicas estão sendo usadas aqui como sinônimos que se referem a atividades ou situações do agir humano que são essencialmente formadoras ou conformadoras do ser hu- 
mano, no sentido de constituir determinados traços que não existiriam sem a atuação dessa matriz, desse agir. Podem ser associadas à ideia de "princípio educativo" quando esta expressão é usada para indicar o que seria uma matriz originária da constituição do ser humano. Assim se compreende a afirmação do trabalho como princípio educativo: ele é a base de constituição da práxis, como totalidade formadora do ser humano." (CALDART, 2009)

Por fim, aborda-se o desafio "metodológico" da condução da educação no/ do campo, considerando as especificidades e particularidades do meio campesino que traduzem a necessidade de manutenção dos chamados vínculos orgânicos entre o ambiente, a comunidade e o sujeito/indivíduo político-social:

- "O desafio aos educadores de escola é também o de buscar compreender os processos de formação humana que acontecem fora dela, compondo um método de condução pedagógica dos processos escolares mais próximo da complexidade da vida da formação humana. Este processo é facilitado quando a escola estabelece algum tipo de vínculo orgânico com outros lugares de formação de sujeitos sociais coletivos, e quando os próprios movimentos sociais ocupam a escola e dela se ocupam, incluindo a formação das novas gerações em sua práxis política e pedagógica." (CALDART, 2009)

\section{DESENVOLVIMENTO: ASPECTOS JURIDICOS DA EDUCAÇAO DO/NO CAMPO}

A partir das reflexões indicadas por Rodrigues \& Bonfim (2017), problematiza-se quais seriam as leis que asseguram a educação do/no campo com qualidade no contexto brasileiro.

Assim, enfoca-se inexoravelmente no público-alvo dessa educação em específico a partir da definição das populações do/no campo constante no decreto legislativo de 2010, trazendo o caráter inclusivo e "independente" da educação do/no campo e diferenciando-a da educação rural.

Dessa maneira, também se tangencia os direitos presentes na Constituição Federal de 1988, destacando a axiologia do princípio da equidade de acesso e permanência na escola entre os ambientes urbano e campesino. 
A partir de então, é preciso comentar sobre a Lei de diretrizes e bases, sobre a política de educação no/do campo e o Pronera de 2010, enquanto políticas públicas transversais e "multissetoriais", trazendo assim discussões e premissas sobre a relação do trabalho e ensino no/do campo, a sua organização escolar própria, as condições de vida e transporte dessas populações, o calendário junto aos ciclos produtivos e climáticos, as metodologias "ativas" adequadas a este contexto, as ações e os projetos políticos aliados às práticas pedagógicas na educação campesina, a valorização das identidades e o fortalecimento dos diálogos entre os atores, bem como as relações com os movimentos sociais e sociedade civil, dentre outras variáveis.

Neste diapasão, os autores acima já mencionados destacam ultimamente o teor dos objetivos e funções da educação no/do campo:

- "A educação do campo surge como forma de garantir melhores condições de vida para a população camponesa através da educação, bem como pretende garantir que o homem do campo permaneça no meio rural não precisando migrar para a cidade em busca de melhores condições de vida e novas oportunidades. Isso significa possibilitar que as crianças e jovens do campo continuem no meio rural e valorize sua cultura e suas tradições sem se sentir insignificante com relação aos que vivem no meio urbano. Denota-se que a Educação do Campo é garantida por meio de leis específicas que determinam que as práticas educacionais devam atender as necessidades e interesses da população camponesa, possibilitando a essa parcela da população uma educação com uma maior qualidade educacional. Bem como conteúdos e metodologias que estejam apropriadas às reais necessidades e interesses dos educandos das zonas rurais." (RODRIGUES; BONFIM, 2017)

Assim, percebe-se a perspectiva do empoderamento dos sujeitos campesinos tangente à educação no/do campo, a partir do ensino qualificado e apropriado aos interesses dessas comunidades.

\section{DESENVOLVIMENTO: POLÍTICAS PUBLICAS}

Molina (2015) traz um recorte em seus estudos que especificamente articula as Políticas públicas ao cenário da educação no/do campo, ressaltando a perspectiva social a partir da investigação da centralidade da categoria e con- 
ceito das políticas públicas no movimento histórico de construção da Educação do/no Campo, constando essa definição na tríade estruturante campo-políticas públicas-educação.

Desse modo, a autora traça o histórico da educação campesina, a partir das categorias conceituais fundamentais quais sejam os direitos, o Estado, os movimentos e a democracia; pelo que traz o aporte teórico de Marilena Chauí e Carvalho, senão vejamos:

- "As políticas sociais constituem um espaço privilegiado de atuação política no (re)desenho do Estado, estabelecendo o vínculo necessário entre conflitos/demandas por direitos e busca de alternativas de emancipação. Sob esse prisma, os movimentos sociais pela definição e implementação de políticas públicas, com suas múltiplas expressões, articulando novas e tradicionais estratégias, constituem-se vias abertas, no confronto com a lógica do capital mundializado". (CARVALHO, 2008, p. 25 apud MOLINA, 2015)

- "A democracia é a única forma política que considera o conflito legal e legítimo, permitindo que seja trabalhado politicamente pela própria sociedade. Significa que os cidadãos são sujeitos de direitos, e que onde eles não estejam garantidos, tem-se o dever de lutar por eles e exigi-los [...]. A mera declaração do direito à igualdade não faz existir os iguais, mas abre o campo para a criação da igualdade através das exigências e demandas dos sujeitos sociais. Em outras palavras: declarado o direito à igualdade, a sociedade pode instituir formas de reivindicação para criá-lo como direito real." (Chauí, 2003, p. 344 apud MOLINA, 2015)

Portanto, Molina vai traduzir principalmente o protagonismo dos movimento sociais no ensino campesino, trazendo ainda a discussão acerca da ideia de igualdade e do papel do Estado democrático de direito, complementando ainda com o referencial gramschiano sobre o teor emancipatório, político e até cultural do ensino e da formação "educativa, sendo preciso recuperar a compreensão de indissociabilidade entre política e cultura possibilitando melhor entendimento acerca da importância da conscientização dessas populações para seu re/união, seu "acúmulo de forças" que potencializa a conquista e o "atingimento das políticas e direitos sociais. 
Assim, Molina (2015) vai finalmente articular a ideia de direito e constitucionalidade que deve conformar a educação no/do campo para assegurar sua função de conscientização política, que é eminentemente histórica-crítica-dialética, abordando ainda as características essenciais das Políticas públicas, com o enfoque particular nas relações de especificidade e universalidade, por exemplo:

- "Se a universalidade se coloca como a principal característica da ideia de direito, a regulamentação jurídica formal, por sua vez, por causa das desigualdades resultantes das contradições fundamentais da sociedade do capital não garante por si só o acesso de fato a esses direitos. A luta por direitos, portanto, é inerente à sociedade do capital e faz a desigualdade no acesso aos direitos transformar-se em fundamento para a demanda por reconhecimento das especificidades históricas que constituem esses sujeitos de direito." (MOLINA, 2015)

\section{CONSIDERAÇOES FINAIS}

A educação no/do campo possui extrema relevância pois enfoca numa perspectiva menos "inferiorizadora" dos sujeitos educandos, tentando atender às demandas/lutas/resistências e "sentidos" mais particulares das comunidades e populações agrícolas e camponesas, pelo que sua trajetória no Brasil detém uma carga eminentemente histórica considerando o paradigma da questão agrária na sociedade brasileira.

Dessa forma, a educação no/do campo possui um caráter sui generis pois não está reduzida à educação rural nem se "afiniza" com as "concepções" de larga escala do agronegócio, detendo atualmente relações imbricadas com esferas abrangentes e multidisciplinares que contemplam a agroecologia, desenvolvimento e sustentabilidade, e meio ambiente, bem como a cidadania, a gestão democrática e comum dos bens coletivos, e a denominada ideologia da fraternidade, considerando esses aspectos e elementos componentes enquanto princípios norteadores da formação ofertada através dessa educação, com seus modos e práticas particulares. 
Neste esteio, a educação no/do campo estrutura-se numa base comunitária e política, e na valorização e desenvolvimento do meio rural, permeando especificamente seus preceitos educativos, abarcando também a diversidade, as relações e padrões de poder, e as intersecções socioterritoriais e dimensões geográficas que são componentes da questão da terra no Brasil.

Considerando o "sentido amplamente autônomo" da educação do/no campo, articula-se o viés prioritariamente emancipador dessas premissas educativas "para e pelo" povo campesino, explicando-se a evolução no entendimento acerca das práticas da educação no/do campo.

Nesse sentido, a educação campesina conforma uma nova pedagogia e engloba hoje os chamados conhecimentos tradicionais relativos ao saber-fazer, à cultura, aos hábitos, à herança e à identidade dos povos do/no campo e famílias agrícolas, nas suas relações de "ancestralidade" entre gerações que com/vivem em determinado meio.

Assim, o ensino no/do campo envolve a discussão acerca dos movimentos sociais e coletivos, bem como os assentamentos rurais, aproximando alguns fatores essenciais à educação "integral”, quais sejam, a família, a terra e o trabalho, pois visa ofertar às comunidades uma capacitação e formação mais empírica e "proativa", engajada e eminentemente ausubeliana, ou seja, significativa para os indivíduos, seguir primordialmente o que se chama de pedagogia da alternância. Portanto, a educação campesina proporciona a "conscientização das massas" empregando análises histórico-críticas e dialéticas da formação educativa.

A aprendizagem significante ou significativa de Ausubel é considerada o processo por meio do qual uma nova informação relaciona-se com um aspecto especificamente relevante da estrutura do conhecimento do indivíduo, estando ancorada em proposição relevantes e preexistentes daquele aprendiz.

Para tanto, a sua teoria define os chamados organizadores prévios enquanto as âncoras da nova aprendizagem, levando ao desenvolvimento dos conceitos 
para apreensão e "estruturação do saber. Assim, esses organizadores conformam-se em verdadeiras estratégias de manipulação da estrutura cognitiva para o conhecer, pois são materiais introdutórios anteriores àquelas informações que serão aprendidas. Ademais, essas variávaies/fatores funcionarão como ponte-interligação entre o que já se conhece e o que se deve conhecer, constituindo o que se pode chamar de Pontes Cognitivas.

O próximo passo para detalhar a aprendizagem significativa seria considerar o material potencialmente significativo: aquele que pode ser relacionável ou incorporável à estrutura cognitiva do aprendiz, não sendo arbitrário ou literal, e sim disponível através dos meios adequados de apreensão do saber. Dessa forma, existe uma relação de dependência com os objetivos do aprendiz em não memorizar ou decorar mecanicamente os conteúdos relevantes mediados pelos organizadores prévios.

Por fim, configura-se a etapa da assimilação através do ordenamento cognitivo, considerando-se esses fenômenos enquanto processos posteriores que ocorrem/acontecem quando já se tem/possui um conjunto adequado de conceitos formados (que previamente envolveram abstrações e generalizações). Nesse sentido, esta etapa final de apreensão envolve esse processo de assimilar, tornar semelhante ou partilhar de certa similitude com o que já se conhece, sendo a assimilação entendida em paralelo aos fenômenos de diferenciação progressiva e reconciliação integrativa que formam o constructo da bagagem cognitiva de determinado agente baseada na inclusão dos conteúdos, que resulta num produto interacional modificado e expõe/demonstra o papel e importância da imersão no meio social do sujeito.

Pois permite a criação de um caminho cognitivo relevante para aquele indivíduo, que após ser gradativamente apreendido, vai sendo justamente moldado e modificado a partir da relação e conexão com demais atores em rede, que atribuem e estabelecem "significados específicos ao saber/conhecimento em meio 
ao contexto de "polissemias e multilinguismos referente ao grupo social.

Desse modo, é perceptível que a educação campesina rechaça propostas pedagógicas majoritariamente dogmáticas e que estejam desvinculadas do desenvolvimento rural aliado ao empoderamento dessas comunidades": o planejamento pedagógico, e a proposta curricular e de avaliação devem estar adequados à realidade campesina, pelo que é necessário transformar o conhecimento comum, regular, disciplinarizado e isolado, dando-lhe um novo sentido prático, visando ultimamente a utilidade e finalidade teleológicas" dos ensinamentos da escola para esses sujeitos e para a sua comunidade.

Destarte, finalmente, o ensino "campesino" possui bases institucionalizadas e formais no Brasil, estando "regulamentado" por diferentes documentos como a Base curricular, e a política da educação do/no campo e o Pronera, abarcando e invocando ainda a implementação de outras políticas públicas para assegurar e priorizar direitos e "espaço" na agenda pública em prol dessas populações campesinas.

\section{REFERENCIAS}

CALDART, R. Educação do Campo: notas para uma análise de percurso. Revista Trab, Educ, Saúde, vol. 7, n 1, 2009. Disponível em: https://www.scielo.br/j/tes/a/ z6LjzpG6H8ghXxbGtMsYG3f/?format=pdf\&lang=pt . Acesso em: 15 nov. 2021.

ECCO; NOGARO. A educação em Paulo Freire como processo de humanização. Disponível em: https://educere.bruc.com.br/arquivo/pdf2015/18184_7792. pdf . Acesso em: 17 nov. 2021.

KLAUSEN. Aprendizagem significativa: um desafio. Disponível em: https:// educere.bruc.com.br/arquivo/pdf2017/25702_12706.pdf . Acesso em: 17 nov. 2021.

MOLINA. A educação do campo e o enfrentamento das tendências das atuais políticas públicas. Revista educação em perspectiva, vol. 6, n 2, 2015. Disponível em: https://periodicos.ufv.br/educacaoemperspectiva/article/view/6809/2772 . Acesso em: 12 nov. 2021. 
RIBEIRO. A educação no campo e a valorização do meio rural como espaço de aprendizagem. Disponível em: https://acervodigital.ufpr.br/bitstream/ handle/1884/50264/R\%20-\%20E\%20-\%20\%20GESSICA\%20RAMOS\%20 LUCAS\%20RIBEIRO.pdf?sequence=1. Acesso em: 13 nov. 2021.

RODRIGUES; BONFIM. A educação do campo e seus aspectos legais. Disponível em: https://educere.bruc.com.br/arquivo/pdf2017/25287_12546.pdf . Acesso em: 16 nov. 2021.

SOUZA. Educação do campo: políticas, práticas pedagógicas e produção científica. Revista Educ. Soc, vol. 29, n 105, 2008. Disponível em: https://www.scielo. br/j/es/a/6S89N7H4cTJRZTbnvykF5rt/?lang=pt\&format=pdf . Acesso em: 14 nov. 2021. 
dol 10.48209/978-65-89949-D2-A

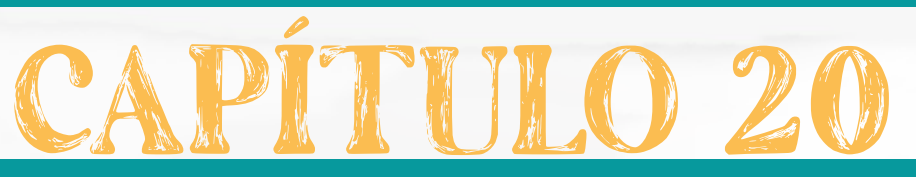

\section{A TATUAGEM E} A PROPRIEDADE INTELECTUAT: ANÁLISE DA LEI DE DIREITO AUTORAL E O DIREITODA
PERSONAIIDADE

Alanna Rodrigues Santana Giovanna Martins Sampaio 
Resumo: O presente artigo tem como objetivo realizar uma análise da tatuagem no âmbito da Propriedade Intelectual, delineando sua trajetória social no intuito de auxiliar a compreensão dos dilemas que circundam este ramo. Para tanto, foi realizado um estudo da lei de Direito Autoral para identificar a proteção jurídica com relação aos tatuadores, também, fez-se necessário analisar aspectos do Código Civil relacionado ao Direito de Personalidade.

Palavras-chave: Tatuagem. Propriedade Intelectual. Direito Autoral. Direito da Personalidade.

Abstract: This article aims to perform an analysis of tattoos within the Intellectual Property field, outlining their social trajectory to Understanding the dilemmas surrounding these phenomena. A study of copyright law was carried out to identify legal protection in relation to tattoo artists. It was also necessary to analyze aspects of the Brazilian Civil Code related to Personality rights.

Keywords: Tattoo. Intellectual property. Copyright. Right of Personality.

\section{INTRODUÇÃ̃O}

A prática de marcar o corpo não é algo recente, em 1991 foi descoberto o registro mais longínquo de uma tatuagem no cadáver de um homem da Idade do Cobre, datado de 5.300 anos antes de Cristo. Os cientistas encontraram em seu corpo, linhas na região das costas, tornozelos, punhos, joelhos e pés. Presume-se que os desenhos tenham sido criados a partir do atrito do carvão em cortes feitos na pele ${ }^{1}$.

Ainda, de acordo com a pesquisa realizada pelo National Geographic, muIheres que dançavam nos funerais egípcios acerca de 2000 anos antes de Cristo tinham desenhos abstratos de traços e pontos. Posteriormente, constatou-se também o surgimento de desenhos no corpo que representavam "Bes", a deusa egípcia da fertilidade e da proteção dos lares.

$1 \quad$ Matéria do jornalista James Owen para o National Geographic (nationalgeographicbrasil.com). 
No período entre 509 a.C. e 27 a.C., em Roma, os desenhos marcados na pele adquiriram outros significados, assumindo diversas utilidades, as quais englobavam cultos religiosos, separação de grupos sociais, camuflagem e até mesmo a marcação de prisioneiros e escravos ${ }^{1}$.

Silvana Jeha, autora do livro "uma história da tatuagem no Brasil" narra a introdução da nomenclatura "tatuagem", vejamos:

"a palavra tatuagem deriva de tattow, registrada pela primeira vez na década de 1780 no relato de viagem do capitão inglês James Cook. Tattow tem origem do termo taitiano tatau. Os taitianos, como quase todos os povos, marcavam a pele com objetos cortantes e/ou pigmentos."

"Por algum acaso, a palavra taitiana passou, ao longo do século XIX, a nomear uma prática de marcar a pele que já existia com outros nomes no Ocidente e em vários lugares do mundo."

Com o decorrer do tempo, marinheiros, presidiários, roqueiros e jovens rebeldes dos anos 1970 atribuíram diversos sentidos coletivos e individuais ao ato de tatuar o corpo. Após a invenção da máquina de tatuagem elétrica, em 1891³, o trabalho se propagou ainda mais pela Europa e pelos EUA, até alcançar um status de individualidade, demonstração de afeto, pertencimento, estética ou quaisquer outros significados que o indivíduo prefira.

No Brasil, a tatuagem expressa a tradição das tribos indígenas, a exemplo dos Bororos, que ainda utilizam a pintura do corpo como forma de distinção entre os clãs e as faixas etárias; os Yanomamis que desenham o corpo para expressar certos estados de espírito, como alegria e agressividade e as tribos Kadiwéu e Tirió que são facilmente identificadas pelos finos desenhos ou tatuagens que decoram o rosto das mulheres ${ }^{4}$.

$1 \quad$ Matéria da jornalista Ana Luiza Cordeiro para o site minutosaudavel.com.br.

2 Silvana Jeha, Uma história da tatuagem no Brasil, São Paulo: Editora Veneta, 2019, p. 14.

3 O americano Samuel F. O'Reilly inventou a primeira máquina de tatuagem, fazendo com que a máquina oscilasse eletromagneticamente e permitindo que a máquina movimentasse agulha. A invenção foi uma adaptação de uma caneta elétrica patenteada por Thomas Edison em 1876.

4 Anderson Schreiber, Direitos da Personalidade, São Paulo: Editora Atlas, 2011, p. 35. 
O primeiro tatuador registrado no Brasil, em 1959, foi o dinamarquês Knud Harald Lucky Gegersen¹. Seu estúdio ficava na zona boêmia de Santos, os principais clientes eram marinheiros e, na porta do estabelecimento, havia os dizeres “It's not a saylor if he hasn't a tattoo.", ou seja, "Você não é um marinheiro se não tiver uma tatuagem".Silvana Jeha, afirma: "Podemos considerar Knud o antes e depois da história da tatuagem no país". Declara ainda, que a restrição da tatuagem em camadas populares e marginalizadas durou até os anos 1980, após este período, a tatuagem difundiu-se para todas as classes sociais e em quase todo o mundo. ${ }^{2}$

A tatuagem também é uma forma do ser humano traçar a sua percepção do mundo, permitindo o registro de sua história de vida. Neste sentido, o tatuador baiano Robson Caldas, conhecido como Finho, criou o projeto "Pele preta tatuada" com obras autorais, muitas baseadas na história do povo preto:

\section{Imagem 1. Tatuagem, Robson Caldas.}

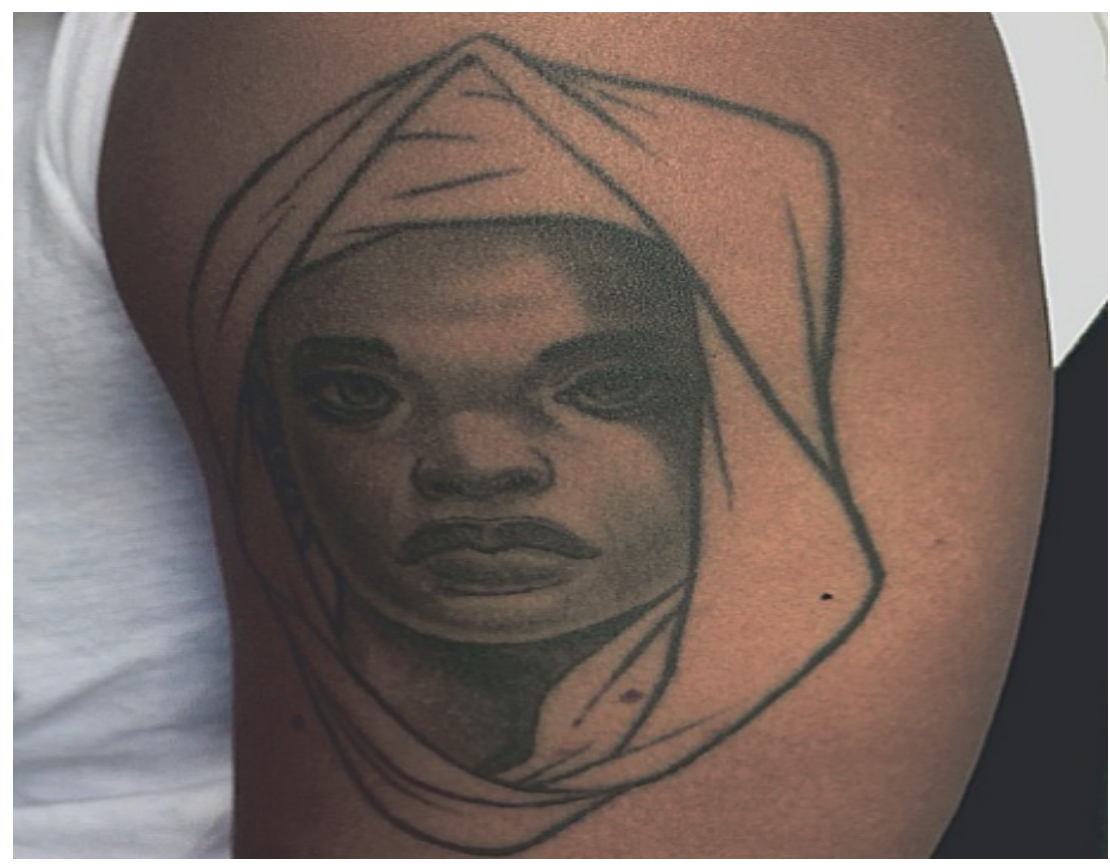

Fonte: reprodução do instagram @estudioretinto, 2020.

$1 \quad$ O tatuador morreu em 1983, aos 55 anos, deixando um legado de 45 mil pessoas tatuadas. Hoje, o Dia Nacional do Tatuador, comemorado em 20 de junho, é em sua homenagem, marcando o dia em que chegou ao Brasil.

2 Silvana Jeha, Uma história da tatuagem no Brasil, São Paulo: Editora Veneta, 2019, p. 18. 
"A gente via sempre modelos naquele padrão caucasiano [branco], tinha toda uma gama de origens diferentes, como a nórdica, oriental, europeia, mas você não via a África sendo representada ali. Raramente algum símbolo, normalmente um adinkra [conjunto de símbolos da África Ocidental]. Minha ideia foi trazer personagens que eram parecidos comigo". 1

A percepção do ato de fazer uma tatuagem se modificou ao longo dos anos e isto extrapola o âmbito meramente artístico, necessitando um olhar para os aspectos jurídicos de proteção ao indivíduo que tatua o seu corpo ${ }^{2}$ e o profissional que realiza o trabalho, tendo em vista que hoje em dia é um ramo que também movimenta a economia dos países.

\section{DESENVOLVIMENTO}

\section{A tatuagem e a Lei de Direito Autoral}

O debate sobre a proteção por direitos autorais das tatuagens é um tema que está no cenário recente de discussão, principalmente em razão da veiculação na mídia de alguns litígios internacionais nas quais figuram como partes, tatuadores e desenvolvedores de jogos eletrônicos, em razão da reprodução de tatuagens realizadas em atletas ${ }^{3}$. No Brasil, há um precedente da Turma Recursal do Rio Grande do Sul envolvendo duas pessoas tatuadas. Uma das partes acusa a outra de ter copiado a sua tatuagem e invocou o direito de autor. ${ }^{4}$

$1 \quad$ Entrevista concedida ao site g1.globo.com/ba em 19 jul. 2019.

2 A tese de repercussão geral do STF, proferida pelo Ministro Luiz Fux (RE 898450), à qual dispõe: "Constitucionalidade da proibição, contida em edital de concurso público, de ingresso em cargo, emprego ou função pública para candidatos que tenham certos tipos de tatuagem em seu corpo", é um exemplo de proteção jurídica à pessoa que faz tatuagem.

3 Daniela Colla, Direito Autoral à flor da pele? Pode o Tatuador ser responsabilizado pela reprodução desautorizada? 2019. Disponível em: https://www.jota.info/opiniao-e-analise/artigos/tatuagem-direito-autoral-a-flor-da-pele-03082019. Acesso em: 03 dez. 2020.

4 Recurso Inominado. Ação de Indenização por danos morais. Ofensas oriundas da realização de tatuagens semelhantes entre ex-colegas de estágio. Ausência de prova de que a ré detinha direito exclusivo à estampa de fl.18. Conduta da ré que expôs a imagem da autora, acompanhada de textos na rede social, com intuito de ofender e atacar. Contexto probatório que conduz à existência dos requisitos para conceder indenização por dano moral. Quantum fixado em $\mathrm{R} \$ 4.000,00$, adequado ao caso. Aplicação do Princípio da Imediatidade. TJ/ RS - Recurso Cível: 71005816228 RS, Relator: Glaucia Dipp Dreher, Data de Julgamento: 26/02/2016, Quarta Turma Recursal Cível, Data de Publicação: Diário da Justiça do dia $3 / 3 / 2016$. 
Sob a perspectiva da legislação brasileira atinente ao direito de autor, lei $n^{\circ}$ 9.610/1998, a primeira análise a ser feita com relação às obras de tatuagem, é identificar se a pele pode ser considerada como suporte. A lei autoral define como obras protegidas, de acordo com o seu artigo $7^{\circ}$ :

"Artigo $7^{\circ}$ São obras intelectuais protegidas as criações do espírito, expressas por qualquer meio ou fixadas em qualquer suporte, tangível ou intangível, conhecido ou que se invente no futuro".

Desta forma, a pele pode estar caracterizada no conceito de suporte tangível, adentrando em outro aspecto de discussão: "o direito do autor à integridade da obra versus direito de propriedade do possuidor do suporte material" 1 . A modificação ou destruição de uma obra de arte plástica poderá trazer consequências jurídicas tendo em vista a proteção ao direito moral do autor. Com relação à tatuagem, a integridade da obra entra na seara do Direito de Personalidade, entrando em conflito com o artigo 77 da Lei de Direito Autoral:

"Artigo 77. Salvo convenção em contrário, o autor de obra de arte plástica, ao alienar o objeto em que ela se materializa, transmite o direito de expô-la, mas não transmite ao adquirente o direito de reproduzi-la."

As tatuagens reproduzidas dos esportistas nos jogos eletrônicos foram fruto de autorização de reprodução da imagem destas pessoas, ou seja, nestes casos, não há como separar a imagem da obra, não haveria cópia fidedigna dos personagens dos jogos sem as suas respectivas tatuagens.

Com relação à criação da tatuagem, esta pode ser uma obra original do tatuador, também, poderá ser elaborada em coautoria com a pessoa que será tatuada ou ainda, apenas uma criação desta e por fim, poderá ser uma criação de terceiro. Neste último caso, haverá necessidade de autorização para utilizar a obra, situação que, na prática, geralmente não ocorre² .

1 Rodrigo Moraes, Os direitos morais do autor, Rio de Janeiro: Editora Lumen Juris, 2008, p. 149.

2 Daniela Colla, Direito Autoral à flor da pele? Pode o Tatuador ser responsabilizado pela reprodução desautorizada? 2019. Disponível em: https://www.jota.info/opiniao-e-analise/artigos/tatuagem-direito-autoral-a-flor-da-pele-03082019. Acesso em: 03 dez. 2020. 
Quando a tatuagem é feita a partir da repetição de desenhos existentes, não há que se falar em direito de autor, pois a simples execução da técnica não gera autoria, pois não há esforço intelectual, apenas físico. Da mesma forma, aquele que paga para ter seu corpo tatuado não será autor da obra pelo simples fato de estar contratando o serviço. ${ }^{1}$

Assim, o debate não abarca todas as tatuagens, apenas aquelas compreendidas como obras intelectuais, decorrentes da criação de espírito do tatuador, em conformidade com a Lei de Direito Autoral e a Convenção de Berna² ${ }^{2}$ da qual o Brasil é signatário.

\section{Direito da Personalidade}

Importante destacar a dualidade do direito da personalidade quando tratamos da tatuagem, de um lado figura o direito da personalidade do tatuador, criador da obra, como bem define o autoralista Rodrigo Moraes:

"Criador e criação estão imbricados de modo absoluto. Não podem ser dissociados. Essa íntima fusão significa que não se pode separar o autor de sua obra. Esse elo inquebrantável, indissolúvel, que consiste no principal fundamento do direito moral, visa a proteger tanto a personalidade do homem-criador como a obra em si mesma."

Em outro polo, além do direito da personalidade do criador da obra, é necessária a análise do direito personalíssimo do tatuado sobre o seu próprio corpo e sua imagem, em conformidade com os dispositivos do Código Civil Brasileiro.

O trabalho de David Allen ${ }^{4}$, "um tatuador que transformou o corpo de pacientes mastectomizadas em obras de arte"5:

$1 \quad$ Luciano Andrade Pinheiro e Carolina Diniz Panzolini, Direito autoral e a tatuagem. 2016. Disponível em: https://www.migalhas.com.br/PI/99,MI248245,51045-Direito+Autoral+e+a+tatuagem. Acesso em: 05 nov. 2021.

2 A Convenção de Berna consiste no primeiro instrumento internacional o qual versa sobre Direito Autoral. Assinada na capital da Suíça, em 1886, ainda está em vigor atualmente, abrangendo cento e setenta e cinco países signatários.

3 Rodrigo Moraes, Os direitos morais do autor, Rio de Janeiro: Editora Lumen Juris, 2008, p. 23.

4 Tatuador americano, seu projeto pode ser visto no site http://www.allentattoo.com/mastectomy.

5 Devido à repercussão do projeto de David Allen foi criada uma plataforma chamada $p$. ink.org para reunir tatuadores especializados em tatuagens após a mastectomia ou cirurgia na mama e conectá-los às pacientes em diversos países. 


\section{Imagem 2. Tatuagens nos seios}

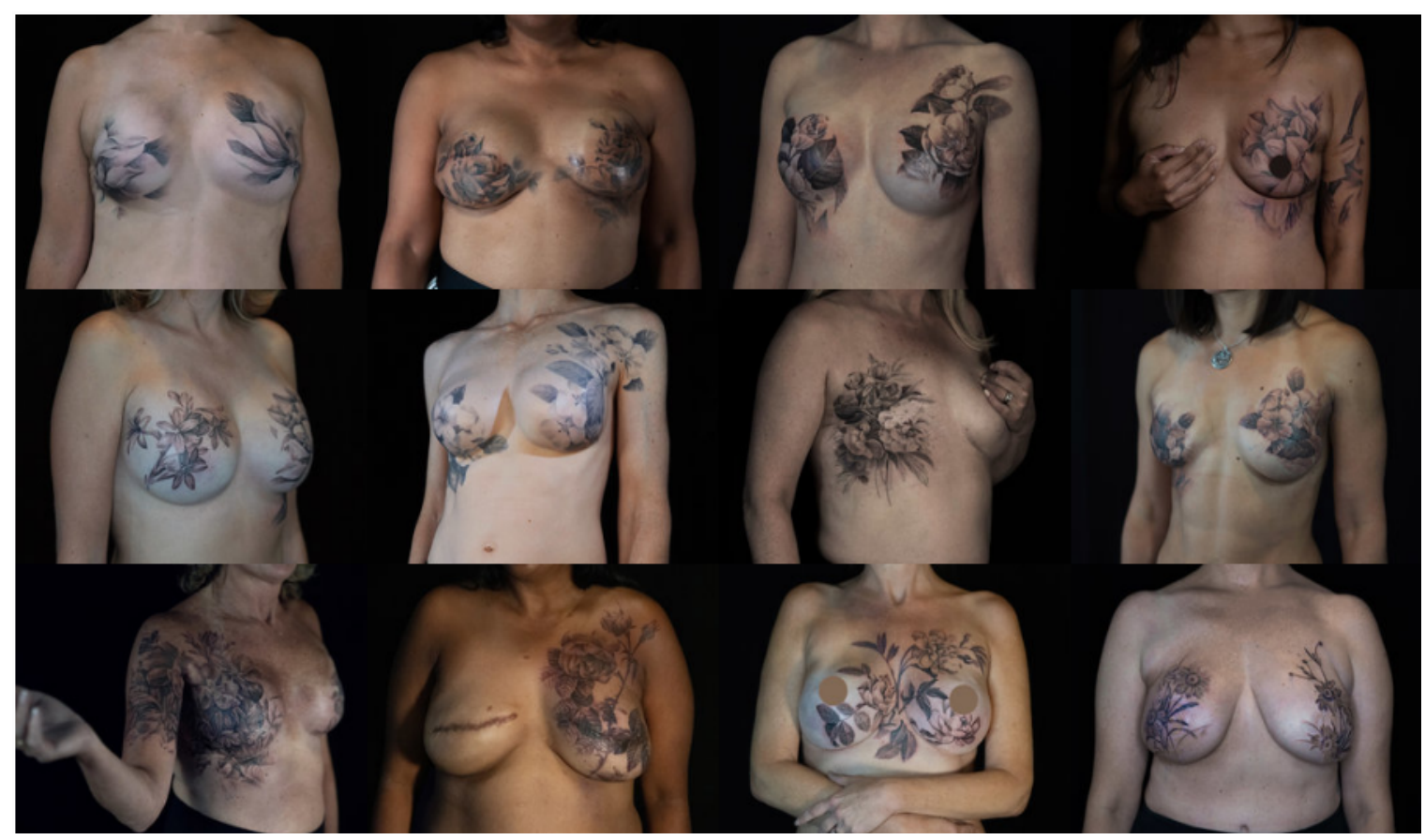

Fonte: allentattoo.com, 2020.

O projeto do tatuador é um exemplo de uma situação em que pessoas tiveram a diminuição permanente da sua integridade física em razão de exigência médica e após desejaram incorporar uma tatuagem no local do corpo, ou seja, a pessoa mastectomizada exerceu o seu direito ao próprio corpo com a realização da tatuagem.

\section{Propriedade Industrial: patentes e prospecção tecnológica}

Na pesquisa prospectiva e de averiguação elaborada a partir de análise de documentos de patentes no sistema Orbit Intelligence, envolvendo publicações de patentes, em todos os segmentos tecnológicos, foram utilizados como palavras-chave, os termos: method of tattoo+, tattoo method+, tattoo product+, tattoo instrument+, tattoo ink+, tattoo needle+, associadas entre si por meio do conector booleano AND.

Para refinamento da pesquisa foram analisados documentos de patentes segundo a classificação de patentes IPC (International Patent Classification) e CPC (Cooperative Patent Classification). 
A pesquisa teve como objetivo mapear as patentes de materiais relacionados à tatuagem, identificando os principais países depositantes e tecnologias relacionadas nesse segmento. Os resultados apontaram o total de 324 depósitos de patentes no período entre 2008 a 2018.

A China configura o país detentor do maior número de família de patentes, 122 no total, seguido dos Estados Unidos com 70 Patentes e Europa com 44 patentes depositadas via Tratado de Cooperação de Patentes (PCT). Na busca realizada, o Brasil foi considerado o $13^{\circ}$ nicho mercadológico, com sete famílias de patentes identificadas.

Os resultados mostraram que, das patentes depositadas no período de 2014 a 2018, 46\% das patentes foram concedidas, 24,07\% estão pendentes, $23,1 \%$ caducaram, 3,4\% expiraram e 2,8\% foram revogadas. Segundo a Lei $n^{\circ}$ 9.279, de 14 de maio de 1996, uma patente será extinta, de acordo com o disposto no artigo 78, qual seja, pela expiração do prazo de vigência; pela renúncia de seu titular, ressalvado o direito de terceiros; pela caducidade; pela falta de pagamento da retribuição anual, nos prazos previstos no $\S 2^{\circ}$ do artigo 84 e no artigo 87 e, por fim, pela inobservância do disposto no artigo 217.

\section{CONSIDERAÇÕES FINAIS}

O presente artigo não é capaz de esgotar a discussão a respeito da tríade: tatuagem, direito de autor e direito da personalidade, mas contribui para uma reflexão ao debate, tendo em vista a peculiaridade da obra artística, pois a tatuagem a todo tempo ganha novas concepções, formas de uso e significados.

As interpretações são diversas nos casos concretos, em razão da multiplicidade de direitos do tatuador e do tatuado. A análise não pode ser feita isoladamente para um ou para o outro, pois, envolve proteções jurídicas em institutos diversos. Quando se trata da aplicabilidade de direitos dos indivíduos, o legislador precisará ter olhar sensível ao examinar direito de autor, direito ao próprio corpo e direito à imagem. 
A jurisprudência ainda é restrita sobre o tema, da mesma forma há certa omissão doutrinária, haja vista que não há na literatura uma abordagem aprofundada no direito autoral a respeito desta obra artística. É necessário o entendimento de que a marginalização da tatuagem ficou em tempo passado e que esta arte em específico precisa ser legitimada e obter o amparo legal de forma concreta, assim como as outras obras protegidas pela Lei de Direito Autoral e pelo Direito da Personalidade.

Diante do número reduzido de precedentes judiciais relacionados à tatuagem, recomenda-se que o negócio jurídico entre tatuador e o cliente que será tatuado sejam regulados através de contratos expressos a fim de que se possa garantir os direitos e deveres das partes.

\section{REFERENCIAS}

COLLA Daniela, Direito Autoral à flor da pele? Pode o Tatuador ser responsabilizado pela reprodução desautorizada? 2019. Disponível em: https:// www.jota.info/opiniao-e-analise/artigos/tatuagem-direito-autoral-a-flor-da-pele-03082019. Acesso em: 03 dez. 2020.

CORDEIRO, Ana Luiza. Tatuagem do bem faz alerta para doenças e esconde cicatrizes. Minuto Saudável, 02.06.2018. Acesso em: 20 ago. 2021.

EQUIPE Find, Conheça a história da tatuagem e sua evolução. 2018. Disponível em: https://findtattoo.com.br/curiosidades/conheca-a-historia-da-tatuagem-e-sua-evolucao. Acesso em: 12 set. 2021.

JEHA Silvana, Uma história da tatuagem no Brasil, São Paulo: Editora Veneta, 2019.

MORAES Rodrigo, Os direitos morais do autor, Rio de Janeiro: Editora Lumen Juris, 2008.

PINHEIRO L.A; PANZOLINI C.D. Direito autoral e a tatuagem. 2016. Disponível em: https://www.migalhas.com.br/PI/99,MI248245,51045-Direito+Autoral+e+a+tatuagem. Acesso em: 10 ago. 2021.

SCHREIBER Anderson, Direitos da Personalidade, São Paulo: Editora Atlas, 201. 
SILVA Valma; SANTANA Rafael; ALENCAR Itana. Afrojob: Falta de referências inspira tatuador a criar projeto e abrir estúdio dedicado à arte em pele negra. 2019. Disponível em: https://g1.globo.com/ba/bahia/noticia/2019/07/19/ afrojob-falta-de-referencias-inspira-tatuador-a-criar-projeto-e-abrir-estudio-dedicado-a-arte-em-pele-negra.ghtml. Acesso em: 31 out. 2021.

ZANINI L.E.A., Direito à Imagem, Curitiba, Editora Juruá, 2018. 
dol 10.48209/978-65-89949-D2-B

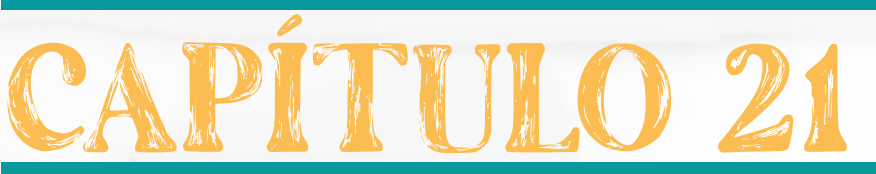

\section{AED: A LEI DOS SALÕES \\ DE BELEZA E EFICIÊNCIA}

Giovanna Martins Sampaio 


\section{INTRODUÇÃO}

Visando estimular um dos setores econômicos que mais se restabelecem no país, no contexto da prolongada crise econômica instaurada, foi promulgada em outubro de 2016 a Lei $n^{\circ} 13.352 / 2016$, que alterou a Lei $n^{\circ} 12.592 / 12$ e trouxe impactos bastante significativos nas relações de trabalho mantidas entre salões de beleza e profissionais que atuam no setor, tais como cabeleireiros, barbeiros, manicures, depiladores, esteticistas, maquiadores etc.

A partir de então, permite-se que empregadores de salões de beleza estabeleçam, por meio de contrato formalizado segundo alguns critérios e cláusulas obrigatórias, relação de parceria com os profissionais que atuam nessas determinadas atividades.

Com a nova Lei, a relação de emprego antes mantida entre os salões de beleza e empregados atuantes no setor passa a ser agora de prestação de serviços, na qual o antigamente considerado trabalhador, denominado agora como "profissional-parceiro", executará suas funções como verdadeiro profissional autônomo, mantendo com o estabelecimento, chamado de "salão-parceiro", relação de legítima parceria, e não de vínculo empregatício.

Destarte, é necessário destacar o que diz o Sebrae (2019), sobre a reabilitação deste setor dos Salões de Beleza, em estudo sobre as "tendências" que já despontam e reaparecem no pequeno reaquecimento da economia que se constata,

Recuperação paulatina das vendas de produtos alimentares, vestuário, calçados, serviços pessoais e pequenas reformas. Em um primeiro momento, espera-se que o consumo retorne àqueles produtos/serviços de menor valor, que foram represados pelas famílias, no período de maior retração da economia (p.ex. gastos com cabeleireiro, alimentação fora de casa, etc). (SEBRAE, 2019) 
Portanto, segundo o que será desenvolvido nos tópicos mais adiante, a Lei do Salão-Parceiro enquadra-se especialmente na análise econômica do direito, no sentido da eficiência, posto que propicia uma compensação social maior, uma maior aferição geral no sentido de "sobre-estimar", aumentar a medida de valor em questão, qual seja, aquela que se refere e visa o crescimento e a consolidação de postos de trabalho no ramo das atividades desenvolvidas nos Salões. Ademais, de acordo com dados digitais encontrados na pesquisa aqui lançada, a iniciativa constante na nova regulamentação dos Contratos de Parceria nos salões de beleza beneficiaria mais de 450 mil profissionais de todo o Brasil (BLOG GUIA TRABALHISTA, 2018), pois promove majoritariamente a possibilidade de formalização de práticas já costumeiras e cotidianas quanto ao exercício dessas atividades de Cabeleireiro, Manicure, Maquiador, Esteticista, Depilador, pelo que este é motivo primordial do qual surgiu o recorte temático do presente artigo acadêmico.

\section{AED E EFICIÊNCIA}

De forma precisa e sucinta, pode-se dizer que a Análise Econômica do Direito (AED) se refere a uma corrente de pensamento que busca relacionar teorias e ferramentas próprias da Economia ao Direito, mais especificamente na interpretação e aplicação das normas legais.

Nesse sentido, considerando-se que o bem-estar individual de cada sujeito significa a utilidade que o agente obtém a partir da decisão que tomou ou não, envolvendo, portanto, custos de oportunidade, o bem-estar social será analisado, e aferido a partir da soma das utilidades que os agentes identificam em determinada circunstância avaliada. Lembrando-se que essa utilidade reflete não só aspectos materiais ou de consumo, mas que engloba aspectos psicológicos e/ou emocionais. Destarte, será eficiente toda medida que tiver como consequência a satisfação em grau majorado, do maior número de indivíduos, pessoas no âmbito da sociedade. 
Dessa forma, a aplicação da AED na seara jurídica busca avaliar a eficiência das normas legais, conferindo ao Direito a responsabilidade e prerrogativa de contribuição e impacto para melhorar o bem-estar social. Portanto, as decisões judiciais devem levar em consideração se o critério jurídico aplicado facilita ou dificulta o uso eficiente dos recursos, elegendo, portanto, aquele que melhor otimize/maximize o estado de bem-estar social dos cidadãos.

Diante da "finitude" dos recursos, portanto, é que se faz necessário o estabelecimento de regras de definição da propriedade privada.

Assim, o modelo da escolha racional é um dos principais mecanismos e instrumentos utilizados na AED visando justificar determinada escolha ou opção, trazendo certa previsibilidade que permite antever a conduta dos juristas;

É necessário trazer em complemento, e pontuar justamente esses inúmeros fatores de ordem objetiva e subjetiva que Compõem o processo de escolha e decisão, limitando, de certa forma, a racionalidade desse sujeito em específico.

Ressalta-se ainda enquanto variável importante a existência de assimetria de informações entre os indivíduos envolvidos em determinados processos de tomada de decisão. Ainda, é válido ressaltar justamente que Muitas informações são ocultadas propositalmente pelas partes envolvidas em transações e negociações, visando o alcance dos seus respectivos objetivos individuais em detrimento da Coletividade.

Ultimamente, após traçados algumas ponderações e anotações essenciais, sobre a análise econômica do Direito, e especificamente o Princípio econômico da Eficiência, a seguir será feita a análise desta recente regulamente dos Contratos de Parceria, dos Salões-Parceiros, para que se possa trazer e concluir alguns pontos a respeito da maior eficiência desta Lei, levando-se em consideração as concepções de maximização do bem-estar social, e de compensação social na AED. (BOTELHO, 2016). 


\section{A LEI DOS SALOES DE BELEZA: ANÁLISE LEGISLATIVA}

Primeiramente, importa ressaltar que a Lei 13.352 (2016) passou a regulamentar uma situação que já existia na prática, qual seja, o regime de parceria entre salão e o profissional-parceiro, pois este comumente já exercia suas funções e atividades de forma mais autônoma (FERNANDES, 2018), mitigando propriamente os caracteres básicos da relação e do vínculo empregatício, nomeadamente o requisito da subordinação jurídica e da pessoalidade. Portanto, a Lei em análise trouxe a possibilidade formal desse tipo de contrato, da contratação do profissional por meio de Parceria, pelo que se colaciona o artigo referente da Lei:

\footnotetext{
"Art. 10-A Os salões de beleza poderão celebrar contratos de parceria, por escrito, nos termos definidos nesta Lei, com os profissionais que desempenham as atividades de Cabeleireiro, Barbeiro, Esteticista, Manicure, Pedicure, Depilador e Maquiador."
}

Assim sendo, esses profissionais atuarão como autônomos, sem vínculo empregatício, desde que respeitadas as condições da parceria estabelecidas no contrato. Os demais empregados dos salões de beleza que atuam em áreas de apoio, recepção, gestão, serviços gerais e limpeza continuam com contratos regidos pela CLT.

Nesta seara, a referida Lei 13.352 prevê expressamente que duas condições primordiais devem ser respeitadas, in verbis

"Art 1: $\S 8^{\circ} \mathrm{O}$ contrato de parceria de que trata esta Lei será firmado entre as partes, mediante ato escrito, homologado pelo sindicato da categoria profissional e laboral e, na ausência desses, pelo órgão local competente do Ministério do Trabalho e Emprego, perante duas testemunhas. $\S 9^{\circ} \mathrm{O}$ profissional-parceiro, mesmo que inscrito como pessoa jurídica, será assistido pelo seu sindicato de categoria profissional e, na ausência deste, pelo órgão local competente do Ministério do Trabalho e Emprego."

Com isso, pode-se perceber que o legislador procurou salvaguardar a posição do profissional-parceiro, ao exigir que o contrato seja firmado de forma es- 
crita, e primordialmente que haja o auxílio ao profissional por parte do Sindicato da categoria (mesmo se tratando de PJ), ou do Ministério Público do Trabalho - MPT, o que demonstra e assinala finalidade de proteção desses agentes, indivíduos, e não uma "constatação legal" de fraude. Nesse sentido, ainda, a Lei também traz em seu teor que não haverá "Sociedade empresarial" na vigência do Contrato de Parceria, o que corrobora um aspecto protetivo, e não "fraudulento", voltado para aquele profissional que exerce as atividades principais descritas em Lei (artigo primeiro da respectiva Lei 13.352, 2016).

Importa recortar, quanto às características de identificação, configuração do vínculo de emprego Celetista, especialmente no que tange ao requisito da não-eventualidade (ou também habitualidade) que esses profissionais descritos já detinham, antes mesmo das inovações provocadas pela nova Lei, uma relativa autonomia que se convencionou chamar de "liberdade de agenda" (ABSB, 2017).

Portanto, se houver controle de horários ou jornada, ou existindo patente subordinação, a relação empregatícia estará conformada, e com todos os quesitos e particularidades próprios a ela. Com isso, ressalta-se a possibilidade de configuração de vínculo empregatício caso existam indícios deste tipo de relação contratual, bem como ao sendo cumpridas, satisfeitas as condições já previamente exigidas pela Lei 13.352 (apoio do sindicato ao da Superintendência respectiva, e contrato formalizado e escrito).

Outrossim, deve-se depreender desses enunciados normativos que aqui também é dominante o princípio laboral da primazia da realidade. Nesta linha de pensamento, "Assim, pouco importa ao Direito do Trabalho - e consequentemente ao processo do trabalho, que é instrumento de salvaguarda do direito material - a forma, se esta não corresponder à realidade fenomênica." (Ibid.)

Ainda, existe previsão neste diploma legislativo de primordiais informações que devem constar no contrato escrito e formal, bem como que enuncia a divisão do valor recebido pelo Salão (pago pelo cliente enquanto terceiro nessa relação), entre cotas-partes percentuais, a serem distribuídas entre o Salão-Parceiro e o Profissional: 
Art. 1: $3^{\circ} \mathrm{O}$ salão-parceiro realizará a retenção de sua cota-parte percentual, fixada no contrato de parceria, bem como dos valores de recolhimento de tributos e contribuições sociais e previdenciárias devidos pelo profissional-parceiro incidentes sobre a cota-parte que a este couber na parceria. $\S 4^{\circ} \mathrm{A}$ cota-parte retida pelo salão-parceiro ocorrerá a título de atividade de aluguel de bens móveis e de utensílios para o desempenho das atividades de serviços de beleza e/ou a título de serviços de gestão, de apoio administrativo, de escritório, de cobrança e de recebimentos de valores transitórios recebidos de clientes das atividades de serviços de beleza, e a cota-parte destinada ao profissional-parceiro ocorrerá a título de atividades de prestação de serviços de beleza. $\S 5^{\circ} \mathrm{A}$ cota-parte destinada ao profissional-parceiro não será considerada para o cômputo da receita bruta do salão-parceiro ainda que adotado sistema de emissão de nota fiscal unificada ao consumidor. I - percentual das retenções pelo salão-parceiro dos valores recebidos por cada serviço prestado pelo profissional-parceiro; III - condições e periodicidade do pagamento do profissional-parceiro, por tipo de serviço oferecido;

Em continuação, "Cabe frisar que o profissional-parceiro não pode assumir as responsabilidades e obrigações decorrentes da administração da pessoa jurídica do salão-parceiro, de ordem contábil, fiscal, trabalhista e previdenciária incidentes, ou quaisquer outras relativas ao funcionamento do negócio" (Ibid.), o que acentua e revela ainda mais o caráter da recente Lei, que formalizou e regulamentou uma realidade que já acontecia nesse mercado, não pretendendo desvirtuar ou fraude a legislação trabalhista.

Ultimamente, mais duas observações devem ser feitas quanto à Lei 13.352: traz que ainda é responsabilidade do Salão a observância e fiscalização das normas de segurança e saúde no ambiente de trabalho (normas de ordem pública), bem como que escreve:

"Art. 10-D O processo de fiscalização, de autuação e de imposição de multas reger-se-á pelo disposto no Título VII da Consolidação das Leis do Trabalho - CLT, aprovada pelo Decreto-Lei $n^{\circ} 5.452$, de $1^{\circ}$ de maio de $1943 . "$

Ademais, como a Lei é específica, em caso de quaisquer lacunas jurídicas, prevalece toda a normatividade geral trabalhista, com seu perfil protetivo, tanto no aspecto material quanto no processual. E também não há previsão do afas- 
tamento da competência da Justiça do Trabalho para dirimir conflitos resultantes dessas relações e contratos de parceria, no âmbito dos salões de beleza, pelo que a justiça trabalhista deverá intervir a fim de salvaguardar uma relação equitativa, "paritária" no teor desses contratos de parceria.

Por fim, necessário se faz avaliar criticamente que, com essa nova regulação, segundo Valor Ecônomico (2019), referindo-se à figura da "pejotização" em comparação à formalização desta modalidade de trabalho, "O fenômeno é menos relevante estatisticamente do que a formalização- transição do trabalho por conta própria sem CNPJ, para com CNPJ".

\section{ANÁLISE DA LEI 13.352/2016 E EFICIÊNCIA ECONÔMICA}

Destarte, o que foi até aqui discutido, já demonstra e reafirma que a lei em questão é eficiente, pelo que proporciona a maximização do bem-estar social considerado em sua generalidade. E, algumas outras pontuações serão traçadas a seguir, a fim de se traduzir e identificar as principais ponderações que fundamentam mais diretamente a afirmação da maior eficiência da Lei de Salão-Parceiro, no âmbito desse setor, segmento de mercado.

Em continuidade ao que já foi dito anteriormente, importante a fala de Zwicker (2018),

Mais uma vez, à luz da opção do nosso Estado Democrático de Direito, de valorização do trabalho humano, exigir-se-á a atuação dos magistrados na aplicação da Carta Cidadã e da legislação do trabalho diante das alterações promovidas pela Lei n. 13.352/2016 na Lei n. 12.592/2012, com o objetivo de se evitar fraudes e precarização do labor. (ZWICKER, 2018)

A Constituição da República, sabiamente, conferiu a juízes especializados a árdua tarefa de bem julgar conflitos oriundos das relações do trabalho (art. 114, CRFB) - especialidade necessária porque se exige do julgador, na solução de conflitos dessa natureza, a sensibilidade em se perceber a relação de assimetria entre empregadores e empregados. (ZWICKER, 2018) 
Assim, portanto, consoante o que já foi explanado no primeiro tópico do desenvolvimento deste trabalho, sobre os quesitos que envolvem a análise econômica do direito, aplicada e relativa ao postulado da eficiência, o acesso devido à justiça está assegurado para a resolução de demandas na relação contratual de parceria, bem como caso haja descumprimento das condições legal e estritamente estabelecidas, ou caso se constate a tentativa de fraude relativamente ao vínculo empregatício.

Aqui, essencial abordar que a Lei 13.532 não é perfeita, principalmente porque não fixa um percentual mínimo de "repasse" a ser acertado, combinado entre o salão e o profissional parceiros. Essa é a linha seguida neste trabalho, em consonância com a perspectiva de Fernandes (2018), pelo que reproduz que

"Uma crítica que deve ser feita à lei em comento é a de ter sido omissa ao não estabelecer um percentual mínimo de repasse ao profissional no acordo entre as partes. A partir dessa omissão legislativa pode se chegar a dois caminhos: a) Ela significa que qualquer porcentagem pode ser estipulada, tendo em vista a liberdade dos contratantes. b) Deve-se recorrer aos mecanismos de integração do sistema jurídico, nos termos do Art. $3^{\circ}$ da LINDB. O primeiro caminho não me parece razoável, tendo em vista que divisões como 90-10 ou até mesmo 99-1 seriam consideradas válidas, o que corrompe a natureza de parceria do contrato e caracterizaria como uma clara precarização da mão de obra (...) Nessa linha, pode-se utilizar da analogia com a figura da parceria rural, pois se trata de outro contrato de parceria existente no ordenamento jurídico entre trabalhador e dono do capital. Apesar de ter objeto distinto do Salão-parceiro, possuem características e situações semelhantes, principalmente pelo fato de que um dos contratantes percebe os lucros e repassa, como contraprestação, ao outro contratante." (FERNANDES, 2018).

Portanto, de acordo com as anotações já desenvolvidas no presente artigo, considera-se mais acertado que uma porcentagem "equitativa" seja estipulada entre as partes, tomando em conta o apoio que recebe o profissional-parceiro do sindicato ao do Ministério Público. Por ora, traz-se e pontua-se a possibilidade da utilização da analogia, proveniente da Teoria Geral do Direito, a fim de se colmatar, completar a lacuna existente quanto à percentagem de "repartição" entre a cota-parte do profissional-parceiro, e a do salão-parceiro. 
Finalmente, é crucial para este trabalho mencionar que os Tribunais e Juízes de primeiro grau, quando se deparavam corriqueiramente e costumeiramente com conflitos, litígios envolvendo os profissionais e os salões de beleza, acabavam decidindo de maneira divergente e muitas vezes contrária a respeito do reconhecimento ou não de vínculo empregatício nessas situações que antes eram predominantemente informais. Em complemento, o mesmo autor, aduz que " Tal situação acarretava o ajuizamento de diversas reclamações trabalhistas por parte dos trabalhadores, o que gerou uma divisão na jurisprudência, pois a depender do caso concreto, a relação de emprego era reconhecida ou o contrato de parceria era declarado válido." (FERNANDES, 2018). Dessa maneira, existe ainda a vantagem da uniformização das decisões judiciais, com a patente possibilidade de se gerar precedentes judiciais consolidados, pelo que é necessário que haja segurança jurídica no julgamento desses casos.

\section{CONCLUSÕES}

Como a recente Lei 13.532 trouxe a formalização e regulamentação dos contratos de parceria no contexto dos salões de beleza, decisões mais seguras, uniformes e eficientes poderão ser consideradas. Ante disso, visualiza-se que a respectiva Lei, apesar de ter lacunas e críticas, deve ser considerada eficiente sob o fulcro da Análise Econômica.

O presente trabalho acadêmico procura ressaltar os pontos positivos advindos da Lei 13.532 (2016), concluindo pela eficiência da Lei 13.532, referente à regulamentação dos contratos de parceria entre determinados profissionais e os salões. A referida Lei se mostra clara, e acredita-se que as suas falhas serão corrigidas. Ainda, invoca-se aqui o papel dos magistrados no sentido de assegurar contratos e relações de parcerias "equilibradas" nos Salões de Beleza, pois deverão intervir na hipótese de constatação de fraude à relação empregatícia. Ademais, acentuam-se as vantagens provenientes de uma maior uniformização das decisões, e consequentemente, da maior segu- 
rança jurídica que exsurge no contexto da formalização das relações de parceria entre salões e profissionais.

Destarte, deixam-se apontadas algumas ideias e inter-relações que poderão ser desenvolvidas em futuros trabalhos, tendo-se assente o panorama do princípio econômico e jurídico da Eficência, em relação à Lei brasileira dos Salões Parceiros: uma abordagem doutrinária mais aprofunda deste postulado, tendo por base um embasamento teórico abalizado composto por grandes obras e autores nacionais, e da literatura jurídica estrangeira; bem como poderiam ser traçadas comparações do assunto relativamente à hipótese do Trabalhador Autônomo Habitual; também, se poderia aplicar o princípio em outros quesitos relacionados à temática, nomeadamente às tendências de "uberização" e terceirização, no âmbito do direito do trabalho, gerando uma visão mais singular e individualizada sobre o assunto.

Ademais, devido à atualidade do tema, posto que a legislação aqui posta em questão é recente e carece de desenvolvimento mais especializado, é um planejamento avaliar os dados empíricos a respeito da geração de postos de trabalho nesse setor de serviços, e do papel dessas micro e pequenas empresas na economia, no contexto da crise econômica atual do país, bem como que a análise das questões tributárias que exsurgem da recente legislação dos Salões-Parceiros; ainda, uma análise dos aspectos processuais, de litigância e de acesso à justiça circundantes ao tema são opções de estudos a serem desenvolvidos. Em adição, o exame das decorrências da Lei do Salão-Parceiro em termos de empreendedorismo, e até "sustentabilidade sócio-econômica". Por fim, continuamente, a análise do princípio da eficiência em confronto com o contexto das políticas públicas no direito laboral conforma um interessante cenário de investigação. 


\section{REFERENCIAS}

ABIHPEC; SEBRAE. Caderno de Tendências 2019-2020. Disponível em: http://m.sebrae.com.br/Sebrae/Portal\%20Sebrae/Anexos/CADERNO\%20DE\%20 TENDENCIAS\%202019-2020\%20Sebrae\%20Abihpec\%20vs\%20final.pdf. Acesso em: 07 jun. 2021.

A REFORMA Trabalhista libera a "Pejotização" nas Empresas?. Anamatra. 14 jul. 2017. 2017. Disponivel em: https://www.anamatra.org.br/imprensa/anamatra-na-midia/25505-a-reforma-trabalhista-libera-a-pejotizacao-nas-empresas. Acesso em: 03 jun. 2021.

BARBOSA, Louise Maria Barros. Análise econômica soluciona conflito entre princípios. Disponível em: https://www.conjur.com.br/2010-abr-24/analise-economica-direito-solucoes-conflitos-principios. Acesso em: 24 jun. 2021.

BOTELHO, Martinho Martins. A Eficiência e o Efeito Kaldor-Hicks: a questão da compensação social. Disponível em: https://www.researchgate.net/publication/322575724_A_Eficiencia_e_o_Efeito_Kaldor-Hicks_A_Questao_da_Compensacao_Social/download. Acesso em: 14 jun. 2021.

BRANCO, Iracema Castelo; MIEBACH, Alessandro Bonadio. Um primeiro olhar sobre a Reforma e seus Impactos Econômicos. Disponível em: http://panoramainternacional.fee.tche.br/article/um-primeiro-olhar-sobre-a-reforma-trabalhista-e-seus-impactos-economicos/. Acesso em: 18 jun. 2021.

CAMARGO, Margarida Maria Lacombe; BALARINI, Flávia Gonçalves. A Segurança Jurídica na Doutrina e nos Tribunais. Disponível em: http://www.publicadireito.com.br/artigos/?cod=1f9b616faddedc02. Acessado em: 30 maio. 2021.

CARRANÇA, Thais. "Pejotização" é fenômeno pequeno e menor que formalização, diz FGV. Valor Econômico. 28 mar. 2019. Disponível em: https://www. valor.com.br/brasil/6187357/\%3Fpejotizacao\%3F-e-fenomeno-pequeno-e-menor-que-formalizacao-diz-fgv. Acesso em: 23 jun. 2021.

FERNANDES, Paulo Roberto. Breves Comentários à Lei do Salão Parceiro (13.352-2016). Disponívelem:https://juslaboris.tst.jus.br/bitstream/handle/20.500.12178/129830/2018_fernandes_paulo_breves_comentarios.pdf?sequence=1. Acesso em: 10 jun. 2021. 
GAGO, Cristiane Matsumoto; OLIVEIRA, Lucas Barbosa. MEl: regularização do trabalho informal ou estímulo à "pejotização". Disponível em: https://www.migaIhas.com.br/dePeso/16,MI277713,101048-MEI+regularizacao+do+trabalho+informal+ou+estimulo+a+pejotizacao. Acesso em: 28 jun. 2021.

GARCIA, Gustavo Filipe Barbosa. Contrato de Parceria em Salão de Beleza: Lei 13.352-2016. Gen Jurídico. 03 nov. 2016. São Paulo. 2016. Disponível em: http://genjuridico.com.br/2016/11/03/contrato-de-parceria-em-salao-de-beleza-lei13-3522016/. Acesso em: 15 jun. 2021.

GUARDIA, Flavio Marcelo. Lei do Salão-Parceiro divide a Opinião de Especialistas em Direito do Trabalho. Disponível em: https://flavioguardia.jusbrasil.com.br/ artigos/401331883/lei-do-salao-parceiro-divide-a-opiniao-de-especialistas-em-direito-do-trabalho. Acesso em: 04 jun. 2020.

LEI Salão-Parceiro. ABSB. 15 set. 2017. 2017. Disponível em: http://www.saloesbrasil.com.br/site/?p=719. Acesso em: 30 jun. 2021.

LEITE, Gisele. Considerações sobre o Conceito de Segurança Jurídica no Ordenamento Jurídico Brasileiro. Disponível em: https://www.jornaljurid.com.br/colunas/gisele-leite/consideracoes-sobre-o-conceito-de-seguranca-juridica-no-ordenamento-juridico-brasileiro. Acesso em: 25 jun. 2021.

LIMA, Bruno de. Negócios na área de serviços são os mais promissores em 2019. Panrotas. 31 jan. 2019. Disponível em: https://www.panrotas.com.br/mercado/pesquisas-e-estatisticas/2019/01/negocios-na-area-de-servicos-sao-os-mais-promissores-em-2019_161996.html. Acesso em: 25 jun. 2021.

MACKAAY, Ejan; ROUSSEAU, Stéphane. Análise Econômica do Direito. Tradução Rachel Sztajn. 2. Ed. São Paulo: Atlas, 2015.

MERCADO Brasileiro de beleza é promissor, mas estabelecimentos enfrentam problemas de informalidade. Exame. 30 ago. 2018. Disponível em: https://exame. abril.com.br/negocios/dino/mercado-de-beleza-brasileiro-e-promissor-mas-estabelecimentos-enfrentam-problemas-de-informalidade/. Acesso em: 02 jun. 2021.

MTB Regulamenta Contratos da Lei do Salão Parceiro. Blog Guia Trabalhista. Curitiba. 05 jul. 2018. Disponível em: https://trabalhista.blog/2018/07/05/mtb-regulamenta-contratos-da-lei-do-salao-parceiro/. Acesso em: 05 jun. 2021. 
NASCIMENTO, Marcelo Mascaro. A Reforma Trabalhista liberou a "Pejotização"?. Exame. 01 fev. 2018. São Paulo. 2018. Disponível em: https://exame.abril.com. br/carreira/a-reforma-trabalhista-liberou-geral-a-pejotizacao/. Acesso em: 28 jun. 2021.

PATI, Camila. Ser PJ e ser terceirizado são duas situações diferentes. Exame. 27 mar. 2017. 2017. Disponível em: https://exame.abril.com.br/carreira/ser-pj-e-ser-terceirizado-sao-duas-situacoes-diferentes-entenda/. Acesso em: 22 jun. 2021.

PERREGIL, Fernanda. O Contrato Autônomo e o Contrato de Colaborador PJ à Luz da Reforma Trabalhista. Disponível em: https://www.migalhas.com.br/dePeso/16,-

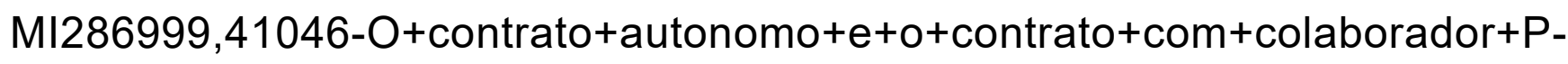
J+a+luz+da+reforma. Acesso em: 10 jun. 2021.

PORTO, Antônio José Maristrello. Análise Econômica do Direito (AED). Disponível em: https://direitorio.fgv.br/sites/direitorio.fgv.br/files/u100/analise_economica_do_direito_20132.pdf. Acesso em: 25 jun. 2021.

RAUFFLET, E.; BRES, L.; FILION, L. J. Desenvolvimento Sustentável e Empreendedorismo. Revista de Empreendedorismo e Gestão de Pequenas Empresas, v. 3, n.1, p.3-32, 2014. Disponível em: http://www.regepe.org.br/regepe/article/ download/119/64. Acesso em: 25 jun. 2021.

REFORMA Trabalhista: Restrição à "Pejotização". Rede Jornal Contábil. 24 abr. 2019. Araguari. 2019. Disponível em: https://www.jornalcontabil.com.br/reforma-trabalhista-restricao-a-pejotizacao/. Acesso em: 08 jun. 2021.

RIBEIRO, Ana Carolina Prado. A Análise Econômica do Direito e sua Aplicação (Law and economics). Disponível em: http://www.ambito-juridico.com.br/site/?n_ link=revista_artigos_leitura\&artigo_id=15586\&revista_caderno=27. Acesso em: 15 jun. 2021.

RUAN, Pablo. Análise econômica do Direito: Método de Abordagem ou Escola de Pensamento?. Disponível me: https://jus.com.br/artigos/70338/analise-economica-do-direito-metodo-de-abordagem-ou-escola-de-pensamento. Acesso em: 20 jun. 2021. 
SALAMA, Bruno Meyerhof. Análise Econômica do Direito. In: CAMPILONGO, Celso Fernandes; GONZAGA, Alvaro de Azevedo; FREIRE, André Luiz (coord.). Enciclopedia Jurídica da PUCSP- Teoria Geral de Filosofia do Direito. Tomo 1. São Paulo. 2017. Disponível em: https://enciclopediajuridica.pucsp.br/pdfs/analise-economica-do-direito_58f8146587d9f.pdf. Acesso em: 10 jun. 2021.

SALAMA, Bruno Meyerhof. Apresentação: direito e economia: textos escolhidos. São Paulo: Saraiva, 2010.

SALAMA, Bruno Meyerhof. Direito, justiça e eficiência: a perspectiva de Richard Posner. São Paulo: Fundação Getúlio Vargas. Disponível em: <http://works.bepress.com/bruno_meyerhof_salama/30>. Acesso em: 4 fev. 2021.

SALÃO Parceiro-Profissional Parceiro. Portal do Empreendedor. 2019. Disponível em: http://www.portaldoempreendedor.gov.br/duvidas-frequentes/salao-parceiro-profissional-parceiro. Acesso em: 20 jun. 2021.

SAMPAIO, Patrícia; PORTO, Antônio Maristrello (org.). Direito e Economia em Dois Mundos - Doutrina Jurídica e Pesquisa Empírica. Rio de Janeiro: FGV Editora, 2014.

SANTOS FILHO, Sirio Vieira dos. A Eficiência sob a Perspectiva da Análise Econômica do Direito. Disponível em: https://pdfs.semanticscholar.org/5e33/ 15c979b7c919404fa2ea98068d9807800f70.pdf. Acesso em: 30 maio. 2021.

SEBRAE. Relatório Especial - Os negócios promissores em 2019. Brasília. 2018. Disponívelem:https://bis.sebrae.com.br/bis/download.zhtml?t=D\&uid=97ad9b9f0e6ec6def623f7697272c05b. Acesso em: 20 jun. 2021.

. Comércio e Serviços: Salões de Beleza e Estética. Disponível em: https://m.sebrae.com.br/Sebrae/Portal\%20Sebrae/UFs/BA/Anexos/Sal\%C3\%B5es\%20de\%20beleza\%20na\%20Bahia.pdf. Acesso em: 12 jun. 2021.

. Profissionais de beleza têm vantagens com regulamentação de Parceria. Disponível em: http://www.sebrae.com.br/sites/PortalSebrae/sebraeaz/profissionais-de-beleza-tem-vantagens-com-regulamentacao-de-parceria,33e4c84a5f050610VgnVCM1000004c00210aRCRD. Acesso em: 17 jun. 2021.

TIMM, Luciano Benetti. Artigos e Ensaios de Direito e Economia. Rio de Janeiro: Lumen luris, 2018. 
TORRES, Dennis José Almanza; RIBEIRO, Marcia Carla Pereira (org.). Análise Econômica do Direito - Da Teoria à Prática. Curitiba: Editora Íthala, 2018.

WU, Xun et al. Guia de Políticas Públicas - Gerenciando Processos. Brasília: ENAP, 2014. Disponível em: http://antigo.enap.gov.br/index.php?option=com docman\&task=doc_view\&gid=3966\&ltemid=307. Acesso em: 30 jun. 2021.

YEUNG, Luciana Luk-Tai. Um dossiê sobre Análise Econômica do Direito. Disponível em: https://www.passeidireto.com/arquivo/59959230/luciana-yeung-analise-economica-da-reforma-trabalhista. Acesso em: 13 jun. 2021.

ZWICKER, Igor de Oliveira. A Relação de Emprego entre Salão-Parceiro e Profissional-Parceiro. Disponível em: https://juslaboris.tst.jus.br/bitstream/handle/20.500.12178/129815/2018_zwicker_igor_relacao_emprego.pdf?sequence=1. Acesso em: 10 jun. 2021. 
dol 10.48209/978-65-89949-D2-C

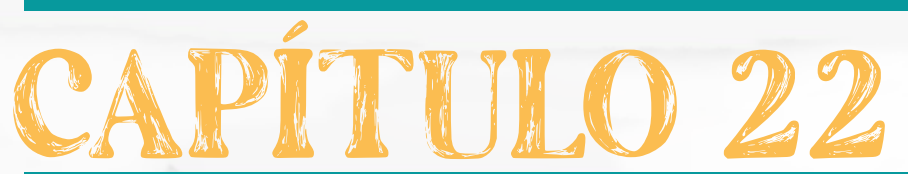

\section{GEOGRAFIA E} CONCEITOS:

UM OLHAR

\section{TRANSFORMADOR}

Giovanna Martins Sampaio Hermes Gomes 


\section{INTRODUÇÃO}

O presente trabalho buscou analisar as concepções de inovação em dicionários de língua francesa, acessíveis livremente online, na interface e recorte temáticos da Geografia.

A metodologia aplicada, segundo a forma de abordagem do problema, foi primordialmente do tipo qualitativa, posto que a representação quantitativa não se conformou no foco e sentido deste trabalho. Segundo o objetivo da pesquisa, a sua metodologia foi do tipo exploratória e descritiva. A pesquisa descritiva visa descrever as características dos fatos e dos fenômenos e o estabelecimento das relações entre as variáveis consideradas". Gil (2010, p. 42) traz que, "as pesquisas descritivas identificam as características de determinada população ou fenômeno". A pesquisa exploratória visa promover uma aproximação com o objeto de estudo. Também conforme o mesmo autor, "a pesquisa exploratória visa proporcionar maior familiaridade com o problema, com vistas a torná-lo mais explícito ou a constituir hipóteses, sendo isso feito ao longo do trabalho". Segundo a coleta de dados, a pesquisa foi do tipo bibliográfica e sistemática.

Portanto, foi investigado o estado da técnica existente sobre o tema no que se refere ao referencial teórico de discussão. Ademais, quanto aos métodos potenciais e relacionados ao presente trabalho, tem-se o emprego de sistemas de inteligência em relação à busca dessa revisão de literatura ora empregada. Ainda, abarca-se também a utilização de estratégias de pesquisa relacionadas a Mapping.

Por fim, foi feita uma espécie de prospecção para a definição do tema/recorte (e justificativa), com a busca das expressões "Geografia da Inovação" Ou "Inovação na Geografia" nas bases de dados digitais e websites; E primordialmente com a filtragem dos trabalhos que comporiam o Referencial teórico do presente artigo, abarcando-se as definições de Inovação dos 8 principais Dicionários franceses de acesso livre online. 


\section{DESENVOLVIMENTO}

\section{CONCEPÇOES}

O dicionário Larousse traz a inovação, segundo o recorte processual da técnica, asseverando os impactos sociais deste "fenômeno:

"Ação para inovar; inovação técnica; Introdução ao processo de produção e / ou venda de um novo o produto, equipamento ou processo; Todo o processo que vai do nascimento de uma ideia a sua materialização (lançamento de um produto), incluindo a pesquisa de mercado, o desenvolvimento do protótipo e as primeiras etapas da produção; Um processo de influência que leva à mudança social, cujo efeito é rejeitar as normas sociais existentes e propor novas.

Já o dicionário La Toupie traz a temática de forma mais aprofundada e terminológica, trabalhando a etimologia e os termos adjacentes à Inovação, seguindo uma perspectiva econômica e sociológica do "ato de inovar; A partir daí, de pronto, o conceito de inovação é trazido sob a ótica da tecnologia, da disruptividade, levando ao progresso, social e científico, considerando-se as "variáveis de tempo e espaço.

Percebe-se também que esta noção do La Toupie invoca a pesquisa enquanto conceito expressante correlato à inovação, não atrelada meramente ao aspecto mercadológico, mas também ao caráter científico da pesquisa, e ainda diferencia a Inovação da Invenção, sendo bastante relevante observarmos o texto deste dicionário:

ETIMOLOGIA: DO LATIM PARA DENTRO E INOVADOR, FAÇA NOVO, RENOVE, REFAÇA, RESTAURE, TRANSFORME, MUDE, INOVE. INOVAÇÃO É A AÇÃO DE INTRODUZIR ALGO NOVO EM TERMOS DE USO, COSTUME, CRENÇA, SISTEMA CIENTÍFICO... EM QUESTÕES ECONÔMICAS, A INOVAÇÃO É UM DESENVOLVIMENTO SIGNIFICATIVO DE UM PRODUTO, SERVIÇO OU PROCESSO DE FABRICAÇÃO QUE TRAZ ALGO NOVO, AINDA DESCONHECIDO OU QUE UTILIZA NOVAS TECNOLOGIAS DA PESQUISA BÁSICA.

A INOVAÇÃO É O RESULTADO DE UMA NOVA IDEIA, APELANDO À CRIATIVIDADE, A UMA REALIZAÇÃO CONCRETA E A RESPOSTA ÀS EXPECTATIVAS DOS CONSUMIDORES. VISA OBTER UMA VANTA- 
GEM COMPETITIVA SATISFAZENDO AS NECESSIDADES DO MERCADO.

A INOVAÇÃO PODE SER PONTUAL E ESTAR RELACIONADA A UM PROJETO, UM PRODUTO. TAMBÉM PODE FAZER PARTE DE UMA ABORDAGEM PERMANENTE DE GERENCIAMENTO DE INOVAÇÃO, A FIM DE PERPETUAR OS GANHOS DE COMPETITIVIDADE QUE GERA...FALAMOS TAMBEM DE INOVAÇÃO SUSTENTÁVEL.

A INOVAÇÃO DIFERE DA INVENÇÃO OU DESCOBERTA POR SUA NATUREZA OPERACIONAL E SUA IMPLEMENTAÇÃO CONCRETA. "INOVAÇÃO TECNOLÓGICA DO PRODUTO SIGNIFICA O DESENVOLVIMENTO / COMERCIALIZAÇÃO DE UM PRODUTO MAIS EFICIENTE, A FIM DE FORNECER AO CONSUMIDOR SERVIÇOS OBJETIVAMENTE NOVOS OU APRIMORADOS.

POR PROCESSO, INOVAÇÃO TECNOLÓGICA SIGNIFICA O DESENVOLVIMENTO / ADOÇÃO DE MÉTODOS DE PRODUÇÃO OU DISTRIBUIÇÃO NOVOS OU SIGNIFICATIVAMENTE APRIMORADOS. PODE ENVOLVER MUDANÇAS QUE AFETAM - SEPARADAMENTE OU SIMULTANEAMENTE - MATERIAIS, RECURSOS HUMANOS OU MÉTODOS DE TRABALHO."

NA SOCIOLOGIA, A INOVAÇÃO É ENTENDIDA COMO UM MEIO DISPONÍVEL PARA UMA MINORIA EXERCER INFLUÊNCIA SOBRE UM GRUPO SOCIAL (CF. INFLUENNCIA MINORITÁRIA).

TERMOS RELACIONADOS OU CONEXOS: DISRUPTIVIDADE; PROGRESSO; PROGRESSISMO; TECNOLOGIA.

Em terceiro lugar, o "Dicionário da Língua Francesa" aduz uma definição mais teórica do termo ora investigado, sob o foco da indústria e negócios, caracterizando a Inovação segundo atributos que abarcam o campo cultural, educacional e instrumental; Nesse esteio, trabalha com o sentido desenvolvido por Perroux, economista françês que estudou a interface econômica na Geografia, e sua teoria será ainda trabalhada no desenvolver deste artigo.

NO CAMPO DA INDÚSTRIA E NEGÓCIOS. PROJETO (S) DE INOVAÇÃO.

PERÍODOS DE CONSTRUÇÃO DE UM BEM DE CAPITAL, PERÍODO DE MATURAÇÃO E ESPECIALMENTE PERÍODO DE TRANSIÇÃO DA INVENÇÃO PARA A INOVAÇÃO (PERROUX, ÉCON. XXES.1964, P. 491).

QUAL SERÁ ESSA INOVAÇÃO: UMA NOVIDADE POSSIVELMENTE MUITO TEMPORÁRIA E FATAL PARA UMA CLIENTELA FINALMENTE 
SUBJUGADA OU UMA NOVIDADE PROPÍCIA AO AUMENTO SUSTENTÁVEL DO PRODUTO REAL GERAL DISPONIBILIZADO À COMUNIDADE? (PERROUX, ÉCON. XXES.1964, P. 454).

RESULTADO DESSA AÇÃO: ALGO NOVO INTRODUZIDO.

CONT: AS INOVAÇÕES TRAZIDAS PELA BARBÁRIE NA DEGENERADA LÍNGUA LATINA (SAINTE-BEUVE, POÉS.1829, P. 80).

CARACTERISTICAS/ATRIBUTOS/TIPOS: GRANDE, PERIGOSA, IMPORTANTE, OUSADA, ENGENHOSA, FRUTÍFERA, FATAL; CULTURAL, INSTRUMENTAL, EDUCACIONAL E TÉCNICA.

Já o quarto dicionário investigado, Educalingo, traz uma nova via de enfoque mercadológico aliado ao institucional e à ideia de Originalidade, pautando-se na acessibilidade e no papel de múltiplos Stakeholders privados e públicos na Inovação, conferindo um critério politico ao fenômeno; Assim, contextualiza a Inovação do ponto de vista "metodológico da ciências da adminsitração e da análise e prática:

INOVAÇÃO É ENCONTRAR UMA MANEIRA MELHOR DE FAZER ALGUMA COISA. A INOVAÇÃO PODE SER VISTA COMO A APLICAÇÃO DE MELHORES SOLUÇÕES QUE ATENDEM A NOVOS REQUISITOS, NECESSIDADES ARTICULADAS OU NECESSIDADES ATUAIS DO MERCADO. ISSO É FEITO ATRAVÉS DE PRODUTOS, PROCESSOS, SERVIÇOS, TECNOLOGIAS OU IDEIAS MAIS EFICIENTES, FACILMENTE ACESSÍVEIS A MERCADOS, GOVERNOS E SOCIEDADE. O TERMO INOVAÇÃO PODE SER DEFINIDO COMO ALGO ORIGINAL E, PORTANTO, NOVO, QUE "PENETRA" O MERCADO OU A SOCIEDADE. UMA DEFINIÇÃO CONSISTENTE COM ESSES ASPECTOS SERIA A SEGUINTE: "UMA INOVAÇÃO É ALGO ORIGINAL, NOVO E IMPORTANTE EM QUALQUER ÁREA QUE ENTRE EM UM MERCADO OU EM UMA SOCIEDADE".

EMBORA ALGO NOVO SEJA FREQUENTEMENTE DESCRITO COMO UMA INOVAÇÃO, EM ECONOMIA, EM CIÊNCIAS DA ADMINISTRAÇÃO E EM OUTROS CAMPOS DE PRÁTICA E ANÁLISE, A INOVAÇAO GERALMENTE É CONSIDERADA UM PROCESSO QUE REÚNE VÁRIAS NOVAS IDEIAS PARA TER UM IMPACTO NA SOCIEDADE.

A INOVAÇÃO DIFERE DA INVENÇÃO, POIS A INOVAÇÃO SE REFERE AO USO DE UMA IDEIA MELHOR E DE UM NOVO MÉTODO, ENQUANTO A INVENÇÃO SE REFERE MAIS DIRETAMENTE À CRIAÇÃO DA IDEIA OU DO PRÓPRIO MÉTODO. 
O dicionário "Le Titre" trabalha com uma acepção mais teórica e histórica da Inovação, trazendo "doutrinas e posicionamentos históricos quanto ao tema, tendo em conta o avanço potencial a partir do fenômeno de Inovar; Também menciona uma perspectiva linguística da palavra Inovação.

ELE [O POVO] LOGO SE ACALMARÁ QUANDO VIR DE UMA MANEIRA QUE NÃO PODE DUVIDAR QUE ESSA INOVAÇÃO TENHA O OBJETIVO PRINCIPAL E MUITO CERTO DE TORNÁ-LO MAIS FELIZ DO QUE ELE (VAUBAN DÎME, P. 209)

TODA INOVAÇÃO DEVE SER TEMIDA EM UM GOVERNO; A MAIS SANTA E DOCE DAS RELIGIÕES, O PRÓPRIO CRISTIANISMO NÃO SE FORTALECEU SEM CAUSAR PERTURBAÇÕES (DIDER. PENS. PHIL. ${ }^{\circ} 43$ )

É A ARTE DE CULTIVAR COMO NAS FÁBRICAS; NÃO HÁ INOVAÇÕES SEM AVANÇOS, SEM RISCOS (CONDORCET DUHAMEL.)

INOVAÇÕES SEM IMPORTÂNCIA NEM SEMPRE SÃO AQUELAS QUE MENOS LEVANTAM OS INIMIGOS DA NOVIDADE (CONDORCET VOLTAIRE.)

O QUE RESULTARIA EM NOVAS E INTERMINÁVEIS OCASIÕES DE NOVOS ERROS E INOVAÇÃO [RENOVAÇÃO] DE VÁRIOS ANTIGOS (M. DU BELLAY 183)

ETIMOLOGIA: PROVENÇ. ENNOVACIO; ESP. INOVAÇÃO; ITAL. INOVAÇÃO; LAT. INNOVATIONEM, INNOVARE.

Em quinto lugar, o dicionário "Le Parisien" enquadra a Inovação numa visão mais abstrata, estabelecendo sinônimos como Fundação, Tranformação e Revolução que intensificam o "caráter mutativo da Ação de Inovar; Ademais, é interessante por salientar o contexto local de Inovação Francês através das Locuções trazidas qua aduzem a Inovação no âmbito de Agências, sociedade abertas, Conselhos Nacional, Academia, Fundos, Institutos, Ministérios, e Redes de atuação; E ressalta-se a caracterização exemplificativa de distintas áreas do "conhecimento como artes, biologia, economia;

SIGNIFICADO: CRIAÇÃO (ABSTRATA) (NOVO DISPOSITIVO OU PROCESSO) RESULTANTE DE ESTUDOS E EXPERIMENTOS.

SINONIMOS: FUNDAÇÃO, AUDÁCIA, MUDANÇA, CRIAÇÃO, DESCOBERTA, OUSADIA, DESCONHECIDO, INVENÇÃO, MODIFICAÇÃO, 
NOVIDADE, NOVAÇÃO, REVOLUÇÃO, TEMERIDADE, TRANSFORMAÇÃO, VARIAÇÃO

VEJA TAMBÉM: ORQUESTRAR, ORGANIZAR

LOCUÇOES - INOVAÇÃO DE PRODUTOS:

AGÊNCIA RÓDANO-ALPES PARA A PROMOÇÃO DA INOVAÇÃO SOCIAL E A MELHORIA DAS CONDIÇÕES DE TRABALHO • AGÊNCIA DE INOVAÇÃO INDUSTRIAL • BIOS - INOVAÇÃO BIOLÓGICA PARA A SOCIEDADE ABERTA • CENTRO DE SOCIOLOGIA DA INOVAÇÃO • CONSELHO NACIONAL DE INOVAÇÃO PARA O SUCESSO ACADÊMICO • DIREÇÃO DE TECNOLOGIA E INOVAÇÃO • FUNDAÇÃO PARA A INOVAÇÃO POLÍTICA • FUNDO COMUM PARA A COLOCAÇÃO EM INOVAÇÃO • GEOGRAFIA DA INOVAÇÃO • INSTITUTO DE PESQUISA E INOVAÇÃO - INSTITUTO INTERNACIONAL DE INOVAÇÃO, CRIAÇÃO E PESQUISA ARTÍSTICA • MINISTÉRIO DO DESENVOLVIMENTO ECONÔMICO, INOVAÇÃO E EXPORTAÇÃO • PRÊMIO INOVATION - PRÊMIO LOCAL DE INOVAÇÃO SOCIAL • REDE DE PESQUISA EM INOVAÇÃO;

Já o Dicionário “L'Internaute” propõe uma maior conexão da Inovação com a Ciência e a tecnologia de ponta, conforme pode ser visto: "Inovação refere-se ao fato de introduzir alguma novidade no governo, ciência ou qualquer outro campo... As inovações no campo da alta tecnologia são tão rápidas que se torna difícil de seguir".

Por fim, o Dicionário "Geoconfluences Lyon" aborda o assunto da Inovação de uma forma bastante extensiva, trazendo um enquadramento multidisciplinar que abarca aspectos de urbanização, "metropolização, migratórios, regulatórios, ambientais, "epistemológicos, comunitários, e até sanitários, no contexto "Glocal de Desenvolvimento (LOURENÇO, 2014). Para tanto, analisa certos fenômenos como as Eurocidades, a Carta Francesa do Meio ambiente, as Metrópoles globais, as Migrações, a "Geografia da Saúde, e a P\&D (Pesquisa e Desenvolvimento), que serão avaliados a seguir.

Ultimamente, o "Geoconfluences" coloca em perspectiva o sentido de área de competência ou setor econômico, no qual ocorre o desenvolvimento de habilidades, recursos e bens diversos (materiais, técnicas e humanas); Assim, conformam-se Clusters territoriais sistemáticos em relação à políticas "desenvolvi- 
mentistas, pautadas na concorrência, fênomeno que foi identificado também pela Doutrina (CORREA, 2020); Acentuando-se a "competitividade de Territórios relacionada aos Ambientes de Inovação que abrigam modelos de negócios emergentes e startups, com uma celeridade única no desenvolvimento de projetos no âmbito de "redes de cooperação:

INOVAÇÃO É A CRIAÇÃO DE NOVIDADE EM UMA ÁREA DE COMPETÊNCIA. EM ECONOMIA, A INOVAÇÃO ABRANGE PESQUISA E DESENVOLVIMENTO (P\&D) E TODOS OS SETORES COM BASE NA DESCOBERTA DE NOVOS PROCESSOS, BEM COMO EM SUA IMPLEMENTAÇÃO TÉCNICA.

A INOVAÇÃO DESEMPENHA UM PAPEL CENTRAL NA COMPETIÇÃO DE TERRITÓRIOS. A COMPETIÇÃO É DISPUTADA PRINCIPALMENTE EM ESCALA GLOBAL, DADA A VELOCIDADE DA DISSEMINAÇÃO DE CONHECIMENTOS E TÉCNICAS, E A LUTA PELOS PRIMEIROS LUGARES É FEROZ. POR OUTRO LADO, É NO NÍVEL LOCAL QUE SE REALIZA O SUCESSO DOS TERRITÓRIOS DE INOVAÇÃO, REUNINDO EM UM ESPAÇO LIMITADO O MAIOR NÚMERO DE HABILIDADES. ESSE É O PRINCÍPIO DO CLUSTER, DO QUAL O VALE DO SILÍCIO, NA CALIFÓRNIA, É UM EXEMPLO EMBLEMÁTICO, AGRUPANDO PESQUISAS CIENTÍFICAS E MILITARES, UNIVERSIDADES, SEDES MULTINACIONAIS E ENXAMES DE STARTUPS. ESSE MODELO É FREQUENTEMENTE VISTO COMO A RECEITA PARA O SUCESSO DE UM TERRITÓRIO DE INOVAÇÃO, E TEM SIDO FREQUENTEMENTE COPIADO: SILICON CAPE TOWN, NA ÁFRICA DO SUL, WADI DE SILÍCIO EM ISRAEL, BANGALORE COMO "VALE DO SILÍCIO" DA ÍNDIA, AO QUAL DEVEM SER ADICIONADOS TODOS OS "VALES", COMO "VALE AEROESPACIAL" OU "VALE COSMÉTICO" NA FRANÇA (CARROUÉ, 2019). O PLATÔ DE SACLAY, NO SUL DE PARIS, É OUTRO EXEMPLO DE UM TERRITÓRIO DE INOVAÇÃO QUE BUSCA OPERAR EM CLUSTERS (CARROUÉ, 2017). OS CLUSTERS DE COMPETITIVIDADE SÃO, NA FRANÇA, UMA POLÍTICA DE DESENVOLVIMENTO QUE VISA INCENTIVAR A INOVAÇÃO (GRANDCLEMENT, 2020).

\section{CONCLUSOES}

Os breves resultados parciais advindos desta pesquisa referem-se à transdisciplinariedade da interface entre Geografia e Inovação, devido primordialmente à relaçnao desse cenário glocal para com a tecnologia, a pesquisa e a ciência, dentre outros fenômenos e institutos da época atual. 
Identifica-se como potenciais estudos futuros, além dos mencionados no corpo deste trabalho, a adoção de um método mais quantitativo para avaliar a Inovação na Geografia e com o "Urbano, na linha do disposto por alguns autores como o fez recentemente Tunes (2020); Ou do ponto de vista mais técnico, conforme trazido por Baldoni e Furtado (2013), pois analisaram ainda a relevante temática da relação das Universidades no desenvolvimento da CTI, P\&D e na "propagação de novas tecnologias emergentes e disruptivas.

Ademais, enquadra-se como centro de continuidade deste artigo a confluência da teoria de Perroux em relação aos pólos de competitividade e desenvolvimento territorial, numa perspetiva sistemática das regiões inteligentes a nível nacional, estudo para o que já foi desenvolvida a pesquisa e prospecção bibliográfica preliminar nos sites dos repositórios de IES brasileiras.

\section{REFERÊNCIAS}

ANDION, Carolina; ALPERSTEDT, Graziela; GRAEFF, Júlia. Ecossistema de inovação social, sustentabilidade e experimentação democrática. Revista de Administração Pública, 2020. Disponível em: https://www.scielo.br/j/rap/a/W8HPVFsSQwhNGzRVF6WddxC/?lang=pt . Acesso em: 01 jun. 2021.

ANDRADE, Herlandí, et al. Transferência de tecnologia: uma discussão sobre os fatores críticos de sucesso para os transmissores e receptores de tecnologia. Revista Espacios, vol. 39, n. 9, 2017. Disponível em: http://www.revistaespacios. com/a18v39n09/a18v39n09p01.pdf . Acesso em: 31 jun. 2021.

ANVERSA, Marcus Vinícius. O território da inovação tecnológica e a inovaçnao do território brasileiro. Disponível em: http://observatoriogeograficoamericalatina.org.mx/egal14/Nuevastecnologias/Sig/07.pdf . Acesso em: 04 jun. 2021.

CARVALHO, Diana dos Reis; SOBRINHO, Fernando Luiz. Geografia econômica e e o estudo da indústria e da inovação na atualidade. Revista Estudos Geográficos, 2017. Disponível em: https://www.google.com/url?sa=t\&rct=j\&$q=\&$ esrc $=s \&$ source $=$ web\&cd $=\& v e d=2$ ahUKEwjv2YP_ulPXAhXOqZUCHQJvA-

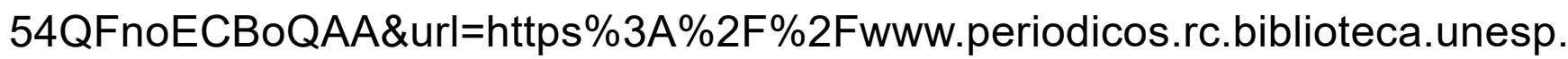
br\%2Findex.php \%2Festgeo\%2Farticle\%2Fdownload\%2F11723\%2F8330\%2F\&usg=AOvVaw3zBqPzS4btbIQpZuP_mvfT . Acesso em: 02 jun. 2021. 
CORDEIRO,René.Aglobalizaçãoea deslocalização.Disponívelem:https://www. ordemeconomistas.pt/xportalv3/membro/diretorio/artigo. $x v w ? p=4073195 \&$ a-globalização-e-a-deslocalização . Acesso em: 03 jun. 2021.

CORREIA, Erice Bezerra. Inovação tecnológica com a relação tempo/espaço na cidade de Campina grande. Disponível em: https://www.google.com/url?sa=$\mathrm{t} \& \mathrm{rct}=\mathrm{j} \& \mathrm{q}=\& \mathrm{esrc}=\mathrm{s} \&$ source $=$ web\& $c d=\& v e d=2$ ahUKEwjv2YP_ulPXAhXOqZUCHQJvA54QFnoECBwQAA\&url=https\%3A\%2F\%2Fperiodicos.ufpe.br\%2Frevistas $\% 2$ Frevistageografia $\% 2 F a r t i c l e \% 2 F d o w n l o a d \% 2 F 228674 \% 2 F 23096 \&$ usg=AOvVaw3F814cCd5r3eML3nGRNsXz . Acesso em: 02 jun. 2021.

CYSNE, Fatima Portela. Transferência de Tecnologia e Desenvolvimento. Revista Ciência da Informação, vol. 25, n. 1, 1995. Disponível em: https://www.

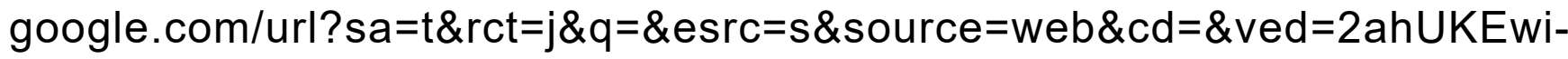
2roKN2YPxAhXhq5UCHXDxBLMQFnoECCIQAA\&url=http \%3A\%2F\%2Frevista.ibict.br\%2Fciinf\%2Farticle\%2Fdownload\%2F672\%2F681\%2F\&usg=AOvVaw0Ri41lhBpPanrjp5wwjlvZ . Acesso em: 03 jun. 2021.

DE MATOS, Guilherme; TEIXEIRA, Clarissa Stefani; PIQUE, Josep Miquel; XIANGDONG, Chen. Ecossistemas regionais de inovação: uma revisão integrative. Disponível em: https://via.ufsc.br/wp-content/uploads/2019/08/Ecossistemas-regionais-de-inovacao_Anprotec-2019.pdf . Acesso em: 05 jun. 2021.

DIAS, Alexandre; PORTO, Geciane Silveira. Gestão da Tranferência de Tecnologia da Inova Unicamp. Disponível em: https://www.scielo.br/j/rac/a/JCLpShSMZRc6NDhPv4tkNJq/?format=pdf\&lang=pt . Acesso em: 04 jun. 2021.

DOS SANTOS, Matheus; ZATTAR, Izabel. A importância da gestão do conhecimento para o funcionamento dos Ecossistemas de inovação. Disponível em: http://www.kmbrasil.org/uploads/6/5/7/6/65766379/anais-kmbr18-paper-42. pdf . Acesso em: 03 jun. 2021.

IKENAMI, Rodrigo; GARNICA, Leonardo; RINGER, Naya. Ecossistemas de inovação: abordagem analítica da perspectiva empresarial para formulação de estratégias de inovação. Disponível em: https://www.researchgate.net/publication/298804168_Ecossistemas_de_inovacao_abordagem_analitica_da_perspectiva_empresarial_para_formulacao_de_estrategias_de_interacao . Acesso em: 04 jun. 2021. 
LOURENÇO, Nelson. Globalização e glocalização: o difícil diálogo entre o global e o local. Revista Angolana de Ciências Sociais, 2014. Disponível em: https:// journals.openedition.org/mulemba/203. Acesso em: 05 jun. 2021.

MOTA, Karla; LUNA, Monica; SANTOS, Jerônimo; ROMERO, Fernando. Uma revisão da literatura sobre transferência de tecnologia. Revista Holos, 2016. Disponível em: https://www.google.com/url?sa=t\&rct=j\&q=\&esrc=s\&source=we$\mathrm{b} \& \mathrm{~cd}=\& \mathrm{ved}=2 \mathrm{ahUKE}$ wi2roKN2YPxAhXhq5UCHXDxBLMQFnoECAIQAA\&urI=http\%3A\%2F\%2Fwww2.ifrn.edu.br\%2Fojs\%2Findex.php\%2FHOLOS\%2Farticle\%2Fdownload\%2F4462\%2Fpdf\&usg=AOvVaw0LwYMfKztNbZVHn7Em1n7e . Acesso em: 30 maio. 2021.

RAEDER, Savio. Geografia e inovação tecnológica. Revista Mercator, vol. 15, n. 2, 2016. Disponível em: https://www.scielo.br/j/mercator/a/8wDg7czprnsRRQyDLpgtWMj/?lang=pt\&format=pdf . Acesso em: 01 jun. 2021.

TAVARES, Hiago. Ecossistemas de inovação e análise de redes. Disponível em: http://anpur.org.br/xviienanpur/principal/publicacoes/XVII.ENANPUR_Anais/ ST_Sessoes_Tematicas/ST\%208/ST\%208.3/ST\%208.3-05.pdf . Disponível em: 03 jun. 2021.

TUNES, Regina. Ambientes de inovação urbanos: uma proposta conceitual para a compreensão da relação urbano e inovação no Brasil. Disponível em: https://revistas.ufpr.br/raega/article/view/66024 . Acesso em: 01 jun. 2021.

TUNES, Regina. Geografia da Inovação: o debate contemporâneo da relação entre território e Inovação. Revista Brasileira de Geografia Econômica, n. 9, 2016. Disponível em: https://journals.openedition.org/espacoeconomia/2410 . Acesso em: 06 jun.2021.

VIA. Ecossistema de inovação: alinhamento conceitual. Disponível em: http:// centrosdeinovacao.sc.gov.br/wp-content/uploads/2020/01/11.Ecossistema-de-inovacao-Alinhamento-Conceitual.pdf . Acesso em: 04 jun. 2021. 


\section{dol 10.48209/978-65-89949-D2-D}

\section{CAPITURO 23}

\section{PROSPECÇÃO DE}

TECNOLOGIAS SUSTENTÁVEIS: UM OLHAR SOBRE AS PATENTES

Hermes Oliveira Gomes Giovanna Martins Sampaio 


\section{INTRODUÇÃO}

Com aceleração das mudanças climáticas que vem afetando a todos no planeta, ações tornam-se necessárias para dar respostas a esses efeitos. Contudo, é sabido que ao longo dos tempos várias convenções e acordos internacionais vem sendo feitos na tentativa de criar conscientização e política publica das nações dominantes para mitigar os efeitos devastadores do consumo e capitalismo. Assim, cabe a nação, a criação de políticas públicas de fomento a um desenvolvimento sustentável.

A exemplo disso, agora nos dias 23 e 24 de abril de 2021, líderes mundiais se juntaram na Cúpula sobre o Clima para discutir mais uma vez como unir de forma sustentável o crescimento econômico e a proteção do meio ambiente de forma que ambos sobrevivam em harmonia. Nisso, um dos representantes dos empresários do mundo tecnológico, Bill Gates, chama a atenção ao dizer que o maior problema das tecnologias verdes é seu alto custo, defendendo investimento público em pesquisa a fim de baratear essas tecnologias.

Em contramão a estas discussões e necessidades de políticas de fomento a defesa do meio ambiente, o governo brasileiro ao apresentar a Lei Orçamentaria Anual (LOA) de 2021 nesta mesma data que encerra a Cúpula sobre o Clima, anuncia vetos de $\mathrm{R} \$ 239,8$ milhões, destes, $R \$ 11,6$ milhões que eram destinados ao controle e fiscalização ambiental. Dessa maneira, mesmo entendendo que os recursos de emendas são discricionais, estes fazem falta nas ações de melhoria e manutenção de um meio ambiente, que já vem impactado há anos, especialmente, em 2019 e 2020, com os piores índices de desmatamentos na Amazônia, segundo dados do Inpe (2021). Toda essa situação, destoa do pronunciamento feito pelo Presidente no primeiro dia de reunião da cúpula, ao afirmar que "medidas de comando e controle são parte da resposta. Apesar das limitações 
orçamentárias do Governo, determinei o fortalecimento dos órgãos ambientais, duplicando os recursos destinados às ações de fiscalização."

O desenvolvimento sustentável é um tema que está sendo estudado em decorrência da preocupação das pessoas e das empresas com o meio ambiente e a sua preservação. Para que essa preservação atinja seus melhores resultados, ações sociais, econômicas e tecnológicas vêm sendo desenvolvidas, a fim de que possam mitigar os impactos ambientais presentes, bem como garantir sustentabilidade para as futuras gerações.

Neste contexto surge as denominadas patentes verdes, que são tecnologias novas ou significativamente melhoradas, voltadas para a preservação e/ou mitigação dos recursos naturais, contribuindo assim para combater os impactos ambientais e as mudanças climáticas.

As patentes verdes passaram a ter uma relevância perante os governos, o que contribuiu para a mudança de procedimentos para a sua concessão, tendo prioridade no seu exame, além de criar estímulos para desenvolvimento de inovações nesse campo de conhecimento.

No Brasil, o Instituto Nacional de Propriedade Intelectual (INPI), é uma autarquia federal responsável pela concessão, pelo registro e concessão de marcas, patentes, desenho industrial, transferência de tecnologia, indicação geográfica, programa de computador e Topografia de Circuito Integrado.

Especificamente, as patentes verdes surgem no Brasil através do programa piloto em abril de 2012 até abril de 2016, sendo a partir de dezembro de 2016 oferecido como um serviço prioritário de exame entre outros pedidos de patentes.

Além disso, o INPI definiu uma lista de tecnologias consideradas verdes baseada no inventario da Organização Mundial de Propriedade Intelectual - OMPI, tendo como 5 áreas prioritárias, sendo: Energias Alternativas; Transportes; Conservação de Energia; Gerenciamento de Resíduos; Agricultura Sustentáveis. 
Mas o que de fato seria uma patente? A Patente é concedida quando se cria um produto, processo ou serviço novo ou significativamente melhorado, podendo ser denominado de patente de invenção ou modelo de utilidade. Na patente de invenção se cria uma tecnologia nova, já nas patentes de modelo de utilidade são implementadas melhorias significativas de algo já existente no mercado.

E os benefícios de ter uma patente concedida? Os benefícios seria o direito de uso e exploração dessa tecnologia por um período, evitando que seja copiado e utilizado indevidamente pelos concorrentes.

Dessa forma, observa-se que o INPI com o Projeto de Patentes Verdes, visa incentivar as inovações ecologicamente sustentável, atender a convenções e acordos internacionais do meio ambiente e dar celeridade em processos internos de concessão de patentes.

Importante ressaltar que para este estudo, considera-se palavras e termos que são associados a patentes verdes, pois, antes mesmo de se tornar uma patente entendida dentre de parâmetros técnicos de patenteabilidade, elas são tecnologias vinda das mais diversas áreas do conhecimento, sendo sinônimos também de tecnologias verdes, limpas, ambientais, sustentáveis, socioambientais, entre outras.

O presente estudo tem como objetivo analisar o panorama das patentes verdes no cenário internacional e especificamente no Brasil, bem como ressaltar a importância das patentes na promoção de um desenvolvimento sustentável.

Para tanto, utiliza de uma pesquisa exploratória de cunho quali-quantitativa, através de leituras de artigos e livros dos últimos 5 anos, assim como do uso de uma base de dados secundária de patentes, como Orbit ${ }^{1}$, Patentscope $^{2}$, com

1 O Orbit.com é um sistema de busca, seleção, análise e exportação de informações contidas em patentes. Disponível em: www.axonal.com.br. Acesso em: 15 abr. 2021.

2 O PATENTSCOPE permite fazer consultas em 95 milhões de documentos de patentes incluindo 4,0 milhões de pedidos de patentes internacionais (PCT) publicados. Disponível em: https://patentscope.wipo.int/. Acesso em: 15 abr. 2021. 
abrangência internacional, assim como a base do INPI com abrangência nacional.

Na tabulação e análise usa uma metodologia interpretativa baseada nas análises gráficas próprias, geradas por meio de ferramentas de edição, bem como a análise das figuras geradas pelos próprios sites e ferramentas de busca internacional de patentes.

Importante destacar que os achados não significam que as patentes encontradas são por unanimidade patentes reivindicadas por serem tecnologias limpas ou ecologicamente sustentáveis, mas por terem termos e/ou palavras chaves encontradas em seus títulos ou resumos. Para um maior aprofundamento, outros filtros e técnicas de análises seriam necessários para comprovar se de fato os depósitos seriam referentes a uma modalidade de patentes com quesitos de tecnologias sustentáveis.

\section{DESENVOLVIMENTO: PROSPECÇÕES DE TECNOLOGIAS SUSTENTÁVEIS INTERNACIONAIS}

Usando o Orbit, software de busca de tecnologias patenteadas, tendo como palavras-chave de busca e operadores boleanos: technology and (green OR clean OR environmental) para as ocorrências em título e resumo, foram encontrados um total de 56024 depósitos, sendo destes 29263 (52\%) encontram-se como ativas e com pendências, e outras 26761 já mortas.

Figura 1 - Os tops 10 conceitos mais abordados nas patentes

Clear water (1675) | Contamination (6197) | Economic benefit (3702) |

Energy conservation (1960) | Environment friendly (675) |

Environmental pollution (6274) | Environmental protection (9804) |

Green tea (929) | Raw material (7275) | Water content (2370) |

Fonte: Questel Orbit, 2021. 
Na figura 1, observa-se que os conceitos de proteção ambiental são recorrentes em 9804 achados, seguidos por matéria prima com 7275 achados e de poluição ambiental com 6274, assim sucessivamente. Mostrando assim que a preocupação com o meio ambiente, seja na sua poluição, as matérias primas e suas formas de proteção, como quesitos principais do centro de discursão.

Figura 2 - As tops 10 tecnologias dominantes agrupadas por familiaridade

Basic materials chemistry (5072) | Chemical engineering (5013) | Civil engineering (2976) | Electrical machinery, apparatus, energy (2976) | Environmental technology (6906) | Food chemistry (7648) | Materials, metallurgy (5502) | Measurement (2567) | Other special machines (5071) | Surface technology, coating (2404) |

Fonte: Questel Orbit, 2021.

Na figura 2 temos as 10 tecnologias mais dominantes entre a amostra pesquisada, sendo a área de Química Alimentar a mais recorrente com 7648 achados, seguidas por Tecnologias Ambientais e Materiais Metalúrgicos, assim sucessivamente. Observa-se uma grande tendência na preocupação com tecnologias voltadas para indústria alimentar, bem como os quesitos de agrotecnologias e tecnologias ambientais de forma geral. 
Figura 3 - Volume de depósitos de patentes em tecnologias verdes nos últimos 20 anos

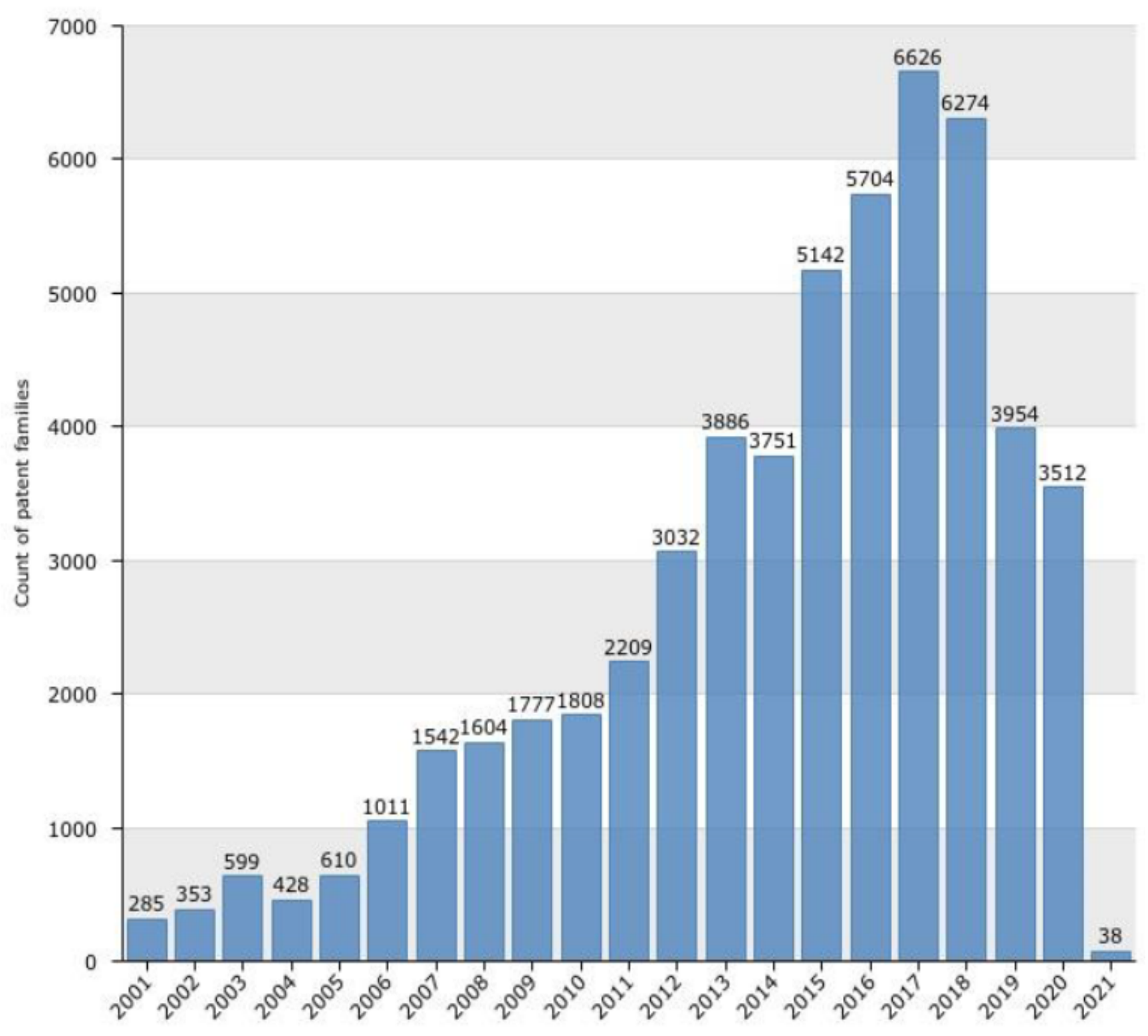

Fonte: Questel Orbit, 2021.

Nota-se na figura 3, no eixo vertical, o volume de patentes familiares com as temáticas ambientais e tecnologias verdes, já no eixo horizontal, a evolução ou declínio delas com o tempo. Assim, observa-se que o volume de produções tecnológicas verdes veio tendo uma crescente até 2017 e posteriormente a isso, registra-se um declínio anualmente. 
Figura 4 - Principais inventores de depósitos de patentes em tecnologias verdes

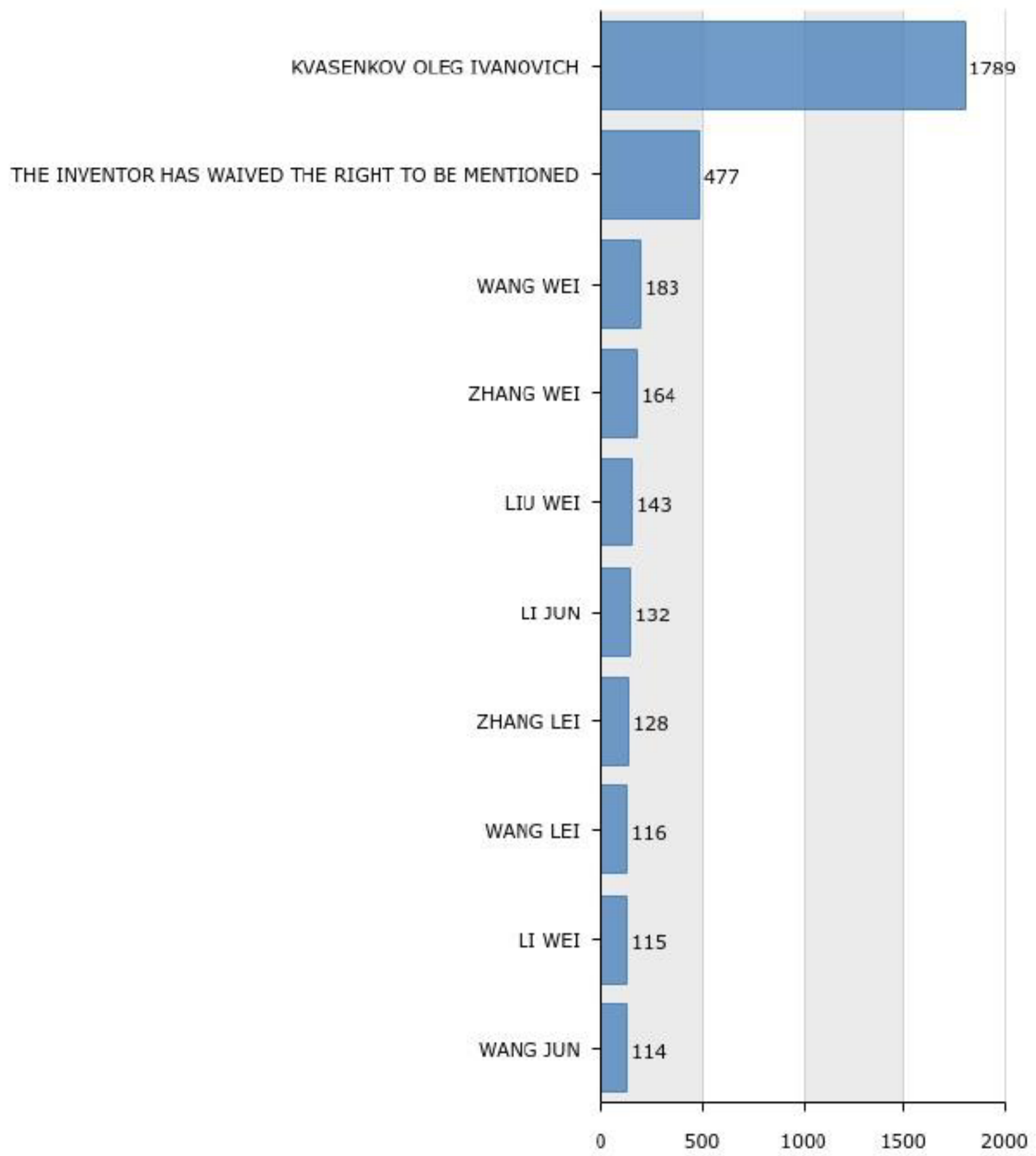

Fonte: Questel Orbit, 2021.

Nesta figura 4 observamos Kvasenkov Oleg Ivanovich como um dos principais inventores, sendo Russo e desenvolvedor de tecnologias voltadas para a indústria de alimentos. Já a segunda colocação está para os inventores que renunciaram os direitos de serem mencionados e os demais pesquisadores listados, em sua maioria, de origem do leste asiático, principalmente, os chineses. 
Figura $5^{1}$ - Depósitos de patentes em tecnologias verdes por países

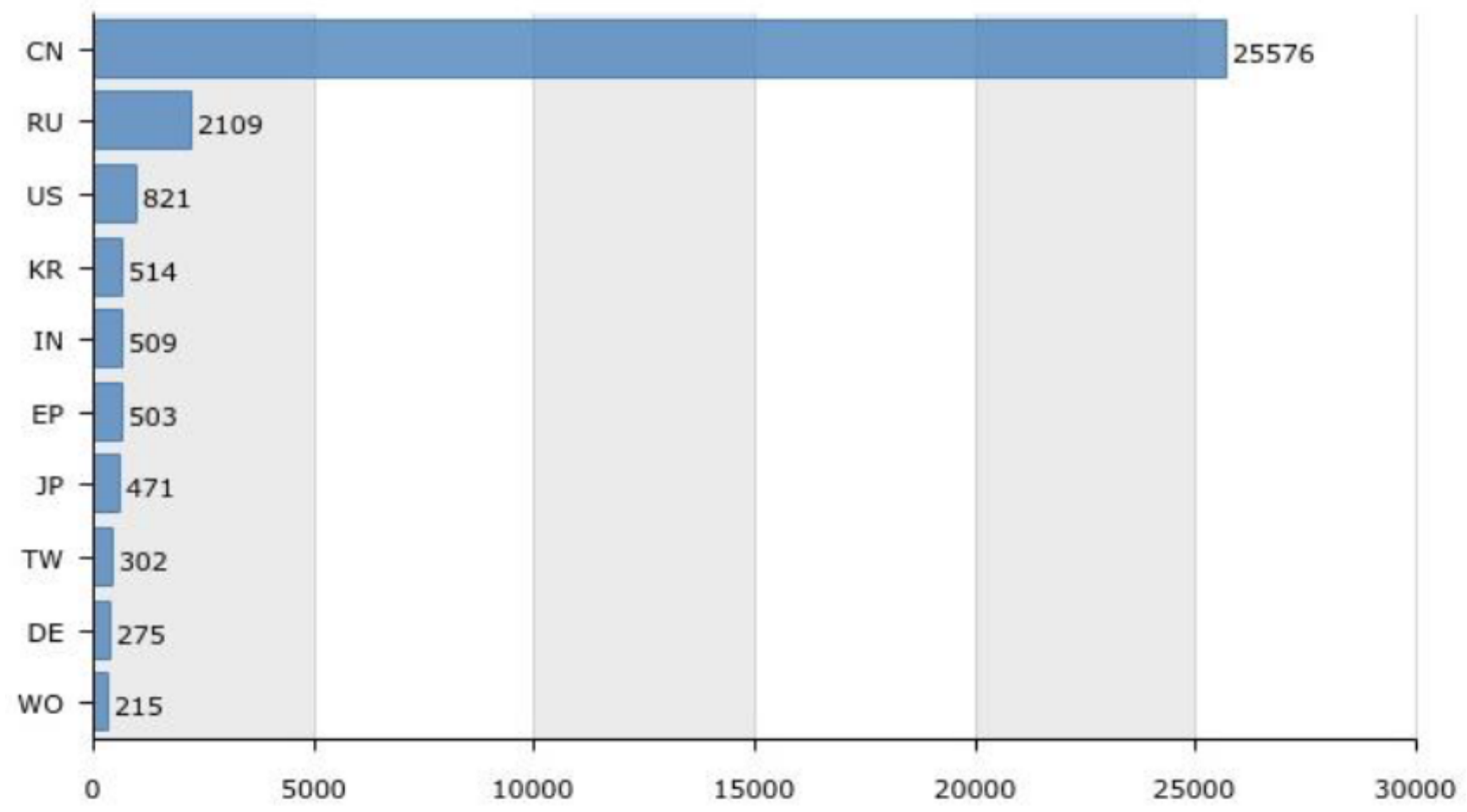

Fonte: Questel Orbit, 2021.

Na figura 5 é notório, de forma expressiva, que os chineses são os maiores detentores destas tecnologias, com 25576 patentes, seguida pela Rússia com 2190 e os Estados Unidos com 821. Ao mesmo passo que os países são os maiores provedores de tecnologias verdes, esses países são também campeões em emissões de poluentes, então, deve-se analisar o quão de sustentabilidade sobra nesta equação ambiental.

1 As iniciais de 2 letras no eixo vertical referem-se a uma codificação de países emitia pela ISO 3166-1. 
Figura 6 - Depósitos de patentes em tecnologias verdes por instituições

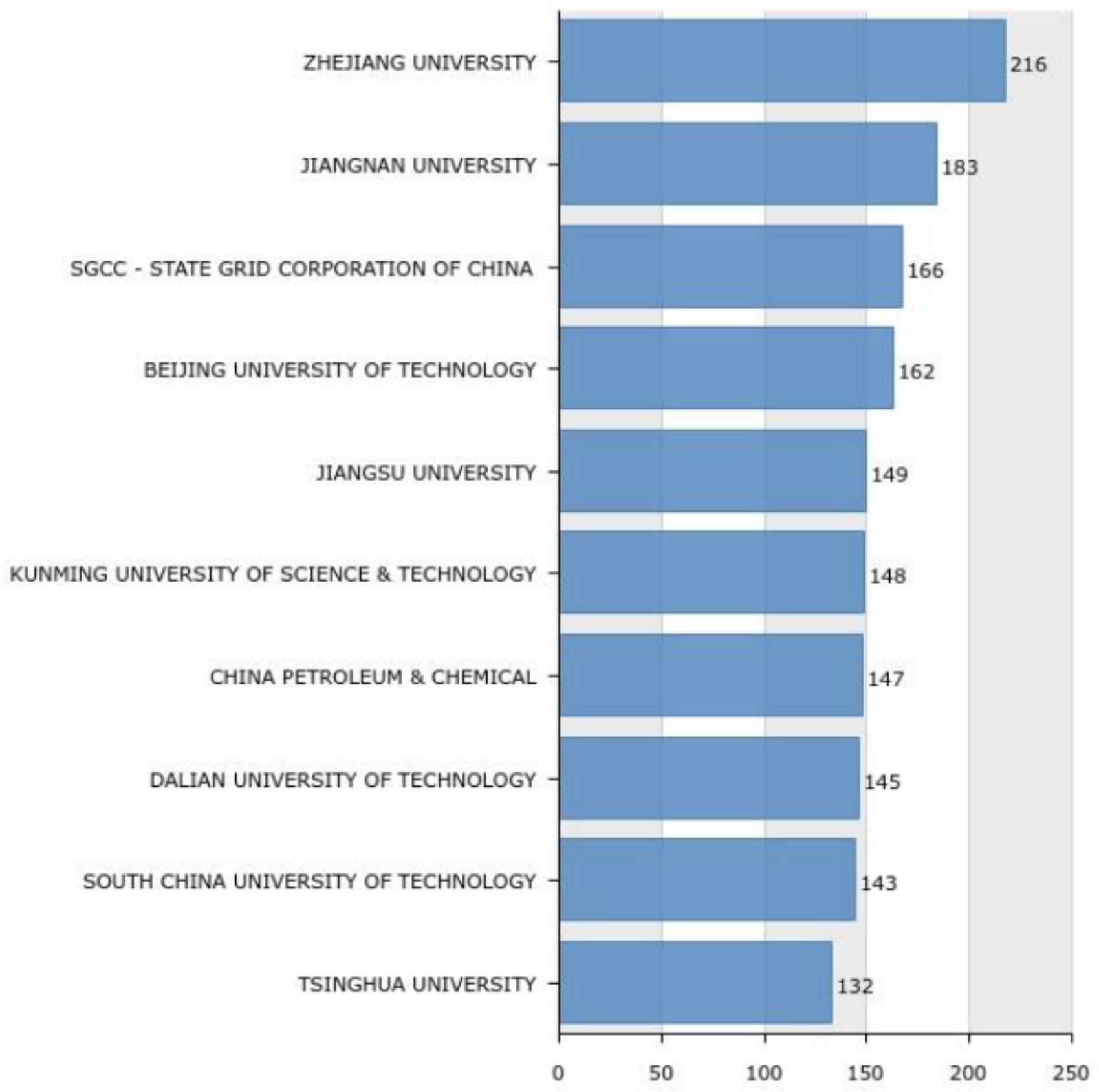

Fonte: Questel Orbit, 2021.

Na figura 6 é apresentada as principais instituições produtoras de tecnologias sustentáveis, na qual estão as universidades como as principais responsáveis por essas pesquisas e patentes geradas. Em primeiro lugar, na geração de tecnologias sustentáveis encontra-se a universidade Zhejiang no Japão, seguida da universidade Jiangnan na China e em terceira colocação, com 166 depósitos de patentes, encontra-se uma empresa de energia elétrica chinesa, responsável pela maior parte da operação de energia do país. 


\section{DESENVOLVIMENTO: PROSPECÇÕES DE TECNOLOGIAS BRASILEIRAS USANDO A BASE DE DADOS DE PATENTES DO INPI}

$\mathrm{Na}$ base de dados de patentes brasileira do INPI foi usado palavras-chave (patentes verdes) em busca avançada, nos campos título e resumo, sendo encontrados 50 depósitos de patentes na base nacional.

Analisando a base de dados de patentes do INPI com a data de 17 de abril de 2021 em revista RPI n² 2623, foram encontrados 50 depósitos, sendo destes $26 \%$ do Modelo de Utilidade e $74 \%$ Patente de Invenção, como pode ser visto na figura 7.

Figura 7 - Tipos de invenção

\section{Tipo de invenção}

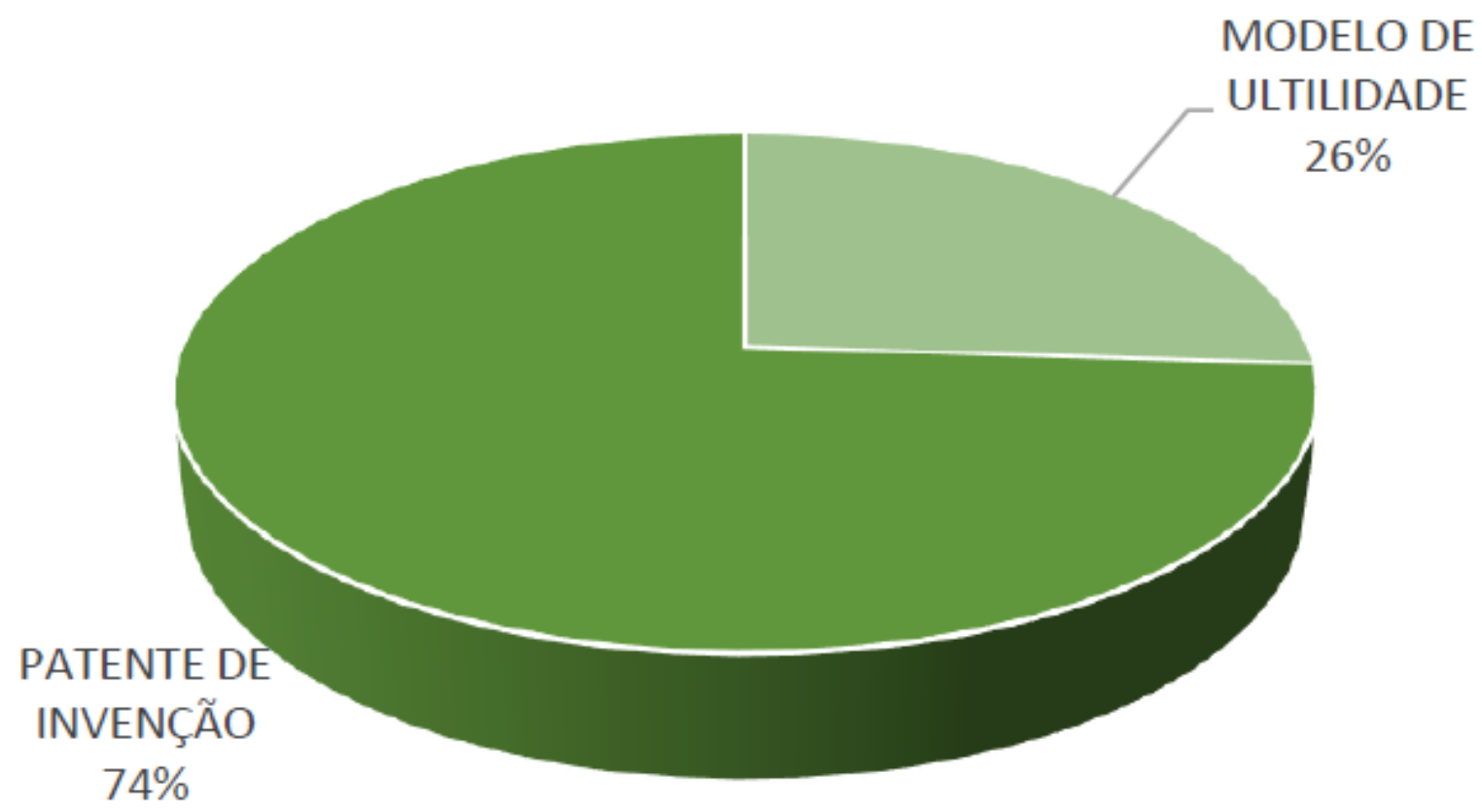

- MODELO DE ULTILIDADE - PATENTE DE INVENÇÃO

Fonte: Autoria própria baseado no INPI, Revista RPI n 2623 de abril de 2021 
A figura 7 mostra que a maioria dos depósitos são de Patentes de Invenção, representando $74 \%$ das tecnologias encontradas.

Figura 8 - Patentes por ano de depósito

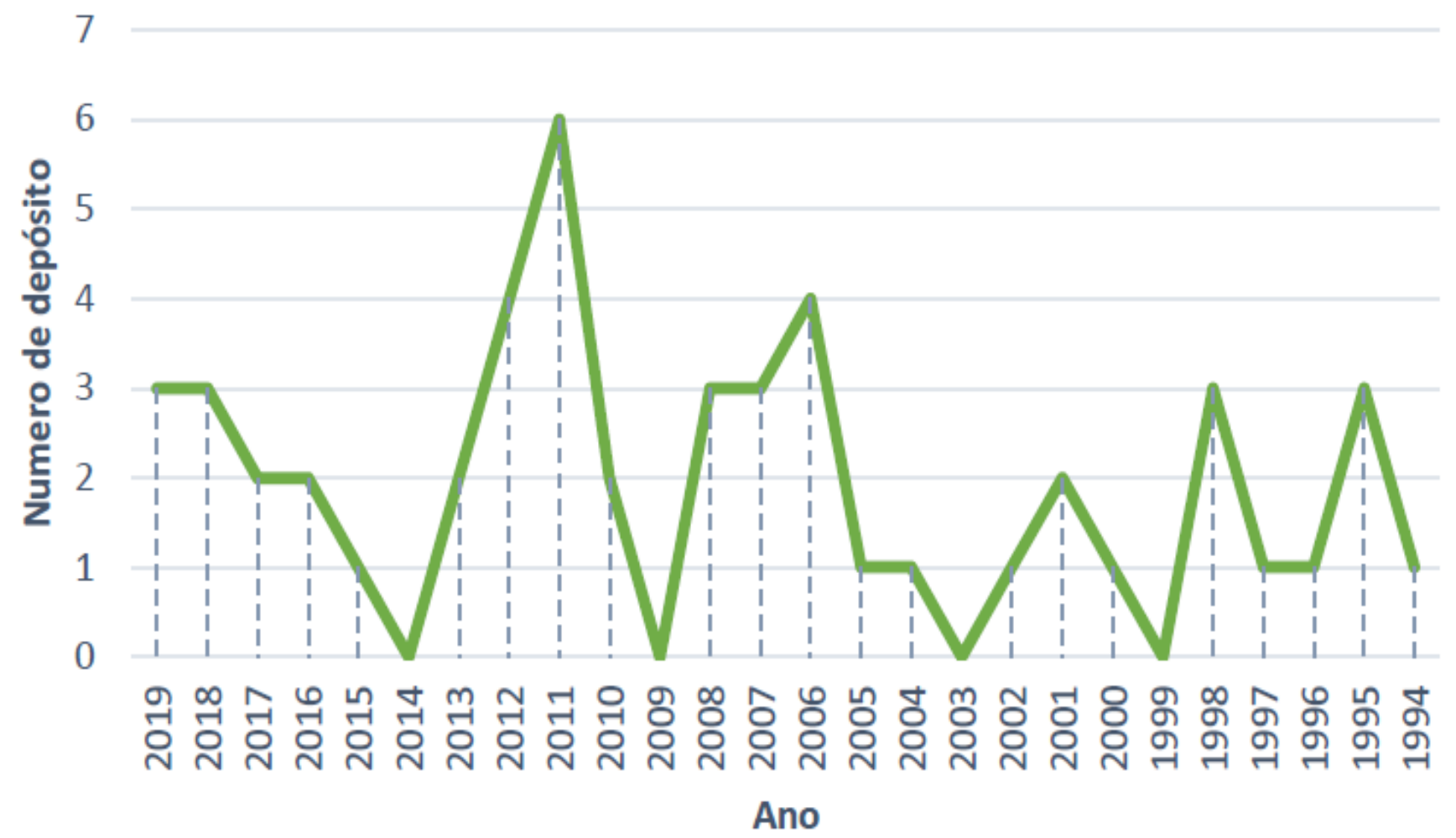

Fonte: Autoria própria baseado no INPI, Revista RPI n 2623 de abril de 2021

A figura 8 mostra o depósito de patentes nos últimos 27 anos constatando que a maior ocorrência foi em 2011, com 6 depósitos, após isso há uma queda até os anos de 2014, e uma retomada de crescimento até 2019.

A figura 10 mostra a classificação dos depósitos das patentes conforme a Classificação Internacional de Patentes (IPC, na sigla em inglês), tendo as seções classificas da letra $A$ até a letra $\mathrm{H}$, cada uma delas representando um grupo de tecnologias patenteáveis, segundo descrição abaixo:

Seção A - Necessidades Humanas;

Seção B - Operações de Processamento, Transporte;

Seção C - Química e Metalurgia;

Seção D - Têxteis e Papel; 
Seção E - Construções Fixas;

Seção F - Engenharia Mecânica, Iluminação, Aquecimento, Armas, Explosão;

Seção G - Física;

Seção H - Eletricidade;

Figura 9 - Patentes por classificação IPC

Depósitos por classificação IPC

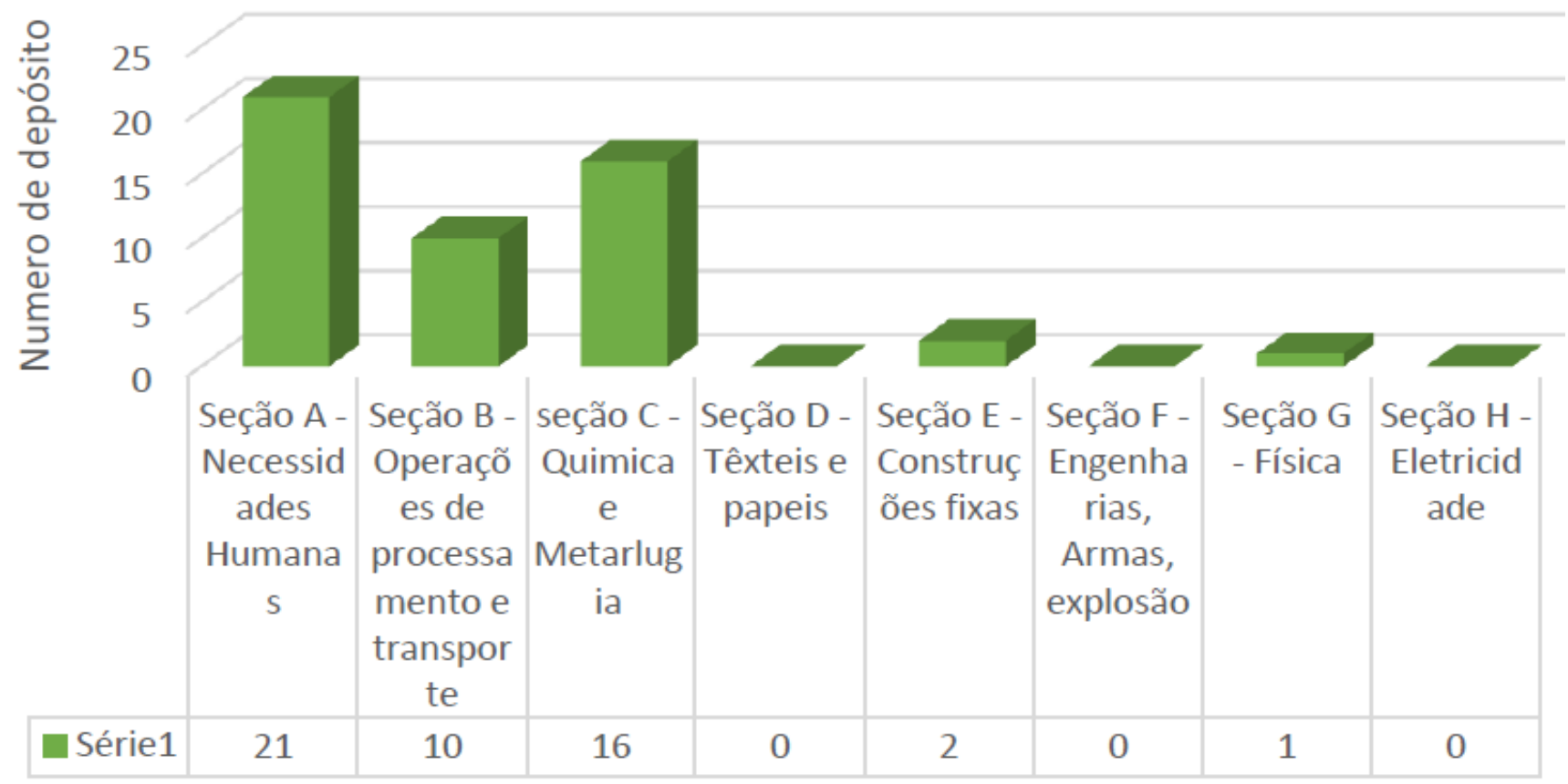

Fonte: Autoria própria baseado no INPI, Revista RPI n 2623 de abril de 2021

Observa na figura 9 que 42\% dos depósitos estão relacionados com a Seção A - Necessidades Humanas, seguido pela Seção C - Química e Metalurgia com $32 \%$ dos depósitos.

\section{CONSIDERAÇÕES FINAIS}

Assim, observa-se que esse direito de proteção além de cooperar com a preservação do direito à propriedade intelectual das organizações inovadoras e seus inventores, também permite incentivo na promoção das políticas socioam- 
bientais que proporciona uma valorização do ativo intangível da sociedade brasileira, além de promover a geração de tecnologias mais sustentáveis.

Como sugestão para futuras pesquisas, seria interessante avaliar como as universidades e organizações empresariais operacionalizam estas tecnologias, seja por meio de concessão, licenças e transferências tecnológicas, a fim de ampliar o poder de transformação destas tecnologias para a construção de um mundo mais sustentável.

Outras conclusões sobre os resultados pautam-se na evidenciação que nos últimos anos a produção de tecnologias verdes, sustentáveis e limpas vêm tendo uma diminuição em termo de patentes reivindicadas, isso causa preocupação, pois é inversamente proporcional ao crescente casos e notícias de impactos ambientais vividos no cotidiano.

\section{REFERENCIAS}

GARRIDO, E.C. Potencial de negócios em patentes verdes: foco em tecnologias para produção de biofertilizantes. 2018. Disponível em: <http://www. profnit.org.br/wp-content/uploads/2019/06/UFBA-Eduardo-Garrido-TCC.pdf> Acesso em: 11 abr.2021.

INSTITUTO NACIONAL DA PROPRIEDADE INDUSTRIAL (INPI). Disponível em: $<$ http://www.inpi.gov.br/portal/>Acesso em: 11 abr. 2021.

MORAIS, S.M.P. Prospecção tecnológica em documentos com patentes verdes. 2014. Disponível em: <https://repositorio.ufpb.br/jspui/bitstream/tede/3966/1/ arquivototal.pdf> Acesso em abri.2021.

OLIVEIRA, R.S. O licenciamento das patentes verdes e o papel da propriedade industrial na economia sustentável. 2017. Disponível em:< https://jus. com.br/artigos/57791/o-licenciamento-das-patentes-verdes-e-o-papel-da-propriedade-industrial-na-economia-sustentavel> Acesso em: 11 abr. 2021.

PATENTSCOPE. Disponível em: <https://patentscope.wipo.int/search/pt/search. jsf>. Acesso em: abri.2021.. 
SILVA, L.F.A.; SILVA, G.P.A.; PROFETA F.A.; GOMES, V.M.; COSTA, R.E.; CALIXTO, W.P. ALVES, A.J. Inovação e Patentes Verdes: práticas para o desenvolvimento sustentável. 2016 Disponível em: <http://online.unisc.br/acadnet/ anais/index.php/semic/article/view/13575>. Acesso em: 11 abr. 2021.

SOUZA, D.F.; RABELO, O.S. Ecoinovação: uma análise através das patentes verdes no Brasil.2015. Disponívelem:<http://engemausp.submissao.com.br/17/ anais/arquivos/250.pdf>. Acesso em: 11 abr. 2021.

SUZIN, Q.P: MARCANZONI, A.P; BITTENCOURT, R.S. Registros de patentes no Brasil com foco nas patentes verdes. 2016. Disponível em:< http://www. ucs.br/etc/conferencias/index.php/mostraucsppga/xvimostrappga/paper/viewFile/4844/1718> Acesso em: 11 abr. 2021. 
dol 10.48209/978-65-89949-D2-F

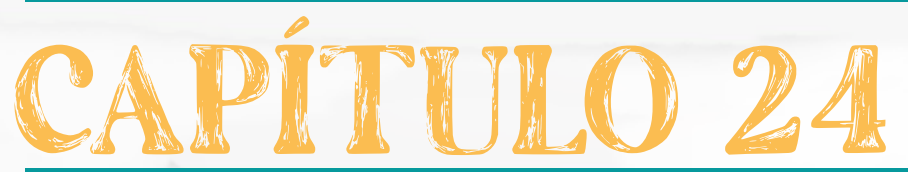

\section{DIREITOS} HUMANOS

\section{NO SISTEMA PRISIONAL}

\section{NA PANDEMIA}

Naiara Ferreira Paim 


\section{INTRODUÇÃO}

Para exemplificar o potencial de contaminação da Covid-19 dentro das prisões, indica-se que, entre os dias 15 e 19 de junho, houve testagem em todas as pessoas presas da Penitenciária II de Sorocaba (SP). Na unidade, onde há 2.073 pessoas ( $77 \%$ a mais do que sua capacidade), 747 (ou seja, $36 \%$ ) estavam infectadas com o vírus. Mesmo após a testagem em massa, a unidade prisional manteve nas mesmas celas superlotadas pessoas que testaram positivo e negativo, em desrespeito com a vida destas pessoas, de servidores e ignorando os protocolos de cuidado já publicados.

Segundo dados colhidos pelo Conselho Nacional de Justiça (CNJ), de maio a início de junho de 2020 , houve aumento de $2.237 \%$ nas taxas de contaminação nos presídios e de, ao menos $288 \%$, dos índices de mortalidade. Os números ainda estão longe de dar conta da realidade já que não há nenhum programa de testes massivos ou sequer significativos no sistema prisional. No que se refere à contagem de casos e à temática da subnotificação, um painel foi lançado pelo Departamento Penitenciário (DEPEN) durante este período sobre presídios. Os dados não produzem, por exemplo, informações sobre número de presos com síndrome gripal, essencial para se avaliar a potencialidade da presença da Covid-19 em cada estado, especialmente se for levado em conta a ausência de testes. Estima-se que no pior cenário do vírus, aproximadamente 10 mil presos podem necessitar de acesso a unidades de tratamento intensivo de saúde, levando em consideração os grupos de risco e as faixas etárias.

O presente artigo tem como objetivo realizar o estudo dos Direitos Humanos no Sistema Prisional na Pandemia através da pesquisa exploratória com conotação qualitativa. Diante dos resultados, foi realizada a análise de conteúdo e discussão dos resultados. 


\section{METODOLOGIA}

A metodologia adotada foi o estudo de caso. Quanto ao tipo de pesquisa foi exploratória e descritiva com conotação qualitativa.

Duarte (2020) descreve a pesquisa descritiva como uma pesquisa com as características de uma população ou fenômeno. Estudo que tem por objetivo fazer o levantamento de opiniões, atitudes, crenças e valores de um determinado grupo.

Segundo Gil (2019), a pesquisa exploratória tem como objetivo propiciar maior familiaridade com o problema, com vistas a construir hipóteses. Seu planejamento tende ser muito flexível, pois interessa considerar os mais diversos aspectos relativos fenômeno estudado.

Rocha (2020) define a pesquisa qualitativa como uma metodologia de caráter exploratório. Seu foco está no caráter subjetivo do objeto analisado. Em outras palavras, busca compreender o comportamento do consumidor, estudando as suas particularidades e experiências individuais, entre outros aspectos. Nesse método, as respostas costumam não ser objetivas, ou seja, os resultados obtidos não são contabilizados em números exatos. A coleta dos dados pode ser feita de diversas maneiras. Por exemplo, através de grupos de discussão (focus groups) e entrevistas qualitativas individuais. Normalmente, a amostra é pequena e os entrevistados são estimulados a se sentirem à vontade para dar sua opinião sobre assuntos que relacionados com o objeto de estudo.

Após a conclusão da etapa de coleta de dados, será realizada a análise de conteúdo.

A análise de conteúdo busca compreender o significado dos dados coletados e tem o objetivo de facilitar o entendimento dos conteúdos através de alguma classificação apresentada de forma sistematizada, que pode ser a divisão em categorias ou pela contagem de palavras e termos contidos nas respostas (MARTINS, 2017).

Diante da análise de conteúdo foi feita a discussão dos resultados. 


\section{RESULTADOS/DISCUSSÃO}

Em pesquisa realizada pela Fundação Oswaldo Cruz (Fiocruz), foi apontado que a tuberculose, doença controlada e de fácil tratamento extramuros, tem incidência 30 vezes maior dentro das prisões. O que se gestou assim, pela falta de acesso à saúde e condições insalubres e degradantes, um contingente incontável de presos com comorbidades, como problemas respiratórios, cardiológicos e diabetes, fatores que colocam pessoas nos grupos de risco da Covid-19. Destacase que, ao falarmos em acesso à saúde, tratamos não apenas de falta de medicamentos e requisitos mínimos de saneamento, mas também de um déficit abissal de profissionais de saúde e condições dignas.

Apesar da alarmante situação, as poucas ações do governo federal são completamente impraticáveis no cenário prisional nacional, como a Portaria Interministerial dos Ministérios da Justiça e Segurança Pública e da Saúde $n^{\circ}$ 7/2020, que prevê medidas de distanciamento social em unidades superlotadas ou protocolos que pressupõem um acesso a profissionais de saúde nos ambulatórios das unidades, cenário completamente diverso do encontrado nas unidades. Vale pontuar, que a Política

Nacional de Atenção Integral à Saúde das Pessoas Privadas de Liberdade no Sistema Prisional (PNAISP), de 2014 e que visava garantir aos presos acesso ao SUS, jamais foi efetivada.

No país, $31 \%$ das unidades prisionais não possuem nenhuma cobertura de saúde, segundo dados produzidos pelo Conselho Nacional do Ministério Público (CNMP)7. No Nordeste, $42,7 \%$ das prisões estão nesta situação e nas demais regiões variam entre 26 e $30 \%$. Assim, em torno de 456 prisões não têm assistência médica. Quando há presença de médicos, estes muitas vezes vão somente duas vezes por semana. Existe, em média, um médico para cada 687 presos, índice inferior ao acesso da população extramuros que possui um médico para 460. 
Além da inércia, as autoridades públicas brasileiras têm, em meio à pandemia, endereçado políticas de retirada ou restrição ainda maior de direitos. A Portaria n. 135 do Ministério da Justiça e Segurança Pública limitou não apenas a entrada de advogados e de visitantes em unidades prisionais federais, mas também o acesso a banho de sol e a atividades de trabalho, lazer e outras, o que foi prontamente replicado nos mais diversos estados da federação. A limitação ao tempo de atividades externas às celas ocasiona violação massiva dos direitos humanos dos presos, que passam a viver em regime absoluto de confinamento, o que aumenta a contaminação por doenças infecciosas. Segundo a Comissão Interamericana de Direitos Humanos, em comunicado emitido em 17 de abril deste ano, a pandemia não pode servir de justificativa para a violação de direitos humanos assumidos a partir de suas obrigações internacionais.

O próprio CNJ reconhece a precariedade de testagem de infecção pelo vírus, especialmente no contexto prisional, indicando o possível não diagnóstico de óbitos de pessoas presas pela ausência de testes da Covid-19. Neste cenário, ainda se vê retrocessos severos em relação ao direito à memória e à dignidade daqueles que vêm a óbito. Em um país em que o desaparecimento forçado em presídios faz parte da realidade local, o risco de subnotificação de óbitos e de encobrimento de mortes violentas durante o período pandêmico torna-se ainda mais agudo. Em plena contrariedade a protocolos básicos de perícia, como Protocolo de Minessota, foi editada a Resolução SEAP/SEPOL n 10 no Rio de Janeiro. A resolução passou a responsabilidade sobre declarações de óbito de presos para os médicos da própria administração penitenciária, retirando dos IMLs tal competência.

Tal ação vem gerando um uso massivo da categoria "causa indeterminada" para determinar o motivo pelos quais presos estão morrendo. Destaca-se uma duplicação do número de óbitos no sistema, que, em 7 de maio, já chegava a 82. Destes 82,58 vieram a óbito entre março e maio (70,73\%), ou seja, duplicou-se a taxa de mortalidade dos presos se comparado aos índices encontrados em janeiro e fevereiro. A situação se torna ainda mais crítica com a constatação 
do Departamento Penitenciário Nacional de que dentro dos muros do cárcere a letalidade da Covid-19 é cinco vezes a daquela que aflige a sociedade. A primeira morte dentro dos estabelecimentos prisionais ocorreu nove dias após o primeiro caso confirmado, enquanto na população em geral ocorreu 20 dias após. É urgente que medidas sejam adotadas para reverter este quadro sob pena de ser impossível a recuperação da memória das vítimas desaparecidas em prisões durante a pandemia da Covid-19.

A superlotação das unidades prisionais brasileiras é um elemento agravador para a vida das pessoas presas e dos profissionais do sistema prisional. $O$ Brasil possui déficit de cerca de 303 mil vagas, acarretando $171,62 \%$ de taxa de ocupação no Sistema Penitenciário. Conforme a Organização Mundial de Saúde, a Comissão Interamericana de Direitos Humanos e a Organização das Nações Unidas, a única medida eficaz para a real contenção da doença é a redução emergencial do encarceramento. No entanto, no Brasil, essa política é fortemente atacada. O Conselho Nacional de Justiça editou a Recomendação $n^{\circ} 62$, que, dentre outras medidas, orienta magistradas/os a: i) reavaliarem todas as prisões provisórias de pessoas que se enquadrem no grupo de risco à contaminação pela Covid-19, presas há mais de 90 dias, ii) determinar a saída antecipada de pessoas do grupo de risco ou que estejam em unidades superlotadas, iii) decretarem novas prisões apenas em casos de crimes com violência ou grave ameaça.

Uma pesquisa realizada pela Defensoria Pública do Estado de São Paulo levantou a proporção entre prisões e liberdade nos casos assistidos por seus defensores em atuação no Departamento de Inquéritos Policiais e Polícia Judiciária da Capital (DIPO) durante os três primeiros dias de vigência da Recomendação $\mathrm{n}^{\circ}$ 62: entre os dias 17 e 19 de março de 2020, foram apresentados 199 autos de prisão em flagrante, nos quais houve concessão de liberdade provisória ou relaxamento da prisão em apenas 57 casos. Tal número se equipara ao período pré- pandemia. Outro levantamento da Defensoria Pública de São Paulo demonstra o cenário de manutenção do superencarceramento: dentro de um universo de 25,8 mil 
processos que tiveram movimentação, apenas 756. pessoas presas pertencentes a grupos de risco para a Covid-19 tiveram alvará de soltura expedidos. Dados do Instituto Pro Bono mostram que de 507 Habeas Corpus impetrados, apenas 25 foram concedidos. No mesmo sentido, caminham as decisões de Habeas Corpus coletivos, cuja negativa vem sendo a regra, apesar dos esforços de diversas defensorias como Amazonas, Rio Grande do Norte, Ceará, Distrito Federal, Espírito Santo, São Paulo e Rio de Janeiro.

Esta postura refratária à implementação mínima de salvaguardas ao grave risco à saúde e vida dos presos é reproduzida tanto nas primeiras instâncias, como no próprio Superior Tribunal de Justiça e Superior Tribunal Federal. O mesmo se observa quanto à situação de mulheres gestantes, lactantes ou mães com filhos de até 12 anos, em que a liberdade ou, no mínimo, a prisão domiciliar deveria ser a regra. Segundo o Marco Legal da Primeira Infância (Lei no 13.257/2016), essa garantia tem como objetivo proteger o direito do nascituro a uma gestação distante do ambiente carcerário e da criança a ter proximidade com a mãe em uma fase tão crítica de seu desenvolvimento. No entanto, apesar das expressas previsões legais e do enquadramento como grupo de risco à contaminação pelo coronavírus, o STJ continua a manter até mesmo mulheres gestantes, puérperas e lactantes presas durante a pandemia que se alastra pelas unidades prisionais.

Quanto incomunicabilidade nas prisões, que já vinha sendo utilizada de forma ilegal e arbitrária como política de Estado, com a declaração da pandemia, se tornou uma das principais políticas de combate à Covid-19 nas prisões, pela já mencionada Portaria n 135 do Ministério da Justiça e Segurança Pública. Embora o discurso tenha sido de isolamento temporário, a prática é de rompimento total de comunicação e contato externo das pessoas presas, uma vez que estes são praticamente apenas realizados por meio das visitas pessoais de familiares, advogados e defensores públicos. Ressalta-se que a incomunicabilidade viola as Regras de Mandela número 56 e 58. 
No cenário de uma pandemia é ainda mais necessário haver a transparência das informações e a constância com que a mesma ocorre, sob o risco de ampliar o medo e a angústia nas pessoas que têm seus familiares em situação tão desfavorecida. É certo que a proibição das visitas é acompanhada da ausência de transparência sobre a situação de saúde e, por vezes, da própria localização das pessoas presas. Nesse sentido, os Mecanismos de Prevenção à Tortura no Brasil e o CNJ construíram documentos orientando e recomendando a criação de espaços interinstitucionais que possam lidar com a dramática situação dos locais de privação de liberdade no Brasil e tentar impedir o cenário generalizado de incomunicabilidade. Contudo, vários são os relatos de que as famílias não falam ou não têm informações dos seus entes há meses. Muitos estados têm apostado no precário e lento sistema de entrega de cartas ou nas visitas por videoconferência para a comunicação entre presos e familiares.

Relatos de familiares dão conta, contudo, de que as cartas têm demorado mais do que o usual para ser entregues e, em alguns casos, sequer o são. As videoconferências, por outro lado, segregam e vulnerabilizam ainda mais uma população que já sobrevive às desigualdades do país. Para garantir um máximo de cinco minutos de contato virtual, famílias tiram recursos do seu próprio sustento para arcar com planos de dados e outras exigências do poder público. Tirar o direito à comunicação com seus familiares, advogados e organizações representativas é colocar em risco o direito à vida das pessoas privadas de liberdade. A falta de informações fidedignas, desencontradas e com pouca comprovação, aponta para a omissão de cuidado com a Covid-19 dentro das prisões. As denúncias de violações de direitos eram, em sua maioria, realizadas aos familiares, durante as visitas, a defensores, em atendimento presencial ou mesmo durante assistência religiosa.

Embora alguns estados já divulguem o planejamento de reabertura e retomada do comércio, restaurantes, escolas etc., condicionando determinadas atividades a índice de contágio e óbitos, não há, em nenhum dos planos até agora 
publicizados, menção a uma estratégia de retomada das visitas por familiares em unidades prisionais. Seguindo a lógica da incomunicabilidade, especialmente grave é a posição adotada pelo DEPEN segundo resposta ao ofício enviado à Secretaria de Administração Penitenciária do Rio de Janeiro em 29 de abril, sobre a aplicação de fundos para sanitização das unidades. No documento, ao explicar sobre os possíveis usos do fundo emergencial para Covid-19, destaca-se que parte do repasse a ser realizado aos estados pode ser utilizado para aquisição de armas menos letais. O DEPEN prevê a possibilidade de que se utilize de violência institucional para romper com possíveis situações de tensionamento que advenham desse isolamento. Neste sentido, pune-se ainda mais os presos por uma política que a priori já se coloca frontalmente contrária aos padrões mínimos de direitos humanos.

Os dados são importantes para a promoção de políticas públicas voltadas para cada região e ressaltam informações importantes, por exemplo: a população carcerária feminina no Brasil está abaixo da média mundial, mas tem crescido nos últimos anos por causa do envolvimento das mulheres no tráfico de drogas.

Em síntese a realidade das instalações prisionais brasileiras não corresponde à previsão legal. Os principais fatores de violação aos direitos humanos são:

\section{- Superlotação}

O sistema penitenciário no Brasil opera com sua capacidade máxima extrapolada em quase $70 \%$. Os presos dormem em valete para caberem todos dentro do mesmo espaço, sofrem violência sexual, agressões físicas e, ocasionalmente, são mortos por membros de facções inimigas indevidamente alocados dentro da mesma carceragem.

\section{- Condições de Higiene}

A superlotação alimenta outro problema: a insalubridade, responsável por infecções, tuberculose e doenças gastrointestinais, entre outras patologias. A assistência médica é limitada, afinal, médicos, enfermeiros e dentistas não 
gostam de atender no sistema prisional. Quando o fazem, têm estrutura física, equipamentos e recursos limitadíssimos.

\section{- Tortura}

As Regras de Mandela, bem como a Constituição Federal, vedam a prática, mas é comum encontrar na mídia notícias de presidiários torturados, submetidos a tratamento desumano ou degradante. Agredidos e privados de necessidades fisiológicas, muitos chegam à loucura, isso quando conseguem resistir.

Das 90 denúncias de violações de direitos monitoradas pela Pastoral entre 15 de março de 31 de outubro do ano passado, $74,4 \%$ dizem respeito à negligência na prestação da assistência à saúde.

As violações ocorreram e seguem sendo registradas em um momento em que o coronavírus segue avançando em alta velocidade dentro dos muros das prisões.

De acordo com o último boletim informativo do Conselho Nacional de Justiça (CNJ), publicado em 18 de janeiro, 57.454 infecções pela covid-19 foram registradas nas unidades, entre servidores e presos. Somente nos primeiros 22 dias de 2021 foram confirmadas mais de 2,3 mil contaminações.

No total, o número de pessoas privadas de liberdade que testaram positivo para o vírus é de 43.799, com o registro de 130 óbitos. Entre os trabalhadores foram relatadas 13.655 contaminações e 99 vítimas fatais.

As denúncias de tortura apresentada pelo relatório englobam também 53 agressões físicas, 52 relatos de condições humilhantes e degradantes de tratamento. Entre elas a ausência de banho de sol, racionamento de água, convívio irrestrito entre presos enfermos e saudáveis e a obrigatoriedade de permanecerem em "posição de procedimento", com cabeça abaixada e mãos para trás, por longos períodos. 
Mais de 50 denúncias envolveram negligência na prestação da assistência material, o que abrange o precário fornecimento de alimentação, vestuário, produtos de higiene pessoal e produtos de limpeza.

Mayra Balan, do setor jurídico da Pastoral Carcerária e uma das autoras do relatório, critica posicionamentos tomados pelo governo federal e a ausência completa de um plano de combate ao vírus no cárcere. "A pandemia e o desgoverno que enfrentamos proporcionaram que a covid-19 fosse usada como um outro instrumento de tortura dentro do cárcere. Quando Jair Bolsonaro vetou o uso obrigatório de máscara dentro das prisões, com uma canetada, ele evidenciou a política de extermínio que segue em curso", afirma Balan.

Dados do Banco de Monitoramento de Prisões, do Conselho Nacional de Justiça (CNJ), apontam que atualmente a população carcerária do Brasil é de 812.564 pessoas. Segundo a advogada, a fiscalização das condições subumanas às quais os presos estão submetidos a pandemia, também foi insuficiente por parte dos órgãos da Justiça, do governo federal e gestões estaduais, assim como a urgência na proteção das pessoas presas.

Um exemplo disso é o vaivém relacionado à inclusão da população carcerária entre os grupos prioritários para a imunização. "Ficou claro que o alto escalão [desses órgãos] entende que as vidas presas valem menos. Quando não há uma política de vacinação efetiva, assistência à saúde, fica claro que as vidas presas não são passíveis de preocupação pelos governos".

O relatório da Pastoral Carcerária alerta que a subnotificação de dados e informações relacionadas à pandemia e seu impacto nas prisões é flagrante. Até outubro do ano passado, conforme contagem do Departamento Penitenciário Nacional (Depen), apenas $9,71 \%$ da população carcerária havia sido testada para o coronavírus.

Além do descaso histórico do próprio Estado, a suspensão das visitas familiares e de assistência religiosa para evitar o contágio impediu que as 
denúncias chegassem aos órgãos externos como a própria Pastoral. "Esses são os principais canais de recebimento das denúncias. É alta a probabilidade que a realidade seja ainda pior", lamenta Balan.

"O cárcere ficou fechado, o mundo vivendo uma anormalidade e enquanto isso as incursões e intervenções continuaram acontecendo. A política de extermínio seguiu firme e forte. Para além do vírus que tem uma letalidade alta, a letalidade que o Estado proporciona dentro das prisões e das favelas Brasil afora continuou operando", ressalta a advogada.

Ela destaca que entre as denúncias de tortura são frequentes os relatos de que os presos que apresentaram sintomas não foram colocados em isolamento ou não receberam o material necessário para a profilaxia, como água, sabonete e álcool gel.

Há ainda depoimentos sobre agravamento do sofrimento mental dos presos e desenvolvimento do adoecimento psicológico em razão da própria brutalidade do cárcere, mas também da desinformação sobre familiares durante a pandemia.

Outras denúncias relataram a interrupção de tratamentos de saúde para doenças crônicas e ainda surtos de outras doenças como tuberculose, que assim como a covid também afeta o sistema respiratório.

Com relação a resolução 62/2020, no início da pandemia, o CNJ alertou para os perigos da proliferação do coronavírus no cárcere e incentivou magistrados a reverem prisões de pessoas de grupos de risco e em final de pena que não tenham cometido crimes violentos ou com grave ameaça.

A adaptação para prisão domiciliar ou monitoração eletrônica sugerida pela Resolução 62/2020 é, justamente, para evitar as aglomerações e barrar o contágio nas prisões. O texto também sugere a reavaliação das prisões provisórias, com prioridade para mulheres gestantes, lactantes, mães ou pessoas responsáveis por crianças de até 12 anos. 
Pessoa com deficiência, idosos, indígenas ou outras pessoas que se enquadrem no grupo de risco também podem ser beneficiadas pela resolução, que tem validade até março.

No entanto, levantamento feito pelo CNJ em junho do ano passado mostra que apenas 32,5 mil pessoas foram retiradas das unidades em razão da pandemia.O número é irrisório e compreende somente $4,8 \%$ do total de pessoas em privação de liberdade, excluídos o regime aberto e presos em delegacias.

Apesardasorientações daResolução, juízes edesembargadores continuaram decretando novas penas em regime fechado, insuflando a população carcerária e ignorando completamente a alta transmissibilidade do vírus dentro das celas. É uma classe altamente punitivista e que não reflete o sistema prisional. Uma classe majoritariamente branca com perspectivas machistas e racistas", comenta a integrante do setor jurídico da organização, enfatizando que "a única forma de parar o contágio da covid é desencarcerando.

\section{CONSIDERAÇÕES FINAIS}

O Estado brasileiro, diante da pandemia, vem baseando sua ação no negacionismo, com a subnotificação de casos, a vedação ao direito à saúde, a manutenção do encarceramento em massa e a incomunicabilidade das pessoas presas, fluxos que produzem o agravamento da tortura, de execuções e de desaparecimentos forçados. O Estado deve proteger vidas e a ele é proibido decretar, generalizada e sistematicamente, a morte cruel das pessoas privadas de liberdade, marcadas pelo desrespeito de seu direito à vida, à saúde, à integridade física, ao acesso à justiça e à memória e verdade.

\section{REFERÊNCIAS}

FIOCRUZ. Presídios têm 30 vezes mais casos de tuberculose: Disponível em:https://portal.fiocruz.br/noticia/presidios-tem-30vezes-mais-casos-detuberculose. Acesso em: 26 jun.2021. 
IGNACIO, Julia. Sistema prisional brasileiro e o respeito aos direitos humanos: entenda! Disponível em: https://www.politize.com.br/sistema-prisional-e-direitoshumanos-entenda/. Acesso em: 26 jun.2021.

JUSBRASIL. Artigo 38 do Decreto Lei n 3.689 de 03 de outubro de 1941. Disponível em: https://www.jusbrasil.com.br/topicos/10676375/artigo-38-do-decreto-lei-n3689-de-03-de-outubro-de-1941. Acesso em: 26 jun.2021.

MACHADO, R. Pandemia, Sistema Carcerário e a Violação Dos Direitos Humanos. Revista Brasileira de Desenvolvimento, Curitiba, v. 7, n. 5 de maio. 2021

MARTINS, Everton. Análise de dados: o que é, metodologia e tipos de análise. In:Mettzer.2017. Disponível em: https://blog.mettzer.com/analise-de-dados/. Acesso em: 26 jun. 2021.

NOVO, Benigno Núñez. Sistema Carcerário Brasileiro: Problemas e Soluções. Disponível em: https://meuartigo.brasilescola.uol.com.br/brasil/sistema-carcerariobrasileiro-problemas-solucoes.htm. Acesso em: 16 jun.2021.

ROCHA, Hugo. O que é Pesquisa Qualitativa, tipos, vantagens, como fazer e exemplos. In:Klickpages.2020. Disponível em: https://klickpages.com.br/blog/oque-e-pesquisa-qualitativa/. Acesso em: 26 jun. 2021.

TUMELERO, Naína. Pesquisa exploratória: conceito, características e aplicação em 4 passos. In: Mettzer. 2019. Disponível em: https://blog.mettzer. com/pesquisa-exploratoria/. Acesso em: 26 nov. 2020.

YIN, Robert K. Estudo de caso: planejamento e métodos. 5.ed. Porto Alegre: Bookman, 2015,p.117. 


\section{dol 10.48209/978-65-89949-D2-G}

\section{CAPITULO 25}

\section{DIGNIDADE HUMANA}

COMO PRINCÍPIO

REITOR À EDUCAÇÃO DO (RE) EDUCANDO:

\section{DA ILHA AO CONTINENTE}

Ulysses Fonseca Louzada Denise Santos da Cruz Adriana Moreira da Rocha Veiga 


\section{INTRODUÇÃO}

Qual o impulso que ao longo da vida te levou adiante? Você já deve ter pensado seriamente nesta questão. E, se não pensou, está será uma boa oportunidade. Podemos pensar que existe um "princípio reitor" que nos impulsiona. A palavra "reitor" reporta ao espanhol rector, significando diretor. Princípio reitor, portanto, pode ser entendido como princípio diretor - aquele que está na base.

Propomos neste artigo defender a dignidade humana como princípio reitor à educação do (re) educando, com o intuito de identificar se a ressocialização é possível nos estabelecimentos totais ou se haveria outra possibilidade recuperativa para os moradores compulsórios desses locais, aos quais denominamos de Ilha, lado de lá, diferente em tudo do lado de cá, o Continente. Ilha, no sentido de Presídio; Continente, no sentido da vida anterior, da sociedade em que vivia e que pretende voltar.

Erving Goffman (2019, p. 16) define os Estabelecimentos Totais como "Instituições criadas para proteger a comunidade contra perigos intencionais, sendo que o bem-estar das pessoas assim isoladas não constitui problema imediato (cadeias, penitenciárias, campos de prisioneiros de guerra, campos de concentração) ". O (re) educando, neste texto é a pessoa isolada nos estabelecimentos totais do Sistema Penitenciário na realidade brasileira atual. Portanto, será a dignidade humana dessas pessoas reclusas que moverá o nosso pensamento como operadores de direito, no sentido stricto, o juiz educador e a pedagoga.

Este artigo utiliza-se da Hermenêutica Gadameriana, para cotejar ideias em busca de saídas possíveis contra a barbárie e a favor da humanização. A nossa percepção reforça a ideia de que a ressocialização é uma utopia, e não uma realidade, da forma que se apresenta aos nossos sentidos o que se passa na Ilha e as frustradas experiências de ressocialização.

Destarte, propomos que a Educação, como processo educativo e de formação humana poderá vir a ser uma caminhada viável, durante o cumprimento da pena privativa da liberdade, para o retorno do recluso ao Continente. Reforçamos 
que não pode ser apenas uma recuperação abstrata e ao acaso, convencional, mas produto de uma conscientização trabalhada para a emancipação, estudada, que proporcione ao recluso refletir profundamente a respeito do delito que protagonizou, errando.

A tomada de consciência do delito e da culpa parece não decorrer apenas do cumprimento da pena de reclusão sem um processo subjetivo e intersubjetivo de compreensão dos valores humanos - perdidos ou nunca adquiridos. Essa autoconsciência requer do morador compulsório se preparar, estar em condições, para retornar ao convívio social - Continente, objetivando não mais retornar à prisão - Ilha.

\section{ESTUDO HISTÓRICO-DESCRITIVO E O HORIZONTE HERMENÊUTICO}

A argumentação neste estudo foi guiada pelo horizonte hermenêutico do pensamento de Hans-Georg Gadamer (2005), pretendendo a interpretação do diálogo entre "passado, presente e futuro" na Educação e na Reeducação como possibilidades no sistema prisional para delinear uma prospecção possível sinalizadoras de importantes contextos e desafios. De acordo com Gadamer (2005, p. 489): "[...] todo compreender é sempre algo mais que a mera compreensão. Nós partimos do conhecimento também de que a compreensão que se exerce nas ciências do espírito é essencialmente histórica".

A hermenêutica permite trabalhar com o texto, percebendo as diferenças no uso da linguagem e localizando-as historicamente, de modo que sejam vistos e reconfigurados em outro contexto. O debruçar-se sobre os textos em busca das respostas foi exercício instigante.

A hermenêutica Gadameriana permitiu a exploração de novos sentidos à apropriação dos resultados do estudo histórico-descritivo. O discurso hermenêutico representa uma condição para pensar a realidade, nos contextos de atuação, indispensável ao processo investigativo como possibilidade. 
Gadamer (1999; 2005), considera a significação de um texto aberta às intenções do autor.

Ao passar de um contexto cultural a outro, o texto pode adquirir novas e imprevistas significações. Procurou-se o inédito-viável, descrito por Ana Maria Araújo Freire (1992, pp. 205-7), o qual neste contexto refere-se à interpretação tornada inédita e passível de ser construída ao se estudar sistematicamente o que torna possível a $[R e]$ educação no Sistema Penitenciário Brasileiro na atualidade.

\section{DA ILHA AO CONTINENTE, SEM VOLTA}

Retomando o nosso tema, estamos em busca de novos impulsos que levem adiante na vida os egressos da Ilha; que os icem da Ilha ao Continente, definitivamente, para que retomem a sua vida com dignidade humana. O "princípio reitor" que nos impulsiona como educadores, pesquisadores da educação, é a dignidade humana. Esta se encontra no cerne dos direitos humanos.

Na Conferência Mundial de Direitos Humanos realizada em Viena, em 1993, foi ratificado que os direitos humanos, em sua totalidade, configuram-se universais, indivisíveis, interdependentes e inter-relacionados, assim reza a Declaração Universal dos Direitos Humanos (MELO, 2021).

A essência do ser humano é única, como identidade própria da pessoa e como identidade comum com os demais indivíduos da espécie, pensando em consonância com o paradigma da complexidade (MORIN, 2015). O ser humano é uno, mas também múltiplo, quanto às diferenças individuais e sociais, biológicas e culturais, merecendo todos respeito e proteção, independentemente de tempo e espaço geográfico. Os moradores compulsórios da llha não sabem disso ou os fizeram esquecer.

No contraponto do que Edgar Morin apresenta-nos nas identidades própria e comum, Erving Goffman (2014) possui uma compreensão central pautada na identidade como processo ambivalente que oferece liberdades, amplitudes de 
ação e pluralidades, produzindo ao mesmo tempo imensa sensação de angústia no indivíduo cujo vínculo social é muito frágil e volátil. Traz a alegoria do camaleão social como um ser que reconfigura seus atributos e identidades à medida em que o contexto assim o exige.

A representação do eu na vida cotidiana caracteriza-se no paradoxo do camaleão que vai mudando de cores e de atuação - o indivíduo tenta obter controle sobre as impressões que causou/causa no Outro. Goffman (2014) utiliza a metáfora da ação teatral para demostrar a estrutura que o indivíduo monta para sua defesa e ação frente a cada situação social que o confronta. Assim, atuando em um papel social, o indivíduo emprega técnicas de verificação para saber como os Outros o enxergam, e convoca estes mesmos a responder que impressão está suscitando. Neste ponto, parece-nos essencial averiguar as ideias circulantes na mente de um indivíduo sobre a noção de realidade que ele deseja transmitir àqueles que o circunda. $\mathrm{O}$ autor descreve dois extremos:

(...) o ator pode estar inteiramente compenetrado de seu próprio número, pode estar sinceramente convencido de que a impressão de realidade que encena é a verdadeira realidade. Quando seu público está também convencido deste modo a respeito do espetáculo que o ator encena - e esta parece ser a regra geral - então, pelo menos no momento, somente o sociólogo ou uma pessoa socialmente descontente terão dúvidas sobre a "realidade" do que é apresentado. No outro extremo verificamos que o ator pode não estar completamente compenetrado de sua própria prática (Idem, p, 48).

As pessoas quando ingressam nos estabelecimentos totais, quase sem sentirem, imperceptivelmente, procuram se adaptar ao novo sistema, e o mais rápido possível, sob pena de sucumbirem à sua própria existência (vida). É o dilema: adapta-te ou sumirás!

A Constituição Federal de 1988 elege como valor primordial a dignidade da pessoa humana. O próprio sistema jurídico, em sua totalidade, estabelece o alicerce da ordem jurídica na dignidade da pessoa humana, dela derivando as condições da vida do homem, dela defluindo o respeito à integridade física e psíquica das pessoas, a admissão da existência de pressupostos materiais (patrimoniais, 
inclusive) mínimos para que se possa viver, e o respeito pelas condições fundamentais de liberdade e igualdade (MELO, 2021).

O Sistema não ressocializa, antes, dessocializa. A edição de mais e mais leis, propostas abstratas, infringências aos Direitos e Garantias Fundamentais, não têm resultado efetivo na recuperação dos reclusos na llha. O Plano Nacional de Política Criminal e Penitenciária (20202023) confirma a existência, de fato, da estigmatização das pessoas egressas do sistema penitenciário brasileiro, gerando dificuldade de colocar-se em empregos e mesmo retornar à vida familiar e à reinserção social. Existe a reincidência criminal recorrente, em torno de $70 \%$, ainda o aumento recente da população reclusa nos estabelecimentos totais em presídios de todo o país, significando cerca de 500 mil indivíduos, em sua maioria do sexo masculino.

Em outra pesquisa (LOUZADA, 2003; 2021 a; 2021b), narramos um Estudo de Caso Criminológico Social, vivenciado no universo de várias pessoas que foram ouvidas, interagindo com elas, percebemos que a maioria acenava positivamente para uma proposta educativa nesses estabelecimentos totais. Verificamos que as formações culturais, educacionais e psicológicas de conscientização desses ideais em busca de novas perspectivas, não poderiam ser dirigidas apenas aos reeducandos, mas a todos que viessem a trabalhar nessa jornada recuperativa, como os agentes penitenciários, psicólogos, psiquiatras e educadores. Para repercussão tão ampla e, ao mesmo tempo, eficaz, anuncia-se a pertinência de propostas socioeducativa e pedagógica específicas, propiciando condições mínimas de retorno ao Continente.

E afirmamos isso, porque durante toda a nossa jornada, trabalhando com o Direito (como Professor ou como Operador do Direito), percebemos claramente que, se, em um primeiro momento, o homem nas relações intersubjetivas de interesses com seus pares, adquire valores que farão parte da sua vivência, formando a sua personalidade, seu próprio "Eu", porque o meio nos proporciona isso. Muitas vezes, essas vivências se destoam da normalidade, trazendo como 
resultado a condenação e o respectivo apenamento. Essa contraprestação, com a vivência na Casa Prisional, proporciona a formação de uma subcultura, necessitando de um enfrentamento a fim de que medidas sejam tomadas e possam impedir essa formação educativa ao avesso.

No mesmo enlace, percebemos que a preocupação nos estabelecimentos totais tem sido específica ao Trabalho e ao Lazer. Embora ainda calcada no mito da ressocialização como realidade, defendemos a importância do estímulo aos estudos, afirmando prioritariamente a necessidade da formação de educadores para essa tarefa educativa e proposta pedagógica diferenciada; assim podemos afirmar o efeito positivo da ambiência emancipatória, compreendida na perspectiva da dignidade da pessoa humana.

Nesse ponto, concordamos. Mas, inquieta-nos, por outro lado, as propostas - como em tantas outras demandas reivindicatórias, se apresentarem de forma genérica. Porque se tem visto somente reivindicações críticas, muitas de caráter político-ideológicas ou, ao sabor desse ou daquele caminhar doutrinário, com pseudoutrinas, como se fossem apenas respostas às expectativas sociais, reclamos públicos e privados sem, efetivamente, trazer uma resposta direta e eficaz. Sem trazer uma solução palpável, concreta, e não resultados abertos, abstratos, como políticas públicas, preocupação do Estado, novas leis, enfim. Tudo muito vago, sem ressonância na realidade brasileira atual.

O que são políticas públicas? E, mesmo respondendo no papel, aceitando nesta qualquer resposta, como fazer valer de pronto? Como obrigarmos ao Estado resolver questão tão complexa, de pronto? E quando se fala em questões político-ideológicas, como a Constituição Federal, o Código de Processo Penal, o Código Penal e a Lei de Execução Penal poderiam conter ideologias, posto que são complexos de leis descritas e de forma abstratas, sem qualquer conotação ideológica ou política?

Vejamos o Artigo 121 do Código Penal, ao descrever - matar alguém: Pena - reclusão, de 6 (seis) a 20 (vinte) anos. Qual a sugestão filosófica, política e 
ideológica, se não a própria norma de não matar, por que se matar estará incurso nas sanções da pena estipulada?

Incongruente, para não dizer utópico, dizermos que, com a simples disposição de emprego na faxina do presídio, na cozinha, assistências à saúde, ao lazer e à escolaridade, conseguirão recuperar o segregado, como se, magicamente, com uma "varinha de condão" cumprida a pena privativa de liberdade. $E$, associados àquelas propostas, retornarão ao Continente totalmente recuperados, despidos de todos os conceitos e preconceitos adquiridos no mundo prisional (subcultura), ou, dos desvios que já possuía quando ingressou na llha - exatamente porque não conseguiu conviver com as regras de conduta estabelecidas pela vida relacional.

Não adianta focarmos apenas nisso. A Constituição Federal, as leis ordinárias, incluindo regulamentos e portarias informam que não é obrigação do Estado, das entidades públicas ou privadas, da sociedade como um todo, propiciar apenas assistência aos condenados, com meras propostas, programas e discursos, e que apenas com o anúncio de que medidas serão tomadas, já se sintam com a obrigação cumprida. Por causa disso, quiçá, estejamos nessa situação hoje em nosso país em quase todos os sentidos). Mas, não mesmo. Com postura, resposta concreta e colocada em prática. Mais do que isso, com efetividade e resultados efetivos.

O que temos visto é muitas propostas inconsistentes, propagandas, informações, estudos, mas pouquíssimas soluções e realizações, não apenas quanto à recuperação dos reeducandos, mas para muitos outros segmentos da vida relacional.

E quando falamos em Educação, não falamos da educação como escolaridade, com o (re) ensino de matemática, português e outras disciplinas. Falamos a quem, se já recebeu esse estudo escolar, aprendeu superficialmente; será que repetindo essas disciplinas irão ajudar à perspectiva aventada? A outros, tratando-se de pessoas que sequer saibam ler e/ou escrever, adiantará o ensino es- 
colar? Enfim, quiçá a mais importante, o livre arbítrio, como o Direito e Garantia Fundamental de escolha, não deverá ser respeitado?

Indagar à pessoa que está segregada se, efetivamente, opta por isso, não seria a primeira coisa a ser feita? Porque ela tem o direito de escolha. Direito de opção. Direito de não se sujeitar a qualquer situação (mesmo a Educação) contra a sua vontade. Independentemente de estar privada de liberdade, ou não, do seu direito de ir, de vir e de ficar, de fazer ou deixar de fazer alguma coisa, senão em virtude de Lei.

Insistimos, o fato de a pessoa ter descumprido o comando da norma penal, disciplinada na vida comunitária do Continente (se condenado tem que cumprir a pena) não pode ser obrigada a fazer alguma coisa que não esteja no estribo da tipicidade, em razão do princípio da reserva legal, que se aplica também à fase de execução penal. Aliás, Princípio este que vem desde a época de Cesare Beccaria $^{1}$, do lluminismo, da Revolução Francesa, da Obra dos Delitos e das Penas.

O recluso está obrigado a cumprir uma pena privativa de liberdade. É ponto. Nada mais. Mas não pode ser obrigado a fazer aquilo que não Ihe indicou a sentença penal condenatória, porque também é sujeito de direitos, ser humano e está abrigado pelo Princípio Fundante da Dignidade da Pessoa Humana.

Como já referido, as penas privativas de liberdade são aquelas que utilizam algum tipo de restrição ao direito de ir, de vir e de ficar, à liberdade do apenado, podendo consistir em cumprir a pena em um estabelecimento prisional público por um determinado período, ou até mesmo, na obrigação de frequentar ou deixar de frequentar periodicamente determinado local. Paula Fernandes Teixeira Canedo $^{2}$ (2010) faz os seguintes comentários, muito pertinentes: a pena privativa de liberdade restringe, com maior ou menor intensidade, a liberdade do condenado,

1 Cesare Beccaria é considerado o principal representante do iluminismo penal e da Escola Clássica do Direito Penal.

2 Escrivã Paula Fernandes Teixeira Canedo, da Delegacia de Polícia (DP) de Senador Canedo, também docente do Departamento de Ciências Jurídicas, da Pontifícia Universidade Católica de Goiás. 
consistindo em permanecer por determinado tempo em algum estabelecimento prisional. As penas privativas de liberdade são cumpridas em regime progressivo. É um programa gradual de cumprimento da privação da liberdade, por fase ou etapas sendo chamadas comumente pela sociedade de "prisão".

Mas não se pode perder o foco. Engana-se, pois, quem pensa que o tempo que o apenado está privado da liberdade, recluso ao estabelecimento total, está ele sendo preparado para o retorno ao Continente de forma consciente e pronto para proceder na vida comunitária (THOMPSON, 2002).

Concordamos parcialmente com Canedo (2010) ao enfatizar que as penas privativas de liberdade são contraditórias em seu fim, desde as épocas mais primitivas. A forma de privação de liberdade do ser humano sempre se mostrou ineficaz para sua ressocialização e reeducação. É praticamente impossível a ressocialização do homem que se encontra preso quando vive em uma comunidade cujos valores são totalmente diferentes daqueles que estão em liberdade.

O estabelecimento prisional, a prisão, historicamente alojou escravos e ex-escravos, amparou menores e crianças de rua, abrigou doentes mentais e, ainda, serviu para encerrar os inimigos políticos. Representante máximo de construção para a exclusão social, com muros altíssimos ao redor, ou ainda ilhas e lugares inóspitos, onde os maus-tratos, a tortura, a promiscuidade e os vícios não ultrapassavam seus limites. Desde tempos idos na história, a prisão ainda na atualidade, apesar dos avanços, ainda se mostra ineficaz, demonstrado na série de eventos graves como rebeliões, fugas em massa, casos de tortura e até mesmo execuções ocorridas diariamente nos estabelecimentos prisionais brasileiros. (CANEDO, 2010). Sabendo disto, compreendemos que a prisão, à lei, não tem a finalidade de ressocialização, mas, tão somente, de punição e prevenção.

Tal, não significa sejamos contrários à ressocialização dos apenados. Não é isso que estamos dizendo - e hoje, no Brasil, devemos ter essa preocupação pelo dualismo que estamos vivendo; se optamos por uma coisa, significa que desprezamos a outra; se optamos por certa ideologia, a outra é errada. Vivemos 
a barbárie social, além de tantas outras, não só pela questão humanitária, mas, fundamentalmente, pelo Princípio da Dignidade da Pessoa Humana - talvez um pleonasmo, porque toda pessoa, no sentido literal, seria humana, o mantra constitucional, Totalidade organizadora dos demais princípios. É imperativo dissecar, a respeito da Dignidade da Pessoa Humana, porque a Constituição Federal simbolizou esse Princípio Universal na parte fundante de nossa Carta Jurídica.

Ao abrirmos a Constituição Federal, verificamos que o Princípio da Dignidade da Pessoa é tratado como fundamento da Ordem Política e Social da República Federativa do Brasil, tanto que vem insculpida no artigo $1^{\circ}$, III, da Constituição Federal, transformando-se na base para qualquer outro princípio. Vem antes, inclusive, dos Direitos e Garantias Fundamentais. Por essa razão, costuma-se se dizer, que os demais princípios são decorrência deste.

De qualquer sorte, nenhuma disputa doutrinaria terá aplicabilidade quando se concorre com o Princípio da Dignidade da Pessoa, o único que está acima de todos os outros, porque alberga toda e qualquer ofensa à condição humana, devendo ser analisada frente ao caso concreto, ao se deparar frente à colisão de direitos fundamentais.

A complexidade inerente ao conceito de dignidade torna dificultosa a determinação do seu conteúdo. O que venha a compor o conceito de dignidade é algo que não pode ser definido abstratamente, mas apenas em concreto, à luz de um determinado ordenamento jurídico e dos influxos históricos e culturais de cada sociedade. Toda essa dificuldade teórica em identificar com precisão o conteúdo da dignidade da pessoa humana decorre da circunstância de que o conceito de dignidade se insere na categoria dos denominados conceitos jurídicos indeterminado, caracterizados pela vagueza e subjetividade de sentido, a exigir do intérprete a formulação de juízos intelectivos mais ou menos complexo. (ANDRADE, 2010, p.10).

Por essa razão a importância de se conhecer a pessoa, tanto a pessoa que está sendo acusada, como a que foi atingida, terceiros. Afirmava Carnelutti (1995, p. 51) que "há muito os juristas se aperceberam de que, para o juízo penal, além do fato, precisa-se conhecer o homem: e não é possível conhecer o 
homem sem reconstruir a sua história”. E quando a lei fala no homem, não está se referindo ao homem abstrato, mas ao homem específico, ao Ser humano que está sendo julgado e ao Ser humano que está sendo agredido.

É preciso que se analise o seu passado e a sua trajetória de vida. Como foi quando criança:

se agredido ou vilipendiado; grau de instrução, pais presentes ou ausentes, enfim suas vivências. E se esse tratamento deve ser dado ao acusado e seus familiares, não apenas, mas à vítima e aos familiares; o terceiro interessado e/ou prejudicado.

É preciso ter a percepção de que a vítima atua também como membro e representante da sociedade, tendo interesse jurídico em participar do processo, porque a ação criminosa deve ser reprimida para maior tranquilidade social, sob pena de se produzir uma vitimização secundária do ofendido, impondo-lhe outro sofrimento, desta vez pelo próprio estado, porque além de falhar na sua proteção, proporciona-lhe desprezo aos seus interesses. (FERNANDES, 1995, p. 124).

A nossa Constituição Federal é principiológica e vinculante. Principiológica porque é a gênese, origem de tudo e, vinculante, porque nenhuma legislação pode vir de encontro a ela. É o predomínio dos princípios sobre o direito posto. Aliás, o Prefácio da Constituição Federal, vindo antes do artigo primeiro da Carta Jurídica, já evidencia o seu caráter principiológico.

Arriscamos a dizer que temos hoje uma Doutrina Constitucionalista, de um lado e, de outro, uma Doutrina Neoconstitucionalista. Constitucionalista porque prevê a necessidade de a Constituição Federal limitar o poder do governante, protegendo o indivíduo contra abusos do próprio Estado, surgindo com a Revolução Francesa e com a Revolução Americana, portanto, mais que bicentenária. O Neoconstitucionalismo seria uma nova leitura do constitucionalismo, em que o positivismo perde vez, cedendo espaço às abstrações.

Enquanto o constitucionalismo tem lugar no Positivismo, o Neoconstitucionalismo permite uma interpretação mais ampla, dando lugar às exegeses indivi- 
duais, e é exatamente com base nessa doutrina que se fala muito no Ativismo Judicial, em que a questão princiológica é a bandeira. É certo que esse Princípio, pelo seu caráter amplo, abstrato, pode propiciar o que hoje vem se chamando de Ativismo Judicial, mas isso porque nossa Constituição Federal de 1988 é analítica. Prevê muitos assuntos, e isso oportuniza que a Corte Suprema possa enfrentar quase todos os temas que, num primeiro momento, deveriam ser julgados apenas pelos juízos monocráticos, e não colegiados. É a predominância dos princípios sobre o direito positivado. A questão principiológica é de uma importância vital para o Neoconstitucionalismo.

Doutrinariamente teríamos, quanto à classificatória, Normas formalmente constitucionais e normas materialmente constitucionais. As formalmente constitucionais seriam aquelas cujo regramento está na Constituição Federal, mas que somente são constitucionais porque estão ali, mas não têm essência de constitucional, porque as que têm essências de constituição são as chamadas normas materiais constitucionais, que regulam a estrutura do Estado, a sua organização e os direitos fundamentais, como v.g. os princípios da Razoabilidade e Proporcionalidade.

Dizemos que a nossa Constituição Federal é uma constituição analítica porque entendemos que ela é gigantesca, analisa tudo e mais um pouco, inclusive o que não precisa, porque são mais de duzentos (200) artigos, que não tem essência de constituição, meramente informais e não materiais. Para que tivesse essência de Constituição Federal, deveria regular apenas a organização dos Poderes, Estrutura do Estado, Processo Legislativo, Sistema de Governo, coisas fundamentais e que precisam estar estabelecidas para que o Estado possa existir.

Os direitos fundamentais devem ser focados à proteção aos diretos à dignidade, à liberdade, à propriedade à igualdade de todos os seres humanos. A expressão Fundamental demonstra que tais direitos são imprescindíveis à condição humana e ao convívio social. Esse é o entendimento de Ingo Sarlet (2001). 
Para que o princípio da dignidade humana não constitua uma promessa não cumprida e "não se desvaneça como mero apelo ético fundamental sua concretização judicial, através de um constante e renovado trabalho de interpretação/aplicação, que busque dar ao princípio a máxima efetividade. Em um país como o nosso, em que grande parte da população carece dos bens e serviços mais básicos, com frequência o princípio da dignidade servirá de fundamentação de direitos prestacionais exigíveis do Estado. (ANDRADE, 2010, p.29).

A Constituição Federal é invocada como se esta resguardasse apenas e tão somente os acusados, esquecendo-se das demais classes sociais. Mais complicado, ainda, quando se vê declarada uma verdadeira guerra contra os demais segmentos comunitários, inclusive as minorias, que estão sendo iludidas e manipuladas e serão as maiores prejudicadas. Estamos falando da justiça dos homens, é claro (porque a outra, não nos é permitida), onde se digladiam dois interesses de grande valia: liberdade e segurança.

Pior que não saber, é aprender errado. Por essa razão devemos ter bastante cuidado com estudos que não provêm de investigação histórica, comparativa e teleológica, caminhando-se, muitas vezes, por falas, embora formalmente doutrinárias, emitindo juízos próprios de acordo com as suas convicções ideológicas, sem o resguardo do compromisso científico, o compromisso imparcial e sem coloração.

Quando a Constituição Federal revela que todos têm direito à educação, entendemos que não pode haver discriminação. Mais do que isso, está revelando que tem que se efetivar tal direito e não é suficiente apenas descrevê-lo como direito, porque a Constituição Federal, como o Código Penal, Processo Penal e Lei de Execução Penal não tem partido e não tem ideologia, não tem lado, sexo, cor e raça. Ela é de todos e a todos deve servir, indistintamente.

Pensarmos diferente não nos parece seja a melhor opção. Interpretá-la diferente não nos parece seja o melhor caminho. Talvez, signifique aumentar as dificuldades, que já não são poucas. 
Imaginemos se começarmos a ideologizar as questões educacionais àqueles que teriam, ou não, direito a ela?

Se já é dificultoso pensarmos que, literalmente, não existe norma expressa que diga que os fins da pena são a ressocialização, porque se trata de uma construção doutrinária, apenas, porque não existe na legislação essa expressão, vamos ainda arrumar outros fantasmas, onde a lei constitucional consagra expressamente que as Garantias Fundamentais pertencem a todos os brasileiros?

Mas, na continuidade, por qualquer ângulo que se examine, a Pena, em si, é um castigo. É fato isso, porque não tem descrição expressa de ressocialização. É uma resposta do Estado àquele indivíduo que cometeu um fato desvalorado e, ao mesmo tempo, uma resposta à sociedade no sentido de que, se alguém fizer a mesma coisa, a resposta será a pena.

A Pena não é educativa - termo aqui utilizado no sentido de aprendizado, sentimento - jamais no sentido de obrigação, coação, algemação do pensamento e da vontade, mas de liberdade de pensar, seja para o bem ou para a mal; educação no sentido de que o homem tem direito de escolha, do que quer para si, mas Retributiva e Preventiva. A esse respeito, Pessina (2008) revela que "o fim único da pena não pode ser buscar a regeneração do condenado, mas que dentro das suas limitações possa ser educativa (p. 177).

Oportuno, por primeiro, distinguir entre Educação e Ressocialização. A Educação precisa ser entendida como a transmissão de conhecimento; como um mecanismo de informação a respeito de alguma coisa, não obstante construtora à formação do $E u$, dando-lhe base para a construção da sua personalidade. A Ressocialização, por consequência, tem como objetivo possibilitar ao preso o retorno ao convívio social da melhor forma possível e de maneira que não precise mais retornar à Ilha.

Destarte, pensando na Educação e na realidade atual, retomamos Adorno (2010) em 
“Educação contra a barbárie". O tema continua pertinente, sendo a questão mais urgente da educação.

Hoje em dia, o problema que se impõe nesta medida é saber se por meio da educação podese transformar algo de decisivo em relação à barbárie. Entendo por barbárie algo muito simples, ou seja, que, estando na civilização do mais alto desenvolvimento tecnológico, as pessoas se encontrem atrasadas de um modo peculiarmente disforme em relação a sua própria civilização - e não apenas por não terem em sua arrasadora maioria experimentado a formação nos termos correspondentes ao conceito de civilização, mas também por se encontrarem tomadas por uma agressividade primitiva, um ódio primitivo ou, na terminologia culta, um impulso de destruição que contribui para aumentar ainda mais o perigo de que toda esta civilização venha a explodir, aliás uma tendência imanente que a caracteriza. (ADORNO, 1995, p.154).

Parece-nos, exemplificando nessa citação, que a perspectiva Adorniana de educação é, simultaneamente, evitar a barbárie e buscar a emancipação humana, questionando a educação autoritária e anunciando outro paradigma de educação. Aqui, tratando-se da ambiência emancipatória que desejamos para a Educação no Sistema Penitenciário brasileiro, concordamos com o autor Frankfurtiano ${ }^{1}$. Levando-se em conta o caráter transitório dos paradigmas educacionais e a possibilidade permanente de inovar no interior da própria pedagogia, considerou-se pertinente trazer neste artigo contribuições de T. Adorno (2010) e de E. Morin (2000, 2011, 2015), cuja proposição central é coerente com o desenvolvimento de indivíduos livres, moralmente responsáveis, íntegros e com um elevado grau de competência social.

Theodor L. W. Adorno teve a preocupação em diagnosticar os problemas da Alemanha pósguerra e analisá-los para torná-los evidentes, incluindo àqueles que se recusavam a reconhecê-los como problemas. Na sua obra "O que significa elaborar o passado", demonstra essa resistência que alguns núcleos da sociedade apresentam em reconhecer o que já não é mais imediato. Essa tendência

1 Theodor Ludwig Wiesengrund Adorno (1903-1969) nasceu em Frankfurt, Alemanha, em 11 de setembro de 1903.

Filósofo, sociólogo e crítico musical alemão, destacado representante da chamada "Teoria Crítica da Sociedade" desenvolvida no Instituto de Pesquisas Sociais (Escola de Frankfurt). 
ao esquecimento fez o autor trazer à tona o genocídio cometido sob o governo nazista nos campos de concentração de Auschwitz.

Todos conhecemos a disposição atual em negar ou minimizar o ocorrido por mais difícil que seja compreender que existem pessoas que não se envergonham de usar um argumento como o de que teriam sido assassinados apenas cinco milhões de judeus, e não seis. Além disso, também é irracional a contabilidade da culpa, como se as mortes de Dresden compensassem as de Auschwitz. Na contabilização de tais cálculos, na pressa de ser dispensado de uma conscientização recorrendo a contra-argumentos, reside de antemão algo de desumano (...) (ADORNO, 2010, p. 31).

Desde então e para sempre, na atitude daqueles que negam ou atenuam a ocorrência de uma barbárie reside um impulso de regressão ao irracional, ao desumano. Isso cala-nos sobremaneira ao pensarmos nas pequenas e grandes tragédias, pessoais, familiares e sociais que cada morador compulsório da llha traz consigo e que o acompanha ao Continente, dificultando ou impossibilitando a sua reinserção social, termo que também questionamos na constatação de que em nosso país impera a exclusão social - imperativo de todas as demais exclusões que impedem a inserção social dos cidadãos. Este conceito remete às políticas públicas de redução da desigualdade social, em termos sociais e econômicos, incluindo as pessoas que estão à margem da sociedade, por meio de projetos educativos, profissionalizantes e de moradia, entre outros.

Ora, quando a Lei refere-se em "preparar o recluso penal para o retorno à sociedade", não abrange, explicitamente, proporcionar-lhe a escolaridade e a profissionalização recuperativa/ressocializadora, ou ainda, as condições dos profissionais para a retomada da sua vida no mundo do trabalho. E sim, a Lei é clara ao referir que o mesmo só voltará ao Continente se respeitar as regras; se cumprir o tempo de encarceramento; se tiver boa conduta, se respeitar os agentes e os demais colegas de infortúnio, e que a assistência social indique que o caminho de retorno será tranquilo. Insiste-se, a lei ordinária em momento algum fala em ressocialização como finalidade da pena, a não ser que o Estado deva proporcionar assistência. 
Convém ressaltar, em um primeiro momento, o presídio não é um Hospital, um consultório psiquiátrico ou consultório psicológico, não que sejamos contrários ao tratamento das causas, mas somos realistas e conhecemos a situação. Se já se apresenta difícil manter o que se tem, imaginemos ter que modificar toda a legislação e os próprios ambientes totais. Isto seria mais uma utopia inviável. Antes, fechamos os olhos à realidade do sistema, à realidade brasileira, inclusive com graves implicações na seara de outras áreas do conhecimento e das políticas públicas, que dificilmente legitimam os benefícios anunciados.

A busca do $E u$, a formação da personalidade, não pode ser à força, mas em um conjugar de vontades, começando pela deliberação do reeducando, como opção. Uma tarefa seria preparar a base para os projetos educacionais, traçando de acordo com as necessidades daquela massa carcerária, mediando-se as suas consequências e interagindo com toda a população do Estabelecimento Total. O direito de escolha deve prevalecer, mormente em um Estado Democrático Social e de Direito.

A chamada ressocialização ou recuperação dos reeducandos não é uma tarefa fácil. Não é preciso muito esforço para identificarmos isso, mormente em razão das circunstâncias internas dos estabelecimentos totais, de completa desarticulação social, onde os valores são completamente diferentes e conflitantes com os regramentos da nossa vida comunitária. A prisão ou qualquer estabelecimento total deixa sequelas profundas não só no físico, mas na alma do segregado. Essas sequelas são produto do fenômeno da prisionização. É um processo que se desenvolve no segregado. A estrutura da personalidade pode manterse a mesma, mas o meio e as interações resultantes da convivência têm um papel decisivo na dinâmica da personalidade. (LOUZADA, 2021 a, p. 133).

Jamais podemos impor as propostas que pensamos devam ser aplicadas, pois trata-se de longa caminhada à compreensão, à reflexão, ao autoconvencimento, como àquele que aceita um Acordo de Não Persecução Penal (ANPP) pelo fato (não se sabe qual outro, mas pode existir), de não ser processado, se aceitar algumas condições. Qual o resultado disso? Aceitou porque se arrependeu mesmo, achou que estava errado e não poderá fazer mais ou, apenas, para 
não ser processado, enfrentar um processo, evitar uma condenação, não obstante tivesse a chance de ser absolvido? Estamos falando o mínimo; falando de um instituto em que a própria Lei Processual Penal autoriza. Da mesma forma a Suspensão Condicional do Processo da Lei 9099/95, Delação Premiada e outros.

E nessa caminhada, concordo com Cezar Bitencourt (2007), quando diz que a ressocialização é uma finalidade na medida do possível, porque não se pode exigir que o direito penal tivesse isso como função, porque não the cabe, mas, sim, a outros microssistemas, outros organismos sociais que devem trabaIhar a ressocialização.

É dizer, a (re) educação é uma das funções da pena, mas não a sua finalidade. Sobre isso, Nucci (2018), diz que "um dos objetivos a serem alcançados quando da aplicação da pena, é apresentar à sociedade o panorama real e efetivo de quem comete o crime". Para o autor, a reeducação nos moldes vigentes é ilusão. Mas jamais (friso), recuperá-lo, não se querendo descartar a bela intenção da inserção.

Afinal, se o preso for ilusoriamente reeducado, poderá tornar à liberdade em situação piorada e a criminalidade somente experimentará incremento. Se o preso não aprender a trabalhar e a gostar de viver da força da sua atividade laborativa, não terá como sobreviver, fora do cárcere, de maneira honesta. (NUCCI, 2018, p.130).

Isto leva-nos a retomarmos a posição Adorniana de colocar como prioridade da educação criar as condições para que a barbárie, em qualquer das suas formas grotescas, não tenha mais lugar na sociedade. Adorno abre o texto "Educação após Auschwitz", com a frase "A exigência que Auschwitz não se repita é a primeira de todas para a educação" (ADORNO, 2010, p. 119).

Para Adorno (Idem, p. 121), "é preciso evitar que as pessoas golpeiem para os lados sem refletir a respeito de si próprias. A educação tem sentido unicamente como educação dirigida a uma autorreflexão crítica". A educação no seu aspecto emancipatório foi o foco do debate entre o filósofo e o jurista alemão 
Hellmut Becker, transcrito em "Educação - para quê? ". H. Becker pontua o caráter abstrato do termo emancipação ao ser discutido apenas no plano teórico, sem considerar a sua aplicabilidade prática.

Frente a isto, o filósofo de Frankfurt aponta para o peso inquestionavelmente superior ao da educação que a ideologia dominante exerce sobre a formação do sujeito, podendo enclausurar a educação emancipatória no idealismo da sua formulação. Temos a clareza de que a educação parece enfrentar o dualismo em seus papéis fundamentais: se por um lado o seu papel se constitui na adaptação do sujeito à realidade, tornando-o apto a se adaptar ao existente, por outro deve dar a esta adaptação um sentido novo - a realidade não deve apenas ser reproduzida, mas tornar-se objeto de reflexão do sujeito. O enfrentamento desta contradição transparece ser mais urgente do que a superação:

A educação seria impotente e ideológica se ignorasse o objetivo de adaptação e não preparasse os homens para se orientarem no mundo. Porém ela seria igualmente questionável se ficasse nisto, produzindo nada além de well adjusted people, pessoas bem ajustadas, em consequência do que a situação existente se impõe precisamente no que tem de pior. Nestes termos, desde o início existe no conceito de educação para a consciência e para a racionalidade uma ambiguidade. Talvez não seja possível superá-la no existente, mas certamente não podemos nos desviar dela (ADORNO, 2010,).

Também no texto que dá nome ao livro, "Educação e emancipação", o filósofo frankfurtiano dialoga com o mesmo jurista, Becker a respeito do obstáculo que o establishment representa ao processo de emancipação. Adorno argumenta, com o que concordamos, quanto mais o desejo de modificar o existente é revelado, maior a resistência encontrada, produzida negativamente pelos que defendem a permanência das coisas tal como elas se encontram. Àqueles, cuja pretensão seja atuar na transformação pela educação, o mesmo pensador alerta quanto às dificuldades:

(...) as tentativas de transformar efetivamente o nosso mundo e um aspecto específico qualquer imediatamente são submetidas à potência avassaladora do existente e parecem condenadas à impotência. Aquele que quer transformar provavelmente só poderá fazê-lo na medida em 
que converter esta impotência, ela mesma, justamente com a sua própria impotência, em um momento daquilo que ele pensa e talvez também daquilo que ele faz (ADORNO, 2010, p. 185).

Por outro lado, ao refletirmos sobre o compromisso social da educação com a sociedade parece-nos gigantesca a obra destinada filosoficamente à Educação. Outras tarefas, eminentemente sociais colocadas à Educação e aos educadores ao cabo esvaem-se em névoas, pois a Educação, sozinha, não muda a sociedade. Paulo Freire (1979, p 84) escreveu, em sua Terceira Carta Pedagógica: "Se a educação sozinha, não transforma a sociedade, sem ela tampouco a sociedade muda". Se a educação sozinha não transforma a sociedade, não transforma o mundo, ela muda pessoas; pessoas transformam o mundo.

Mas isso não significa, que não devamos buscar a recuperação das pessoas, tendo em face o Princípio da Dignidade Humana. A Lei de Execuções Penais (LEP) prevê a educação escolar nos presídios nos Artigos 17 a 21 . Um passo significativo foi a elaboração das Diretrizes Nacionais para a Educação nas Prisões, expressas na Resolução $n^{\circ}$ 03/2009, aprovado no Conselho Nacional de política pública do Ministério da Justiça. Bem como nos artigos 205 e 208, inciso I, da Carta Jurídica.

A inserção do $\S 4 .^{\circ}$ ao art. 83, fruto da Lei 12.245/2010, complementa o determinado pelo caput, no sentido de que o estabelecimento penal deve contar com dependências voltadas à educação. Esmiúça-se o âmbito do ensino objetivado para o preso, fixando a meta de formá-lo nos níveis fundamental e médio, sendo que, neste último caso, associa-se o programa profissionalizante, perfeitamente compatível com essa fase do estudo. Por isso, nos termos do art. 36-B, I, da Lei 9.394/96, deve-se conduzir o programa do ensino médio em harmonia com o ensino profissionalizante. Idealiza-se cumprir, na prática, o horizonte do art. 208, I, da Constituição Federal, garantindo-se a todos a "educação básica obrigatória e gratuita (...)". Certamente, colocando-se em funcionamento as aulas de ensino básico e profissionalizante, pode-se mais adequadamente seguir o disposto no art. 126 desta Lei de Execução Penal, com a redação dada pela Lei 12.433/2011, regularizando o estudo como forma de remição da pena dos sentenciados. Assim, os presos terão condições de auferir melhores condições intelectuais e profissionais para enfrentar o mercado de trabaIho, quando deixarem o cárcere. (NUCCl, 2018, p.130). 
Tratando-se de Estabelecimento Total (Ilha), o direito à educação apareceu pela primeira vez regulamentada, em Genebra, na Instituição das Regras Mínimas para o Tratamento do Prisioneiro (1955). Sendo que no Brasil vem amparado pela nossa Constituição Federal (1988), Artigo 227, e pela LEP, sendo que apenas o ensino Básico será obrigatório $\mathrm{E}$, apenas $10 \%$ da população segregada nos Brasil estão envoltas com a educação, o ensino médio e superior não é obrigatório (art. 17 e 18 da LEP).

Cordeiro (2019) analisa que, apesar de ser um avanço, o atual Sistema Penitenciário Brasileiro está longe de garantir condições mínimas de sobrevivência, mais ainda de recuperação (ressocialização), em razão de ser, sem meios pedagógicos e ferramentas concretas que garantam acesso à educação nesses estabelecimentos, impossível qualquer tentativa de aplicabilidade da educação nos presídios.

A implementação da educação nos presídios traz à tona inúmeras questões relacionadas à organização e ao cotidiano do estabelecimento penal, confrontando com o prescrito nas resoluções que tratam das diretrizes nacionais para o setor, por sinal, bem abrangentes. A Resolução N. 3, de 11/03/2009, dispõe sobre as diretrizes nacionais para a oferta de educação nos estabelecimentos penais. A Resolução $n^{\circ}$ 2, de 19 de maio de 2010, dispõe sobre as Diretrizes Nacionais para a oferta de educação para jovens e adultos em situação de privação de liberdade nos estabelecimentos penais do Ministério da Educação/Secretaria de Educação Continuada. Alfabetização e Diversidade, e subsequentes.

Além dessas, citamos as diretrizes básicas para arquitetura prisional (Resolução CNPCP nº 09 - CNPCP, 2011) que legisla sobre a previsão de módulos educativos, laborais, de esporte e de lazer na construção de novas unidades penais; o Decreto Presidencial nº 7.626 (BRASIL, 2011b) que institui o Plano Estratégico de Educação no Âmbito Prisional. As muitas sessões e documentos da Conferência Nacional de Educação - CONAE de 2002 em diante, sendo o próximo em 2022, se constituem em um espaço democrático aberto pelo Poder Públi- 
co e articulado com a sociedade para que todos participem do desenvolvimento da Educação Nacional. Em caráter permanente, o Fórum Nacional de Educação decorre do CONAE, sendo criado pela Portaria do Ministério da Educação N. 1.407, de 14 de dezembro de 2010, publicada no Diário Oficial da União de 16 de dezembro de 2010, e instituído por lei com a aprovação do Plano Nacional de Educação (PNE) - Lei Federal no 13005/2014, PNE 2014-2024.

Observando esse universo de políticas públicas voltamos à argumentação de que não falta a constatação e teorização dos fatos, porém isto não tem tido força de transformação. Embora se reconheça como direito do preso a educação, poucos têm acesso. Ainda assim são necessários estudos que mapeiem as experiências educacionais em prisões brasileiras, fornecendo informações detalhadas sobre as oportunidades existentes, a sua localização geográfica e o efetivo resultado na integração do egresso do sistema penitenciário no cotidiano da vida e do trabalho.

Têm-se a ideia corrente de que as ações conjuntas e troca de informações entre órgãos federais, estaduais e do Distrito Federal, com atribuições nas áreas de educação e de execução penal seria positivo para o desenvolvimento da educação em prisões. Também o incentivo aos planos estaduais de educação para o sistema prisional, com metas e estratégias de formação educacional da população carcerária e dos profissionais envolvidos em sua implementação, inclusive os profissionais da Educação.

No entanto, a universalização da alfabetização e a ampliação da oferta da educação no sistema prisional caminha de modo lento, quiçá a integração da educação profissional e tecnológica com a educação de jovens e adultos no sistema prisional, o que seria de se esperar trouxesse excelentes resultados.

A educação, não somente o trabalho e a escolaridade, mostra-se como o grande instrumento de efetivarmos concretamente a ressocialização nos ambientes totais, porque além de cumprir com os mandamentos constitucionais e infraconstitucionais, abordará o sistema (quase) falido e propiciará uma barreira na formação das subculturas. (LOUZADA; VEIGA; CRUZ, 2021, P.16). 
O sistema educacional possui a experiência nessas áreas e o sistema prisional possui a realidade vivida no dia-a-dia dos cárceres. Parece-nos que o diálogo entre esses sistemas, balizado pelo real desejo de promover a dignidade humana seria uma via de acesso à educação contra as forças atuantes dentro e fora dos presídios para manter os indivíduos mergulhados na vulnerabilidade e criminalidade. Para vencer essas forças ocultas nas subculturas da marginalidade e sendo, ainda alto, o índice de insucesso na vida do indivíduo após o cumprimento da pena, as condições para a continuidade dos estudos dos egressos do sistema prisional e a questão primordial da empregabilidade, necessitam ser pensadas e viabilizadas.

\section{À GUISA DE CONCLUSÃO, SEMPRE PROVISÓRIA}

A Educação nos presídios deve ser concebida a partir da possibilidade de se constituírem ambiências emancipatórias, de encontro e socialização ao mundo livre em que saber é apenas um dos elementos para a sua constituição. Precisamos romper com aquela concepção tradicional, reducionista da escola, cujo objetivo central na aquisição de conteúdos pragmáticos é muitas vezes descontextualizado do ambiente em que vivemos principalmente no mundo moderno.

Para isso é fundamental que se tenha uma cultura em que realmente se privilegie políticas inter e transdisciplinares de mediação à educação e formação humana ao reeducando, onde não se torne inviável a participação. O modelo que predomina na escola tradicional, a escola cujo único fim é transmitir conteúdos, com inspeção escolar corpo-a-corpo e regras abstratas a serem cumpridas, migradas de outras culturas - normalmente oriunda de países ricos, é um modelo que precisa ser confrontado com a realidade vivida nas comunidades, inclusive as carcerárias.

Tudo isso, porque, a pena e o cárcere não têm a finalidade de reeducar, mas operacionalizam a possibilidade de [res] socialização. Por isso, parece inadequado que a sanção penal assuma a responsabilidade sobre a transformação 
interior de uma pessoa, a sua conversão para o bem. O compromisso com o cumprimento da Lei é para toda a sociedade, e não só para os condenados. O condenado, querendo, poderá se redimir e mudar o seu mundo.

Ainda recluso, tomando a sua decisão interior, movida pelo seu livre arbítrio, pode aprender uma profissão e trabalhar, como dever para quem cumpre pena nos regimes fechado, semiaberto ou aberto. Ainda, pode estudar, e tudo leva à remição - reportando ao sentido etimológico de resgate ou reaquisição onerosa de algo. Para quem decidiu interiormente pela mudança, ter oportunidades, ainda cumprindo pena, de reiniciar a sua ressocialização, poderá ser por ele assumida como benção.

Efetivamente, não há uma cultura de reconhecimento da recuperação dos reclusos, menos ainda pela educação, porque a maioria acha que é um desperdício, seja de tempo e de dinheiro, e que haveriam coisas mais importantes e sérias para serem custodiadas. Contudo, a proposta deve continuar. Em 2013, o CNJ, através da Recomendação $n^{\circ} 44$, constituiu um avanço ao reconhecer a Remição pelo estudo para pessoas privativas de liberdade. Prevê que o condenado que cumpre a pena em regime fechado ou semiaberto poderá remir, por trabalho ou por estudo, parte do tempo de execução da pena. Neste caso, a bem que estude, trabalhe ou estude e trabalhe, cabe-nos ressalvar, no sentido de que o desejo poderá estar voltado muito mais à remição do que às aprendizagens e profissionalização.

De tudo o que estudamos sobre o tema, reafirmamos ser muito rara a correção do sentenciado, não se podendo atribuir à pena uma finalidade só alcançada excepcionalmente. Por isso não é finalidade da pena reeducar, mas propiciar meios, e depende da vontade do preso. Ele poderá regozijar-se no mal e nele permanecer, porque esta é a sua opção de vida, ou poderá ainda agir a partir de fatores patológicos que o induzem a isso, e não será isso onerado às instâncias sociais, familiares, judiciais ou educacionais. 
Parece-nos ainda importante estabelecer a distinção entre Educar e Ressocializar. Educar significa ensinar algo, compartilhar e mediar conhecimentos, oferecer boas condições para uma pessoa desenvolver a sua personalidade. Reeducar significa retomar tudo isso, podendo ou não ser assimilado e significar mudança efetiva e proativa do comportamento. Chegados os 18 anos, admitimos que a personalidade já está consolidada. Logo, ao ser aplicada uma pena a alguém que cometeu um crime, a reeducação é algo imponderado e incerto.

Por outro lado, Ressocializar significa proporcionar ao preso o retorno ao convívio social da melhor maneira possível. Prepará-lo para o retorno à vida social, e nisso, obrigatoriamente, não se encontra a Educação nos moldes que aludimos antes, mas também não significa que seja impossível a sua realização.

Será possível conquistarmos isso, diante do fato de que a Constituição Federal do Brasil (1988) assegura a todos, incluindo-se aqui os reclusos, o Direito à Educação como forma recuperativa e Princípio da Dignidade da Pessoa Humana?

Alguns obstáculos se apresentam, sendo o primeiro o dimensionamento pedagógico dos estudos, cujo plano é confeccionado em nível Federal, embora o sistema prisional, a justiça, sistema policial e da SUSEPE, ser em nível Estadual, com planos e políticas muitas vezes diferentes, diversas. O segundo ponto é a concorrência entre a educação e o trabalho, este último preferencial, porque o retorno para a casa prisional é muito maior (LEMGRUBER, p. 135). O terceiro ponto refere-se à formação de qualidade para o preparo dos agentes penitenciários inclusive para o transporte até o local da aula. E, indiscutivelmente, a gestão da docência e da formação contínua dos educadores, considerando as diferenças estruturais e culturais que demandam outros fazeres e saberes, pouco formulados e discutidos nos cursos de licenciatura, responsáveis pela formação inicial.

No entanto, um Projeto Inter e Transdisciplinar de Educação para os Estabelecimentos Totais, movimentaria forças favoráveis para que o Princípio da Dignidade da Pessoa Humana guiasse os profissionais envolvidos e, especial- 
mente, os educadores na construção de ambiências educativas ou socioeducativas diferenciadas. Em linhas gerais, trata-se de investimos na ampla discussão sobre a educação no sistema penitenciário e o espaço que poderá vir a ocupar de fato como agente de humanização.

\section{REFERENCIAS}

ADORNO, Theodor Ludwig Wiesengrund. Emancipação e educação. Tradução Wolfgang Leo Maar. Rio de Janeiro: Paz e Terra, 2010.

ANDRADE, André G. C. de. O princípio fundamental da dignidade humana e sua concretização judicial. (pp.01-33). Em: <http://www.tjrj.jus.br > document_library > get_file>.

BECCARIA, Cesare. Obra dos Delitos e das Penas. Rio de Janeiro: Pillares, 2013.

BITENCOURT, Cezar R. Criminologia Crítica e o Mito da função ressocializadora da pena. In: BITTAR, Valter B. (coord). A Criminologia no Século XXI. Rio de Janeiro: Lumen Juris, 2007.

BRASIL. Lei de Execução Penal. Lei n 7.210, de julho de 1984. Brasília: Ministério da Justiça. Departamento Penitenciário Nacional.

BRASIL. Lei n. 9.394/1996, de 20 de dezembro de 1996. Lei de Diretrizes e Bases da Educação Nacional. Diário Oficial da União, Brasília, DF, p.27833, 23 dez. 1996. Seção 1.

BRASIL. Conferências Nacionais de Educação Básica (Documento final). Brasília, DF: MEC, 2008.

BRASIL. Conferências Nacionais de Educação: construindo o sistema nacional articulado de educação - o Plano Nacional de Educação, Diretrizes e Estratégias de Ação (Documento final). Brasília, DF: MEC, 2010.

BRASIL. Decreto n. 7.626, de 24 de novembro de 2011. Institui o Plano Estratégico de Educação no âmbito do Sistema Prisional. Diário Oficial da União, Brasília, DF, p. 2, 25 nov. 2011b. 
BRASIL. Conferências Nacionais de Educação: o PNE na articulação do sistema nacional de educação (Documento final). Brasília, DF: MEC, 2014a.

BRASIL. Lei no 13.005 de 25 de junho de 2014. Aprova o Plano Nacional de Educação. Diário Oficial da União, Brasília, DF, p. 1, 26 jun. 2014b. Seção 1, Edição Extra.

BRASIL. Conselho Nacional de Educação (CNE). Resolução CNE/CEB n. 2, de 2010. Dispõe sobre as Diretrizes Nacionais para a oferta de educação para jovens e adultos em situação de privação de liberdade nos estabelecimentos penais. Brasília, DF: CNE, 2010.

BRASIL. Conselho Nacional de Política Criminal e Penitenciária (CNPCP). Resolução CNPCP n. 3, de 2009. Dispõe sobre as Diretrizes Nacionais para a Oferta de Educação nos estabelecimentos penais. Brasília, DF: CNPCP, 2009.

BRASIL. Resolução CNPCP n. 09, de 2011. Diretrizes básicas para arquitetura prisional. Brasília, DF: CNPCP, 2011.

CANEDO, Paula F. T. O histórico das penas privativas de liberdade aplicadas pelo judiciário. Conteúdo Jurídico. (16/09/2010). Em: < conteúdo jurídico.com.br>.

CORDEIRO, Andria Magalhães. A Educação nas Prisões. Rev. Mult. Psic. V.13, N. 48 p. 214-223, Dezembro/2019 - ISSN 1981-1179 Edição eletrônica em http:// idonline.emnuvens.com.br/id

GOFFMAN, Erving. A representação do eu na vida cotidiana. $20^{\mathrm{a}}$ ed. Rio de Janeiro: Vozes, 2014.

GOFFMAN, Erving. Manicômios, Prisões e Conventos. 9a ed. São Paulo. Perspectiva, 2019.

LEME, José Antonio Gonçalves. A cela de aula: tirando a pena com letras. In. ONOFRE, Elenice Maria Cammarosano (Org). Educação escolar entre as grades. São Paulo: EdUFSCar, 2007. p. 111-160. 
LOUZADA, Ulysses F. Ressocialização: Realidade ou Utopia? Dissertação (Mestrado em Educação Brasileira). Universidade Federal de Santa Maria: Programa de Pós-Graduação em Educação. Santa Maria, RS, 2003.

LOUZADA, Ulysses F. Desalgemando o sistema ressocializador. Clamor à educação. Santa Maria: Arco Editores, 2021.

LOUZADA, Ulysses F. VEIGA, Adriana M. da R. CRUZ, Denise S. da. Ressocialização na Instituição Total pela Educação; Realidade ou utopia? Research, Society and Development. V. 10, n. 17, (1-17), 2021.

MELO, Nehemias D. de. O princípio da dignidade humana e a interpretação dos direitos humanos. Revista Jus Navigandi, Teresina, ano 26, n. 6395, 3 jan. 2021. Em <https://jus.com.br/artigos/87693>.

MORIN, Edgar. A cabeça bem-feita. 26ed. Bertrand Brasil, 2000.

MORIN, Edgar. Saberes globais e saberes locais. O olhar transdisciplinar. [Participação de Marcos Terena]. Garamond, 2011.

MORIN, Edgar. Introdução ao pensamento complexo. Sulina, 2015.

NUCCI, Guilherme de S. Curso de Execução Penal. Rio de Janeiro: Forense, 2018.

ONOFRE, Elenice Maria Cammarosano. Escola da Prisão: espaço de construção da identidade do homem aprisionado? In. ONOFRE, Elenice Maria Cammarosano (Org). Educação escolar entre as grades. São Paulo: EdUFSCar, 2007. p. $11-28$

PESSINA, Enrico. Teoria do Delito e da Pena. Porto Alegre: Rideel, 2008.

REGRAS MÍNIMAS PARA O TRATAMENTO DE PRISIONEIROS. Genebra, 1955. Disponível em: <http://www.dhnet.org.br/direitos/sip/onu/fpena/lex52.htm>.

SANTOS, Silvio dos. A educação escolar na prisão sob a ótica de detentos. In. ONOFRE, Elenice Maria Cammarosano (Org). Educação escolar entre as grades. São Paulo: EdUFSCar, 2007. p. 93-109. 
SARLET, Ingo W. Dignidade da Pessoa Humana e Direitos Fundamentais na Constituição Federal de 1988. Porto Alegre: Livraria do Advogado. 2001.

THOMPSON, Augusto. A questão penitenciária. Rio de Janeiro: Forense, 2002.

UNESCO. Educando para a liberdade: trajetórias, debates e proposições de um projeto para a educação nas prisões brasileiras. Brasília: UNESCO, 2006.

UNESCO. Educação em prisões na América Latina: direito, liberdade e cidadania. Brasília: UNESCO, 2009. 
dol 10.48209/978-65-89949-D2-H

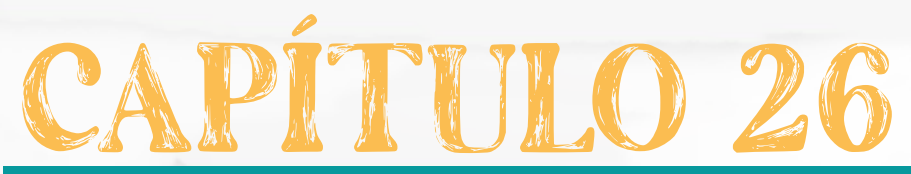

\section{OS DESAFIOS DAS} TECNOLOGIAS

\section{E DA SAÚDE EMOCIONAL:}

UMA REFLEX̃̃O DA PRÁTICA DOCENTE

Maricélia de Almeida Vieira Denise Santos da Cruz 


\section{INTRODUÇÃO}

As tecnologias e os processos educativos propostos nas mídias estão disponíveis para qualquer profissional da prática educativa, com objetivo de (re) significar as práticas e aperfeiçoar os conteúdos didáticos. Atualmente, os professores estão sofrendo pressão no contexto educativo para ampliação das ferramentas metodológicas a partir de capacitações oferecidas pelas instituições. A partir de uma busca de revisão rápida em algumas bases teóricas pretendeu-se fazer uma reflexão sobre novos estudos e sobre a prática docente com o objetivo de despertar reflexões a partir dos estudos feitos embasados teoricamente.

No atual contexto educativo existe uma exigência de novas adequações e utilização de ferramentas tecnológicas, na intenção de modificar o perfil metodológico dos programas pedagógicos dos cursos superiores. Neste momento, importante fazer uma análise dos novos desafios profissionais, em que os docentes se encontram a partir das ofertas de capacitações institucionais, bem como formar e adquirir habilidade na fluência tecnológica. Os ambientes virtuais aprendizagem, as ferramentas tecnológicas, aula virtual, plataformas digitais, Webs, Sites, links, e outras tantas nomenclaturas que desafiam o contexto educacional, tornaram ferramentas importantes para o professor.

Assim como a crescente utilização das mídias digitais e das redes de tecnologias, os docentes são orientados a realizar aperfeiçoamentos e adequação aos novos modelos de práticas educativas modernas, para que possam favorecer o aprendizado dos docentes para uma nova era educacional.

Além disso, os profissionais da educação foram orientados a se adequar rapidamente ao contexto da pandemia e as novas tecnologias, que nem eram tão novas assim.

Com isso, o contexto educacional já vinha sofrendo inúmeras críticas e reflexões de mudanças de paradigmas e novas concepções educacionais na busca por atualizações, a revelar pelo descompasso de ideias entre os educandos e educadores e pelo uso obrigatório das ferramentas digitais nas instituições. 
A importante reflexão que se faz é com relação aos cuidados da saúde emocional docente, a partir da (re) significação das práticas metodológicas e da incorporação das tecnologias digitais no contexto de trabalho. Esse é o enfrentamento e a reflexão que se pretende realizar a partir dos novos movimentos educacionais e novas apropriações de ferramentas tecnológicas nesta proposta.

\section{DOCENTE (RE) SIGNIFICANDO PRÁTICAS EDUCATIVAS NA ERA DIGITAL}

O desenvolvimento tecnológico associado ao contexto educativo é um fator de mudanças em muitas instituições, nos últimos anos, e mesmo fora do contexto de sala de aula, os atores que estão envolvido neste contexto mudaram suas percepções de aprendizado e de uso de novas ferramentas. Os educadores foram colocados mediantes treinamentos e muitas capacitações para ampliar seus conhecimentos educativos, visando ampliar a criatividade e a interação através das mídias digitais.

Nas instituições privadas e públicas, os docentes procuram encontrar formas de se manter ativos no contexto de sala de aula virtual, a partir do aprendizado e uso de ferramentas impostas no contexto novo educacional. Para tanto, as tecnologias digitais favoreceram novos aprendizados aos docentes que viabilizaram o gerenciamento do tempo para novas habilidades e competências nas novas abordagens educativas.

É evidente que as mudanças no contexto educacional e social realizadas nos últimos anos proporcionaram sofrimentos aos aspectos de autonomia e desconstrução do papel do docente, mas foi possível a (re) significação e a produção de novos papéis, além de novos conteúdos pelos docentes, o que leva Imbernón (2009) a falar de mudanças dos meios de comunicação de massas e da tecnologia que transformam a vida pessoal e profissional. Nesse sentido, as mudanças já se anunciavam nas práticas educativas e os professores ampliaram suas formações. 
A proposta do governo para reorganizar o formato das aulas no período de interrupção das aulas presenciais com o Ensino Remoto Emergencial - ERE, fez com que muitos docentes ampliassem seus conhecimentos metodológicos educativos de modo abrupto, rompendo com todos os fatores emocionais do educador. Para Silva (2011), os professores utilizaram vários materiais didáticos para interagir com os alunos, sedo utilizados em atividades pedagógicas e desenvolvidas por meios multimídia e hipermídia, o que possibilitou uma linguagem dinâmica através de podcast, vídeos, animação, infográfico, áudio e outras linguagens de hipertextos.

A educação e a nova etapa de transição das mídias digitais para Moran (1997) na internet encontram-se vários tipos de aplicações educacionais, considerando a comunicação entre grupos, professores, e a divulgação das instituições, consolidando a internet como um processo de educação continuada. A motivação dos alunos em participar de pesquisas, participar em grupos como uma mudança positiva em relação às ferramentas das redes nas aulas presenciais. A demanda para novas capacitações aos atores envolvidos no processo educacional tecnológico aponta para novas construções de paradigmas educacionais.

O processo de ensinar exige consciência do inacabamento que para Freire (2001), o sujeito como um ser inacabado e que dentro do seu inacabamento pode inventar, e para além disso, se (re) inventar nas suas ações na prática formadora. Além disso, o professor tem a escolha da mudança, da criatividade, do aprendizado e das transformações no percurso educacional. Contudo, cabe ao professor direcionar o seu saber, suas escolhas e habilidades, além dos seus conhecimentos diante dos desafios das novas práticas pedagógicas, buscando (re) significar o seu saber, enfrentando os desafios do desenvolvimento profissional.

Para que o professor tenha um trabalho fundamentado nas tecnologias é importante ter, de acordo com Tardif (2014), o reconhecimento do indivíduo, sujeito individual que possuem suas diferenças no contexto ao mesmo tempo. Por 
isso, as relações que se estabelecem com seu objeto de trabalho são as relações humanas e individuais, tão logo, as tecnologias servem apenas um apoio metodológico.

Para Pimenta e Anastasiou (2002), a profissão docente é uma prática educativa como tantas outras e que tem o foco intervir na realidade social mediante os aspectos sociais. Além disso, a ação se refere aos sujeitos que a partir dos seus modos de pensar seus valores e ações, com seus conhecimentos, e métodos de leitura do mundo, ampliando através das práticas institucionais. Portanto, os docentes constituem-se em seres de mudança social, vinculadas ao contexto de transformação dos sujeitos e das instituições.

Nesta perspectiva que as tecnologias digitais servem para os docentes como ferramentas que colaboram para suas práticas e beneficiam a ampliação dos processos de aprendizados. Portanto, é necessário considerar os professores como sujeitos transformadores sociais, agentes que proliferam ideias, e motivando para o processo educacional do futuro.

\section{SAÚdE EMOCIONAL DO DOCENTE NAS PRÁticas EDUCATIVAS TECNOLÓGICAS}

A Saúde emocional tem sido tema de várias pesquisas nas instituições em distintas propostas de temas de pesquisas e em áreas do conhecimento. Nesta proposta, buscamos contextualizar algumas reflexões teóricas, fundamentando como referentes autores. Para Freitas (2013), o adoecimento do docente surge de possíveis sofrimentos no trabalho que envolvem a desvalorização social, a exigência por domínio temático, turmas super lotadas, extensa jornada de trabalho e demandas de horas trabalhadas. A relação de prazer e sofrimentos se tornam linhas tênues para o professor, mediante fatores de relacionamento do contexto presencial. Ainda para a autora, o prazer se manifesta pelo reconhecimento, a valorização profissional e a liberdade de expressão. Ao contrário do 
sofrimento que advém do esgotamento emocional, do desgaste e da frustração, como também, o estresse também pode ser a causa pelo intenso trabalho com o computador.

Com isso, muitos estudos nos mostram que os docentes, mesmo antes da exigência do contexto de pandemia já apresentavam fatores que demandavam habilidade e gerenciamento de tempo nas suas atividades realizadas, que para Freitas (2013), que os docentes se apresentam esgotados profissionalmente diante da sobre carga de trabalho e da falta de reconhecimento social e, muitas vezes, por ausência de reconhecimentos dos próprios estudantes.

A reflexão que devemos ter com relação ao profissional docente segundo Codo (2006), o objetivo do trabalho do professor é a aprendizagem dos alunos, mas com um fator fundamental que é a afetividade. As reflexões podem gerar novos pensamentos e questionamentos em questões que diante da tecnologia, pois a afetividade disseminada entre os professores e alunos independe das metodologias educacionais utilizadas, mas, contudo, que se tenha um objetivo concreto de educação.

Para Dejours (1999), o trabalho nunca é neutro quando a relação está direcionada ao contexto de saúde, pois pode promover e levar ao adoecimento. De acordo com o autor, o trabalho pode ser ora patogênico e ora estruturante, logo o poder do sofrimento psíquico, implica em um agravamento ou em um processo de transformação. Desta forma, se há reconhecimento do fazer docente, o sofrimento pode não encontrar vias para transformação de sentido em prazer, e levando ao procedimento de suprimir sentido para seus esforços levando ao adoecimento.

Para Traesel e Merlo (2013), a mediação das relações do trabalhador docente com seu trabalho, possui flexibilidade ou rigidez na organização, bem como do próprio profissional, considerando a existência social e a competência da profissão da docência. 
Faz-se importante salientar que, mesmo diante deste cenário, pode-se considerar que o trabalho docente tem uma grande responsabilidade na sua construção e (re) significação profissional, por meio de novos aprendizados colaborativos dentro do contexto educacional.

\section{CONSIDERAÇÕES FINAIS}

Para análise proposta apresenta uma revisão teórica e foram pesquisadas em forma revisão breve, alguns estudos que versavam a proposta temática buscando valorizar e (re) significar a docência no contexto das tecnologias.

Neste estudo focalizamos o professor diante dos desafios das novas tecnologias partindo do protagonismo e da valorização da humanização da profissão. Verifica-se a necessidade de reconhecer as mudanças na educação, com influencias das mídias digitais e das tecnologias como ferramentas de transformação, mas também de novos processos consciência que o professor pode ser o protagonista desta mudança social.

As tecnologias já estão incorporadas na nossa sociedade, e mesmo assim, o professor é possui o papel de ator fundamental no contexto educativo, pois somente ele fará com que as tecnologias tenham significado para a construção do conhecimento e do desenvolvimento humano. Além disso, é fundamental que o professor possa observar suas questões relacionadas à saúde emocional para promover um bem-estar no trabalho, visando o benefício das tecnologias aliadas ao seu contexto de trabalho.

Portanto, neste cenário social e educacional transformador, o professor tem um novo a responsabilidade de criar e de mediar diante do processo que requer novas relações de comunicação, mesmo com as modernas tecnologias, mas que possam promover o valor e reconhecimento da humanização dos caminhos de transformação educacional. 


\section{REFERENCIAS}

FREIRE, Paulo. Pedagogia da autonomia. São Paulo. Editora: Paz e Terra; 2001.

FREITAS, Lêda G.; Prazer e sofrimento no trabalho docente. Editora Jiruá; 2013.

INBERNÓM, Francisco. Formação permanente do professorado. São Paulo; Cortez; 2009.

MORAN, José Manuel. Como utilizar a Internet na Educação. Disponível em www.scielo.br/pdf/ci/v26n2/v26n2-5.pdf Acesso em 21/01/2022.

PIMENTA, Selma G.; ANASTASIOU, Léa G. C.; Docência no ensino superior. 5 ed. São Paulo. Editora Cortez; 2014.

SILVA, Robson S. Objetos de aprendizagem para a educação a distância. São Paulo: Novatec, 2011.

TARDIF, Maurice. Saberes Docentes e Formação Profissional. Petrópolis, RJ. Vozes, 2014.

TRAESEL, Elisete S.; MERLO, Álvaro R.; A psicodinâmica do trabalho docente no contexto de uma escola pública do Rio Grande do Sul. Org. Juriá Editora. P. 129-148. 


\section{dol $10.48209 / 978-65-89949-D 2-J$}

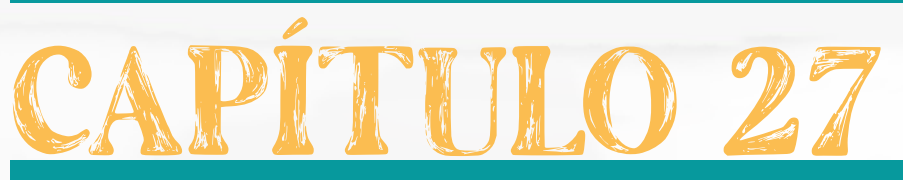

\section{ESTRATÉGIA UTILIZADA PELAS COOPERATIVAS DE CRÉDITO PARA \\ OBTER VANTAGEM COMPETITIVA EM RELAÇÃO A B BANCOS


Resumo: Este estudo tem como objetivo identificar se existe vantagem competitiva entre cooperativas de crédito e bancos privados. Foi utilizado como base de dados estudo de caráter bibliográfico no qual foi realizadas pesquisas sobre o tema discutido, e para análise dos dados obtidos foi utilizado o método de análise de conteúdo. Quanto aos resultados foi identificado que as cooperativas de crédito possuem vantagem competitiva em relação aos bancos privados, tanto no atendimento sendo este o principal fator que contribui para o destaque das cooperativas quanto às taxas cobradas.

Palavras chaves: Estratégia Competitiva, Cooperativa de crédito, bancos, vantagem competitiva.

\section{INTRODUÇÃ̃O}

Atualmente, as organizações vêm vivenciando grandes transformações econômicas, ambientais e sociais. Neste cenário de intensa competitividade, as empresas buscam se diferenciar por meio de estratégias competitivas que assegurem um resultado satisfatório, difícil de ser copiado e de longo prazo.

De acordo com Matos (1993), as organizações modernas se caracterizam pela adoção de novas idéias e novas tecnologias para sobreviver no mercado. Independente do segmento da empresa, do tamanho que possui a competição existe, umas menos acirradas como empresas multinacionais monopolistas outras mais acirradas como empresas creditícias.

Prestes (2015) a gestão de cooperativas diferencia-se da gestão de outros tipos de empresas pela própria forma de constituição jurídica e os princípios cooperativos aos quais deve seguir. De acordo com a lei $n^{\circ} 5.764 / 71$ Art. $4^{\circ}$ As cooperativas são sociedades de pessoas, com forma e natureza jurídica próprias, de natureza civil, não sujeitas à falência, constituídas para prestar serviços aos associados.

Conforme Frainer (2006) o usuário das operações bancárias é o cliente, que não exerce qualquer influência na definição do preço do produto; já nas coo- 
perativas o usuário é o próprio dono, o cooperativado, que juntamente com os demais decide a política operacional das cooperativas. Se nos bancos há distinção e os usuários são tratados de uma forma diferente, nas cooperativas, o que vale para um, vale para todos.

Com base no entendimento de Frainer (2006) percebemos que a sociedade está cada vez mais inserida na sociedade cooperativa. Segundo a revista Época Negócios a expectativa de crescimento das cooperativas de crédito no ano de 2017 será superior a 20\% o que representa a significância e importância do tema. Desta forma, este trabalho tem como objetivo identificar se existe vantagem competitiva entre cooperativas de crédito e bancos privados. Para alcançar o objetivo proposto o método utilizado foi de modelo qualitativo de caráter bibliográfico e documental.

\section{REFERENCIAL TEÓRICO}

\section{Estratégia e Vantagem Cooperativa}

Mintzberg (2006, pag. 24) trata estratégia como uma "ação consciente, uma diretriz para lidar com uma situação. Uma criança tem uma 'estratégia' para pular uma cerca, uma corporação tem uma estratégia para capturar um mercado". A identificação de um novo mercado por uma empresa permite agregar mais valor à marca, para isso, os empreendedores devem estar atentos ao surgimento de novas oportunidades, criando estratégias ou adaptando estratégias já existentes para sair na frente dos concorrentes.

Henderson (1998) define estratégia como a busca deliberada de uma ação para o desenvolvimento e ajuste da vantagem de competição de uma empresa, e esta vantagem deve ser significativa frente às outras empresas do mesmo segmento.

As estratégias devem criar diferenciais para a organização e para seus clientes. Para os consumidores, as estratégias devem evidenciar valor agregado 
em seus produtos e serviços e para os gestores, devem proporcionar ganhos competitivos no mercado em que estão inseridos.

Porter (1992) argumenta que a estratégia competitiva é a busca de uma posição favorável em uma empresa, a diferenciação em uma organização pode estar relacionada ao seu modelo de inovação, sua capacidade de planejamento, utilização de seus recursos, possibilidades de gerar oportunidades.

Thompson (1998) comenta que uma empresa possui vantagem competitiva toda vez que possuir algum diferencial em relação a seus rivais. Isto é, a empresa obtém vantagem competitiva produzindo um produto com a melhor qualidade do mercado, o melhor serviço e atendimento ao consumidor, custos mais baixos que os concorrentes ou o espaço geográfico que a empresa encontra-se.

O conhecimento da vantagem competitiva segundo Maximiano (2000) é importante uma vez que possibilita a comparação da empresa com seus concorrentes possibilitando perceber as razões pelas quais os consumidores escolhem um serviço a outro.

Existem inúmeros autores que falam sobre estratégia e vantagem competitiva, Porter (1986) um dos autores mais com maior destaque quando se fala de competitividade, diz que a vantagem competitiva deriva do planejamento e execução bem sucedida de uma estratégia.

Porter (1986) elaborou um modelo muito utilizado para a análise da empresa no mercado em que atua, formado por cinco forças que permite analisar o grau de atratividade de um setor da economia. Ele identifica os fatores que afetam a competitividade, dentre os quais uma das forças está dentro do próprio setor, sendo que os demais são externos, sendo eles: a rivalidade entre as empresas estabelecidas a ameaça de novas empresas que estão entrando no mercado, o poder de negociação dos compradores, o poder de negociação dos fornecedores, e a ameaça de produtos substitutos. 
Silva (2001) também fala sobre a competição e segundo o mesmo, diz que existem três fatores que determinam a competitividade: 1) fatores sistêmicos relacionado ao ambiente macroeconômico, político, social, legal; 2) fatores estruturais- formação e estruturação da oferta e da demanda que são fatores externos a empresa, relacionados somente ao mercado onde atua; 3 ) fatores internos- determinam diretamente a ação da empresa, sob o expresso controle da empresa, a sua capacidade de gerenciar o negócio, inovação e a informação.

\section{Cooperativismo}

De acordo com Bialoskorski Neto (1997), o cooperativismo teve seu surgimento na pré-história, mas somente no século XIX com a Revolução Industrial ele teve o seu maior desenvolvimento devido às condições que o capitalismo impunha sobre a sociedade no período.

Robert Owen (1771 - 1858), industrial e filantropo, realizou importantes ações no ramo industrial; como a redução da jornada de trabalho dos operários que trabalhavam na sua fábrica e a promoção de uma série de ações que objetivavam a regeneração moral dos indivíduos bem como o aumento da autoestima dos mesmos enquanto operários, implantou restaurantes e alojamentos, proibiu a força de trabalho infantil de crianças com menos de dez anos de idade. Todas essas iniciativas praticadas por ele na sua empresa o induziram a se converter ao socialismo associacionista e cooperativista que acabou por fomentar o movimento operário para a prática concreta do cooperativismo (Rêgo, 2016).

As idéias do socialismo utópico começaram a surgir após pensadores refletirem sobre os aspectos sociais e econômicos da época, a população estava marginalizada, a jornada de trabalho era maçante, condições de trabalho precárias, com a implantação das fábricas a população do campo se mudava para as cidades, grande quantidade de força de trabalho infantil.

A população se dividia em duas: a burguesia dona do maquinário e do capital. E os trabalhadores que possuíam apenas a sua força de trabalho. Nesse ce- 
nário onde se encontravam inúmeros miseráveis e explorados, os trabalhadores começam a se reunir para reivindicar seus direitos por meio dos sindicatos, inicia se assim idéias de cooperação, e os socialistas utópicos começam a expor suas idéias de contribuição para melhorar a vida da população que se encontra desgastada por conta dos processos capitalistas, esse processo ocorreu na Europa, Inglaterra e França (Pinto, 2009).

Para a organização e desenvolvimento do cooperativismo foi necessária a criação de princípios que regulam e orientam todos os integrantes do sistema, sendo eles: adesão livre e voluntária, gestão democrática, participação econômica, autonomia e independência, educação, formação e informação, cooperação entre cooperativas e preocupação com a comunidade.

De acordo com Sousa (2009) existem vários ramos do cooperativismo: agropecuário, de consumo, de crédito, educacional, habitacional, de infraestrutura, mineral, de produção, saúde, trabalho, transporte, turismo e lazer. Diferenciam-se os modelos de consumo, que visam à união de pessoas para comprar produtos em comum a preços reduzidos; os habitacionais, que se destinam à construção de conjuntos residenciais para seus cooperados, os de crédito, com finalidade de promover a poupança e financiar empreendimentos dos associados.

\section{Cooperativas de Crédito}

De acordo com Fontana (2013) em 1850 por iniciativa de Herman Schulze, surge na Alemanha as cooperativas de crédito. No Brasil a ida conforme Fontana o cooperativismo de crédito surgiu na cidade de Nova Petrópolis- RS, sendo a primeira cooperativa de crédito da América Latina, a Caixa de Economia Amstad hoje conhecida como Sicredi Pioneira- RS.

Schimmelfenig (2010) afirma que uma cooperativa de crédito assemelha-se a um banco. Possui produtos e serviços como um banco qualquer. É uma instituição financeira formada por uma associação de pessoas, com forma jurídica própria e de natureza civil. 
Santos (2009) A cooperativa de crédito é uma instituição financeira, uma sociedade de pessoas com forma e natureza jurídicas próprias, de natureza civil, sem fins lucrativos e não sujeita à falência, conforme as Leis $n^{\circ} 5.764 / 71$, de 16 de dezembro de 1971 (BRASIL, 1971) e n 4.595, de 31 de dezembro de 1964 (BRASIL, 1964), os atos normativos baixados pelo Conselho Monetário e pelo Banco Central do Brasil, principalmente a Resolução $n^{\circ} 3.106$ de 25 de junho de 2003 (BANCO..., 2003) e pelo respectivo Estatuto Social.

Conforme Pinho (2004), embora exista muita semelhança entre a figura jurídica das cooperativas de crédito com a dos bancos, as cooperativas socializam os créditos criando a possibilidade de crescer sem geração de lucro. As cooperativas diferente dos bancos aplicam o dinheiro na comunidade onde está inserida, ao contrário do banco que transmitem o dinheiro para os grandes centros.

Segundo Schimmelfenig (2010), atualmente não podemos analisar a evolução da economia brasileira sem descartar a evolução das cooperativas de crédito, pois estas são grandes fornecedoras de tendências da economia do país. No Brasil o atual sistema cooperativista de crédito é organizado em cinco grandes principais sistemas: Sicredi, Sicoob, Unicred, Cecred e Confesol.

\section{Bancos Privados e Estatais}

O sistema bancário brasileiro é formado principalmente por grandes bancos multinacionais que se instalaram no país, vários destas instituição adquiriram antigas estatais como é caso do Banestado adquirido no ano 2000 pelo Itaú, Banespa adquirido também no ano de 2000 pelo Santander e Baneb adquirido pelo Bradesco em 1999, isso para citar apenas 03 casos de grandes bancos estaduais privatizados. Algumas agências estaduais ainda atuam em suas regiões como é o caso do banco Banrisul que atua na região sul do país, mas possui agências em diversos estados, Banestes - Banco do Estado do Espírito Santos e Banpará - Banco do estado do Pará, entre outras diversas agência nacionais, como a Caixa Econômica Federal e Banco do Brasil. 
De acordo com Paula (1998) sistema bancário brasileiro é resultado, em boa medida, das modificações institucionais ocorridas desde a reforma de 1965, passando pela reforma de 1988 (criação dos bancos múltiplos) e, mais recentemente, pela diminuição nas barreiras legais à entrada dos bancos estrangeiros no país.

Em 1964 foi sancionada a lei $n^{\circ} 4595$, que passou a vigorar em 1965, e instituiu diversas mudanças no sistema bancário nacional, como a criação do Conselho Monetário Nacional, BACEN - Banco Central do Brasil criou-se também inúmeras regras operacionais, que passaram a reger o funcionamento e procedimentos das instituições financeiras no país. No ano de 1988 o CMN através da resolução $n^{\circ} 1524$, permitiu que os bancos comerciais, de investimentos ou de desenvolvimento, as sociedades de crédito, financiamento e investimento, as sociedades de crédito imobiliário se re organizarem como uma única instituição financeira, o banco múltiplo, sendo assim um único banco poderia atuar em diversas operações que antes eram vetadas, ao sistema bancário. Segundo Paula (1998) Na prática, observou-se não só a transformação dos antigos conglomerados em uma única instituição múltipla, como também uma proliferação de pequenos e médios bancos.

A rede bancária oferece uma diversa gama de produtos como: Contas poupança e corrente, aplicações, investimentos, cartões de crédito, empréstimos, financiamentos, seguros, títulos de capitalização, previdência privada, venda de bens e imóveis.

Segundo o Banco Central, Banco do Brasil, Itaú-Unibanco, Bradesco, Caixa, Santander somavam em dezembro do ano $2015 \mathrm{R} \$ 5,15$ trilhões em ativos ou $82,5 \%$ de um total de $\mathrm{R} \$ 6,25$ trilhões do somatório das posições contábeis dos bancos com operações comerciais. Dados preocupantes já que em um país tão grande quanto o Brasil apenas cinco instituições detêm mais de $80 \%$ das operações bancárias, é notório da economia que quanto menor for à concorrência maiores serão os preços dos produtos ofertados. 


\section{METODOLOGIA}

Conforme a definição de Gil (2012, p.19) "pode-se definir pesquisa como o procedimento racional e sistemático que tem como objetivo proporcionar respostas aos problemas que são propostos" visa descobrir respostas a questionamentos acerca de qualquer área do conhecimento.

O método utilizado neste artigo foi à pesquisa bibliográfica e documental, realizada em livro e publicações acadêmicas na internet.

A pesquisa documental é tratado por Gil (2002) como materiais que ainda não receberam um tratamento analítico, cartas, diários, memorandos, regulamentos.

Quanto à pesquisa bibliográfica de acordo com Fonseca (2002) é realizada a partir de referências já analisadas, publicadas em livros, revistas, internet; permite ao pesquisador conhecer o que já foi escrito sobre o tema.

Para a análise, será realizada por meio da análise de conteúdo que segundo Moraes (1999) é utilizada para descrever e interpretar o conteúdo de todas as classes de documentos e textos ajudando na compreensão do estudo e significados que vão além de uma leitura comum. Assim como Moraes, Minayo (2011) afirma que a análise de conteúdo é mais que um conjunto de técnicas, a análise verifica hipóteses que está por trás dos conteúdos.

\section{RESULTADOS}

Neste tópico serão apresentados trabalhos já realizados sobre o tema proposto, trabalhos acadêmicos, científicos a fim de alcançar o objetivo proposto, sendo ele: Identificar se existe vantagem competitiva entre cooperativas de crédito e bancos privados. 


\section{Cooperativas de Crédito X Bancos}

As cooperativas estão se fortalecendo ao passar dos anos com o entendimento de que este sistema de união, de cooperar vem trazer maiores benefícios tanto social, cultural e econômico. Sistema que surgiu para minimizar o impacto causado pelo sistema capitalista que marginalizou e deixou várias famílias sem alguma fonte de renda na era da revolução indústria.

$\mathrm{Na}$ "contramão" do cooperativismo vem à sociedade de interesse privado com obsessão ao lucro, sem nenhuma preocupação com a sociedade ou com a região onde esta inserida e o lucro desta sociedade com fins lucrativos fica com seus donos e acionistas.

Em um estudo realizado por Frainer e Souza (2007) na cidade de Blumenau, Santa Catarina na qual foi analisado dados coletados por meio questionários caracterizado como um estudo de campo nos bancos, Banco do Brasil, Banco do Estado de Santa Catarina (BESC), Bradesco, Banco Itaú, Banco ABN AMRO Real S/A e Caixa Econômica Federal.

Dentre as cooperativas de crédito participaram a Cooperativa de Crédito dos Empregados em empresas Têxteis (CREDTÊXTIL), Cooperativa de Economia e Crédito Mútuo dos Médicos e Demais profissionais de Saúde de Blumenau e Vale do Itajaí (CONCREDI), Cooperativa de Crédito do Vale do Itajaí (VIACREDI), Cooperativa de Economia e Crédito Mútuo do Setor Odontológico (CREDIODONTO) e Cooperativa de Economia e Crédito Mútuo dos Servidores Públicos do Vale do Itajaí (BLUCREDI).

Os autores buscaram identificar diferenciais competitivos entre as cooperativas de crédito e os bancos questionados. De acordo com a análise dos questionários, identificaram que nas contas ativas, ou seja, quando a instituição discrimina um determinado número de transações realizadas por seus sócios ou 
clientes a fim de firmar suas relações; identificou-se que as cooperativas isentam a manutenção de conta para os sócios ativos enquanto os bancos cobram taxa mínima no valor de $\mathrm{R} \$ 7,00$ e no máximo $\mathrm{R} \$ 22,50$.

Para a renovação do cadastro apenas uma cooperativa das seis pesquisadas cobra taxa no valor de $R \$ 9,50$ anualmente e os bancos cobram até $R \$ 35,00$. Quanto à abertura de crédito (TAC) as cooperativas cobram até $R \$ 30,00$ enquanto os bancos até $R \$ 300,00$.

Bertolini (2014) por meio de um estudo de caso na cooperativa de crédito Sicoob, em uma agencia no Espírito Santo identificou que o principal fator competitivo é o atendimento ao associado como o principal fator de vantagem competitiva, aspecto o qual a cooperativa obteve grande avanço frente aos bancos, permitindo obter bons resultados em novas associações.

Pessoa (2012) por meio de entrevistas semi estruturadas aplicadas para clientes e associados de bancos e cooperativas de crédito no estado de Minas Gerais e Bahia, identificou condições favoráveis as cooperativas quanto a qualidade da infra estrutura, facilidade na resolução de problemas, atendimento devido a proximidade entre o atendimento e o associado, acesso facilitado a áreas funcionais e contato com a diretoria, facilidade na renegociação de créditos, preocupação com a sociedade. Identificou também pontos fracos como taxas de juros elevadas em relação aos bancos, inexistência de estacionamentos.

Com base nestes autores e em vários outros que pesquisam sobre o tema e comparam não somente instituições cooperativas creditícias, mas também de educação, saúde apontam para uma melhor qualidade no atendimento com os associados, preços praticados mais baixos que as empresas privadas e a preocupação com a sociedade. 


\section{CONCLUSÃO}

Como o tema em discussão é farto e seu estudo inesgotável, percebemos que as cooperativas de crédito possuem vantagem competitiva em relação aos bancos, tanto no atendimento, nas taxas cobradas, na preocupação com a comunidade, visto que, como as cooperativas de créditos e os bancos possuem ações parecidas no desempenho de suas atividades e ambas reguladas pelo Banco Central, as cooperativas distribuem sobras entre seus membros caso haja, diferente dos bancos que possuem acionistas que lucram com os produtos e serviços prestados.

\section{REFERENCIAS}

BERTOLINI, Esp Dayane et al. Um Estudo sobre a Influência da Estratégia de Diferenciação em uma Cooperativa de Crédito. SIMPÓSIO DE EXCELÊNCIA EM GESTÃO E TECNOLOGIA, v. 8, 2014.

BIALOSKORSKI NETO, Sigismundo Gestão do Agribusiness Cooperativo. Gestão agroindustrial. $2^{\mathrm{a}}$ ed., São Paulo, Atlas, 515-543, 1997.

BRASIL. LEI N ${ }^{\circ}$ 5.764, de 16 de dez. de 1971. Define a Política Nacional de Cooperativismo, institui o regime jurídico das sociedades cooperativas, e dá outras providências, BRASÍLIA, DF. Disponível em: <http://www.planalto.gov.br/ccivil_03/Leis/L5764.htm>. Acesso em: 20 nov. 2017.

FONTANA, Elaine. Trajetória dos 25 anos de cooperação e desenvolvimento da Sicredi Altos da Serra RS/SC. Porto Alegre: Sescoop/RS, 2013.

FONSECA, J. J. S. Metodologia da pesquisa científica. Fortaleza: UEC, 2002.

FRAINER, RosemariGlatz; SOUZA, Jurema Inês Dallabona. Bancos Comerciais $\mathrm{X}$ Cooperativas de Crédito de Blumenau: Uma Análise Comparativa das Vantagens Oferecidas a Partir das Valorações de Produtos e Serviços. Disponível em: <rica.unibes.com.br/index.php/rica/article/viewFile/74/70>. Acesso em: 10 nov. 2017.

GIL, Antônio Carlos. Como classificar as pesquisas. Como elaborar projetos de pesquisa, v. 4, p. 44-45, 2012. 
HENDERSON, Bruce D. As origens da estratégia. In.: MONTGOMERY, Cyntia A.; PORTER, Michael E. Estratégia: a busca da vantagem competitiva. Rio de Janeiro: Campus, 1998.

MATOS, Francisco Gomes de. Estratégia de empresa. São Paulo: Makron Books, 1993.

MAXIMIANO, Antônio César Amaru. Teoria Geral Da Administração: Da Revolução Urbana À Revolução Digital . Editora Atlas SA, 2000.

MINAYO, Maria Cecília de Souza. Pesquisa social: teoria, método e criatividade. Petrópolis Editora Vozes, Limitada, 2011.

MINTZBERG, Henry, et al. O processo da estratégia: conceitos, contextos e casos selecionados. $4^{\text {a }}$ Edição. Porto Alegre. Editora Brookman, 2006.

MORAES, Claudio A. de; ZILBER, Moises Ari. Estratégia e vantagem competitiva: Um estudo do setor petroquímico brasileiro. Revista de administração Mackenzie, v.5, n. 1, 2008.

PAULA, Luiz Fernandes Rodrigues de. Tamanho, dimensão e concentração do sistema bancário no contexto de alta e baixa inflação no Brasil. Disponível em: <https://goo.gl/gZybgc>. Acesso em: 18 nov.2017.

PESSOA, Jose Klemens Duarte. Estudo de caso em uma Cooperativa de Crédito no setor publico na cidade de Belo Horizonte, (Mestrado em Administração) Faculdade Novos Horizontes, Belo Horizonte, 2012.

PINHO, Diva Benevides. Economia e cooperativismo. O cooperativismo no Brasil - da vertente pioneira à vertente solidária. São Paulo: Saraiva, 2004.

PINTO, Florentino Carvalho. Uma História do Cooperativismo sob a Perspectiva Utópica. Disponível em: <www.reacfat.com.br/index.php/reac/article/viewFile/6/7>. Acesso em: 01 Nov. 2017.

PORTER, Michael Eugene. Estratégia competitiva: técnicas para análise de indústrias e da concorrência. Rio de Janeiro: Campus, 1986. 
PRESTES, Ruhan Valadares. Desafios e vantagens no cooperativismo: Estudo de caso em uma cooperativa de flores e plantas ornamentais do Distrito Federal. Disponível em: <http://bdm.unb.br/bitstream/10483/13836/1/2015_ RuhanValadaresPrestes.pdf>. Acesso em: 19 nov.2017.

RÊGO, Eduardo Ernesto do; MOREIRA,Emília. Cooperativismo: Uma breve discussão teórico-conceitual perpassando pelo socialismo utópico, marxista e anarquista. Disponível em: <www.okara.ufpb.br/ojs/index.php/okara/article/download/16111/9186>. Acesso em 01 nov. 2017.

SANTOS, Ivantuil Antunes dos. Estratégias Competitivas das Cooperativas de Crédito e Sua Influência no Desempenho: Um Estudo Multicaso. Disponivel em:<http://acervodigital.ufpr.br/bitstream/handle/1884/23429/lvantuil\%20 Antunes\%2020Dissertação\%20..?sequence=1>. Acesso em: 01 nov. 2017.

SCHIMMELFENIG, Cristiano. COOPERATIVISMO DE CRÉDITO: UMA TENDÊNCIA. Disponível em em: <http://www.ideau.com.br/getulio/restrito/upload/revistasartigos/84_1.pdf>. Acesso em: 20 nov. 2017.

SILVA, Jairo Barbosa da; FERREIRA, Ademilsom; A importância do fluxo de caixa como ferramenta fundamental na média e pequena empresa. Disponível em: <http://faef.revista.inf.br/imagens_arquivos/arquivos_destaque/2BbFGJ6GucodWhr_2013-4-29-16-28-38.pdf> Acesso em: 18 nov. 2017.

SOUSA, Letícia Pucildes de. Cooperativismo: conceitos e desafios à implantação da economia solidária. Disponível em: <www.fae.edu/galeria/getlmage/1/732687471628267.pdf>. Acesso em: 20 nov. 2017.

THOMPSON JR, Arhur A.; FORMBY, John P. Microeconomia da firma: teoria e prática. PHB, 1998. 


\section{dol 10.48209/978-65-89949-D2-K}

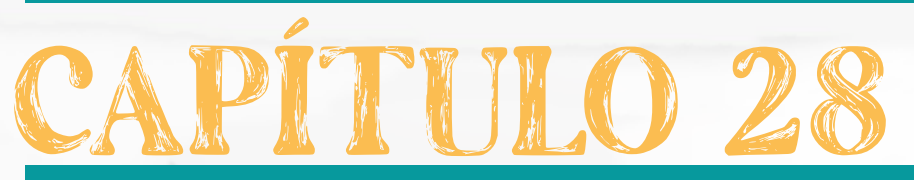

\section{USO DE JOGOS DIDÁTICOS NO ENSINO DE BIOLOGIA: UMA REVISÃO}

Soleika Gorete Lunkes Maria Fatima Menegazzo Nicodem José Gilmar Kurtz Paulo Sérgio Mohr Natalina das Graças Bitencourt Ronny Ramos da Silva 


\section{INTRODUÇÃO}

Cunha (2012) cita que apesar de por muito tempo se pensar que o insucesso no aprendizado do estudante fosse culpa somente sua, hoje é também considerado uma consequência da metodologia utilizada pelo professor. E como Cunha (2012) ainda acrescenta "a ideia do ensino despertado pelo interesse do estudante passou a ser um desafio à competência do docente".

Entretanto, Lepienski e Pinho (2009) enfatizam que o ensino de biologia ainda se apresenta restrito às aulas expositivas e com mínima participação dos alunos além de o trabalho escolar, como acrescenta Krasilchik (2004), na maioria das vezes, estar dissociado do cotidiano do aluno.

Com isso, os jogos didáticos ganham espaço como instrumento motivador para a aprendizagem de conhecimentos à medida que propõe estímulo ao interesse do estudante. Além disso, segundo Campos et al (2003) desenvolvem níveis diferentes de experiência pessoal e social, ajuda na construção de novas descobertas, desenvolve e enriquece sua personalidade e configura-se como um instrumento pedagógico que leva o professor à condição de condutor, estimulador e avaliados da aprendizagem.

Diante o exposto, este trabalho aborda a importância de aulas expositivas, principalmente, com o uso de jogos didáticos no ensino de Biologia, com uma revisão em periódicos e demais trabalhos no período de 1987 até 2016.

\section{DESENVOLVIMENTO}

\section{ENSINO DE BIOLOGIA}

De acordo com Schnetzler (2000), a biologia é o estudo dos seres vivos (bios = vida e logos = estudo), sobre as características e o comportamento dos organismos, a origem de espécies e indivíduos, e a forma como estes interagem uns com os outros e com o seu ambiente. 
Entretanto, para Fernandes (1998) a Biologia é vista, pela maioria dos alunos, como uma disciplina de nomes, ciclos e tabelas para se decorar. E como cita Krasilchik (2005), esta matéria pode ser de duas formas: uma das disciplinas mais relevantes e merecedoras de atenção ou uma das mais insignificantes, e isso dependem do que for ensinado e a forma de ensino.

Neste sentido, a autora descreve quatro níveis de alfabetização biológica:

$1^{\circ}$ - Nominal - quando o estudante reconhece os termos, mas não sabe seu significado biológico. $2^{\circ}$ - Funcional - quando os termos memorizados são definidos corretamente, sem que os estudantes compreendam seu significado. $3^{\circ}$ - Estrutural - quando os estudantes são capazes de explicar adequadamente, em suas próprias palavras e baseando-se em experiências pessoais, os conceitos biológicos. $4^{\circ}$ - Multidimensional quando os estudantes aplicam o conhecimento e habilidades adquiridas, relacionando-as com o conhecimento de outras áreas, para resolver problemas reais (KRASILCHIK, 2005, p.12).

Além disso, como explica Borges e Lima (2007), o ensino de Biologia se organiza de modo a privilegiar o estudo de conceitos, linguagem e metodologias, tornando as aprendizagens pouco eficientes para interpretação e intervenção na realidade e de acordo com Sobrinho (2009) isso é percebido no rendimento dos alunos.

Segundo Krasilchik (2004), aprender conceitos básicos é consequência de analisar o processo de pesquisa científica, as implicações sociais da ciência e da tecnologia. Desta forma, a finalidade do ensino de biologia prevista nos currículos escolares é desenvolver a capacidade de pensar lógica e criticamente e deve contribuir no cotidiano para ampliar o entendimento que o indivíduo tem da sua própria organização biológica, do lugar que ocupa na natureza e na sociedade, e na possibilidade de interferir na dinamicidade dos mesmos, através de uma ação mais coletiva, visando a melhoria da qualidade de vida. 


\section{DIFICULDADES NO ENSINO DE BIOLOGIA}

Keller et al (2011) explicam que o ensino de Biologia permanece ainda, na maioria dos casos, restrito às aulas expositivas com mínima participação dos alunos.

As causas comumente apontadas como responsáveis pelas dificuldades no ensino de Biologia, de acordo com Hennig (1998), são:

a) deficiente preparo profissional do professor;

b) falta de oportunidade e meios para o professor atualizar-se;

c) deficiências das condições materiais da maioria das escolas.

Além disso, Silva et al (2011) expõem que os termos científicos utilizados também são um fator que têm prejudicado a aprendizagem de Biologia isso porque é preciso que o professore apresente aos seus alunos da forma correta e sempre difunda o seu significado. $\mathrm{E}$ apesar de tantos recursos didáticos há o problema em relação à quantidade e disponibilidade desses recursos dentro dos estabelecimentos de ensino.

Demo (2002) apresenta outro fator que é relatado como problema no ensino desta disciplina são os extensos conteúdos encontrados nos livros didáticos e a maneira como são trabalhados, isso porque podem fazer o aluno perder o interesse pelos assuntos. Krasilchik (1987) enfatiza que as Ciências têm sido ensinadas como uma coleção de fatos, descrição de fenômenos, enunciados de teorias a decorar, e não se procura fazer com que os estudantes discutam as causas dos fenômenos, estabeleçam relações causais, ou seja, entendam os mecanismos dos processos que estão estudando.

Desta forma, Melo e Alves (2011) explicam que é necessário investigar e tentar entender onde estão as principais dificuldades dos alunos nessa disciplina, pode fazer com que eles mudem o seu modo de estudar ou até passem a se interessar mais pelo assunto. $E$ assim, cabe ao professor e à escola buscar uma forma de melhorar isso. 


\section{IMPORTÂNCIA DE AULAS PRÁticas E DINÂMICAS NO ENSINO DA BIOLOGIA}

De acordo com Krasilchik (2005) as aulas expositivas ocorrem geralmente com função de informar, porém exige dos alunos maior nível de concentração durante as aulas e dessa forma, há pouca interação entre professor/aluno. Porém, Sobrinho (2009) acredita que é possível que uma aula expositiva seja informativa e divertida se o professor for competente para isto e o uso de jogos didáticos aliado a esse tipo de aula favorece o aprendizado dos estudantes.

Sobrinho (2009) apresenta diversas modalidades didáticas para auxiliar na melhoria do ensino de Biologia, como:

- Discussões: construção de um diálogo em sala de aula. Quando os conceitos são apresentados por meio de uma discussão, tornam-se mais agradáveis e interessantes, pois, desafiam a imaginação dos estudantes;

- Demonstrações: servem para apresentar à turma espécimes ou fenômenos de difícil representação ou duração longa do experimento;

- Aulas práticas: permitem aos educandos o contato direto com os fenômenos, manuseio de equipamentos e observação de organismos;

- Excursões;

- Projetos: permite aos estudantes o desenvolvimento de iniciativas, a capacidade de decidir, a capacidade de estabelecer um roteiro para suas tarefas e finalmente redigir um relatório no qual constam as conclusões obtidas;

- Mapas conceituais: a construção de um mapa conceitual estimula o aluno a refletir, a pesquisar, a selecionar, a analisar, a elaborar o conhecimento e aprender de uma maneira significativa;

- Mídia e ensino. 
Outros autores apresentam sua opinião referente ao ensino diferenciado, como Demo (2002) explica que o curso não deve ser excessivamente teórico ou excessivamente prático, porque ambos são importantes. O autor acrescenta ainda que as atividades experimentas unidas às teóricas propiciam a construção de uma rede de esquemas mentais, auxiliando de um modo lógico e ordenado à compreensão dos conteúdos em Biologia.

Além disso, Sobrinho (2009) acrescenta que as práticas vinculadas às atividades teóricas auxiliam na reconstrução de conceitos científicos significativos para o aluno, proporcionam condições para que haja o questionamento e reflexão na ação dos temas trabalhados, fortalece várias atitudes esperadas na educação e aprendizagem como: a argumentação, a criatividade, a intuição, a abstração, a autonomia e a competência do aluno.

Caon (2005) também explica as vantagens do uso da experimentação no ensino da Biologia. O autor cita que ao incluir ações como manejar materiais específicos, desenvolver tarefas, identificar o problema, estabelecer objetivos e hipóteses, relacionar a prática com os fundamentos teóricos, no intuito de analisar os resultados e escrever conclusões, oportuniza ao aluno o desenvolvimento de habilidades motoras, bem como a participação, a socialização, a crítica, a argumentação, o debate, a autonomia e a abstração do estudante.

As aulas com experimentação, quando bem planejadas, são grandes aliadas no processo pedagógico por combinarem a ação e reflexão, desenvolvendo o raciocínio lógico, a abstração, o senso crítico, os pensamentos formais e a argumentação do educando, gerando significações que poderão ser adaptadas e aplicadas em outras novas situações (CAON, 2005, p. 40).

Seniciato e Cavassan (2004) defendem a ideia de utilizar aulas de campo no ensino de Ciências e Biologia. Os autores acreditam que aulas em ambientes naturais são uma metodologia eficaz tanto por envolverem e motivarem crianças e jovens nas atividades educativas, quanto por constituírem um instrumento de superação da fragmentação do conhecimento. 
Já Lepienski e Pinho (2009) sugerem aulas práticas, uso de equipamentos audiovisuais, a fotografia que apesar de não ser uma ferramenta educacional tem potencial para a exploração e investigação do ambiente natural, a utilização da internet, projetos de estudo, aulas de campo, análise crítica de informações científicas veiculadas pela mídia, análise de casos reais, utilização da sala de aula como "sala de ciências", trazendo o material biológico para estudo e desenvolvendo pequenos projetos de investigação, feiras de ciências e visitas orientadas a museus, reservas ecológicas, instituições de pesquisa etc.

Silva et al. (2011) cita como recursos didáticos para alcançar o objetivo da disciplina de Biologia a utilização de quadro negro, retroprojetores, filmes, dispositivos (data show e PCTV) e modelos.

Carmo e Schimin (2008) também defendem as aulas práticas/experimentais como uma modalidade pedagógica de vital importância, onde os alunos colocam em prática hipóteses e ideias aprendidas em sala de aula sobre fenômenos naturais ou tecnológicos e que estão presentes no dia-a-dia. Além disso, com as aulas práticas espera-se que o estudante construa um conhecimento significativo e não de memorização.

\section{JOGOS DIDÁTICOS NA EDUCAÇÃO}

Outra modalidade didática que pode ser utilizada para melhorar o ensino da Biologia é o uso de jogos pedagógicos. Cunha (1988) conceitua o jogo pedagógico ou didático àquele que é fabricado com o objetivo de proporcionar determinadas aprendizagens, com aspecto lúdico. Gomes et al (2001) acrescenta que o jogo didático é uma alternativa para se melhorar o desempenho dos estudantes em conteúdos de difícil aprendizagem.

Miranda (2001) cita que o uso de jogos pedagógicos influencia no desenvolvimento da inteligência e da personalidade (aspecto cognitivo), no desenvol- 
vimento da sensibilidade e da estima e atuação no sentido de estreitar laços de amizade e afetividade (aspecto afetivo), na simulação de vida em grupo (aspecto social), no envolvimento da ação, do desafio e mobilização da curiosidade (aspecto motivação) e na criatividade.

Assim, a utilização de jogos didáticos ou pedagógicos no ensino de Biologia é uma alternativa viável, visto que este material pode influenciar na correção de problemas no processo de transmissão/recepção de conhecimentos. Além disso, favorece "a construção pelos alunos de seus próprios conhecimentos num trabaIho em grupo, a socialização de conhecimentos prévios e sua utilização para a construção de conhecimentos novos e mais elaborados" (CAMPOS et al, 2002).

Neste sentido, o jogo ganha um espaço como a ferramenta ideal da aprendizagem, na medida em que propõe estímulo ao interesse do aluno, desenvolve níveis diferentes de experiência pessoal e social, ajuda a construir suas novas descobertas, desenvolve e enriquece sua personalidade, e simboliza um instrumento pedagógico que leva o professor à condição de condutor, estimulador e avaliador da aprendizagem. Ele pode ser utilizado como promotor de aprendizagem das práticas escolares, possibilitando a aproximação dos alunos ao conhecimento científico, levando os a ter uma vivência, mesmo que virtual, de solução de problemas que são muitas vezes muito próximas da realidade que o homem enfrenta ou enfrentou (CAMPOS et al, 2002).

Pozo (1998) explica que o docente deve auxiliar na tarefa de formulação e de reformulação de conceitos ativando o conhecimento prévio dos alunos com uma introdução da matéria que articule esses conhecimentos à nova informação que está sendo apresentada, e para isso Campos et al (2002) explicam que é preciso utilizar recursos didáticos para facilitar a compreensão do discente.

Desta forma, o jogo didático constitui-se em um importante recurso para o professor na resolução de problemas, favorecendo a apropriação de conceitos e informações que a disciplina apresenta. 


\section{RESULTADOS E DISCUSSÃO}

Sabendo da importância do uso de jogos didáticos no ensino da Biologia, fe-se um levantamento que de diversos autores (Tabela 1), que buscaram temas de difícil compreensão para os alunos e criaram jogos pedagógicos para facilitar o processo de ensino/aprendizagem.

Tabela 1 - Jogos didáticos confeccionados para o ensino da Biologia

\begin{tabular}{|c|c|c|c|}
\hline NOME DO JOGO & $\begin{array}{c}\text { TEMA } \\
\text { ABORDADO }\end{array}$ & TIPO DE JOGO & AUTOR \\
\hline $\begin{array}{l}\text { Evolução: a luta } \\
\text { pela sobrevivência }\end{array}$ & $\begin{array}{l}\text { Evolução de } \\
\text { Vertebrados }\end{array}$ & Tabuleiro & $\begin{array}{l}\text { Campos et al. } \\
\qquad(2002)\end{array}$ \\
\hline $\begin{array}{l}\text { Heredograma sem } \\
\text { Mistério }\end{array}$ & Genética & Tabuleiro & $\begin{array}{l}\text { Campos et al. } \\
\qquad(2002)\end{array}$ \\
\hline $\begin{array}{c}\text { Desenvolvimento } \\
\text { das fases embrionárias }\end{array}$ & Embriologia & $\begin{array}{c}\text { Confecção da } \\
\text { fase embrionária }\end{array}$ & $\begin{array}{c}\text { Casas e Azevedo } \\
(2011)\end{array}$ \\
\hline Jornada de um embrião & Embriologia & Tabuleiro & $\begin{array}{l}\text { Escolano et al } \\
\qquad(2011)\end{array}$ \\
\hline Biologia limitada & $\begin{array}{c}\text { Revisão } \\
\text { de Biologia no } \\
\text { Ensino Médio }\end{array}$ & Cartas & Jorge et al (2009) \\
\hline $\begin{array}{l}\text { Estrutura da molécula de } \\
\text { DNA }\end{array}$ & DNA & $\begin{array}{c}\text { Peças da } \\
\text { estrutura do DNA }\end{array}$ & $\begin{array}{l}\text { Jann e Leite } \\
\text { (2010) }\end{array}$ \\
\hline $\begin{array}{l}\text { Baralho didático: temas de } \\
\text { biologia para ensino médio }\end{array}$ & $\begin{array}{c}\text { Revisão } \\
\text { de Biologia no } \\
\text { Ensino Médio }\end{array}$ & Baralho & $\begin{array}{l}\text { Fernandes et al } \\
\qquad(2014)\end{array}$ \\
\hline Jogo da sabedoria & Genética & Forca & $\begin{array}{c}\text { Freitas et al } \\
(2013)\end{array}$ \\
\hline
\end{tabular}




\begin{tabular}{|c|c|c|c|}
\hline $\begin{array}{l}\text { Super trunfo árvores } \\
\text { brasileiras }\end{array}$ & $\begin{array}{l}\text { Árvores } \\
\text { Brasileiras }\end{array}$ & Cartas & $\begin{array}{c}\text { Canto e Zacarias } \\
\text { (2009) }\end{array}$ \\
\hline $\begin{array}{l}\text { Baralho dos animais } \\
\text { invertebrados }\end{array}$ & $\begin{array}{l}\text { Características } \\
\text { morfofisiológicas } \\
\text { dos oito filos } \\
\text { dos animais } \\
\text { invertebrados }\end{array}$ & Cartas-pergunta & Silva et al (2014) \\
\hline Dominando os micro-vilões & Vírus & Dominó & Lima et al (2015) \\
\hline $\begin{array}{l}\text { Divisão Celular: } \\
\text { mitose e meiose }\end{array}$ & Divisão celular & Tabuleiro & Lima et al (2016) \\
\hline $\begin{array}{l}\text { Conhecendo } \\
\text { as parasitoses do Brasil }\end{array}$ & Parasitos & Tabuleiro & $\begin{array}{l}\text { Silva e Dantas } \\
\qquad(2014)\end{array}$ \\
\hline $\begin{array}{c}\text { Cromossomos, gene e } \\
\text { DNA }\end{array}$ & Genética & $\begin{array}{c}\text { Kit de peças } \\
\text { do DNA, gene } \\
\text { e cromossomos }\end{array}$ & Temp et al (2011) \\
\hline Perfil Botânico & $\begin{array}{l}\text { Biologia vegetal } \\
\text { do Ensino Médio }\end{array}$ & Tabuleiro & $\begin{array}{c}\text { Branco et al } \\
\text { (2011) }\end{array}$ \\
\hline
\end{tabular}

Fonte: Dados colhidos pelos autores.

Verificados estes estudos, nota-se que os jogos didáticos podem estimular a fixação, assimilação e construção de novos conhecimentos. Neste sentido, Santana (2008) destaca que introduzir jogos didáticos no cotidiano escolar é importante em função de sua influência frente aos alunos, pois quando eles estão envolvidos nesta atividade torna-se mais fácil e dinâmico o processo de ensino e aprendizagem. 


\section{CONCLUSÃO}

O uso de jogos didáticos apresenta inúmeras vantagens que influenciam na aprendizagem dos estudantes. São importantes, pois estimulam a cognição, a assimilação de conteúdos diversos e favorecem a fixação de conhecimentos.

O jogo pedagógico pode ser incorporado no ambiente escolar em paralelo com as aulas expositivas e serve como uma atividade prática para facilitar a transmissão de conhecimentos entre professor e aluno.

Perante o estudo realizado e a vasta pesquisa em trabalhos que abordam esse tema, foi possível perceber a importância de se utilizar esse tipo de didática em sala de aula, tanto para o aprendizado do aluno como para facilitar a transmissão de conhecimento do professor para a turma.

\section{REFERENCIAS}

BORGES, R. M. R.; LIMA, V. M. do R. Tendências contemporâneas do ensino de Biologia no Brasil. In. Revista Electrónica de Enseñanza de las Ciências. 2007, vol. 6, n. 1.

BRANCO, A. L. C.; VIANA, I. B.; RIGOLON, R. G. A utilização do jogo "Perfil Botânico" como estratégia para o ensino de botânica. In: VIII ENCONTRO NACIONAL DE PESQUISA EM EDUCAÇÃO EM CIÊNCIAS, VIII, 2011, Campinas. Anais... Campinas: UNICAMP, 2011.

CAMPOS, L. M. L.; BORTOLOTO, T. M.; FELÍCIO, A. K. C. A produção de jogos didáticos para o ensino de Ciências e Biologia: uma proposta para favorecer a aprendizagem. Núcleos de Ensino da Unesp, São Paulo, 2003. Disponível em: < http://www.unesp.br/prograd/PDFNE2002/aproducaodejogos.pdf > Acesso em: 30 nov. 2021.

CAMPOS, L. M. L.; FELICIO, A. K. C.; BORTOLOTO, T. M. A produção de jogos didáticos para o ensino de Ciências e Biologia: uma proposta para favorecer a aprendizagem. In. Cadernos dos Núcleos de Ensino, São Paulo, p. 35-48, 2002. 
CANTO, A. R.; ZACARIAS, M. A. Utilização do jogo Super Trunfo Árvores Brasileiras como instrumento facilitador no ensino dos biomas brasileiros. In. Ciências e Cognição. 2009, vol. 14, n. 1, pp. 144-153.

CAON, C. M. Concepções de professores sobre o ensino e aprendizagem de Ciências e de Biologia. 2005. 94 f. Dissertação (Mestrado em Educação em Ciências e Matemática) - Pontifícia Universidade Católica do Rio Grande do Sul, Porto Alegre, 2005.

CARMO, S.; SCHIMIN, E. S. O ensino da biologia através da experimentação. 2008. Disponível em: < http://www.diaadiaeducacao.pr.gov.br/portals/pde/arquivos/1085-4.pdf>. Acesso em: 29 nov. 2021.

CASAS, L. L.; AZEVEDO, R. O. M. Contribuições do jogo didático no ensino de embriologia. In. Revista Amazônica de Ensino de Ciências. 2011, vol. 4, n. 6, pp. 80-91.

CUNHA, M. B. Jogos no ensino de Química: considerações teóricas para sua utilização em sala de aula. In. Química Nova na Escola. 2012, vol. 34, n. 2, pp. 92-98.

CUNHA, N. Brinquedo, desafio e descoberta. Rio de Janeiro: FAE. 1988.

DEMO, Pedro. Educar pela pesquisa. São Paulo: Autores Associados, 2002.

ESCOLANO, A. C. M.; GENEROZO, D. B.; DORNFELD, C. B. Jogos: uma propost lúdica para a aprendizagem de Biologia. In: Anais do $3^{\circ}$ Congresso Internacional de Educação, 2011, Ponta Grossa. Ponta Grossa: UEPG, 2011.

FERNANDES, H. L. Um naturalista na sala de aula. In. Ciência e Ensino. Campinas, Vol. 5, 1998.

FERNANDES, S. M. A.; MAVIGNIER, R. D.; SILVA, R. D. S.; SILVA, F. D. R.; DANTAS, S. M. M. M. Baralho didático: temas de Biologia para Ensino Médio. In. Revista SBEnBio. 2014, n. 7.

FREITAS, D. L. R.; COSTA, A. C. P., MIRANDA, F. F.; MELO, A. A., BARBOSA, J. S. Jogo da sabedoria: proposta de jogo didático para o ensino da Genética. In: Anais do IX Congresso de Iniciação Científica do IFRN, Currais Novos, 2013. Currais Novos, 2013, p. 1916-1922. 
GOMES, R. R.; FRIEDRICH, M. A Contribuição dos jogos didáticos na aprendizagem de conteúdos de Ciências e Biologia. In: EREBIO,1, Rio de Janeiro, 2001, Anais..., Rio de Janeiro, 2001, p.389-92.

HENNIG, Georg J. Metodologia do Ensino de Ciências. $2^{\mathrm{a}}$ ed. Porto Alegre: Mercado Aberto, 1998. Cap. 1, p.22-97.

JANN, P. N.; LEITE, M. F. Jogo do DNA: um instrumento pedagógico para o ensino de Ciências e Biologia. In. Ciências e Cognição. 2010, vol. 15, n. 1, pp. 282-293.

JORGE, V. L.; GUEDES, A. G.; FONTOURA, M. T. S.; PEREIRA, R. M. M. Biologia limitada: um jogo interativo para alunos do terceiro ano do Ensino Médio. In: Anais do VII Encontro Nacional de Pesquisa em Educação em Ciências, 2009, Florianópolis. Florianópolis, 2009.

KELLER, L. BARBOSA, S.; BAIOTTO, C. R.; SILVA, V. M. da. A importância da experimentação no ensino de Biologia. In: Anais do XVI Seminário Interinstitucional de Ensino, Pesquisa e Extensão, 2011, Cruz Alta. Cruz Alta: Universidade de Cruz alta, 2011.

KRASILCHIK, M. O professor e o currículo de ciências. São Paulo: Editora da Universidade de São Paulo, 1987. 80p.

KRASILCHIK, M. Prática de ensino de Biologia. São Paulo: Editora da Universidade de São Paulo, 2004.

KRASILCHIK, M. Práticas de ensino de Biologia. 4ª ed. São Paulo: Editora da Universidade de São Paulo, 2005.

LEPIENSKI, L. M.; PINHO, K. E. P. Recursos didáticos no ensino de Biologia e Ciências. 2009. Disponível em: < http://www.diadiaeducacao.pr.gov.br/portals/ pde/arquivos/400-2.pdf?PHPSESSID=2009071511113042> Acesso em: 29 nov. 2021.

LIMA, A. K. M.; SANTOS, P. B.; SOUSA, P. S. Dominando os micro-vilões: uma estratégia de ensino/aprendizagem para o ensino de Ciências. In: Anais do II Congresso Nacional de Educação, 2015, Campina Grande. Campina Grande: 2015. 
LIMA, R. M. de.; SILVA, M. S. L. da.; ALMEIDA, J. M. de.; VÉRAS, M. A. S.; CAVALCANTI, M. L. F. Construção de um jogo lúdico para compreensão do processo de divisão celular: uma proposta alternativa no ensino de Biologia. IN: Anais do I Congresso de Pesquisa e Ensino em Ciências, 2016, Campina Grande. Campina Grande: 2016.

MELO, G. S.; ALVES, L. A. Dificuldades no processo de ensino-aprendizagem de biologia celular em iniciantes do curso de graduação em Ciências Biológicas. 2011. 43 f. Trabalho de Conclusão de Curso (Graduação) - Curso Superior de Ciências Biológicas. Universidade Presbiteriana Mackenzie, São Paulo, 2011.

MIRANDA, S. No fascínio do jogo, a alegria de aprender. In. Ciência Hoje. 2001, vol.28, pp. 64-66.

POZO, J. I. Teorias Cognitivas da Aprendizagem. 3. ed. Porto Alegre: Artes médicas, 1998. 284p.

SANTANA, E. M. A Influência de atividades lúdicas na aprendizagem de conceitos químicos. In: Anais do SENEPT, 2008, Belo Horizonte. São Paulo: Universidade de São Paulo, Instituto de Física - Programa de Pós-Graduação, 2008. pp. 1-12.

SCHNETZLER, R. P. e Aragão, Rosália M. R. (orgs). Ensino de Ciências: fundamentos e abordagens. Campinas: R. Vieira Gráfica e Editora, 2000.

SENICIATO, T.; CAVASSAN, O. Aulas de campo em ambientes naturais e aprendizagem em Ciências - um estudo com alunos do ensino fundamental. In. Ciência e Educação. 2004, vol. 10, n. 1, pp. 133-147.

SILVA, F. S. da.; MORAIS, L. J. O.; CUNHA, I. P. R. Dificuldades dos professores de Biologia em ministrar aulas práticas em escolas públicas e privadas do município de Imperatriz (MA). In. Revista UNI. 2011, vol. 1, n. 1, pp. 135-149.

SILVA, J. S.; SOUSA, F. S.; SANTOS, F. C.; DANTAS, S. M. M. M. "Baralho dos animais invertebrados": aprendendo de forma dinâmica. In. Revista SBEnBio. 2014, n. 7.

SILVA, J.; DANTAS, S. M. M. M. "Conhecendo as parasitoses do Brasil”: jogo de tabuleiro. In. Revista SBEnBio. 2014, n. 7. 
SOBRINHO, R. de S. A importância do ensino da Biologia para o cotidiano. 2009. 40 f. Monografia (Licenciatura em Biologia no Programa Especial de Formação Pedagógica de Docentes) - Faculdade Integrada da Grande Fortaleza, Fortaleza, 2009.

TEMP, D. S.; CARPILOVSKY, C. K.; GUERRA, L. Cromossomos, gene e DNA: utilização de modelo didático. In. Genética na Escola. 2011, vol. 06, n. 01, pp. $9-11$. 


\section{dol 10.48209/978-65-89949-D2-L.}

\section{CAPÍTULO 29}

\section{O FINANCIAMENTO}

PÚBLICO PARA A EDUCAÇÃO ESPECIAL: UMA ANÁLISE DO

\section{FUNDEF E DO FUNDEB}

Diniz da Cunha Silveira 


\section{INTRODUÇÃO}

No âmbito das políticas públicas para a educação, temos vários programas e ações governamentais que são instrumentos de vital importância para a sua execução, dentre os quais, aqueles atrelados ao financiamento educacional.

Este estudo baseou metodologicamente uma pesquisa documental, qualitativa e descritiva, por meio de material científico, legislações, bem como documentos oficiais estatais.

Neste contexto, este trabalho tem por objetivo apresentar o financiamento público da educação especial do Brasil, na escala federal, a partir da análise de alguns releventes instrumentos de política pública, a saber: o Fundef (1998), (Fundo de Manutenção e Desenvolvimento do Ensino Fundamental e de Valorização do Magistério) e o Fundeb (2007), (Fundo de Manutenção e Desenvolvimento da Educação Básica e de Valorização dos Profissionais da Educação), por meio de uma exposição objetiva e simples, visando oferecer uma análise compilada para todos aqueles interessados pela temática.

Tais Fundos, foram criadas nas décadas de 1990 e 2000 no âmbito das discussões no que tange os recursos que assegurem um padrão mínimo de qualidade de ensino para a clientela da educação especial.

Cabe ressaltar, na Constituição Federal de 1988, relata que seja destinado recursos públicos às entidades da sociedade civil para atendimento às pessoas com deficiência, Transtorno Global do Desenvolvimento (TGD) e altas habilidades/superdotação. Além do mais, a Carta Magna também enfatiza o dever do Estado no que se refere à Educação Especial que garante o "atendimento educacional especializado as pessoas com deficiências, preferencialmente na rede regular de ensino" (BRASIL, 1988).

Todavia, faz-se necessário análises capazes de apresentar dados mais consistentes a respeito dos custos envolvidos no provimento de atendimento ao 
alunado com deficiências em nosso país. Cabe a União, estado e municípios informar os dados de maneira transparente para que a sociedade possa ter acesso às informações oriundas dessa modalidade.

\section{DESENVOLVIMENTO}

Conforme o Decreto Federal $n^{0} 7.611$ (2014), que dispõe sobre a educação especial, o atendimento educacional especializado, dentre outros elementos, enfatiza que a União prestará apoio técnico e financeiro aos sistemas públicos de ensino dos Estados, Municípios e Distrito Federal, e as instituições comunitárias, confessionais ou filantrópicas sem fins lucrativos, com a finalidade de ampliar a oferta do atendimento educacional especializado aos estudantes com deficiência, transtorno globais do desenvolvimento e altas habilidades ou superdotação, matriculados na rede pública de ensino regular (BRASIL, 2014).

Nesta perspectiva temos o Fundef que foi instituído pela Emenda Constitucional 1996 (EC/96) e regulamentado pela Lei Federal 9.424, o Fundef (BRASIL, 1996a), como fundo de natureza contábil em cada unidade da federação. Com esse mecanismo, $60 \%$ dos recursos dos impostos e transferências do Distrito Federal, estado e municípios foram direcionados ao ensino fundamental.

O restante dos recursos manteve sua destinação às outras etapas e modalidades da educação básica, conforme a responsabilidade na oferta do Distrito Federal, estados e municípios, estabelecidos no art. 211 da CF/ 88. (BRASIL, 1988). O Fundef nasce em um contexto de forte alinhamento do governo Fernando Henrique Cardoso com os organismos internacionais, em especial com o Banco Mundial, na perspectiva da focalização no Ensino Fundamental e na descentralização (PINTO, 2002).

Os recursos e distribuição do Fundef era proporcional ao número de alunos nas respectivas redes de ensino fundamental. (BRASIL,1996a). E sua normatização determinava que, no mínimo, $60 \%$ dos recursos do fundo deveriam 
ser aplicados ao pagamento dos professores do ensino fundamental em efetivo exercício do magistério e os $40 \%$ deveriam ser destinados na manutenção e desenvolvimento do ensino fundamental. (BRASIL,1996a).

A Emenda Constitucional (EC/96) (BRASIL, 1996b) estabeleceu, ainda, a instituição de um valor mínimo, definido nacionalmente pelo governo federal, a ser aplicado por aluno em cada ano, cabendo a União complementar os fundos dos estados que não apresentassem condições de fazê-lo com recursos próprios. Esse desenho operacional era justificado para minimizar as desigualdades de condições de oferta do ensino fundamental nos estado brasileiros.

O Fundef fortaleceu o processo de municipalização da educação básica, agregando a merenda e o transporte escolar, reformas em manutenção de prédios, provimentos de pessoal para escolas privadas e estaduais, incluindo também a oferta do Atendimento Educacional Especializado (AEE) e/ou criação de políticas para a educação especial (SOTO, 2012).

Em relação a educação especial, especificamente aos alunos matriculados no ensino fundamental, a legislação do Fundef definiu o valor mínimo por aluno-ano diferenciando do valor mínimo nacional, de acordo com o nível de ensino e o tipo de estabelecimento, que levasse em conta o custo por aluno. (BRASIL,1996a). Entre 2000 a 2004 estipulou-se um acréscimo de 5\% (1,05) para alunos de $5^{\mathrm{a}}$ a $8^{\mathrm{a}}$ séries e da educação especial, superior ao definido para o das séries iniciais urbanas do ensino fundamental $(1,00)$.

Após análise de estudos sobre o tema abordado que é o financiamento da educação especial podemos dizer que a gestão pública ainda tem pouco divulgado os números expressivos no que se dispõem a refletir acerca desse custeio. Ressaltando ainda que de acordo com o documento oficial intitulado Política Nacional de Educação Especial na Perspectiva da Educação Inclusiva,

[...] considera-se pessoas com deficiência aquela que tem impedimentos de longo prazo, de natureza física, mental ou sensorial que, em interação com diversas barreiras, podem ter restringida sua participação plena e efetiva na escola e na sociedade. Os alunos com transtornos globais 
do desenvolvimento são aqueles que apresentam alterações qualitativas das interações sociais recíprocas e na comunicação, um repertório de interesses e atividades restritos, estereotipados e repetitivo. Incluem-se nesse grupo alunos com autismo, síndromes do espectro autista e psicose infantil. Alunos com altas habilidades/superdotação demostram potencial elevado em qualquer uma das seguintes áreas, isoladas ou combinadas: intelectual, acadêmica, liderança, psicomotricidade e artes, além de apresentar grande criatividade, envolvimento na aprendizagem e realização de tarefas em áreas de seu interesse. (BRASIL, 2008, p.15).

Caracterizando esse direito, Oliveira (2001) comenta que esse direito tem dupla obrigatoriedade, pois:

Refere-se, de um lado, o dever do Estado de garantir a efetivação de tal direito e, de outro, ao dever do pai ou responsável de provê-la, uma vez que passa a não fazer parte de seu arbítrio a opção de não levar o filho à escola (OLIVEIRA, 2001, p. 15)

Além de ser um direito social, a educação está inscrita na Constituição Federal como direito subjetivo (BRASIL, 1988).

Para Duarte (2004),

A figura do direito público subjetivo, quando utilizada para proteger um bem que é ao mesmo tempo individual e social, deve se prestar à exigibilidade do carácter coletivo de tais direitos, ou seja, à exigibilidade de políticas públicas (DUARTE, 2004, p. 116).

A resolução do Conselho Nacional de Educação (2001) CNE/CEB nº 2 de 11 de setembro de 2001 Institui Diretrizes para a Educação Especial na Educação Básica e o Art. $2^{\mathrm{a}}$ informa que os sistemas devem matricular todos os alunos, cabendo às escolas organizar-se para o atendimento aos educandos com necessidades educacionais especiais, assegurando as condições necessárias para uma educação de qualidade para todos.

No que diz o Fundef em 2005 a nova diferenciação elevou o fator de ponderação para 7\% $(1,07)$ para essa modalidade, com o Decreto $n^{\circ} 5.374$, de 17 de fevereiro (BRASIL, 2005). Assim, tendo como base o valor do fator de ponderação por aluno no ensino fundamental estabelecido para alunos da educação especial do ensino fundamental urbano e rural, o valor mínimo nacional garantido 
pela União em 2005 para educação especial foi de $R \$ 664,00$. A Lei $n^{\circ} 9.424 / 96$ (BRASIL, 1996) estabelecia ainda que a distribuição de recursos do Fundef deveria considerar a diferenciação de custo por aluno, segundo os níveis de ensino e tipos de estabelecimento, adotando-se a metodologia de cálculo e as correspondentes ponderações. Observa-se, assim, o predomínio de uma lógica pragmática de financiamento em detrimento de uma racionalidade ético-política. (FARENZENA, 2006).

No período de 1999 a 2006 de acordo com a observação de Viegas e Bassi (2009) houve uma expansão no número de matrículas de educação especial no ensino regular, em classe comum, e atribuem ao fundo, por meio das diferenciações promovidas no valor aluno-ano em 2000 e, em 2005, a um fator decisivo no estímulo e expansão de matrícula no setor público, ainda que induzidas pela busca de recursos do Fundef.

$\mathrm{Na}$ apuração das matrículas na educação básica, considerando as matrículas em escola exclusivamente ou em classes especiais de escolas regulares e em classes comuns, com e sem salas de recursos, nota-se um crescimento de $87 \%$ da oferta total. Os autores ainda destacam a existências de programas e recursos de FNDE (Fundo Nacional de Desenvolvimento da Educação) e as iniciativas da Secretaria de Educação Especial (Seesp), que direcionaram fontes educacionais de recursos financeiros para essa modalidade de ensino. (VIEGAS; BASSI, 2009).

Nesse sentido, apesar da melhoria na equiparação do valor nacional por aluno-ano no ensino público e das diferenciações feitas a partir de 2000 , faz-se necessário atentar, como apontam Viegas e Bassi (2009), para os baixos valores anuais gastos por aluno, muito distantes de um custo-aluno condizente e suficiente.

Ademais, em 2007 foi implantado o Fundeb, em substituição ao Fundef, que vigorou no período de 1998 a 2006. 
O Fundeb constitui um fundo especial, de natureza contábil, no âmbito estadual, e sua formação resulta da aplicação de percentuais, vinculados a receita arrecadada de impostos do Distrito Federal, estados e municípios, direcionados à educação por força do disposto no art. 212 da Constituição Federal (BRASIL, 1998).

A título de complementação o Fundeb complementa uma parcela de recursos da União, sempre que, âmbito do Estado, seu valor não alcançar o mínimo definido nacionalmente, em cada uma das etapas ou modalidades de ensino, fixado pelo poder executivo, de acordo com o inciso $\mathrm{V}$, do art. $2^{\circ}$ da Emenda Constitucional $n^{\circ}$ 53/06 (BRASIL, 2006). Essa participação foi estabelecida originalmente em $R \$ 2$ bilhões para 2007, R\$ 3 bilhões para 2008, R\$ 4,5 milhões para 2009 e, a partir de 2010, em 10\% do valor total da contribuição do Distrito Federal, estados e municípios. Independentemente da origem, todo o recurso gerado é redistribuído para aplicação exclusiva na educação básica.

O período de vigência estabelecido para o Fundeb foi de 2007 a 2020, sua implantação começou em $1^{\circ}$ de janeiro de 2007, sendo concluída em 2009, quando o total de alunos matriculados na rede pública foi considerado na distribuição dos recursos e percentual de contribuição do Distrito Federal, estados e municípios para a formação do Fundo atingiu o patamar de $20 \%$.

Conforme prevê a Constituição Federal de 1988, as escolas devem informar os alunos computados no ano anterior para o senso escolar, assim os municípios recebem os recursos do Fundeb com base no número de alunos da educação infantil e do ensino fundamental e os estados com os alunos do ensino fundamental e médio (BRASIL, 1988). Na versão final do Fundeb foram acrescentados as matrículas de educação infantil e da educação especial da rede conveniada sem fins lucrativos. A distribuição de recursos também considera os fatores de ponderação que são definidos anualmente pela Comissão Intergovernamental 
de Financiamento para a Educação Básica de Qualidade, conforme previsto no inciso I, do art. 13 da lei 11.494/2007 (BRASIL, 2007), lei que regulamenta o FUNDEB.

Assim, de acordo com Viegas e Bassi (2009), as etapas e modalidades são consideradas com pesos diferentes na distribuição de recursos no novo desenho do financiamento da educação nessa escala entre 0,7 a 1,3 pontos. Desse modo, a posição de cada especificidade nessa escala toma como referência o fator de ponderação de valor 1,0 definido para a matrícula das séries iniciais urbanas do ensino fundamental.

O valor mínimo por aluno-ano da educação especial passa a receber um peso ponderado $20 \%$ superior ao valor de referência, em uma escala cujo vaIor mais elevado alcança $30 \%$. Os critérios utilizados na definição de recursos, segundo Pinto (2007, p. 891), "esteve longe de ser o custo real dessa etapa e modalidades", uma que a decisão ficou restrita a negociações políticas entre estados e municípios e não apresentaram dados técnicos que justificassem ou explicitassem os fatores que levaram às diferenças entre os valores de ponderação.

No tocante as políticas centralizadoras, segundo Dourado (2007, p. 927), para a desarticulação de políticas direcionadas à educação básica no âmbito dos municípios e à adoção de projetos ligados às políticas do governo federal "em função da necessidade dos sistemas e escolas buscarem fontes complementares de recursos".

Neste antagonismo, para Plestch (2011), ao longo do mandato do Presidente Luiz Inácio Lula da Silva (2003-2010) houve uma ampliação de investimentos financeiros voltados à garantia dos direitos das pessoas com deficiência, TGD, altas habilidades/superdotação, no contexto de implementação de políticas de inclusão social e educacional direcionados a diferentes grupos sociais. No caso 
da educação especial, as iniciativas se desenvolveram por meio de programas, voltados à educação básica e ao ensino superior.

E mudanças significativas na estrutura e funcionamento da educação especial, tendo em vista a elaboração de diretrizes para formulação de políticas públicas, entre as quais destacamos: a Política Nacional da Educação Especial na Perspectiva da Educação Inclusiva - (PNEE-PEI/08) - (BRASIL, 2008); o Decreto Presidencial de $\mathrm{n}^{\circ}$ 7.611, de 17 de novembro de 2011 (BRASIL, 2011) - e a Resolução n 4, de 2 de outubro de 2009 (BRASIL. 2009).

O Fundeb repassou R\$ 293 milhões para as Apaes e instituições especializadas em alunos com deficiência em 2010. O valor em 2009 foi de $R \$ 282$ milhões, seguindo uma política pública de aumento de verbas para a educação especial. Em 2007, quando os recursos eram repassados via Programa de Atendimento Especializado (PAED), o repasse foi de apenas $\mathrm{R} \$$ 6,7 milhões.

O Fundo passou a contar em dobro as matriculas de pessoas com deficiência que estudam em dois turnos, sendo um na escola regular e outro em instituições de atendimento educacional especializado. Quanto ao transporte escolar. O Fundo Nacional de Desenvolvimento da Educação (FNDE) repassa recursos que podem ser usados para a aquisição de veículos para o transporte de alunos.

O FNDE envia recursos às instituições filantrópicas para merenda, livros e aqueles originários do Programa Dinheiro Direto na Escola (PDDE). Nos últimos três anos, foram repassados $\mathrm{R} \$ 53.641,94$, destinados a essas ações.

Mais alunos da educação especial estão em classes comuns do ensino regular em relação a 2002, quando havia 106.630 matrículas. Dados do Censo Escolar da Educação Básica de 2009 já apontam 365.796 estudantes incluídos em classes regulares. Levando-se em conta toda a educação especial na rede pública, o número de vagas passou de 241.234 para 454.927. 


\section{RESULTADOS E DISCUSÕES}

O crescimento na quantidade de estudantes com deficiência que estudam em classes regulares é resultado da política do Ministério da Educação a favor da inclusão. Apoio técnico e financeiro do MEC permite ações como adequações de prédios escolares para a acessibilidade, a formação continuada de professores da educação especial e a implantação de salas de recursos multifuncionais.

Um dos desafios recorrentes nos estudos de financiamento da educação no Brasil refere-se ao acesso às informações. Isso porque, apesar dos avanços realizados "pelos órgãos públicos no levantamento e disseminação de informações de gastos educacionais, ainda não existe uma confiabilidade plena nos dados disponibilizados" (PINTO; AMARAL; CASTRO, 2011, p. 643). Entretanto, nas últimas décadas, observamos um esforço do Estado brasileiro para coletar, processar, disseminar e tornar pública as informações referentes às verbas da educação dos estados, do Distrito Federal e dos municípios (ARAÚJO, 2012).

Conforme o Portal do MEC, (BRASIL, 2011) o Fundo Nacional de Desenvolvimento da Educação (FNDE) repassou recursos no valor de $\mathrm{R} \$ 100$ milhões a 3.433 municípios. Os recursos destinaram-se, prioritariamente, à promoção da acessibilidade arquitetônica de 12.165 mil escolas públicas municipais, estaduais e do Distrito Federal. Na aplicação de itens como cadeiras de rodas ou softwares específicos. Para Martinha Clarete Dutra (2011), que foi diretora de políticas públicas de educação especial do Ministério da Educação, "Trata-se de um apoio que a União oferece aos sistemas de ensino". A iniciativa teve o apoio do programa Escola Acessível.

Cada unidade de ensino receberia cerca de $\mathrm{R} \$ 6$ mil a $\mathrm{R} \$ 9$ mil. Cada unidade receberia recursos que vão de $\mathrm{R} \$ 6$ mil a $\mathrm{R} \$ 9$ mil, de acordo com o número de alunos. O dinheiro destinava a aquisição de material para construção de ram- 
pas, alargamento de portas, adequação de corredores, sanitários, bibliotecas e quadras de esportes. "Os estudantes com deficiências devem ter acesso a todas as dependências da escola". Concluiu a Martinha Clarete.

\section{CONCLUSÃO}

A partir de 2007 o financiamento da educação constituído pelo Fundef ampliou os recursos para a educação e destacou elementos específicos para a educação especial, porém o valor ainda insuficiente para esta modalidade não condiz com os parâmetros de direito à educação da população brasileira estabelecidos na Constituição Federal (BRASIL, 1988). Ainda faltam ajustes.

Verifica-se, com este estudo, que o valor mínimo nacional por aluno/ano redistribuído pelo Fundef para as matrículas de educação especial, assim como para todo o ensino fundamental, ficou muito abaixo de suprir um custo por aluno que seja adequado e suficiente para que o atendimento fosse oferecido com um padrão de qualidade aceitável.

Estudos a respeito do financiamento da educação especial, ainda tem pouca divulgação dessa verba para garantia de oferta de recursos e serviços dessa modalidade da educação pela gestão pública. Em vista disso, esta pesquisa busca contribuir com o debate para que a sociedade cobre e tenha ciência sobre o financiamento da educação especial no Brasil.

\section{REFERENCIAS}

ARAÚJO, Raimundo Luiz Silva. Desvendando o perfil dos gastos educacionais dos municípios brasileiros. Educação \& Sociedade, Campinas, v. 33, n. 121, p. 1215-1233, out./dez. 2012.

BRASIL. Constituição da República Federativa do Brasil de 1988. Brasília, DF: Presidência da República. Disponível em: http://www.planalto.gov.br/ccivil_03/constituicao/constituicao.htm Acesso em: 1 ago. 2019. 
BRASIL. Lei Federal n 9.424, 1996a. Fundo de Manutenção e Desenvolvimento do Ensino Fundamental e de Valorização do Magistério. Disponível em: <http://portal.mec.gov.br/arquivos/pdf/Legis.pdf> Acesso: 29 de jun de 2019.

BRASIL. Emenda Constitucional no 14. Modifica os artigos 34, 208, 211 e 212 da Constituição Federal e dá nova redação ao art. 60 do Ato das Disposições constitucionais Transitórias. 1996b. Disponível em http://www.planalto.gov.br/ccivil_03/ Constituicao/Emendas/Emc/emc14.htm\#art5. Acesso: 26 de jun. de 2019.

BRASIL. Fundo de Manutenção e Desenvolvimento do Ensino Fundamental e de Valorização do Magistério. Fundef 1998.

BRASIL. Resolução CNE/CEB N 2, de 11 de setembro de 2001. Institui Diretrizes Nacionais para a Educação Especial na Educação Básica. Disponível em: http://portal.mec.gov.br/cne/arquivos/pdf/CEB0201.pdf Acesso em: 26 de jun. de 2019.

BRASIL. Decreto n. 5.374. (Revogado) Fixa, para o exercício de 2005, o valor mínimo anual por aluno de que trata o art. $6^{\circ}, \S 1^{\circ}$, da Lei n. 9.424, de 24 de dezembro de 1996, e dá outras providências. Diário Oficial [da] República Federativa do Brasil, Brasília, 18 fev. 2005.

BRASIL. EMENDA Constitucional $n^{\circ}$ 53. Dá nova redação aos artigos $7^{\circ}, 23,30$, 206, 208, 211 e 212 da Constituição Federal e ao art. 60 do Ato das Disposições Constitucionais Transitórias. 2006. Disponível em: <http://www.planalto.gov.br/ ccivil_03/Constituicao/Emendas/Emc/emc53.htm\#art2\%20.> Acesso: 26 de jun. de 2019.

BRASIL. Fundo de Manutenção e Desenvolvimento da Educação Básica e de Valorização dos Profissionais da Educação. Fundeb 2007.

BRASIL. Política Nacional de Educação Especial na Perspectiva da Educação Inclusiva. Brasil: MEC/SEESP, 2008.

BRASIL. Decreto Presidencial $n^{\circ} 7611,2011$. Dispõe sobre a educação especial, o atendimento educacional especializado e dá outras providências. Disponível em: http://www.planalto.gov.br/ccivil_03/_ato2011-2014/2011/decreto/ d7611.htm. Acesso em: 1 ago. 2019. 
BRASIL. Decreto 7.611, 2014. Dispõe sobre a educação especial, o atendimento educacional especializado e dá outras providências. Disponível em:<http://www.planalto.gov.br/ccivil_03/_Ato20112014/2011/Decreto/D7611.htm\#art11>. Acesso em: 25 de jun. de 2019.

BRASIL. Nota técnica $n^{\circ} 4,2014$. Orientação quanto a documentos comprobatórios de alunos com deficiência, transtornos globais do desenvolvimento e altas habilidades/superdotação no Censo Escolar. Disponível em: $\quad<$ http://portal.mec.gov.br/index.php?option=com_docman\&view=download\&alias=15898-nott04-secadi-dpee-23012014\&category_slug=julho-2014-pdf\&Itemid=30192> Acesso: 28 de jun de 2019.

DOURADO, Luiz Fernandes. Políticas e gestão da educação básica no Brasil: limites e perspectivas. Educação \& Sociedade, n. 100, p. 921-946, out. 2007.

DUARTE, C.S. Direito público subjetivo e políticas educacionais. São Paulo em perspectiva, 18(2): 113-118, 2004.

DUTRA, Martinha Clarete. Políticas Públicas e Acessibilidade. 2011. (Apresentação de Trabalho/Seminário).

FARENZENA, Nalú. A política de financiamento da educação básica: rumos da legislação brasileira. Porto Alegre, RS: UFRGS, 2006.

MEC, portal. Repasse dos recursos para educação especial. Disponível em: <http://portal.mec.gov.br/busca-geral/205-noticias/1349433645/15972-repasse-de-recursos-chega-a-r-293-milhoes-este-ano> Acesso em: 25 de junho de 2019.

MEC, portal. Repasse para acessibilidade. http://portal.mec.gov.br/busca-geral/205-noticias/1349433645/16707-escolas-terao-r-100-milhoes-para-melhorar-acessibilidade> Acesso em: 25 de junho de 2019.

OLIVEIRA, R.P.; ADRIÃO, T. (Orgs.). Gestão, financiamento e direito à educação: análise da LDB e da Constituição Federal. São Paulo: Xamã, 2001.

PINTO, José Marcelino de Rezende; AMARAL, Nelson Cardoso; CASTRO, Jorge Abrahão de. Financiamento do ensino médio no Brasil: de uma escola boa para poucos à massificação barata da rede pública. Educação \& Sociedade, Campinas, v. 32, n. 116, p. 639-665, jul./set. 2011. 
PINTO, J.M.R. A política recente de fundos para o financiamento da educação e seus efeitos no pacto federativo. Educação \& Sociedade, v. 28, n. 100 , p. $877-897$, out. 2007. Disponível em: <http://dx.doi.org/10.1590/ S010173302007000300012>. Acesso em: 26 de junho de 2019.

PINTO, C. V. - Organização e Gestão da Manutenção. 2. ed. Lisboa: Edições Monitor, 2002.

PLETSCH, Márcia D. A dialética da inclusão/exclusão nas políticas educacionais para pessoas com deficiências: um balanço do Governo Lula (20032010). Revista Teias, Rio de Janeiro, v. 2, n. 24, p. 39-55, jan./abr., 2011.

SOTO, Antônio. Financiamento da educação no Brasil na arena do público e do privado (2012). P 359-376.

VIEGAS, L. T.; BASSI, M. E. A educação especial no âmbito da política de fundos no financiamento da educação. Reflexão e ação, Santa Cruz do Sul, v. 17 , p. 54-87, 2009. 


\section{SOBRE OS ORGANIZADORES}

\section{GABRIERLA ELDERETI MACHADO}

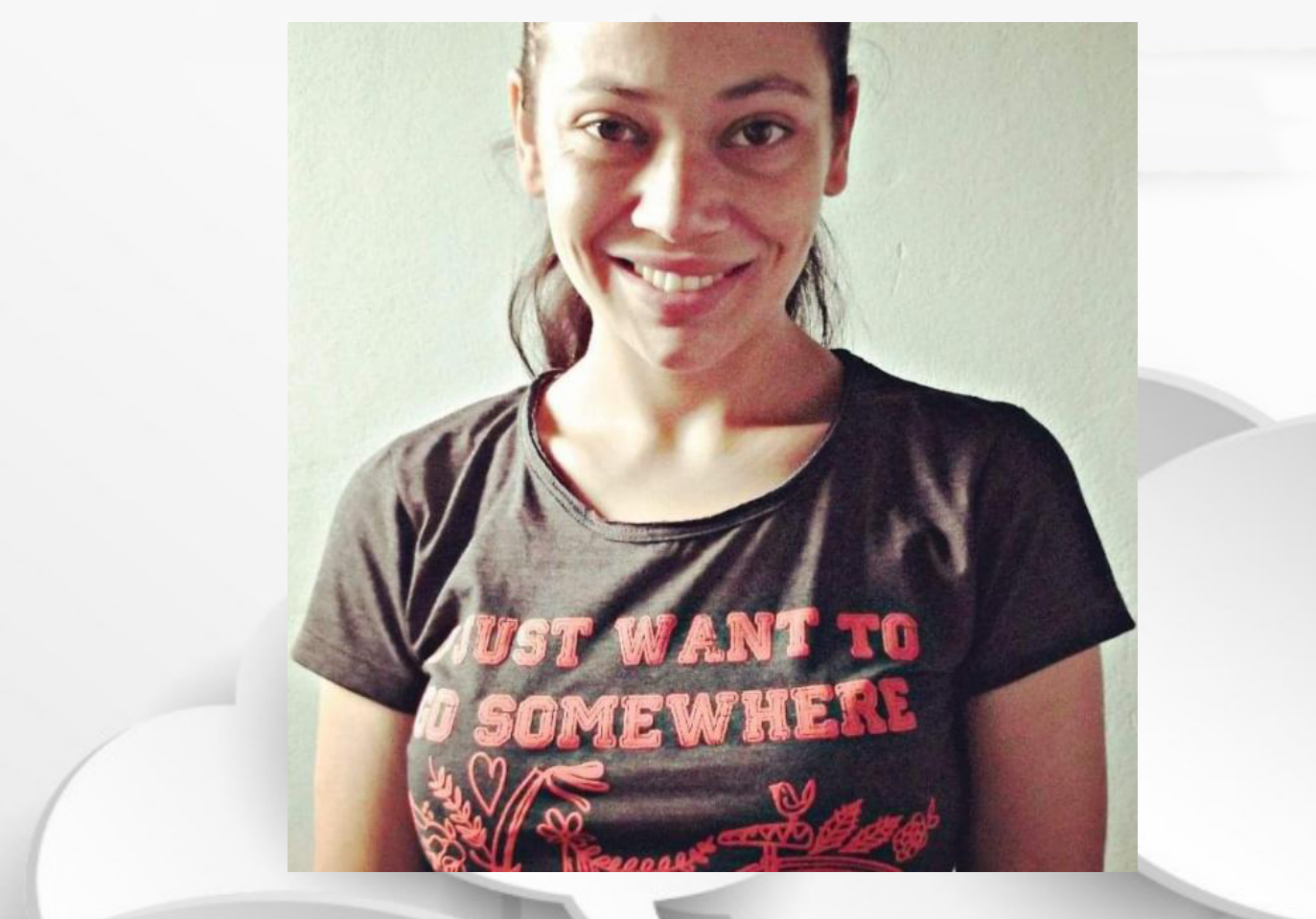

É Licenciada em Química pelo Instituto Federal de Educação, Ciência e Tecnologia Farroupilha-IFFar-Campus Alegrete (2015) ePedagoga pelo Centro Universitário Facvest - Unifacvest (2020). Especialista Educação Ambiental pela Universidade Federal de Santa Maria (2016), Mestre em Educação pela Universidade Federal de Santa Maria (2018). Atualmente é Discente do Programa de Pós - Graduação em Educação - Doutorado em Educação na Universidade Federal de Santa Maria. Participou do Grupo de Estudo e pesquisa Feministas (UFSM); do-Grupo de Estudos em Políticas e Gestão Educacional (IFar - Campus Alegrete); do Grupo de Agroecologia Terra Sul(UFSM). Atualmente participa do Núcleo de Pesquisa em Desenvolvimento Territorial do Pampa (IFar - Campus Alegrete) e atua como pesquisadora no Grupo de Estudos e Pesquisas em Educação e Imaginário Social - GEPEIS (UFSM). Trabalha na área da Educação, com ênfase na Formação de Professores e Imaginário Social. 


\section{RODRIGO DUARTE FACGIN}

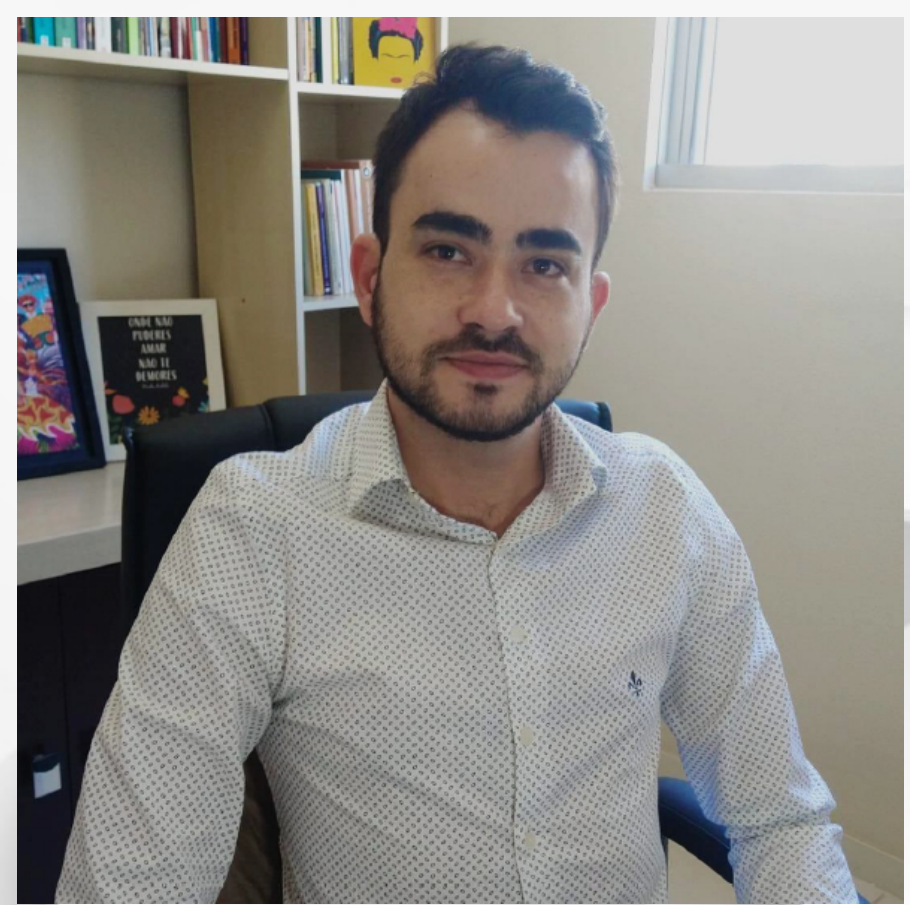

Bacharel em Administração pela Universidade Regional Integrada do AltoUruguai e das Missões, Campus Santiago, e Mestre em Extensão Rural pela Universidade Federal de Santa Maria. Atualmente aluno na UFSM no Programa Especial de Graduação de Formação de Professores Para a Educação Profissional (PEG). Doutor em Extensão Rural pela Universidade Federal de Santa Maria. 


\section{SABRINA COPETTI DA COSTA}

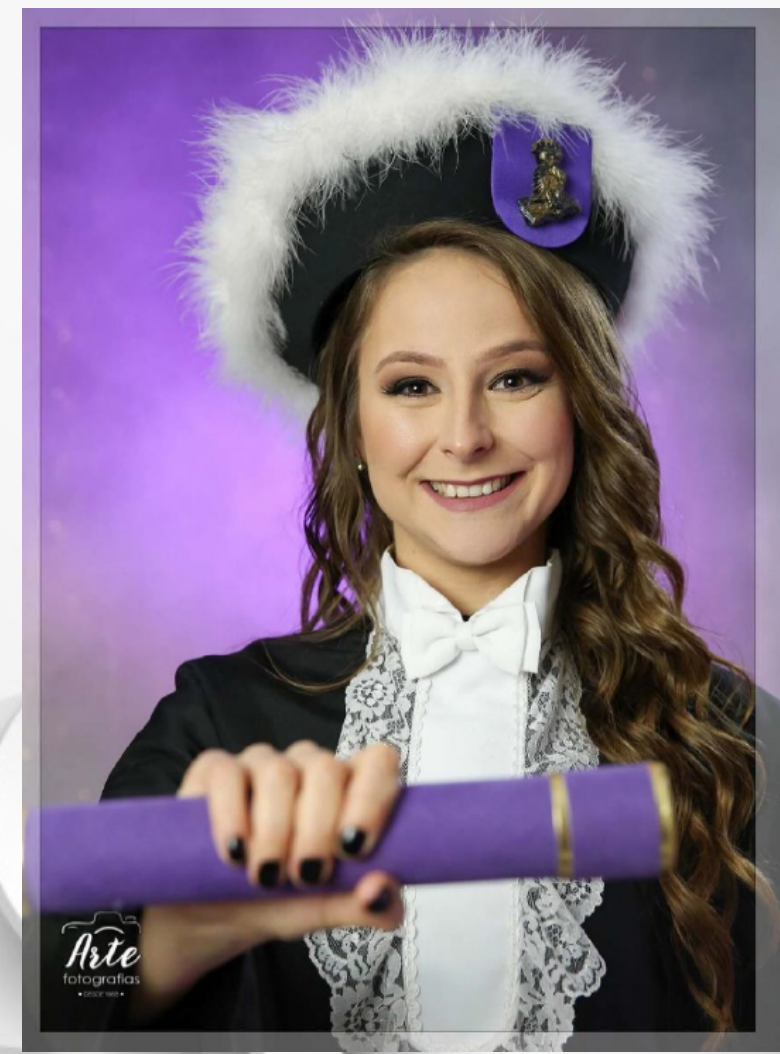

Mestranda em Educação pela Universidade Federal de Santa Maria - UFSM e especializanda em "Educação: espaços e possibilidades para a educação continuada" pelo IFSul. Possui graduação em Pedagogia pela UFSM e participa como voluntária no Grupo de Estudos e Pesquisas em Educação e Imaginário Social - GEPEIS - da UFSM.

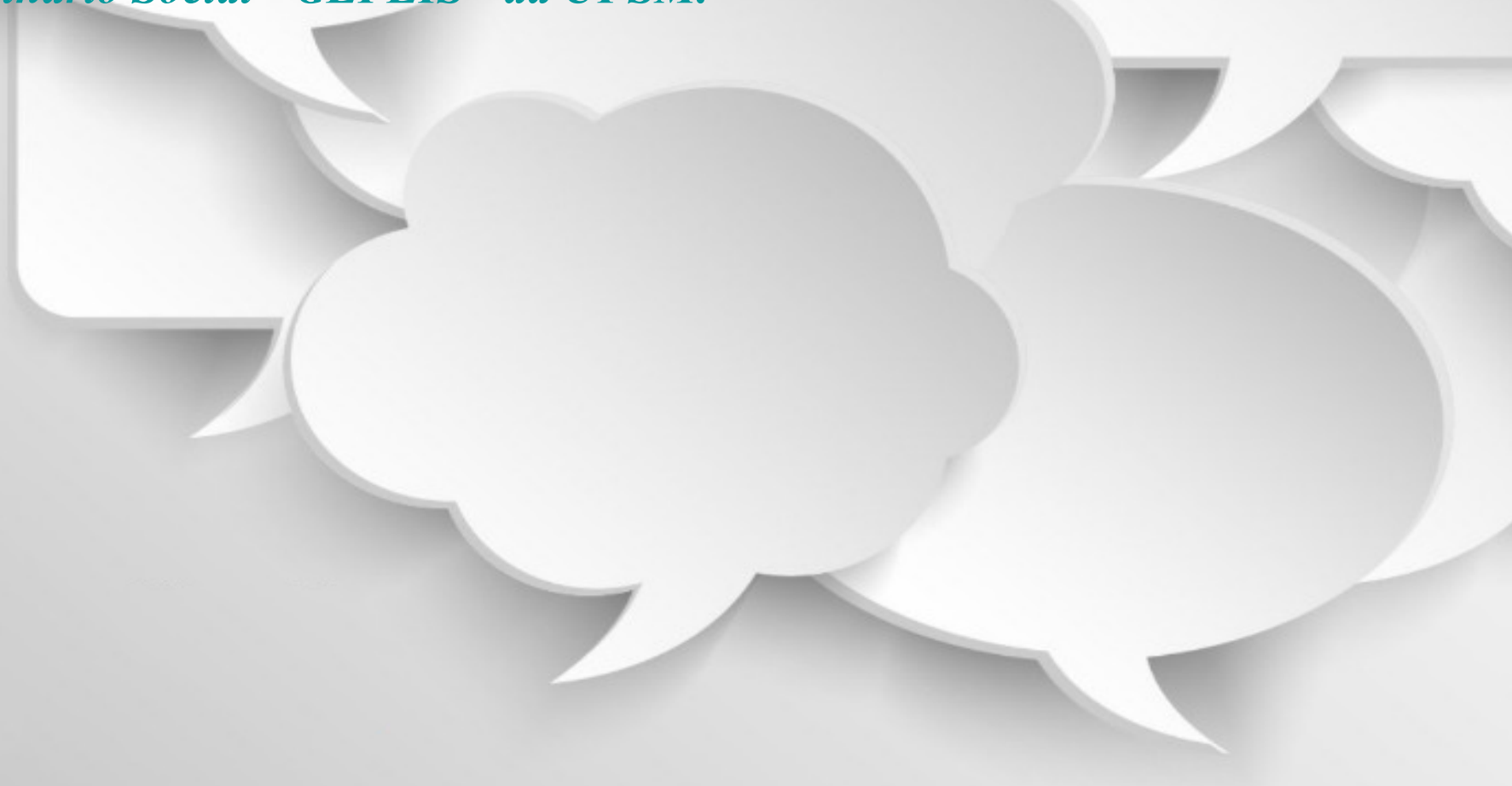




\section{SOBRE AS AUTORAS E OS AUTORES}

\section{Amanda Marinho Rodrigues}

Especialista em Gestão Escolar pelo Instituto de Estudos e Desenvolvimentos Humanos -Ieducare. Formada em Educação Física pela Unversidade Estadual Vale do Acaraú- UVA. Coordenadora Pedagógica da rede municipal de Sobral. Ce. Email: amanda.rodrigues@edu.sobral.ce.gov.br.

\section{Angelo Maurício de Amorim}

Professor Assistente da Universidade do Estado da Bahia. Doutor em Educação Física (UFSC), graduando em Filosofia (UFBA).

E-mail: amamorim@uneb.br.

\section{Anair Meirelles Quadrado}

Graduada em Pedagogia - Pontifícia Universidade Católica do Rio Grande do Sul (PUCRS), Espe-cialista em Informática na Educação (PUCRS), Neuropsicopedagogia e Desenvolvimento Humano (UNIASSELVI), Educação Especial e Inclusiva e Metodologia de Ensino (FAVENI), Graduanda em Psicologia (UNISUL), Mestranda em Tecnologias Emergentes em Educação - MUST University. E-mail: anairquadrado@yahoo.com.br

\section{Alanna Rodrigues Santana}

Mestranda em Propriedade Intelectual e Transferência de Tecnologia para Inovação (UFBA). Pós-Graduada em Direito do Estado pela Fundação Faculdade de Direito (UFBA). Pesquisadora do Grupo de Pesquisa em Propriedade Intelectual (UFBA). Graduada em Direito (UCSAL). Advogada. Técnica Universitária (UNEB).

Lattes: http://lattes.cnpq.br/3883393052590763

E-mail: lannars@gmail.com

\section{Ariel Costa dos Santos}

Graduado e Mestre em Geografia pela Universidade Federal de Mato Grosso, e Doutorando em Geografia pela Universidade Federal da Grande Dourados. E-mail: ariel.costa.geo@gmail.com, orcid.org/0000-0002-0482-3827. Atualmente é Professor substituto da Universidade Federal de Rondonópolis e Professor da Educação Básica do estado de Mato Grosso 


\section{Adriana Moreira da Rocha Veiga}

Licenciada em Pedagogia (1985) e Especialista em Psicopedagogia pela Faculdade de Filosofia, Ciências e Letras Imaculada Conceição, Santa Maria, RS (1992). Mestre em Educação Brasileira pela Universidade Federal de Santa Maria, em Santa Maria, RS (1995). Doutora em Educação pela Universidade Estadual de Campinas, em Campinas, SP (2000). Professora Associada na Universidade Federal de Santa Maria, Departamento de Fundamentos da Educação, Centro de Educação; Professora permanente do Programa de Pós-Graduação em Educação, atuando na Linha de Pesquisa, Docência, Saberes e Desenvolvimento Profissional e do Programa de Pós-Graduação em Políticas Públicas e Gestão Educacional, atuando na linha de pesquisa ?Gestão Pedagógica e Contextos Educativos.

\section{Cauana Peyrot Conceição}

Universidade Federal de Santa Maria (UFSM)

\section{Cristiana Rohrs Lembo}

Psicóloga formada pela PUC-SP (2015) e Mestre em Psicologia Clínica (2019) pela mesma instituição. Atua em consultório particular, atendendo adultos, em São Paulo, SP. E-mail: crisrlembo@gmail.com

\section{Carla Letícia Oliveira Figueiredo}

Graduada em Direito pelo Centro Universitário UNDB, no ano de 2019. Advogada regulamente inscrita na OAB/MA desde 29/10/2019. Pós-Graduada (lato sensu) em Processo Civil pela Universidade Candido Mendes (UCAM-RJ). Mestranda do Programa de Pós-Graduação em Direito da Pontifícia Universidade Católica do Rio Grande do Sul, na modalidade interinstitucional (MINTER/PUCRS-UNDB). http://lattes.cnpq.br/2344039003911575.

E-mail: carla_leticia10@hotmail.com

\section{Denise Santos da Cruz}

Doutoranda em Educação no PPGE/UFSM, com tese qualificada em 2019, centrada no tema, Pedagogia da Bricolagem: Ofício de Educadores/as Artífices. Bio [trans] formação, Práxis criadora e Ambiências bio [trans] formativas?. Mestra em Educação (PPGE, UFSM, 2017). Professora licenciada pelo Programa Especial de Graduação de Formação de Professores para a Educação Profissional (PEG) - Licenciatura Plena, pela Universidade Federal de Santa Maria (UFSM, RS, 2015); Especialista em Psicopedagogia Clínica e Institucional (UNINTER, PR, 2019); Especialista em Educação à Distância com Ênfase na Docência e na Tutoria pela Pontifícia Universidade Católica do Rio Grande do Sul (PUCRS, 2013); Licenciada em Pedagogia pelo Centro Universitário (ETEP- SP, 2021); Bacharel em Administração de Empresas (Universidade de Santo Amaro, SP, 2011). Participante do Grupo de Pesquisas GPKOSMOS -Grupo de Pesquisas em Educação na Cultura Digital e Redes de Formação $\mathrm{UFSM} / \mathrm{CNPq}$. 


\section{Edileuza Gomes de Souza}

Graduada em Pedagogia - Universidade Estadual da Bahia (UNEB), Coordenadora Pedagógica da área de Linguagem no Ensino Fundamental II; Especialista em Psicologia Educacional (FIP-FFM-PB), Gestão Educacional e Alfabetização e Letramento (FSS /BA), Mestranda em Tecnologias Emergentes em Educação pela Must University.

E-mail: souza.edileuza5@gmail.com

http://lattes.cnpq.br/7562956765841140

\section{Fábio Ferreira Santos}

Doutor em Geografia pela Universidade Federal da Paraíba, Professor Da rede Municipal de ensino em Itabaiana-SE, Membro do grupo de pesquisa CEGETSecção Paraíba, e pesquisador do grupo de Pesquisa Relação Sociedade-Natureza do Espaço Geográfico (PROGEO) DGEI/UFS.

\section{Giovanna Martins Sampaio}

Advogada, Mestre LLM em Direito internacional dos Negócios, e Mestranda em PI e TT para Inovação, PROFNIT - UFBA; Graduanda em Administração. Email: giovanna.martins@ufba.br

\section{Gabriella Eldereti Machado}

É Licenciada em Química pelo Instituto Federal de Educação, Ciência e Tecnologia Farroupilha - IFFar - Campus Alegrete (2015) e Pedagoga pelo Centro Universitário Facvest - Unifacvest (2020). Especialista Educação Ambiental pela Universidade Federal de Santa Maria (2016), Mestre em Educação pela Universidade Federal_de Santa Maria (2018). Atualmente é Discente do Programa de Pós - Graduação em Educação - Doutorado em Educação na Universidade Federal de Santa Maria. Participou do Grupo de Estudo e pesquisa Feministas (UFSM); do Grupo de Estudos em Políticas e Gestão Educacional (IFar - Campus Alegrete); do Grupo de Agroecologia Terra Sul (UFSM). Atualmente participa do Núcleo de Pesquisa em Desenvolvimento Territorial do Pampa (IFar - Campus Alegrete) e atua como pesquisadora no Grupo de Estudos e Pesquisas em Educação e Imaginário Social - GEPEIS (UFSM). Trabalha na área da Educação, com ênfase na Formação de Professores e Imaginário Social. 


\section{Hermes Gomes}

Administrador, Contador e Mestre em Propriedade Intelectual e Transferência de Tecnologia para a Inovação, PROFNIT - UFBA.

Email: hermesk25@hotmail.com

\section{Ivanio Folmer}

Graduado em Geografia Licenciatura pela Universidade Federal de Santa Maria (2014). Mestre em Geografia pelo Programa de Pós Graduação em Geografia-PPGGEO/UFSM (2018). Doutorando em Geografia-PPGGEO/UFSM com previsão de término em 2022. Participante de diversos projetos de pesquisa e extensão, com as temáticas de Educação no campo; Território; Sujeitos do Campo; Educação Ambiental; Gênero e sexualidade; Mortalidade Infantil; Catadores e Memória e Patrimônio Cultural. É professor da Rede Estadual do RS na Área das Humanas - Componente Curricular: Geografia. Tutor EAD no Curso Licenciatura em Educação do Campo UAB/UFSM desde 2018. Integrante do Grupo de Pesquisa Girassol - Grupo de Pesquisa em Agroecologia, Educação do Campo e Inovações Sociais - UFSM; Grupo de Pesquisa em Educação e Território- GPET - UFSM e Agricultura e Urbanização na América Latina - USP. É integrante da AcademiaLuso-Brasileira de Letras do Rio Grande do Sul.

\section{José Gilmar Kurtz}

Graduado em Educação Física pela Uniguaçu Faesi (2008). Licenciado em Filosofia pela Unipar - Universidade Paranaense (2018). Especialista em Metodologia do Ensino de Filosofia e Sociologia e Educação do Campo pela Faculdade São Luís (2020).E-mail: gilmarkurtz80@gmail.com

\section{Liliana Bernardo de Oliveira Onofre}

Licenciada em Ciências para o Primeiro Grau - Habilitação em Matemática Segundo Grau (FAFI). Especialização em Planejamento Educacional (UNIVERSO). Mestranda em Tecnologias Emergentes em Educação pela Must University/Florida_USA. E-mail: lilianaonofre@hotmail.com.

\section{Liziany Müller}

Doutora. Professora do Curso de Educação do Campo UFSM.

Email: lizianym@hotmail.com 


\section{Luciano Araujo da Costa}

Graduado em Licenciatura Plena em História pela Universidade Estácio de Sá, Licenciatura Plena em Sociolo-gia pela Universidade do Paraná, Licenciatura Plena em Filosofia pela Universidade Católica Dom Bosco, Ba-charel em Teologia pela Faculdade Unida de Vitória e Tecnólogo em Informática pela Faculdade São José. Pós-graduado nas áreas de História e Cultura Afro-Brasileira e Ciência da Religião pela Universidade Cândido Mendes e Salesianidade pela Universidade Católica Dom Bosco. Graduando em Licenciatura Plena em Peda-gogia e Licenciatura em Psicopedagogia pelo Centro Universitário Leonardo da Vinci - Uniasselvi, Pós-graduando em Tecnologias Digitais Aplicadas a Educação e Ensino a Distância (Gestão e Tutoria) pelo Centro Universitário Leonardo da Vinci - Uniasselvi, Informática Aplicada a Educação pelo IFMS - Instituto Federal de Educação, Ciência e Tecnologia de Mato Grosso do Sul, Tecnologias Digitais Para Educação pela FAINSEP - Faculdade Instituto Superior de Educação Paraná, Mestrando em Tecnologias Emergentes em Educação pela Universidade MUST (Flórida-USA).

E-mail:/ucianoarj@gmail.com.

Lattes: http://lattes.cnpq.br/1895259576553534.

Orcid: https://orcid.org/0000-0003-1582-1891.

\section{Mirian Luzia de Lima Vaz}

Graduada em Licenciatura plena em Química pela Universidade Federal do Espírito Santo (UFES). Especialista no Ensino de Química e Matemática pela Faculdade de Nanuque (FANAN). Professora atuante na Secretaria de Estado da Educação do Espírito Santo SEDU-ES. Tutora presencial no curso de Licenciatura plena em Química pela Universidade Federal do Espírito Santo (UFES). Mestranda em Tecnologias Emergentes em Educação-pela Must University/ Florida - USA.

E-mail: mirianvaz0@gmail.com.

Currículo Lattes: http://lattes.cnpq.br/7302809763477166.

ORCID: https://orcid.org/0000-0003-0741-0064

\section{Maricélia de Almeida Vieira}

Mestra em Educação (UFSM). Professora de Letras da Faculdade Integrada de Santa Maria-FISMA (RS). 


\section{Maria Fatima Menegazzo Nicodem}

Doutora em Educação/ UEM, Pós Doc em Educação do Campo/ UEM. Professora UTFPR- Universidade Tecnológica Federal do Paraná. E-mail: fatimanicodem@hotmail.com

\section{Natalina das Graças Bitencourt}

Graduada em Bacharel e Pedagogia Empresarial pela Unoesc- Universidade do Oeste de Santa Catarina (2008). Formação Pedagógica em Pedagogia pela UNIASSELVI-Centro Universitário Leonardo Da Vinci de Indaial -SC (2020). Especialistas em Docência na Educação e Anos Iniciais - Faculdade Única de Ipatinga - MG (2021). E-mail: bitencourtnatalina@gmail.com

\section{Naiara Ferreira Paim}

Ulbra, Brasil. E-mail: naiaraferreirapaim@gmail.com

\section{Pedro Valdir da Conceição}

Universidade Federal de Santa Maria (UFSM)

\section{Paulo Sérgio Mohr}

Graduado em Educação Física pela Unipar - Universidade Paranaense (2004). Especialista em Metodologias Inovadoras Aplicadas à Educação e Educação Especial Inclusiva pela Faculdade Internacional dé Curitiba - Facinter (2008). Associado ao CREF - PR como treinador esportivo. Atuação na rede Estadual e Privada de ensino. E-mail: paulo.mohr@bol.com.br

\section{Rodrigo Duarte Faccin}

Bacharel em Administração pela Universidade Regional Integrada do Alto Uruguai e das Missões, Campus Santiago, e Mestre em Extensão Rural pela Universidade Federal de Santa Maria. Atualmente é doutorando na Universidade Federal de Santa Maria no Programa de Pós-Graduação em Extensão Rural e aluno na mesma instituição do Programa Especial de Graduação de Formação de Professores Para a Educação Profissional (PEG).

\section{Rogério Oliveira Pinheiro}

Possui graduação em Zootecnia pela Universidade Federal de Santa Maria (2000) e Mestrado no Programa de Pós Graduação em Tecnologias Educacionais em Rede - PPGTER/UFSM. (2016) 


\section{Renata Freitas Siqueira}

Mestra em Economia pela UFMT, Professora Efetiva de Educação Básica do Estado de Mato Grosso. Email: renatarnuke@gmail.com

\section{Ronny Ramos da Silva}

Graduado em Licenciatura Plena em Música - Universidade do Estado do Pará/ UEPA, Belém - PA (2007). Especialização em Educação Musical e Ensino de Artes. Universidade Cândido Mendes - UCAM, Rio de Janeiro (2019). Integrante do Conselho Editorial do $8^{\circ}$ Boletim Técnico ano 2015 da Fundação Casa da Cultura de Marabá - FCCM - PA. Atualmente em Marabá-PA professor de Música da Rede Municipal - Fccm e do Serviço Social do Comércio - Sesc. E-mail: ronny.da.silva@gmail.com

\section{Sonia Aparecida Machado}

Acadêmicos do Curso de Ciências Econômicas, da Universidade Federal da Fronteira Sul

\section{Soleika Gorete Lunkes}

Graduada em Tecnologia em Gestão Ambiental pela Universidade Tecnológica Federaldo Paraná-UTFPR (2011). Especialista em Educação Especial, Psicomotricidade, Educação do Campo e Gestão Escolar. Possui Licenciatura em Química, Ciências Biológicas e Pedaggogia.

E-mail: soleikalunkes@gmail.com

\section{Ueudison Alves Guimarães}

Graduado em Pedagogia - Universidade Luterana do Brasil - (ULBRA), Química - Faculdade Cidade João Pinheiro - (FCJP), Matemática - Centro Universitário Claretiano - (CLARETIANO), Geografia - Faculdade Mozarteum de São Paulo - (FAMOSP) e Física - Centro Universitário Faveni - (UNIFAVENI); Professor de Pedagogia, Química, Matemática, Geografia e Física atuante na Educação Básica e Ensino Superior; Especialista em Gênero e Diversidade na Escola - (UFMT), Educação das Relações Étnico-Raciais no Contexto da Educação de Jovens e Adultos - (UFMT), Metodologia do Ensino em Química - (FIJ-RJ), Libras e Educação Inclusiva - (IFMT) e Docência para a Educação Profissional e Tecnológica - (IFES); Mestrando em Educação: Especialização em Formação de Professores - Universidad Europea del Atlántico - Espanha (UNEA), Mestrado Profissional em Ensino de Física - Universidade Federal de Mato Grosso (UFMT) e Mestrado em Tecnologias Emergentes em Educação (Must University).

E-mail: ueudisonverde@hotmail.com

Lattes: http://lattes.cnpq.br/7975329809972139 


\section{Ulysses Fonseca Louzada}

Natural de Rio Grande, Rio Grande do Sul (RS), Brasil. É Bacharel em Ciências Jurídicas e Sociais (Direito) pela Fundação Universidade Federal do Rio Grande (1984) e Mestre em Educação pela Universidade Federal de Santa Maria (2003). Professor Adjunto do Departamento de Direito da Universidade Federal de Santa Maria, Rio Grande do Sul (RS), Brasil. Juiz de Direito do Estado do Rio Grande do Sul, exercendo a magistratura na $1^{\mathrm{a}}$. Vara Criminal de Santa Maria, RS. Comanda a vara de execuções, sendo responsável pela Região Central. Na trajetória profissional e acadêmica segue as trilhas da Educação, com a lupa no Sistema Penitenciário Brasileiro atual, trazendo esta temática como importante questão, mobilizando-o como pesquisador e cidadão comprometido com a humanização. Lidera o Centro de Referência em Educação e Formação Humana no Sistema Penitenciário Brasileiro Atual, nasce do diálogo entre as ciências humanas, sociais e sociais aplicadas, movimentado pelos pesquisadores e estudantes com o objetivo de ?caminhar nas trilhas da educação e formação humana com uma lupa no sistema penitenciário brasileiro atual.

\section{Wanderson Teixeira Gomes}

Graduado em Ciências Biológicas- Universidade de Uberaba- (UNIUBE), Professor de Ciências atuante na Educação Básica,Especialista em Educação Ambiental - (IPEMIG), Mestrando em Tecnologias Emergentes em Educação (MUST University).

E-mail:wandertg04@gmail.com.

Lattes: http://lattes.cnpq.br/0258880363350197 
www.arcoeditores.com

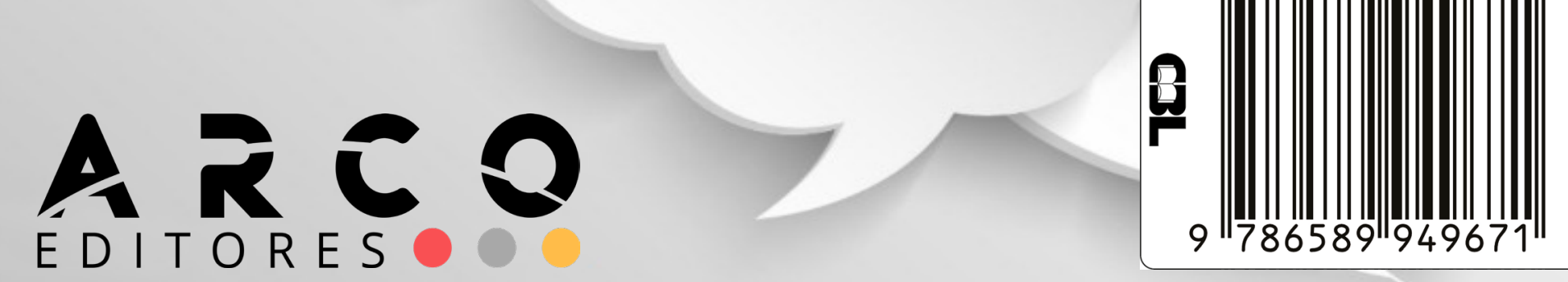

